Universidad de Lima

Facultad de Ingeniería y Arquitectura

Carrera de Arquitectura

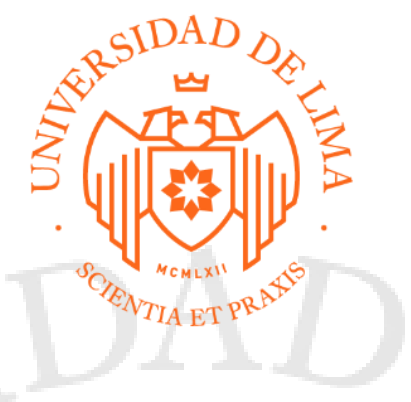

\title{
CENTRO CULTURAL EN LA ESTACIÓN PLAZA LAS FLORES DE BARRANCO COMO ANIMADOR URBANO
}

Trabajo de suficiencia profesional para optar el Título Profesional de Arquitecto Proyecto de Fin de Carrera

\section{Ana Francesca Battilana Flores}

Código 20091997

Gonzalo Antonio Cortez Arenas

Código 20102027

Asesor

Marina Francesca Vella Estremadoyro De Tschudi

Lima - Perú

Octubre de 2019 


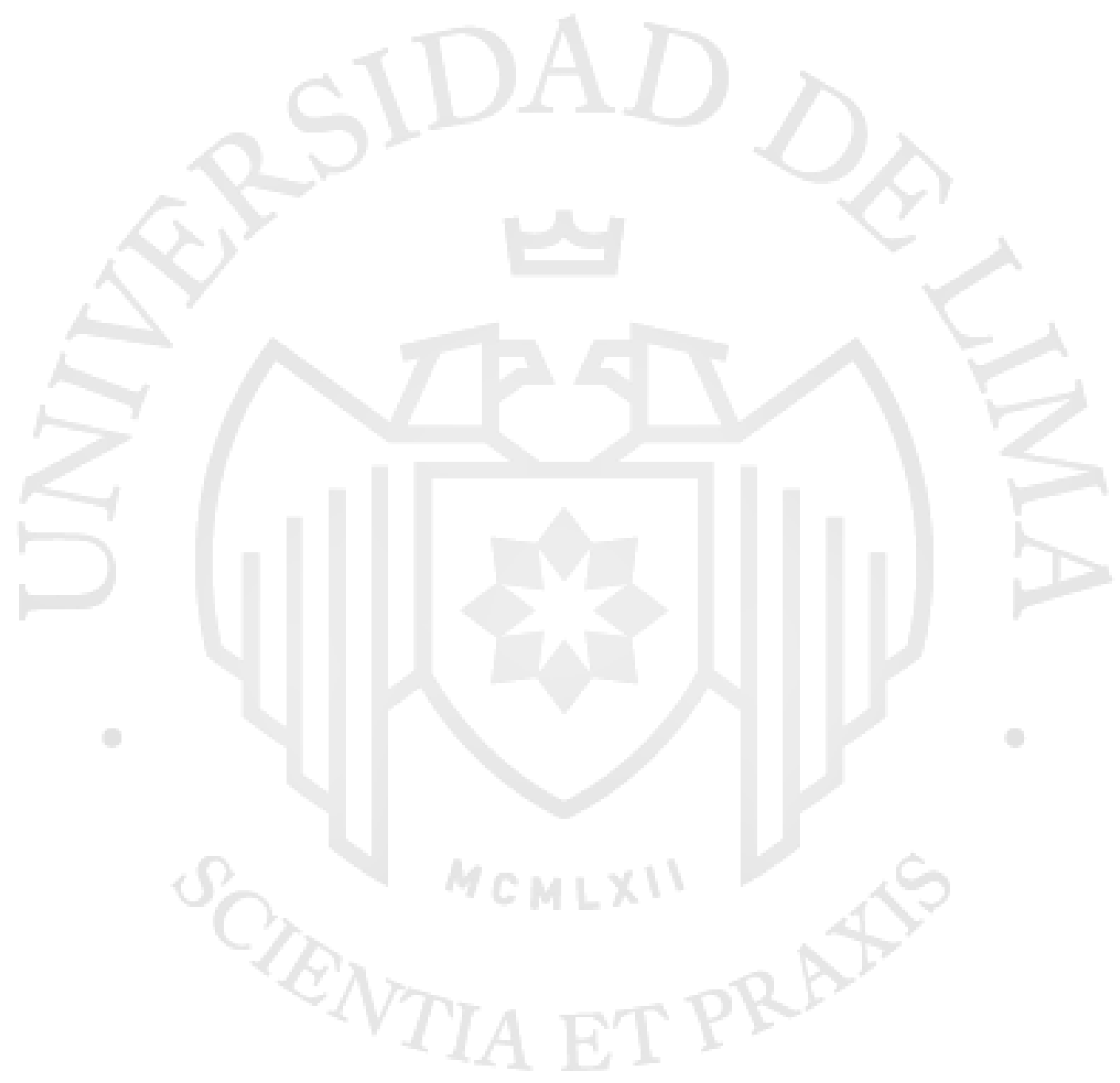


CENTRO CULTURAL EN LA ESTACIÓN PLAZA LAS FLORES DE BARRANCO COMO ANIMADOR URBANO 


\section{INDICE}

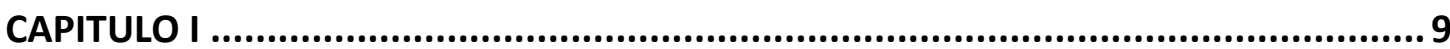

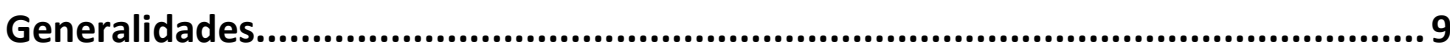

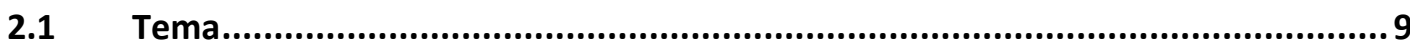

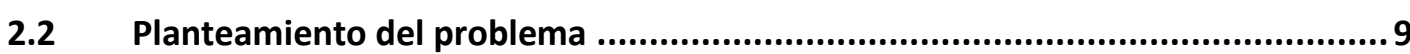

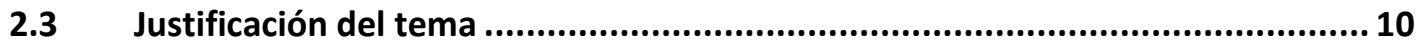

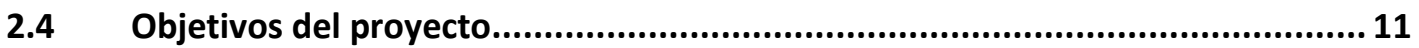

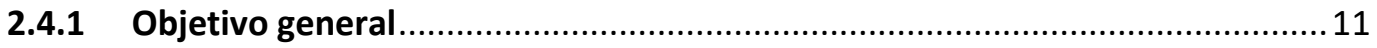

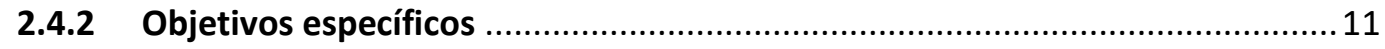

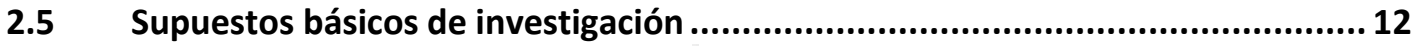

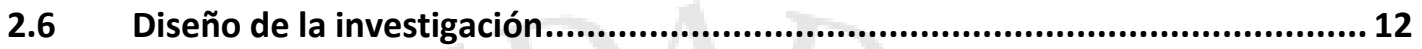

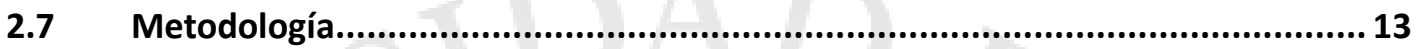

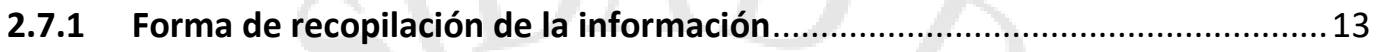

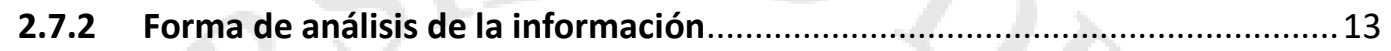

2.7.3 Forma de presentación de la información .................................................... 13

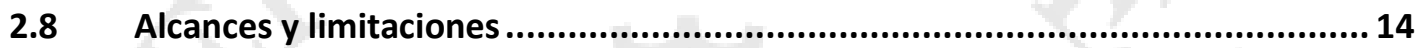

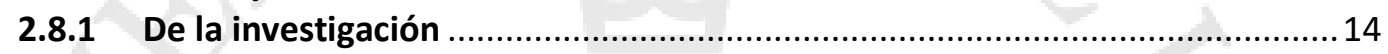

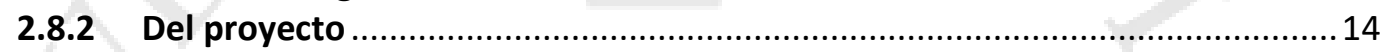

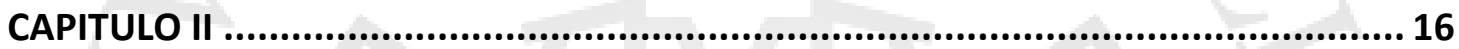

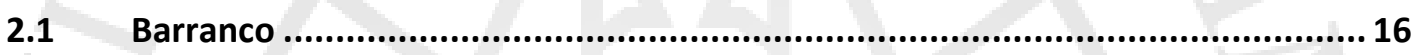

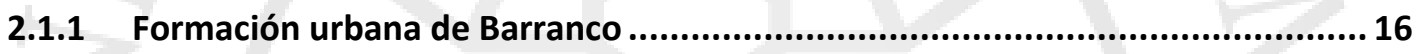

2.1.1.1 Periodo Prehispánico (5000 a.C - 1500 d.C) .............................................. 16

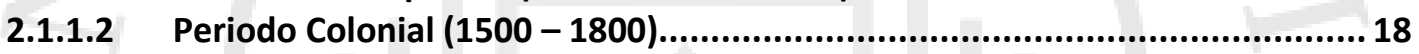

2.1.1.2.1 Primera etapa de desarrollo urbano................................................. 19

2.1.1.2.2 Leyenda de la formación de Barranco............................................... 21

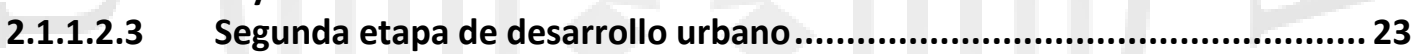

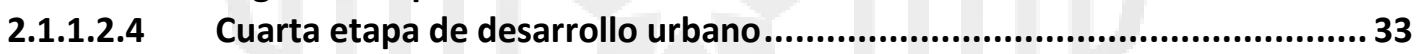

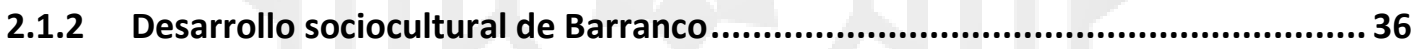

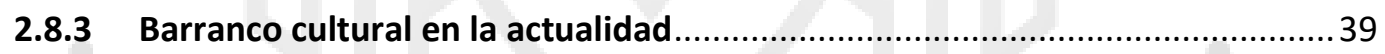

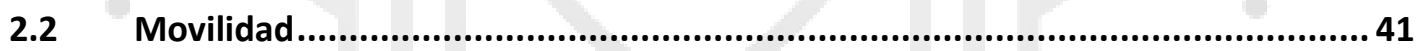

2.2.1 Antecedentes de Planes viales de Lima Metropolitana ................................. 41

2.2.2 PLANDEMET: Plan de Desarrollo Metropolitano Lima Callao - Esquema Director

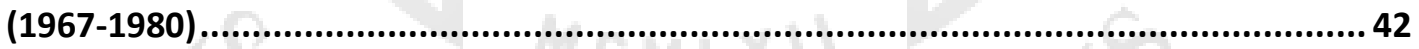

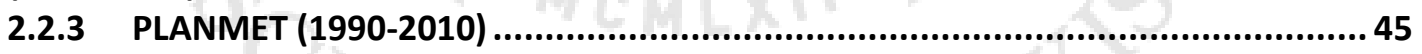

2.2.4 Plan Regional de Desarrollo Concertado de Lima (2012-2025) ........................ 51

2.3 Transporte Masivo Rápido en Buses (BRT o TMRB) ........................................55

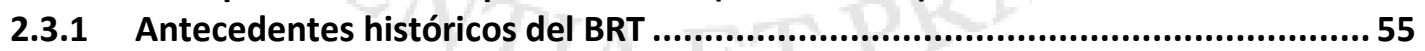

2.3.1.1 Transporte masivo rápido de buses (BRT) en Perú .....................................56

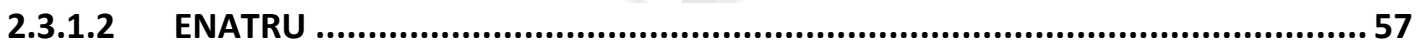

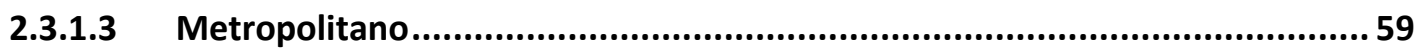

2.3.2 Referente de BRT en Latinoamérica: TransMilenio de Bogotá. ....................... 62

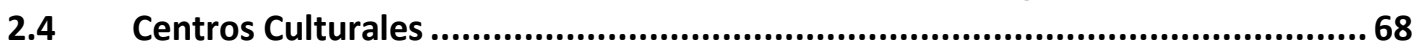

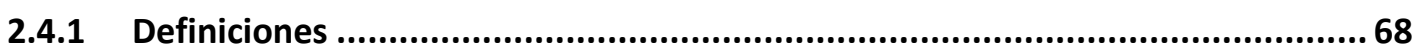

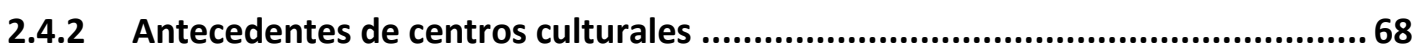

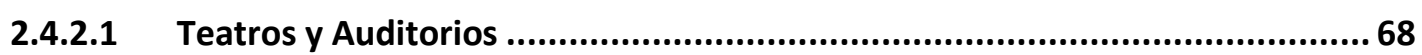

2.4.2.2 Museos y salas de exposición................................................................... 70

2.4.2.3 Centro cultural como animador urbano ..................................................... 70

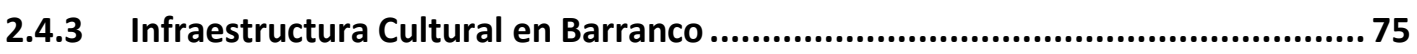

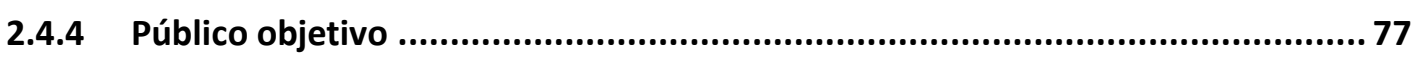




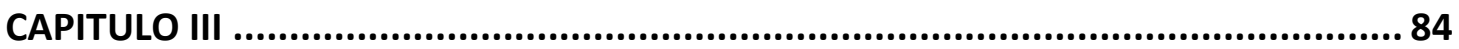

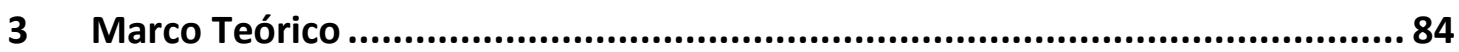

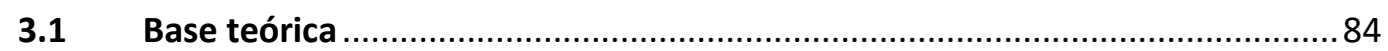

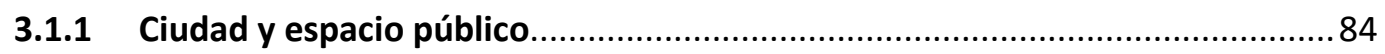

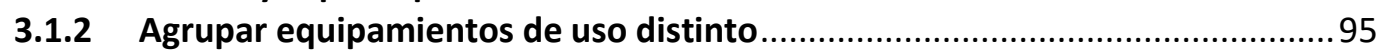

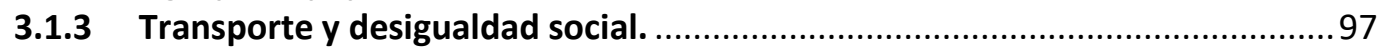

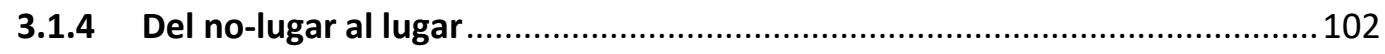

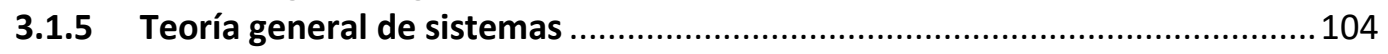

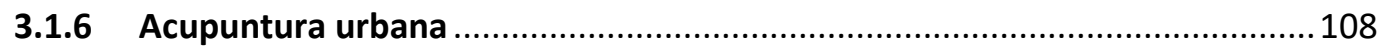

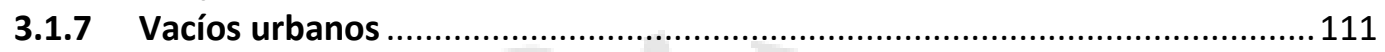

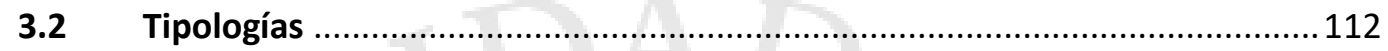

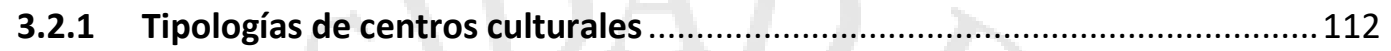

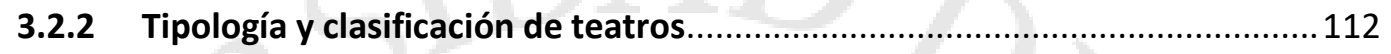

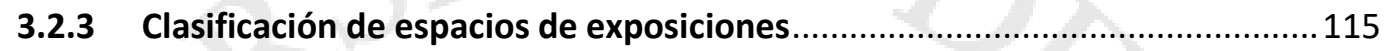

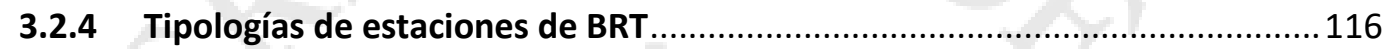

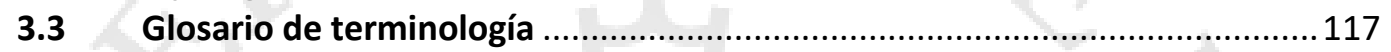

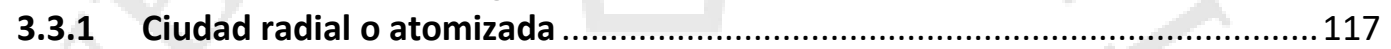

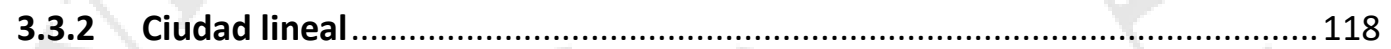

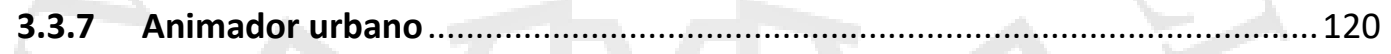

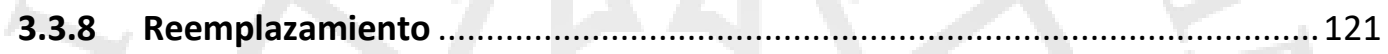

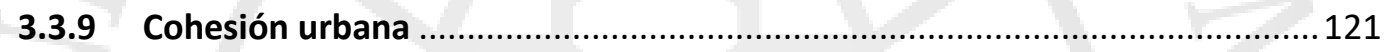

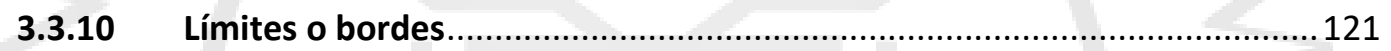

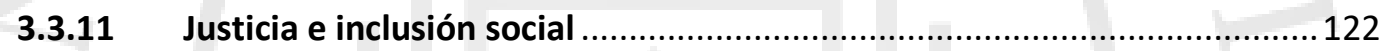

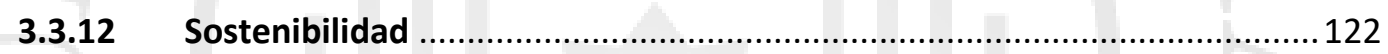

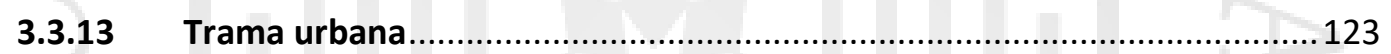

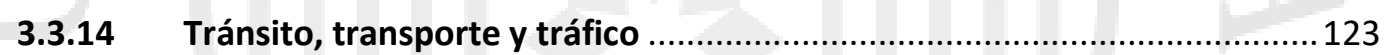

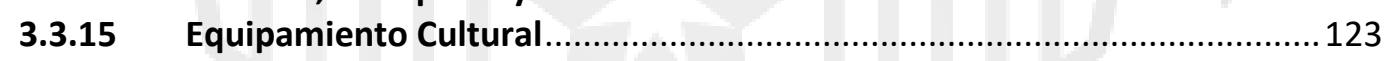

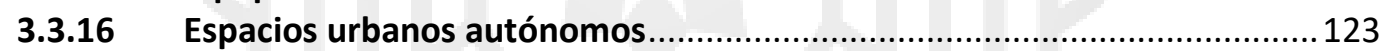

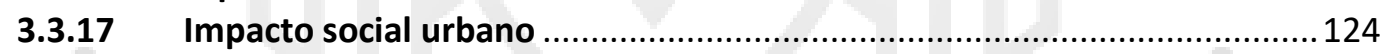

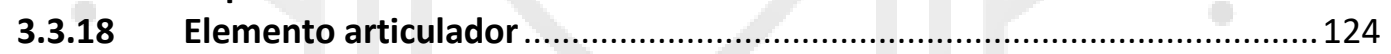

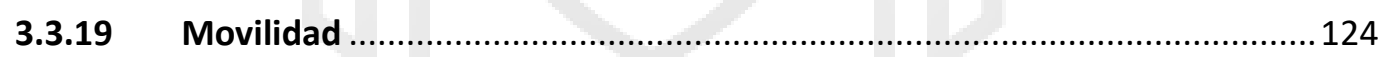

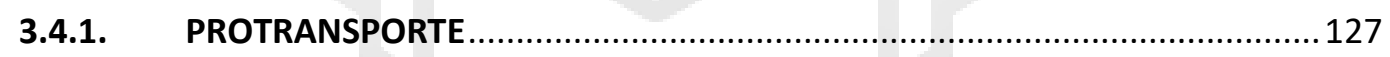

3.4.2. Ministerio de Transporte y Comunicaciones (MTC) ............................... 127

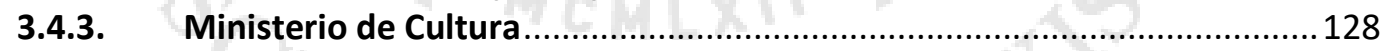

3.4.4. Municipalidad Metropolitana de Lima (MML) …................................... 128

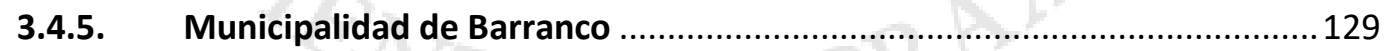

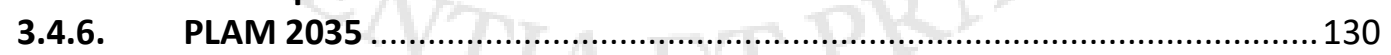

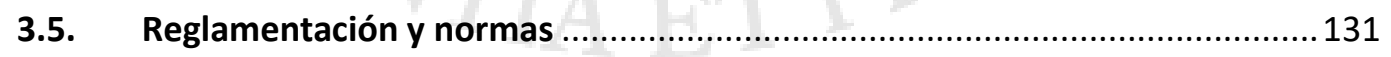

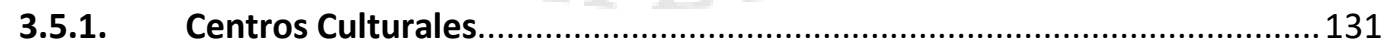

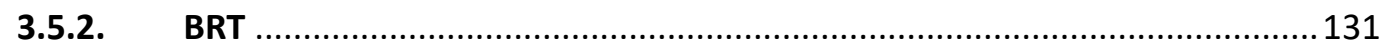

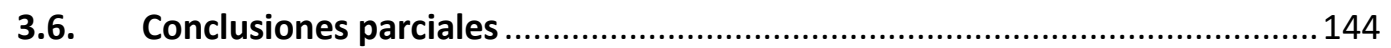

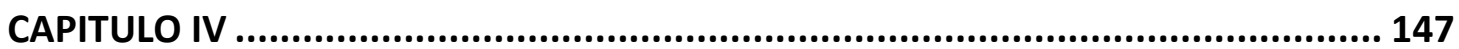

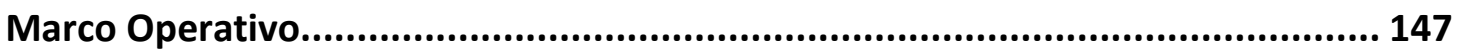

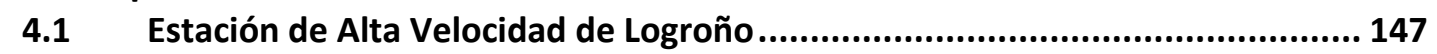

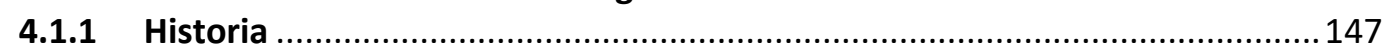

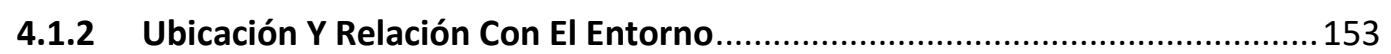

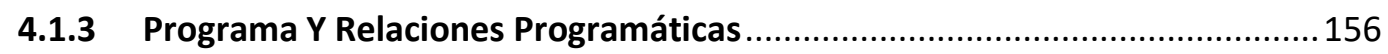

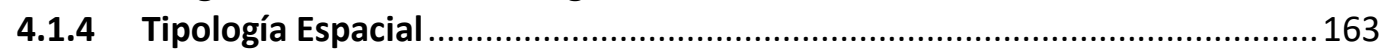




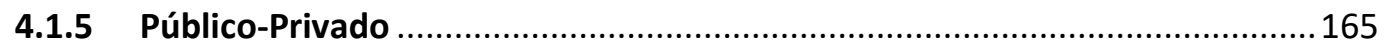

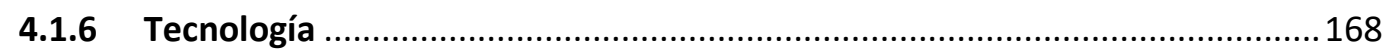

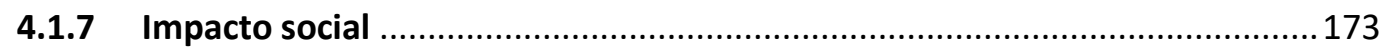

4.2 Estación de autobuses y biblioteca de Ronda (Málaga) ................................ 174

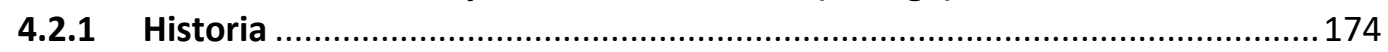

4.2.2 Ubicación Y Relación Con El Entorno.........................................................179

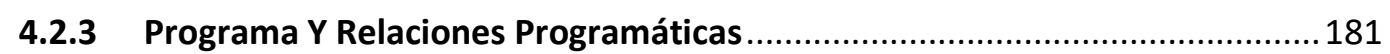

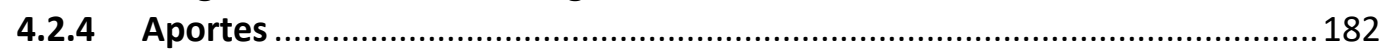

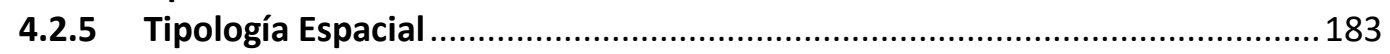

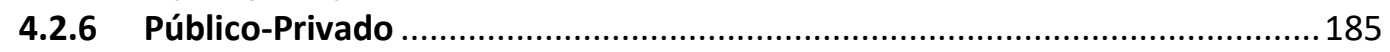

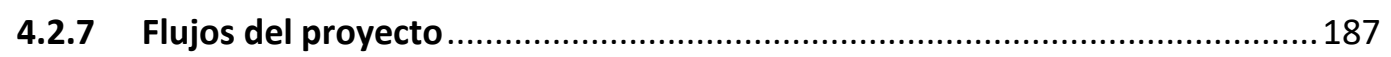

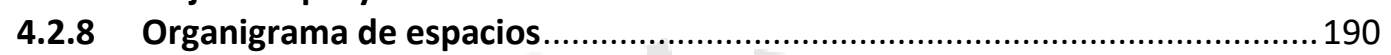

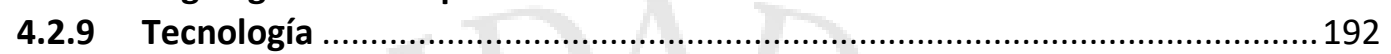

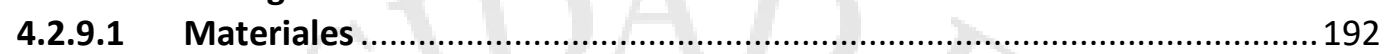

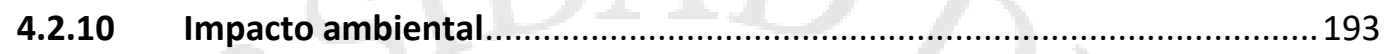

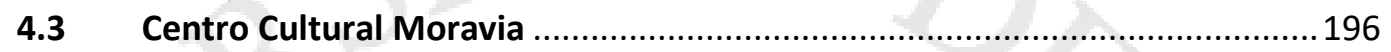

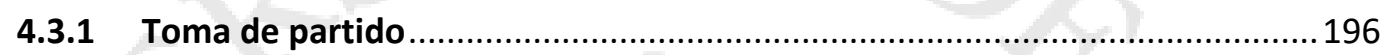

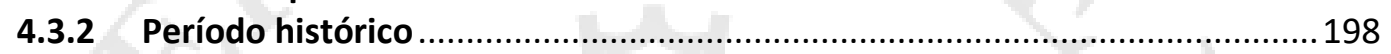

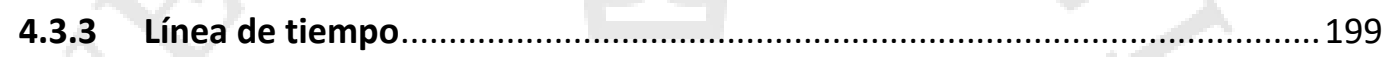

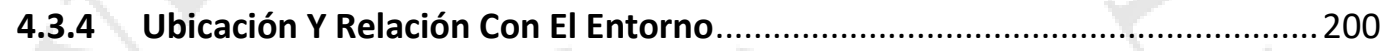

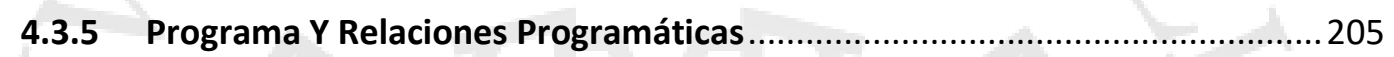

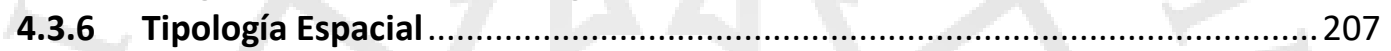

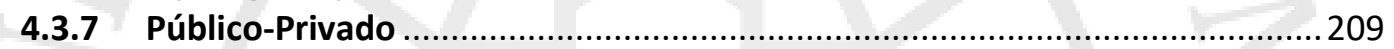

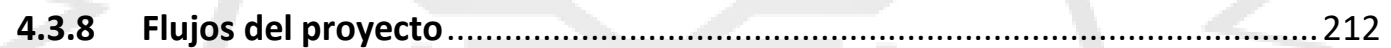

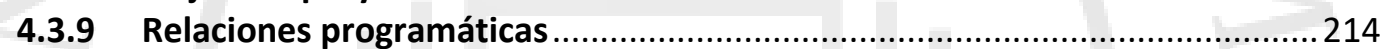

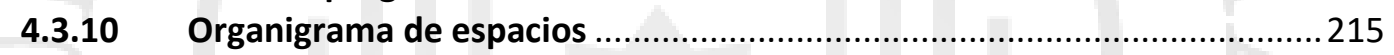

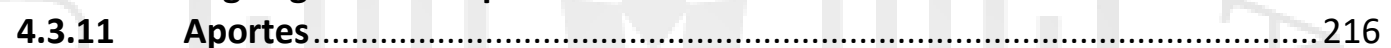

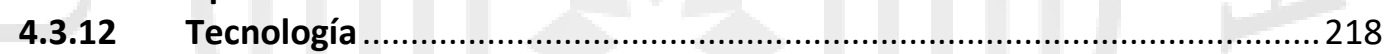

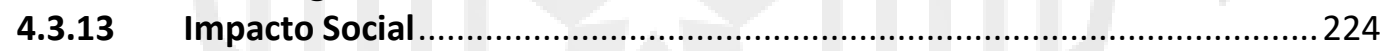

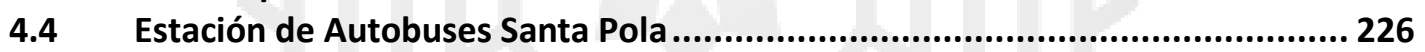

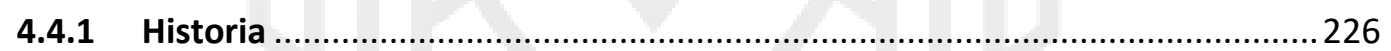

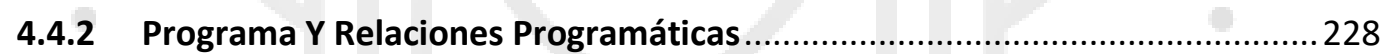

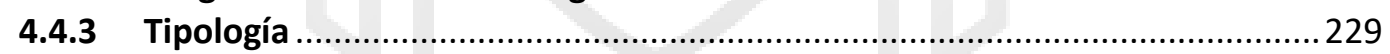

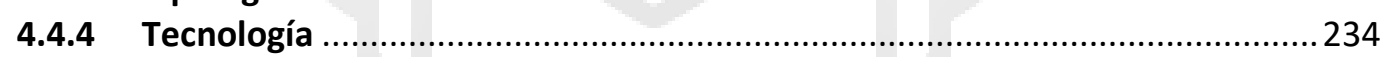

4.5 Estación del BRT Ecovía Casa de la Cultura, Quito. ..................................... 236

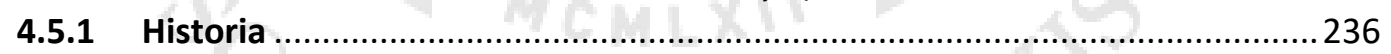

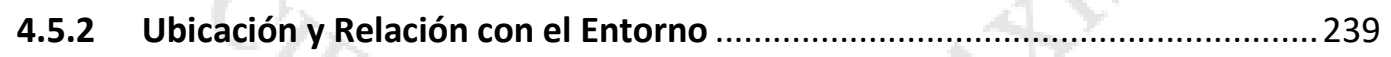

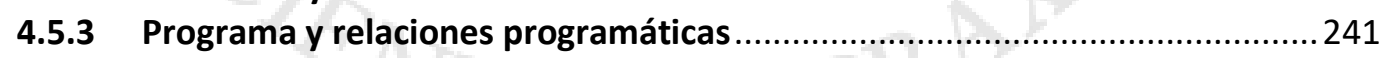

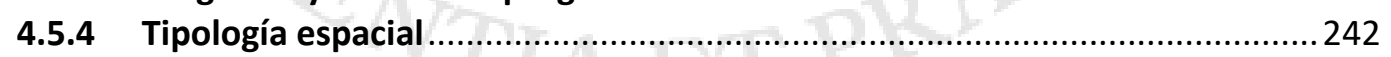

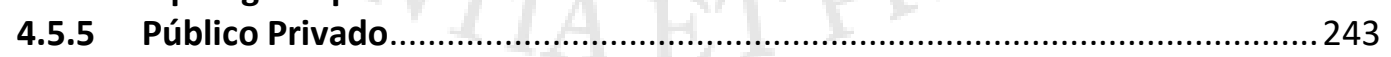

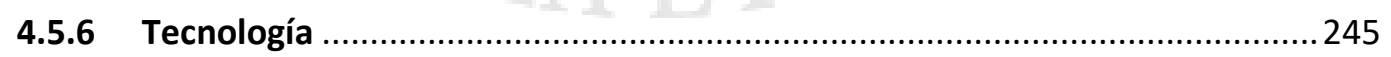

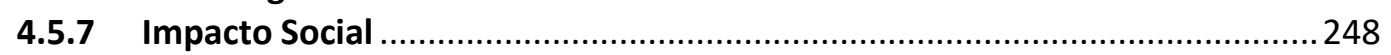

4.6 Centro Cultural Gabriela Mistral, Santiago de Chile........................................ 250

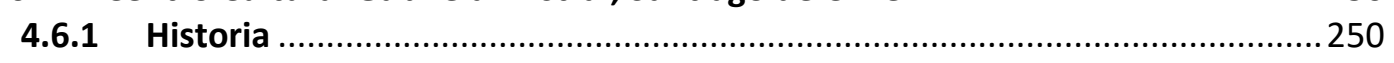

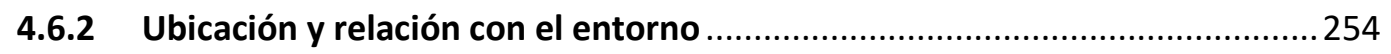

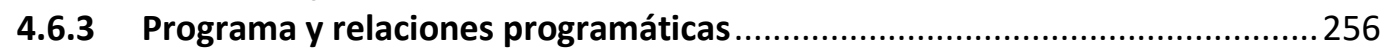

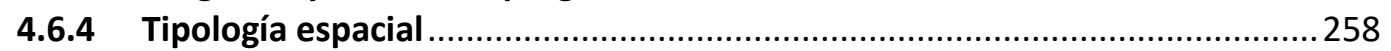

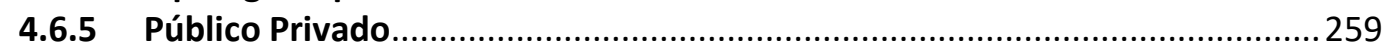

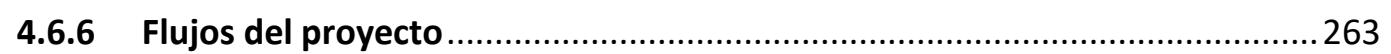

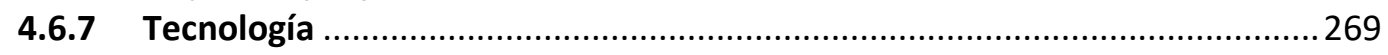

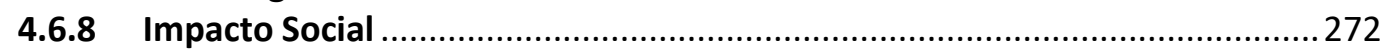




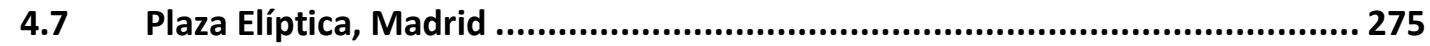

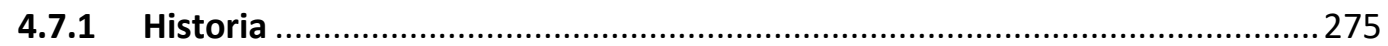

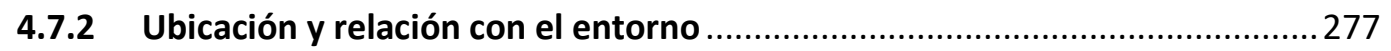

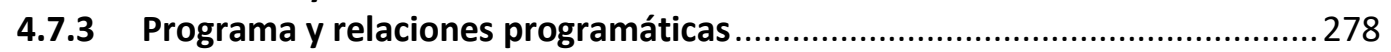

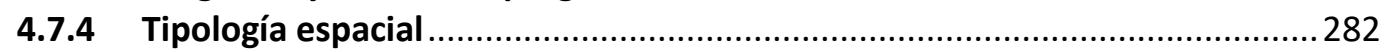

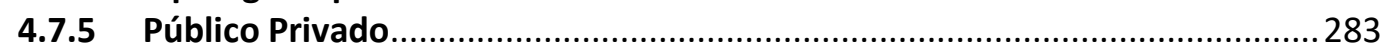

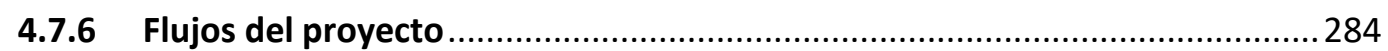

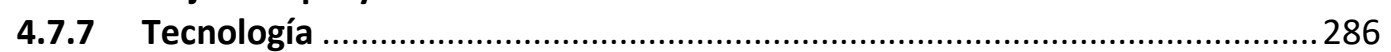

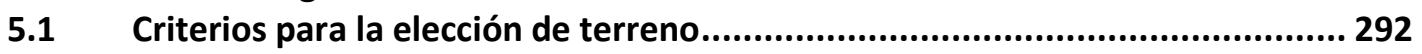

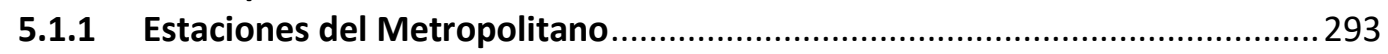

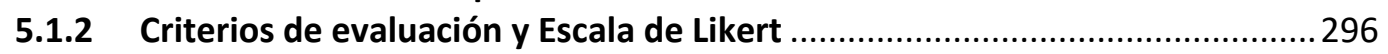

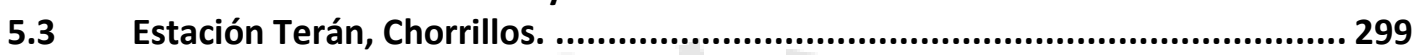

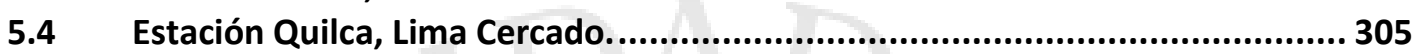

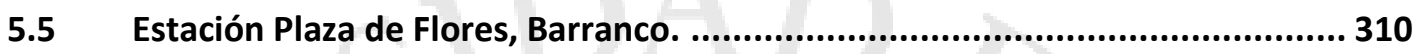

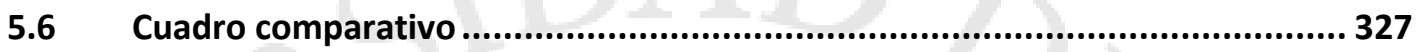

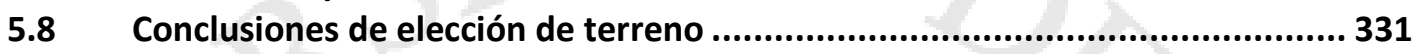

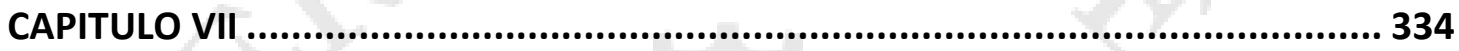

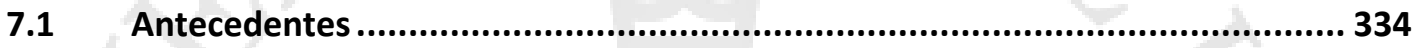

7.1.1 Vía Expresa Sur y Plaza de Intercambio 360 del Metropolitano....................334

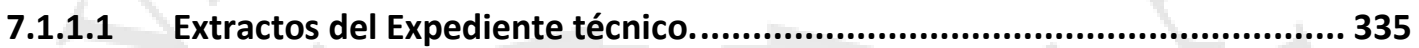

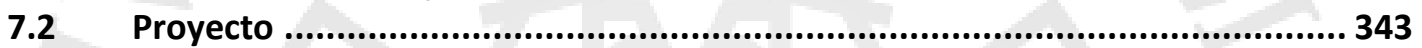

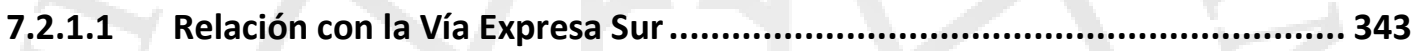

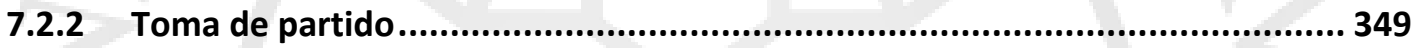

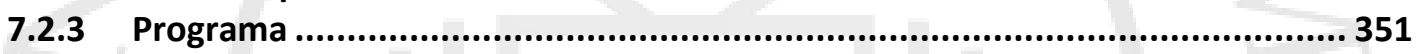

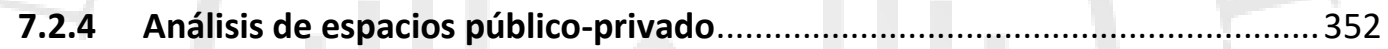

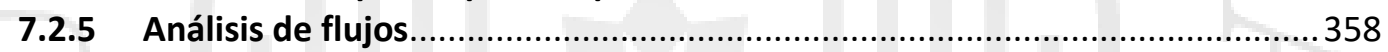

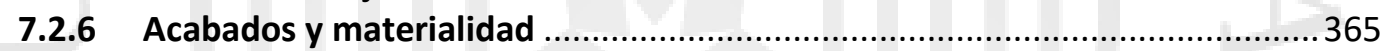

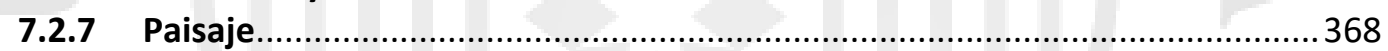

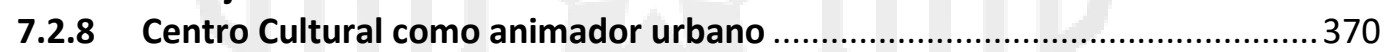

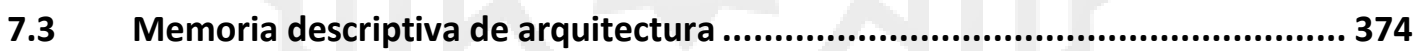

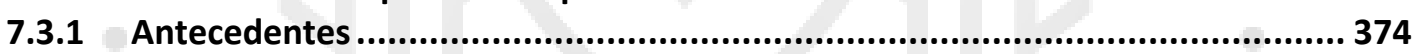

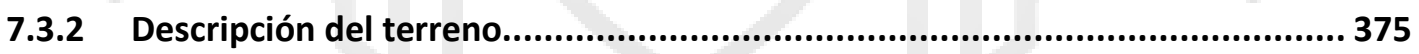

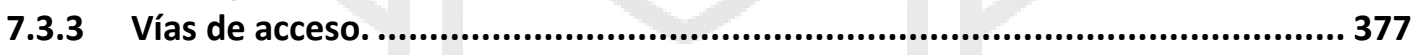

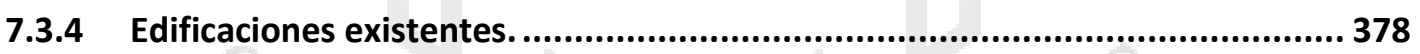

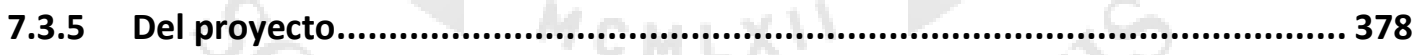

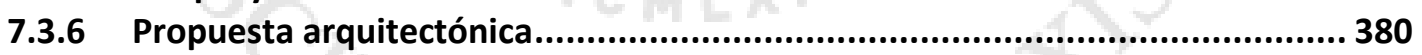

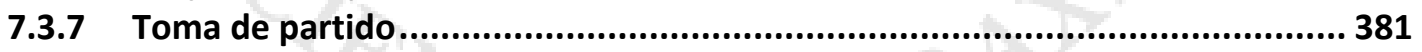

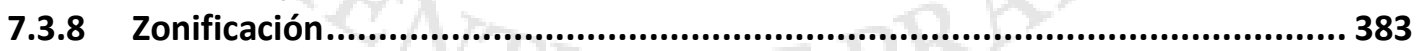

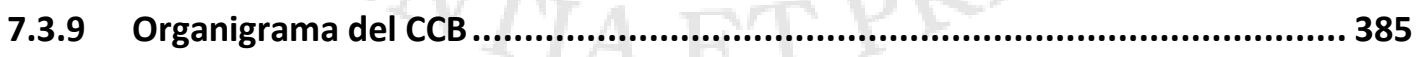

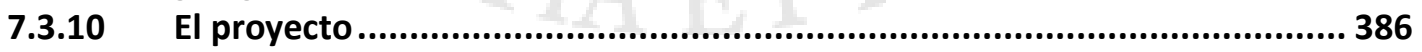

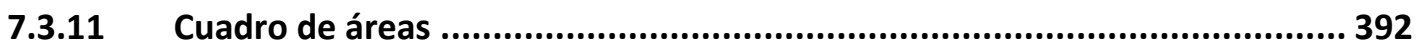

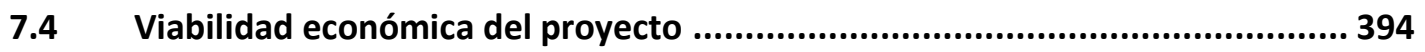

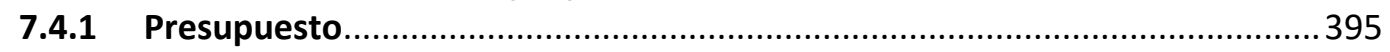

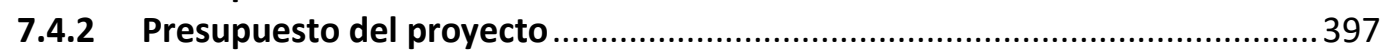

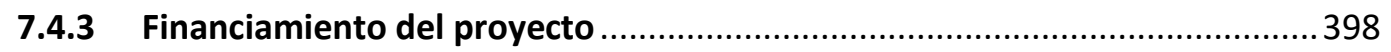

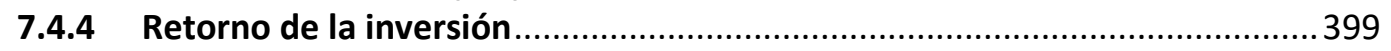

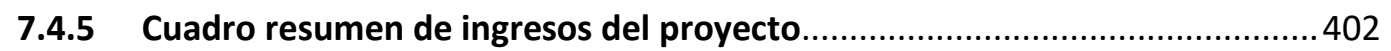

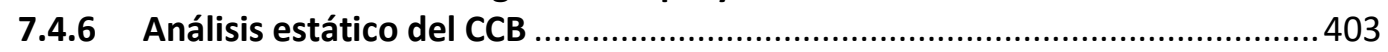

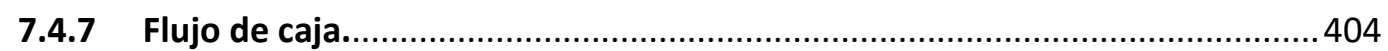

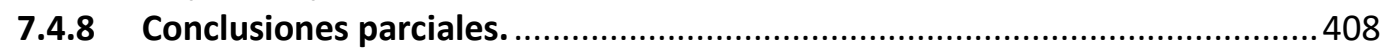

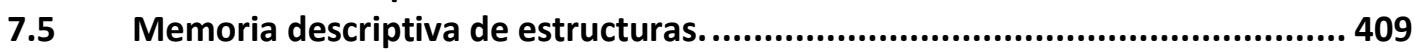


7.6 Memoria descriptiva de instalaciones eléctricas ........................................... 411

7.7 Memoria descriptiva de instalaciones sanitarias............................................. 414

7.8 Memoria descriptiva de instalaciones mecánicas........................................ 417

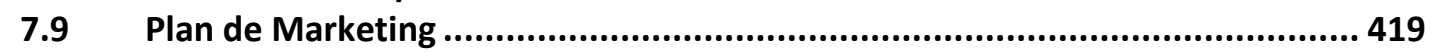

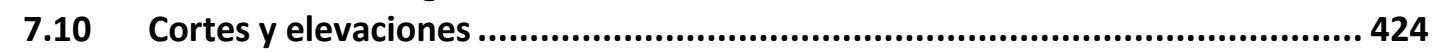

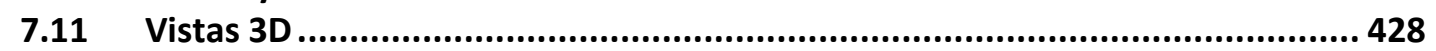

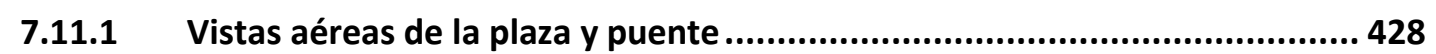

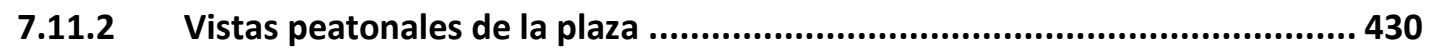

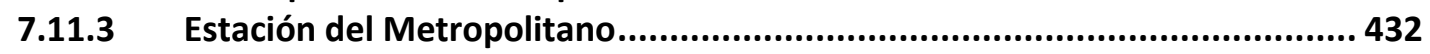

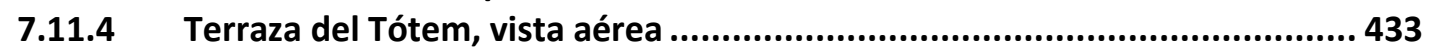

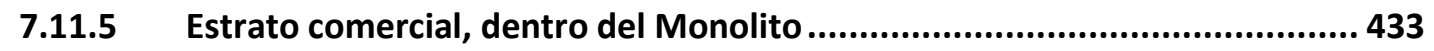

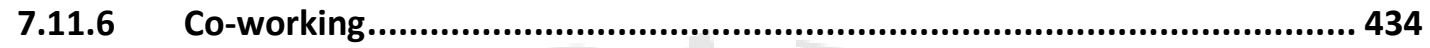

7.11.7 Terraza del Restaurante en el Monolito................................................... 434

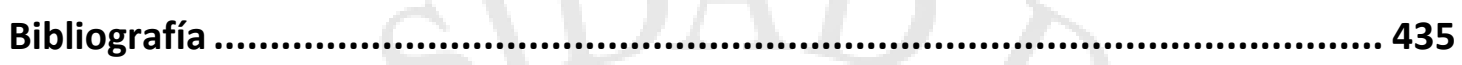

Anexos ¡Error! Marcador no definido. 


\section{CAPITULO I}

\section{Generalidades}

\subsection{Tema}

El presente trabajo busca una solución a la fragmentación urbana a través de estrategias de movilidad y la implementación de equipamiento cultural en la Estación del Metropolitano Plaza de Flores en Barranco.

Se mostrará la problemática física que una estación y su vía implican a nivel barrial y distrital; y evidenciará el potencial de una estación de transporte como lugar de encuentro e intercambio para la ciudad.

El centro cultural que acompañará a la estación ocupará un vacío urbano que actualmente genera problemáticas vecinales. La investigación explicará de qué manera, un equipamiento cultural logra incidir en la vida social de su entorno urbano. Y el proyecto mostrará cómo se puede cohesionar espacios autónomos a nivel urbano.

Un leve replanteo de la movilidad en la estación y la implementación de un equipamiento cultural pretenderá resolver la fragmentación urbana y social de la zona.

\subsection{Planteamiento del problema}

¿Es posible transformar la estación Plaza de Flores del Metropolitano con el objetivo de cohesionar espacios urbanos autónomos y minimizar problemáticas sociales mediante la implementación de un espacio público y centro cultural? 


\subsection{Justificación del tema}

El sistema de transporte de buses del Metropolitano en Lima mantiene una vía rápida exclusiva a lo largo de la vía expresa Paseo de la República que separa algunos distritos en dos partes. Esto genera espacios urbanos autónomos y de escaso intercambio, con estaciones que no aportan a su entorno físico inmediato. Sin embargo, una estación de transporte es una oportunidad de encuentro e intercambio entre ciudadanos debido al flujo y alcance que implica.

Debido a un emplazamiento que no toma en cuenta al usuario, ni a su entorno, la estación Plaza las Flores del Metropolitano en Barranco no logra amarrarse a la trama urbana ni incluirse al flujo peatonal del lugar. Por el contrario, su emplazamiento la convierte en un límite físico y esto trae consecuencias negativas en la vida social del distrito.

La estación está ubicada en el límite de tres distritos: Barranco, Miraflores y Surco. Los dos primeros, son balnearios de legado cultural y artístico; el tercero, distrito formado a partir de la división de antiguas haciendas y viñedos. Actualmente, está desconectada de los espacios importantes del entorno, como el Centro Histórico de Barranco, la Universidad de Ingeniería y Tecnología, los mercados de flores de Barranco y el Malecón. Al estar adosada a un terreno sin uso, por donde recorren vías metropolitanas que dificultan el paso peatonal, la oportunidad está en utilizar el espacio público de la estación, como punto de encuentro entre diferentes barrios y distritos.

El terreno se encuentra dentro del distrito de Barranco. Tiene como límites los distritos Surco y Miraflores. Los tres, se encuentran divididos por la vía del Metropolitano, que se convierte en una barrera para la movilidad fluida entre los ellos. Se consideran espacios autónomos y diferenciados en calidad de servicios, construcción de edificaciones y nivel socioeconómico. Además, a nivel barrial, Barranco cuenta con tres zonas. La llamada Zona 3, al este del terreno, presenta mayores denuncias en alcoholismo callejero, consumo de drogas y pandillaje. (Municipalidad de Barranco, 2015) 
Por ello, con una estación adecuadamente emplazada en el lugar, se busca solucionar la problemática social en un vacío urbano físicamente desaprovechado. El programa cultural complementario buscará ser un espacio público en el cual se den intercambios y encuentros que promuevan la rehabilitación urbana e inclusión.

Por otro lado, la implementación de un centro cultural en el vacío urbano del metropolitano atenderá a la necesidad de una oferta cultural descentralizada y pública, puesto que la oferta cultural en Barranco se encuentra casi completamente en la Zona 1 del distrito y el $96 \%$ de esta es privada. En este sentido, un nuevo centro cultural contribuirá con la unificación social de los sectores y habitantes de Barranco, Miraflores y Surco, así como, fortalecerá la vocación e identidad cultural de la zona de manera inclusiva y accesible.

\subsection{Objetivos del proyecto}

\subsubsection{Objetivo general}

Se estudiará teorías y casos relacionados al impacto social y urbano de las estaciones de transporte y centros culturales en su entorno. Se aplicará dichos conocimientos a un proyecto que cohesione espacios urbanos autónomos a través de la implementación de un centro cultural en una estación de transporte.

\subsubsection{Objetivos específicos}

2.4.2.1 Elaborar un estudio del desarrollo histórico y social de estaciones de transporte y equipamientos culturales, con el propósito de entender el contexto en el cual se propondrá juntar esos programas. 
2.4.2.2 Comprender de forma teórica y conceptual el rol de un sistema de transporte masivo rápido en buses en su entorno inmediato, así como su importancia a nivel metropolitano. También, conocer las oportunidades de los espacios públicos y centros culturales como animadores urbanos.

2.4.2.3 Elaborar un estudio del lugar, para conocer su oferta cultural y su sistema vial. Identificar los problemas sociales a nivel distrital y barrial.

2.4.2.4 Realizar un estudio de casos previos de estaciones de transporte complementadas con equipamiento cultural, su impacto en el entorno y estrategias de emplazamiento que las amarren a la trama urbana.

2.4.2.5 Replantear a nivel esquema la Estación Plaza de Flores del Metropolitano.

2.4.2.6 Proyectar un Centro Cultural y Plaza pública en un vacío urbano, priorizando al peatón.

\subsection{Supuestos básicos de investigación}

Si se transforma la estación Plaza de Flores del Metropolitano con espacio público y centro cultural, entonces, se logrará rehabilitar y cohesionar los espacios urbanos autónomos de Barranco y Surco, y reactivar el entorno económicamente.

2.6 Diseño de la investigación

La investigación será descriptiva. Se estudiará el contexto inmediato y distrital de la estación Plaza de Flores del Metropolitano en Barranco y su rol dentro del sistema de transporte de Lima. Para ello, se revisará los conceptos teóricos pertinentes al tema. Asimismo, se analizará el impacto social urbano a nivel barrial y metropolitano en casos de estaciones de transporte con equipamiento cultural. 


\subsection{Metodología}

\subsubsection{Forma de recopilación de la información}

La información será recopilada en bibliotecas y buscadores académicos. Se consultará libros, tesis académicas, artículos e información brindada por instituciones como: Municipalidad de Lima Metropolitana, Municipalidad de Barranco, Ministerio de transportes y comunicaciones, Ministerio de cultura, INEI, entre otros, para recopilar datos demográficos actuales e información sobre el estado de la infraestructura urbana.

\subsubsection{Forma de análisis de la información}

Se sintetizará y organizará la información recopilada de textos teóricos, para aplicarla al estudio del lugar y diseño del proyecto.

A través de fuentes confiables, se investigará demográfica y espacialmente el entorno del terreno elegido. Se cruzará y comparará información de diferentes indicadores, con el objetivo de llegar a conclusiones que aporten al impacto positivo del proyecto, según las necesidades halladas.

Además, se recogerán casos análogos de proyectos similares, donde exista una estación de transporte con equipamiento o espacio público. Se tendrán en cuenta relaciones programáticas, materiales, tecnología, flujos e impacto en el entorno de cada proyecto. Al finalizar, se creará un cuadro comparativo con lo más resaltante, de manera que la propuesta pueda contar con importantes referencias.

\subsubsection{Forma de presentación de la información}

La información será presentada por escrito, estructurada en capítulos y detallada en el índice. Se complementará con imágenes de apoyo y cuadros recopilados y de elaboración propia. La bibliografía y citas bibliográficas serán presentadas bajo el sistema APA. 


\subsection{Alcances y limitaciones}

\subsubsection{De la investigación}

\subsubsection{Alcances:}

- Se recopilará información demográfica de Barranco; sus deficiencias y oportunidades social urbanas.

- Se investigará los beneficios de un equipamiento cultural en una zona de conflicto barrial, así como la importancia del adecuado emplazamiento de una estación de transporte de escala metropolitana en un contexto distrital.

- Se alcanzará un nivel esquemático de estudio urbano del distrito de Barranco, y se hará énfasis en el estudio del lugar.

- Se encontrará teorías urbanísticas que soporten el supuesto básico de investigación planteado.

\subsubsection{Limitaciones:}

- Debido a la ausencia de un plano catastral actualizado por la Municipalidad de Barranco, aquel con el que se trabajará será de elaboración propia y aproximada.

\subsubsection{Del proyecto}

\subsubsection{Alcances:}

- Se diseñará a nivel de proyecto la infraestructura arquitectónica del centro cultural y su emplazamiento en relación a la estación Plaza las Flores. 
- Se trabajará a nivel esquemático la Vía Metropolitana desde su llegada a la Estación Plaza las Flores hasta la Estación Balta y su relación con la red cultural de Barranco.

\subsubsection{Limitaciones:}

- La Estación Plaza de Flores será diseñada a nivel anteproyecto, basándose en proyecto existente de la Municipalidad de Lima y la constructora Graña y Montero, de manera que converse efectivamente con el proyecto de Centro Cultural y Plaza pública.

- El ordenamiento vial se resolverá a nivel esquemático, según el Manual de Carreteras, de manera que se priorice al peatón y el terreno para espacio público.

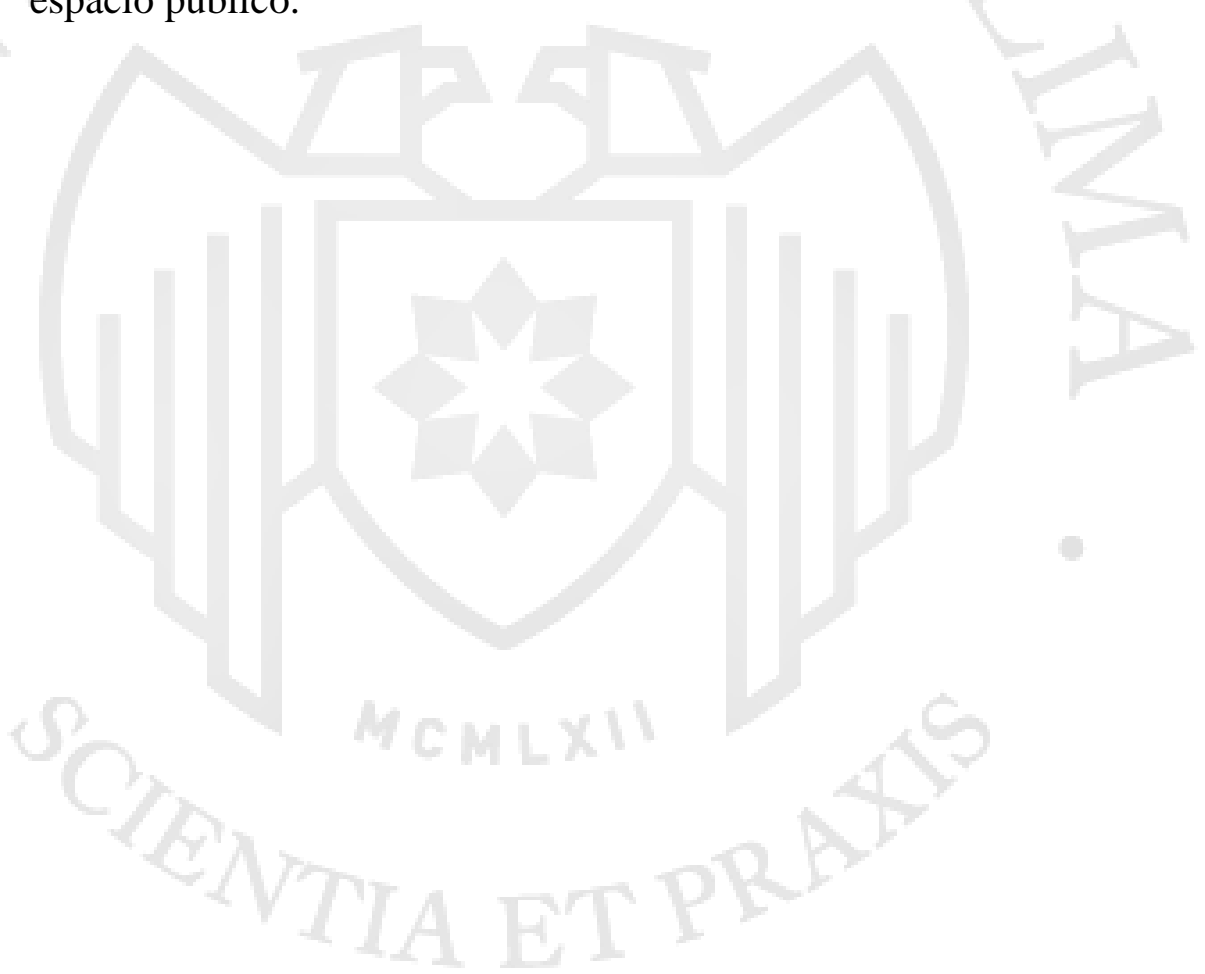




\section{CAPITULO II}

\section{Marco Referencial}

\subsection{Barranco}

\subsubsection{Formación urbana de Barranco}

\subsubsection{Periodo Prehispánico (5000 a.C - 1500 d.C)}

Durante el período prehispánico, el Valle del Rímac estaba segmentando en tres grandes señoríos: Carabayllo, Maranga y Sulco ${ }^{1}$. Este último, comprendía los actuales distritos de Surco, Surquillo, Miraflores, Barranco, Chorrillos y Pachacámac.

La etapa pre urbana del distrito inicia desde el periodo prehispánico hasta el colonial. Durante el periodo prehispánico, Barranco pertenecía al Señorío de Sulco.

Este señorío estaba conectado por una red de caminos prehispánicos conformada por dos vías principales. La primera de ellas fue el camino de norte a sur, que se posaba sobre la actual Av. Grau y conectaba el santuario de Lima con Armatambo ${ }^{2}$. Posteriormente, en la época de la colonia, lo transitaron conquistadores y viajeros para conocer las playas desde Miraflores hasta Chorrillos (Camino Real). Y la segunda vía principal, fue la del camino de este a oeste, que conectaba desde el asentamiento de la comunidad Ydcay $^{3}$ hasta la quebrada que conducía al mar, que más tarde sería el escenario de la leyenda de formación de Barranco.

\footnotetext{
${ }^{1}$ Sulco: Hoy se escribe y pronuncia Surco.

${ }^{2}$ Armatambo: El principal de los cuatro Ayllus que componían el Señorío de Sulco, Actualmente en Chorrillos.

${ }^{3}$ Ydcay: Comunidad de la en la zona oeste del Señorío de Sulco. Actualmente es el pueblo de Surco. (Toro, 2015)
} 


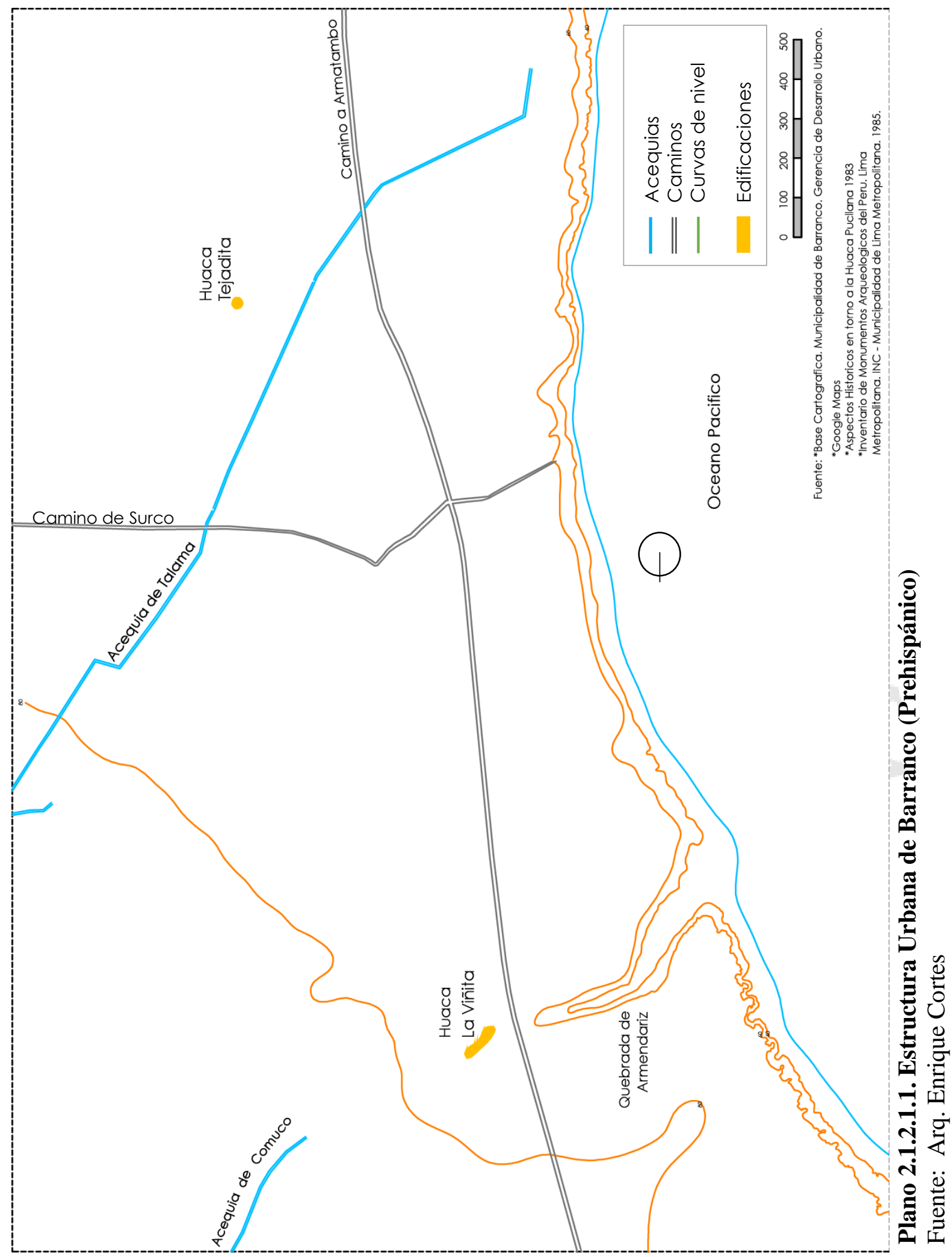




\subsubsection{Periodo Colonial $(1500-1800)$}

La llegada de la corona española a el señorío de Sulco se dio en febrero de 1533, cuando la vida tranquila y metódica de los habitantes indígenas de la zona fue interrumpida por un grupo de quince jinetes que usaban armaduras de hierro y estaban armados con lanzas. Los nativos no conocían estos materiales, animales ni comportamientos, por lo que fueron inmediatamente sometidos. (Tord, 2015)

Posteriormente, Francisco Pizarro fundó la Ciudad de Reyes el 18 de enero de 1535. Con la consolidación del nuevo centro de poder español en Lima, se da inicio a las reducciones: un proceso de evangelización a través del cual se forzaba a la mano de obra para la construcción de la ciudad, además del cobro de tributos, como lo explica Ossio en su libro Los indios del Perú, de 1995.

El señorío de Sulco se puso en manos del curaca $^{4}$ Francisco Tantachumbi, quien lo encomendó a la protección de Santiago Apóstol. En su mandato se traza la Plaza Mayor, se selecciona el solar para la iglesia, la casa parroquial, el cementerio, un mercado y una cárcel. De este modo se trazan las primeras calles y cordel y se distribuyen las manzanas en forma cuadrada, siguiendo los parámetros establecidos por las Leyes de Indias. (Tord, 2015)

Así, el señorío de Sulco se convirtió en Santiago de Surco, en nombre de su primer protector. Se volvió popular entre los españoles y mestizos que lo visitaban para disfrutar del clima, los frutos de sus huertos y los balnearios.

Luego del terremoto y maremoto del 28 de octubre de 1746, se perdieron la mayoría de sus construcciones, a excepción de la Iglesia de la Plaza Mayor, que aún se mantiene bajo el nombre de Iglesia de Santiago Apóstol.

Ante las pérdidas causadas por los desastres naturales en Santiago de Surco, la zona que actualmente es Barranco comenzó a tomar forma e identidad independiente. Se volvió popular como una zona dedicada a la pesca y al cultivo de pacaes.

\footnotetext{
${ }^{4}$ En el imperio incaico, jefe o gobernador de un ayllu o pueblo. (Oxford Dictionaries)
} 


\subsection{Primera etapa de desarrollo urbano}

Durante la colonia, Barranco comienza a tomar importancia, con la presencia de cuatro pacayales o fincas en que se cultivaban pacaes. "Estas propiedades han pasado a la posteridad con el nombre o títulos nobiliarios de sus propietarios: Pacayar de la Condesa; Pacayar del Premio Real; Pacayar de San Antonio y Pacayar de Larrión.” (Toro, 2015, p. 32)

Ante el crecimiento de la población local, a consecuencia de la popularidad de la zona, se comienza a generar un crecimiento urbano lineal sobre el Camino de Surco, especialmente en su cruce con el Camino Real.

La construcción de la Iglesia de la Hermita también fomenta el asentamiento de la población cerca al barranco y a la bajada existente; dándole el nombre actual al distrito.

Por otro lado, la construcción del tercer ferrocarril del Perú en 1858 sobre parte del camino norte - sur (Camino Real) para unir Lima con Chorrillos ${ }^{5}$. Este último fue el balneario de las altas clases sociales, y el ferrocarril unía el centro de Lima a la costa, con paradas en Miraflores y Barranco. Sirvió como potenciador a la formación urbana de Barranco, al ser la primera construcción vial formal en atravesar la zona. Sin embargo, con la vía se genera la primera división física entre la zona oeste, que ocupaba los importantes pacayares y la zona este, en la que había grandes haciendas.

Hacia el 1870 se comienza a lotizar, en un sentido alargado organizado alrededor de la Plaza Bolívar. El crecimiento urbano se acomoda a la forma topográfica del lugar y sus vías. Asimismo, se aprovecha la accesibilidad de la apertura de la bajada de baños para generar una mejor conexión entre la nueva urbanización y el océano. (Tord, 2015)

\footnotetext{
${ }^{5}$ Actualmente, la Av. Bolognesi sustituye el ferrocarril Lima Chorrillos.
} 


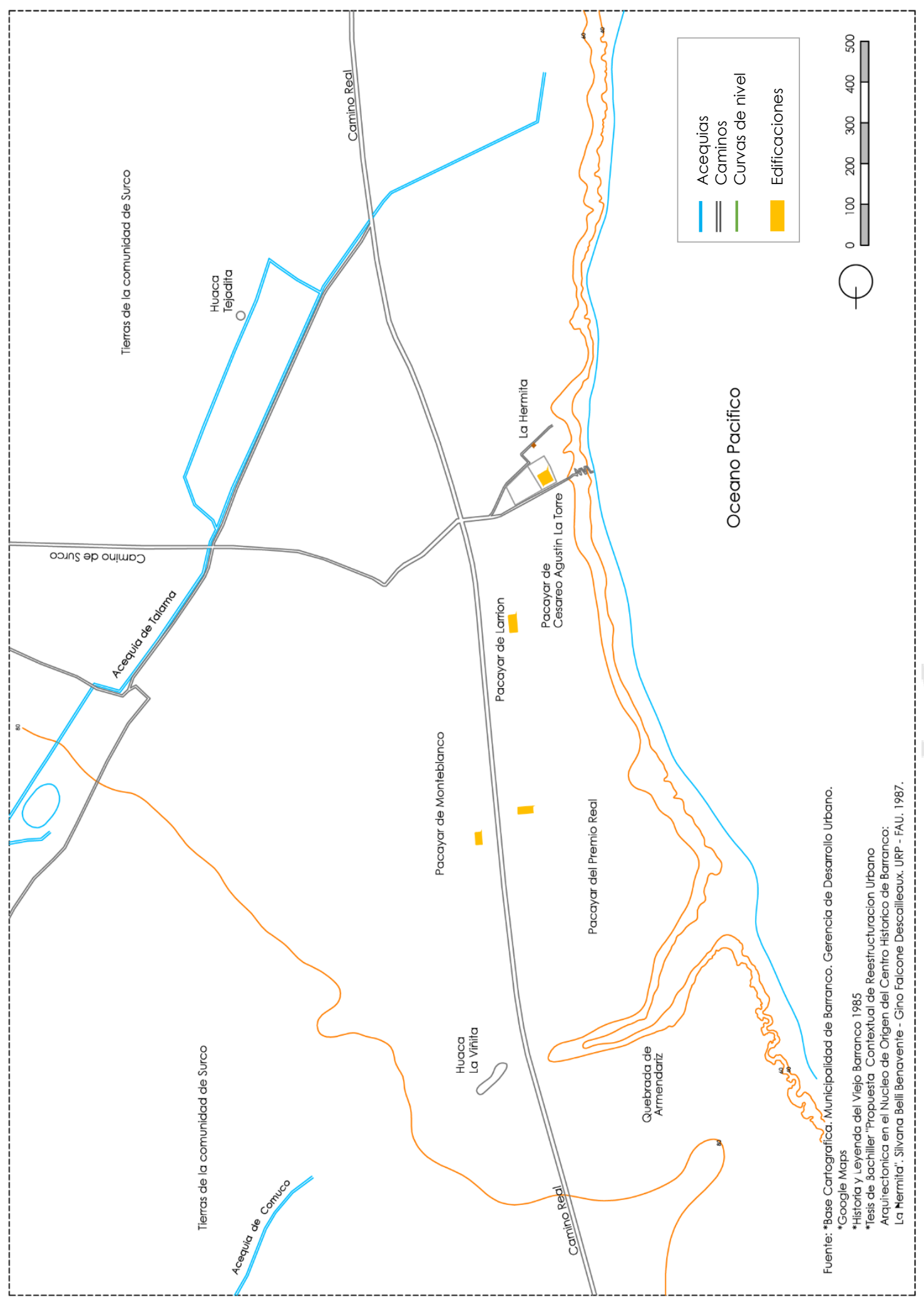

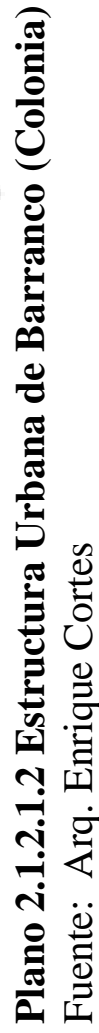




\subsection{Leyenda de la formación de Barranco}

A la población que vivía ubicada cerca al barranco de Surco, se le comienza a llamar 'Ermita de Barranco' debido a la leyenda que explica su formación.

Emprendieron su marcha siguiendo la luz y estando cerca desapareció, examinando el lugar de donde salió encontraron la imagen de un crucifijo pintada sobre el mismo barranco. Este acontecimiento movió la piedad de los fieles, se encomendaron a dicha imagen y se verificaron algunos milagros, no se sabe cuáles eran y solo se da cuenta de la sanidad de la esposa de un panadero del Carmen, nombrado Caicedo, el cual fabricó la Capilla sin que se sepa con qué finalidades se hizo, dejándola concluida con su sacristía y una pieza contigua a ella. (De la Fuente Chávez, 1908)

\subsubsection{Barranco en la República}

El distrito de Barranco, luego de incorporarse brevemente a la Provincia Litoral de El Callao, vuelve a ser parte de Lima en 1839. El distrito toma importancia debido a su crecimiento demográfico y la construcción del Ferrocarril de Lima - Chorrillos que atraviesa Barranco en 1858 durante el gobierno de Ramón Castilla. En 1874 el presidente Manuel Prado y Lavalle formalizó la creación del nuevo Distrito de Barranco. (Toro, 2015)

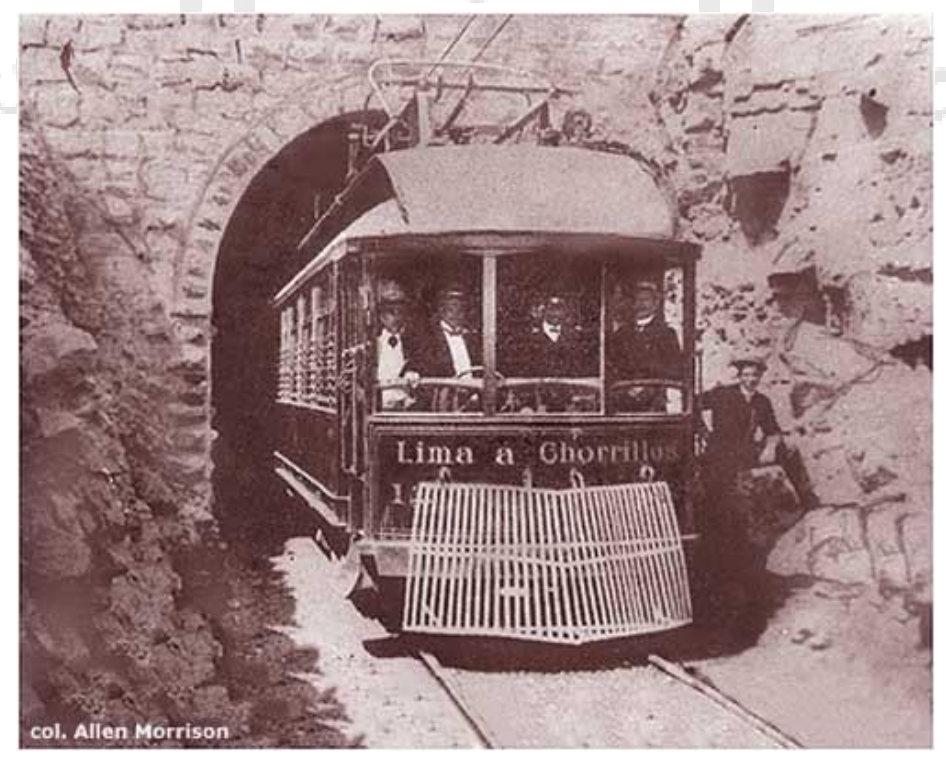

Imagen: Tren Lima-Chorrillos en el túnel de La Herradura (Allen Morrison) 
<smiles>C1=C[Si][Si]=C1</smiles> 


\subsection{Segunda etapa de desarrollo urbano}

La arquitectura de Barranco cambiado acorde al período del distrito. Ha sido primero, área rural; luego, exclusivamente balneario; y, finalmente, una adhesión distrital a la ciudad de Lima. A continuación, hablaremos de estas últimas etapas.

Actualmente, el distrito es una muestra de arquitectura limeña de diversos movimientos, épocas y usos. Las primeras construcciones, fueron meramente casas rurales construidas sobre los campos de pacaes. Las siguientes, cuando Barranco estaba aún unido a Santiago de Surco, son consideradas las primeras expresiones propiamente urbanas': los ranchos, el Puente de Los Suspiros (1876), la Bajada a los Baños y sus instalaciones, la línea del tren rumbo de Chorrillos, etc. (Tord, 2015)

Después de la construcción del Ferrocarril Lima Chorrillos y la implementación de una estación en su cruce con el Camino de Surco, se generaron caminos que comunicaron ese cruce con la bajada de los baños y el acantilado. Así mismo, surgió la necesidad de conectar los dos lados de la quebrada y se construyó el Puente de los Suspiros en 1876.

Posteriormente al saqueo e incendio de $1881^{6}$, y hasta el terremoto de 1940 , Barranco se consolida como un balneario, como Miraflores y Chorrillos. Aunque el uso predominante de las residencias era permanente, muchas de ellas fueron construidas con el concepto de 'casa de playa' temporal.

El crecimiento urbano continúa centrándose en el cruce de los ejes principales y se comienzan a desarrollar caminos irregulares en ese entorno. A lo largo del eje del Camino Surco, surgen los Caminos Domeyer, Unión, Salaverry y Roosevelt.

Durante el gobierno del alcalde Pedro Solari (1895-1899), se percibe el cambio de rural a urbano con mayor intensidad. Los terrenos que unían la Escuela Militar

${ }^{6}$ Con solo siete años de fundado, Barranco fue escenario de un saqueo e incendio provocado por las tropas chilenas durante la Guerra del Pacífico. También sufrieron Chorrillos y Miraflores. 
desde Chorrillos hasta Barranco fueron cedidos para construir las avenidas del norte y del sur; se intensifica la construcción de ranchos en viviendas rurales; la empresa de agua construye nuevas instalaciones de agua y desagüe; y, principalmente, la empresa del gas aumentó el número de faroles de alumbrado público.

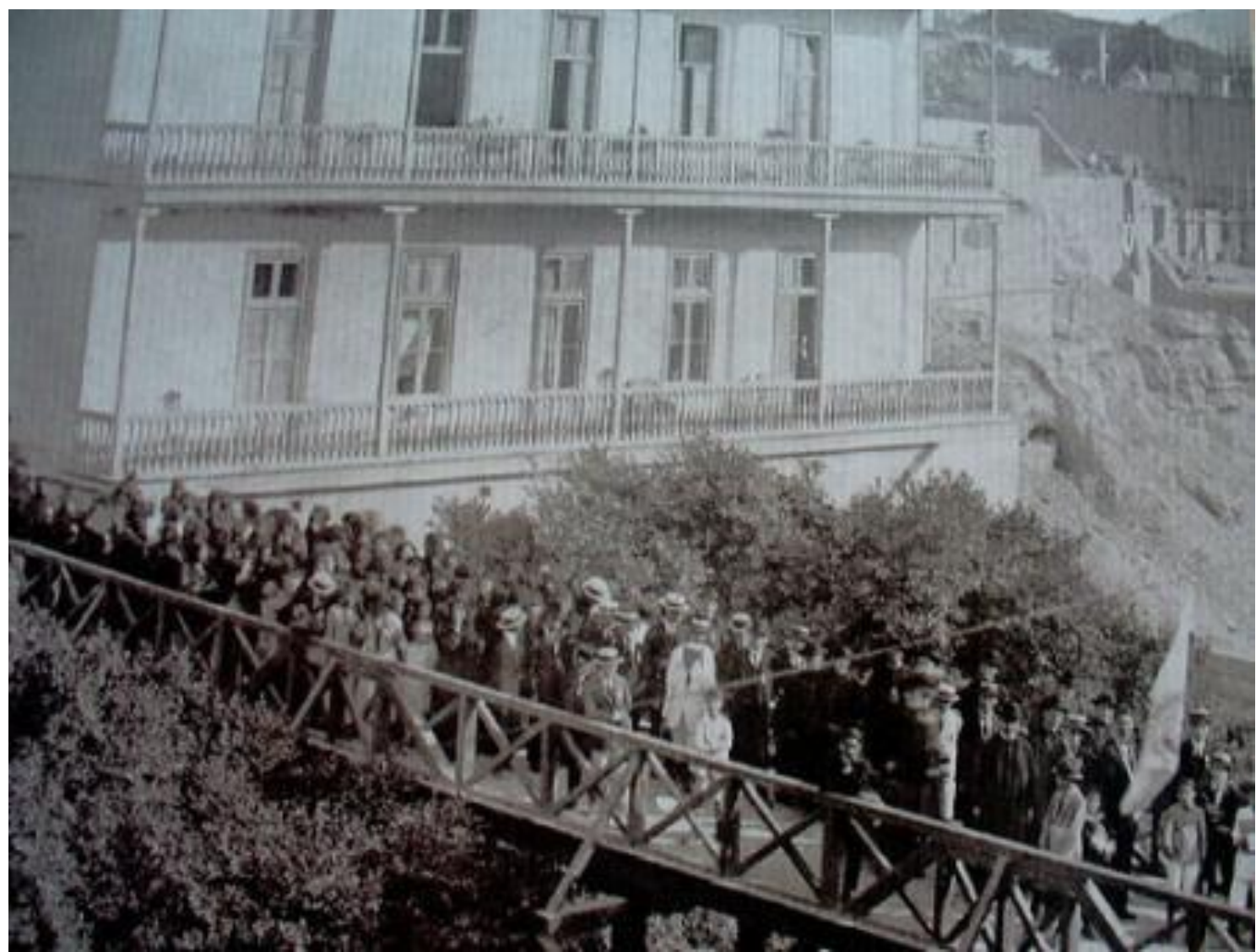

Imagen: Puente de los suspiros, finales del siglo XIX. (Blog de Marco Gamarra Galindo)

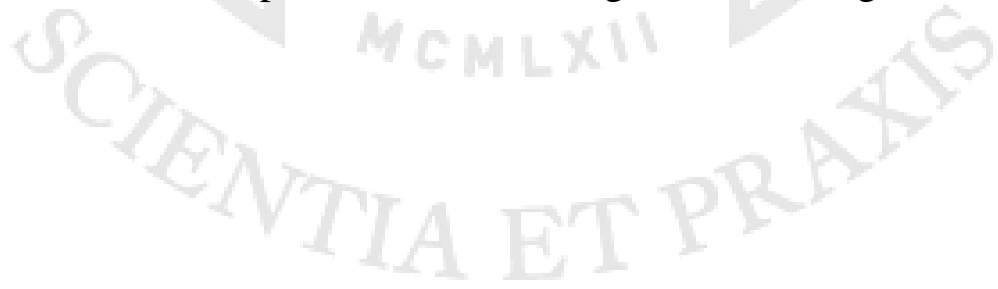




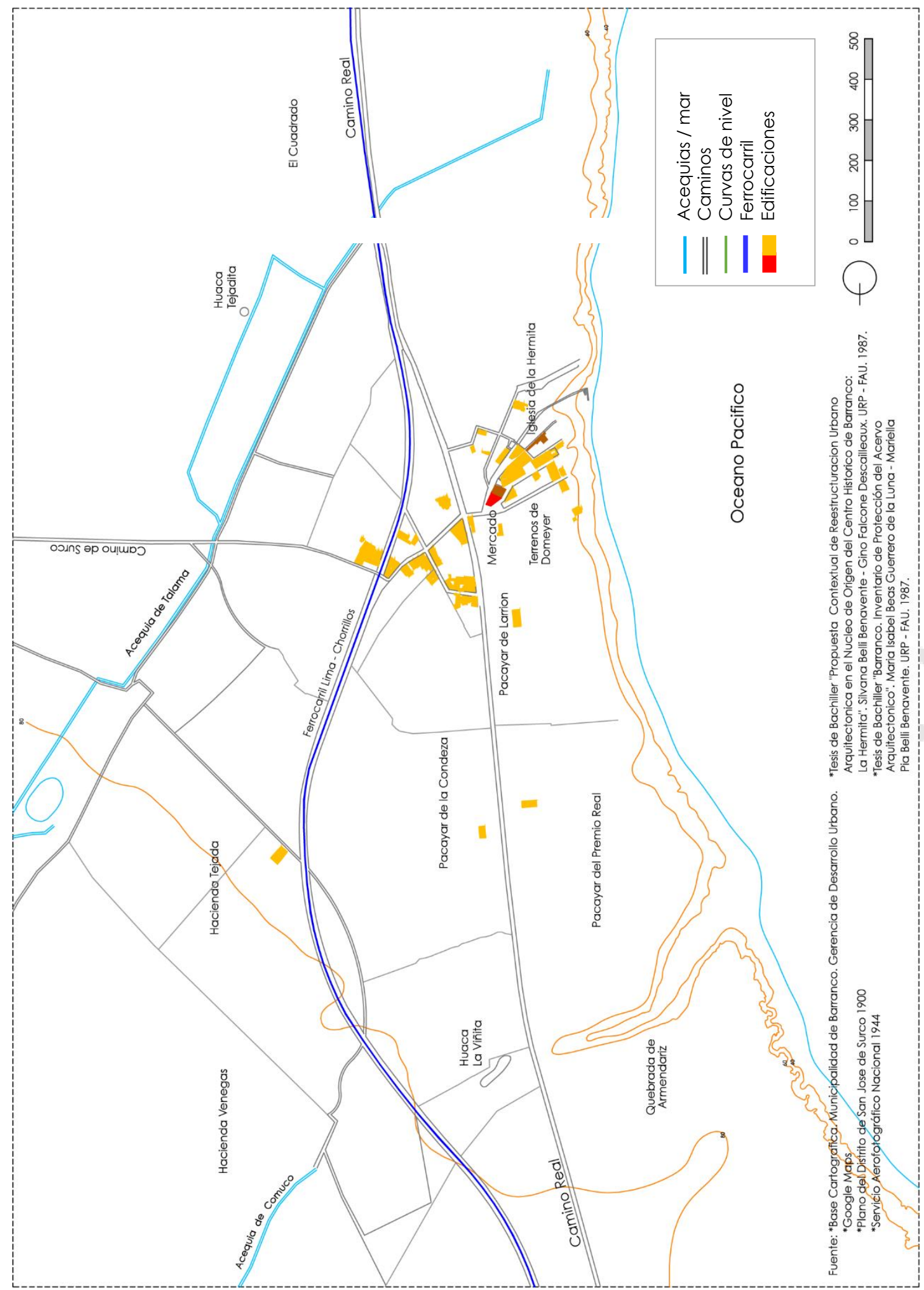

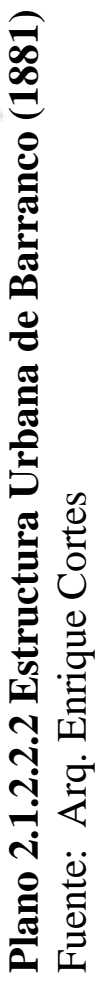


Tercera etapa de desarrollo urbano

En 1900, luego de la construcción del Parque Municipal y el Palacio Municipal, "se genera un nuevo nodo central que entra en competencia con el antiguo núcleo de la plaza Bolívar y la Ermita” (Cortes, 2013).

Con el alcalde Pedro Heroaud (1901-1904), se mejora el servicio de la electricidad; se dio gran importancia a la educación, imponiendo multas a los padres que no enviaran a sus hijos a la escuela, adquiriendo nuevo material, y mantuvieron la implementación de clases nocturnas.

Durante el periodo de 1906 a 1912, Aurelio Sousa da prioridad a la estética del distrito. Con él, se construyen fuentes en las plazas y se adhiere el reloj a la Biblioteca Municipal, actualmente símbolo importante del-distrito. En general, Sousa pone en valor las vías con losetas finas y caminos de piedra. Durante este periodo, el Paseo Sáenz Peña recibe tratamiento de pisos y paisajismo, marcando el inicio del desarrollo del sector norte del balneario (Tord, 2015). Con esto, abren nuevos malecones, se construyen residencias de nivel alto y se anexan calles aledañas.

Asimismo, Sousa ordena la ciudad con tres arterias principales: Bolognesi, Grau y Lima. También ordena las manzanas con numeración decenar o centenar. Prácticamente, la ciudad se ordena según las vías, principalmente la actual Bolognesi, donde recorría el tranvía Lima-Chorrillos-Lima.

Durante esta etapa, se da inicio la movida cultural y social de Barranco que conocemos hoy. 


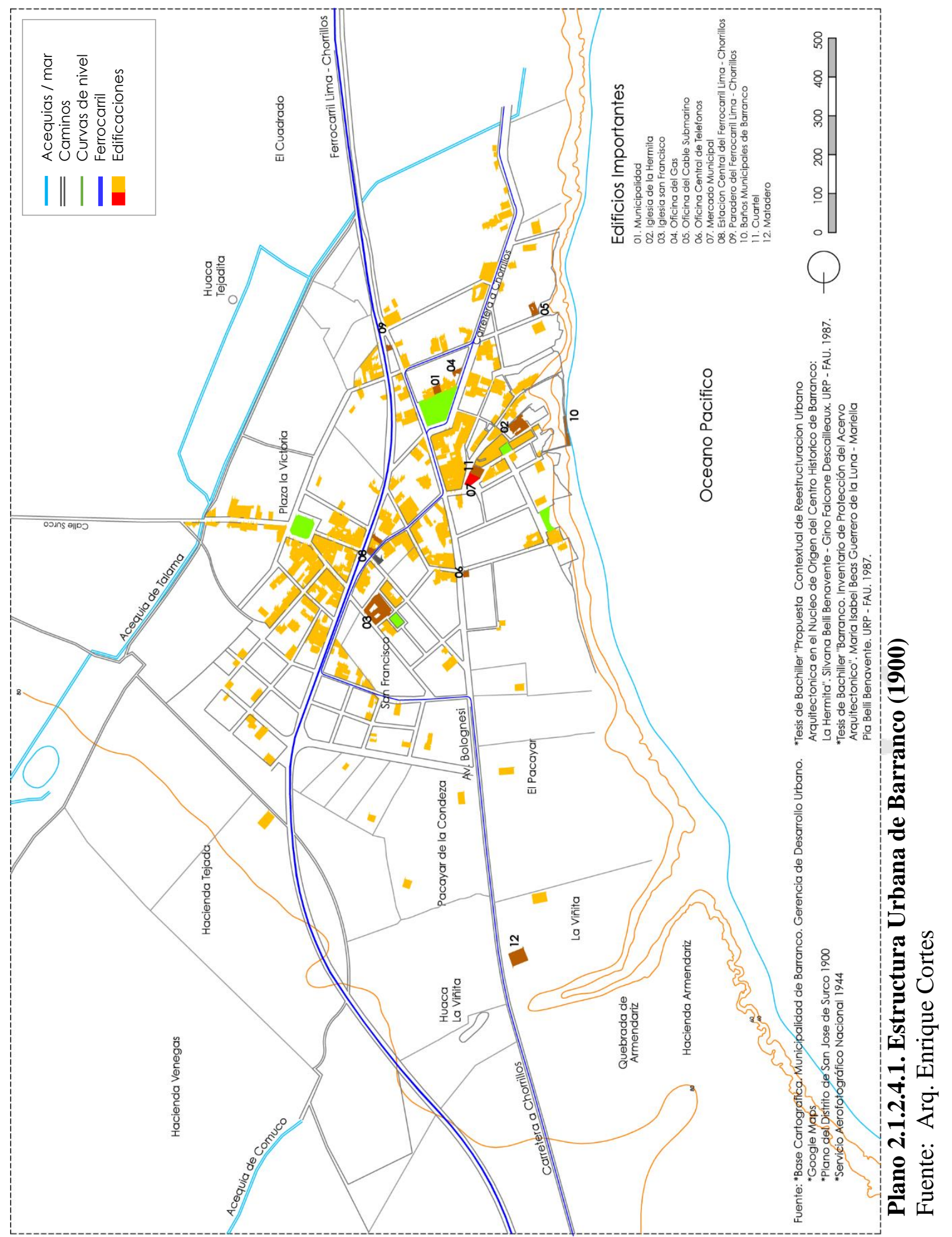


Entre 1910 y 1920, se levantan las casonas de la tercera etapa arquitectónica de Barranco $^{7}$ : las villas. Estas casonas muestran el trabajo de arquitectos formados bajo conceptos de estilo victoriano, afrancesado, de sajones y vascos. Incluso, algunas edificaciones toman la dimensión y forma de palacetes de diseño neocolonial, art-decó y neoclásico. Este desarrollo ocurre en paralelo a la expansión del distrito hacia el recién inaugurado paseo Saenz Peña y la avenida San Martín donde, hasta el día de hoy, podemos apreciar características edificaciones barranquinas.

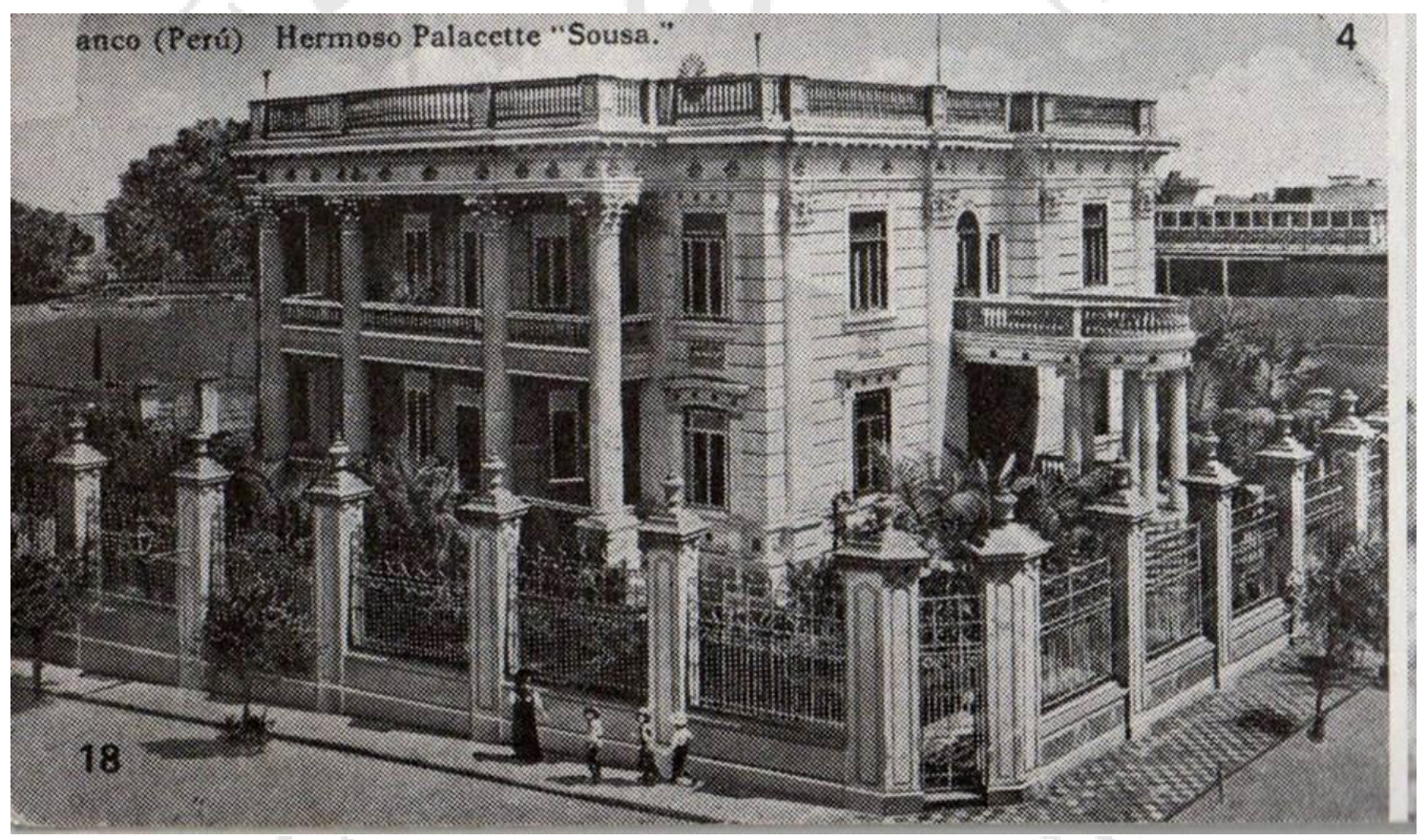

Imagen: Palacete Sousa (fuente no identificada)

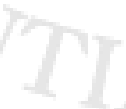

Con Pedro Martinto, de 1927 a 1930, y coincidente con el oncenio de Leguía, el distrito consolida su prestigio de balneario de Lima con los Baños Municipales, sus malecones, parques y jardines. A partir de la década del '30 y el terremoto del '40, la destrucción llevó al uso más frecuente de nuevos sistemas de construcción, ladrillo y concreto armado (Tord, 2015).

${ }^{7}$ La primera etapa se refiere a los ranchos: edificaciones de adobe, quincha, barro y fierro. Eran de habitaciones sencillas y temporales de balneario. En la segunda etapa, evolucionan los ranchos a casonas de planta en forma de $\mathrm{U}$, con elementos decorativos de yeso en vez de madera. 
Entre 1930 y 1940, se crean nuevas urbanizaciones al noreste del distrito con villas y ranchos más sencillos. Asimismo, hay un crecimiento de casonas con espacios de comercio, residencias multifamiliares y quintas ${ }^{8}$.

El territorio sigue ocupándose cerca de las vías principales que hasta hoy lo mantienen segmentado. Asimismo, el distrito se continúa equipando de nuevos espacios públicos y equipamientos urbanos importantes, como colegios e iglesias. Se lotiza el pacayar La Condesa y las parcelas que la rodean, al igual que la hacienda Tejeda. Esto extiende la ocupación del distrito hacia el norte y este.

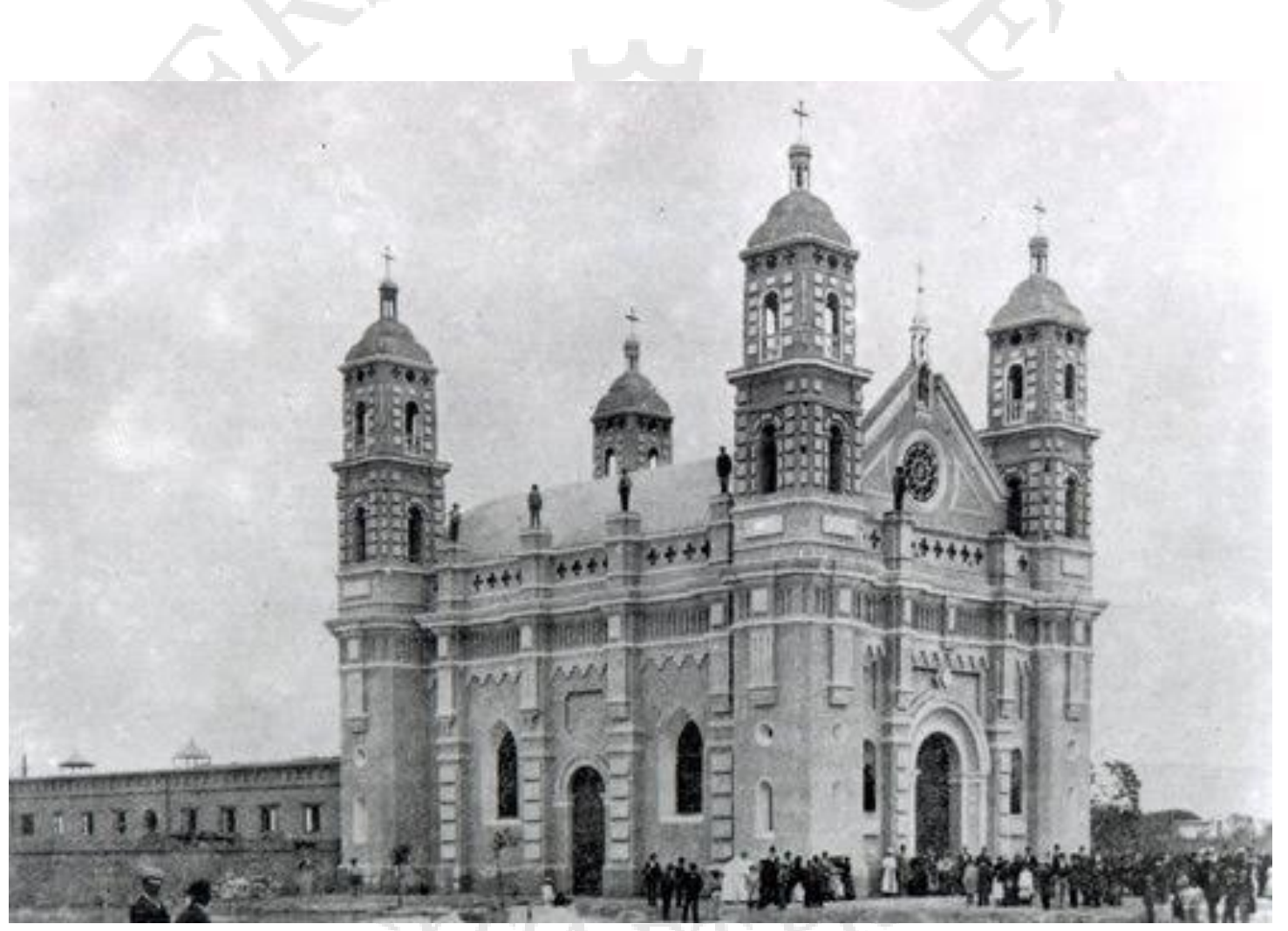

Imagen: Iglesia San Francisco, inicios del siglo XX (Blog San Francisco en Barranco)

${ }^{8}$ Conjunto de viviendas que se comunican con la calle a través de un pasaje común. Edificaciones comunes en otros distritos limeños desde épocas anteriores. 


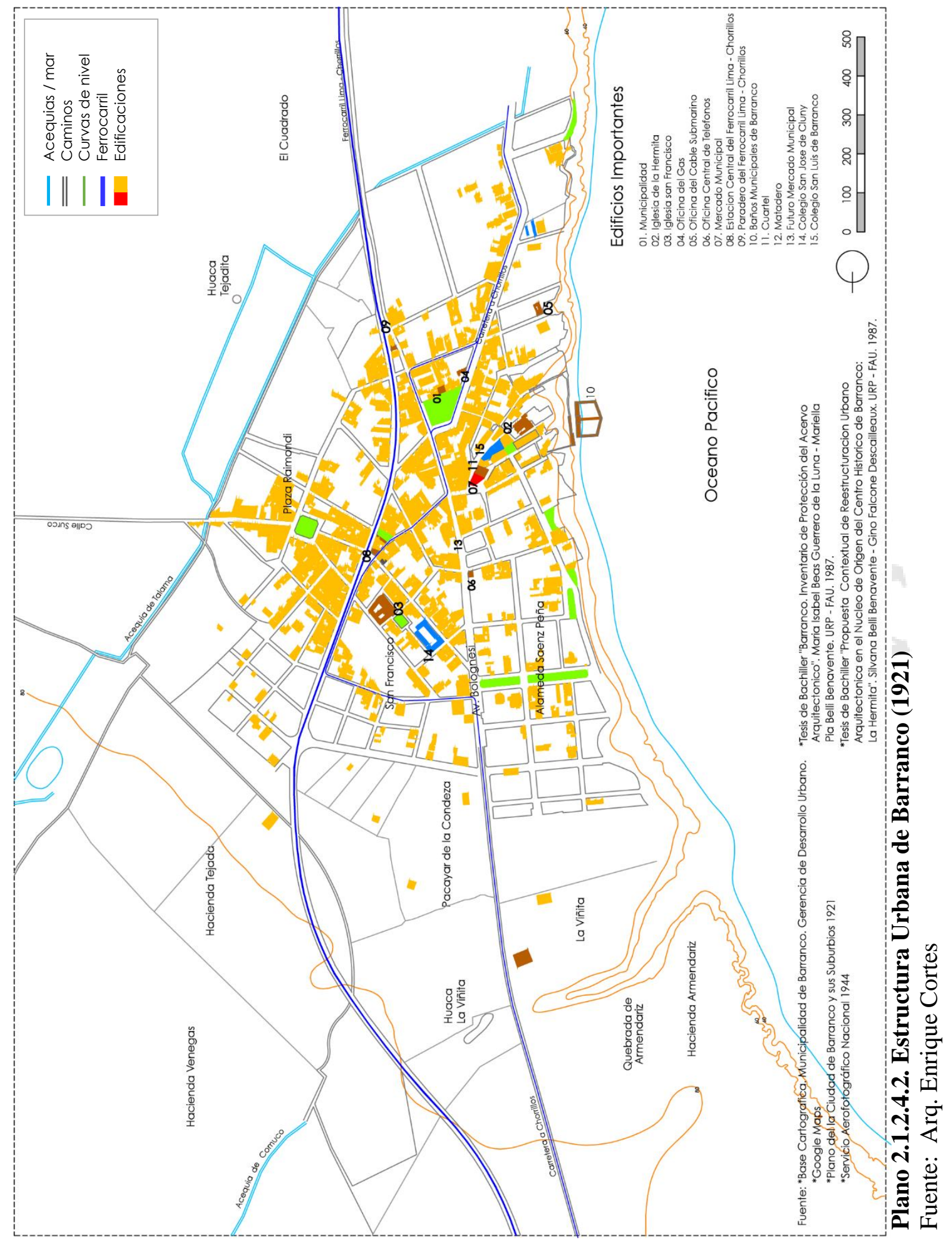


Luego del terremoto de 1940, Barranco, ya incorporado a la capital, comenzó a cambiar la cuadrícula urbana y arquitectura debido a varios factores. El principal fue el espontáneo crecimiento de la población. Otros factores fueron referentes a la topografía del distrito y las residencias modernas se acomodaban al terreno costero. Por este crecimiento no previsto, en el distrito se observan cuadrículas de diferente dimensión y forma. Actualmente, hallamos las manzanas en cuadrícula, las de forma octogonal tendiendo a cuadrícula, y las irregulares poligonales (Tord, 2015).

En esta etapa, gran parte del territorio del distrito era parte de la urbanización; solo quedaron algunas zonas agrícolas libres en los limites periféricos.

"La estructura urbana se había modificado, pasando de un sistema lineal este - oeste a una configuración casi alargada en sentido norte - sur, con las avenidas Grau y Bolognesi (antiguo ferrocarril Lima Chorrillos) como ejes ordenadores del espacio, y un eje secundario que es la Avenida Pedro de Osma en el lado sur" (Cortes, 2013).

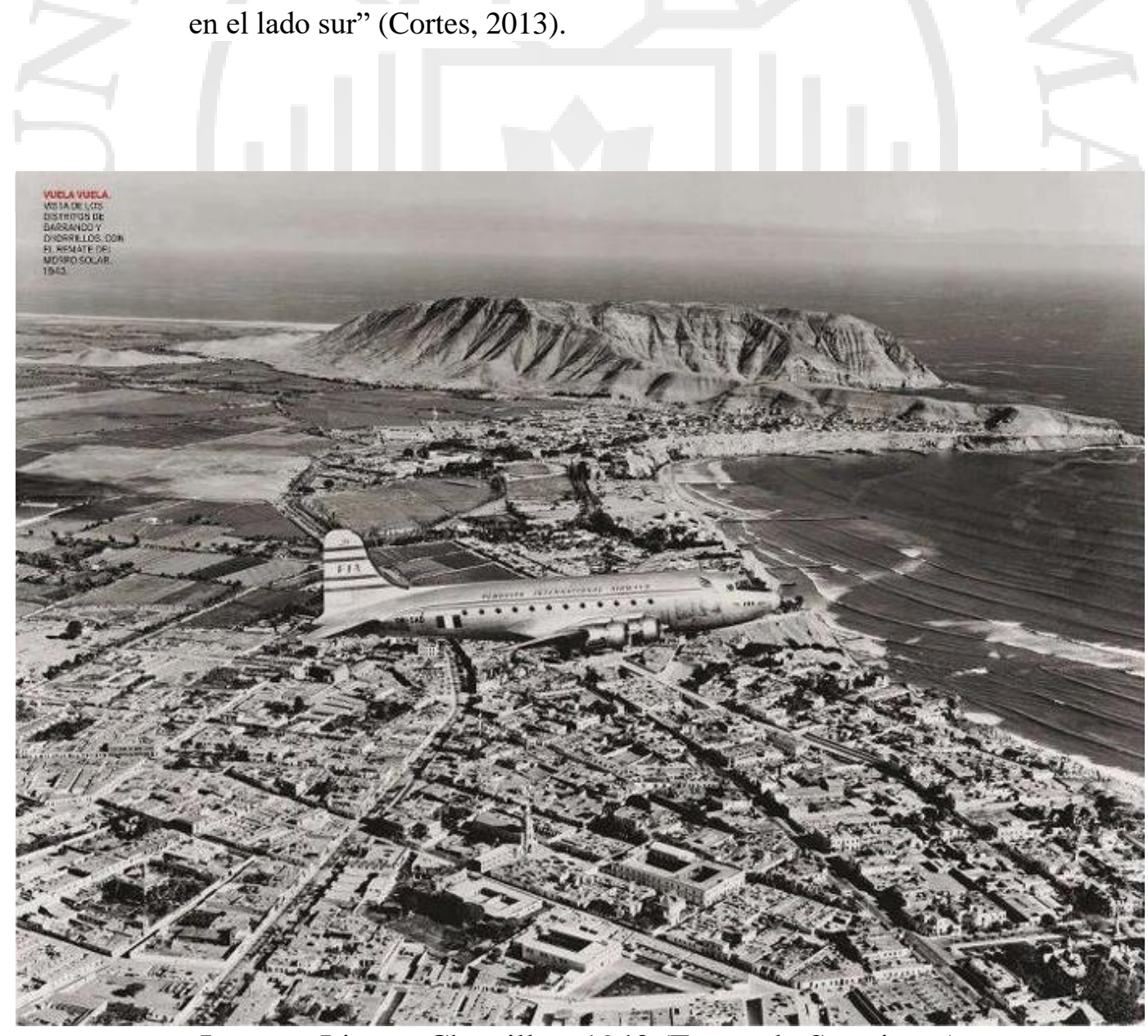

Imagen: Lima y Chorrillos, 1943 (Fernando Sarmiento) 


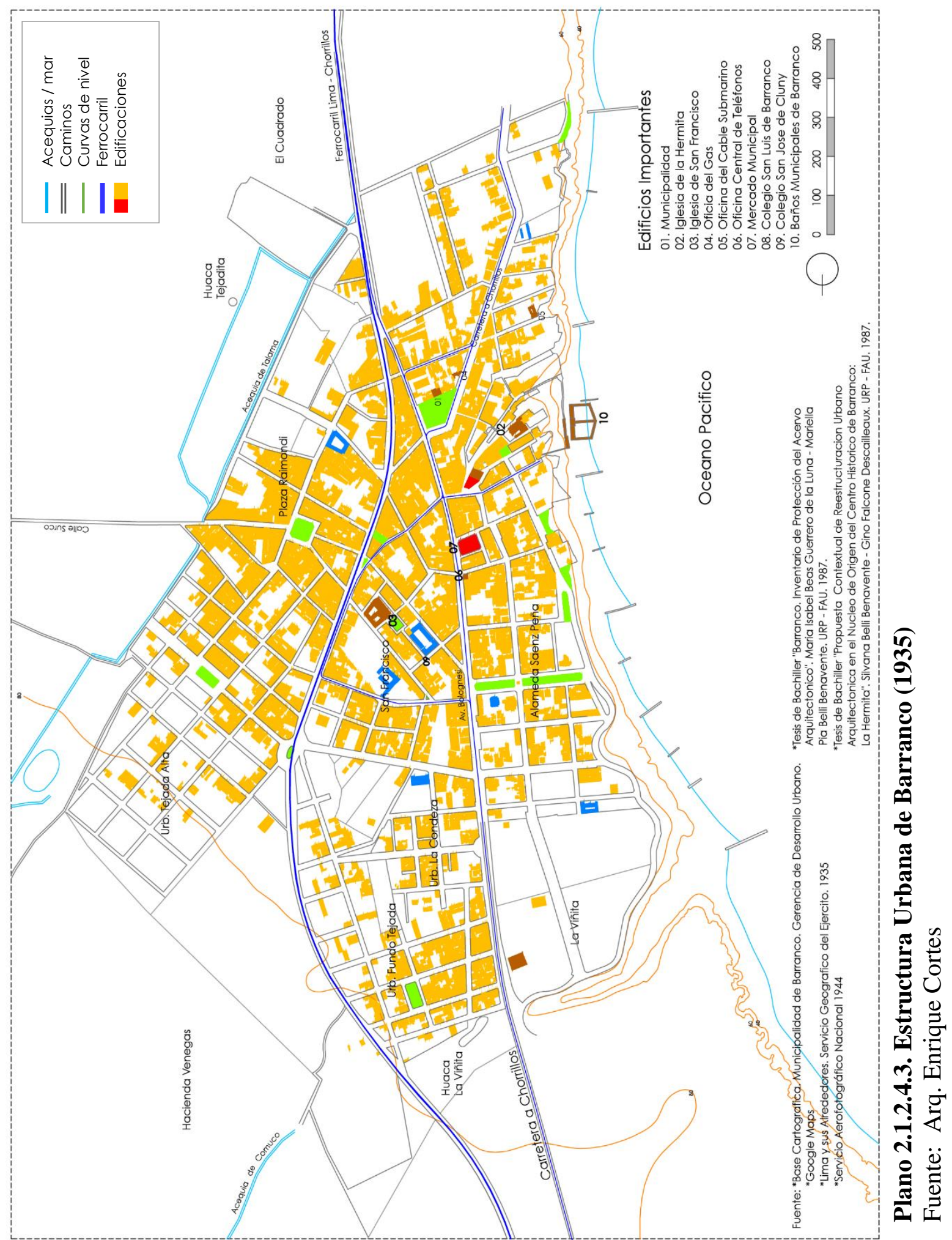




\subsection{Cuarta etapa de desarrollo urbano}

A nivel macro, luego de la construcción de la vía expresa Paseo de la República en la década del 60, el distrito terminó de expandirse hacia sus extremos y se consolidó como una zona urbana. La vía expresa termina su recorrido al llegar a la Av. República de Panamá. Se ocupó informalmente ese espacio con un mercado de flores. Sin embargo, fue desalojado para la construcción de la estación Plaza las Flores del Metropolitano.

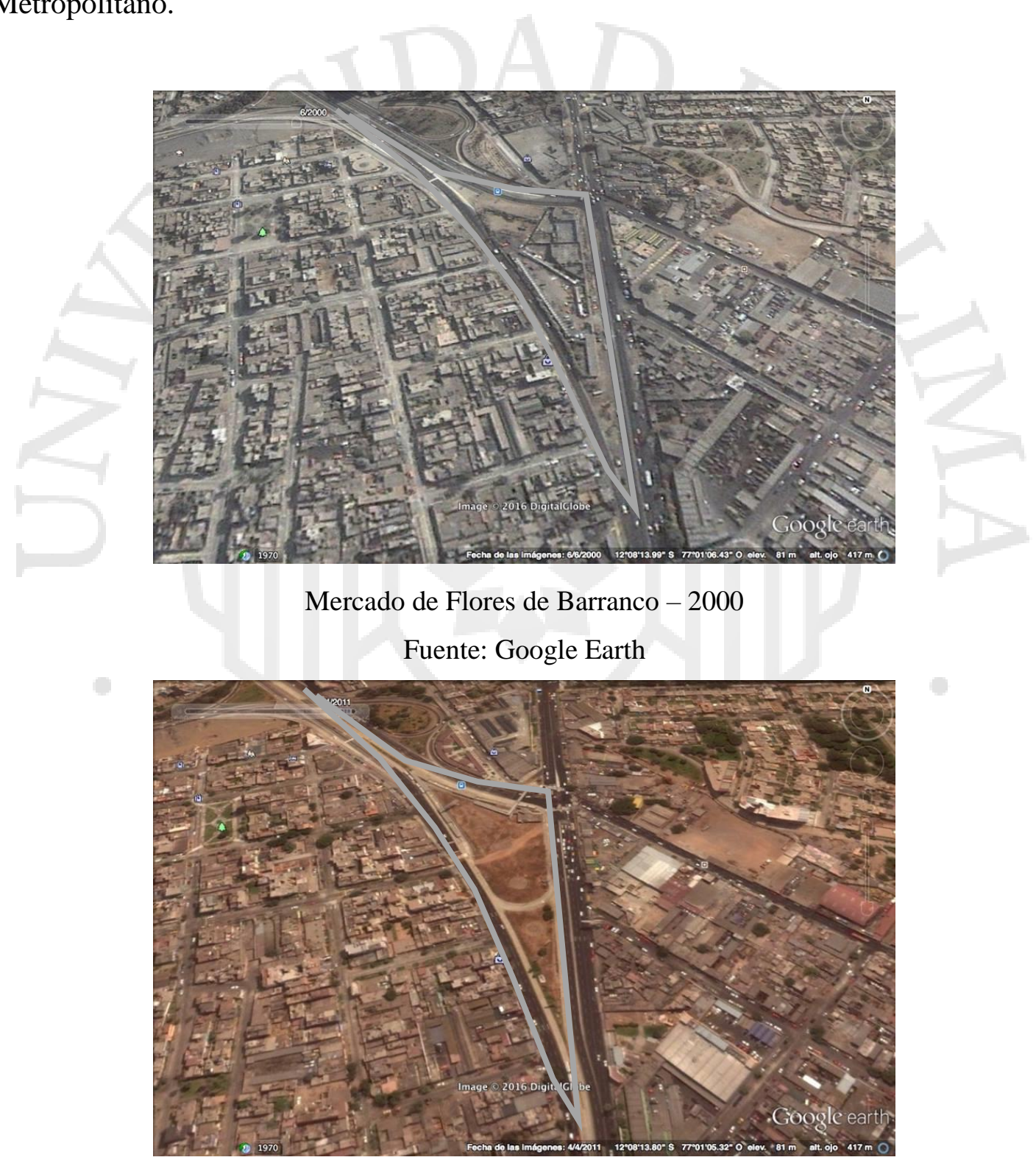

Vacío urbano Generado por el Metropolitano - 2016

Fuente: Google Earth 
En la actualidad, los caminos que iniciaron el desarrollo urbano del distrito se mantienen como los ejes principales. Son estos los que sirven para segmentar Barranco formalmente. Esta división se observa en la zonificación oficial del distrito, desarrollada por la Municipalidad de Barranco, donde se perciben tres zonas (ver plano 2.1.2.5.1).

La Zona 1 se encuentra hacia el oeste y abarca desde el acantilado hasta la Av. Grau. Esta zona cuenta con la mayor cantidad de monumentos históricos del distrito. Es una zona residencial en la que se ubican las principales instituciones públicas y privadas del distrito. También es la zona de mayor atractivo turístico pues, en ella, se encuentran diversos centros de esparcimiento. Así to afirma la Municipalidad de Barranco en el Plan Distrital de Seguridad Ciudadana, realizado en el 2016.

A la Zona 2 se le conoce como la 'zona media' de Barranco, pues se encuentra en un momento de crecimiento comercial e inmobiliario. Es el territorio delimitado entre la Av. Grau, la Av. República de Panamá y la Av. Bolognesi.

Finalmente, la Zona 3, se encuentra delimitada por las avenidas República de Panamá y Bolognesi, y por el límite de Barranco con Surco y Chorrillos. "Su proceso de ocupación ha sido producto del remanente de la zona agrícola de Surco, siendo en promedio de un estrato socio económico menor que el del resto del distrito." (Municipalidad de Barranco, 2015)

A nivel arquitectónico y micro, los terremotos de 1970 y 1974 vuelven a chocar Barranco con la destrucción de los ranchos antiguos. Así, el distrito aprovecha para levantar edificaciones y residencias modernas. Los Baños Municipales y algunos espacios tradicionales fueron cerrados. Sin embargo, "la tradición intelectual de Barranco no solo se ha preservado, sino que ha crecido con la instalación de museos, galerías de arte, centros culturales, la multiplicación de actividades artísticas y la delimitación definitiva de la zona monumental” (Tord, 2015). 


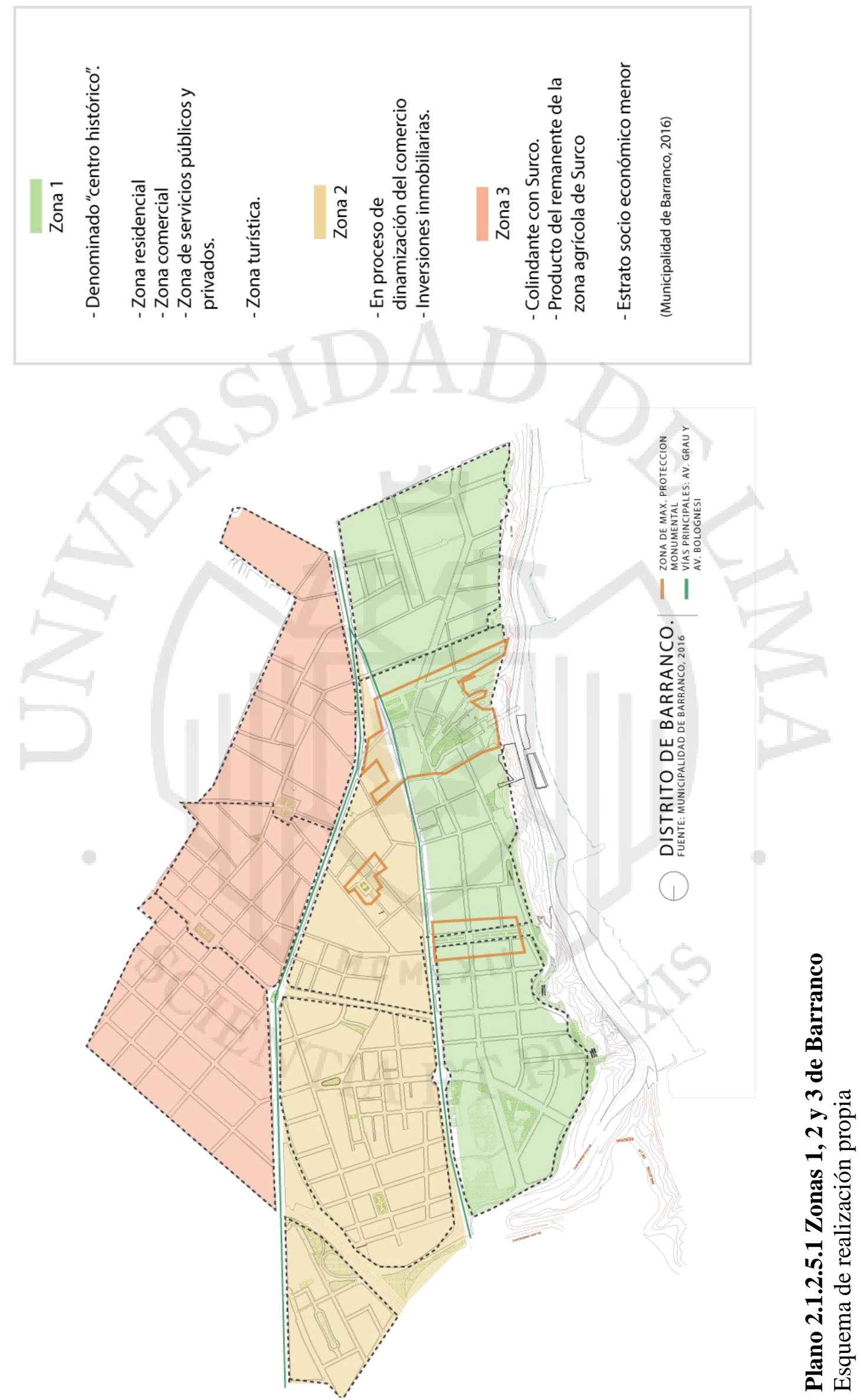




\subsubsection{Desarrollo sociocultural de Barranco}

Barranco y sus alrededores están, hoy, culturalmente ligados a su desarrollo urbano en el pasado. Desde el periodo prehispánico hasta el colonial, el Señorío de Sulco comprendía los distritos de Surco, Surquillo, Miraflores, Barranco, Chorrillos y Pachacamac. A la llegada de la corona española en febrero de 1533, los habitantes indígenas quedaron bajo su control. Con la implementación de la colonia española en Lima, se les evangeliza religiosamente y somete a trabajos forzados.

El Señorío de Sulco se convirtió en Santiago de Surco y los españoles y mestizos visitaban el lugar para disfrutar del clima, los frutos de sus huertos y los balnearios. Durante la colonia, el distrito comienza a tomar importancia y se construyen viviendas donde existían grandes campos agrícolas. Ante el crecimiento de la población local, a consecuencia de la popularidad de la zona, se comienza a generar un crecimiento urbano lineal sobre el Camino de Surco, especialmente en su cruce con el Camino Real. A su vez, se divide la zona Este de Oeste.

Es así que, luego de la construcción del tercer ferrocarril, se conecta al resto de Lima con los balnearios. Sin embargo, con la vía se genera la primera división física entre la zona oeste, que ocupaba los importantes pacayares y la zona este, en la que había grandes haciendas.

Con el paso de los años y la llegada de la república, al este se mantienen los lotes determinados para los trabajadores de las fincas, y al oeste, se construyen casas para los patrones y adinerados. Esta disposición se debió a la ubicación del mar y a la relación de los limeños con los balnearios, considerados exclusivos de altas clases sociales.

Posteriormente al saqueo e incendio de $1881^{9}$, y hasta el terremoto de 1940, Barranco se consolida como un balneario, como Miraflores y Chorrillos. Aunque el uso

\footnotetext{
${ }^{9}$ Con solo siete años de fundado, Barranco fue escenario de un saqueo e incendio provocado por las tropas chilenas durante la Guerra del Pacífico. También sufrieron Chorrillos y Miraflores.
} 
predominante de las residencias era permanente, muchas de ellas fueron construidas con el concepto de 'casa de playa' temporal.

Durante esta etapa, se da inicio la movida cultural y social de Barranco que conocemos hoy.

El desarrollo urbano de Barranco ha estado directamente ligado su carácter literario y cultural desde el inicio de la república. A través del libro de Luis Enrique Tord, 'Barranco: historia, leyenda y tradición', podemos hacernos una idea de cómo fue la evolución de balneario a distrito cultural.

Es durante la alcadía de Sousa que se proponen los eventos culturales como tal. Al ver los bailes de máscaras en Madrid y Chachapoyas, intenta instaurar dichas reuniones en las calles de Barranco. Con ello, intenta potenciar el intercambio social entre ambos sexos y diferentes razas. Lamentablemente, no llega a tener acogida, porque las señoras aún lo consideraban inaceptable.

Por la época, el distrito contaba con el pequeño teatro en el solar de la Berninson; y un escenario en el hotel del Loro de propiedad del señor Zapata. El 19 de marzo de 1910, se informa que el Cinema Teatro habia sido inaugurado, y se proyecta la primera película peruana llamada 'Negocio al agua', con actores de Lima y Barranco. A la par de la mejora de los Baños de Barranco, que se convierten en los mejores de la ciudad, los cines Cinema Teatro y Cinema Moreno compiten por las más exitosas reproducciones de películas por el año 1912. Esto llama la atención de profesionales extranjeros que vinieron, incluso, a dar conferencias sobre el ámbito teatral. 


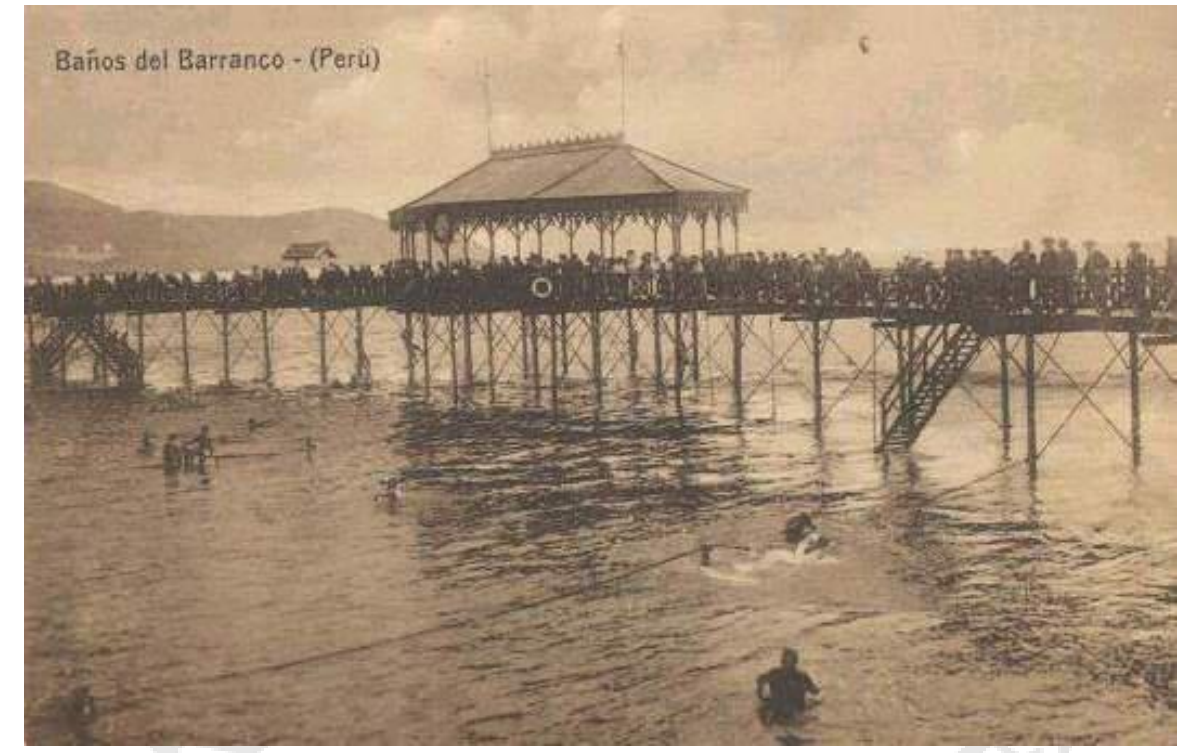

Imagen: Baños de Barranco (Municipalidad de Barranco)

Cuando se mejora el alumbrado público, los bailes de máscara y carnavales toman mayor importancia.

En la alcadía de Enrique de las Casas (1920-1927), el nuevo Cinema Barranco contrata una dinamo con motor a petróleo para iluminar el local y proyectar películas ininterrumpidamente. Al finalizar el oncenio de Leguía (1927-1930), las obras más importantes se referían a parques, malecones y espacios públicos. La vida social fuera de las residencias se ve impulsada gracias a la variedad de equipamiento cultural y al aire libre.

Algunos de estos espacios fueron los Malecones. Hoy en día, el malecón de Lima parece uno solo. Sin embargo, en el siglo XX, comienzan a construirse malecones separados y con nombre propio. Con Aurelio Sousa, del malecón Saenz Peña, se cambian antiguas barandas de madera por muros de concreto, y se construye una bajada a la playa y una glorieta con mirador. Posteriormente, se siguen cediendo terrenos de antiguos pacayares para otros malecones. El malecon de los Ingleses, fue el espacio de la costa que albergó a los primeros vecinos extranjeros.

Estos cambios arquitectónicos, urbanísticos y paisajistas, traen consigo la evolución de la vida social del distrito. Donde antes existía una residencia rural privada, ahora se realizaban encuentros los fines de semana. La estética de Barranco 
comenzó a tomar el aire de balneario con aires europeos que tiene hoy, gracias a los alcaldes visionarios que tuvo.

En 1913, finalmente se establece como evento oficial, el Carnaval de Barranco. Tras una evolución del concepto de vida social en el distrito, la Municipalidad de Barranco reparte invitaciones a una fiesta de ambiente fantástico. El propósito fue hacer que los asistentes sintieran, durante tres días seguidos, que estaban en el Carnaval de Venecia.

Por supuesto, con el pasar de los años, la moda musical variaba. Y con ella, las fiestas y sus celebraciones. Existieron los desfiles de carros alegóricos por los paseos Saenz Peña, Miguel Grau y Pedro de Osma. Incluso, se elegían reinas del carnaval. Durante el gobierno de Manuel Prado Ugarteche (1956-1962), se elimina el Carnaval de Barranco, no sin antes haber plasmado la fama de distrito fantàstico, a través de diversos medios de comunicación, fotos y murales.

\subsubsection{Barranco cultural en la actualidad}

Luego de perder algunas tradiciones, y desde hace algunas décadas, Barranco recupera parte del carácter de inicios del siglo XX. Esto se logra mediante el esfuerzo de vecinos, autoridades y entidades que promueven la preservación de monumentos, edificios y áreas históricas.

A nivel cultural, Barranco cuenta con 4 grandes museos: Museo Prado de Osma, Museo de Arte Contemporáneo (MAC), el Museo de Arte Mario Testino (MATE) y el Museo de la Electricidad.

El Museo Prado de Osma, inicia con la colección de Pedro de Osma Gildemeister, hijo del alcalde de la ciudad (1912-1914). En la residencia recibía a los interesados y conversaba de las obras, acompañado de tradicionales piscos sours (Tord, 2015). Luego de su fallecimiento, la fundación familiar continúa administrando el museo en la misma casona, construida en 1906. Actualmente, existe una galería moderna que 
sirve para conferencias y exposiciones de arte y literatura. Además, se proyecta un nuevo crecimiento que incluye hoteles, comercio y espacio público.

El MAC-Lima abre en el 2013 y surge como la alianza del Instituto de Arte Contemporáneo (IAC) y el Concejo Distrital de Barranco. Si bien la Municipalidad de Barranco se encarga económicamente de algunas edificaciones y equipos, gran parte de la colección es donación de artistas nacionales e internacionales. Además, tiene proyectos como 'Arte en tu parque' ${ }^{10}$, actividad premiada a nivel internacional.

El MATE fue fundado en el 2012 por el fotógrafo Mario Testino; y el Museo de la Electricidad, es obra de Electroperú S.A. desde 1997. Este último, cuenta con la instalación de un tranvía a lo largo de la Av. Pedro de Osma, que hace paseos educativos y de demostración.

Finalmente, Barranco cuenta con galerías de arte a lo largo del paseo Saenz Peña, y otros espacios cerca al malecón. Además, es la escena artística de muchos cantautores, actores, poetas y literarios. Sus presentaciones son habituales en los bares y teatros barranquinos.

${ }^{10}$ Programa parte de los talleres educativos y las actividades culturales del museo. 


\subsection{Movilidad}

\subsubsection{Antecedentes de Planes viales de Lima Metropolitana}

A partir del Siglo XX, con el crecimiento demográfico y urbano de Lima Metropolitana, se pensó en planes que ordenaran las vías de la ciudad acorde a la trama urbana proyectada. Algunos de estos planes propusieron reforma del transporte en sus lineamientos. Tres fueron los principales: Plan de Desarrollo Metropolitano a 1980 (PLANDEMET), Plan de Desarrollo Metropolitano de Lima al 2010 (PLANMET), y el Plan Regional de Desarrollo Concertad de Lima al 2025 (Ortiz de Zevallos, 1992; Municipalidad Metropolitana de Lima, 2012). Posteriormente, se propuso el Plan de Desarrollo Urbano de Lima y Callao al 2035 (PLAM 35), actualmente en espera de aprobación.

Entre los períodos de aprobación de cada plan, se realizaron diversos estudios y acotaciones de parte de entidades del Estado. Algunos de ellos fueron:

- Plan de Desarrollo Metropolitano a 1980 - Ministerio de Vivienda, 1970

- Estudio de Factibilidad Técnico Económico y Anteproyecto de Transporte Rápido Masivo de Pasajeros, Metrolima 1974

- Proyecto de Desarrollo Urbano de Lima Metropolitana, elaborado por la Comisión Multisectorial de Transporte, 1984

- Estudio de Clasificación de Vías Urbanas - Comisión Multisectorial Coordinadora 1986

- Plan de Estructuración Urbana, Acuerdo 270 de la Municipalidad de Lima Metropolitana.

- Estudios Complementarios del Plan de Desarrollo Urbano de Lima Metropolitana y del Callao. Transporte sub-Class. Enero 1990

- Plan de Desarrollo Metropolitano de Lima al 2010. Plan Met 1990-2010.

- Plan Regional de Desarrollo Concertado de Lima al 2025, Municipalidad de Lima

- Plan Regional de Desarrollo Concertado de Lima al 2035, realizado por un conjunto de arquitectos, urbanistas y especialistas de diversas áreas. Convocado por la Municipalidad Metropolitana de Lima. 
A continuación, se desarrolla una explicación sobre los lineamientos de movilidad de los tres planes urbanos más importantes para Lima Metropolitana.

\subsubsection{PLANDEMET: Plan de Desarrollo Metropolitano Lima Callao - Esquema Director (1967-1980)}

El Plan de Desarrollo Metropolitano de Lima (PLANDEMET) fue el primer análisis de la mayor cantidad de variables que se involucran en un sistema urbano. Se realizó un diagnóstico y un plan que proyecta el crecimiento y expansión de Lima hacia 1980. Como menciona el arquitecto José Alonso Oviedo Lira ${ }^{11}$ (2011), este fue el punto inicial de propuestas que, poco a poco, modificaban el plan según las demandas de la ciudad. Sin embargo, las metas y políticas a cumplir en 1980 no tuvieron en cuenta la migración de la población del interior del país hacia Lima en $1990^{12}$.

11 “Arquitecto graduado en la Universidad Nacional San Agustín de Arequipa; Master MDI en Dirección y Gestión de Empresas Constructoras e Inmobiliarias en la Universidad Politécnica de Madrid y Pontificia Universidad Católica del Perú. Especialización en Planeamiento Vial y Diseño Geométrico Vial Urbano en UNI, PUCP, Fonam, IGC y otros; y PEA ESAN en Proyectos de Asociación Público-Privada" (Oviedo Lira, PLANDEMET: Plan de Desarrollo Metropolitano Lima Callao - Esquema Director 1967-1980 [mensaje en un blog], 2011). Experiencia en el sector de Planeamiento urbano de la Municipalidad Metropolitana de Lima, asociaciones público privadas y en el sector privado.

12 "La migración de campesinos andinos hacia la costa criolla, y particularmente a Lima, es un fenómeno secular que se acentuó en la segunda mitad del siglo XX, cuando el crecimiento demográfico desbordó la capacidad productiva de la tierra y las expectativas de la población rural se multiplicaron, al debilitarse o desaparecer las restricciones a la movilidad territorial impuestas por el sistema colonial... La intensificación de la migración a partir de los años ochenta, en un contexto de aguda crisis económica y política y de guerra interna, cambió la fisonomía de Lima. La ciudad criolla y moderna se vio invadida y se sintió amenazada por la población andina, portadora de una cultura distinta, ajena a la de sus viejos habitantes. En 1993, $40 \%$ de la población del departamento de Lima había nacido en otros departamentos.” (Escárgaza, Abanto Llaque, \& Chamorro G., 2002) 
Entre otros parámetros, se estructuró los planes integrales urbanos y viales en el Reglamento Nacional de Edificaciones (RNE) del 1970.

En transporte, se observa una red de $388 \mathrm{~km}$ de vías expresas, arteriales y colectoras para regular el ingreso al Centro de un parque automotor total de 20675 buses públicos y 134000 pasajeros en hora punta. (Instituto Metropolitano de Planificación, 1992) Asimismo, Oviedo Lira (2011) relata que la red vial se encontraba descentralizada y discontinua. Por ello se plantea la "apertura de nuevas rutas interiores basadas en fortalecer el Sistema de Redes de Transporte Público".

Plano: PLANDEMET - Red Urbana de Transportes: Esquema director 1967-80

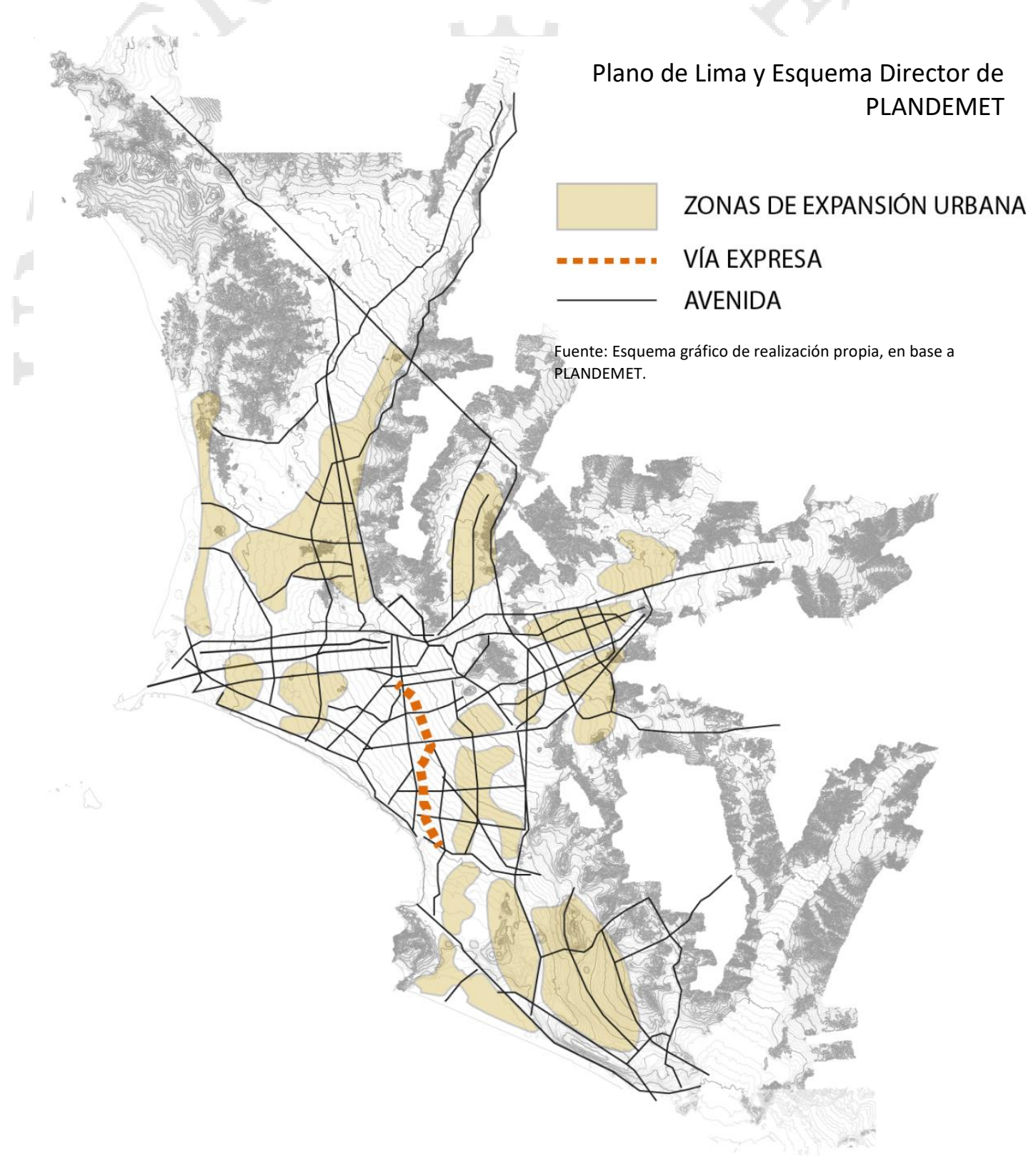


El Plan de Desarrollo Metropolitano de Lima (PLANDEMET) fue diseñado en 1967, y durante la década de 1970, no se consideró como un plan integral de desarrollo de país en términos de ciudad. En 1980 se incorporan funciones relativas a vivienda a los Municipios, cambiando esta visión metropolitana.

Según Marta Rosa Llona ${ }^{13}$ (1986), con el inicio de la visión de ciudad, "se analizó la ubicación de terminales terrestres, las vías preferenciales por donde se desplazan los ómnibus y los conflictos que se producen en los puntos de salida de la ciudad." Así, se pudo dar prioridad a las inversiones en vías como la Avenida Javier Prado, Avenida Universitaria, y la Avenida Paseo de la República. (Colegio de Ingenieros del Perú; Fundación Friedrich Ebert (Eds.), 1986)

A partir de 1980, el transporte metropolitano fue considerado como "componente del problema integral de Lima Metropolitana". Bajo ese concepto, una estación de transporte produciría un cambio importante en el uso de suelo a un radio de influencia alrededor de su ruta y vías.

El principal problema de la época del PLANDEMET fue que la administración no se concentraba, aún, exclusivamente en temas de transporte. Para ello, Augusto Dall'Orto (1986) ${ }^{14}$ describe "planteamientos constitucionales para el sistema de transporte urbano" (Colegio de Ingenieros del Perú; Fundación Friedrich Ebert (Eds.), 1986). Estos, incluian la pavimentacion y rehabilitación de vías que fueron dañados, en un $90 \%$, por empresas de servicios de la ciudad que no pertenecían al gobierno local, y sin un concepto de cuidado del pavimento. Además, buscaban completar la estructura y lineamientos de antiguos planes viales de Lima, para mejorarla y adaptarla a la nueva demanda con recursos como los de INVERMET.

\footnotetext{
${ }^{13}$ Expositora dentro de la compilación Desarrollo Metropolitano de la Ciudad de Lima, libro que "recoge las principales opiniones vertidas durante el fórum organizado por el Colegio de Ingenieros del Perú y la Fundación Friedrich Ebert, el 5 y 6 de setiembre en Lima" (Colegio de Ingenieros del Perú; Fundación Friedrich Ebert (Eds.), 1986, p. 9)

${ }^{14}$ IDEM
} 
En cuanto a organización vial, los lineamientos mencionaban implantar y coordinar al menos 800 intersecciones, señalizar calles y modificar sentidos de tránsito. Además, el centro histórico debía ser de tránsito mejor controlado, por lo que buscaban racionalizar el transporte con rutas radiales hacia el centro, complementándolas con transversales de alimentación y/o distribución. Asimismo, se buscó implementar el sistema de Bus- ductos, buses en vías exclusivas y segregadas inspirado en Paseo de la República. (Ortiz de Zevallos, 1992)

Finalmente, en temas de inversión, el PLANDEMET propuso, debido a la carencia en comparación al creciente parque automotor, construir edificios de estacionamientos o promover con incentivos la construcción de los mismos por medios privados. La inversión en equipamiento de transporte fue proyectada a, que, para el año 2000, Lima debía contar con 9000 buses e iniciar la construcción del Tren Metropolitano, pendiente en esa época. (Colegio de Ingenieros del Perú; Fundación Friedrich Ebert (Eds.), 1986)

\subsubsection{PLANMET (1990-2010)}

A fines de 1989 se aprobaron dos planes urbanos: el Plan de Desarrollo Metropolitano Plan Met (PLANMET) y el Plan del Centro de Lima. Ambos presentaban lineamientos a corto y largo plazo en todos los ámbitos urbanos de la ciudad y centro, respectivamente. El PLANMET incluía: al uso del suelo; a la habilitación y edificación urbana; equipamiento urbano; vivienda; transporte; vialidad; renovación urbana; medioambiente; servicios públicos; promoción de participación ciudadana; y planificación, gestión y administración. (Ortiz de Zevallos, 1992)

Los lineamientos de Transporte del PLANMET con visión al 2010 fueron los siguientes (ver plano 1.2.1.1):

- Establecer un sistema integrado de transporte metropolitano, considerando las diversas modalidades del transporte público y privado, que privilegie la modalidad de transporte rápido y masivo.

- “Optimizar la red vial existente, con los diseños adecuados para la operación de los diversos modos de transporte" (Ortiz de Zevallos, 1992). 
- Apoyar, a través de la Secretaría Municipal de Transporte Urbano, la racionalización del transporte público, priorizando el ordenamiento de las rutas en base a los lineamientos que formulen los planes de desarrollo

- Potenciar a las empresas de transporte masivo, a fin de hacer posible la renovación de la flota de vehículos de transporte urbano de pasajeros y aumentar, así, su participación en la oferta del transporte dentro de la metrópoli.

- Racionalizar la estructura del transporte de carga y pasajeros mediante:

- La conformación de un sistema de terminales de transporte interregional, conectando al sistema de transporte urbano.

- El establecimiento de un circuito vial para el transporte de carga, formulando normas para su circulación y la distribución de las mercancías. (Ortiz de Zevallos, 1992

Plano: Sistema de terminales terrestres para Lima Metropolitana (localización referencial)

Fuente: Ortiz de Zevallos, 1992

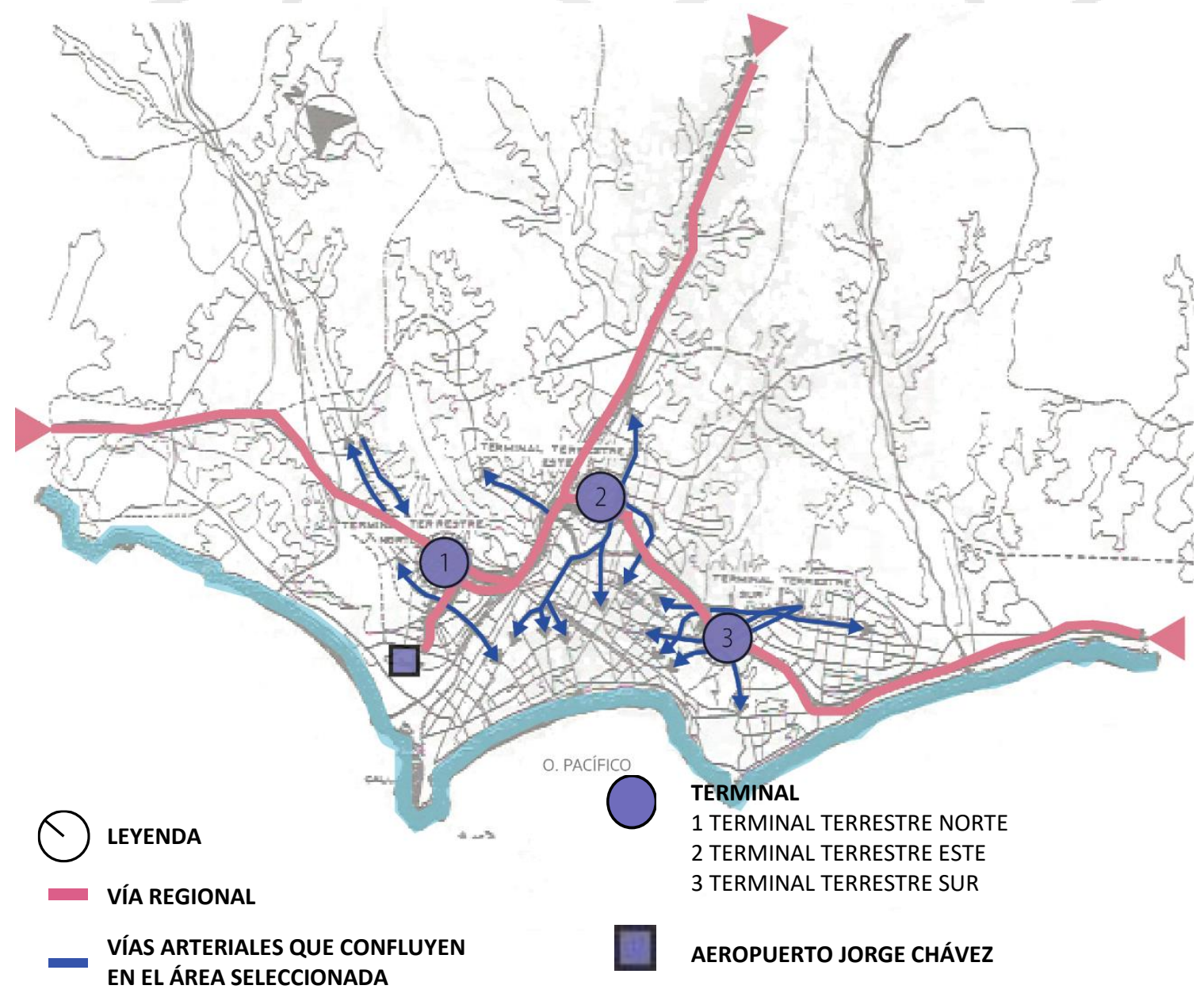


En cuanto a Vialidad, los lineamientos se referían a la articulación general de la ciudad (ver plano 1.2.1.2; plano 1.2.1.3):

- Integración de la Metrópoli y resto de la región optimizando actuales accesos y mejorando o creando nuevos ejes viales de interrelación.

- Potenciar la red vial, desarrollándola, con la finalidad de crear un sistema que garantice y homogenice el acceso hacia y desde los principales centros de generación y atracción de viajes dentro del área urbana metropolitana.

- Priorizar programas de inversión en las vías arteriales y colectoras, dando preeminencia a la red de corredores (vías con carriles exclusivos para transporte masivo).

- Programar la construcción de vías que integren áreas de expansión urbana inmediata de la metrópoli (la periferia) con los centros de equipamiento metropolitano (comercio y servicios) a fin de facilitar el acceso a sus actividades. (Ortiz de Zevallos, 1992)

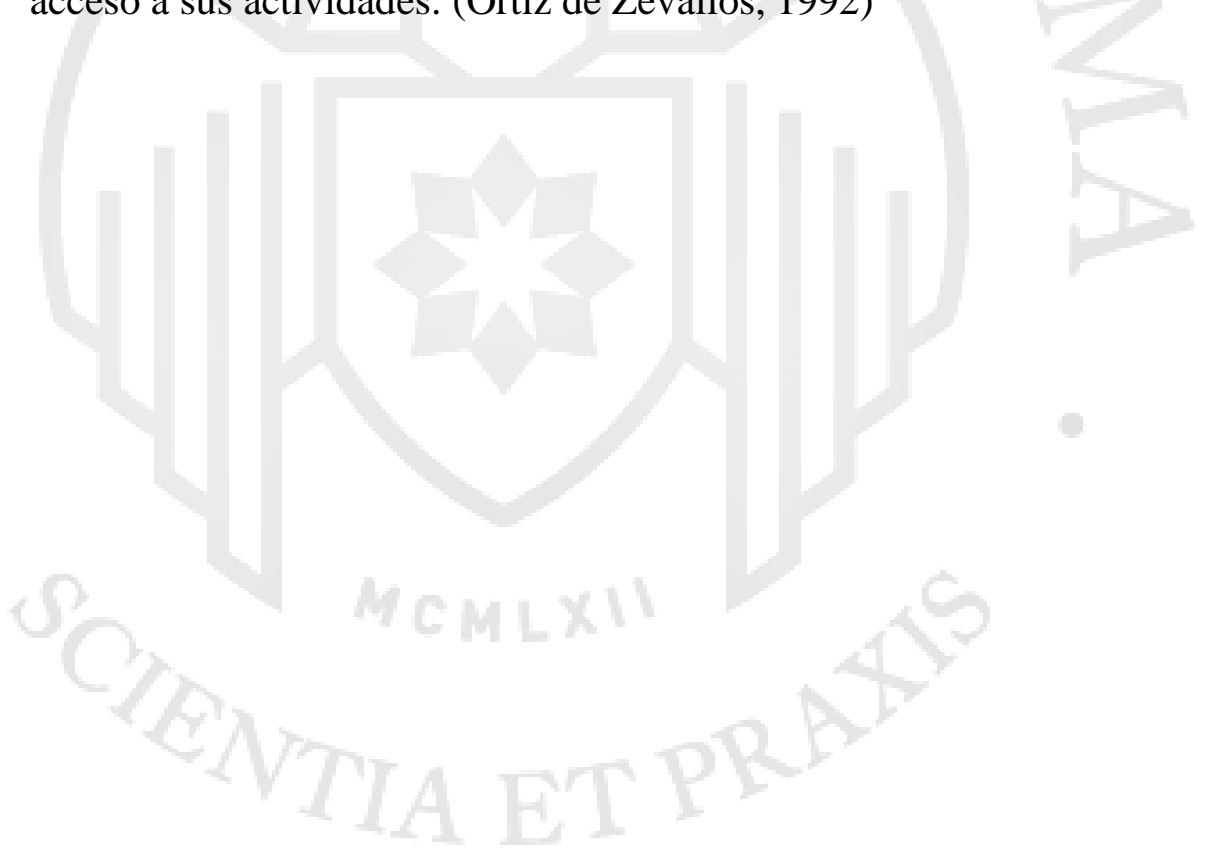


Plano: Prolongación Javier Prado Este - Esquema de propuesta a 1996 Fuente: Ortiz de Zevallos, 1992

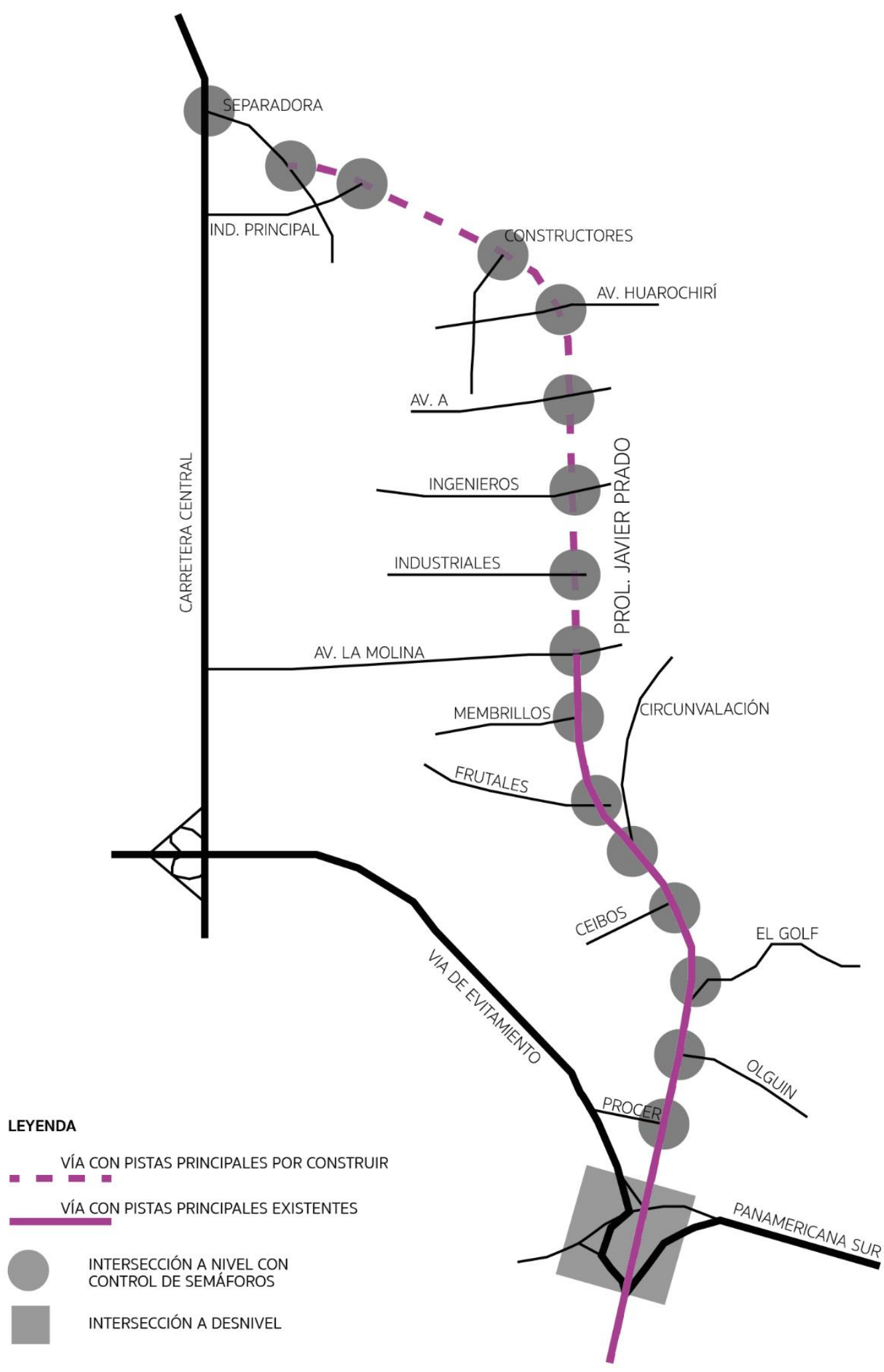


Plano: Sistema vial de Lima Metropolitana al 2010

Fuente: Ortiz de Zevallos, 1992; Instituto Metropolitano de Planificación, 1992

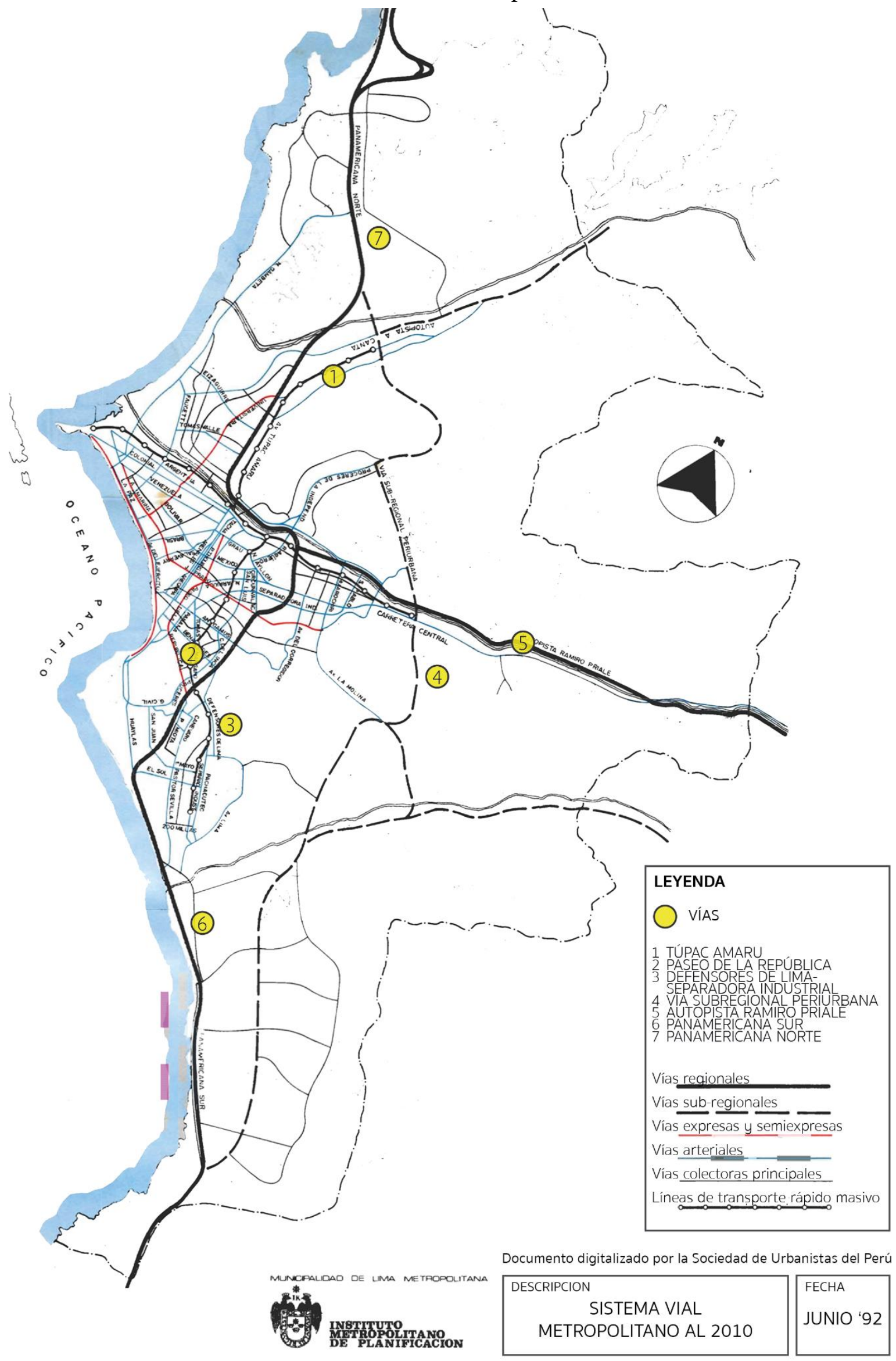


Para la administración y desarrollo de ambos planes, se creó la Oficina Metropolitana de Urbanismo, Planificación, Programas y Proyectos (Pro-Urbe). Inicialmente, mantuvo la responsabilidad de formular el programa de inversiones en convenio con Invermet. (Ortiz de Zevallos, 1992)

Actualmente, se considera que el PLANMET no cumplió con sus objetivos debido al proceso de reglamentación, escasa gestión distrital de control urbano, y las condiciones políticas y sociales de los '90, donde las invasiones ocuparon áreas de reserva estratégicas para equipamiento, recreación y vías. Además, se dieron otras construcciones de edificaciones sin licencia.

"A consecuencia de ello, se ha complicado más cumplir con la visión integral de desarrollo de la ciudad; se han diferenciado más aún las antiguas áreas urbanas centrales formales que concentran la oferta inmobiliaria y comercial, de las áreas periféricas informales en donde se han ido reduciendo las posibilidades de consolidar vías y equipamiento urbano, y su capacidad de generar valor y atraer al mercado inmobiliario (salvo excepciones puntuales donde se ha podido ejecutar infraestructura).

Poco antes del término de vigencia del horizonte temporal del PLANMET, el Gobierno Central aprueba el Reglamento de Acondicionamiento Territorial y Desarrollo Urbano con el Decreto Supremo No 027-2003 VIVIENDA con nuevas políticas urbanas, modifica la metodología de los instrumentos de planificación, además de elevar la densidad de los parámetros urbanísticos, lo que generado que Lima apruebe la Ordenanza $\mathrm{N}^{\circ}$ 620-MML y declare el inicio de un nuevo plan de desarrollo metropolitano: el PLAM de Lima [...]." (Oviedo Lira, 2011) 


\title{
2.2.4 Plan Regional de Desarrollo Concertado de Lima (2012-2025)
}

El Plan de desarrollo para Lima al 2025 fue presentado como documento en 2012 con ejes estratégicos y lineamientos sobre cada uno de los puntos que incluyen a la ciudad. Sin embargo, aquel que se refiere al transporte es el Eje estratégico 2:

\begin{abstract}
"Lima es una ciudad policéntrica, articulada y sostenible, que redefine el uso de su territorio en armonía con sus ecosistemas circundantes y que brinda servicios adecuados sin discriminación. Es importante resaltar que una ciudad policéntrica, requiere un sistema vial que permita el intercambio fluido de pasajeros y mercancías, mejorando así la competitividad de las actividades económicas. Además, un eficiente sistema de transporte multimodal que se complemente y disminuya sustantivamente el tiempo de viajes." (Municipalidad Metropolitana de Lima, 2012, p. 347)
\end{abstract}

Los objetivos, finalmente, buscan construir un sistema integrado de funciones sostenibles en una ciudad de rápido crecimiento como Lima. Estos son definidos como un sistema urbano por la MML (ver Plano 1.2.1.3):

- “Ciudad Policéntrica y conectada.

- Densificación ordenada con provisión de servicios.

- Cuencas protegidas y parques agrícolas.

- Cinturón ecológico y agricultura urbana.

- Borde Costero recreativo-turístico y residencial.

- Áreas de expansión autosostenibles" (Municipalidad Metropolitana de Lima, 2012).

El plan hace hincapié en que la población de distritos segregados y marginados de servicios tenga accesos al igual que quienes viven en los lugares céntricos. Por ello, "es importante colocar al transporte como un servicio estratégico en el funcionamiento de la ciudad... dentro del proceso de desconcentración de actividades en la ciudad." (Municipalidad Metropolitana de Lima, 2012)

Durante el proceso de desconcentración territorial, se fortalecerán los nuevos centros en las áreas interdistritales, ahora prioritariamente 
relacionados con las actividades económicas, los cuales deberán ser complementados con los servicios descentralizados de los organismos del gobierno nacional, y, también, con servicios y equipamientos que prioricen los caminos peatonales, para 'humanizar' la ciudad (Municipalidad Metropolitana de Lima, 2012).

Metas estratégicas en cuanto a transporte según el informe de la MML (2012):

- " $100 \%$ de empresas de transporte organizadas y formalizadas en la propiedad de su flota.

- En funcionamiento el Sistema Intermodal de Transporte Urbano, habiéndose implementado las líneas 1 y 2 del Tren Urbano, los corredores complementarios, de integración y de interconexión Lima - Callao; y un sistema de transporte no motorizado" (Municipalidad Metropolitana de Lima, 2012).

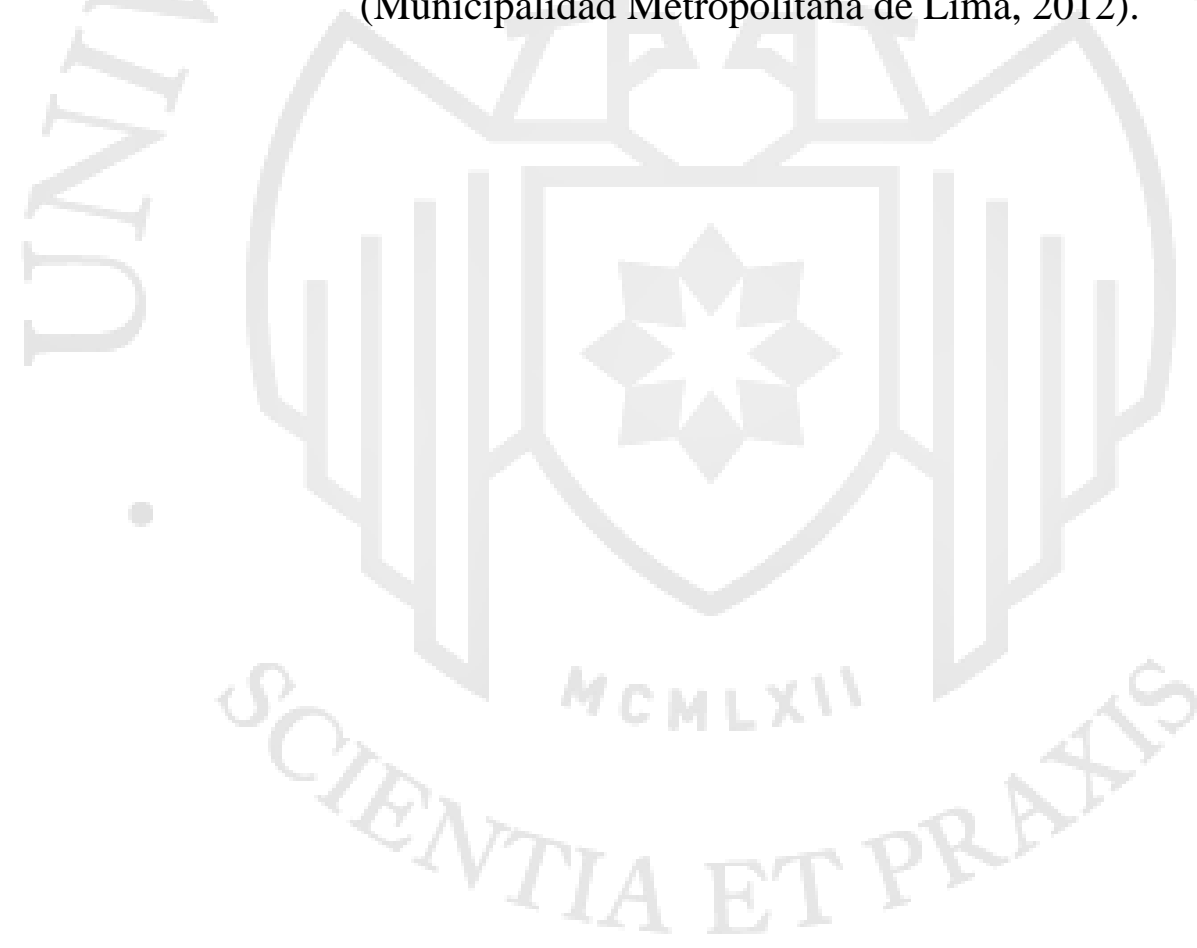


Cuadro: Objetivos específicos de la MML.

Fuente: Municipalidad Metropolitana de Lima, 2012

\begin{tabular}{|c|c|c|c|c|}
\hline \multirow{5}{*}{$\begin{array}{l}\text { } \\
\\
\\
\text { Promover las } \\
\text { condiciones de } \\
\text { habitabilidad segura } \\
\text { como un derecho } \\
\text { ciudadano, a través } \\
\text { del acceso y mejora de } \\
\text { la vivienda, la } \\
\text { movilidad, el } \\
\text { transporte, los } \\
\text { servicios básicos, la } \\
\text { recreación, los } \\
\text { espacios públicos y } \\
\text { otros, reduciendo las } \\
\text { condiciones de } \\
\text { vulnerabilidad. }\end{array}$} & \multirow{3}{*}{ OE 2.4} & \multirow{3}{*}{$\begin{array}{l}\text { Incremento de } \\
\text { la Superficie de } \\
\text { áreas } \\
\text { recreacionales, } \\
\text { incorporando } \\
\text { enfoques } \\
\text { participativos y } \\
\text { socioambiental } \\
\text { es }\end{array}$} & OESP 2.4.1 & $\begin{array}{l}\text { Desarrollo de estrategias de } \\
\text { sensibilización y toma de } \\
\text { conciencia a la población y } \\
\text { autoridades en la importancia y } \\
\text { mantenimiento de las áreas verdes } \\
\text { y espacios públicos. }\end{array}$ \\
\hline & & & OESP 2.4.2 & $\begin{array}{l}\text { Implementación de nuevas áreas } \\
\text { como espacios públicos e } \\
\text { infraestructura deportiva, para el } \\
\text { mejoramiento de la salubridad y } \\
\text { prácticas recreativas en el territorio }\end{array}$ \\
\hline & & & OESP 2.4 .3 & $\begin{array}{l}\text { Dotar de nuevos espacios urbanos } \\
\text { habilitando y acondicionando } \\
\text { áreas con potencial paisajístico en } \\
\text { la ciudad }\end{array}$ \\
\hline & OE 2.5 & $\begin{array}{l}\text { Impulso de } \\
\text { una movilidad } \\
\text { sostenible, } \\
\text { segura e } \\
\text { inclusiva que } \\
\text { contribuya a la } \\
\text { articulación }\end{array}$ & OESP 2.5 .1 & $\begin{array}{l}\text { Desarrollar una movilidad } \\
\text { urbana sostenible con prioridad } \\
\text { para los peatones, ciclistas y } \\
\text { transporte público, } \\
\text { implementando los sistemas de } \\
\text { transporte no motorizados y de } \\
\text { transporte público masivo, } \\
\text { obteniendo una eficiente } \\
\text { distribución y equilibrio modal } \\
\text { de los viajes metropolitanos. }\end{array}$ \\
\hline & & metropoli. & OESP 2.5 .2 & $\begin{array}{l}\text { Ejecución sostenida de un } \\
\text { proceso de reordenamiento del } \\
\text { transporte público y del tránsito } \\
\text { metropolitano. }\end{array}$ \\
\hline
\end{tabular}


Plano: Objetivo vial integrado y policéntrico al 2025

Fuente: Municipalidad Metropolitana de Lima, 2012

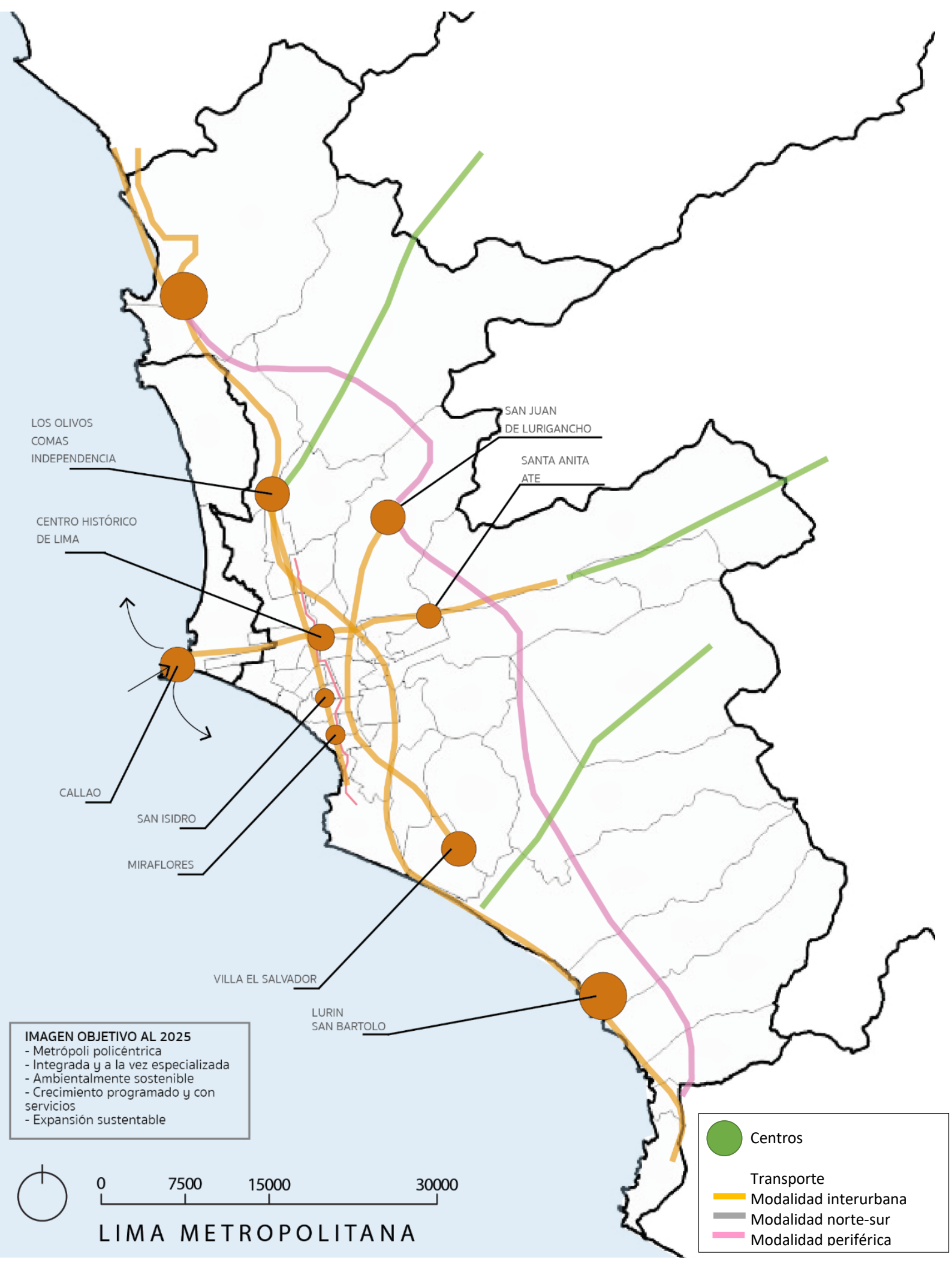




\title{
2.3 Transporte Masivo Rápido en Buses (BRT o TMRB)
}

\subsubsection{Antecedentes históricos del BRT}

El sistema de Transporte Masivo Rápido en Buses (TMRB y BRT en inglés) fue implementado por primera vez en Chicago, en 1937, al convertir líneas antiguas de tren en vías rápidas de buses. Sin embargo, las medidas y reglamentaciones fueron tomadas en Nueva York en 1963. Luego, comenzaron a operar en París y, en St. Louis y Bélgica se crearon vías centrales exclusivas para los buses rápidos. En Sudamérica, la primera vía exclusiva central llega en 1972 a Lima. (Maeso-González \& Pérez-Cerón, 2014)

\begin{abstract}
A nivel internacional, cuando se busca instalar un sistema de transporte público distinto a trenes y metros, se ha optado por los proyectos de transporte masivo en buses (TMRB)... Este sistema combina infraestructura segregada, estaciones convencionales y de transferencia, planificación y sistemas inteligentes de transporte... (De
\end{abstract} Mattos \& Ludeña, 2011, p. 129)

A inicios de 1970, la ciudad de Curitiba en Brasil implementa el BRT. Fue creado para simular la función, velocidad y capacidad de un sistema de Metro a un precio moderado para la ciudad. (Wright, 2010). Se trataba de corredores y vías exclusivas para buses de gran tamaño y capacidad con paraderos y terminales determinadas.

La atención a nivel mundial en el sistema se dio en 1999 con el lanzamiento del TransMilenio en Bogotá: un sistema de transporte de gran envergadura. Sin embargo, aunque se considere a Latinoamérica como la cuna del BRT, el concepto estaba inmerso en Europa y Norteamérica a inicios de los 60s. (Wright, 2010).

Este sistema de corredor exclusivo y rápido de buses funciona en muchas ciudades en combinación con otros sistemas de transporte, como trenes o buses informales. 


\subsubsection{Transporte masivo rápido de buses (BRT) en Perú}

Lima Metropolitana es una ciudad que, a lo largo de sus planes urbanos, ha favorecido al crecimiento urbano y ordenamiento vial. Sin embargo, el tema de transporte público sigue pendiente. La prioridad que se da al transporte privado en la ciudad solo beneficia a un $15 \%$ de los ciudadanos aproximadamente ${ }^{15}$ : quienes poseen auto. El resto de la población limeña debe movilizarse a través de transporte público.

Lima cuenta con dos medios de transporte implementados por entidades del Estado: El tren de Lima y el bus Metropolitano. Estos atendieron, en el año 2012, al $20 \%$ de la población (Muñoz, 2012). La población restante se movilizó en transporte público dirigido por empresas del sector privado.

La mayor parte del transporte público de la ciudad, actualmente, está gestionado por empresas privadas sin control estatal. Esto genera un servicio deficiente y de intereses meramente económicos para los dueños de las unidades vehiculares (Montezuma, 2003).

Según Gino $\operatorname{Costa}^{16}$ (2012), un tema importante para la población Limeña es la contaminación ambiental. El principal causante de contaminación ambiental es la contaminación vehicular, sonora y el aire que generan las unidades.

“Otros aspectos de la cuestión ambiental tienen que ver con la escasez de árboles y áreas verdes, el todavía deficiente recojo de basura en muchos distritos y el elevado nivel del ruido producido por los vehículos. [...] en el 2014, de acuerdo con la PNP, tocar bocina en exceso fue la principal infracción al reglamento de tránsito.

\footnotetext{
${ }^{15}$ Cifra obtenida según la división de Población total en Lima al 2013 (9 540996 hab.) y parque automotor en Lima 2013 (1 453028 unid.), según INEI y la Oficina General de Planificación y Presupuesto del Ministerio de Transportes y Comunicaciones. En dicha cifra se incluyen, incluso, automóviles adquiridos por empresas privadas para transporte público.

16 Gino Francisco Costa Santolalla, abogado y político peruano, especialista en seguridad ciudadana.
} 
Estoy seguro de que, si el uso de alarmas de vehículos constituyera una infracción de tránsito, esta sería la más numerosa, pues a diferencia de las bocinas, que son esporádicas, su ruido suele ser más agudo y extendido, y con frecuencia recurrente." (Costa, 2015)

El escenario de la ciudad, además, presenta problemas de inclusión social debido a la poca atención a los paraderos públicos y la calidad de servicio que ofrecen las empresas privadas, sin estándares que cumplir y una alta demanda de transporte (el restante $80 \%$ de la población que se moviliza en transporte público). El confort para el pasajero no existe en el concepto de 'vagón de tren' que los buses mantienen hasta el día de hoy. (Muñoz, 2012)

A continuación, se explicarán los antecedentes del sistema de transporte de BRT en el Perú, pues, existió un sistema similar al Metropolitano en la década de 1960. Su desaparición y reemplazo por un sistema de transporte privado tuvo un contexto sociopolítico ubicado en las últimas décadas de la historia de Perú.

\subsubsection{ENATRU}

A principios del siglo $\mathrm{XX}$, la reducida demanda de transporte público era cubierta por el tranvía y los autos particulares de la época. En 1964, un año antes de la desaparición del tranvía, la Municipalidad Metropolitana de Lima ingresa buses de gran tamaño a la ciudad en reemplazo. Así, se crea la Administradora Paramundial de Transportes de Lima (APTL), posteriormente nombrada Empresa Nacional de Transporte Urbano (ENATRU). Ésta funciona en Lima Metropolitana como el primer sistema de 'transporte masivo rápido de buses' de América Latina. (De Mattos \& Ludeña, 2011). En 1972 se inaugura, en Paseo de la República, un carril exclusivo para los buses y, en 1976, comienzan a operar los ENATRU. 


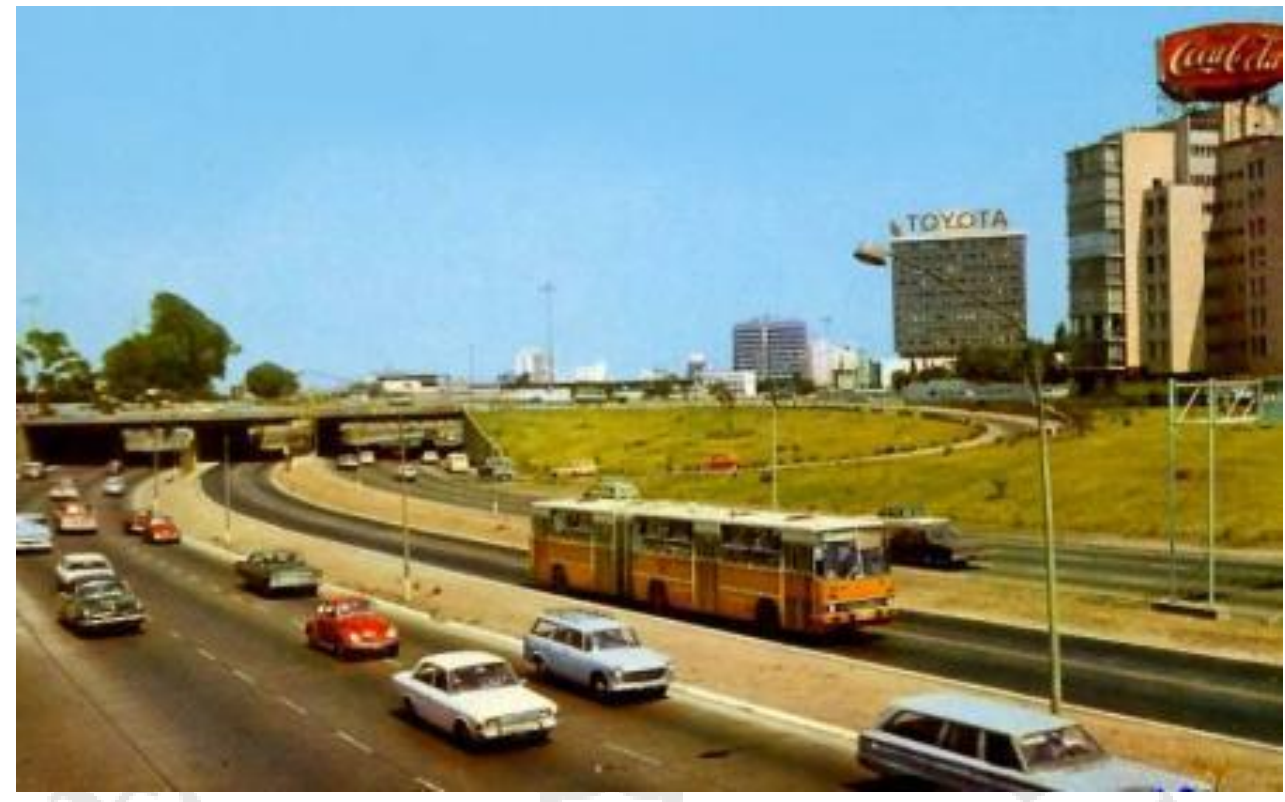

Imagen: Bus del ENATRU conocido como Ikarus circulando por Paseo de la República, 1976. Es la misma que hoy utiliza el Metropolitano.

Fuente: Orrego, 2011

Sin embargo, el crecimiento de la población en Lima entre 1976 y 1992 del área urbana provocan, en julio de 1991, el gobierno decida liberalizar el transporte y desaparecerla; el ENATRU no satisfacía las necesidades. El gobierno de Alberto Fujimori declara mediante el Decreto Legislativo 651, el libre acceso a las rutas de servicio de transporte público. Además, derogó todas las disposiciones y leyes que prohibían la entrada de bienes usados al país, incluyendo vehículos. Con estas acciones, intentó generar una mejora en la calidad, oportunidad y seguridad en el transporte. Asimismo, la importación de autos usados de todo el mundo buscaba generar empleos a través de la privatización de empresas de transporte.

Sin embargo, las leyes, según la Asociación Automotriz del Perú, provocaron que ingresen más de 650,000 autos usados al Perú entre 1992 y 2008. Principalmente, utilizaban diésel de combustible y es aquel que le hace más daño al medio ambiente por su alto contenido de azufre y partículas en suspensión. 


\subsubsection{Metropolitano}

Luego de la reforma que liberalizó y privatizó el transporte del gobierno de 1990, siguió existiendo una parte de la población desatendida, un sistema de transporte caótico, dividido y sin un sentido de movilidad integral. (De Mattos \& Ludeña, 2011, p. 318). La mayor parte de sistema de transporte nacional era el ómnibus informal, generando una gran congestión vehicular.

Cuadro: PARQUE VEHICULAR DE EMPRESAS DE TRANSPORTE DE PASAJEROS, SEGÚN ÁMBITO Y CLASE DE VEHÍCULO, 2004 - 2012 (unidades)

\begin{tabular}{|c|c|c|c|c|c|c|c|c|c|}
\hline $\begin{array}{c}\text { Ámbito y } \\
\text { clase de vehículo }\end{array}$ & 2004 & 2005 & 2006 & 2007 & 2008 & 2009 & 2010 & 2011 & 2012 \\
\hline Total & 4371 & 4106 & 4622 & 5341 & 6342 & 6916 & 7973 & 7737 & 8448 \\
\hline Nacional & 4332 & 4052 & 4570 & 5275 & 6270 & 6760 & 7655 & 7564 & 8305 \\
\hline Automóvil & 17 & 11 & 8 & 8 & 16 & 6 & 6 & 6 & 9 \\
\hline Station Wagon & -11 & 36 & 114 & 149 & 172 & 153 & 108 & 9 & 26 \\
\hline Camioneta Rural & 27 & 38 & 112 & 247 & 516 & 792 & 1185 & 1573 & 1797 \\
\hline Ómnibus & 4277 & 3967 & 4336 & 4871 & 5566 & 5809 & 6356 & 5976 & 6473 \\
\hline Internacional & 39 & 54 & 52 & 66 & 72 & 156 & 318 & 173 & 143 \\
\hline Ómnibus & 39 & 54 & 52 & 66 & 72 & 156 & 318 & 173 & 143 \\
\hline
\end{tabular}

Fuente: Ministerio de Transportes y Comunicaciones - Oficina General de Planificación y Presupuesto.

Dentro de las propuestas de transporte actuales, se implementa la del Sistema Metropolitano de Transporte o El Metropolitano (antes Sistema de Corredores Segregados de Buses de Alta Capacidad - COSAC), financiado por el Banco Mundial y el Banco Interamericano de Desarrollo en el año 2010. Es un sistema integrado de transporte que cuenta con:

- Autobuses de módico rendimiento a gas natural

- Buses alimentadores a los extremos sur y norte de menor capacidad

- Estación central subterránea de buses en el centro de Lima 
La implementación del Metropolitano trajo consigo beneficios en rapidez y organización de transporte. También se considera que existen factores negativos a considerar cuando se utiliza este servicio en la ciudad. Algunos de ellos son:

- Puede requerir la construcción de nuevas vías, en una ciudad donde ya no hay espacio para hacerlo.

- Demoras y conflictos en las intersecciones cuando las vías se cruzan con las particulares y regulares de la ciudad

- Cambios forzados en las costumbres de los ciudadanos. (Thomson, 2007)

Sin embargo, el corredor del Metropolitano solo atiende al $8 \%$ del movimiento en Lima (De Mattos \& Ludeña, 2011). Este recorre a lo largo de la vía expresa Paseo de la República, la misma ruta del ENATRU, que fue ampliada hacia Barranco para una mejor cobertura de transporte.

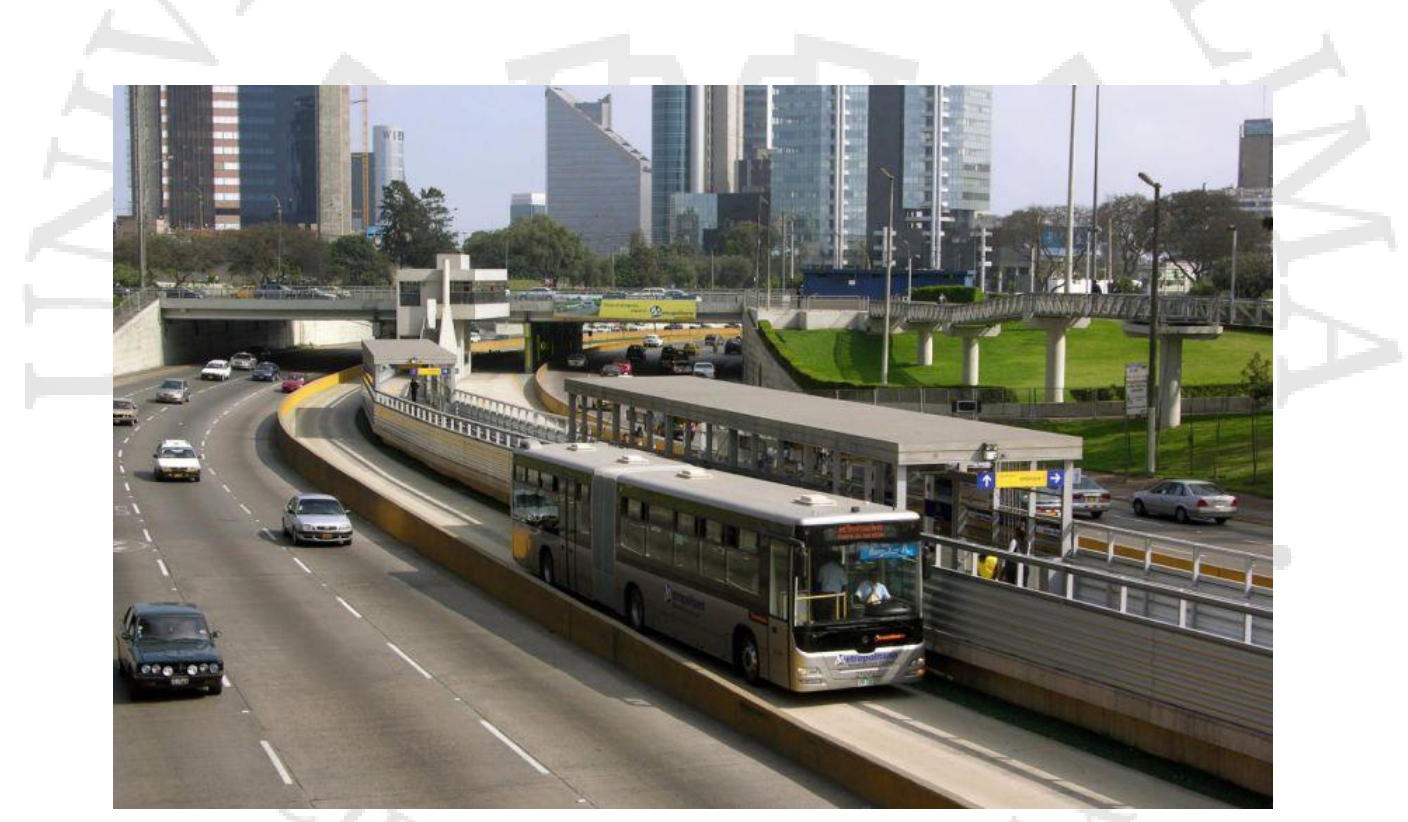

Imagen: Estación tipo de paso en la Vía Expresa Paseo de la República

Fuente: Protransporte, 2015 


\section{Plano: Ruta y estaciones del Metropolitano}

Fuente: Realización propia; basado en Municipalidad Metropolitana de Lima, 2016

\section{METROPOLITANO}

VIAS | ESTACIONES

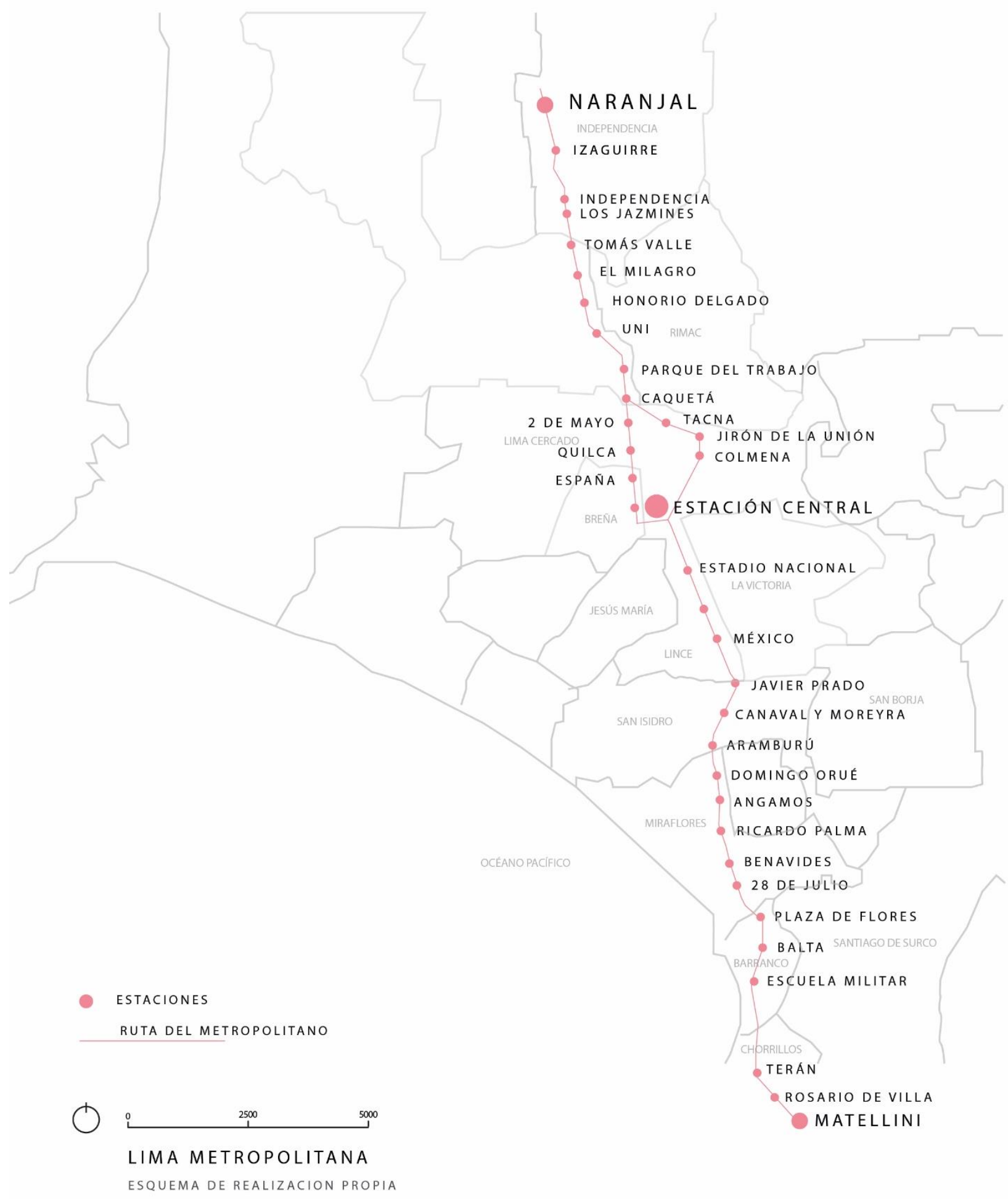




\subsubsection{Referente de BRT en Latinoamérica: TransMilenio de Bogotá.}

El Sistema de Transporte Rápido Masivo (STRM) TransMilenio, se implementa en Bogotá (Colombia) en el año 2000. Fue basado en la nueva visión de transporte masivo de Curitiba, en Brasil, y acondicionado a las necesidades de una ciudad de 7 millones de habitantes en su año de inauguración. Para el 2009, el sistema contaba con 84 km de troncales en vía exclusiva, 1100 buses articulados y $551 \mathrm{~km}$ de rutas alimentadoras con 512 buses. Esto movilizaba aproximadamente a 1,4 millones de pasajeros diariamente (12\% de las necesidades de movilidad en Bogotá). (Urazán Bonells \& Rondón Quintana, 2010)

Desde su planeamiento, ha considerado importante al usuario y el espacio de emplazamiento de vías y estaciones. Los espacios públicos y peatonales de la ciudad incrementaron durante las Etapas I y II de la construcción del sistema de transporte masivo.

“Entre los años 2000 y 2002, el indicador de espacio público peatonal fue constante, con un promedio de $2,93 \mathrm{~m}^{2} / \mathrm{hab}$. Sin embargo, entre el 2002 y el 2003 hubo un incremento sustancial de este indicador a 4.83 m²/hab., situación que se explica por la adecuación y construcción de andenes ligados a las primeras fases de Transmilenio, al incremento de zonas verdes como resultado de un incremento en el auge inmobiliario y a la recuperación de espacio público en toda la ciudad.

Entre los años 2003 y 2004 se construyeron $877.922 \mathrm{~m}^{2}$ de espacio público peatonal, indicador que se incrementó de manera sustancial en los años 2005 y 2006, principalmente por la inversión de la Fase II de Transmilenio en la NQS y la avenida Suba que habilitó la construcción de $1.160 .511 \mathrm{~m}^{2}$. El área de espacio público peatonal construido disminuye aproximadamente una tercera parte entre el $2006\left(503.070 \mathrm{~m}^{2}\right)$ y los años $2007\left(143.666 \mathrm{~m}^{2}\right)$ y 2008 (190.280), puesto que en esos años el IDU no construyó espacio público peatonal en la magnitud que lo hizo entre los años 2000 a 2006, y esto se debe en gran medida a que la mayoría de la construcción realizada por el IDU se encuentra ligada a las fases I y II de Transmilenio" (Cámara de Comercio de Bogotá, 2009) 
El sistema completo del Transmilenio no solo contempla obras relacionadas a las vías del bus. Si no, también considera trabajos que influenciaron en el ordenamiento urbano. Esto se traduce en carriles exclusivos y de transporte mixto, según el espacio de ruta; rehabilitación de vías para rutas alimentadoras; espacio público circundante al sistema y sus estaciones; garajes e intersecciones. Estas últimas, fueron cuidadas para que el corredor funcione eficientemente. (Transmilenio, 2005)

Además, el Transmilenio fue implementado de la mano con el Plan Maestro de Espacio Público para Bogotá de 2005, que evalúa la correlación entre transporte y espacio de consolidación urbana. Asimismo, existe el Plan de Ordenamiento Territorial de julio del 2005, donde se decretan las normas de diseño vial para las secciones de calle por donde circula el Transmilenio. Esto incluye a las estaciones, a las vías exclusivas, de autos y peatonales.

En las zonas en que opera Transmilenio, la infraestructura peatonal de acceso a las estaciones desde zonas cercanas $(\leq 500 \mathrm{~m})$ hace parte integral del concepto de "movilidad peatonal", el cual invita a los usuarios a desplazarse hacia y desde distintas estaciones en modo "a pie". (Urazán Bonells \& Rondón Quintana, 2010)

El STRM (que incluye a los BRT, metros y tranvías) requiere proyectar los espacios públicos circundantes porque determinan el área que necesitan y la forma de emplazamiento de la estación y sus entradas. En el caso del Transmilenio, se aplicaron patrones según la ubicación de las estaciones y vías, para mantener un perfil de calle que respete los demás tipos de movilidad.

"Si bien es cierto que el esquema de demanda de usuarios rige en primera instancia cuáles serán las zonas de operación del sistema, el trazado de la infraestructura debe buscar en ellas los espacios o ejes viales que le permitan cumplir con el ancho del perfil vial requerido" (Chaparro, 2002)

Como mencionan Urazán Bonells y Rondón Quintana (2010), el problema espacial de las redes de transporte surge cuando se les pretende implementar posteriormente a la consolidación de una zona urbana. Esta zona urbana, precisamente 
ha crecido en las zonas con mayor demanda de viajes, por la necesidad de movilidad sin un plan de transporte adecuado. Esto concluye en una red de vías improvisadas en ciudades como Lima, donde el Metropolitano abarca más de la mitad de la sección de calle, porque su implementación no considera el espacio público aledaño. Esto difiere de ciudades planificadas como Barcelona, donde se construyeron las Manzanas de Cerdá con esquinas redondeadas, de manera que el tranvía pueda dar un giro libre y sin complicar el paso de otras formas de movilidad.

Bajo la premisa de considerar el espacio público del sistema, se ponen tres casos ejemplo. El primer caso, cita a la Troncal de Caracas, con un cruce peatonal a nivel de la calle. El acceso peatonal se regula por las intersecciones de semáforo. Así, se ahorra el espacio que una rampa o escaleras requieren en la vía.

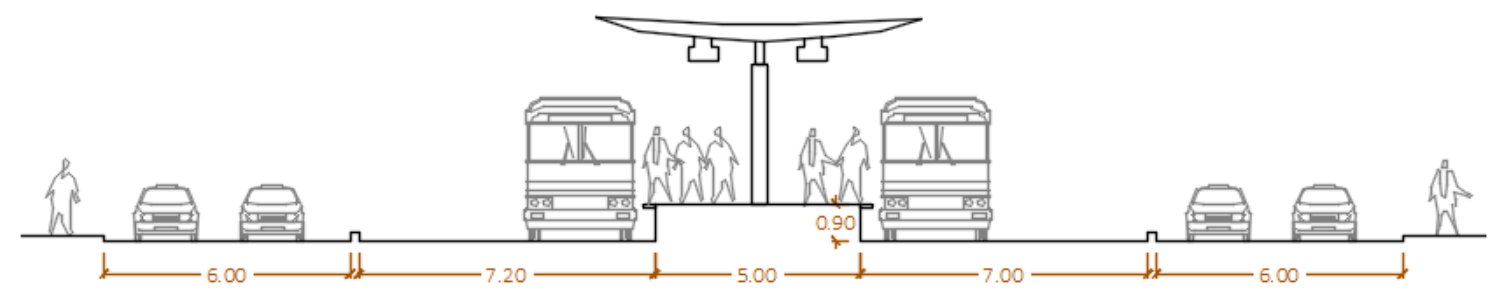

Esquema: Perfil vial en una estación tipo de parada en la troncal de la Caracas, Bogotá, D.C. Fuente: Adaptación propia, basado en Chaparro, 2002.

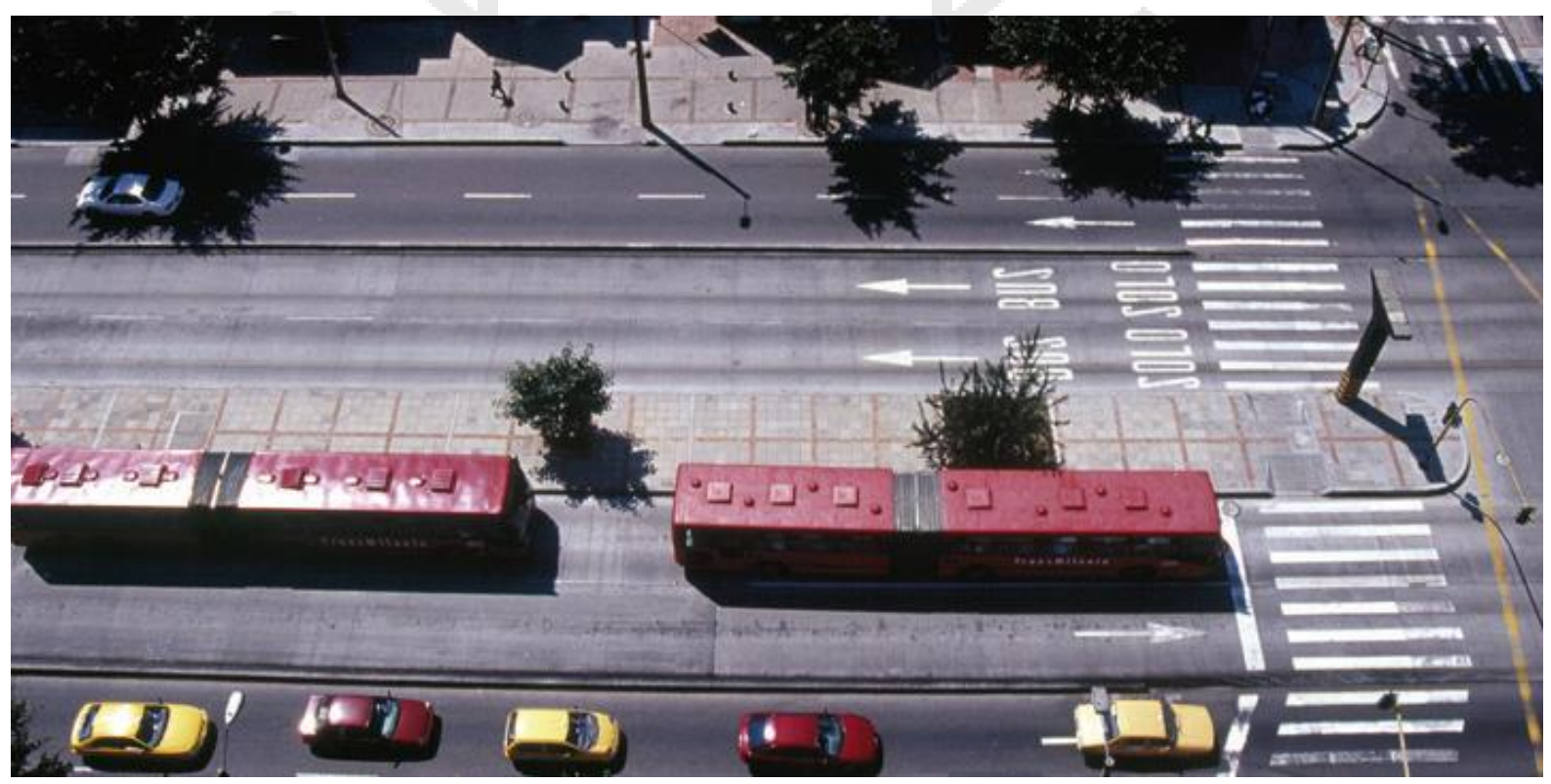


Imagen: Acceso a nivel (cebra) para estaciones de Transmilenio, troncal de la Caracas, Bogotá Fuente: (Urazán Bonells \& Rondón Quintana, 2010);

http://www.bogotaturismo.gov.co/postales/

En el segundo caso, se toma el Eje Ambiental, donde la relación entre la calle y la estación es a través de corredores peatonales; el peatón toma la prioridad y complementa al Transmilenio como únicos sistemas de movilidad.

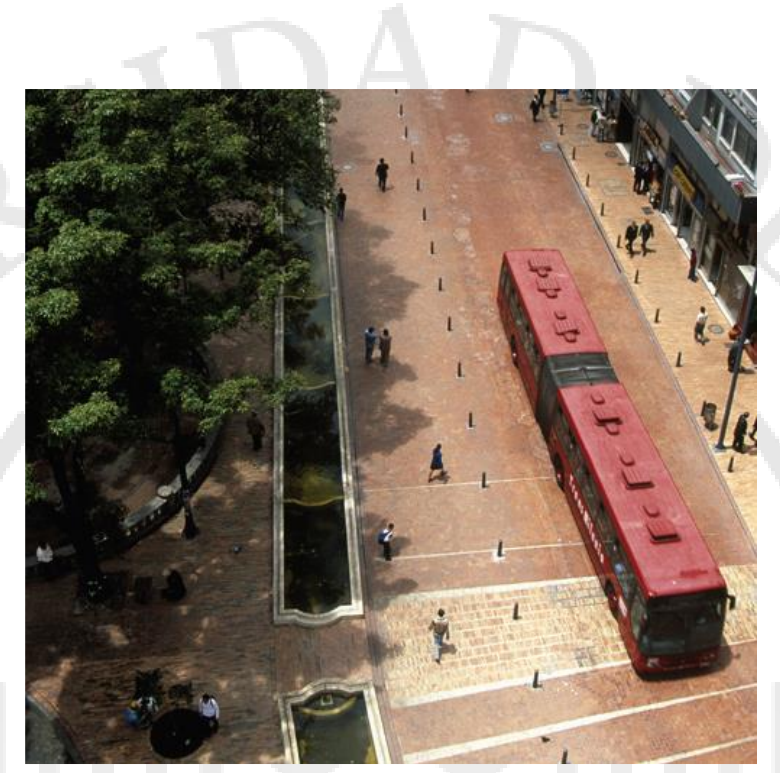

Imagen: Corredor peatonal como acceso a las estaciones en el Eje Ambiental de Transmilenio, Bogotá, D.C. Fuente: http://www.bogotaturismo.gov.co/postales/

La Cámara de Comercio de Bogotá (2007) afirma que el eje ambiental sirvió para reactivar y revitalizar a los espacios públicos aledaños, entre parques y plazas. Así, el proyecto del Transmilenio se convirtió en un cambio integral que favoreció enteramente a los peatones.

Este cambio físico favoreció la intermodalidad de movilidad, entre caminar y el Sistema de BRT. La combinación entre ambos facilita el recorrido a pie y mejora la calidad de movilidad. Se brinda espacios considerables por cada peatón (mayor a $2.00 \mathrm{~m} 2$ ) e interacción con intersecciones vehiculares poco frecuentes (Urazán Bonells \& Rondón Quintana, 2010). 
Existe un tercer caso: cuando el ingreso a la estación es mediante un puente elevado. Esto ocurre cuando las intersecciones no favorecen el paso peatonal, o no cuentan con semáforos ni señalización. Por ejemplo, en las vías rápidas y de alto flujo vehicular. La troncal NQS del Transmilenio cuenta con estas características.
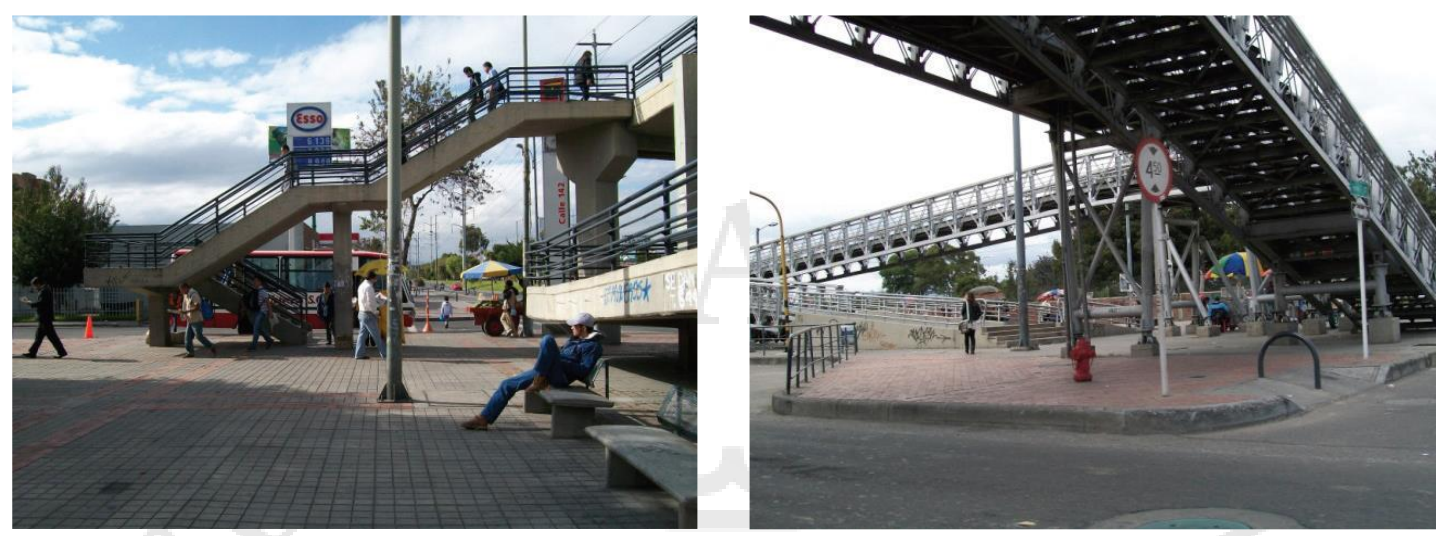

Imagen: Acceso a puente peatonal elevado. Estación Calle 142, troncal NQS, Transmilenio, Bogotá, D.C.

Fuente: (Urazán Bonells \& Rondón Quintana, 2010)

Como punto de referencia, las rampas al Transmilenio sobre el nivel del suelo ocupan un $20 \%$ más que las entradas subterráneas más sencillas del Metro de Barcelona (de 30m2 aproximadamente). Asimismo, un acceso subterráneo de dicho metro corresponde al 40\% del espacio que ocupa el acceso elevado de Estación Calle 142. (Urazán Bonells \& Rondón Quintana, 2010)

Por lo tanto, los sistemas de transporte en superficie requieren de un diseño vial que contemple el área necesaria para carriles, estaciones y los espacios públicos. En los sistemas de transporte subterráneos, el único espacio a considerar en la superficie, son los accesos peatonales. Este factor es importante al momento de evaluar el sistema de transporte que se implementará en la ciudad. Un sistema de BRT más económico que el subterráneo, pero debe ir de la mano de un plan urbano que tenga en cuenta el espacio que ocupará dentro de la ciudad. Asimismo, es importante implementar una cultura de movilidad, donde se respeten las vías exclusivas para buses, autos, peatones y bicicletas.

En Bogotá, en el 2010, el transporte representaba el 70\% de las emisiones que afectaban la calidad del aire (Urazán Bonells \& Rondón Quintana, 2010). La implementación del sistema del Transmilenio desencadenó una serie de acciones de 
movilidad. Hubo un mejoramiento de tecnologías, reorganización de la movilidad y control de la sobreoferta del transporte colectivo. Asimismo, se generaron ciclovías y espacios complementarios para favorecer la intermodalidad. En general, los principales beneficios ambientales que trajo consigo el Transmilenio fueron: cinco veces menos factores de emisión de los buses frente al transporte público colectivo; "reducción anual de 336,666 toneladas de CO2; disminución del 43\% en SO2; disminución del 18\% en NO2; reducción de material particulado del 12\% y reducción de contaminación auditiva en un 30\%" (Camara de Comercio de Bogotá, 2009).

En general, en Transmilenio ha desencadenado una serie de eventos favorecedores para la movilidad de Bogotá. Incluyendo vías, espacios públicos y un cambio de cultura. El sistema fue integrado a la ciudad junto con un plan urbano, para no desligar el impacto del BRT a nivel social y urbano. Es importante tomar en cuenta el entorno y sus necesidades, más que imponer un sistema de transporte solo porque el estado lo decide.

Al momento de elegir el Sistema de Transporte Rápido más adecuado para la ciudad, debe ponerse en balanza el costo económico y el costo socio urbano. En Lima, tal vez, se debería evaluar el costo-beneficio de un Sistema subterráneo; es una ciudad de trama cambiante y de nulo planeamiento urbano. El BRT agrega una variante más a la dinámica sobre el nivel del suelo y, por ahorrar en transporte, podríamos poner en riesgo la calidad de vida del peatón. 


\subsection{Centros Culturales}

\subsubsection{Definiciones}

Centro viene del latín centrum de significado "aguijón, punta del compás en la que se apoya el trazado de la circunferencia” (Real Academia Española, 2001).

Entre sus significados en la lengua española está "Lugar donde se reúnen o acuden personas o grupos por algún motivo concreto” (Real Academia Española, 2001).

Cultura, por otro lado, viene del latín cultus, cuyo significado es cultivo. Entre sus significados está: "Conjunto de modos de vida y costumbres, conocimientos y grado de desarrollo artístico, científico, industrial, en una época y grupo social" (Real Academia Española, 2001)

Se entiende, entonces, por centro cultural como un espacio en que se realizan diversas actividades de índole cultural con una finalidad social o educativa.

En la actualidad, los centros culturales están equipados con espacios como auditorio, sala de exposiciones, salas de usos múltiples, espacios de estudio (bibliotecas o mediatecas). En ellos se realizan actividades relacionadas a la música, las artes escénicas y visuales, y el estudio o educación.

\subsubsection{Antecedentes de centros culturales}

Debido a que los centros culturales como un programa arquitectónico son un concepto del Sigo XX, sus antecedentes son los programas independientes que alberga. En esta investigación se va a conocer los procesos históricos del teatro, auditorios, museos y salas de exposiciones en el tiempo.

\subsubsection{Teatros y Auditorios}

El origen de los teatros y auditorios como espacios con un diseño específico para su función procede a la práctica de la actuación. Desde la prehistoria, cuándo el hombre comenzó a tomar conciencia de la importancia de la comunicación para la vida social, 
se comenzaron a practicar artes escénicas durante sus ritos, a través de movimientos corporales y sonidos. Esta es la primera evidencia del uso social de las actividades teatrales.

El teatro antiguo, se desarrolla el teatro griego, cuyo fin central era educativo, pues se pretendía la transmisión de valores a los espectadores, así como generar en ellos una catarsis. Estas obras se realizaban, en un inicio en grandes espacios abiertos y posteriormente se buscó generar graderías en pendientes del terreno.

El teatro romano, incorporaba de manera más trascendental la música y los bailes que el griego, así mismo su arquitectura difería de él, al ser una planta semicircular en la que se construía la gradería en una sola estructura con el escenario.

Durante el periodo medieval, el teatro como práctica cultural y social ya había comenzado a proliferar y era parte de todas las sociedades. Principalmente, se trataban temas de índole religioso y los actores eran sacerdotes. También se realizaban producciones de temas no religiosos a las cuales se les llama profanas. Al igual que el teatro antiguo, este se usaba como una herramienta para la comunicación de mensajes de tipo social (religioso y profano).

El teatro del renacimiento se centró en representar la realidad de la vida del momento, en este sentido, cumplió una función política. Asimismo, surgieron teorías orientadas a las prácticas teatrales que tenían en cuenta el tiempo, el espacio y el movimiento, dando pie al uso de más elementos que complementaran las acciones.

Durante el periodo barroco, se reforzó el uso de la escenografía y el vestuario como elementos importantes en las producciones, acorde con la identidad ornamentada del barroco.

En el siglo XVIII, en el marco de la revolución francesa, la producción de montajes de diferentes escalas tomó mayor importancia y entró en mayor contacto con el público, dejando de ser una tradición de las clases altas. Esta tendencia se expandirá durante el siglo XIX, en el cual el teatro y las artes escénicas continuarán volviéndose más accesibles a toda clase de usuarios. 
En el siglo XX y hasta la actualidad, el teatro evoluciona de forma paralela a las demás artes en la corriente de la vanguardia. Se dan mayores oportunidades para la exploración de temáticas sociales tabú, y se profundiza en su impacto psicológico a través del desarrollo de los métodos de actuación. También, se pone mayor énfasis en la puesta en escena y el espectáculo, dando pie a el desarrollo de la arquitectura en la que se realiza.

\subsubsection{Museos y salas de exposición}

El origen de los museos proviene de Alejandría, cuando el gobernador Ptolomeo ordenó levantar un santuario dedicado a la investigación, y lo llamó museo pues su significado original es el de 'la casa de las musas' y estas eran las diosas de la sabiduría y la memoria. Se fundó en el 290 a.C y fue destruido después de enfrentamiento civiles en el 270 d.C.

En la antigua Grecia, los grandes templos se decoraban con esculturas, jarrones, pinturas, adornos, todos dedicados a los dioses y se exhibían para el público. Del mismo modo, en Roma se decoraban los teatros y demás templos con obras artísticas.

Al igual que el teatro, durante el medioevo y la edad moderna, las obras de arte se exhibían solo para la clase alta y es por eso que se encontraban en los palacios e iglesias. El termino galería de arte surge para referirse a las galerías de los palacios que estaban decoradas con pinturas y esculturas.

Hacia el siglo XVII y XVII el arte se comercializa con mayor facilidad y las colecciones de arte de los más poderosos se exhibía para un público más amplio.

\subsubsection{Centro cultural como animador urbano}

"Los centros culturales contribuyen con su dinámica y trabajo a estimular el diseño de políticas culturales que rinden un beneficio directo a cada población y muy especialmente a su entorno.” (Pachano Olivares, 2009) 
La principal meta de un centro cultural es alcanzar una estrecha relación con el usuario o público y es de esa manera que logra generar cambios e impacto en las sociedades y el entorno que los rodea. A través de actividades que fomenten la participación de las personas, se desintegra la noción de espectador y se forja una complicidad entre el usuario, sus vecinos y la institución. (Pachano Olivares, 2009) Sin embargo, es difícil medir el impacto que genera sobre una sociedad, debido a la falta de herramientas cuantitativas para medir la influencia social de la cultura (Instituto de estadítica UNESCO, 2009)

Se conoce que la cultura y las artes inciden en el imaginario colectivo de una sociedad, dándole a los consumidores una nueva y más amplia perspectiva frente a una problemática. Comparten experiencias, sentimientos y costumbres a través del arte, impulsando a un cambio social. Sin embargo, no existe forma cuantitativa de medir la influencia de la cultura sobre una comunidad. En algunos casos latinoamericanos, se ha ingeniado un sistema cualitativo para sacar conclusiones sobre la relación entre cultura y sociedad.

En Buenos Aires se ha desarrollado la revista digital 'Emprende Cultura', plataforma en la que participan diversos gestores culturales (artistas, organizadores y emprendedores). Fue lanzada gracias a la colaboración económica de varios gestores. Su objetivo es informar, conectar y escribir sobre proyectos culturales para abrir un debate público sobre su impacto, influencia e importancia. 'Emprende Cultura', ha identificado la participación social como una herramienta fundamental para cuantificar el uso e impacto de espacios culturales en Buenos Aires. Asimismo, la UNESCO, afirma que la participación puede abarcar tanto el comportamiento activo como el pasivo, es decir si el usuario es parte de las actividades culturales o si es sólo un espectador.

La recopilación de datos de 'Emprende Cultura' se basa en la información ofrecida por la Dirección General de Educación y Cultura (DGEyC) y el Observatorio de Industrias Creativas, ambas instituciones son patrocinadas por el Gobierno de la Ciudad de Buenos Aires. Además, la plataforma realiza encuestas y entrevistas a sus seguidores y a artistas invitados, de donde extrae información relevante. 
Según el informe de 'Emprende Cultura', el número de usuarios de centros culturales barriales, centros de divulgación musical y bibliotecas, creció exponencialmente en Buenos Aires. En el año 2008 se registraron aproximadamente, 500,000 visitantes; mientras que, en el 2012 se registraron más de 1 millón de asistentes. También señala que la mayor cantidad de actividades culturales, durante ese periodo, se realizaron en centros culturales barriales.

Otro caso en Latinoamérica es el documento que desarrolló el Ministerio de Cultura de Colombia en el marco de la Reunión Internacional de Expertos en Mediciones del Aporte de la Cultura al Desarrollo del año 2013, que identifica la accesibilidad a cultura como una dimensión para el análisis del impacto social de la cultura. Esto se refiere a la oferta de infraestructura cultural como museos, bibliotecas o centros culturales, y a su alcance a todos los usuarios por igual. A partir de esto, el documento infiere que el impacto de la cultura en la sociedad es mayor en la medida en que la oferta sea equitativa en el territorio. Esto podría traducirse en que la distribución equitativa de programa cultural incide a manera de bola de nieve sobre el interés colectivo en las artes.

Además, existen casos de equipamiento cultural con un impacto positivo en su entorno. El centro cultural Estación Mapocho en Santiago de Chile, es la recuperación de una antigua estación de trenes. Durante la década de los ' 80 , esta construcción abandonada constituía un alto foco de delincuencia y diversas problemáticas sociales. Durante la primera mitad de los ' 90 , se recuperó esta edificación para ocuparla con espacios culturales que atendieran a su entorno inmediato conformado por jóvenes y niños. (Centro Cultural Estación Mapocho, 2013) 


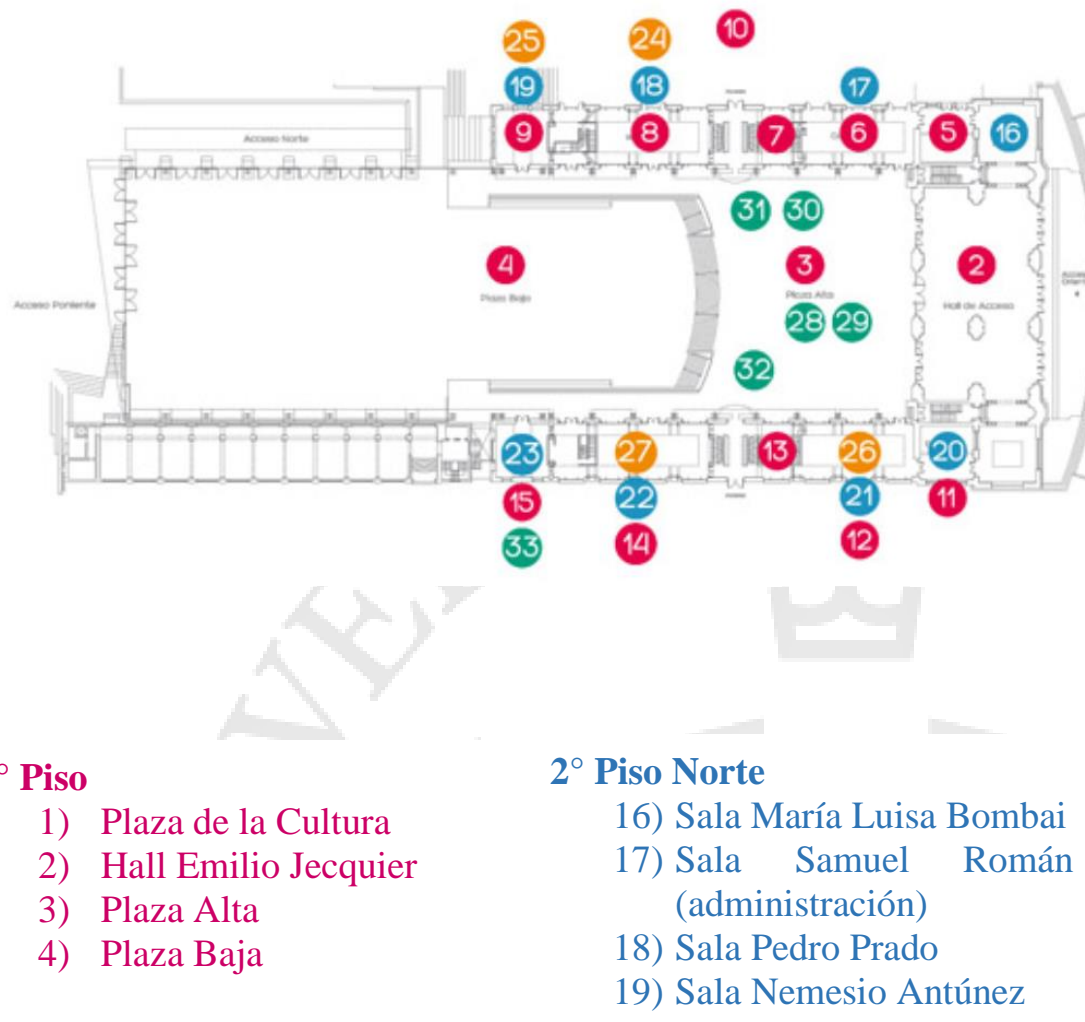

$1^{\circ}$ Piso Norte
5) Boletería
6) Restaurante
7) Ascensor
8) Restaurante
9) Sala Fernando Rosas (administración)
10) Paseo Norte

\section{$1^{\circ}$ Piso Sur}

11) Galería Bicentenario

12) Sala Lily Garafulic

13) Ascensor

14) Cafetería

15) Sala Gonzalo Roajas

\section{$2^{\circ}$ Piso Sur}

20) Sala Joaquín Edwards Bello

21) Sala Camilo Mori

22) Sala Acario Cotapos

23) Sala Pedro de la Barra

\section{Subterráneo}

\section{$3^{\circ}$ Piso Norte}

24) Sala Tennyson Ferranda

25) Sala José Donoso

\section{$3^{\circ}$ Piso Sur \\ 26) Sala Ana González \\ 27) Sala Isidora Aguirre}

28) Foyer Sala de las Artes

29) Sala de las Artes

Subterráneo Norte

30) Baños norte

31) Enfermería

\section{Subterráneo Sur \\ 32) Baños Sur \\ 33) Sala Raúl Ruiz}

El CC Estación Mapocho cuenta con 33 espacios disponibles al público. Entre ellos, están la plaza exterior, Hall de acceso, gran nave (Plaza Alta y Baja), foyer y 9 salas implementadas. Además, dos ascensores, dos restaurantes, una cafetería, cinco boleterías, 160 estacionamientos y $140 \mathrm{~m} 2$ de SSHH. (Centro Cultural Estación Mapocho, 2013) 


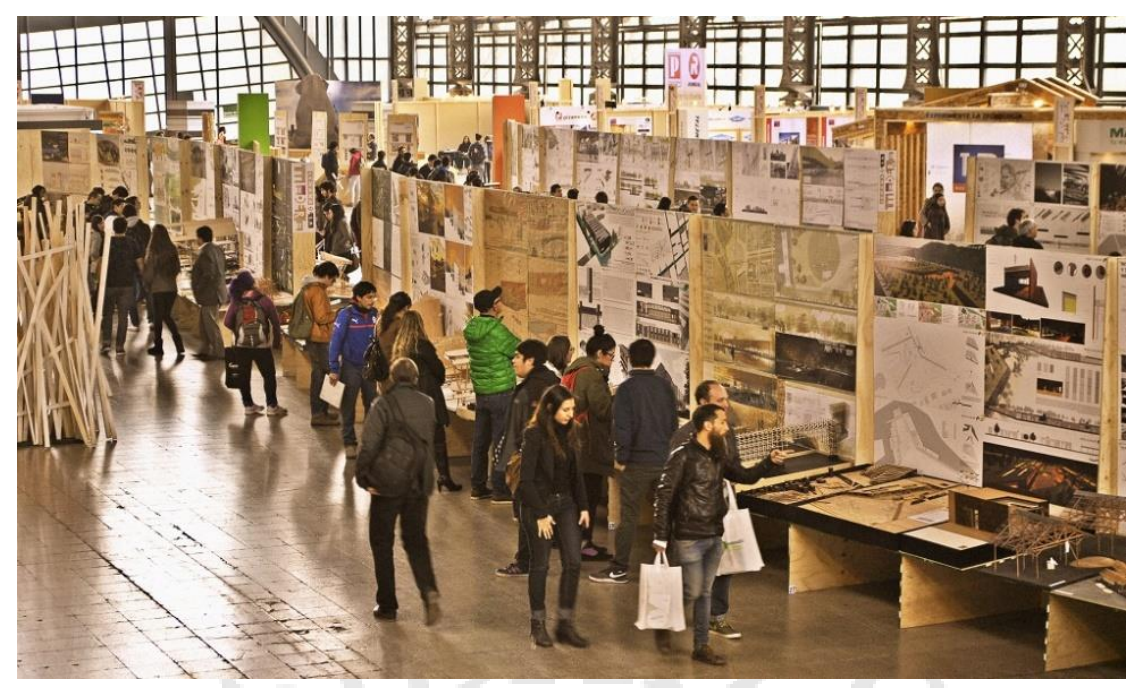

Imagen: Exposición de Arquitectura (Fuente: Estación Mapocho)

El centro cultural Estación Mapocho “conforma un espacio de esparcimiento, recreación y educación que cumple una responsabilidad social beneficiosa para la población en todas las áreas del saber. Su dinámica cultural lo ha transformado en una referencia." (Pachano Olivares, 2009)

En Venezuela, el Centro de Arte de Maracaibo "Lía Bermúdez" es un centro cultural multidisciplinario que ocupa un antiguo mercado. Su gestión se guía por su importante ubicación en el centro de la ciudad, y promueve actividades que fomentan la revalorización y rescate del espacio urbano. "Es decir que no sólo produce y genera actividades y programas culturales en un recinto interno, ... sino que diseña y estimula la mirada de la ciudad como objeto cultural" (Pachano Olivares, 2009) 


\subsubsection{Infraestructura Cultural en Barranco}

En el distrito de Barranco se encuentra una gran parte de la oferta cultural en Lima. Se encuentran cuatro de los principales museos de la ciudad: Museo Pedro de Osma, Museo de Arte Mario Testino (MATE), Museo de la Electricidad y el Museo de Arte Contemporáneo (MAC).

El Museo Pedro de Osma, que cuenta con una colección de piezas virreinales de los siglos XVI, XVII y XVIII, se levantó en la residencia del alcalde de la ciudad Pedro de Osma y Pardo (1912-1914). Hoy cuenta con once salas con piezas de diversos géneros, y una edificación más moderna en la que se realizan exhibiciones temporales de arte, conferencias y presentaciones de libros. (Toro, 2015)

El Museo de Arte Mario Testino, se inauguró en el 2012 en un antiguo rancho de finales del siglo XIX. Tiene una muestra permanente pertenece al fotógrafo peruano Mario Testino, y también realiza exhibiciones temporales de artistas peruanos y extranjeros, además de contar con programas educativos y sociales. (Toro, 2015)

El Museo de la Electricidad fue inaugurado en 1997 y muestra la historia de la electricidad en el mundo y el Perú a través de paneles didácticos. (Toro, 2015)

Estos tres importantes museos en el distrito y la ciudad de Lima se ubican sobre la Av. Pedro de Osma, la misma que conecta el distrito con Chorrillos y pasa por las zonas más emblemáticas de Barranco.

Por otro lado, el museo MAC se encuentra en la avenida Grau, cerca al límite de Barranco y Miraflores. Éste, se inauguró en el año 2013 y es "uno de los espacios con mayor actividad de la capital" (Toro, 2015). Sus instalaciones incluyen tres espacios para diferentes tipos de exhibiciones, así como un parque en el que se desarrollan diversas actividades culturales. 
Asimismo, en el distrito existen numerosas galerías de arte:

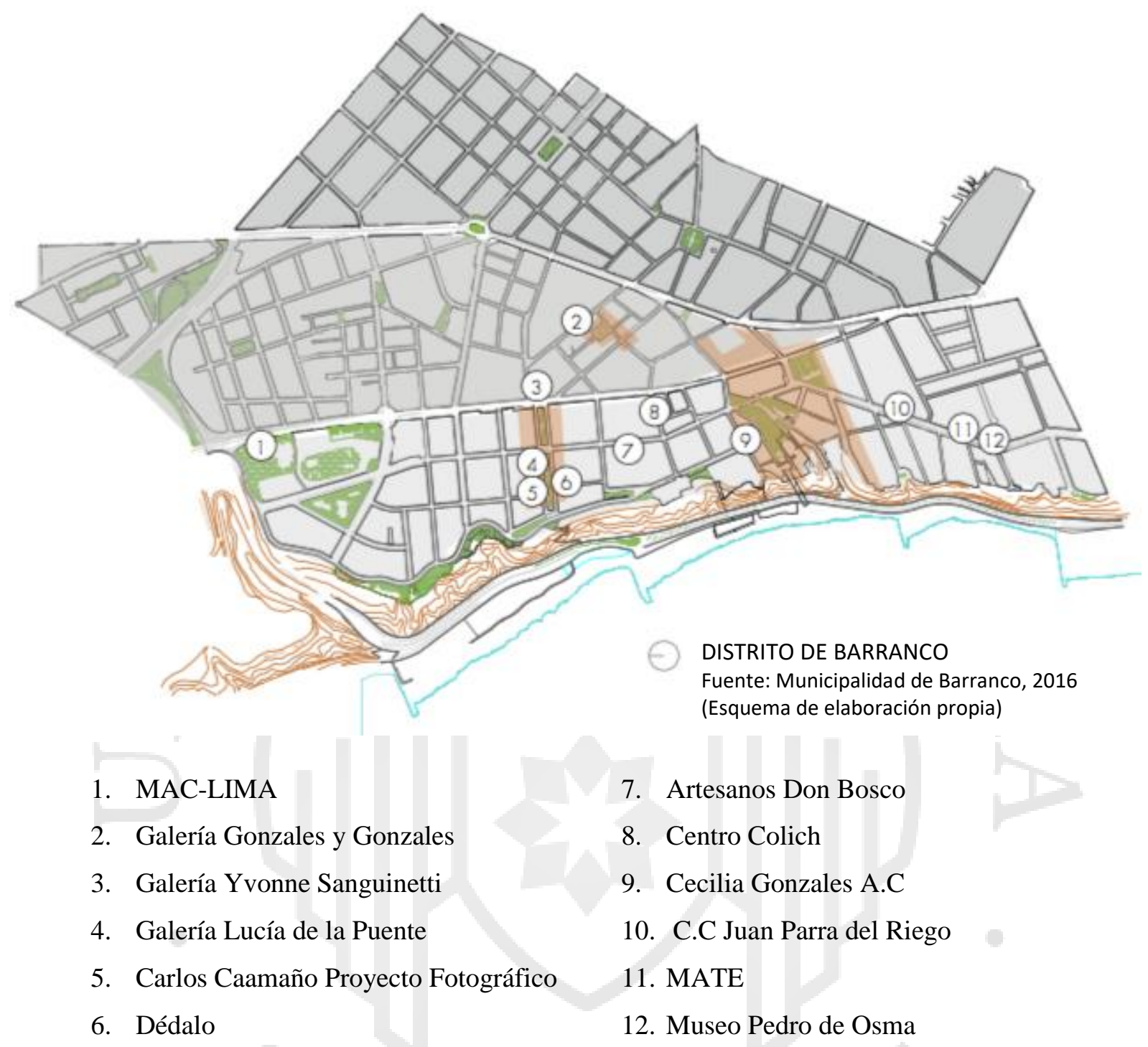

El plano muestra que la mayoría de los centros de gran tamaño, a excepción del MAC, se encuentran ubicados en la "Zona 1"' del distrito. En la "Zona 2", se ubican sólo dos galerías de arte de los 12 espacios culturales, y ninguno en la "Zona 3".

Debido a la presencia de numerosos espacios de oferta cultural en Barranco, este ha desarrollado la imagen e identidad de ser el distrito de vocación cultural de la ciudad. Asimismo, existe una deficiencia de equipamiento cultural de tipo público, que atienda a usuarios de las Zonas 1 y 2 del distrito. Este es uno de los resultados de la fragmentación urbana que se da en el distrito, como lo explica su Plan Concertado de 
Cultura 2016 - 2021. La separación física ha generado desproporción en los equipamientos culturales.

De los museos y galerías existentes, se debe resaltar el programa y trasladar al ámbito público. En un nuevo espacio cultural, se debe ofrecer también galerías de arte, talleres, exposiciones y libre expresión. Incluso, debería generarse una red de equipamientos dentro de la zona.

\subsubsection{Público objetivo}

Actualmente, alrededor del terreno de estudio, encontramos viviendas taller y viviendas de menos de 4 pisos. Sin embargo, la zonificación del entorno inmediato muestra que podrá existir un crecimiento urbano en los próximos años. Gran parte del entorno tiene la condición Residencial de densidad alta, con posibilidad de construir multifamiliares de más de 14 metros. Además, la actual gestión de la Municipalidad de Barranco plantea cambiar en algunos predios la zonificación de vivienda taller por Residencial de densidad alta, para permitir edificios de hasta 20 pisos donde ahora existen viviendas de un piso (ver plano de zonificación). (Cruzado, 2018)

Al momento ya se han construido 3 edificios de más de 10 pisos, contrastando con el resto del perfil urbano. Uno de ellos es el edificio Ser-K, que cuenta con dos etapas. La segunda, es un edificio de 15 pisos y 190 departamentos. El más pequeño tiene $41.00 \mathrm{~m} 2$ y, el más grande, $70.00 \mathrm{~m} 2$ con 3 habitaciones (Construcción y vivienda, 2017). Este se encuentra en una anterior zona de comercio zonal ubicada al este del terreno de estudio, en la Zona 3 de Barranco. 

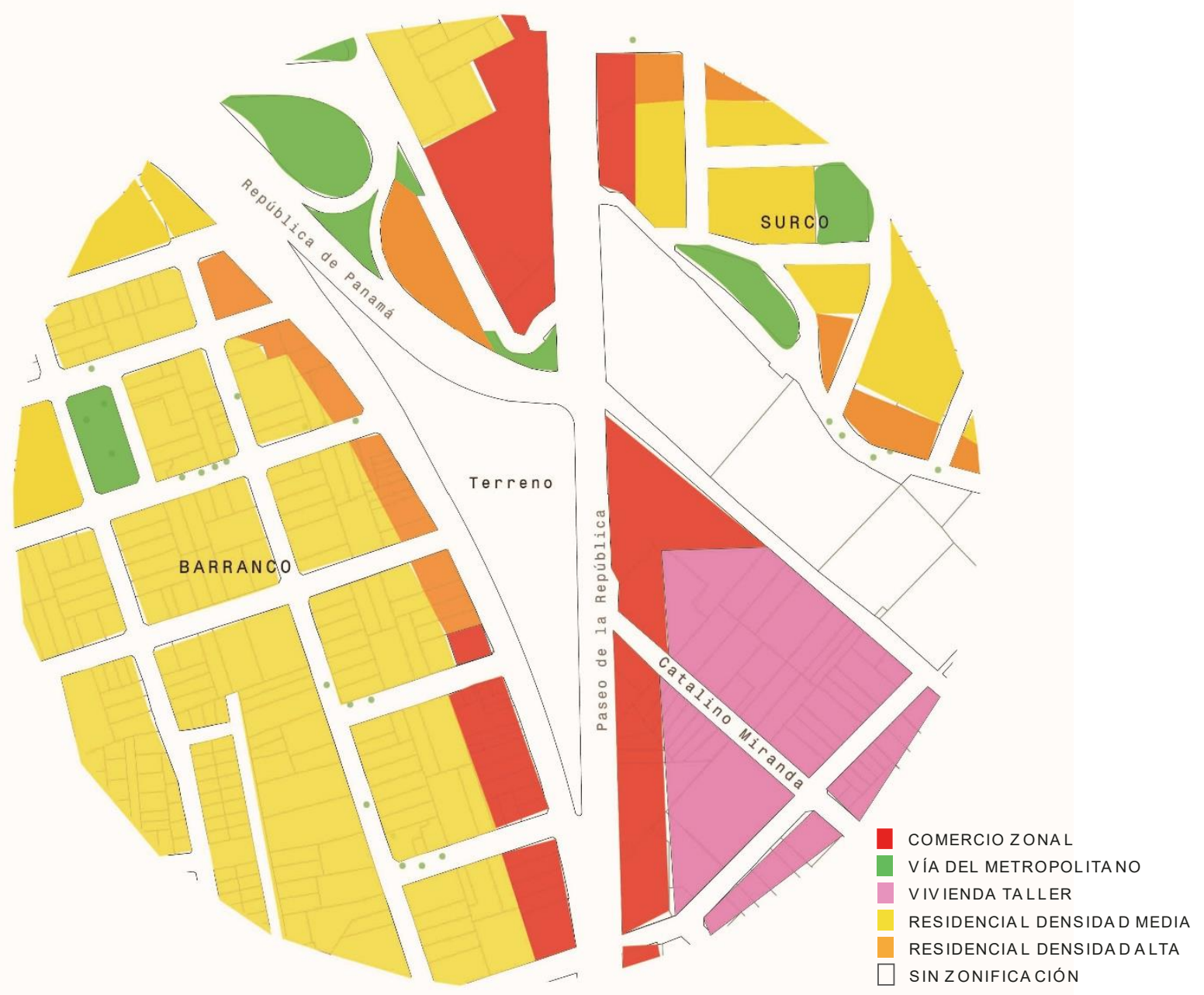

Plano: Zonificación contexto inmediato del terreno. Realización propia, en base a documentos de la Municipalidad de Surco y Municipalidad de Barranco.

$\mathrm{Si}$ asumimos un ritmo acelerado de crecimiento urbano, en algunos años tendremos nuevas familias en el entorno inmediato de estudio, con alturas de más de $45.00 \mathrm{~m}$. Y basándonos en el formato de estos 3 nuevos edificios, dirigidos a los sectores A2, B1, B2 y C, albergarán a más de 2000 familias por cada perfil longitudinal del terreno. 


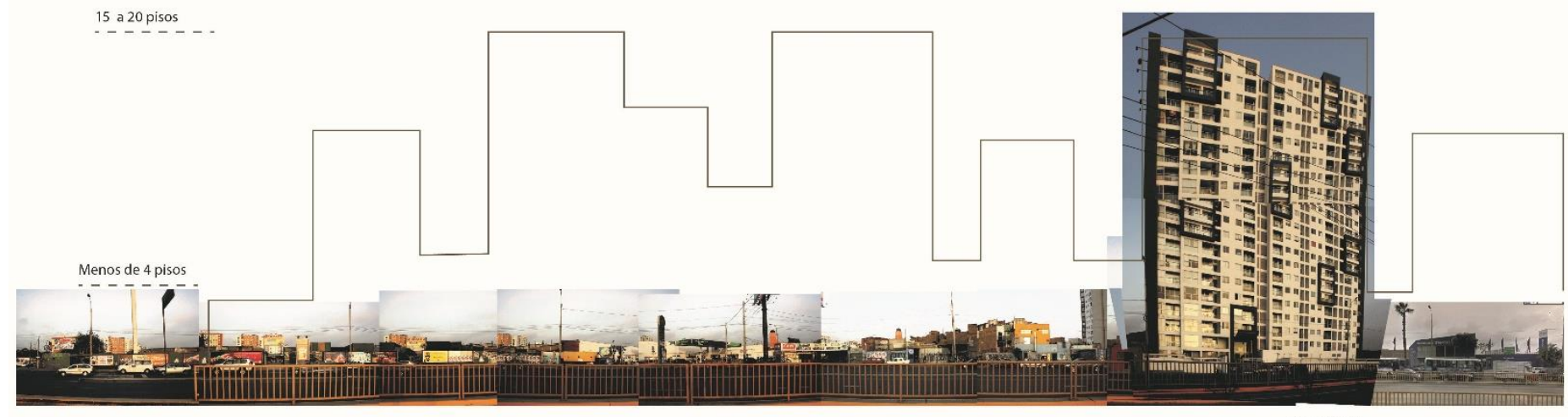

Imagen: Lado Oeste de Terreno - Perfil urbano actual comparado con crecimiento proyectado.

Las nuevas familias necesitarán espacio de esparcimiento, debido al formato de vivienda ofrecido. Y según el espacio de los departamentos, parte del público objetivo son familias nuevas con niños. Además, la densificación de predios y las nuevas alturas se alejan de la escala barrial que respeta la escala humana. El vacío urbano es una oportunidad para generar un descanso dentro de altas construcciones.

Por otro lado, existe una problemática dentro del barrio, que comprende la micro comercialización de droga, alcoholismo callejero, pandillaje y robos al paso. Se les considera problemas de convivencia vecinal, pues se diferencia de otros tipos de delincuencia en la ciudad. A partir de esto, se busca implementar servicios en el vacío urbano que genere oportunidades de mejora social.

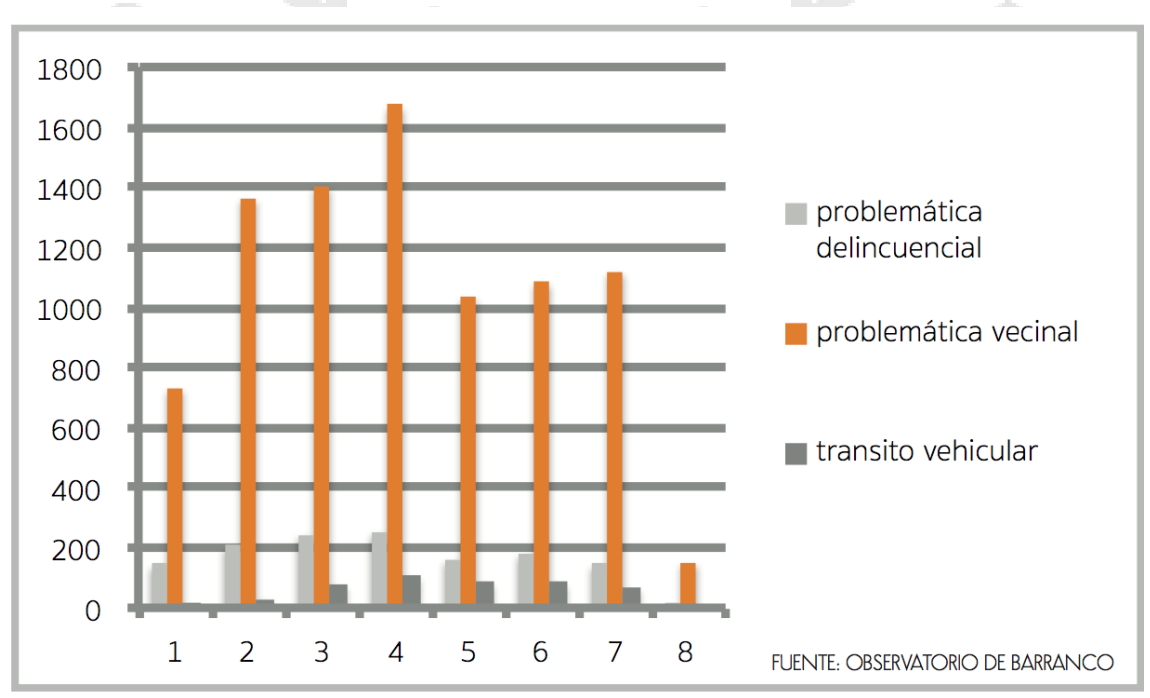

Gráfico: Casos reportados a la Comisaría de Barranco al año (2015) 
La división social entre barrios de un mismo distrito genera una exclusión social preocupante dentro de un mismo espacio político.

"La implementación del Plan de Cultura de Barranco 2016 -2021 constituye una oportunidad clave para aportar a la reducción de la delincuencia y violencia desde el arte y la cultura; tomando en cuenta además que el Plan Local de Seguridad Ciudadana incluye el concepto de convivencia y la ejecución de actividades culturales como parte de sus estrategias. Y así mismo es una oportunidad para generar espacios de encuentro e intercambio en los espacios públicos que aporten a la integración vecinal”. (Municipalidad de Barranco, 2015)

En los capítulos siguientes, se graficará la influencia positiva del implementar planes culturales en el estilo de vida de niños, jóvenes y adultos. Por ende, los habitantes del entorno inmediato actual son también usuarios clave para la implementación de un espacio que brinde actividades y servicios complementarios, como oficio o entretenimiento.

Mediante la organización Mi Entorno Perú, se analizó la población en un radio de $1 \mathrm{~km}$ alrededor del terreno. A continuación, los resultados.

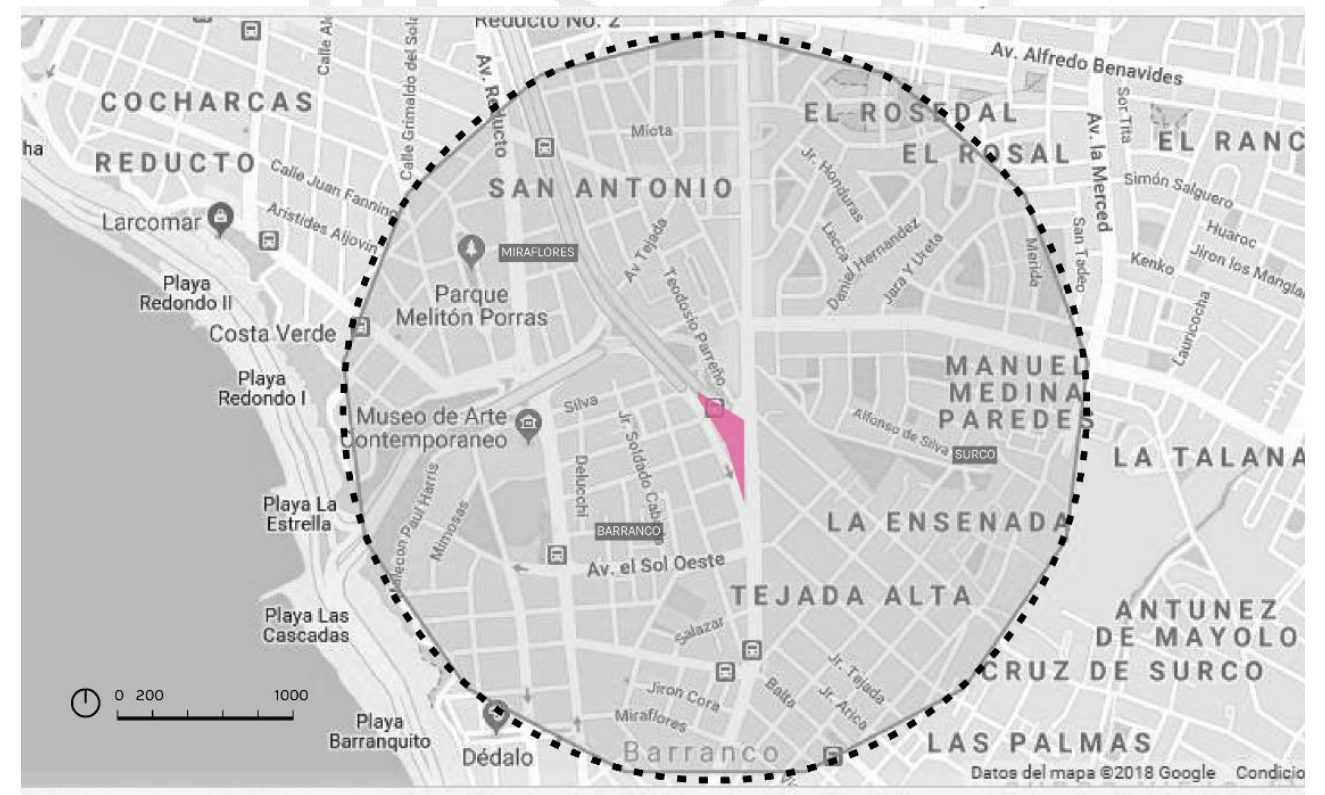

Mapa: Población tomada en cuenta en 1 radio de km del terreno. 


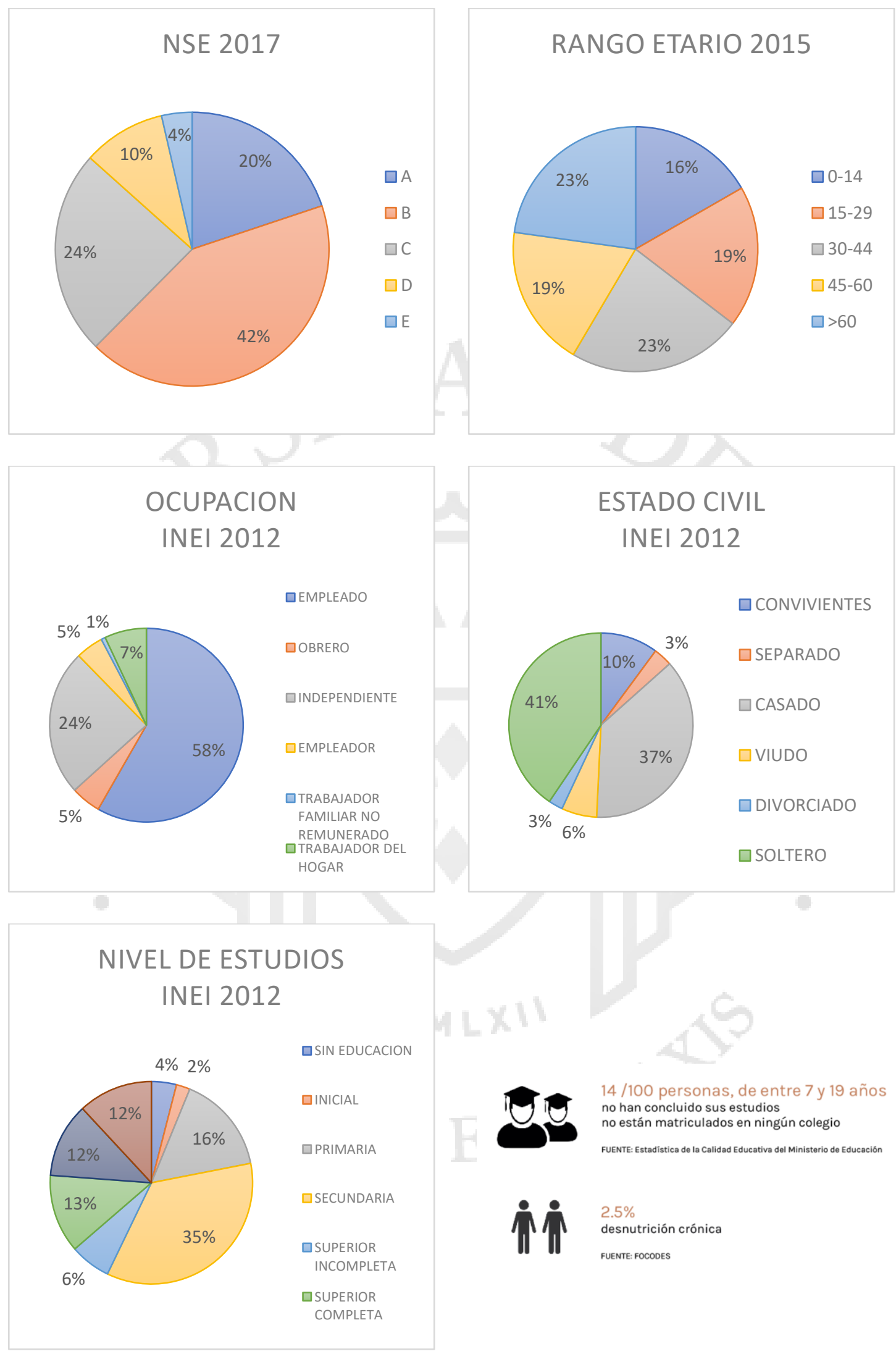


Finalmente, el terreno se encuentra sobre una vía metropolitana, con un sistema de transporte público que atiende aproximadamente 700 mil viajes diarios. Esta es una herramienta para impulsar que, ciudadanos de todo Lima, puedan hacer uso del equipamiento cultural y la plaza pública como espacio de educación, recreación u ocio.

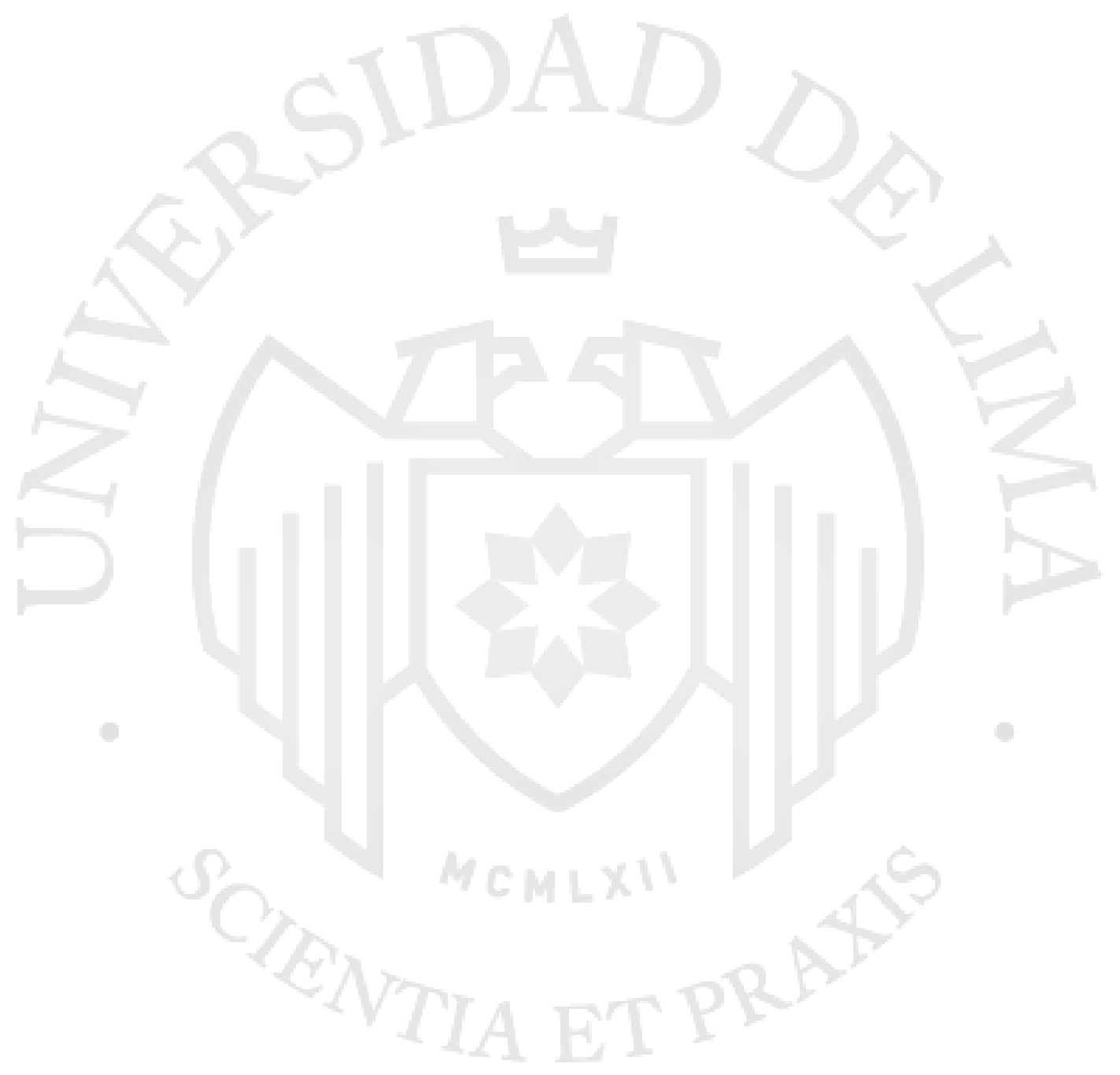




\subsection{Conclusiones Parciales}

Desde antes de los incas, el hombre se ubicaba alrededor del eje de los ríos y acequias, creando asentamientos separados por este elemento. Posteriormente, algunos de estos ejes se convirtieron en caminos para recorrer la ciudad y sirvieron de guía a la actual trama urbana. En el caso de Barranco, las actuales vías del Metropolitano y la Avenida Grau, fueron caminos incas y perduran como parte de la problemática urbana del distrito, pues las tramas siguen el ángulo de cada camino, sin coordinar entre ellas.

El terreno de estudio, aledaño a la Estación Plaza Las Flores, no tiene una historia detrás. Es un espacio vacío que produjo el encuentro de dos tramas urbanas paralelas y diferentes en Barranco. La única función que tuvo antes de la construcción de la Estación fue la de Mercado de Flores informal. Actualmente, el vacío no es aprovechado y tiene zonificación de berma central, sin uso ni área verde.

En Lima Metropolitana surgen planes metropolitanos de desarrollo urbanos que, en casos como el de PLANMET, se ven interrumpidos por el crecimiento urbano informal acelerado y una rápida densificación. Dentro de ellos hay lineamientos de ordenamiento vial que reclaman el espacio para movilidad en la ciudad. Estos planes, desde 1970, han tenido cada vez lineamientos más humanos y sociales. Sin embargo, la manera de abordar sigue siendo desde el transporte y no la accesibilidad como un concepto que engloba otros tipos de movilidad. Son escasas las menciones y planes en Lima Metropolitana y Callao respecto al peatón o ciclista.

Las zonas 2 y 3 de Barranco son ejemplos de ello. La vía del Metropolitano sirve a la ciudad a nivel macro, pero la escala física barrial ha sido dejada de lado. Sin embargo, dicho medio de transporte tiene una eficacia comprobada para cierto porcentaje de la ciudad y es importante mantenerlo. Este sistema es el regreso del BRT en Lima como respuesta a una demanda de transporte masivo rápido dentro de una ciudad cuyo primer problema en agenda pública es el caos vehicular, la informalidad, contaminación y accidentes que el mismo causan. La solución va de la mano con una descentralización de servicios que todos los planes urbanos de Lima han buscado abordar a través de los años. 
Tanto la descentralización, como un sistema de transporte público eficiente, son necesarios para resolver problemas de movilidad, congestión vehicular en Lima y división urbana. Además, la desigualdad en implementación de equipamientos urbanos y dificultad en llegar a ellos genera una diferencia social y contaminación visual y sonora.

La implementación de equipamiento urbano y espacios públicos de calidad debe ir de la mano con una movilidad accesible y cómoda que acerque a la mayor cantidad de gente posible. El uso de un centro cultural no debe verse limitado por la distancia de los viajes o por la falta de una red de transporte. Es por eso, que ubicar un centro cultural junto a una estación de transporte importante, facilitará la llegada de interesados desde varios distritos de Lima que carecen de ofertas culturales y artísticas. Además, el Metropolitano cuenta con un flujo constante de viajeros, quienes podrán aprovechar la parada y consumir actividades en calidad de espectador o visitante.

A nivel micro y barrial, dicha implementación es una herramienta para regenerar la relación entre dos zonas conflictivas, a través de un vacío urbano. Finalmente, este vacío puede convertirse en un espacio de identidad barrial que conecte las Zonas 2 y 3 de Barranco, además de albergar a todos los habitantes de la ciudad. 


\section{CAPITULO III}

\section{Marco Teórico}

\subsection{Base teórica}

\subsubsection{Ciudad y espacio público}

\subsubsection{Usos sociales del espacio público}

Para conocer la importancia social del espacio público, primero se debe acordar a qué se refiere la expresión 'espacio público'. Es difícil entender el espacio público bajo un concepto absoluto, pues su definición está sujeta a las percepciones y experiencias únicas de cada individuo.

Dos de las definiciones que ofrece la RAE de espacio son: "Extensión que contiene toda la materia existente" y "lugar entre dos cuerpos" (RAE, s.f.). Se puede entender, entonces, que un espacio es un lugar, situado en el vacío generado por la distancia entre dos cuerpos (edificios), que contiene la materia existente.

Por otro lado, la RAE define público como "Conjunto de personas que forman una colectividad" y como algo "conocido o sabido por todos" (RAE, s.f.). A consecuencia: público es aquello conocido por todas las personas que forman una colectividad.

Asimismo, la unión de ambos términos no es únicamente gramatical, pues el concepto de espacio público trasciende las definiciones de sus partes, pero el conocerlas ayuda a entender que este concepto engloba aquello que se refiere a un lugar y a aquello que se refiere a las personas.

La cualidad pública de un espacio, entonces, es aquella que lo acerca a las personas y, por lo tanto, a la sociedad. De esta manera es que los espacios públicos tienen un valor importante en una ciudad. 
En "Espacio público, ciudad y ciudadanía", Borja explica que el concepto de espacio público como un lugar específico, en el que se desarrollen actividades, y se den intercambios sociales, es una adaptación de la tradición real del espacio público que lo valora como organizador de la ciudad.

"La tradición urbanística que heredamos no hace del espacio público un elemento especializado y refugio de peatones en un tejido urbano concebido como la suma de edificios y vías para vehículos, sino que se identifica con la misma forma de la ciudad y está presente en toda ella" (Borja, 2000, pág. 46).

En el siglo XX, se desvirtuó el espacio público como regulador de la ciudad y se convirtió “en un elemento especializado, un 'equipamiento' más de la ciudad, que a menudo incluye espacios segregados y monovalentes" (Borja, 2000, pág. 48). De esta manera, se pierden sus dos funciones principales:

- "Dar forma y sentido al conjunto de la ciudad, garantizar trayectos y elementos de continuidad y resaltar las diferencias entre edificios, manzanas y áreas urbanas.

- Ordenar las relaciones entre edificios, equipamientos, monumentos, solares, vías, espacios de transición y espacios abiertos" (Borja, 2000, pág. 49).

Es su función organizadora la que da al espacio público su poder de unificar o dividir a las personas y sociedades.

Por otro lado, en una entrevista para la revista mexicana Disonante, Jan Gehl define el espacio público por su rol: “[...] el espacio público siempre ha tenido tres funciones tradicionales: el lugar de reunión de las personas, el lugar de mercado en el cual puedes intercambiar servicios y productos, y el espacio de conexión" (Gehl, Socialización en el espacio público, 2014). Asimismo, en "La humanización del espacio urbano" resalta y explica la importancia de la función social de los espacios públicos:

"La oportunidad para reunirnos y realizar actividades cotidianas en los espacios públicos de una ciudad o un barrio residencial nos permiten estar entre otras 
personas, verlas y oírlas, así como experimentar cómo otra gente se desenvuelve en diversas situaciones" (Gehl, La humanización del espacio público: la vida social entre los edificios, 2006, pág. 23).

Tanto Gehl, como Borja, le atribuyen al espacio público el poder de generar impactos en la personas y sociedades en las que se encuentran. Sin embargo, lo proponen desde enfoques diferentes. Como se mostró previamente, Borja explica el valor social de los espacios públicos desde su sol espacial en una ciudad; mientras que Gehl, lo hace desde la oportunidad de reunir personas en él.

Para el proyecto, se tomarán en cuenta ambas definiciones de espacio público. Sin embargo, se optará por una función compuesta, que responde al contexto físico y social actual del momento de la investigación. Deberá, físicamente, aportar a la ciudad como ordenador urbano; y, socialmente, brindar a la gente un lugar de intercambio y valor comunal donde desarrollar actividades.

\subsubsection{Ciudad vital, sostenible, segura y sana.}

Se dice que "primero moldeamos a las ciudades, y luego ellas nos moldean a nosotros". Durante el siglo XIX existían los bulevares ${ }^{17}$ culturales, que proveían a los habitantes de anchas veredas, numerosos cafés y paseos que poblaban las calles. Sin embargo, en el siglo $\mathrm{XX}$, se dispuso de todo el espacio libre al tránsito y estacionamiento vehicular, acabando con la preferencia peatonal. (Gehl, Ciudades para la gente, 2004)

Muchas ciudades se encuentran en camino a revertir esta situación, mejorando "las condiciones de circulación para los peatones al no darle prioridad en su gestión al transporte automotor" (Gehl, Ciudades para la gente, 2004, pág. 4) Se han tomado medidas de seguridad vial y se ha introducido el tráfico de velocidad moderada en ciertas vías, pero no es una medida suficiente.

\footnotetext{
${ }^{17}$ Los sistemas de bulevares surgen en París. Son amplias aceras arborizadas e iluminadas donde el mobiliario urbano conformaba un nuevo espacio público en la calle.
} 
Actualmente, el urbanismo debe pretender retomar las antiguas costumbres y regresar la identidad a una ciudad mediante sus espacios públicos. Estos son, para Gamboa Saper (2003), un bien cultural. La tendencia de retomar centros históricos en los últimos años viene de la mano con recrear la identidad ciudadana y colectiva que ayuda a una convivencia vital, sostenible, segura y sana.

Es básico hacer énfasis en la medida y escala humana al proyectar la ciudad. Al incrementar el bienestar de los peatones y de los ciclistas, se logran cuatro objetivos principales en una ciudad: vitalidad, seguridad, sostenibilidad y salubridad. (Gehl, Ciudades para la gente, 2004)

Una ciudad vital es aquella donde la mayor cantidad posible de gente camina, usa bicicleta y reside dentro de la porción urbana de la ciudad. Para ello, es "importante tener espacios públicos ricos y variados en cantidad, como así también poder generar oportunidades para encuentros sociales y ofrecer propuestas culturales" (Gehl, Ciudades para la gente, 2004, pág. 6). Esto contrasta con las condiciones urbanas que el Movimiento Moderno impone, donde los espacios públicos sólo cumplen con una función determinada.

Asimismo, una ciudad segura necesita de los espacios públicos atractivos, ricos y variados para alentar a sus ciudadanos a compartir y conocerse dentro de un espacio urbano determinado. La ciudad sostenible, a su vez, debe presentar un buen sistema de transporte público que funcione en conjunto con la red de atractivos espacios públicos y facilitar la movilidad a escala humana y peatonal. Los costos (comparado con otras inversiones sociales) de tener en cuenta la escala humana en el diseño urbano son tan bajos, que cualquier ciudad puede incluirlos en su infraestructura con un buen planeamiento. (Gehl, Ciudades para la gente, 2004)

Un ejemplo de cambio de prioridades es la ciudad de San Francisco. Tras el terremoto de 1989 una de sus vías vehiculares principales, Embarcadero, sufrió tales daños que debió ser clausurada. Al desaparecer una de las principales arterias de la ciudad, los ciudadanos debieron modificar su comportamiento y rutina sin ella, y funcionaba bien. Por ello, antes de iniciar con las obras de reconstrucción, se replanteó la antigua autopista de varios niveles como un nuevo "bulevar urbano repleto de 
vegetación, con anchas veredas y un tranvía" (Gehl, Ciudades para la gente, 2004, pág. 11). Este caso nos enseña que las ciudades que nosotros moldeamos, nos moldean. Bajo esa premisa, podemos revertir el efecto de la modernidad que nos privó de espacios públicos ricos y de calidad cultural.

Por otro lado, en Copenhague encontramos una ciudad dominada por los ciclistas. Esto se debe a un conjunto de políticas y condiciones que lo fomentaron. Durante el primer año de cambio y reducción de parque automotor, "los peatones aumentaron en un $35 \%$... Era más cómodo caminar y había más espacio para hacerlo" (Gehl, Ciudades para la gente, 2004, pág. 13). Por casos como este, donde el urbanismo defiende desde su inicio al peatón y su escala "ya no sorprende encontrar que existe una relación directa entre alentar un comportamiento y ver un cambio en los patrones de uso, referida en este caso a la conexión entre el tránsito peatonal y la vida urbana" (Gehl, Ciudades para la gente, 2004, pág. 12) Es decir, con mejores condiciones para la vida urbana, habrá más vida urbana. Entonces, al "alentar a las personas al pedestrismo, la vida urbana aumenta decididamente" (Gehl, Ciudades para la gente, 2004, pág. 15).

En Melbourne de 1980, el conjunto de edificios de oficina era inservibles y sin vida. Sin embargo, se generaron políticas e instaló el concepto de Melbourne como 'ciudad amigable y verde' mediante plantación de árboles y generar sombra en las veredas. Además, iniciativas culturales como "vea arte en la ciudad" y la instalación de la adecuada iluminación para las horas oscuras del día, llevaron a un programa urbano que invitó a los ciudadanos a salir a las calles, darles vida y uso. Claramente, las autoridades cumplieron la función de dar una razón de caminar y permanecer en la ciudad a sus peatones. "Las actividades de permanencia también han aumentado de forma dramática. Las nuevas plazas... ofrecen nuevas y atractivas posibilidades de recorrer y permanecer en la ciudad, mientras que el nivel de actividad se ha triplicado en los días laborales" (Gehl, Ciudades para la gente, 2004, pág. 16)

A través de los años, el espacio público de las ciudades ha variado según lo que los urbanistas consideraban las necesidades de la época. Esto se debía al cambio de moda, evolución o aparición de nuevas costumbres y cambios demográficos en la población, que modificaban los requisitos en la forma de urbanización. 
"El espacio público es ante todo un concepto urbano, es decir que está y ha estado relacionado con la ciudad, pues es allí donde surgió. Es en la ciudad, lugar de la civilización y la cultura, aquel dispositivo topográfico y social capaz de hacer eficaz al máximo el encuentro y el intercambio entre los hombres" (Gamboa Saper, 2003, pág. 13)

Este espacio colectivo debe ser considerado el más importante de la ciudad pues, gracias a él es que, las ciudades se diferencian una de la otra. Al ser espacios para desarrollar actividades humanas en sociedad, se implementan en base a la comunidad en la que se encuentran. En el contexto urbano, el espacio público es un lugar de encuentro que se diferencia al perfil urbano de viviendas y edificios en tipología de construcción y emplazamiento. A diferencia del espacio privado, su arquitectura debiera invitar al usuario mediante niveles de porosidad y permeabilidad, ya fuese un espacio abierto o construido.

Por otro lado, el espacio público es donde se desarrollan actividades culturales, de identidad de ciudad y comunidad; es allí donde se vierte la particularidad de sus habitantes. (Gamboa Saper, 2003)

Durante el período de la modernidad ${ }^{18}$, se generan nuevas necesidades y tendencias en uso de la ciudad. Se urbanizó considerando espacios públicos y equipamiento limitado y exclusivo a ciertas actividades en particular. Esto provocó distanciamiento entre infraestructuras de diferente función, como laboral, habitacional y recreacional. Bajo este concepto de ciudad, las personas deben caminar y atravesarla más. Pero, el propósito de caminar ya no es de curiosidad y recreación; actualmente se camina con el fin de transitar y llegar.

En el libro Muerte y Vida de las Grandes Ciudades, Jane Jacobs (1961) menciona la importancia de no continuar con las tendencias del Movimiento Moderno, que, al

\footnotetext{
${ }^{18}$ Época dominada arquitectónica y urbanísticamente por el Movimiento Moderno que, “apoyándose en las utopías del Siglo XIX y consciente de los problemas de congestión, hacinamiento y 'desorden"” (Gamboa Saper, 2003) proponen un nuevo orden de ciudad, donde cada actividad social tiene un lugar específico.
} 
separar los usos sociales, destruía la vida urbana. Esto daba como resultado ciudades sin personas, vida social, ni actividades.

El propósito de cambiar de tendencia es regresar a una ciudad que valore el carácter independiente que los espacios públicos aportan. Hoy en día, permanecemos con un diseño urbano antiguo, donde "la ciudad moderna no se recorre, como se hacía con los bulevares..., sino que se atraviesa; no se recorre porque cada vez son más reducidos los lugares (significación y orden formal) que puedan tener un sentido social de relación e intercambio." (Gamboa Saper, 2003, pág. 16)

\subsubsection{La ciudad como lugar de encuentro.}

"Durante muchos años, el tráfico peatonal fue tratado como una forma de circulación que pertenecía a la órbita de la planificación del transporte. Bajo esta forma de operar, las sutilezas y las oportunidades que brinda la vida urbana fueron virtualmente ignoradas... se hablaba de 'capacidad de vereda', 'tráfico de a pie', 'flujos de peatones' y 'cruces seguros de intersecciones'... Pero en la ciudad, ¡caminar es mucho más que solo circular! Hay contacto entre las personas y la comunidad..." (Gehl, Ciudades para la gente, 2004, pág. 19)

Caminar es mucho más que circular; durante una caminata existen intercambios, paradas, observaciones, comportamientos humanos de sociabilización voluntarios e involuntarios. El flujo peatonal es diferente al flujo vehicular pues, las actividades y actitudes de un individuo no necesariamente se reflejan al conducir un automóvil; ni la escala de movilidad es la misma. Por ello, debe tenerse en cuenta el flujo peatonal al igual que el vehicular; no se le puede incluir dentro de él como un factor más.

Existen tres tipos de actividades que los humanos realizan: obligatorias, opcionales y sociales, y, se realizan distinto a pie o en auto. Las primeras son aquellas integradas a nuestra vida, y frente a las cuales no tenemos opción ni decisión alguna; éstas se deben realizan bajo cualquier condición. Las segundas, son recreativas y tienen como prerrequisito una calidad espacial y de ciudad. Y, las terceras, son aquellas que incluyen contacto entre las personas y pueden ocurrir en cualquier parte de la ciudad. (Gehl, Ciudades para la gente, 2004) 
Sin embargo, es importante dar confort a los diferentes espacios urbanos públicos, sin importar el tipo de actividad que se realice en él. A medida que se le proporciona calidad y condiciones favorables de espacios a la ciudad, las personas desarrollan una necesidad de disfrutar actividades al aire libre. Si bien el clima es un factor determinante, el estado físico de un espacio público y urbano aporta de manera importante. "Para alentar a la gente a usarlos también hay que incluir protección, seguridad, y una razonable cantidad de espacio y equipamiento adecuado que provea un atractivo visual." (Gehl, Ciudades para la gente, 2004, pág. 21) Es importante que lo público y urbano sea vital y variado. Mientras se provea de espacios de recorrido, estancia y encuentro adecuados, las actividades obligatorias serán confortables y menos estresantes para los ciudadanos. Además, éstos llevan a un mayor y mejor uso del espacio colectivo al realizar actividades recreacionales y sociales. El uso o desuso de un espacio no debe condicionar su calidad ya que, es posible que la ciudad nos amolde a ella, siempre y cuando invite a un espacio que considera a los usuarios.

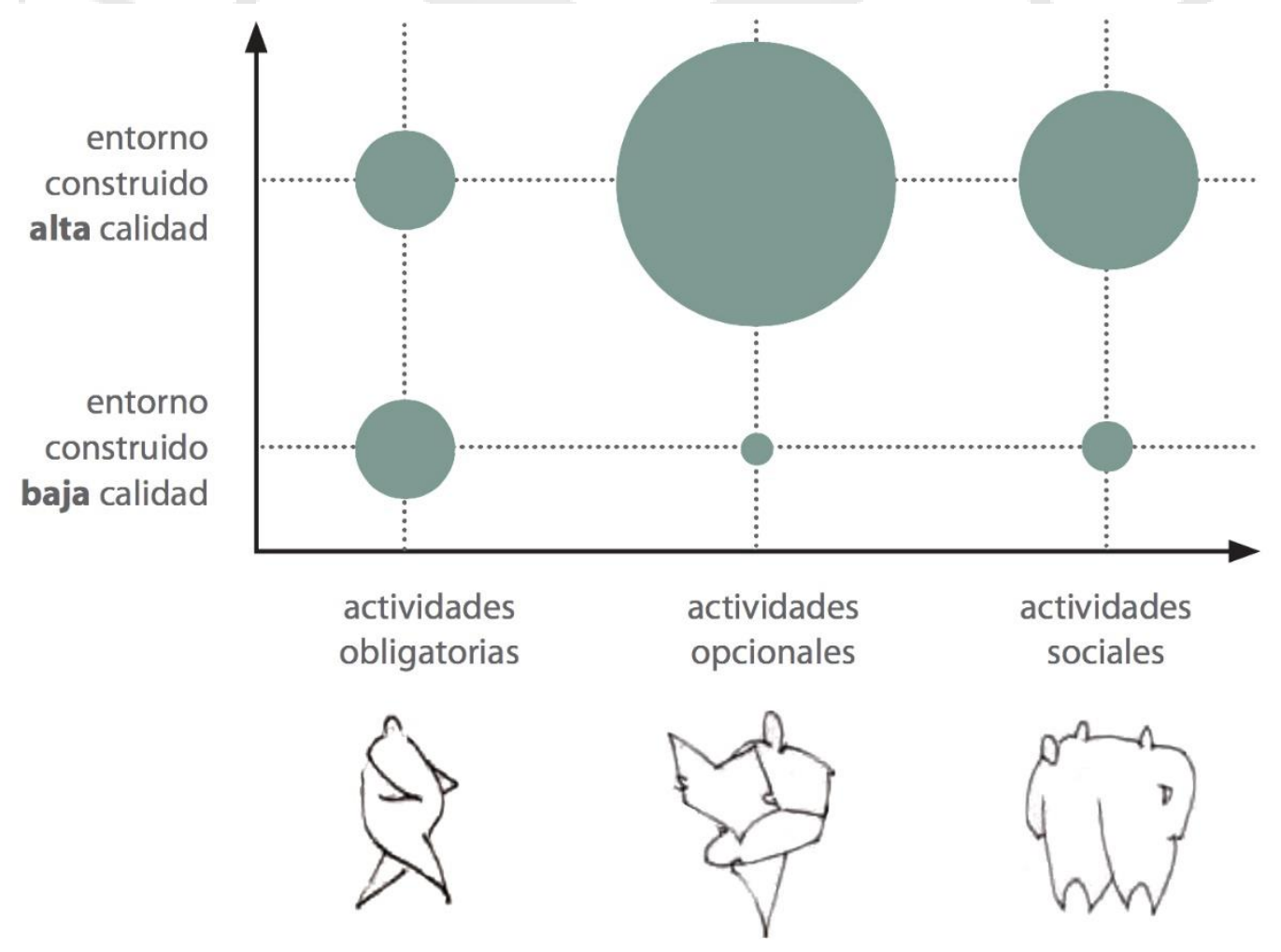

Gráfico: conexión entre actividad al aire libre y el estado del entorno. (Gehl, Ciudades para la gente, 2004, pág. 21) 
Si se refuerza la vida urbana, se genera una mayor actividad social dentro de un mismo entorno. Dentro de las actividades sociales encontramos dos tipos: las de carácter pasivo y las de carácter activo. Las primeras se limitan a mirar y escuchar lo que ocurre en el entorno. Sin embargo, las segundas son de contacto directo, donde los actores intercambian palabras, saludos y comidas. Esto se inclina hacia una ciudad segura, donde un adecuado espacio urbano podría provocar que los peatones se reconozcan. Además, al surgir temas de conversación e intereses en común, estos espacios se convierten en unos de permanencia y encuentro, donde las personas pasan el tiempo compartiendo con los demás. Finalmente, estas actividades se pueden catalogar como comunes o planeadas: ir de compras, asistir a fiestas populares, procesiones tradicionales y manifestaciones. (Gehl, Ciudades para la gente, 2004)

"La seguridad, la confianza, el fortalecimiento de los lazos sociales, la democracia y la libre expresión son concepto clave a la hora de tratar de describir qué tipo de ideales están atados a esta idea de la ciudad como lugar de encuentro." (Gehl, Ciudades para la gente, 2004, pág. 29)

Un espacio urbano de calidad debe permitir las actividades sociales que funcionan para evidenciar las particularidades de cada ciudad. Así, se conocerá qué diferencia a este grupo de gente de los demás y qué los une como comunidad. Además, es importante que el espacio público tenga la calidad de público, como su nombre lo dice. En él, se debe mantener un respeto y concepto de ciudadanía implantada desde un inicio. Para eso, el espacio debe hablar por sí mismo y significar para las personas un bien común.

\subsubsection{Gestión cultural y gestión urbana}

Las actividades culturales y la vida en ciudad están intrínsecamente relacionadas. Para lograr una vida urbana cohesionada e inclusiva, todos los ciudadanos deben tener conciencia de sus deberes y derechos. 
"Incidir en el imaginario colectivo desde el arte y la cultura, fomentando una mayor conciencia de deberes y derechos ciudadanos para reducir formas de exclusión y discriminación social.” (UNESCO, 2008)

La Agenda 21, es un documento realizado por La Organización de las Naciones Unidas para la Educación, la Ciencia y la Cultura (UNESCO) que explica la relación entre la cultura y los derechos humanos. Este documento propone una serie de estrategias y lineamientos para generar cambios en las sociedades a través de actividades culturales, dándoles un valor importante en la vida de todas las personas pues se afirma que: "la diversidad cultural es tan necesaria para el género humano como la biodiversidad para los seres vivos" (UNESCO, 2008)

Actualmente, cerca de 300 ciudades en el mundo están asociadas a la Agenda 21. Dentro de los lineamientos básicos de la Agenda2, está promover el uso de los espacios públicos, pues reconocen que estos son bienes colectivos que les pertenecen a todos, y encuentran en ellos un potencial uso social que contribuirá con la convivencia e integración vecinal.

En Lima, la Municipalidad de Barranco a adaptado los lineamientos de la Agenda 21 y ha elaborado un plan cultural a partir de él. Este, es un saludable esfuerzo local en potenciar el espacio público y explotar la vocación cultural de un distrito para generar los cambios sociales que este necesite.

"Para que estas acciones tengan un efecto importante dentro del distrito es imprescindible seguir trabajando en los espacios públicos. Las plazas, los parques, las calles deben dejar de ser únicamente lugares de paso y volver a convertirse en lugares de encuentro para los vecinos y vecinas. En ese sentido la cultura y el arte son aliados estratégicos para darles vida, convirtiéndolos en ambientes propicios para la integración vecinal, para reducir la inseguridad ciudadana y para que los vecinos puedan ejercer plenamente sus derechos culturales" (Municipalidad de Barranco, 2016). 


\subsubsection{Activar espacios públicos}

Se ha explicado previamente la importancia de los espacios públicos para lograr una ciudad inclusiva y cohesionada; también se ha señalado que una estrategia importante para generar cambios sociales es el equipamiento cultural, puesto que incide sobre el imaginario colectivo de las personas y eso afecta su forma de relacionarse entre si y con la ciudad.

Asimismo, como explica Jan Ghel en su libro Ciudades para la Gente, se debe pensar en formas de mantener los espacios públicos activos y con un flujo de usuarios contaste, puesto que "la gente se concentra donde pasan las cosas y espontáneamente busca la presencia de otros" (Gehl, Ciudades para la gente, 2004, pág. 58)

Angelique Trachana, arquitecta e investigadora de la Universidad Politécnica de Madrid, explica que las estrategias para activar espacios públicos deben adecuarse al estilo de vida actual de las personas.

\footnotetext{
"La velocidad con la que nos vemos obligados a desplazarnos constantemente en este modelo de ciudad no nos permite ninguna relación con el entorno, sin embargo, el uso de tecnologías telemáticas (internet, teléfono) nos permite recibir información en este entorno en tiempo real." (Trachana, 2013)
}

En ese sentido, ella cuestiona el espacio público tradicional; pues explica que, hoy en día, los debates e intercambios sociales, públicos y políticos se llevan a cabo en espacios virtuales. Esto se debe a que el internet ofrece escenarios alternativos para las relaciones sociales.

Esta realidad de la actualidad podría significar que los espacios públicos físicos ya no son el espacio en el cual se forman las relaciones entre ciudadanos y que estos podrían quedar vacíos. Sin embargo, esto puede ser considerado como una oportunidad para crear las condiciones necesarias para fortalecer las relaciones de socialización que ocurren en los espacios virtuales.

Una estrategia para llevar las relaciones virtuales al espacio físico es permitir al espacio público ser altamente flexible. De esta manera no se acotan las funciones del 
espacio según su equipamiento o mobiliario, sino que está disponible para ser intervenido por usuarios que ya están desarrollando actividades sociales que el internet les permite tener. (Trachana, 2013)

Por otro lado, y de forma más tradicional, los espacios públicos se pueden mantener activos con espacios comerciales diversos, puesto que estos mantienen el flujo de los usuarios. "La aparición de nuevos espacios públicos requiere nuevos 'equipamientos civiles': [...] sobre todo nuevas funciones comerciales y culturales dedicadas al tiempo libre, al encuentro y al intercambio, tales como cafés, teatros, grandes almacenes y pasajes comerciales"'(Gamboa, 2003)

\subsubsection{Agrupar equipamientos de uso distinto}

Como se explicó previamente, el espacio público es fundamental para lograr una vida urbana saludable, pues es ahí donde se genera la mayor y más diversa cantidad de intercambios entre personas. En ese sentido, "si las actividades y las personas se agrupan, es posible [...] que los acontecimientos individuales se estimulen mutuamente" (Gehl, 2006, pág. 93).

Como señala Jan Gehl, se debe generar diversos estímulos para logar que las personas salgan de sus casas:

\footnotetext{
"Salimos por una razón plausible y racional: ir de compras, dar un paseo, tomar el aire fresco, comprar el periódico, lavar el coche, etcétera. Quizás sea erróneo hablar de que salir a comprar es un pretexto para el contacto y estímulo, porque muy poca gente que sale a comprar aceptará el hecho de que la necesidad de contacto y estímulo tiene un papel en sus planes de compra". (Gehl, 2006, pág. 127)

En el marco de esta investigación que propone descubrir de qué manera se debe intervenir un espacio desatendido y fracturado de la ciudad para convertirlo en un animador urbano en su entorno, el juntar diversas actividades en el supone una gran oportunidad para
} alcanzar un mayor alcance. 
"La integración de varias actividades y funciones en los espacios públicos y a su alrededor permite que las personas implicadas actúen juntas y que se estimulen e inspiren unas a otras" (Gehl, 2006, pág. 113).

Las ciudades requieren de movilidad constantemente, debido a las distancias que separan a las personas de su destino. Por ello, las estaciones de transporte son de primera necesidad en una sociedad, como Lima, que no contempla la descentralización de centros económicos y equipamientos importantes. Las personas utilizan los paraderos y estaciones varias veces al día, haciendo uso de los espacios públicos de manera transitoria. Sin embargo, por su naturaleza de total necesidad, dicho espacio tiene potencial para convertirse en un terreno de intercambio social.

Por ejemplo, pensemos en todas las veces que alguien ha llegado con media hora de anticipación a un destino. El espacio de la estación, acondicionado para ser transitorio, automáticamente, expulsa a la persona a la calle, convirtiéndola en un peatón con media hora libre. Tener algo que mirar o algo que recorrer; dónde sentarse, desde dónde observar a los demás; esa es la propuesta que se obtiene al mezclar equipamiento de diferente uso.

Los equipamientos culturales ofrecen actividades que no son, en apariencia, de primera necesidad para una sociedad. Es probable que muchos habitantes o consumidores no se interesen por desconocimiento o problemas de accesibilidad.

Es por ello que observamos una potencialidad en combinar un espacio necesario y transitado, con un espacio de estadía. Ambos tienen funciones y usos diferentes, pero no excluyentes. Las personas necesitan el intercambio con otras, aunque no lo perciban. De esta manera, se aprovecha la necesidad de transporte de las personas para que conozcan y utilicen los equipamientos con los que se complementa. 


\subsubsection{Transporte y desigualdad social.}

La tipología de una ciudad tiene una estrecha relación con el transporte público. Este, ha sido un determinante en el desarrollo de las urbes a lo largo de los últimos siglos; las poblaciones han solido desarrollarse a lo largo de sus vías.

Los asentamientos de la época colonial, donde el principal tipo de movilidad era peatonal, fueron compactos. Luego, cuando aparece el tranvía, las ciudades crecían de manera lineal, siguiendo las vías del transporte. Más adelante, el tranvía fue reemplazado por el autobús, y la ciudad se vuelve radial, creciendo exponencialmente alrededor de las diferentes líneas del sistema de transporte. Actualmente, y sobre todo en América Latina, tenemos ciudades semi-compactas, caracterizadas por el "déficit de infraestructuras de transporte, el aumento explosivo del automóvil y el funcionamiento deficiente del transporte colectivo.” (Montezuma, 2003, pág. 185)

Este nuevo modelo de ciudad semi-compacta, donde la centralización ${ }^{19}$ demanda más y más largos viajes, debe ser acompañado por un sistema de movilidad integrado, donde el transporte y el peatón tengan la misma relevancia.

Cuando hablamos de movilidad, debemos tener en cuenta más que el transporte privado. Se refiere a todas las formas que tiene una persona de acceder a un lugar mediante auto, bus, bicicleta, peatonalmente, u otros. Con un sistema integrado de movilidad, los ciudadanos alcanzan sin problemas, la accesibilidad a las dinámicas de la ciudad.

\footnotetext{
"Accesibilidad hace referencia a la facilidad con que cada persona puede superar la distancia que separa dos lugares y de esta forma ejercer su derecho como ciudadano [...] la accesibilidad, además de una dimensión territorial, también es una característica individual con relación al número de opciones que tienen los diferentes ciudadanos para acceder a los lugares y a las actividades" (MirallesGuasch \& Cebollada i Frontera, 2003)
}

\footnotetext{
${ }^{19}$ Reunir varias cosas en un centro común (RAE). En este caso, reunir los principales servicios y equipamiento en un centro urbano.
} 
Los sistemas de movilidad integrados, por lo tanto, nos proveen la capacidad de llegar a un lugar con la menor cantidad de obstáculos posibles.

Un problema de movilidad dentro de las ciudades de América Latina surge a partir de 1950, cuando las urbes crecieron exponencialmente y se generó una expansión sin planificación. Algunas ciudades contaban sólo con planes de crecimiento que tenían como punto de partida las vías de transporte, sin tener en cuenta condiciones óptimas para movilidad pública y peatonal. ${ }^{20}$

En la región latina, las ciudades tienen aspectos comunes. Algunos son: el crecimiento de la precariedad y desempleo; la distribución desigual de ingresos, bienes y servicios, profundizando la brecha entre los que más y menos tienen; y la desaparición de empresas públicas de transporte, dando paso a empresas privadas que gestionan el sistema de transporte público de la ciudad (Gutierrez, 2005).

"La movilidad es una condición clave de acceso al mercado laboral, a una vivienda, a la educación, a la cultura y el ocio, a la familia. El derecho a trabajar, a tener una vivienda, a recibir capacitación, ahora implica el derecho a la movilidad [...] en cierto sentido este derecho a la movilidad es una precondición de los otros derechos." (Ascher, 2005)

Existe una relación directa entre movilidad territorial y movilidad social. La primera, se refiere a la capacidad de llegar a lugares, bienes y servicios dentro de la ciudad. La segunda, es la consecuencia de poder acceder a dichos lugares, bienes y servicios como ciudadanos; el acceso a oportunidades un determinante para el desarrollo socioeconómico de personas y familias. Es así, que algunas veces, la segregación comienza por quien tiene la capacidad de moverse, y quién no.

\footnotetext{
${ }^{20}$ Un caso es Lima Metropolitana, que desde 1967 con el PLANDEMET (el primer plan urbano de la ciudad moderno) mostraron proyecciones a nivel de infraestructura vial y ordenamiento urbano. Sin embargo, el plan no ahondaba en escalas peatonales, ni mencionaba el equipamiento respectivo en transporte público y servicios a través de la ciudad.
} 
Una característica de tipologías de ciudades como Lima Metropolitana, es el gran porcentaje de espacio utilizado en transporte privado, en comparación al público y colectivo. "Entre el 55\% y el 85\% de los desplazamientos en las grandes metrópolis de América Latina se realizan en transporte colectivo. No existe una sola ciudad en este continente donde la movilidad motorizada individual sea mayor que la colectiva" (Montezuma, 2003). En Lima, aproximadamente el 25\% de los viajes cotidianos se da en transporte individual ${ }^{21}$. Entonces, ¿por qué seguir priorizando la infraestructura para el vehículo privado en Lima Metropolitana?

En las ciudades de la región, con la privatización del transporte público, se genera una desarticulación entre el desarrollo urbano y la movilidad colectiva. En principio, ambos aspectos deben ser gestionados por el Estado. En la práctica, las empresas privadas, dueñas de las unidades de transporte, son quienes determinan las dinámicas públicas en la ciudad: definen políticas del servicio, recorridos de rutas, tarifas, horarios, conductores y vehículos del transporte colectivo. Al no ser regulado por el Estado, el sistema de transporte público suele priorizar aspectos en beneficio de la empresa privada, degradando el servicio ofrecido al ciudadano.

En una ciudad centralizada y sin un sistema de movilidad integrado y cómodo, las oportunidades se encuentran al alcance de los ciudadanos con capacidad de recorrer más y más largos viajes. Ya sea mediante transporte colectivo de tarifas elevadas o de forma privada, quien tiene mayores ingresos es quien tiene mayor accesibilidad (Montezuma, 2003).

\footnotetext{
"La estructuración del espacio urbano de la mayoría de las ciudades en desarrollo no se ha regulado mediante planes de urbanismo u otros tipos de orientaciones técnicas; es más el resultado de procesos especulativos de manejo del suelo urbano según el nivel económico de sus habitantes” (Montezuma, 2003, pág. 179)
}

\footnotetext{
${ }^{21}$ Informe de principal modo de viajes cotidianos en Lima: Aproximadamente $25 \%$ en transporte individual; $52 \%$ en transporte colectivo; $23 \%$ a pie. (Montezuma, 2003).
} 
Los ciudadanos con mayores ingresos económicos, tienen mayor accesibilidad a las dinámicas de la ciudad. Se suele ubicar equipamiento y servicio en los centros urbanos, antes que en la periferia (Montezuma, 2003). La segregación socioeconómica en países en vía de desarrollo, no solo se refiere al territorio que habitan las personas; si no, también, a la capacidad que poseen de asistir o acceder a un servicio básico o de lujo. Por lo tanto, el grado de eficiencia de movilidad de una persona puede determinar su nivel socioeconómico, al potenciar o dificultar el acceso a oportunidades de cada ciudadano.

En ocasiones, las familias de bajos recursos económicos, ven su situación agravada por la ausencia de un sistema de transporte colectivo de calidad, ya que no pueden involucrarse en actividades cotidianas de la ciudad. Es considerado un derecho que un ciudadano se integre a la dinámica urbana, y se debe brindar los recursos necesarios para ello.

“[...] resulta ineludible el rol ejercido por el Estado que, a través de sus intervenciones, políticas públicas y asociaciones público-privadas, produce y distribuye capital espacial ${ }^{22}$ desigualmente entre los grupos sociales, pudiendo construir nuevos escenarios de desplazamiento." (Apaolaza, y otros, 2016, pág. 23)

Lima Metropolitana es una ciudad centralizada, con servicios agrupados en un solo espacio. Esto, sumado a la falta de infraestructura de transporte público, potencia la desigualdad para los ciudadanos de bajos recursos socioeconómicos que no tienen la oportunidad de hacer largos viajes. Por ejemplo, los problemas de accesibilidad al trabajo podrían resolverse llevando oportunidades laborales más cerca a todos los centros poblados; o llevando a los ciudadanos a las oportunidades, mediante un efectivo sistema de movilidad y transporte.

“[...] se ha producido un proceso de segregación socio-territorial mediante el cual las clases populares se han concentrado fundamentalmente en las nuevas

${ }^{22}$ Capital espacial se refiere a las configuraciones espaciales, dotaciones de infraestructura, características de accesibilidad, servicios, etc. de un territorio. (Apaolaza, y otros, 2016) 
periferias metropolitanas $[\ldots]$ los elevados costes de la vivienda en los espacios centrales han significado que la mayor parte de las personas de bajos ingresos establezcan su residencia allí [...] en la periferia de la ciudad. De esta forma, los grupos de menos recursos han sido expulsados de las áreas de centralidad replegándose en los extensos espacios metropolitanos periféricos.” (Avellaneda, 2008, pág. 20)

La infradotación de servicios en la periferia ha dado lugar a un estrecho vínculo entre la ciudad 'popular' y los centros de actividad de Lima. La ciudad periférica ha generado este vínculo en calidad de dependencia, ya que la necesidad entre ambos territorios no es mutua (Avellaneda, 2008).

Los desplazamientos, entonces, son el criterio estructurador de la vida cotidiana. En Sao Paulo, los ciudadanos con auto privado muestran niveles de desplazamientos de 2 a 5 veces superiores al de quien no posee uno (Montezuma, 2003, pág. 181). El poder de adquisición de un vehículo privado no debería ser condicionante para la capacidad de movilidad de una persona. En el caso de Lima, por ejemplo, algunas mujeres que viven en la periferia deciden trabajar desde sus hogares (Avellaneda, 2008). Esto disminuye la cantidad de viajes por familia y la inversión que esto requiere; así, el principal ingreso económico familiar termina siendo el de un solo integrante de la familia.

Acceder a oportunidades depende de la capacidad de movilidad de un ciudadano o de un grupo de ellos. Paradójicamente, la capacidad de movilidad en Lima, depende de los ingresos y oportunidades de las personas. Entonces, los limeños de bajos recursos, no tendrán acceso a los centros de trabajo, salud o estudios que ayuden a disminuir la brecha que los separa del resto de la ciudad. Es el Estado quien debe proveer a todos equitativamente de condiciones favorables para la movilidad y accesibilidad.

Es necesario comenzar a hablar de movilidad, y no sólo de transporte. En Lima, se prioriza a las vías de parque automotor sobre espacios de calidad al ciudadano. Centrarnos en la persona que se moviliza, antes que, en el método de hacerlo, permite tomar en cuenta de forma particular a los habitantes de escasos recursos (Montezuma, 2003). Así, también se acercan oportunidades a los limeños de menores recursos, a los 
de movilidad limitada, y a quienes necesitan asistencia de cualquier clase para recorrer la ciudad. Es decir, debemos pensar en el 'quién', antes del 'cómo'.

\subsubsection{Del no-lugar al lugar}

Un lugar es el espacio que habitamos, un espacio con sentido y etimología de por medio. Un lugar no es lo mismo que un espacio. Para Michel de Certeau ${ }^{23}$, un espacio "es un 'lugar practicado', 'un cruce de elementos en movimiento': los caminantes son los que transforman en espacio la calle geométricamente definida como lugar por el urbanismo" (Augé, 2000, pág. 85). Es así como el espacio geométrico que se crea en el espacio urbano no es igual al espacio antropológico, aquel que está intervenido por las acciones y actividades de sus transeúntes.

Bajo esa premisa, un lugar es un espacio intervenido y atribuido de identidad, relacional e histórico. Por lo tanto, un espacio que no tiene ni identidad, ni es relacional, ni tiene historia, será un no lugar (Augé, 2000).

Por otro lado, existe el concepto de 'sitio', una relación directa entre el individuo en sí y la superficie de espacio que ocupa en un momento determinado. Este es "la extensión, la superficie y el volumen que un individuo ocupa en el espacio físico, sus dimensiones y su volumen exterior" (Bordieu, 2003; Nates Cruz, 2011).

"Esta concepción del espacio se expresa, como hemos visto, en los cambios en escala, en la multiplicación de las referencias imaginadas e imaginarias y en la espectacular aceleración de los medios de transporte y conduce concretamente a modificaciones físicas considerables: concentraciones urbanas, traslados de poblaciones y multiplicación de lo que llamaríamos los 'no lugares'... Los no lugares son tanto las instalaciones necesarias para la circulación acelerada de personas y bienes (vías rápidas, empalmes de rutas, aeropuertos) como los medios de transporte mismos o los grandes centros comerciales, o también los campos de transito prolongado donde se estacionan los refugiados del planeta.” (Augé, 2000, pág. 40)

${ }^{23}$ Michel de Certeau (1925-1986) fue un jesuita francés cuyo trabajo incluía temas en ciencias sociales, historia, psicoanálisis y filosofía. 
Los no lugares, por el momento, son espacios con ausencia de historia e importancia en el tiempo. Son vacíos urbanos a nivel social, donde la velocidad de tránsito es tan acelerada que se pierde la oportunidad de intercambio. Los no-lugares son los lugares del mundo contemporáneo. Un no-lugar es un "modo de civilización característico que se opone al modelo tradicional de los lugares históricos" (Nates Cruz, 2011), carecen de tradición e historia, no tienen ubicación, ni son naturales. La teoría no quiere decir que un no lugar sea malo ni innecesario. Sin embargo, puede existir un espacio con potencial a ser un lugar para la comunidad que se encuentre desperdiciado.

Los no-lugares se encuentran, sobre todo, en autopistas y 'habitáculos móviles' llamados 'medios de transporte' (Augé, 2000). Es el caso de las estaciones de transporte, que reciben y despiden a pasajeros, son un espacio de tránsito y una conexión, pero nunca un lugar de encuentro. Además, son espacios ajenos a la identidad de sus usuarios. Existen y se emplazan sin importar sus ocupaciones, cultura o tradiciones.

Si la experiencia lejana nos ha enseñado a descentralizar nuestra mirada, debemos sacar provecho de esta experiencia. El mundo de la supermodernidad no tiene las medidas exactas de aquel en el cual creemos vivir, pues vivimos en un mundo que no hemos aprendido a mirar todavía. Tenemos que aprender de nuevo a pensar el espacio. (Augé, 2000)

Descentralizar, en una ciudad, significa la creación de nuevos polos de atracción. Las estaciones, al convertirse en lugares, debieran responder a las prácticas espaciales de sus usuarios finales. La espacialidad, función y forma del lugar no puede "ceñirse únicamente a las prácticas discursivas de los sectores dominantes que imponen los términos bajo los cuales se enuncia" (Nates Cruz, 2011). Si el lugar se impone a una sociedad, pierde toda la connotación cultural, histórica y tradicional de la misma. Automáticamente, se convertirá en un no-lugar; en sólo un sitio para recorrer y no permanecer. Quienes utilizan un lugar son los habitantes; quienes utilizan un no-lugar son consumidores.

Sin embargo, la temporalidad como "la circulación del tiempo físico y del tiempo social" (Augé, 2000), es un factor determinante en la denominación de un lugar o no- 
lugar. Más allá de la espacialidad, se deberían juzgar según las prácticas y gente que lo habita o utiliza en determinado espacio de tiempo.

Pongamos por caso el de un terremoto: en los momentos de caos y dolor, el lugar con su peso histórico y de identidad se convierte en un no-lugar, en un espacio no re-conocido y lleno de gentes que circulan sin mayor reconocimiento. Otro elemento a subrayar son los llamados territorios de socialización públicos (plazas, parques, centros de recreo...). Por su naturaleza de circulación constante dan la impresión de ser de todos y de nadie. Lo que marca su referencia de lugar o no-lugar va a ser las prácticas sociales que allí se realicen. ... "una fiesta callejera" hará de una plaza un no-lugar si recurrimos a su definición "de hombres anónimos, ajenos por un período de tiempo a su identidad (más allá de la generación), origen u ocupación". Pero en cuanto la limpieza llegue y amanezca el día con paseantes jubilados o madres tomando el aire con sus hijos pequeños, esa plaza se convierte en el lugar de referencia e identidad del barrio, del pueblo. (Nates Cruz, 2011)

En ambos ejemplos, el lugar o no-lugar no puede ser definido por su funcionalidad momentánea, ni por su forma o tipología. Ambos conceptos se relacionan entre sí, y pueden pasar a ser el uno o el otro dependiendo de la temporalidad en la que se le juzgue. Lo que se debe evaluar, en cada caso, es qué vuelve a un no-lugar en un lugar, y viceversa según las necesidades de sus habitantes o consumidores. Es primordial tener en cuenta al usuario final.

\subsubsection{Teoría general de sistemas}

La ciencia es el estudio empírico de lo que nos rodea ${ }^{24}$. Con el paso de diferentes épocas, la ciencia se fue desintegrando en áreas tales como la geografía, biología, física, sociología, entre muchas más. Cada vez, la especialización y estudios de cada área son más limitados. Cada una de ellas se enfoca en una parte del todo; no comparten objetivos ni descubrimientos entre sí.

${ }^{24}$ Definición propia, en referencia a la lectura de Teoría general de los Sistemas, de Ludwig von Bertalanffy. 
La teoría general de sistemas de Bertanlanffy (1989) surge, en parte, como un intento de recuperar la ciencia y el estudio integral y que las especialidades conversen y lleguen a conclusiones que aporten mutuamente para comprender el todo. Muchas ciencias tienen los mismos problemas, las mismas conclusiones, o necesitan algo de la otra para seguir adelante.

Muchos de los estudios se dedican a los sistemas existentes. Un sistema, según la RAE, es un 'conjunto de cosas que relacionadas entre sí ordenadamente contribuyen a determinado objeto'. Es, en general, la agrupación de las partes de un todo y su relación. Un sistema puede ser abierto o cerrado. Por ejemplo, la Física clásica se ocupa en estudios de sistemas cerrados, donde las ecuaciones y reacciones responden a una causaconsecuencia lineal. Estos sistemas se encuentran totalmente aislados y son ajenos a los factores del entorno. Esto significa que, eventualmente y por la fuerza de entropía ${ }^{25}$, el proceso del sistema llegará a su máximo y se detendrá al alcanzar el estado de equilibrio o punto muerto. La tendencia es siempre hacia el máximo nivel de desorden que un cuerpo pueda conseguir dentro del sistema cerrado.

Por otro lado, tenemos a los sistemas que estudia, por ejemplo, la Biología. Los organismos vivos son sistemas abiertos, con variables más allá de su cuerpo. "Se mantiene en continua incorporación y eliminación de materia, constituyendo y demoliendo componentes, sin alcanzar, mientras la vida dure, un estado de equilibrio químico y termodinámico, sino manteniéndose en un estado llamado uniforme (steady) que difiere de aquél." (Bertalanffy, 1989)

La Historia, por otro lado, es una ciencia estudiada longitudinalmente, donde los hechos son consecuencia de algo o alguien, en una fecha determinada. Por ejemplo, la Segunda Guerra Mundial se debió sólo a "la perversidad de Hitler y la proclividad bélica de los alemanes” (Bertalanffy, 1989, pág. 5). El estudio de la historia es del tipo 'ideográfico', o de 'quién-hizo-qué'. Actualmente, como sociedad, no debemos aceptar que los sucesos ocurran por la decisión de una persona.

${ }^{25}$ Definición de la RAE: Medida del desorden de un sistema / Magnitud termodinámica que mide la parte de la energía no utilizable para realizar trabajo. 
"Los acontecimientos parecen envolver algo más que las decisiones y acciones individuales, y estar determinados más bien por "sistemas" socioculturales, trátese de prejuicios, ideologías, grupos de presión, tendencias sociales, el crecimiento y la decadencia de civilizaciones y quién sabe cuánto más. Sabemos científica y precisamente cuáles van a ser los efectos de la contaminación, el despilfarro de los recursos naturales, la explosión demográfica, la carrera armamentista, etc. Cada día nos los repiten incontables críticos que esgrimen argumentos irrefutables. Pero ni los guías nacionales ni la sociedad en conjunto parecen en condiciones de hacer nada por remediarlo.” (Bertalanffy, 1989, pág.

6)

La teoría enmarca que la única forma de estudiar los sucesos es analizarla como un sistema abierto y orgánico, con variables mutuamente dependientes entre sí y con su entorno. Es más provechoso tener en cuenta todas las variables que rodean a un suceso, antes que limitarlo a una acción aleatoria.

Un ejemplo de esto y recurrente en Lima son los accidentes de tránsito en la Carretera Panamericana $\operatorname{Sur}^{26}$. Cuando un automóvil se encuentra con un transeúnte atravesando la carretera sin usar los puentes peatonales, automáticamente se culpa y condena al peatón por no utilizar los puentes peatonales. Sin embargo, pocos se detienen a considerar que, kilómetros de la vía no cuentan con ellos; para el peatón, caminar hasta un puente podría significar más de 30 minutos. A quien se debe condenar es al responsable de bien atravesar asentamientos sin los puentes adecuados, o de permitir la construcción de industrias, comercios y viviendas.

El 01 de marzo de 2017, en la Panamericana Sur, un tráiler colisionó con un bus de transporte colectivo que frenó intempestivamente a recoger pasajeros en un paradero no autorizado. Esto condujo a la muerte de 6 personas. Inicialmente, la culpa recae sobre los pasajeros o el conductor del bus que no caminaron 70 metros al paradero autorizado. Sin embargo, las entrevistas a los pobladores destaparon factores considerados causantes indirectos.

${ }^{26}$ Tramo sur de la peruana Carretera Panamericana, que recorre desde la Región Lima hasta la frontera con Chile. En el año 2013, el 72.4\% de los accidentes de tránsito del país se debieron a factores humanos. De este porcentaje, el 7.6\% es imprudencia del peatón. (Observatorio de Criminalidad, Ministerio Público) 
'La gente para (toma el carro) en este lugar porque en el paradero autorizado en la mañana, tarde y noche roban, a cualquier hora te asaltan', mencionó Alcides Atencio.” (Perú 21, 2017)

La 'imprudencia de los peatones', muchas veces tiene variables asociadas y válidas. Quién-hizo-qué es menos relevante que por-qué-hizo-qué. Mientras siga la delincuencia en el paradero, los peatones continuarán arriesgando su vida en espacios no autorizados. Es esencial encontrar el factor problema dentro de un sistema o todos los demás se verán afectados.

Al considerar la ciudad como un sistema orgánico, podemos aplicar la homeostasis, que consiste en autorregular el sistema interno de un organismo a pesar de los cambios en el entorno. Así, existe la constante estabilidad dentro del sistema vivo (como la temperatura o alcalinidad). Otra capacidad de los sistemas vivos y abiertos es la ósmosis, que permite la influencia recíproca entre dos sistemas en contacto a través de sus límites (Bertalanffy, 1989).

De la misma manera, un sistema que funciona mal puede cambiar si uno de sus factores o su entorno se modifica para bien, como un nuevo engranaje aceitado en una máquina que funciona a medias. Las ciencias, como mencionamos previamente, no comparten entre ellas. La influencia recíproca e intercambio de información limita el conocimiento sobre el todo.

La ciudad como sistema tiene partes que interactúan constantemente y, tan rápido, que los factores problemáticos se confunden. Un civil o ciudadano de a pie, suele ver la última parte afectada del sistema. Nosotros nos topamos con una porción del sistema y la culpamos, cuando el problema de fondo va mucho más allá. El tráfico vehicular, la delincuencia y el hambre, por ejemplo, son los problemas que vemos y sentimos a diario. Sin embargo, tienen relación directa con otras partes de la ciudad y sociedad como la educación, el deficiente transporte público y la gestión pública. Queremos solucionar el hambre, pero se necesita trabajo y para ello, educación.

En la ciudad, es importante que las áreas socioeconómicas conversen y cooperen entre sí. La influencia entre ministerios, por ejemplo, lleva a un mejor resultado porque 
observa más de un aspecto del sistema. Transporte y cultura podrían mantener una estrecha relación y acercar colectivamente al ciudadano o consumidor al turismo y la cultura.

La teoría, sin embargo, tiene detractores. Algunos mencionan que, dentro de un sistema, el hombre quedará como una pequeña parte sin mayor influencia o poder. Asumen que no se toma en cuenta las singularidades de cada ciudadano (Bertalanffy, 1989). Si bien las personas son lo principal en una ciudad, es importante vernos como una parte del todo. Algunos factores, como la delincuencia, ya escapan de la parte 'persona' y toman espacio propio en el sistema. Independizando la delincuencia, tal vez se puede prevenir y no solo castigar. De esta manera, dejaremos de condenar a los ciudadanos como el quién-hizo-qué de la Historia, evaluar dónde se encuentra la problemática y corregirla.

Las ciudades y sus partes son sistemas vivos y abiertos, en constante intercambio con su entorno. Se debe aprovechar las condiciones propias de un organismo y potenciar la influencia positiva entre las variables que tenemos a la mano como ciudadanos. Por ende, la teoría de sistemas se aplica al proyecto, que busca resultados mediante dos prácticas. La primera, es aprovechar las oportunidades de la movilidad como parte del sistema y su la cercanía física al terreno de estudio. Y, la segunda, es potenciar el funcionamiento de la ciudad mediante la renovación e implementación de un componente del sistema, como es la cultura en un espacio social y urbanísticamente problemático.

\subsubsection{Acupuntura urbana}

Una ciudad ha sido descrita de tantas maneras como gente que la conoce. Sus interpretaciones son diversas y sus usos, infinitos. Citando a Marco Casagrande (2010), definimos a la ciudad como un organismo pluri-dimensional, energético y sensorial; un ecosistema vivo. Sobre este organismo se pueden plantear operaciones casi quirúrgicas que, luego de un diagnóstico, pudiesen presentar complicaciones o buenas reacciones desencadenadas por una puntual intervención. Así, surge el relacionar estas intervenciones en la ciudad con la ancestral técnica china de la acupuntura en el cuerpo humano (Casagrande, 2010). 
La buena acupuntura, tanto en humanos como en ciudades, se basa en comprender que ningún individuo o comunidad es igual al otro. En las ciudades, se trata de comprender qué se encuentra desatendido en cada vecindario antes de diseñar (Ghel; Lerner, 2014). Imponer infraestructura y relaciones ajenas a las necesidades del lugar, no ayuda a arreglar espacios con problemas urbanos.

Así como la efectividad de la medicina depende de una buena comunicación entre médico y paciente, la perseverancia y buenas expectativas, la acupuntura en la ciudad es formular reacciones en cadena y relaciones entre ciudad y ciudadanos. Se trata de encontrar estímulos donde se daba un elemento por perdido y revitalizar para el mejor funcionamiento de lo urbano (Lerner, 2014).

"Siempre tuve la ilusión y la esperanza de que con un pinchazo de aguja sería posible curar las enfermedades. El principio de recuperar la energía de un punto enfermo o cansado por medio de un simple pinchazo tiene que ver con la revitalización de ese punto y del área que hay a su alrededor.

Creo que podemos y debemos aplicar algunas "magias" de la medicina a las ciudades, pues muchas están enfermas, algunas casi en estado terminal. Del mismo modo en que la medicina necesita la interacción entre el médico y el paciente, en el urbanismo también es necesario hacer que la ciudad reaccione. Tocar un área de tal modo que pueda ayudar a curar, mejorar, crear reacciones positivas y en cadena. Es necesario intervenir para revitalizar, hacer que el organismo trabaje de otro modo". (Lerner, 2014, pág. 1)

La acupuntura urbana consiste en estudiar a una porción de la ciudad y comprender las causas y consecuencias de sus carencias. A partir de las causas, se pretende intervenir puntualmente para desencadenar una serie de eventos favorables en la ciudad y su comunidad. No se trata de una teoría que apoye el cambio drástico de un espacio, si no, que ofrezca la herramienta precisa para que su radio de influencia sea mayor y mejor progresivamente.

Algunas intervenciones son equipamiento, una nueva costumbre, o incluso cuestiones intangibles pero que se perciben por sus habitantes y usuarios. Estas 
intervenciones no deben limitarse a la implementación de un nuevo punto de encuentro, si no también, en regenerar o ingresar un articulador sociocultural, que evoque pertenencia en los usuarios. Ejemplos de ello son la revitalización de Puerto Madero en Buenos Aires, o del distrito Cannery en San Francisco. Ambos reactivaron un espacio que no generaba comodidad en la ciudad. Su cambio puntual, generó el desarrollo social, económico y, posteriormente, inmobiliario. En esta línea, se encuentra también la restauración de la Gran Estación Central de Nueva York. Gracias a ella, el sistema de transporte e intercambios viales en la ciudad tomó un nuevo rumbo hacia lo positivo. Además, se convirtió en uno de los principales puntos de encuentro de la Gran Manzana y de Estados Unidos en general. Es, hoy en día, un ícono cultural alrededor del mundo y un ejemplo a seguir en desarrollo del transporte público. Sin embargo, la grandeza de la estación no fue gratuita ni inesperada: los efectos que su restauración desencadenaron alrededor de ésta fueron parte del efecto que la acupuntura urbana tanto recalca y la importancia de descubrir dónde una ciudad necesita ser sanada para revitalizar el organismo entero. (Lerner, 2014)

Jaime Lerner (2014), describe que cada intervención es particular y diferente pues, depende de las necesidades y cultura de la sociedad donde se encuentra. Si es una imposición sin previo análisis, la respuesta podría no favorecer al desarrollo de la urbe y sociedad.

La acupuntura urbana tiene el propósito de evaluar paisajes dejados a menos que forman parte de la memoria del lugar. Esto es, muchas veces, lo que una comunidad necesita, más que una nueva y costosa construcción. La idea de retomar un escenario que funcionó como punto de encuentro en el pasado, y reinventarlo con tecnología, salva del olvido aquello que el pueblo necesita. Además, es importante evaluar temas desatendidos. Alrededor de esta restauración, una comunidad puede ganar confianza, unión y participación en conjunto. 


\title{
3.1.7 Vacíos urbanos
}

Los vacíos urbanos no son necesariamente espacios urbanos no construidos. Éstos pueden ser llamados así porque no soportan una vida pública. Es "el espacio que está entre las cosas... entre mi casa y la de mi vecino... entre su oficina y la mía es atravesado por extraños, no es un lugar de encuentro; se ha vuelto 'vacío' porque carece de un rol reconocible." (Secchi, 1993).

\begin{abstract}
"Muchos de los grandes problemas urbanos se dan por falta de continuidad. El vacío de una región sin actividad o sin habitantes se puede sumar al vacío de las tierras baldías... También es importante incluir la función que falta en determinada región. Si solo existe la actividad económica y falta gente, es esencial incentivar a la gente para que la habite. Si lo que ocurre es que falta actividad, es importante incentivar los servicios.

Si un terreno se va quedando vacío, hay que traer alguna cosa a ese lugar. Hace algunos años, al sentir que algunos cafés, que eran verdaderos puntos de encuentro, iban desapareciendo, instalamos en el área peatonal de Curitiba un café provisional.
\end{abstract}

Cuando un lugar está vacío, tiene que llenarse inmediatamente, preferiblemente con alguna actividad de animación. $\mathrm{E}$ incluso instalando estructuras provisionales para consolidar algunas actividades hasta que surjan nuevos proyectos... Si falta actividad. Si faltan lugares de ocio nocturno, se monta una estructura de ocio. Si, por otro lado, faltan residencias, se traen residencias. Pero todo eso rápidamente, casi instantáneamente." (Lerner, 2014)

Durante la modernidad, los edificios fueron tratados como objetos monumentales y rodeados por espacio libre no diseñado, espacio que luego se convierte en vacíos entre los objetos, que tiende a ser neutro y abstracto. (Gamboa Saper, 2003) Es por esto, que la ciudad moderna ya no se recorre, si no se atraviesa. Ya no existen lugares diseñados para la permanencia ni para soportar el encuentro social.

Dentro de categoría de vacíos vamos a considerar a las vías, puesto que no funcionan como espacios urbanos de encuentro. Las ciudades se han vuelto más viales y menos urbanas debido a la predominancia del automóvil sobre el peatón. 


\subsection{Tipologías}

\subsubsection{Tipologías de centros culturales}

Como se ha mencionado previamente, el centro cultural es un nuevo concepto de equipamiento urbano. Además, su forma y función dependen de la sociedad en la que se construya y las necesidades que se presenten. Los usos son tan variados que nos basaremos en las tipologías de Teatros y Espacios de Exposiciones.

\subsubsection{Tipología y clasificación de teatros}

\section{Por el edificio con respecto al entorno}

- Abierto

El que se construye al aire libre, por lo general, en una plaza, un parque, etc. Se utilizan para actos públicos propios y de grupos de teatro experimental de la localidad. No cuenta con instalaciones fijas de iluminación, aire acondicionado y sonido. Su número de espectadores depende de la localización geográfica y de la institución que representa.

- Cerrado

El que agrupa los espacios en un edificio cerrado de volúmenes simétricos o largos prismas acostados en el suelo donde una mitad aloja cómodamente a los espectadores y la otra mitad del prisma da cabida al escenario con las instalaciones necesarias.

(Plazola Cisneros, 2001)

\section{Por su concepto}

- Contemporáneo. Requiere de un espacio propio y organizado para su fin específico

- De masas. Edificio destinado a albergar una cantidad considerable de público de diversos estratos sociales que gustan de las representaciones populares

- De repertorio. El de repertorio de producciones que cambia semanal o diariamente; o el que lleva a cabo producciones con intervalos de dos a tres semanas 
- De vanguardia. La relación entre el escenario y el público es una repetición de los escenarios de proscenio, redondos o abiertos.

- Experimental. En estos locales no existe una separación clara entre la escena y la zona de espectadores y la representación se dirige a todos los puntos del recinto.

- Móvil. El que puede trasladarse e instalarse en cualquier lugar.

- Municipal, estatal, nacional. Los que diseña el estado para cumplir con las demandas sociales de dar cultura a las clases populares.

- Nuevo. Busca desarrollar nuevos ámbitos y espacios acorde a los adelantos tecnológicos (materiales, técnicas constructivas e instalaciones)

- Polivalente. Edificio acondicionado para todo tipo de representaciones. Por lo general es una sala alargada con escenario al frente

- Por el tipo de producción. Según el agrupamiento de espacios: Teatro a gran escala; gran ópera; ópera de cámara

- Unitario. Emplea los recursos a la mano para atacar todos los aspectos que intervienen para desarrollar el proyecto y no desperdiciar espacio

- Universitario. Producciones de tipo estudiantil y profesional de una institución

- Urbano. Se localiza en grandes ciudades, en el que se montan obras de importancia que son proyectadas a nivel internacional.

(Plazola Cisneros, 2001)

\section{Por la forma de la planta de la sala}

- Círculo. Apertura de $360^{\circ}$

- Con escenarios anulares

- Con escenario fondo. Apertura de $135^{\circ}$

- Con foros laterales

- De proscenio

- Escenario de abanico. Apertura de $90^{\circ}$

- Griego. Apertura de $210^{\circ}$

- Italiano

- Isabelino

- Total 
- Tradicional. Puede ser de escenario grande, normal o ancho; giratorio con gradas grandes. El ancho de boca de escena es de $30 \mathrm{~m}$, el ciclorama de $45 \mathrm{~m}$ de ancho, aparte un escenario normal de $14 \mathrm{~m}$ de apertura; un escenario y dos tablados laterales rodeados de pequeños cicloramas y un área interior móvil a proscenio para lograr buena visibilidad.

- Teatro-arena
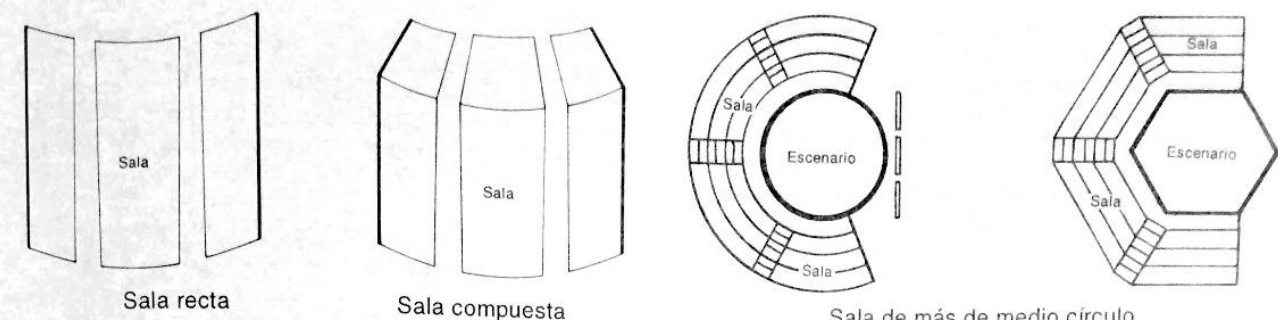

Sala de más de medio círculo
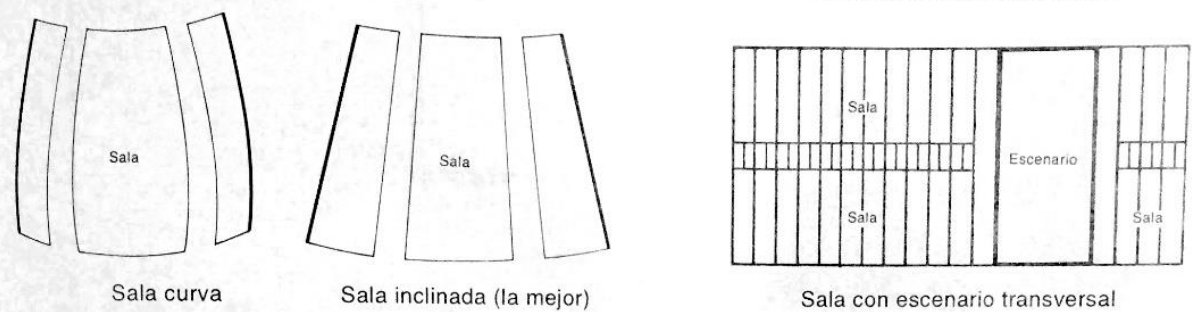

Sala con escenario transversa!

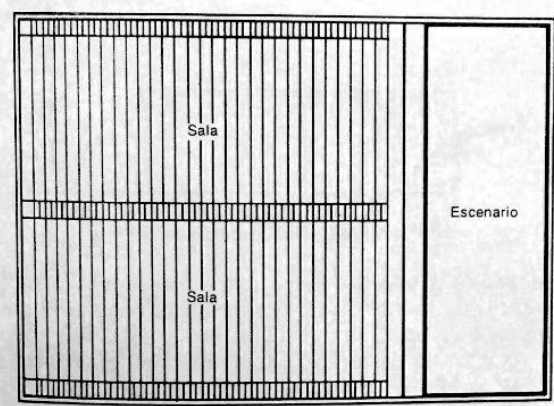

Teatro tipo italiano
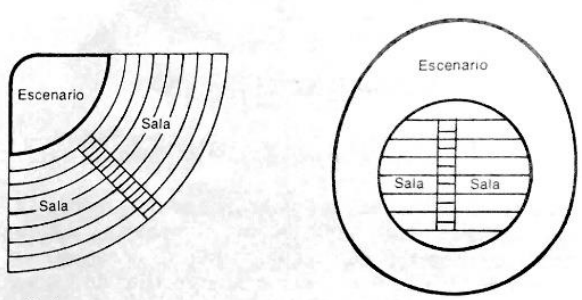

Sala que ocupa un cuarto de circulo
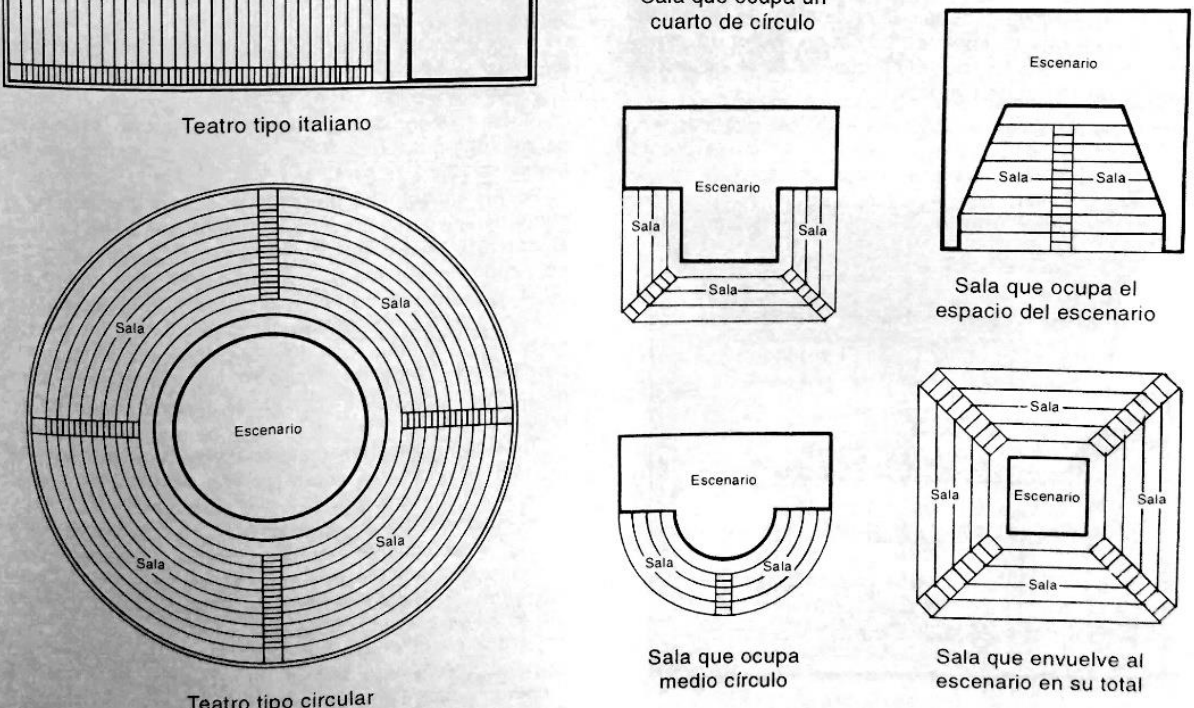

Sala que ocupa el espacio del escenario

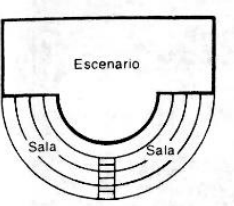

Sala que ocupa medio círculo

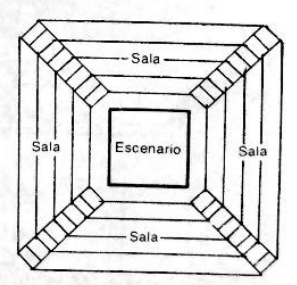

Sala que envuelve al escenario en su total

Tipos de salas para teatro

(Plazola Cisneros, 2001) 


\section{Por especialidad}

- Auditorio

- Cabaret

- Carpa

- Ópera

- Sala de conciertos

- Salón de usos múltiples. Se llevan a cabo conciertos, espectáculos de danza, teatro, también sirve como auditorio pero no alcanza la perfección en alguna disciplina especifica por la austeridad en sus instalaciones. Son espacios dispuestos en plan libre, con acceso, área al público, servicios sanitarios para hombres y para mujeres, foro y área para músicos.

(Plazola Cisneros, 2001)

\subsubsection{Clasificación de espacios de exposiciones}

- Centro de Convenciones

"Edificios de reunión para empresarios, artistas, instituciones educativas, políticos o instituciones financieras para intercambiar ideas, promover productos y capacitar a las personas. Cuentan con las instalaciones necesarias para escuchar, gozar, ver, intercambiar ideas, comer, descansar circular y estacionar un vehículo”. (Plazola Cisneros, 2001)

- Centro de Exposiciones

Son edificios creados para "mostrar el desarrollo tecnológico y los avances en la mercadotecnia para exponer determinados productos nuevos, relacionados con la industria de la transformación para su presentación y venta en un tiempo determinado" (Plazola Cisneros, 2001, pág. 585). Sirven para impulsar sectores en crecimiento del país y son organizadas por grupos de comerciantes o instituciones culturales. 


\subsubsection{Tipologías de estaciones de BRT}

Las estaciones de BRT (o TMRB) son, realmente, consideradas plataformas de embarque y desembarque de pasajeros debido a su tamaño pequeño. Sin embargo, es posible que alguna de ellas cuente con equipamiento adicional.

No existe un estándar de estación ni plataforma en este caso en el manual de "Bus Rapid Transit Planning Guide", pero se provee un número de funciones matemáticas para calcular los espacios y requerimientos mínimos de cada estación. (Hermant, 2014) Es por ello que, a continuación, se verá el caso de una estación de BRT promedio.

Se puede dar 5 clasificaciones para el movimiento de pasajeros dentro de la estación:

- Llegada a una plataforma / o embarque y desembarque, y esperando en una plataforma

- Caminar hacia o fuera de la plataforma

- Al pasar por los torniquetes

- Caminar por la acera inmediata fuera de la estación

- En un escenario de evacuación o emergencia. (Hermant, 2014)

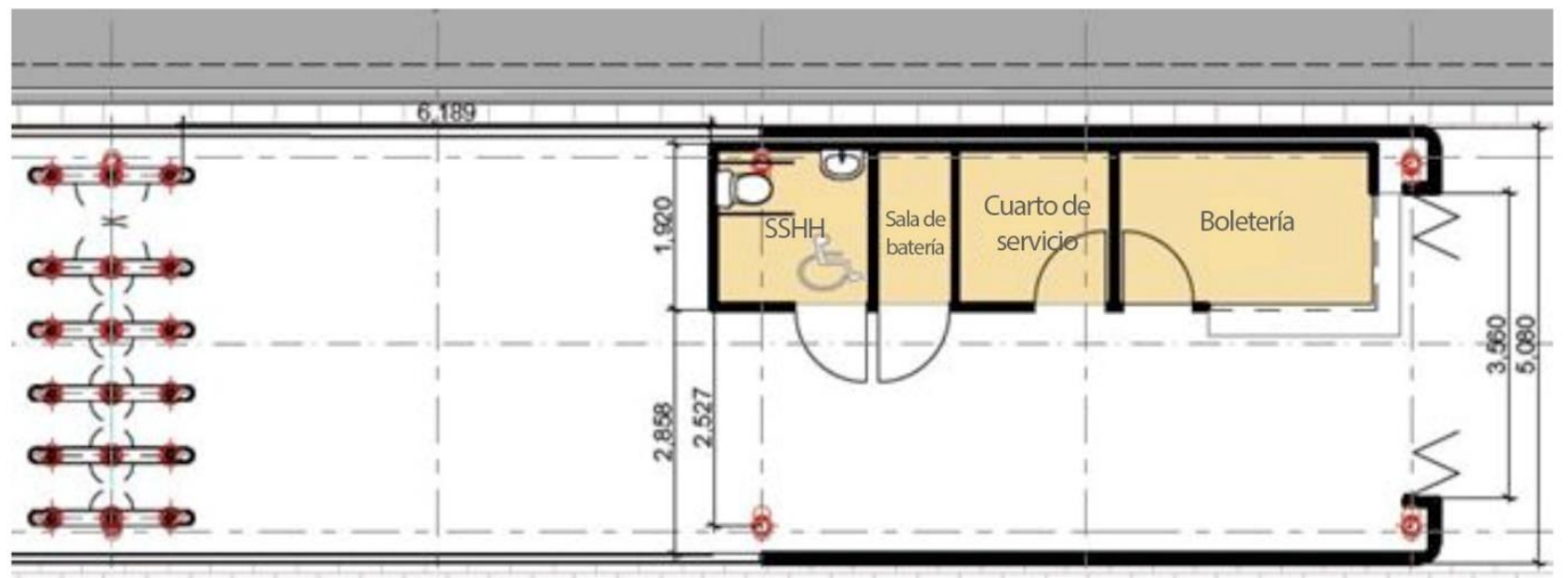

-

Planta: Organización interna típica de una estación de BRT

(Goba (Pty) Ltd., 2013) 
Por otro lado, en América Latina se realizó un estudio de varias estaciones de BRT y se les clasificó según las variables más importantes encontradas respecto a su infraestructura y entorno. Las nueve variables finales fueron:

- “Aptitud para peatones, con espacios públicos y áreas verdes conectados

- Usos residenciales de viviendas unifamiliares adosadas localizadas en áreas no centrales

- Residencial multifamiliar de alta densidad

- Suelo sin desarrollar

- Áreas de uso mixto con buen estado y mantenimiento

- Espacios verdes con buen estado y mantenimiento

- Equipamientos de carácter público para usos institucionales orientados al sistema de BRT

- Desarrollos comerciales a gran escala

- Área urbana consolidada sin usos del suelo". (Rodriguez \& Vergel Tovar, 2013)

\subsection{Glosario de terminología}

\subsubsection{Ciudad radial o atomizada}

Geometría de la ciudad amplia, radio céntrica, de expansión regular por todos sus lados. $\mathrm{Su}$ red de comunicaciones favorece al desarrollo y gobernación de un Estado centralizado. La forma se da en capitales donde convergen y desde donde nacen grandes carreteras que, radialmente, las conectan con el resto del país. (Prieto Pérez, 2007)

Las siguientes imágenes, de Prieto Pérez (2007), son el Diagrama n. ${ }^{\circ} 3$ de Ebenezer Howard para una Ciudad Jardín de 32.000 habitantes; y Democracity, la futura ciudad del año 2039 imaginada por Henry Dreyfuss con motivo de la Feria Mundial de Nueva York de 1939. Ambas, ciudades de morfología radial. 

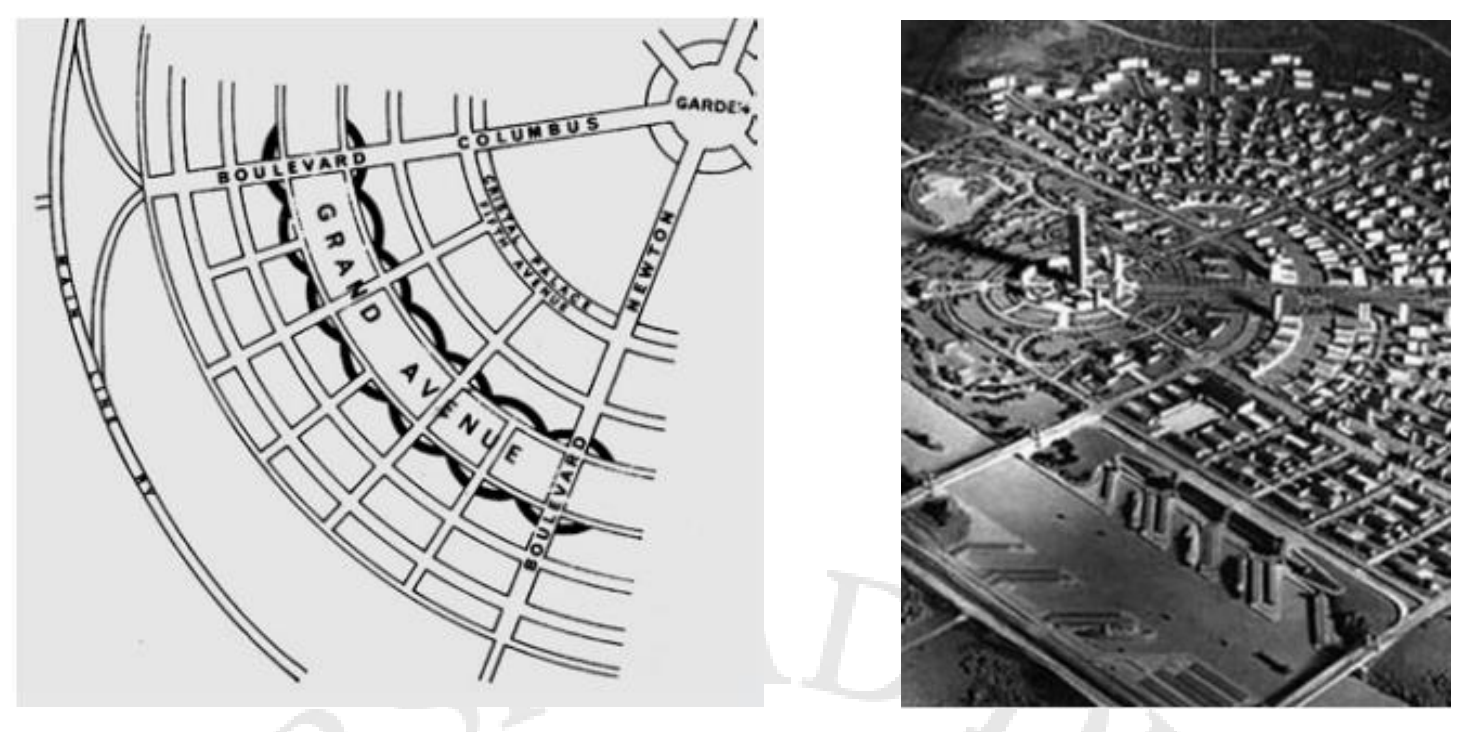

\subsubsection{Ciudad lineal}

Urbanizaciones cuya morfología se ve definida por carreteras o grandes vías. Por lo general, fueron ciudades que existieron en siglos pasados y su organización cambió con los años.
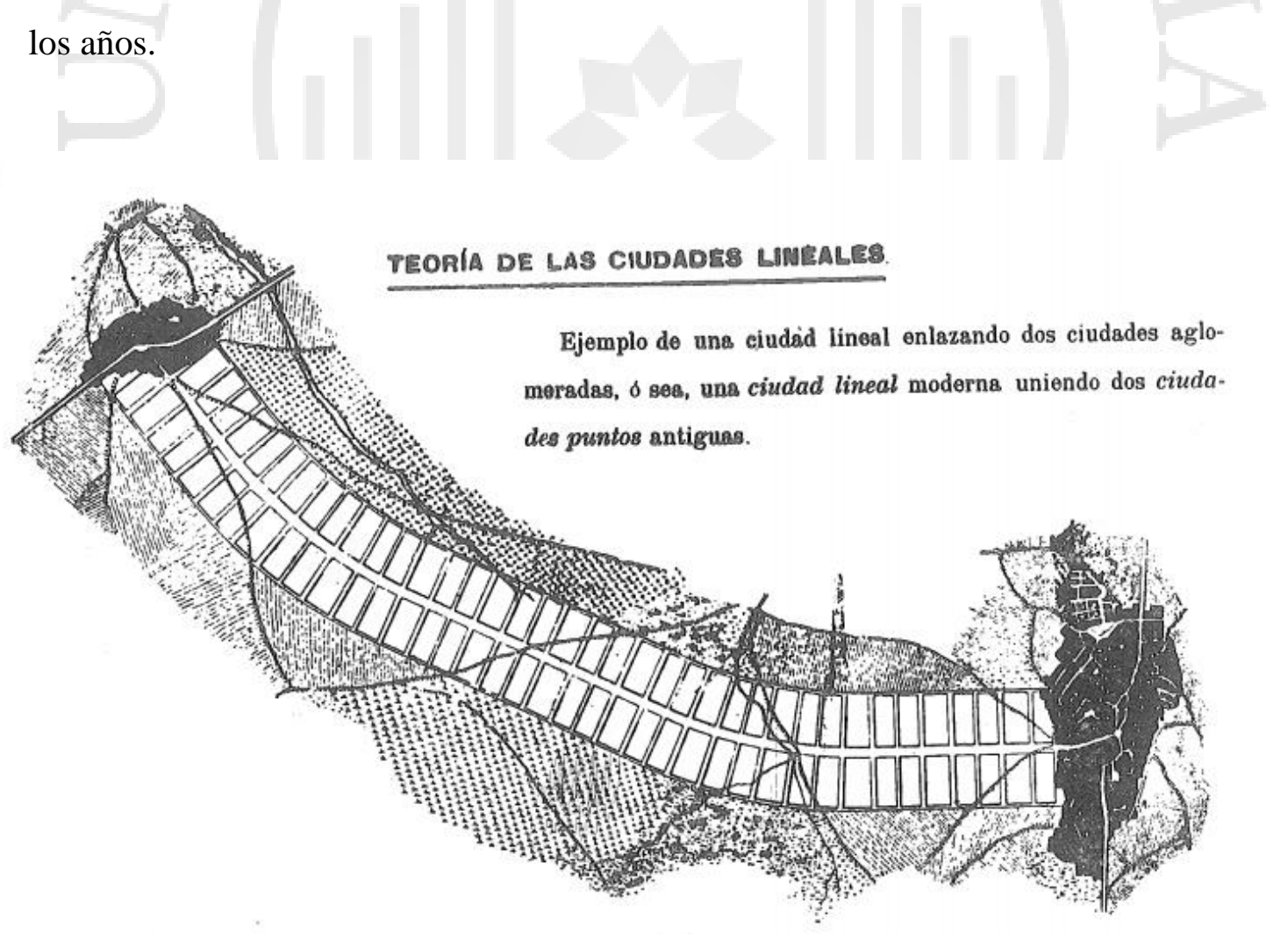


\section{Tuestra Giudad cheal thene 50 billometros propectados.}

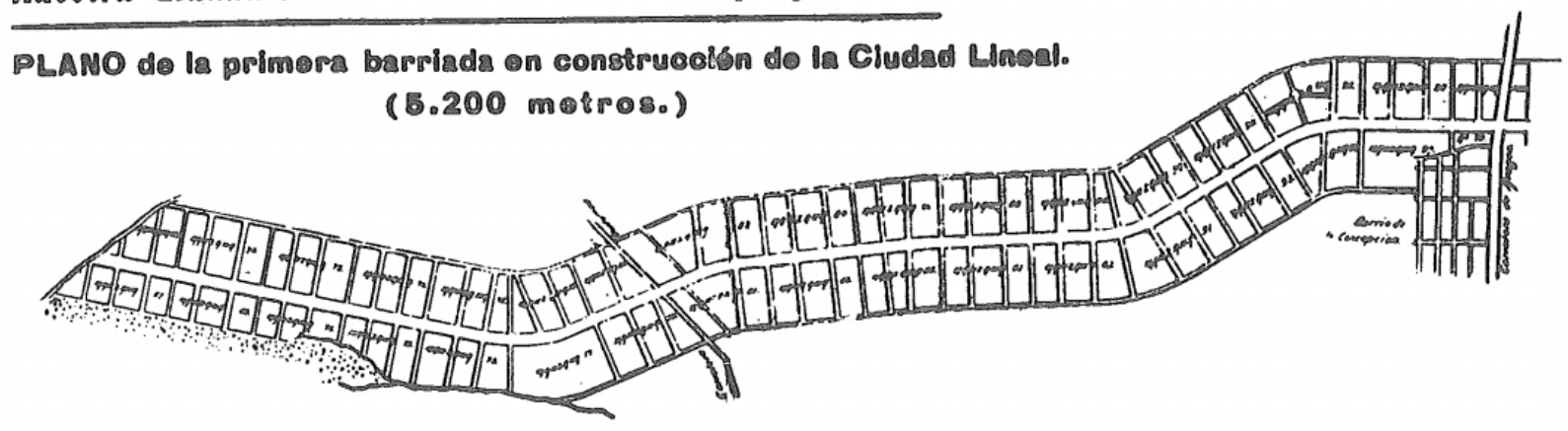

Planos: Arturo Soria (1964)

\subsubsection{Ciudad compacta}

Tipo de ciudad cuya estructura mantiene a todos sus elementos dentro de una superficie limitada y está caracterizada por un crecimiento vertical. Es densa, de continuidad formal, multifuncional, heterogénea y diversa. Algunos autores se refieren a ella como un modelo de ahorro energético, económico y de suelo donde, además, es posible mantener las afueras de la ciudad como rurales y agrícolas (Moliní \& Salgado, 2010).

La cantidad de funciones que se llevan a cabo en tan poco espacio, genera que la ciudad compacta sea de relaciones complejas en su interior.

\subsubsection{Ciudad integrada}

Más que una estructura física, la ciudad integrada es aquella, compacta o difusa, que articula todas sus zonas a través de sistemas integrados de movilidad y sociales. Cada espacio físico cuenta con comunicación entre sí.

\subsubsection{Ciudad policéntrica}

Tipología de ciudad conformada por más de un centro urbano, donde se concentran actividades económicas y sociales. Cada uno tiene funciones residenciales y productivas interdependientes. 
"El poli centrismo urbano es un proceso espontáneo de organización de las actividades económicas en áreas limitadas, con creciente población e inversión de capitales en el espacio, cuya distribución permite reproducir el proceso." (Gonzales de Olarte \& del Pozo Segura, 2012)

\subsubsection{Fragmentación urbana}

La fragmentación es uno de los fenómenos más comunes de las ciudades contemporáneas. Cuando se habla de fragmentación "se busca dar cuenta de una ruptura en la concepción integral de la ciudad”. (Jirón \& Mansilla, 2014).

Muchas veces los sectores en los que se fragmenta la ciudad no cuentan con los mismos equipamientos y por lo tanto las mismas oportunidades, lo cual constituye su mayor defecto e impacto social. "Es decir, la ciudad se fragmenta en espacios ganadores $\mathrm{y}$ perdedores, territorios iluminados y oscuros, islas de riqueza sobre mares de precariedad y vulnerabilidad"' (De Mattos, 2006)

\subsubsection{Animador urbano}

El concepto de animador, desde un punto de vista social,

Puede definirse como un estímulo mental, físico y emotivo, que en un sector determinado, incita a la gente a iniciar una gama de experiencias que los permita expandirse y expresar su personalidad y desarrollar en ellas el sentimiento de pertenecer a una comunidad sobre la cual pueden ejercer cierta influencia. (Chacón Blanco, 2010)

El concepto de lo urbano está compuesto por diversas características: "fundamentalmente, el tamaño y la densidad, el aspecto del núcleo, la actividad no agrícola y el modo de vida, así como ciertas características sociales, tales como la heterogeneidad, la 'cultura urbana' y el grado de interacción social.” (Capel, 1975).

Entonces, un animador urbano es un elemento (Infraestructura) que sirve como un estímulo social para las personas que viven en un entorno urbano. 


\subsubsection{Reemplazamiento}

Reemplazamiento se refiere al volver a emplazar dentro de la trama urbana de una ciudad un elemento que actualmente está generando conflictos.

\subsubsection{Cohesión urbana}

“Acción y efecto de reunirse o adherirse las cosas entre sí o la materia de que están formadas." (RAE, s.f.)

En este contexto, el termino se usa para referirse a la unión de espacios urbanos autónomos.

\subsubsection{Límites o bordes}

En un nivel barrial, existen diferentes maneras de entender un límite. Kevin Lynch lo entiende como aquellos elementos que dividen y que no pueden ser usados.

Los bordes son aquellos elementos lineales que no son considerados sendas; son por lo común, pero no siempre necesariamente, los límites entre zonas de dos clases diferentes. ... Los bordes que parece más fuertes son aquellos que no sólo son visualmente prominentes, sino que también tienen una forma continua y son impenetrables al movimiento transversal (Lynch, 2010)

Por otro lado, Jan Gehl entiende el borde o límite desde la relación entre un espacio de acceso público o uno de acceso privado.

Los límites muy definidos - como los que encontramos en las viviendas en altura, donde o bien estamos e un territorio totalmente privado (dentro y arriba) o bien en una zona totalmente pública (fuera, en las escaleras, en el ascensor o en la calle) - dificultarán en muchas situaciones el traslado al entorno público si no es necesario hacerlo. (Gehl, 2006) 
En todas las aproximaciones al concepto de borde o límite mencionadas, se le atribuye al mismo el poder de dividir. Sin embargo, también podría entenderse como un elemento usado para delimitar los espacios que son privados de los espacios que son públicos, sin la necesidad de cerrar uno en relación al otro.

\subsubsection{Justicia e inclusión social}

La inclusión social es una situación en la cual, a todos los ciudadanos, sin excepción, se les asegura el poder de "ejercer sus derechos, aprovechar sus habilidades y tomar ventaja de las oportunidades que encuentran en su medio." (Ministerio de Desarrollo e Inclusión Social, s.f.)

Asimismo, la justicia social,

Se refiere a las nociones fundamentales de igualdad de oportunidades y derechos humanos, más allá del concepto tradicional de justicia legal. Está basada en la equidad y es imprescindible para que los individuos puedan desarrollar su máximo potencial y para que se pueda instaurar una paz duradera. (UNICEF, 2000)

\subsubsection{Sostenibilidad}

Equilibrio entre el Poder Social, el Poder Económico, y el Poder Ambiental. Del desarrollo paralelo y equitativo de los tres, depende el desarrollo sostenible de un sistema (Brundtland, 1987). Actualmente, los humanos contamos con un sistema lineal de extracción, producción, consumo y deshecho que agota los bienes y contamina el medio. Por ello, ser sostenible es inclinarse al modelo de los ecosistemas naturales; estos son cerrados y cíclicos, donde el propio sistema produce, consume y aprovecha los productos residuales para volver a producir.

Como ciudad y sociedad, ser sostenibles es cubrir poder las necesidades humanas sin comprometer las de generaciones futuras. 


\subsubsection{Trama urbana}

La trama urbana es la forma y orden que toma una ciudad, según la organización de vías y edificios. Es un mapa mental relativo, según la perspectiva del habitante: peatón, vehículos o transporte público; y los usos que cada uno atribuye a la ciudad. (Borja, 2000)

\subsubsection{Tránsito, transporte y tráfico}

Transporte, "es la acción y efecto de transportar o transportarse de un lugar a otro" (Cárdenas Grisales, 1998). Los diferentes sistemas de transporte que se han creado en las ciudades sirven para satisfacer la demanda de movilidad de las personas.

Tránsito es la acción de pasar por lugar para llegar a otro. Se ve cuantificada en la cantidad de autos, buses, bicicletas (sistemas de transporte) estén en una sección o tramo de una vía.

Tráfico se refiere a el tránsito de las personas y circulación de vehículos en una ruta o serie de rutas.

\subsubsection{Equipamiento Cultural}

Con equipamiento cultural nos referimos a cualquier infraestructura pública en la que se desarrollen actividades culturales y educativas. Los equipamientos culturales de una ciudad pueden ser: Teatros, museos, galerías de arte, cines, centros de educación artística, centros culturales, etcétera.

\subsubsection{Espacios urbanos autónomos}

Los espacios urbanos autónomos son zonas de una misma ciudad que funcionan independientemente uno del otro. Cada uno con sus propia problemática y estructura 
social, sin embargo, ambos pertenecen a la misma trama urbana. (Jirón \& Mansilla, 2014)

\subsubsection{Impacto social urbano}

Se refiere a los cambios que una acción o nueva infraestructura puede generar. En cuanto a lo social, se habla de las personas que viven en el entorno inmediato, y sobre la forma en la que una acción puede afectar de manera positiva o negativa su vida diaria, así como su vida social. Lo urbano, se refiere a aquello que puede cambiar la forma en la que las personas usan la ciudad, desde su movilidad hasta su accesibilidad.

\subsubsection{Elemento articulador}

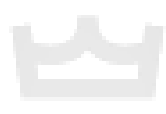

Un elemento articulador es aquel que funciona como un eje conector entre dos zonas separadas. Este elemento es una intervención urbana que tiene como fin atraer a diferentes tipos de usuario, que se encuentren en zonas divorciadas socialmente. Su uso, por lo tanto, su uso las cohesiona.

Asimismo, un elemento articulador es aquel que conecta a nivel físico-urbano dos espacios autónomos.

\subsubsection{Movilidad}

\subsubsection{Vías expresas}

Son aquellas que sirven al tránsito de paso con accesos controlados mediante rampas e intersecciones a desnivel. Generalmente, están conectadas entre sí y/o con las vías arteriales (avenidas). (Ortiz de Zevallos, 1992, pag.143) 


\subsubsection{Vías arteriales o avenidas}

Sirven preferentemente al tránsito de paso. Funcionan a nivel y son controladas por semáforos. Al permitir una velocidad relativamente elevada, produce preferencia al tránsito vehicular en la circulación.

Para el transporte público, se debe diseñar adecuadamente paraderos en las avenidas para no interferir con la circulación vehicular. (Ortiz de Zevallos, 1992, pag. 143)

\subsubsection{Vías colectoras}

"Tienen como función colectar el tránsito de las calles locales hasta el sistema arterial" (Ortiz de Zevallos, 1992, pag. 161). Se permite el estacionamiento en la vía y los paraderos de transporte público también deben estar debidamente diseñados y localizados.

\subsubsection{Vía local o calle local}

"Son las que sirven exclusivamente para dar acceso a la propiedad. Conducen sólo al tránsito local." (Ortiz de Zevallos, 1992, pag. 144)

\subsubsection{Desarrollo urbano}

Es el proceso de materializaciones físicas en la ciudad que lleva a una comunidad a lograr bienestar de vida y hábitat. Además, se "relaciona directamente con el adecuado uso del espacio y el territorio, de los recursos ambientales y de la ciudad existente" (Ortiz de Zevallos, 1992, pag. 16). Desarrollo no (necesariamente) significa expansión física, si no un equilibrio de la ciudad donde se fomente lo colectivo y la identidad. 


\subsubsection{Plan de desarrollo urbano}

Es un conjunto de acciones concertadas hacia un objetivo. Toma la forma de escritos, normal, y planos que pueden ser ordenadores o prescriptivos, y son preparados por las autoridades y organismos a los que compete la labor de planificación urbana y territorial. (Ortiz de Zevallos, 1992, pag.16)

\subsubsection{La eficiencia en el sistema vial}

Se refiere a un adecuado diseño, donde cada transporte recorre la vía que corresponde; existe una jerarquía clara de vías; cada tramo cuenta con los adecuados dispositivos de control (semáforos, rampas, desniveles, etc.); y un adecuado diseño y disposición de aquellos elementos que puedan perturbar el flujo vehicular (paraderos, zonas de carga y descarga, etc.) (Ortiz de Zevallos, 1992, pag. 144)

\subsubsection{Estación intermodal}

La Intermodalidad es una "característica de un sistema de transporte en virtual de la cual se utilizan de forma integrada al menos dos modos de transporte diferentes para completar una cadena de transporte puerta a puerta" (Autoridad Portuaria de Guijón, 2008, pág. 4).

Una Estación intermodal de pasajeros es aquella que recibe más de un sistema de transporte de usuarios, coordinando transbordos y optimizando tarifas. A través de este sistema, los pasajeros pueden recorrer mayores distancias formalmente entre puntos de la ciudad. 


\subsection{Instituciones afines}

\subsubsection{PROTRANSPORTE}

PROTRANSPORTE es el instituto de transporte de Lima. Es una entidad de la Municipalidad Metropolitana de Lima (MML), creada para lograr mejor el sistema de transporte público de nuestra ciudad. Actualmente, es encargado de la ejecución del Metropolitano de Lima.

Entre sus objetivos se encuentran:

- "Darle prioridad al transporte público como la forma más importante de movilización de personas por la ciudad.

- Ordenar el sistema de transporte público tomando en cuenta la diversidad de soluciones técnicas y la infraestructura y sistema existentes para transportar a gran número de personas de forma eficiente.

- Asegurar que el nuevo sistema sea económicamente, financieramente y ecológicamente sostenible.

- Promover la inversión pública y privada en proyectos estratégicos de infraestructura urbana.

- Reactivar la economía e inversión en el sector transporte a través del sistema de concesiones.

- Tecnificar y modernizar las instituciones municipales rectoras del transporte público conjuntamente con las empresas privadas del sector para que estos logren su eficiencia organizacional.

- Consolidar la legalidad e institucionalidad en el sistema.

- Educar al usuario en una nueva cultura de transporte.” (PROTRANSPORTE, 2013)

\subsubsection{Ministerio de Transporte y Comunicaciones (MTC)}

Es una entidad ejecutiva del estado, que se encarga de desarrollar los sistemas transporte y la infraestructura de comunicaciones y telecomunicaciones del país. Gestiona los 
sistemas terrestres, marítimos y aéreos de transporte, así como la operación de estaciones de radio y seña abierta en todo el Perú.

En cuanto a este trabajo, el ministerio de transporte y comunicaciones, se relaciona con la infraestructura vial, puesto que es "promotor de iniciativas destinadas a la construcción de nuevas carreteras así como la puesta en marcha de grandes sistemas de transporte público” (MTC: Ministerio de transportes y comunicaciones, s.f.)

\subsubsection{Ministerio de Cultura}

Es el organismo del Poder Ejecutivo que se encarga de todas las competencias culturales del país. Éste, ejerce poder sobre:

- "Patrimonio cultural de la nación, material e inmaterial

- Creación cultural contemporánea y artes vivas

- Gestión cultural e industrias culturales

- Pluralidad étnica y cultural de la nación" (Ministerio de Cultura, 2016)

Mantiene una relación organizacional con el Gran Teatro Nacional y La Biblioteca Nacional del Perú, a manera de espacio estratégico de desarrollo estratégico de conocimiento y producción artística en la sociedad.

\subsubsection{Municipalidad Metropolitana de Lima (MML)}

Es la municipalidad provincial encargada de Lima Metropolitana. El alcalde, al año 2018, es Luis Castañeda Lossio y se compone por los siguientes organismos:

- Concejo Metropolitano

- Alcaldía Metropolitana

- Asamblea Metropolitana

- Órganos de Asesoramiento Metropolitano.

- Gerencias Municipales

- Gerencia Municipal Metropolitana

- Gerencia de Comunicación Social y Relaciones Públicas

- Gerencia de Defensa del Ciudadano 
- Gerencia de Administración

○ Gerencia de Desarrollo Social

- Gerencia de la Mujer

- Gerencia de Educación y Deportes

- Gerencia de Cultura

- Gerencia de Participación Vecinal

○ Gerencia de Finanzas

- Procuraduría Pública Municipal

- Gerencia de Asuntos Jurídicos

- Gerencia de Planificación

- Gerencia de Desarrollo Económico

- Gerencia de Servicios a la Ciudad y Gestión Ambiental

- Gerencia de Seguridad Ciudadana

- Gerencia de Desarrollo Urbano

- Gerencia de Fiscalización y Control

- Gerencia de Transporte Urbano

- Gerencia de Promoción de la Inversión Privada.

- Empresas Municipales

(Municipalidad Metropolitana de Lima, 2016)

\subsubsection{Municipalidad de Barranco}

Es la municipalidad distrital de uno de los principales distritos turísticos y tradicionales de Lima. Tiene como propósito mantener el patrimonio histórico que los caracteriza. Su actual alcalde es Antonio Mezarina y también cuenta con Gerencias similares a las de la Municipalidad de Lima.

La Municipalidad ha segmentado al distrito en 3 zonas divididas por dos avenidas principales y las clasifica según nivel de construcción, infraestructura y nivel socioeconómico. Además, se ha encargado de realizar un profundo diagnóstico demográfico en Barranco para lograr los lineamientos planteados en Agenda 21, un documento basado en términos de las Naciones Unidas, que pretende aumentar la oferta cultural del distrito. 


\subsubsection{PLAM 2035}

El Plan Metropolitano de desarrollo urbano de Lima-Callao (Plam), es un instrumento técnico que busca dirigir estratégicamente el crecimiento de nuestra ciudad. Por ello, es imprescindible contar con una visión de desarrollo que oriente los esfuerzos que realizarán las diferentes gestiones metropolitanas, alcaldes distritales, empresarios, vecinos y la sociedad en su conjunto, a fin de encauzarnos hacia un futuro más equitativo, ordenado y competitivo, con acceso a mejores servicios y equipamientos para la ciudad. (Arce, Vargas Vila, \& Zucchetti, 2015)

Este plan se ha elaborado en base a nueve lineamientos para Lima:

- "Justa e incluyente, que garantiza una provisión equitativa de servicios, equipamientos e infraestructuras de uso público en todo el territorio metropolitano.

- Patrimonial y creativa, que promueve el desarrollo de capacidades de su población.

- Sostenible, saludable y resiliente, que hace uso racional de sus recursos, reduce la vulnerabilidad de sus zonas críticas y protege sus líneas vitales.

- Compacta, que se densifica y equipa en áreas estratégicas.

- Integrada, que se articula a través de un sistema integrado de movilidad sostenible.

- Policéntrica, que reduce la dependencia de sus periferias con respecto al área central metropolitana.

- Dinamizadora del Perú y proyectada al mundo, que se proyecta internacionalmente a la cuenca del Pacífico Sur.

- Competitiva, que mejora sus redes logísticas, incrementa sus zonas productivas y crea condiciones favorables para el desarrollo económico.

- Planificada y gobernable, que facilita su gobernanza." (García Calderón, 2015) 


\subsection{Reglamentación y normas}

\subsubsection{Centros Culturales}

El Reglamento Nacional de Edificaciones no contempla a centro culturales como un equipamiento, sin embargo, se usarán las normas establecidas para edificaciones recreativas y deportivas que se encuentran en la norma A100.

\subsubsection{BRT}

\subsubsection{Ancho mínimo de carriles para sistemas BRT}

\begin{tabular}{|l|c|}
\hline \multicolumn{1}{|c|}{ Tipo de carril } & $\begin{array}{c}\text { Ancho mínimo } \\
\text { recomendado } \\
\text { por sentido }\end{array}$ \\
\hline Andén & 3 \\
\hline Ciclovía & 2.5 \\
\hline Carril de buses en la estación & 3 \\
\hline Carril de buses en el corredor & 3.5 \\
\hline $\begin{array}{l}\text { Divisor del separador en el } \\
\text { corredor }\end{array}$ & 0.5 \\
\hline Carril para tráfico mixto & 3.5 \\
\hline Otros carriles para tráfico mixto & 3 \\
\hline Ancho de la estación & 3 \\
\hline
\end{tabular}

"El ancho de la estación depende en gran medida de la capacidad; la mínima presentada aquí es una cifra real del sistema de BRT de Quito" (Wright \& Hook, 2010).

- Consideraciones de Diseño para buses articulados

Fuente: MANUAL DE CARRETERAS: DISEÑO GEOMÉTRICO DG-2018, MTC 
Tabla: Radios de giro para ómnibus articulado

Ómnibus articulado (BA-1)

Radios máximos/mínimos y ángulos

\begin{tabular}{|c|c|c|c|c|}
\hline $\begin{array}{c}\text { Ángulo } \\
\text { trayectoria }\end{array}$ & $\begin{array}{c}\text { R máx. } \\
\text { exterior } \\
\text { vehículo (E) }\end{array}$ & $\begin{array}{c}\text { R mín. } \\
\text { interior } \\
\text { vehículo (I) }\end{array}$ & $\begin{array}{c}\text { Ángulo Máximo } \\
\text { dirección }\end{array}$ & $\begin{array}{c}\text { Ángulo } \\
\text { Máximo } \\
\text { articulación }\end{array}$ \\
\hline $30^{\circ}$ & $13.66 \mathrm{~m}$ & $9.06 \mathrm{~m}$ & $19.0^{\circ}$ & 11.60 \\
\hline $60^{\circ}$ & $14.08 \mathrm{~m}$ & $8.41 \mathrm{~m}$ & $26.4^{\circ}$ & $21.3^{\circ}$ \\
\hline $90^{\circ}$ & $14.25 \mathrm{~m}$ & $8.05 \mathrm{~m}$ & $29.4^{\circ}$ & $27.5^{\circ}$ \\
\hline $120^{\circ}$ & $14.30 \mathrm{~m}$ & $7.86 \mathrm{~m}$ & 30.6 & 30.90 \\
\hline $150^{\circ}$ & $14.32 \mathrm{~m}$ & $7.76 \mathrm{~m}$ & $31.2^{\circ}$ & $32.7^{\circ}$ \\
\hline $180^{\circ}$ & $14.33 \mathrm{~m}$ & $7.72 \mathrm{~m}$ & 31.40 & 33.60 \\
\hline
\end{tabular}

Similar a "Minimum Turning Path for Articulated Bus (A-BUS) Design Vehicle" en la norma AASHTO.|

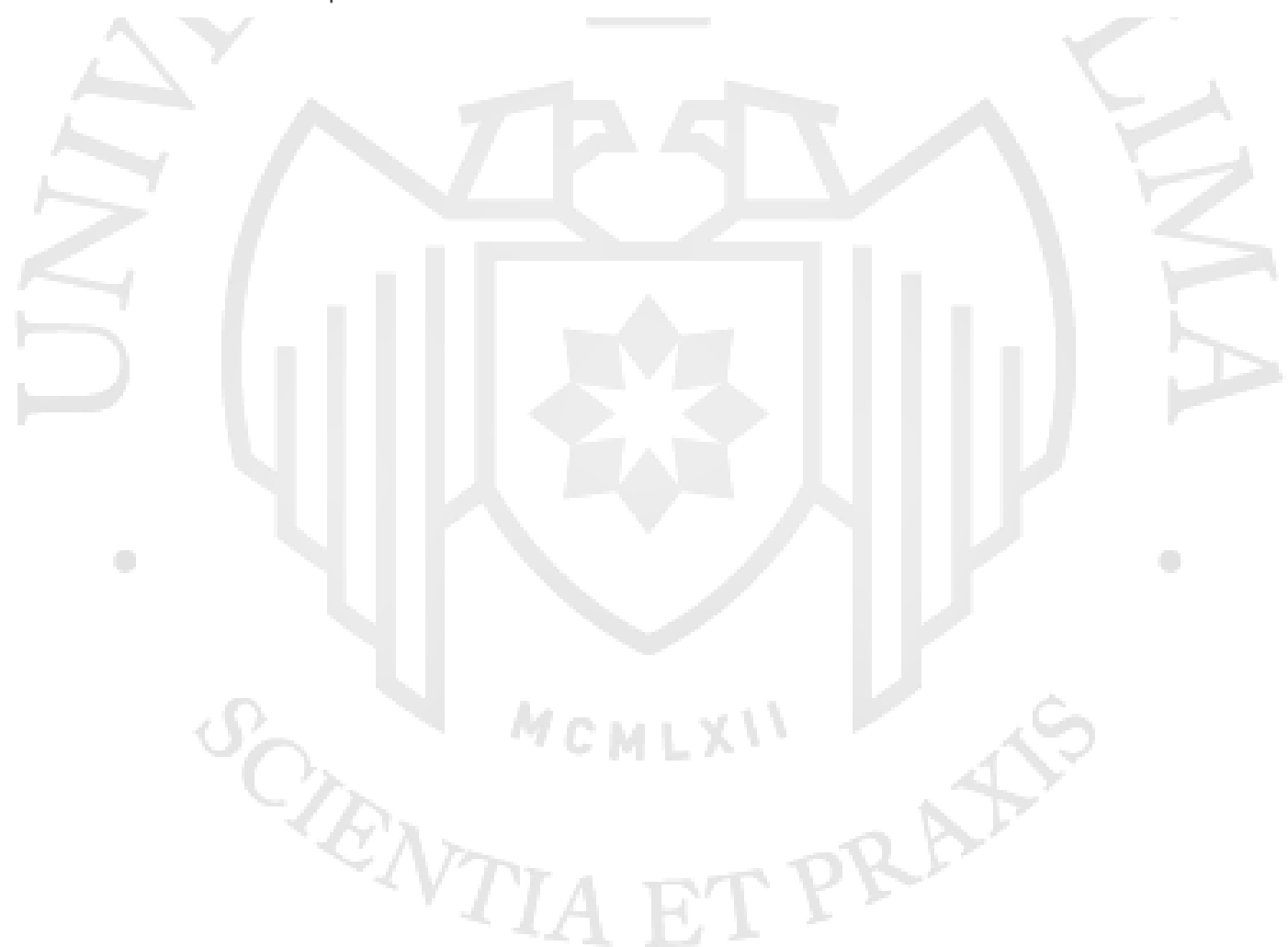


Esquema: Giro mínimo para ómnibus articulados (BA-1) Trayectoria 30

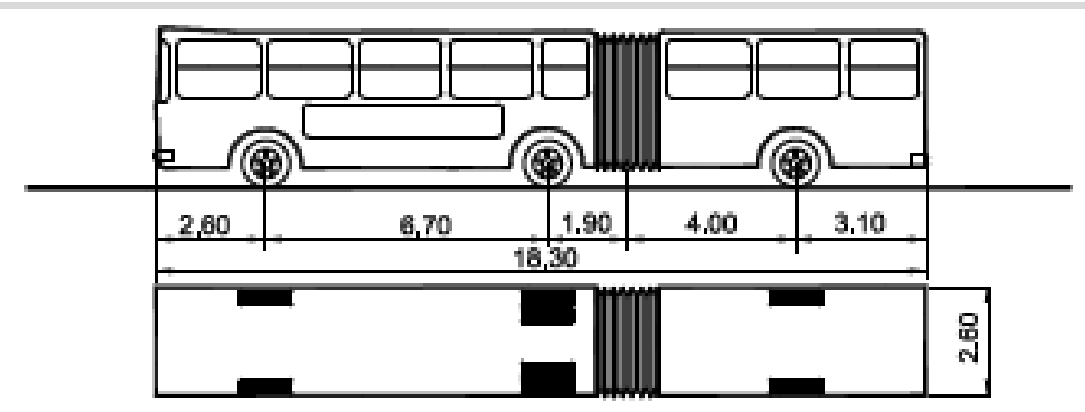

escala en metros

$\begin{array}{llllll}0,5 & 1 & 2 & 3 & 4 & 5\end{array}$

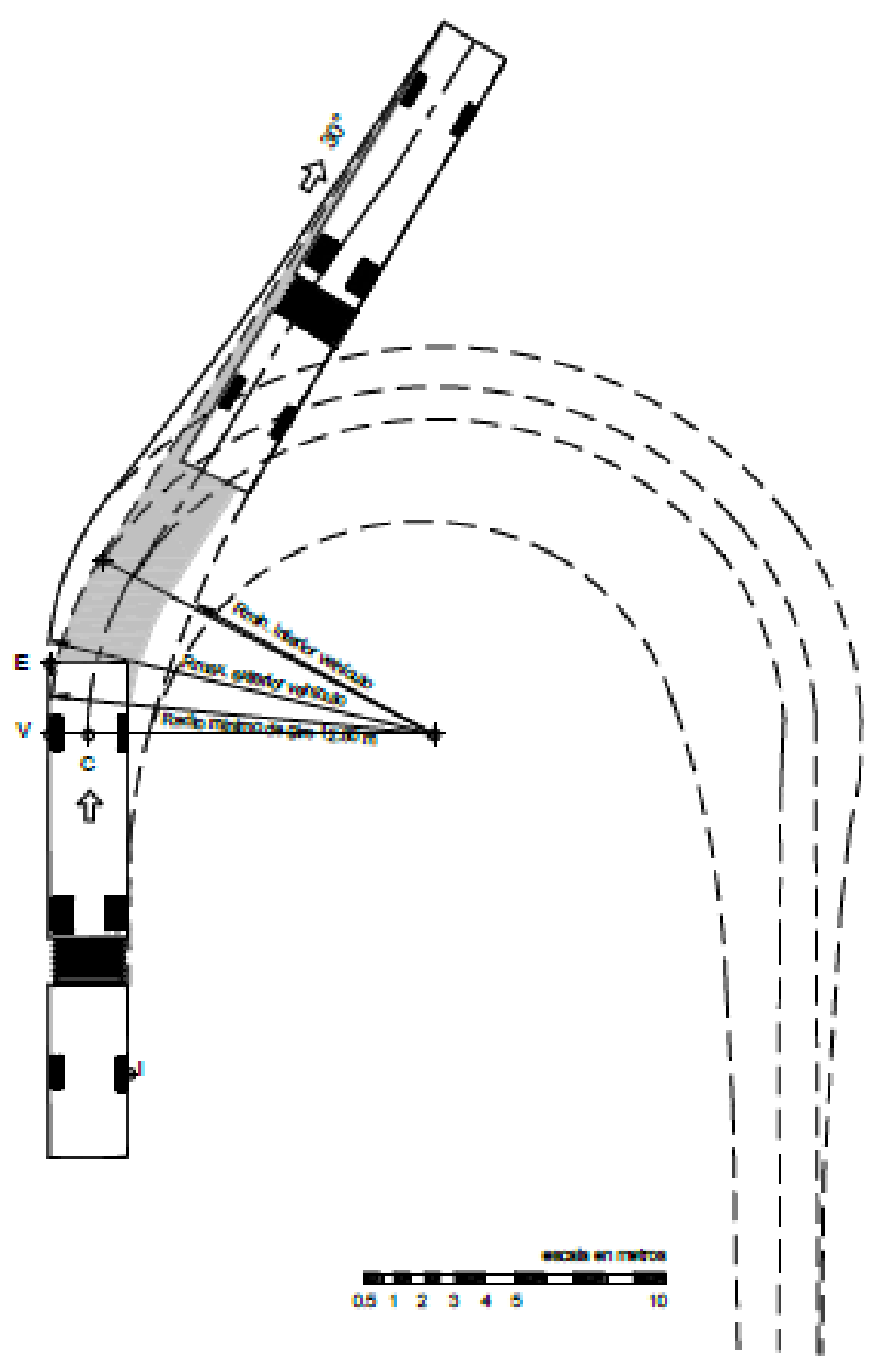


Giro mínimo para ómnibus articulados (BA-1) Trayectoria $60^{\circ}$

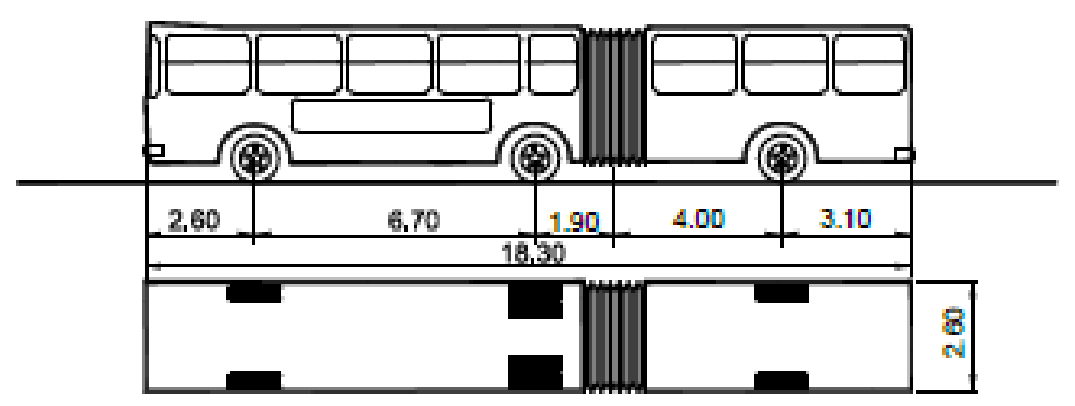

escala en metros

$\begin{array}{llllll}0.5 & 1 & 2 & 3 & 4 & 5\end{array}$

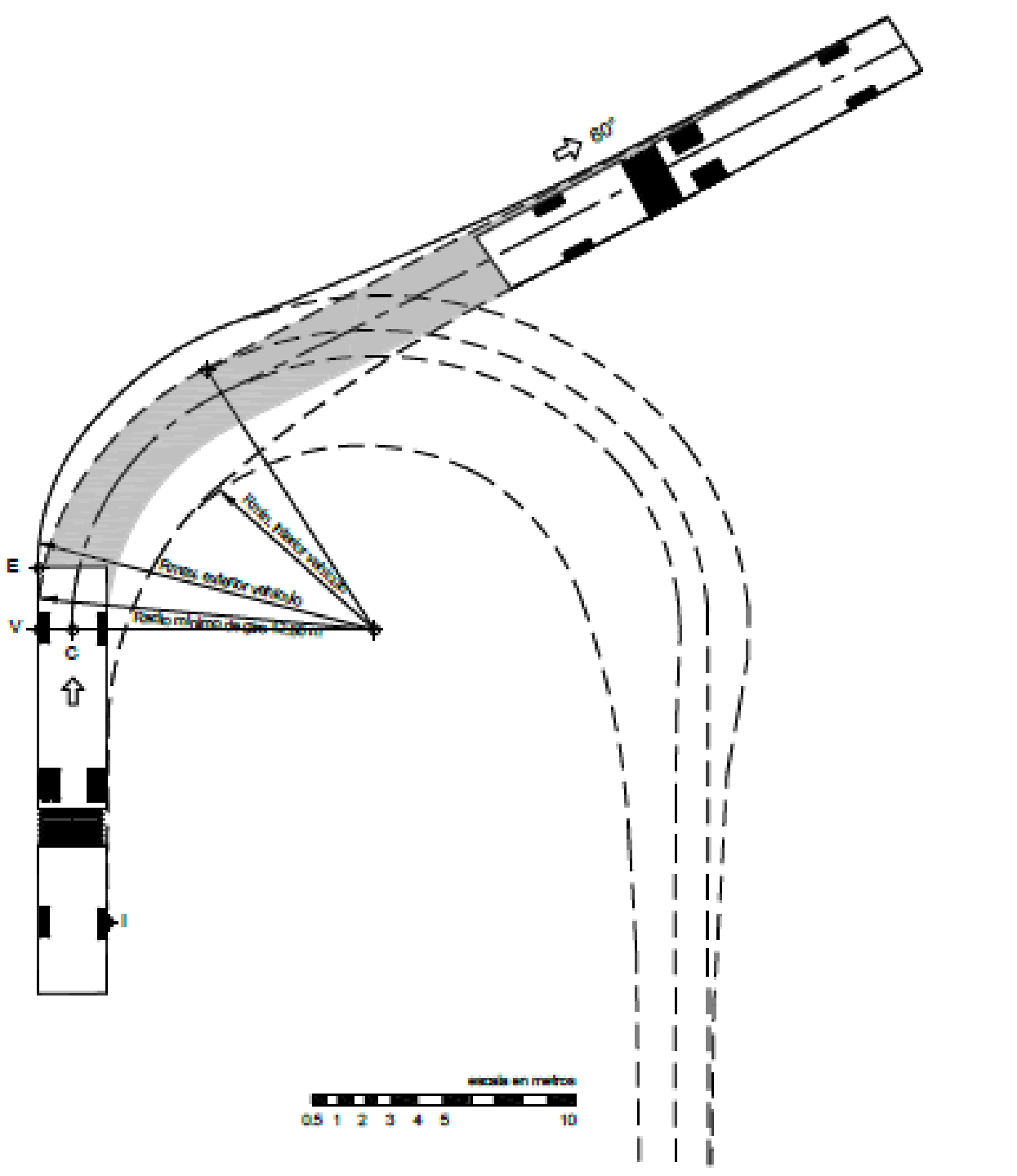


Giro mínimo para ómnibus articulados (BA-1) Trayectoria $90^{\circ}$
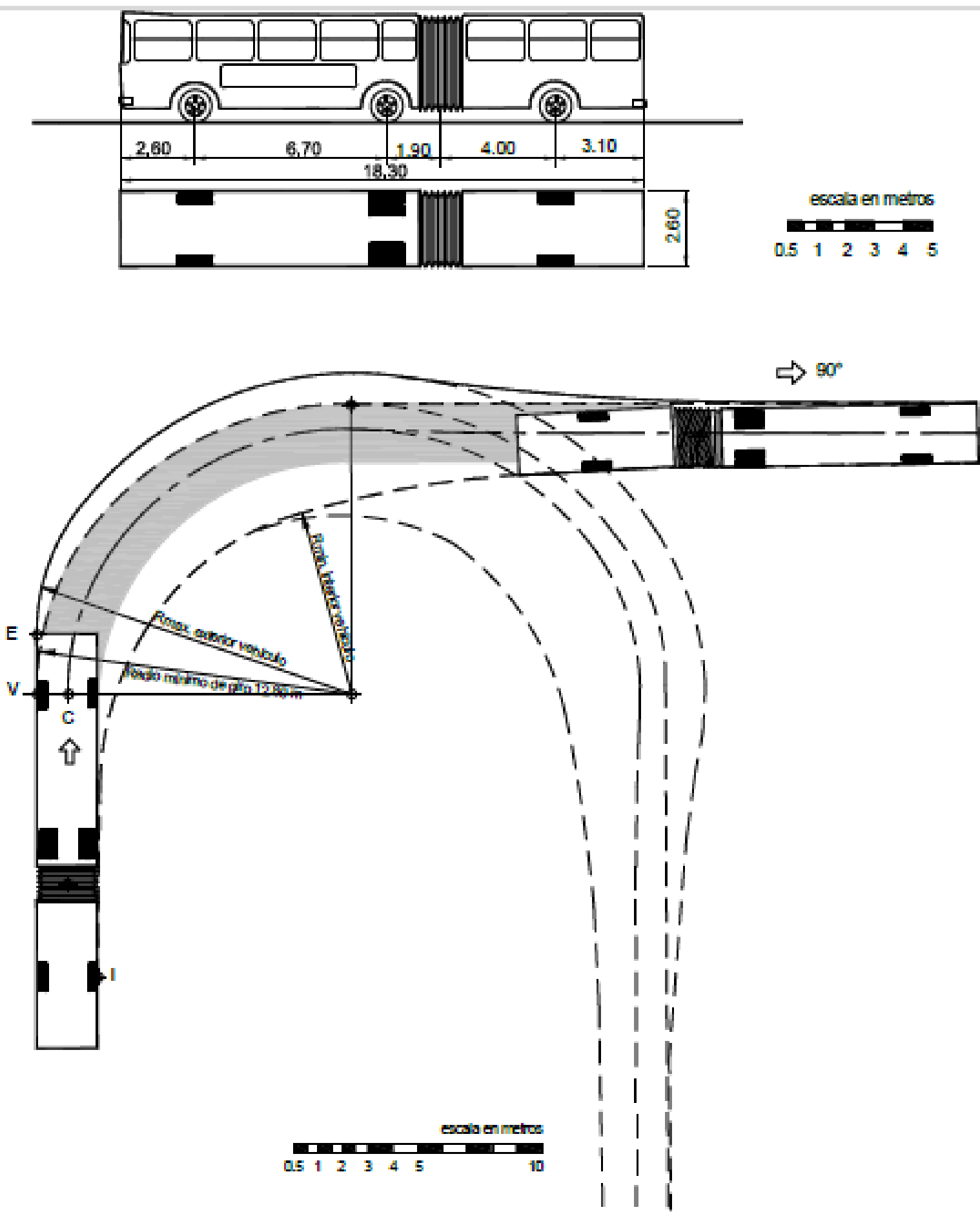
Giro mínimo para ómnibus articulados (BA-1) Trayectoria $120^{\circ}$

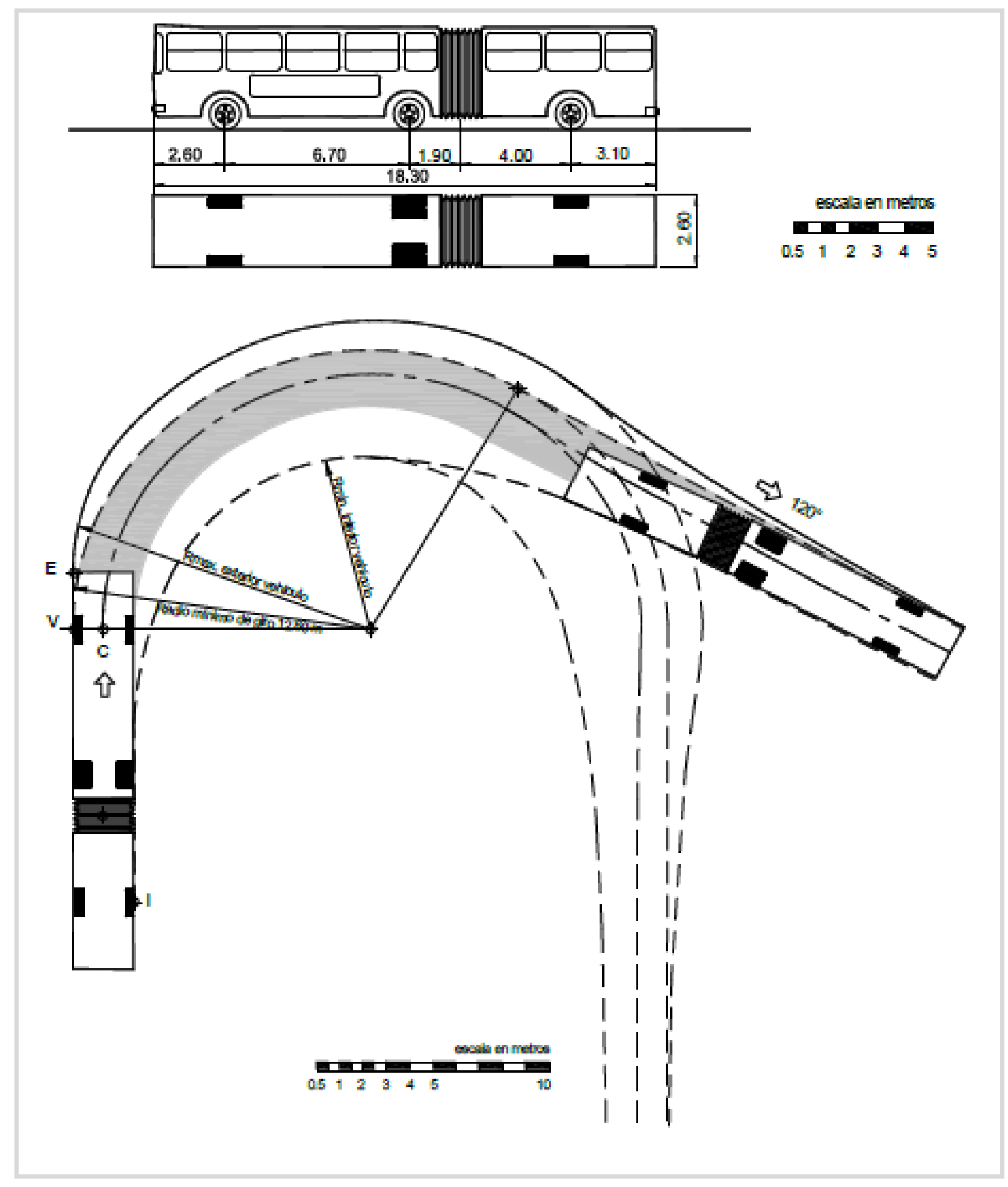


Giro mínimo para ómnibus articulados (BA-1) Trayectoria $150^{\circ}$

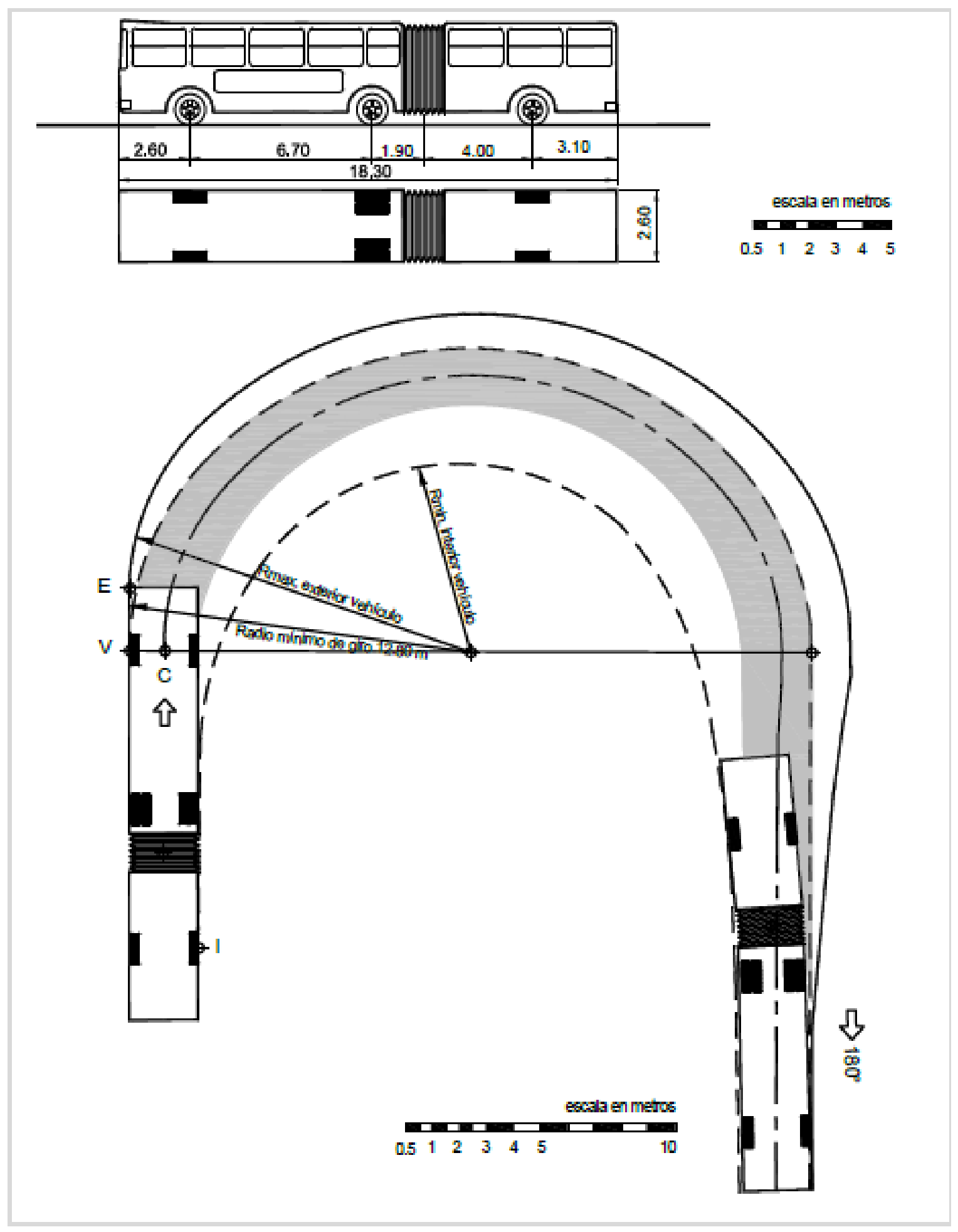


Giro mínimo para ómnibus articulados (BA-1) Trayectoria $180^{\circ}$

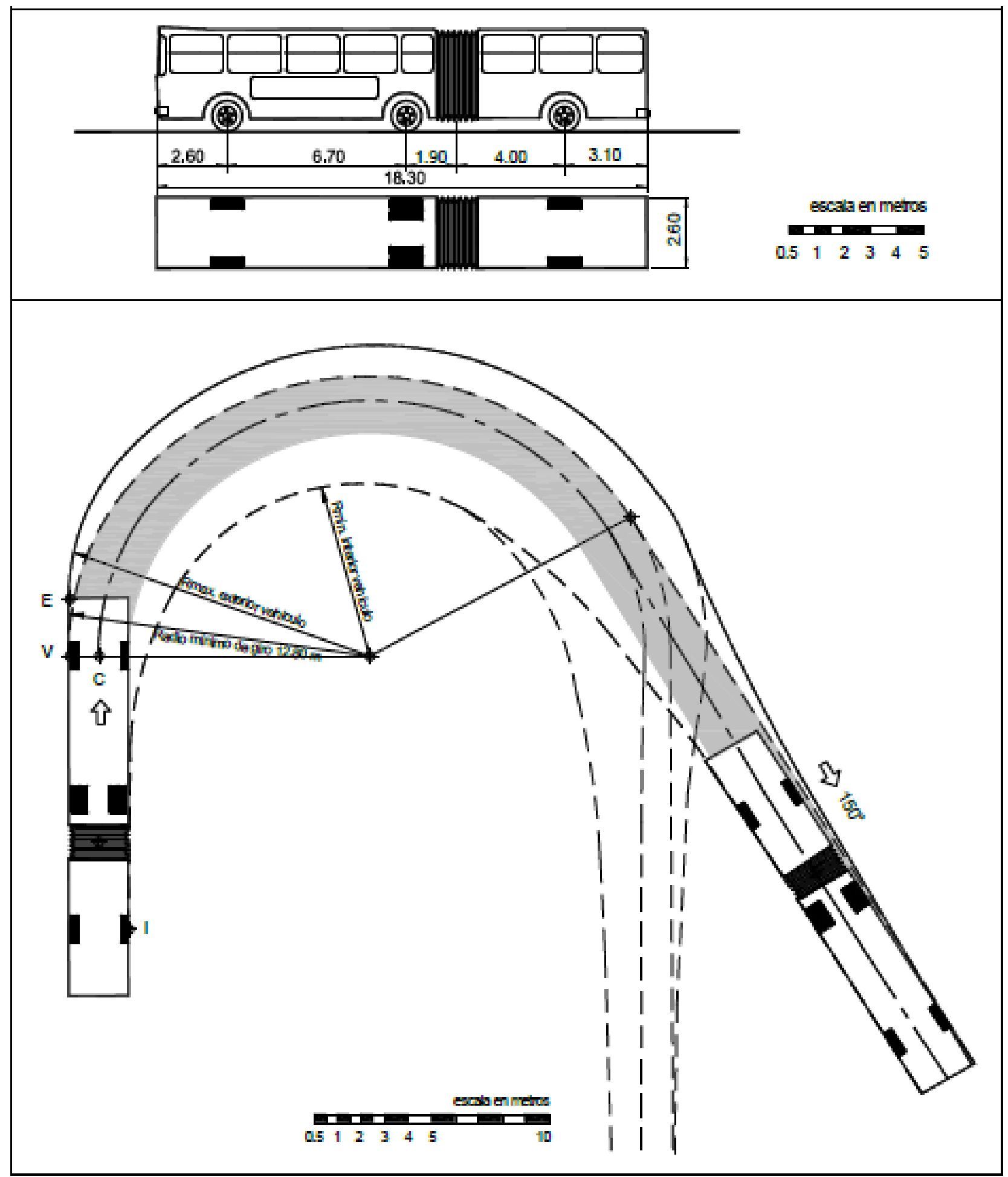




\section{- Norma Peruana para Terminales terrestres.}

Fuente transcripta: Reglamento Nacional de Edificaciones, Norma A110 Subcapítulo II

Artículo 5.- Para la locación de terminales terrestres se considerará lo siguiente:

a. Su ubicación debería estar de acuerdo a lo establecido en el Plan Urbano.

b. B. El terreno deberá tener un área que permita albergar en forma simultánea al número de unidades que puedan maniobrar y circular sin interferir unas con otras en horas de máxima demanda.

c. El área destinada a maniobras y circulación debe ser independiente a las áreas que se edifiquen para los servicios de administración, control, depósitos, así como servicios generales para pasajeros.

d. Deberán presentar un Estudio de Impacto vial e Impacto Ambiental.

e. Deberán contar con áreas para el estacionamiento y guardianía de vehículos de los usuarios y de servicio público de taxis dentro del perímetro del terreno del terminal.

Artículo 6.- Las edificaciones para terminales terrestres deberán cumplir con los siguientes requisitos:

a. Los accesos para salida y llegada de pasajeros deben ser independientes.

b. Debe existir un área destinada al recojo de equipaje

c. El acceso y salida de los buses al terminal debe resolverse de manera que exista visibilidad de la vereda desde el asiento del conductor.

d. La zona de abordaje a los buses debe estar bajo techo y permitir su acceso a personas con discapacidad.

e. Deben contar con sistemas de comunicación visual y sonora.

Artículo 7.- Las edificaciones para terminales terrestres, estarán provistas de servicios sanitarios según lo que se establece a continuación. 
Según el número de personas

Hombres Mujeres

De 0 a 100 personas

$1 \mathrm{~L}, 1 \mathrm{u}, 1 \mathrm{l} \quad 1 \mathrm{~L}, 1 \mathrm{I}$

De 101 a 200

$2 \mathrm{~L}, 2 \mathrm{u}, 2 \mathrm{I} \quad 2 \mathrm{~L}, 2 \mathrm{I}$

De 201 a 500

$3 \mathrm{~L}, 3 \mathrm{u}, 3 \mathrm{I} \quad 3 \mathrm{~L}, 3$

Cada 300 personas adicionales

$1 \mathrm{~L}, 1 \mathrm{u}, 1 \mathrm{l} \quad 1 \mathrm{~L}, 1 \mathrm{I}$

$\mathrm{L}=$ lavatorio, $\mathrm{u}=$ urinario, $\mathrm{I}=$ Inodoro

Los servicios higiénicos estarán sectorizados de acuerdo a la distribución de las salas de espera de pasajeros.

Adicionalmente deben proveerse servicios sanitarios para el personal de acuerdo a la demanda para oficinas, para los avientes de uso comercial como restaurantes o cafeterías y para personal de mantenimiento.

\subsubsection{Ciclovías}

Gráficos extraídos del documento del Ministerio de Vivienda de Norma técnica CE.030 OBRAS ESPECIALES Y COMPLEMENTARIAS (Ministerio de Vivienda, 2010):

- Ejemplo de ciclovía ubicada entre vereda y estacionamiento perpendicular a la vía.

\section{Vista Frontal}

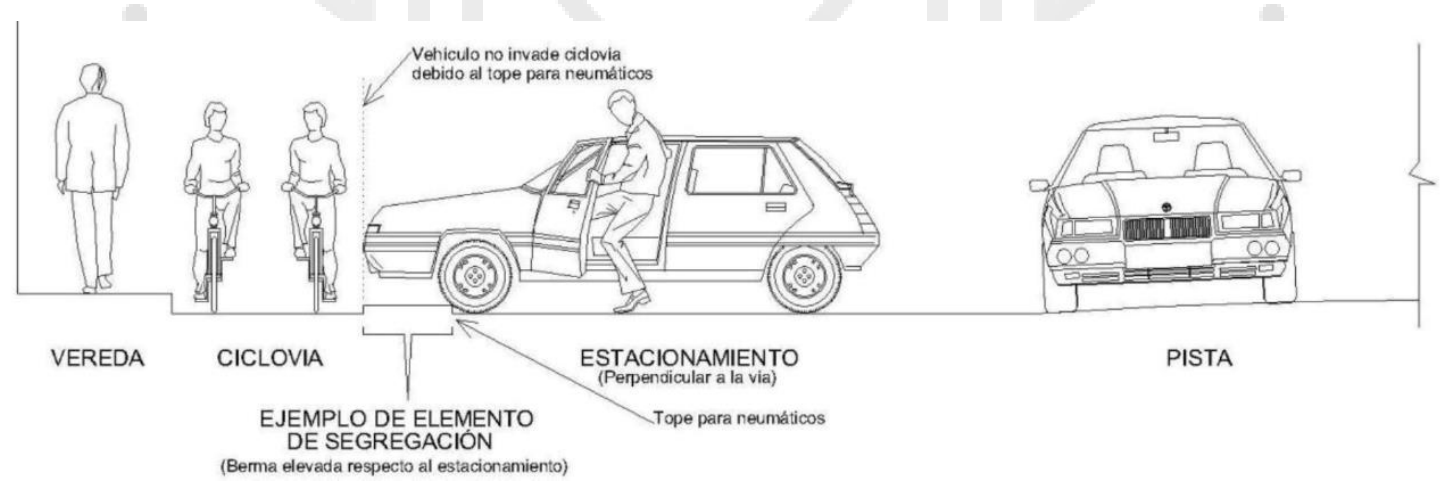

Vista en planta 


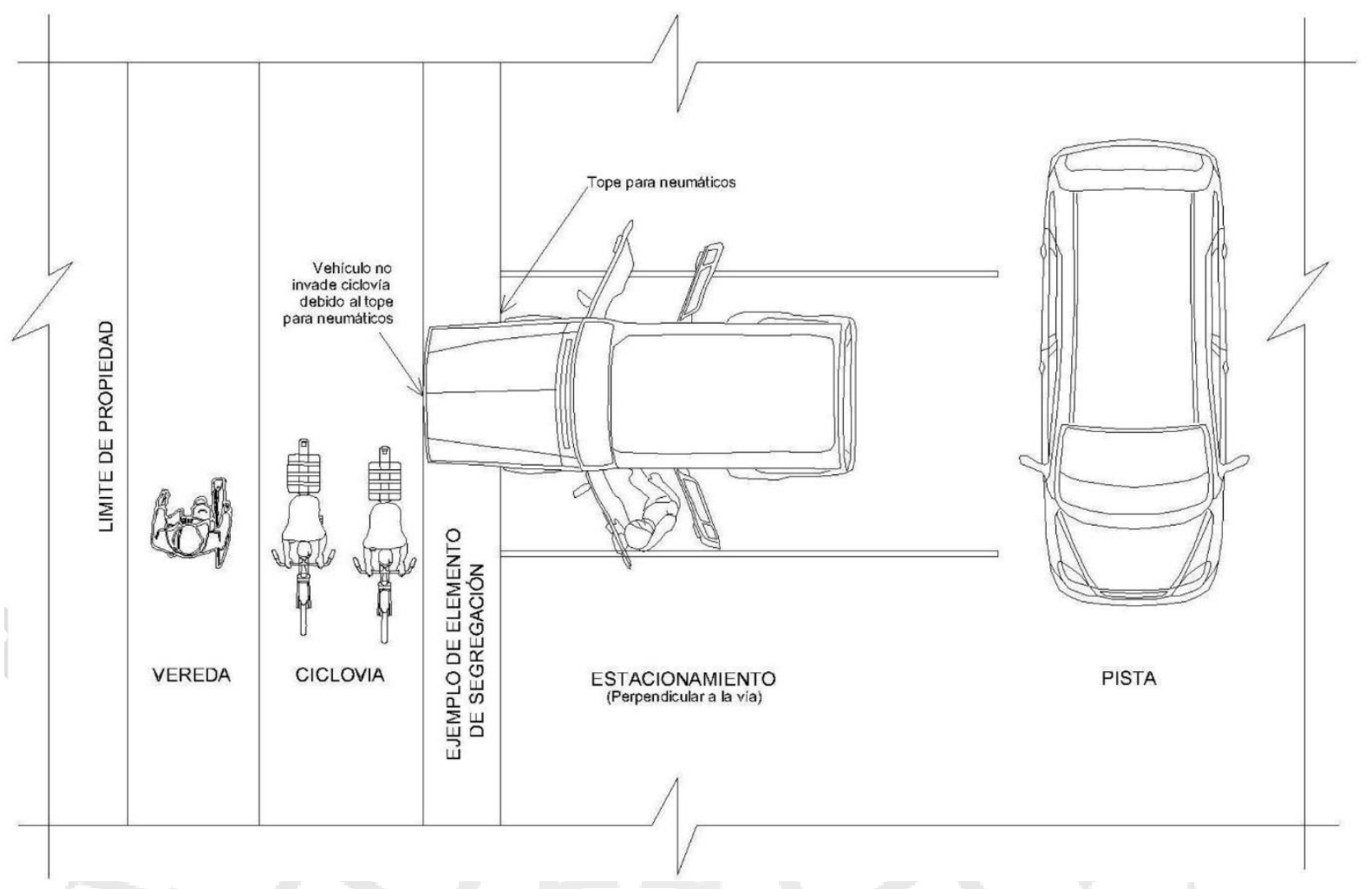

- Ejemplo de ciclovía ubicada entre vereda y pista

\section{Vista Frontal}
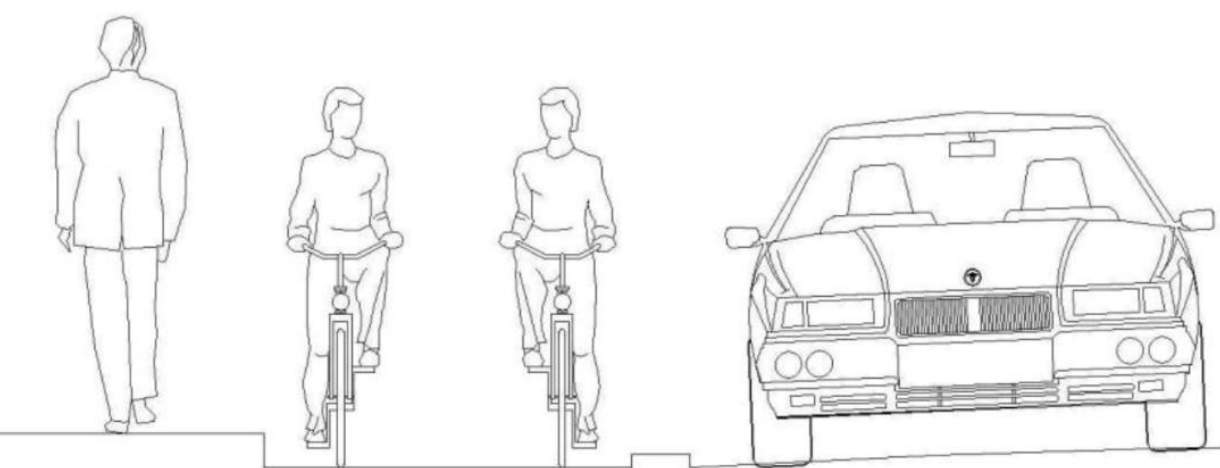

PISTA

VEREDA

CICLOVIA
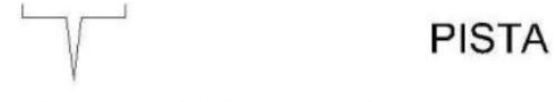

EJEMPLO DE ELEMENTO DE SEGREGACION

(Tachones entre dos franjas pintadas de un ancho de $10 \mathrm{~cm}$.)

Vista en planta 


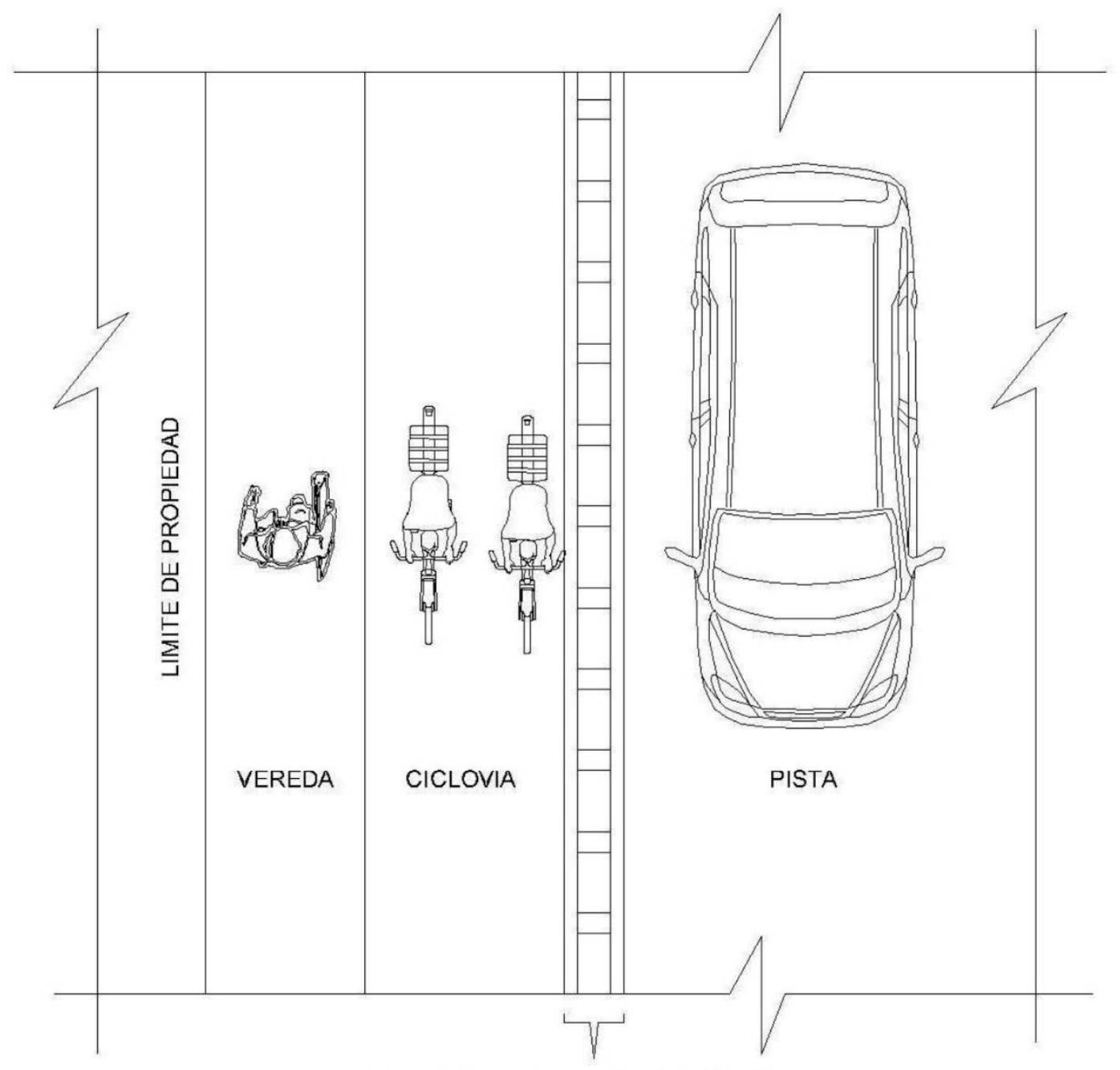

EJEMPLO DE ELEMENTO DE SEGREGACION

(Tachones entre dos franjas pintadas y de un ancho de $10 \mathrm{~cm}$.) 
- Estacionamientos

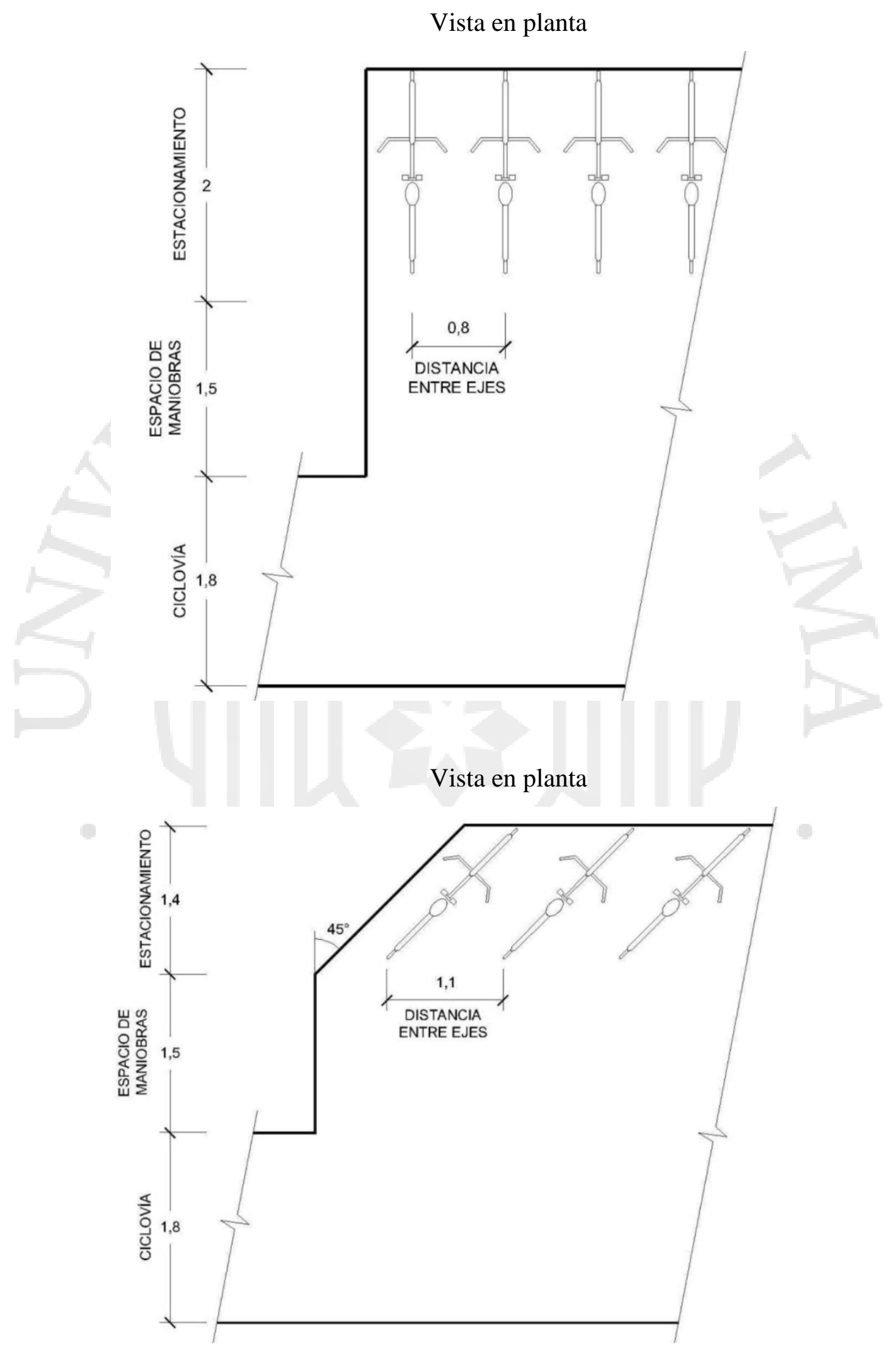




\subsection{Conclusiones parciales}

La importancia social de los espacios públicos radica en que estos son los lugares de encuentro físicos de la ciudad. En ellos, los individuos de una sociedad pueden dejar de lado diferencias y compartir como comunidad.

Los patrones de uso urbano en una ciudad cambian constantemente y, con mejores condiciones peatonales, aumenta la vida pública y urbana. Existe una conexión directa entre la calidad de espacio urbano y su uso adecuado. Actualmente, el internet cumple con mantener relaciones interpersonales en espacios virtuales, acortando la distancia y disminuyendo la demanda por espacio físico de encuentro. Así, generar lugares públicos interesantes, una oportunidad para que esos intercambios se trasladen a un espacio físico y mantener gente en la calle.

Para que los espacios se vuelvan lugares de encuentro, es importante recordar que 'caminar no sólo es circular'. Se necesita mirar, parar, retroceder, evaluar, recorrer, analizar y tener dónde 'estar'. Las vías toman gran espacio de la ciudad y están desplazando a la vida urbana. Debe retomarse la escala y dimensión humana como factor principal del diseño urbano. Un lugar de encuentro de calidad reforzará la vida urbana y las actividades sociales en Barranco y la zona de estudio, cohesionando los barrios aledaños.

Si bien se busca que las personas acudan a un nuevo espacio público por actividades opcionales, sociales y recreativas, es necesario instalar equipamiento de actividades obligatorias sin olvidar el prerrequisito de calidad urbana. Esto, la ciudad sea un lugar de encuentro de actividades diferentes, pero todas realizadas con confort. Además, en un espacio así, se busca generar actividades planeadas que, con el tiempo, provoquen actividades no planeadas (como encuentros o congregaciones), pues la gente comenzará a sentirlo como propio.

Sin embargo, se considera que las intervenciones urbanas y/o arquitectónicas no se limitan a evaluar un impacto meramente formal en el espacio que se emplaza, si no también, deben entender a la comunidad bajo premisas que no se observan a simple vista. Esto se refiere a recopilar el pasado, el presente y el futuro al que sus pobladores 
se proyectan; sus costumbres; sus vivencias a puertas cerradas y tantas otras cosas que un mapeo no considera.

Bajo la premisa de los no lugares, un lugar es un espacio intervenido y atribuido de identidad, relacional e histórico. Por lo tanto, debemos lograr que el vacío urbano muestre su potencial como lugar comunitario, social e histórico.

La cultura y el arte son herramientas para incidir en el imaginario colectivo de las personas, de esa manera pueden lograr efectos positivos en ellas. Los centros culturales son oportunidades para generar cambios en la sociedad en la que se ubican.

Las actividades que se pueden dar dentro de un espacio público funcionan para evidenciar las particularidades de cada comunidad. Entre ellos, es necesario que conozcan lo que los diferencia de los demás, sus potencialidades, y deficiencias (incluyendo la inseguridad). Así, es probable que se genere una mayor cohesión social para querer lograr un bien común y democrático. Dos zonas divorciadas y parte de un mismo distrito, merecen tener un espacio en común que las ayude a cohesionarse como sociedad y potenciar el carácter cultural que tanto poseen. Además, incluir las zonas y aledañas y sus habitantes en Miraflores y Surco. 


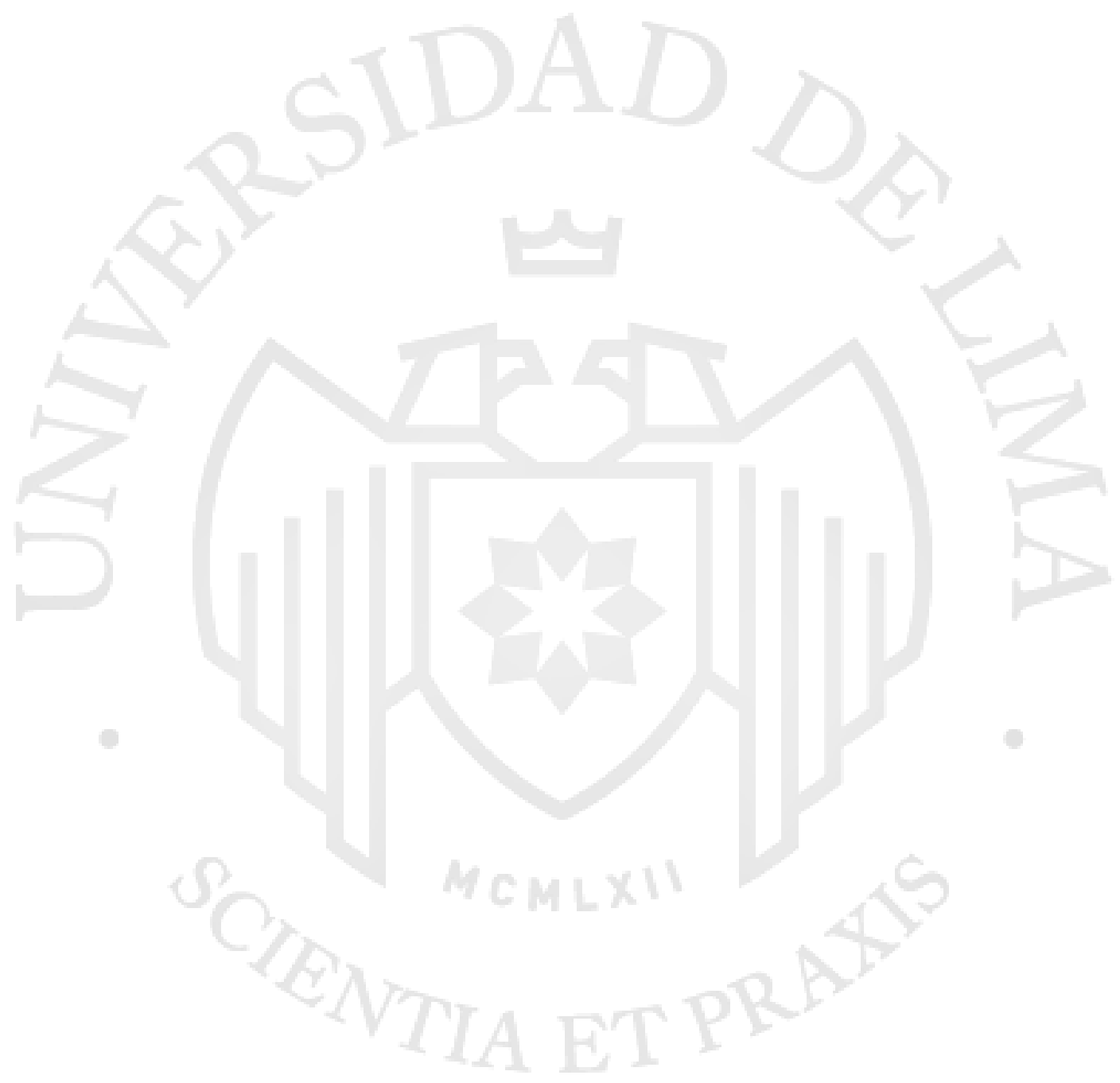




\section{CAPITULO IV}

\section{Marco Operativo}

\subsection{Estación de Alta Velocidad de Logroño}

\subsubsection{Historia}

\subsubsection{Información del proyecto}

- Arquitecto del Proyecto: Ábalos + Sentikiewicz arquitectos

- Estado: Construido (por etapas)

- Proyecto: 2006-2012

- Dirección del proyecto: Francisco Cifuentes (Ineco), Pelayo Suárez (Sener)

- Dirección del proyecto de arquitectura: Iñaki Ábalos, Alfonso Miguel, Renata Sentkiewicz

- Colaboradores: Jorge Álvarez-Builla, Yeray Brito, Aaron Forest, Victor Garzón, Pablo de la Hoz, Ismael Martín, Laura Torres, Rodrigo Rieiro, José Rodríguez

- Dirección de la obra: INECO (Eduardo Muñoz) TYPSA (Ricardo Castejón)

- Ingeniería, Estructura e Instalaciones: UTE Ineco-Sener

- Constructora: SACYR

- Paisajismo: Arquitectura Agronomía (Teresa Galí-Izard)

- Cliente: LIF 2002 SA, Santiago Miyares, Maria Cruz Gutiérrez (Ábalos + Sentkiewicz, s.f.)

\subsubsection{Toma de partido}

Desde un inicio, los arquitectos pensaron unificar la estación ferroviaria y la de buses para provocar beneficios de función y crear espacios peatonales a nivel del suelo. Esto sería generado mediante la implementación de un gran espacio verde, colinas y anillos ininterrumpidos de carácter público en el lugar donde, anteriormente, se emplazaban las vías de tránsito rápido y dividían la ciudad en dos. 
Se pretendió aprovechar el subterráneo de las vías existentes y de la estación del ferrocarril para crear una nueva centralidad, como mezcla de urbano y natural.

Bajo la cubierta de geometría triangular se encontrarían las estaciones de trenes y autobuses.

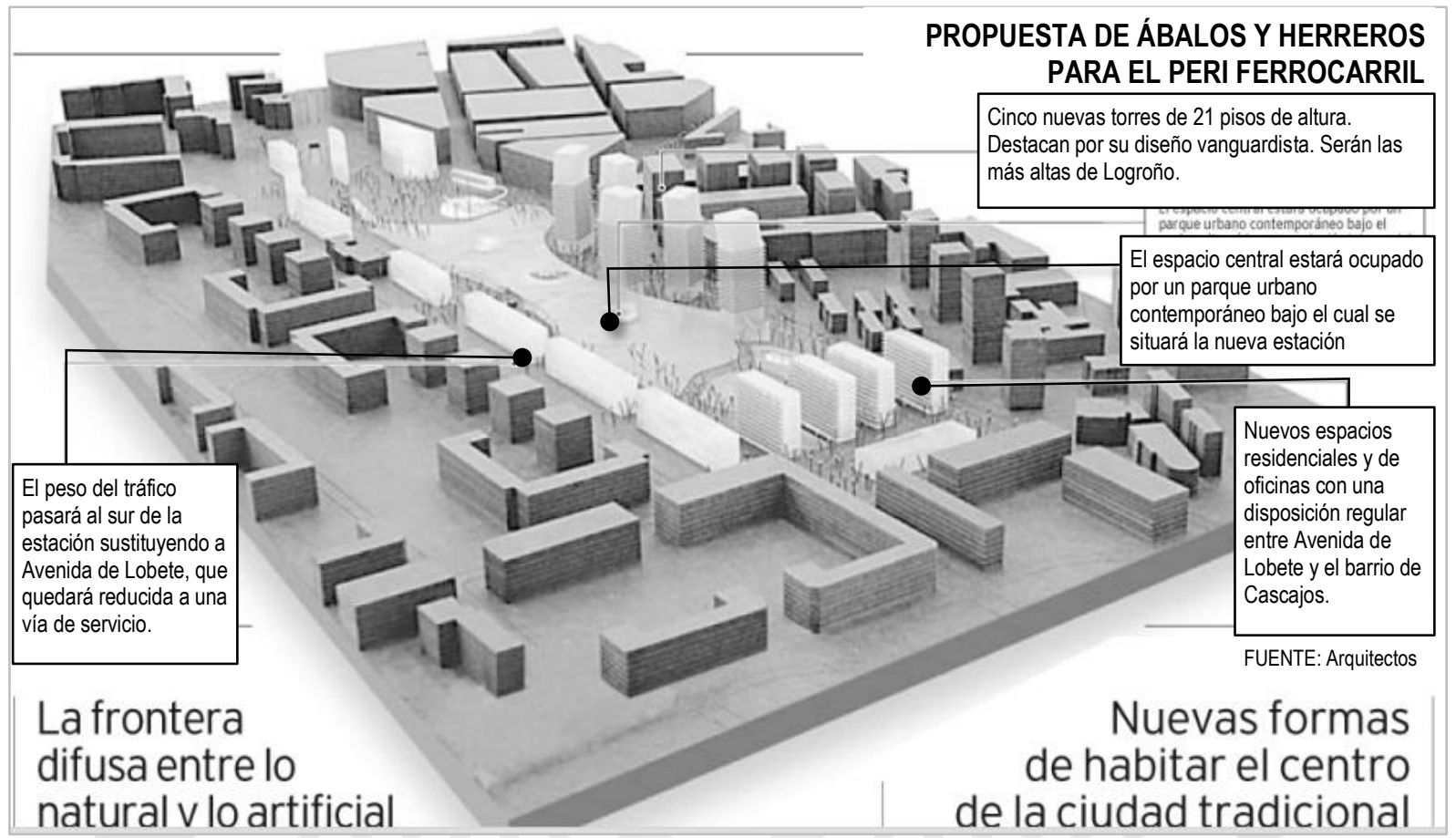

Imagen: Maqueta inicial del proyecto urbano integral, 2005 Fuente especificada no

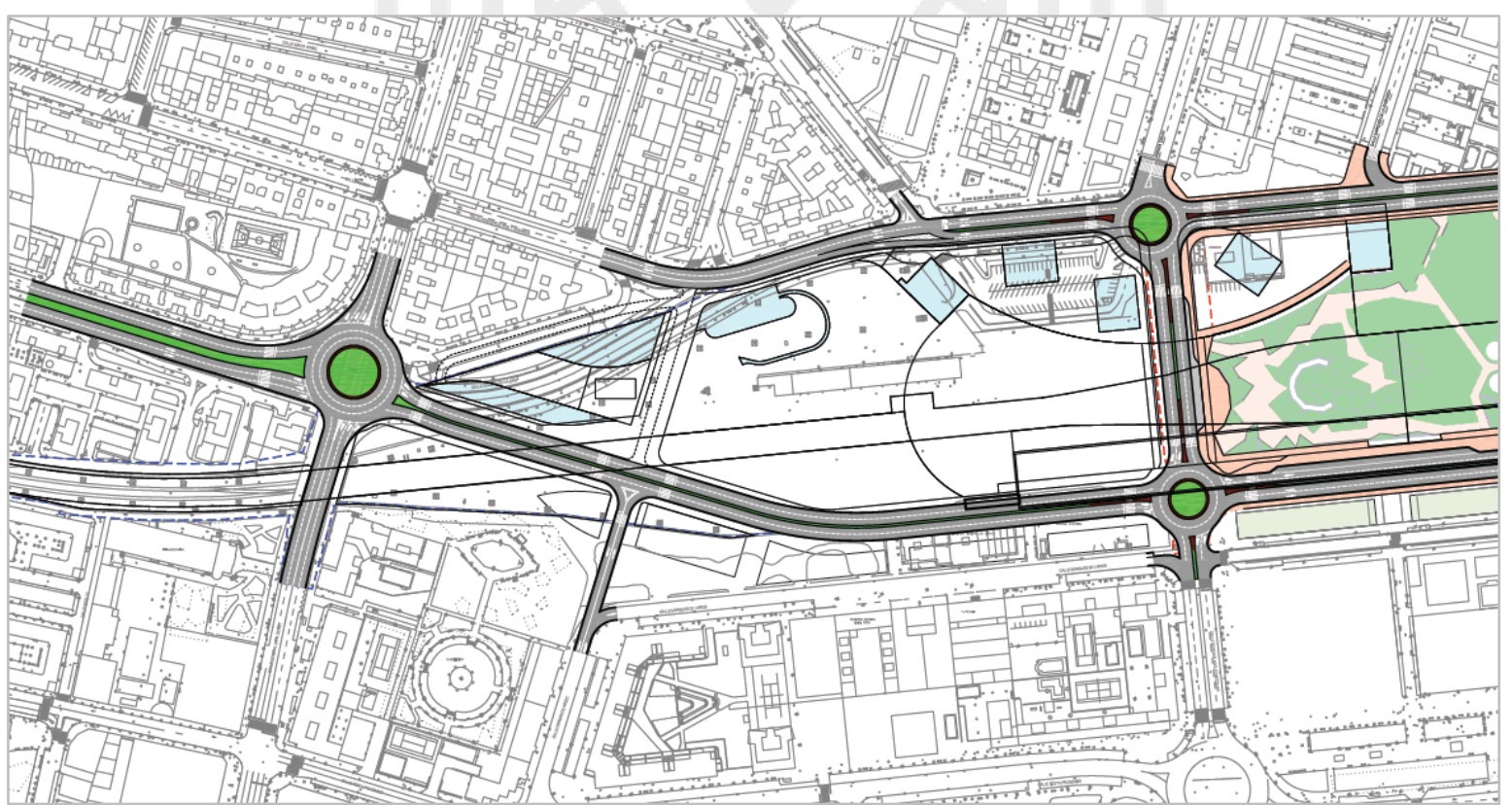

Imagen: Reorganización urbana a partir de la trama existente (Ábalos + Sentkiewicz, 


\subsubsection{Período histórico.}

Para el año 1863, Logroño, en la Rioja, España, ya contaba con una vía férrea que lo atravesaba. Sin embargo, debido al crecimiento urbano apresurado, el Gobierno de Franco decreta en 1946 de carácter urgente la construcción de una estación en la ciudad y una variante en el trazado ferroviario. Esto se debió a que la trama urbana ya no era la misma de 1863

El 12 de julio de 1948 inicia la construcción de la estación de Ferrocarril de Logroño y se inaugura el 9 de noviembre de 1958, junto al nuevo trazado.

En el año 2002 se constituye la sociedad pública Logroño Integración del Ferrocarril, grupo encargado del mismo, sus estaciones y vías. Se conversa y decide tener las vías férreas y sus estaciones en el subsuelo lo más posible. Y, por ello, en 2008 se llama a un concurso de regeneración urbana y construcción de la nueva Estación de Tren de Logroño. En 2009, el estudio Ábalos + Sentkiewicz Arquitectos gana el concurso, con una estación a la que llaman Estación de Alta Velocidad. Ésta contaría con la reorganización de las vías de autos que atravesaban e interrumpían la vía férrea; 5 torres de vivienda; y la adición de una estación de autobuses frente a la del tren, para que fuese una intermodal.

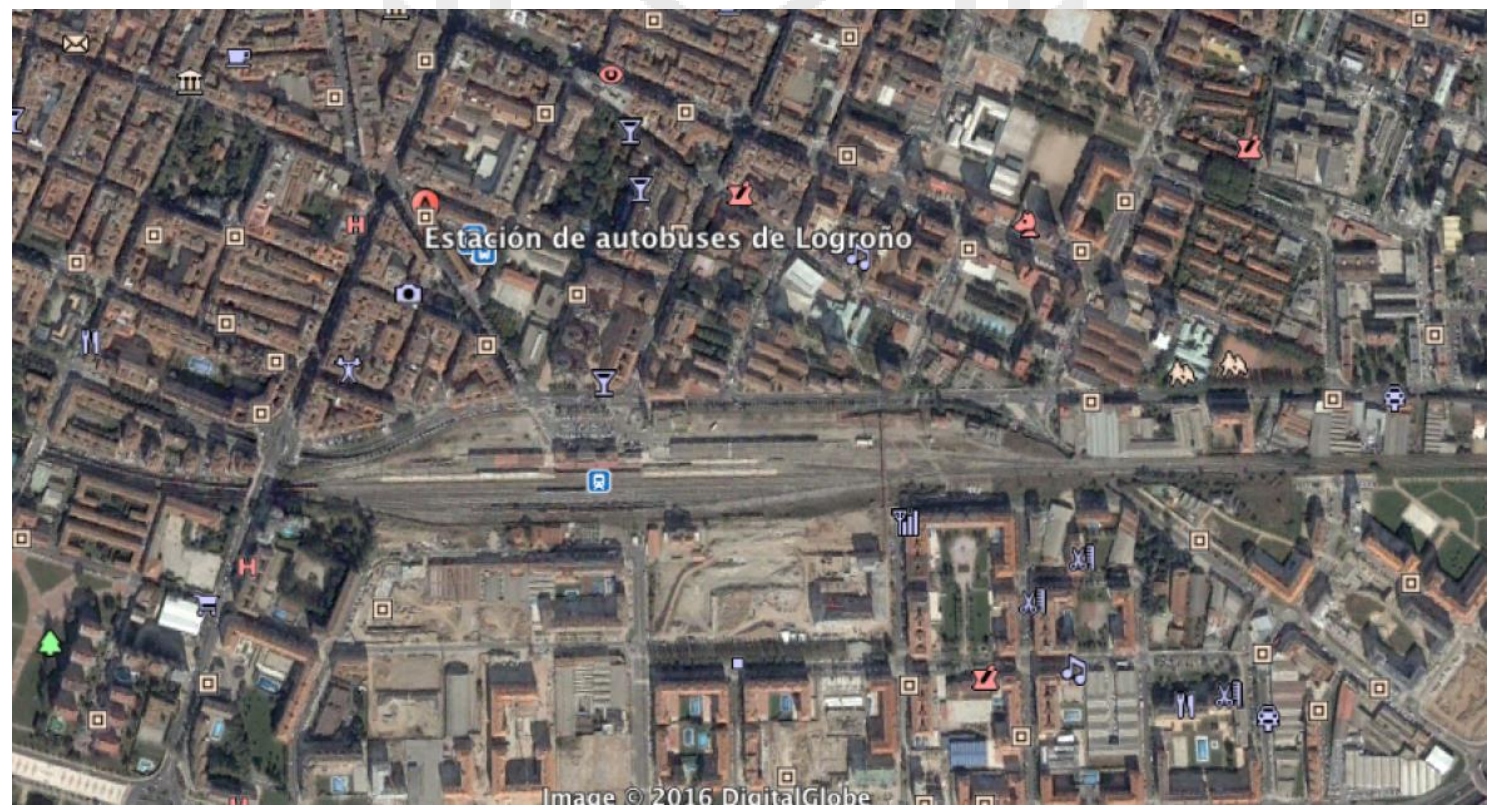

Imagen: Vías férreas de Logroño en 2004 (Google Earth, 2016) 
En el año 2010 se demuele la antigua estación de trenes y en 2011 inicia el funcionamiento de la nueva Estación de Alta Velocidad. La primera etapa cuenta con el soterramiento de las vías de tren, reorganización de vías de autos, ajardinamiento de la plaza, y la construcción de estación de tren. La estación de autobuses comenzó a construirse en el 2016.
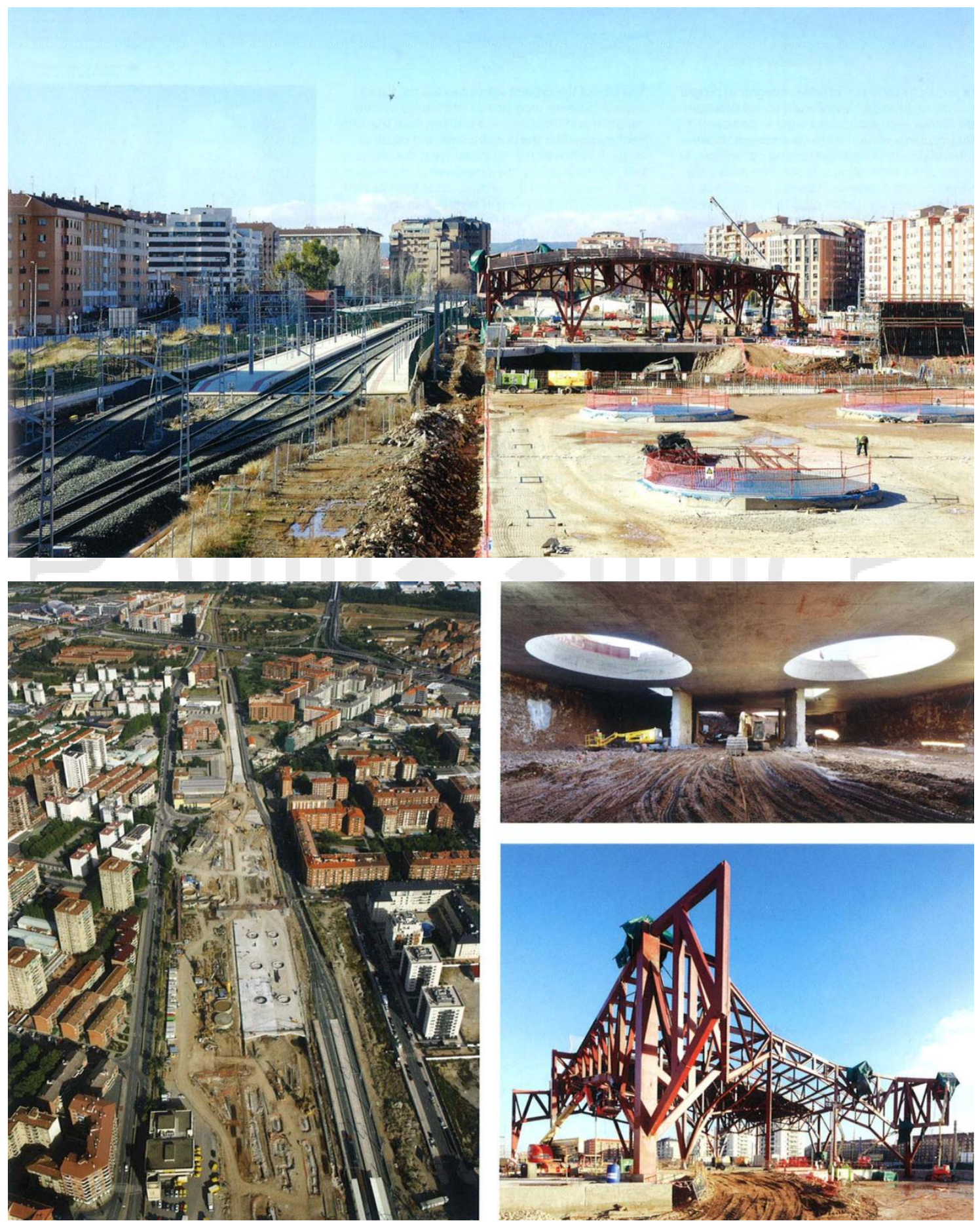

Imágenes: Soterramiento de las vías férreas y estación Fuente especificada no válida. 


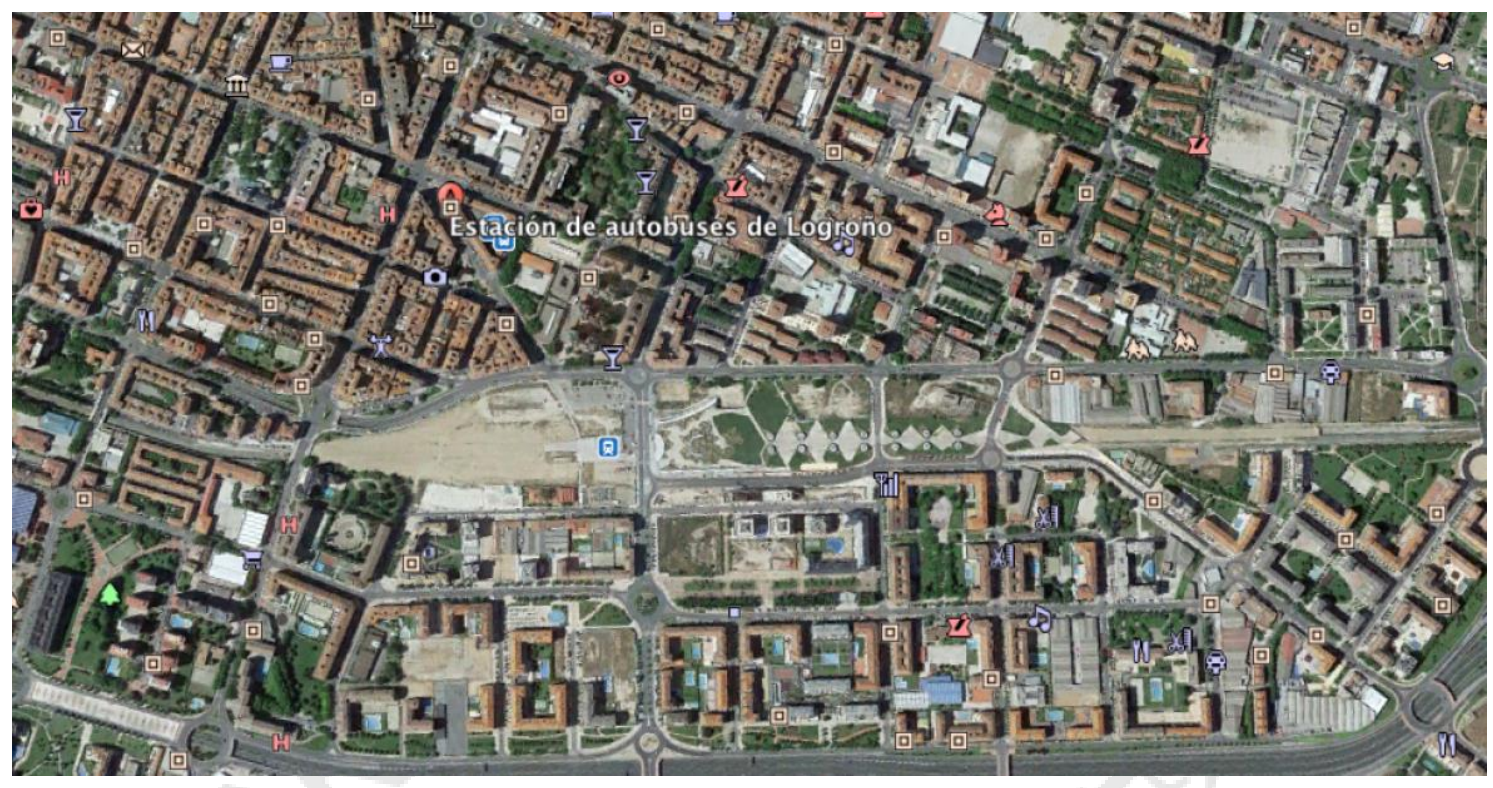

Imagen: Plaza a nivel de calle y Estación sobre las vías subterráneas de Logroño en 2015 (Google Earth, 2016)

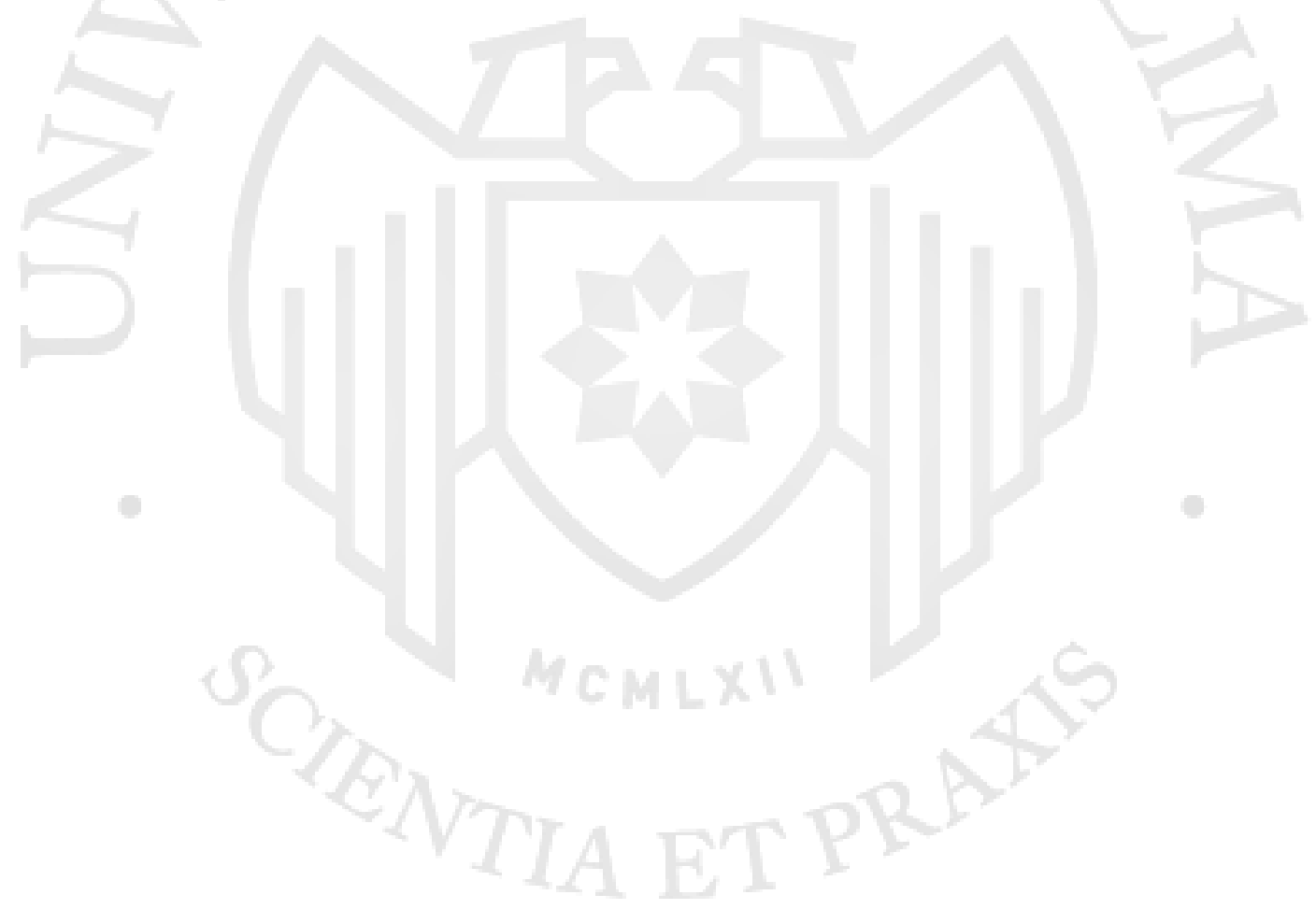




\subsubsection{Línea de Tiempo.}

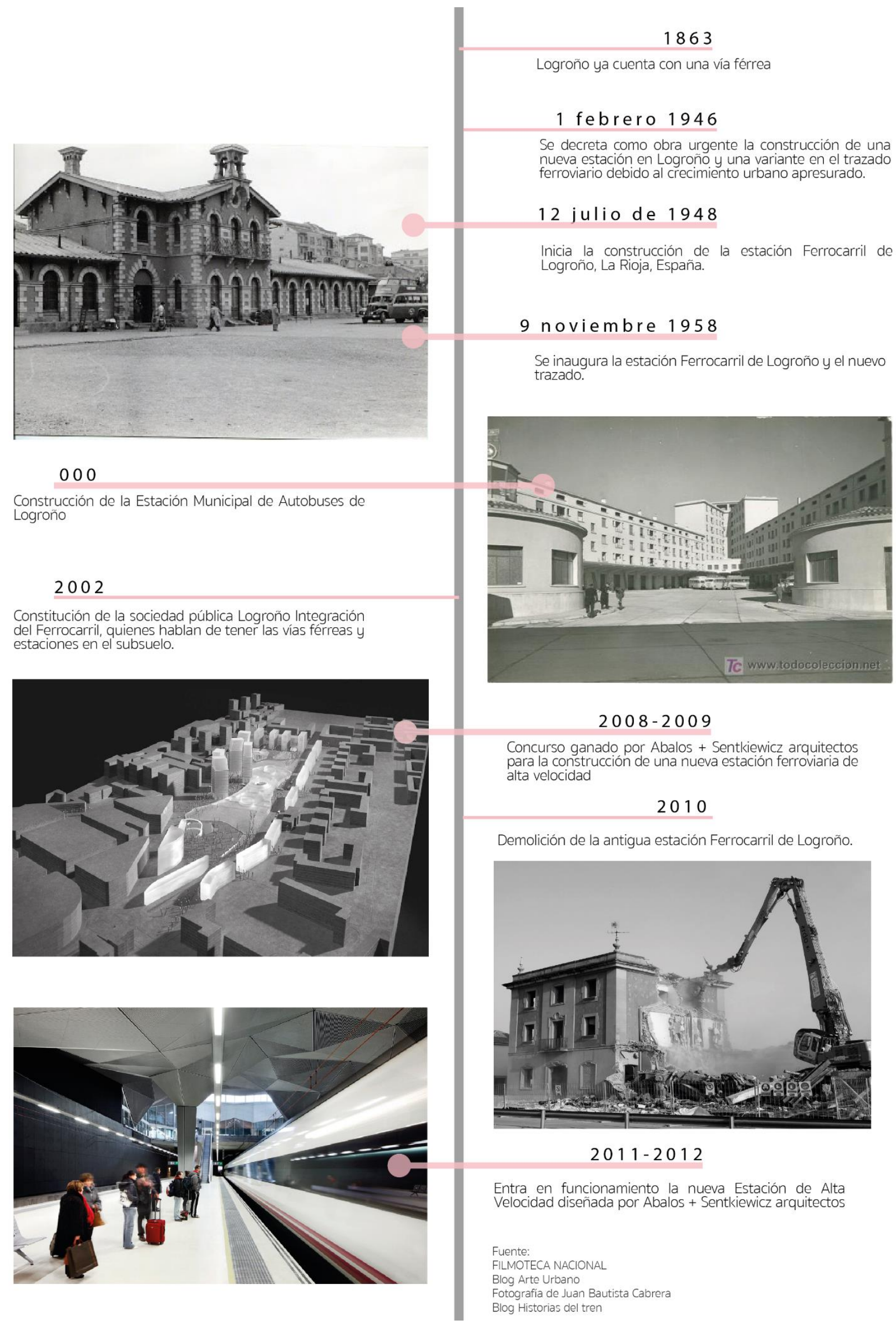




\subsubsection{Ubicación Y Relación Con EI Entorno}
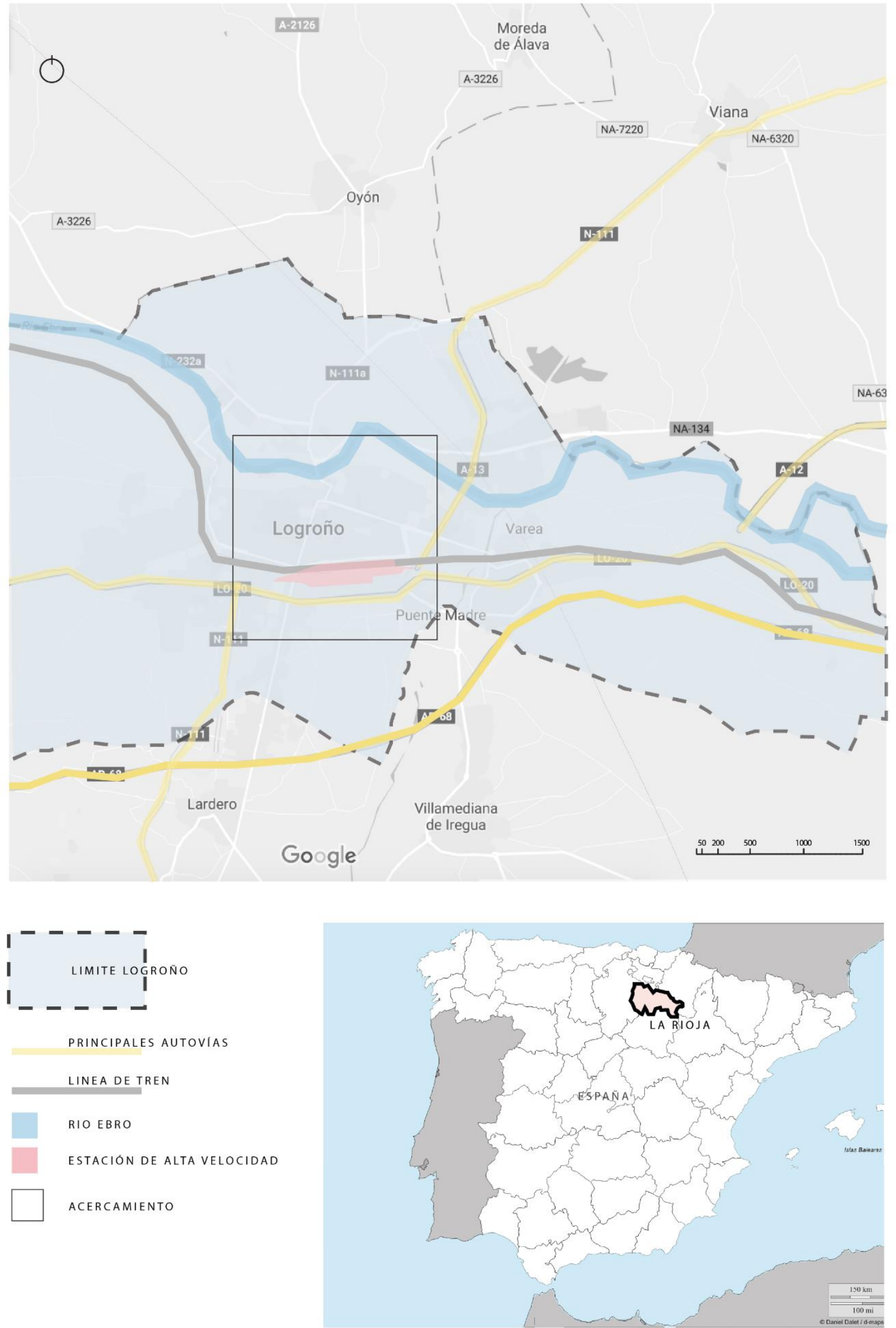


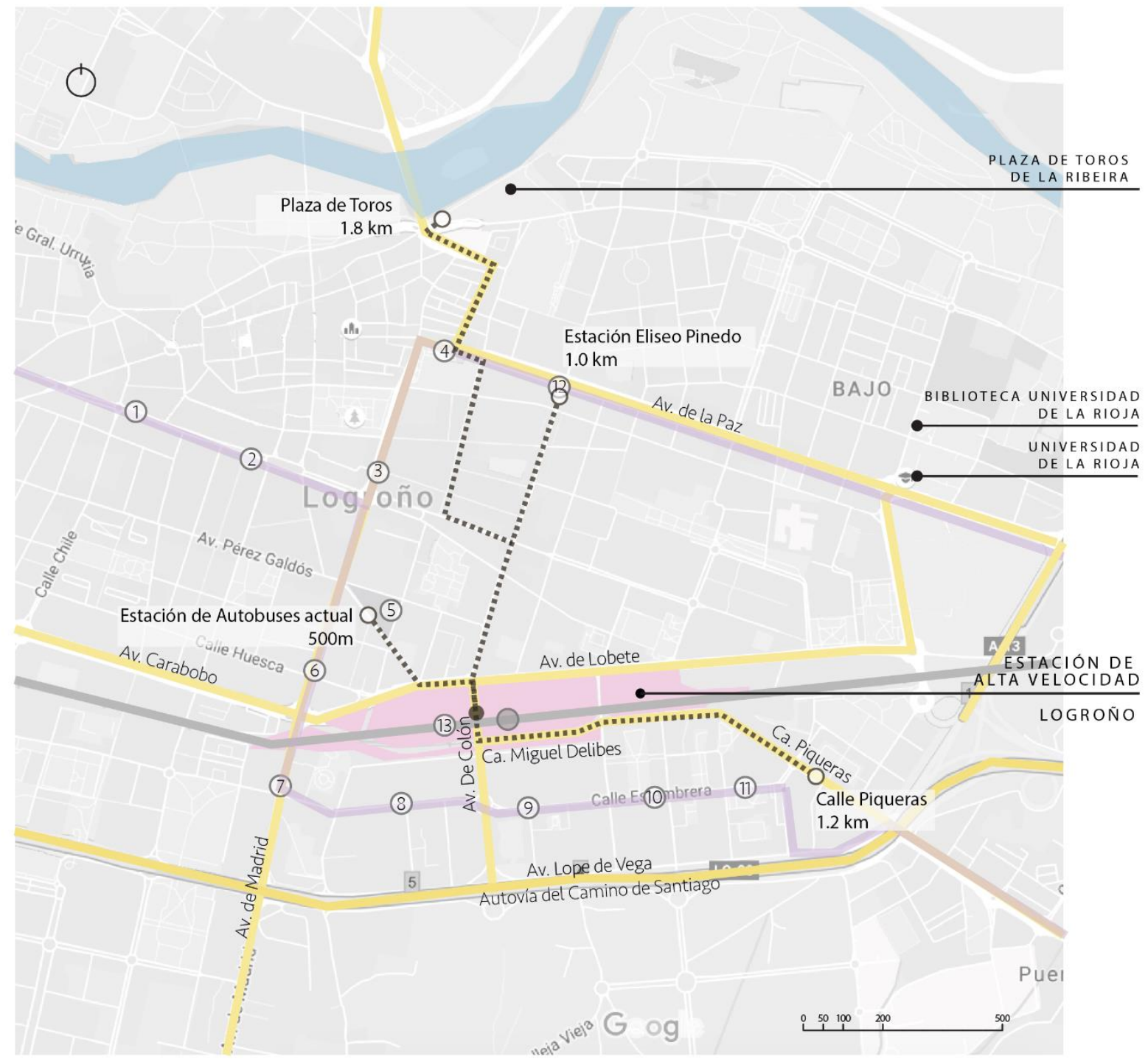

PRINCIPALES AUTOVIAAS

LINEA DE TREN

RUTA DE AUTOBUSES

RUTAS PEATONALES

RIO EBRO

ESTACIÓN DE ALTA VELOCIDAD

(estaciones de autobuses

1 Labradores

Torre de Logroño

Monumento al Labrador

4 Marques de la Ensenad

Estacion de Autobuses

6 Huesca

7lub Deportivo

Gustavo Adolfo Bécquer

9 Gustavo Adolfo
10 Juan Boscan

10 Juan Boscan

12 Eliseo Pinedo

13 Estación de Autobuses de Alta Velocidad

EStación De tRen

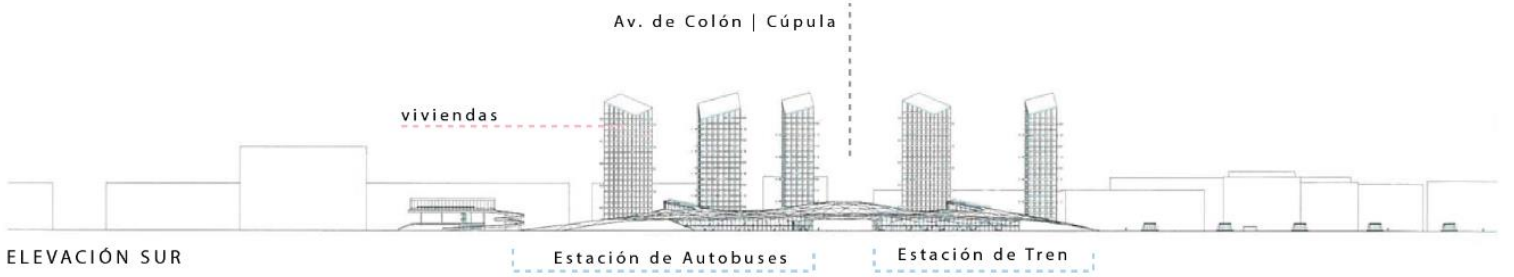

Proyecto de regeneración urbana | Parque Felipe VI 


\subsubsection{Aportes}

El proyecto de Estación intermodal de Logroño tiene aportes tanto medioambientales, como sociales y arquitectónicos. Es un equipamiento que combina en un solo espacio urbanismo, arquitectura, ecología, economía y paisaje. Establece un nuevo modelo de gestión, enfocado a las constantes innovaciones en todas las etapas del proceso de proyecto. (Bojovic, 2013) Es por eso, que se dice que la Estación de Alta Velocidad y la Estación de Buses de Logroño es una experiencia pionera en "landform buildings ${ }^{27}$ ", y urbanismo ecológico. (Alley \& McQuade, 2011)

Además, mediante una estrategia urbanística y paisajística, conecta las zonas Norte y Sur de Logroño; provee a la comunidad de un espacio público y área verde donde, previamente, existían vías férreas que suponían una brusca división y corte en la continuidad urbana.

La estación es una oportunidad para "transformar la ciudad, crear espacio público, desarrollar anillos verdes, fomentar la movilidad peatonal y en bicicleta... que intensifique la experiencia de la ciudad como hecho colectivo" (Gordon, 2012). En general, la estación conforma un gran complejo de comunicaciones intermodales dentro y fuera de la ciudad de Logroño.

${ }^{27}$ Landform Building es definido por Alley y McQuade como mucho más que una estrategia. Aplicar nuevas tecnologías, técnicas de diseño y una demanda por una relación medioambiental han llevado a repensar en la relación tradicional de la arquitectura con el suelo y la tierra. Por lo tanto, este movimiento explora las manifestaciones de la ecología y los paisajes naturales como nuevas técnicas de diseño y estrategias formales a aplicar en la arquitectura. 


\subsubsection{Programa Y Relaciones Programáticas}

\subsubsection{Flujo peatonal y de transporte}

Ambas estaciones (de tren y autobuses) tienen una entrada peatonal y fachada principal hacia la calle Colón. Sin embargo, la estación de tren permite la entrada peatonal desde los servicios complementarios que ofrece, como el café de la esquina norte, que activa la calle con pequeños gestos de mobiliario urbano en la acera pública.

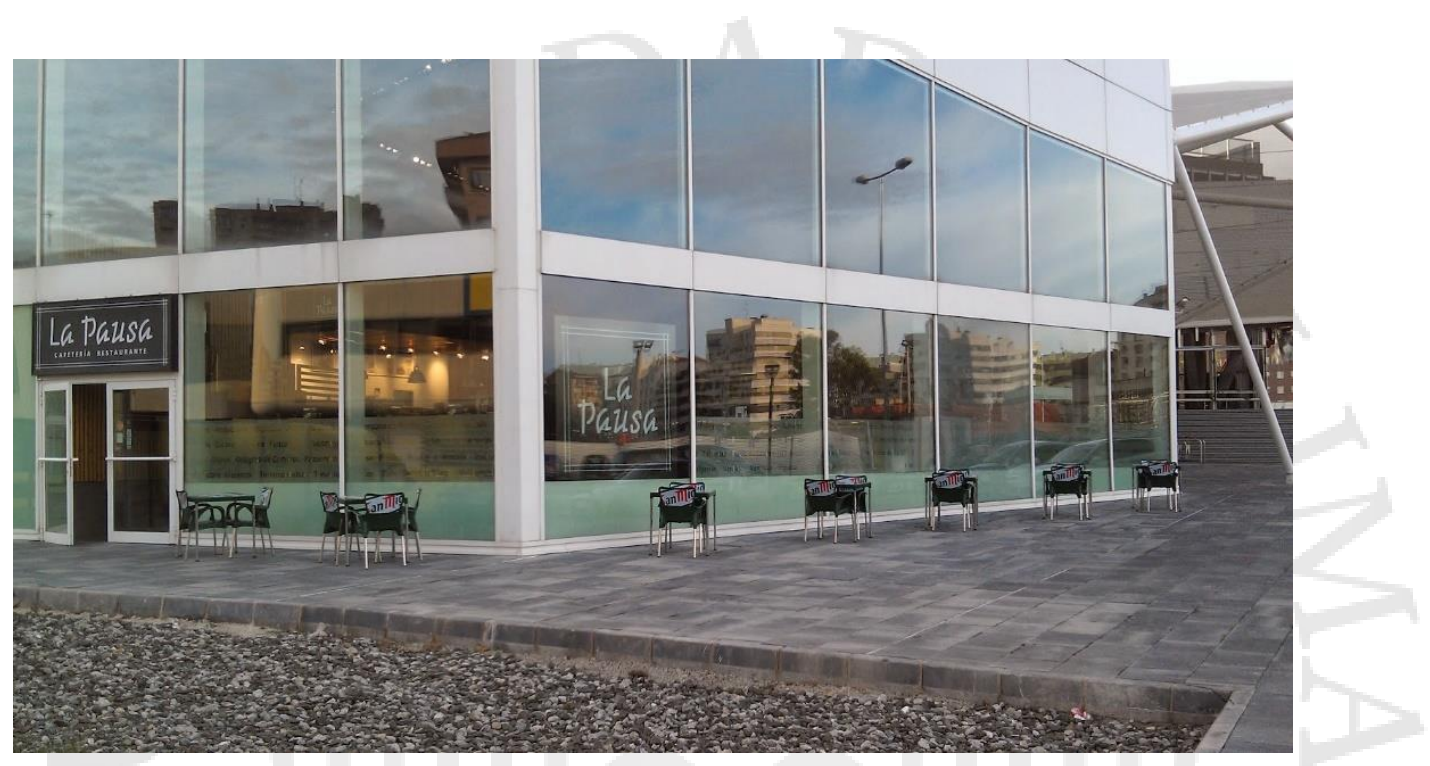

Fuente: Cascotes blog.

Sin embargo, desde la calle también se accede directamente a los espacios privados de administración y control, que se encuentran en las fachadas laterales de las estaciones.

Posteriormente, un hall recibe a los pasajeros y, desde ahí, pueden recorrer negocios y comercios dispuestos de diferente manera en cada estación. El abordaje y control posterior, en el caso de la estación de Autobuses, dispersa a las personas; mientras, la estación de tren las junta en los andenes.

El flujo de automóviles y buses se encuentra limitado a las pistas de abordaje alrededor de la estación y los estacionamientos para buses y mantenimiento. Al igual que en los rieles del tren, a estas zonas solo ingresa personal autorizado y su flujo es casi nulo. 


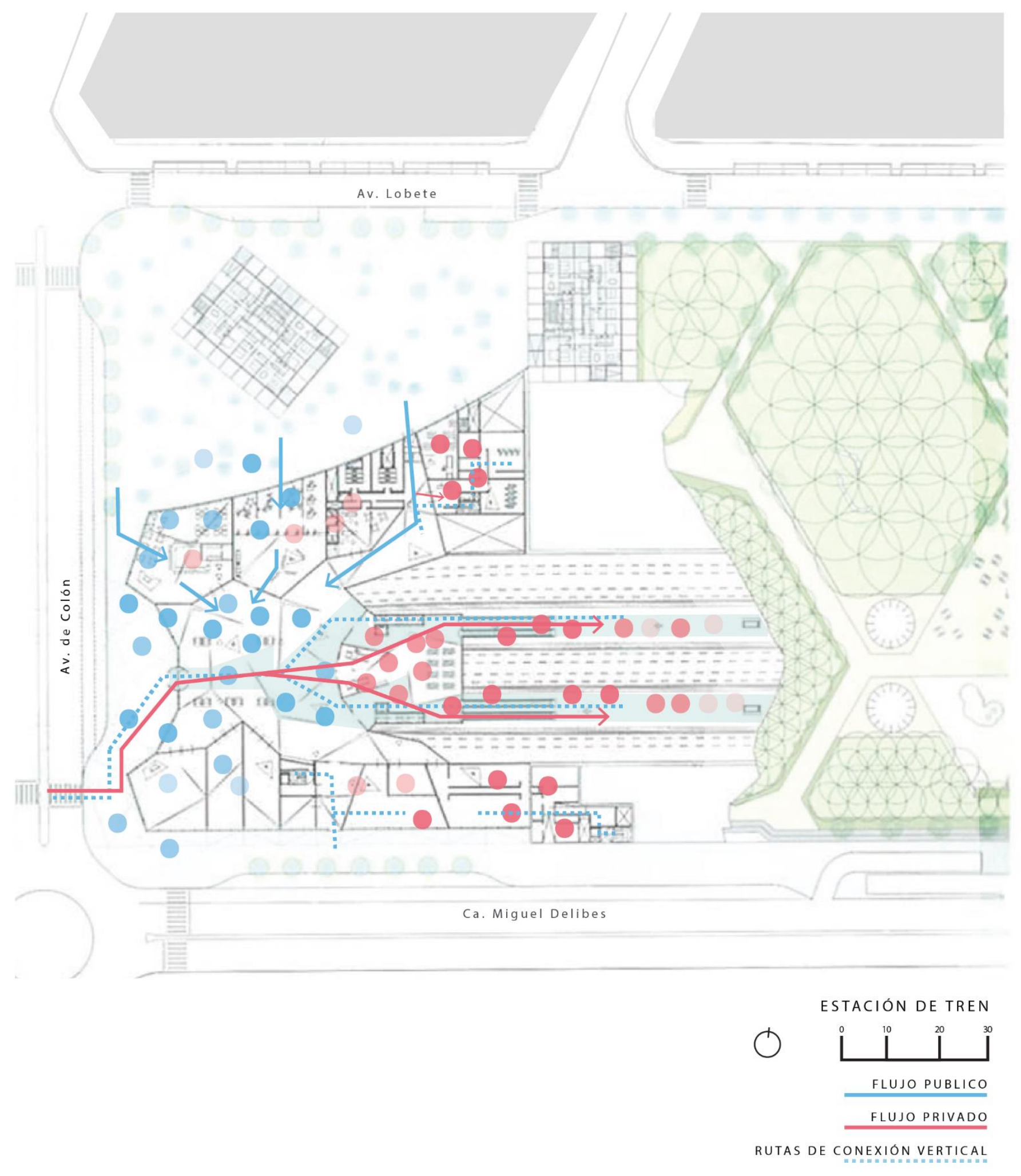

ESPACIO DEDICADO A CIRCULACIÓN

INTENSIDAD DE USO - ESPACIOS PÚBLICOS

00 O

INTENSIDAD DE USO - ESPACIOS SEMI PUBLICOS / PRIVADOS

OOOO 

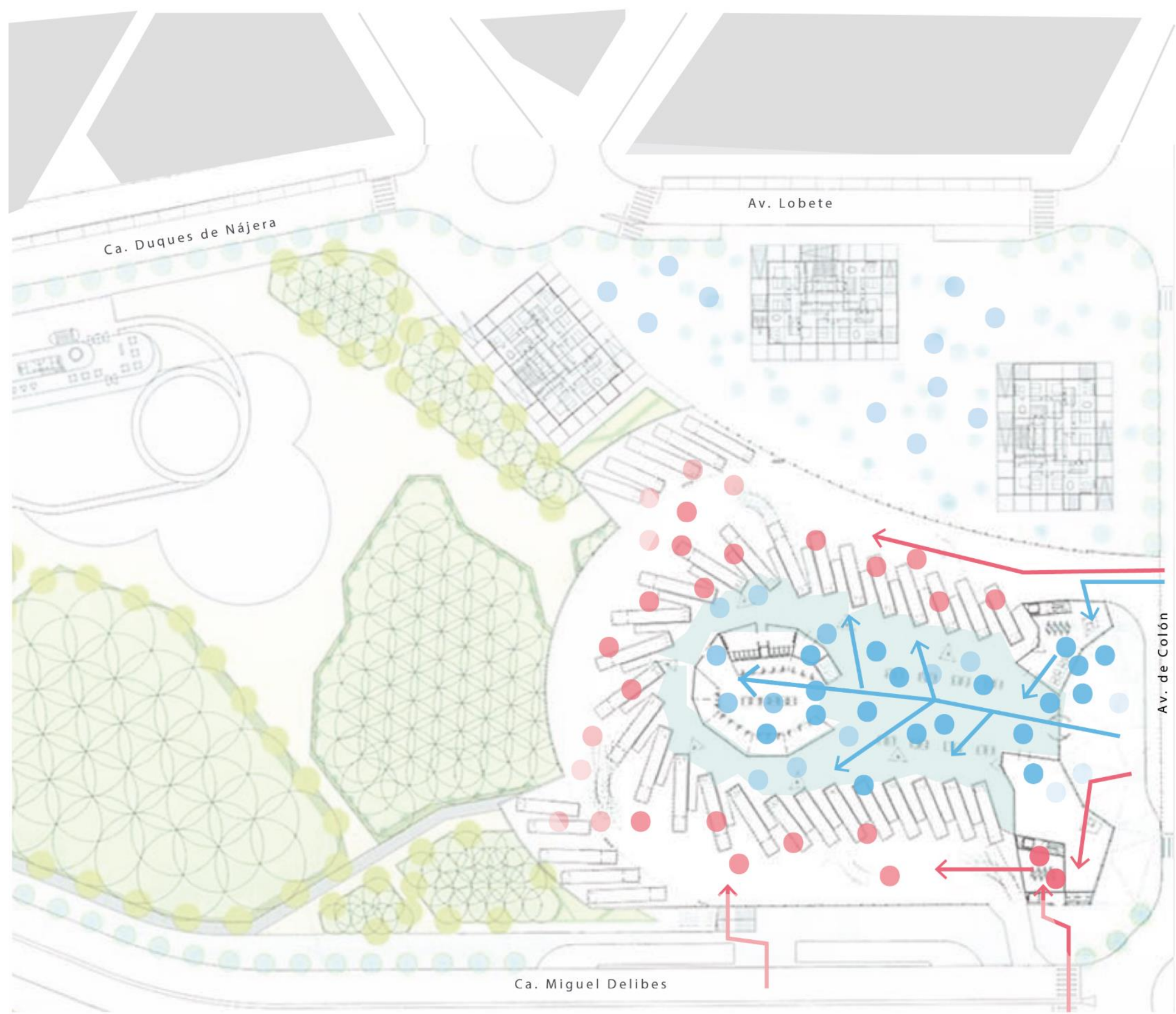

ESTACIÓN DE AUTOBUSES

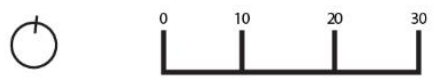

FLUJO PUBLICO

FLUJO PRIVADO

RUTAS DE CONEXIÓN VERTICAL

ESPACIO DEDICADO A CIRCULACIÓN

INTENSIDAD DE USO - ESPACIOS PÚBLICOS

000 (1)

INTENSIDAD DE USO - ESPACIOS SEMI PUBLICOS / PRIVADOS 


\subsubsection{Cuadro de áreas}

Cuadro: Cuadro de áreas de la Estación de Autobuses de Logroño

Fuente: de realización propia, a partir de planos (Ábalos + Sentkiewicz, s.f.)

\begin{tabular}{|c|l|r|c|c|}
\hline \multicolumn{1}{|c|}{ AREAS } & \multicolumn{1}{|c|}{ SUB AREAS } & SUPERFICE $\mathrm{m} 2$ & $\begin{array}{c}\text { AREA TOTAL } \\
\mathrm{m} 2\end{array}$ & $\%$ \\
\hline \multirow{5}{*}{ PUBLICO } & ESPACIO PUBLICO & 1155 & & \\
& CAFETERIA & 227 & 1881 & $\mathbf{1 7 . 3 3}$ \\
& TAQUILLA & 363 & & \\
& CONTROL BUSES & 136 & & \\
\hline \multirow{3}{*}{ HALL } & COMERCIO & 666 & & \multirow{2}{*}{$\mathbf{3 8 . 8 2}$} \\
& ESPERA & 2347 & 4213 & \\
\hline \multirow{2}{*}{ SISTEMA DE } & DALL INGRESO & 1200 & & \multirow{2}{*}{$\mathbf{4 3 . 8 4}$} \\
TRANSPORTE & ESTACIONAMIENTO BUSES & 3725 & 4758 & \\
\hline
\end{tabular}




\subsubsection{Relaciones programáticas}

ESTACIÓN DE AUTOBUSES
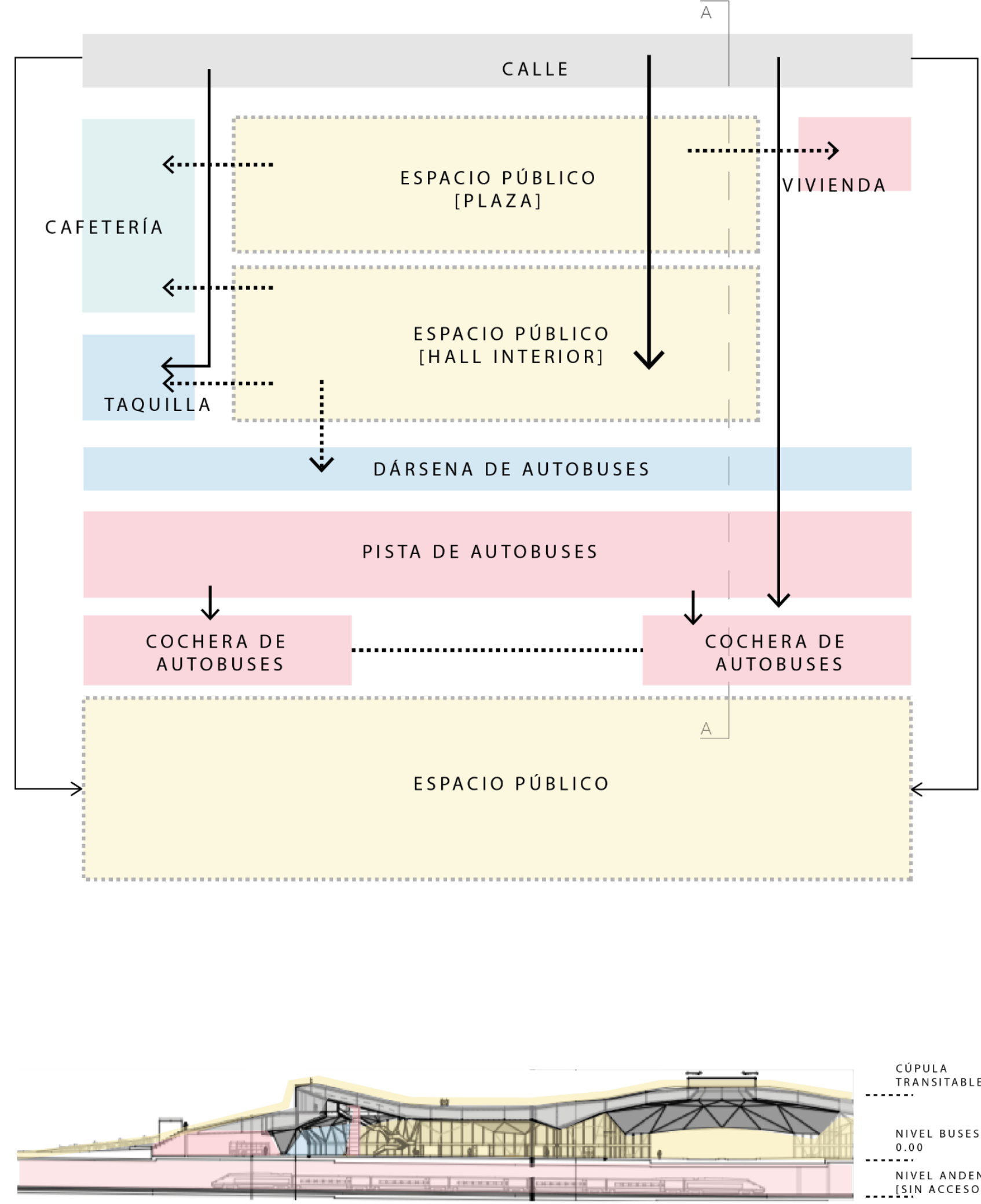

CÚPULA 


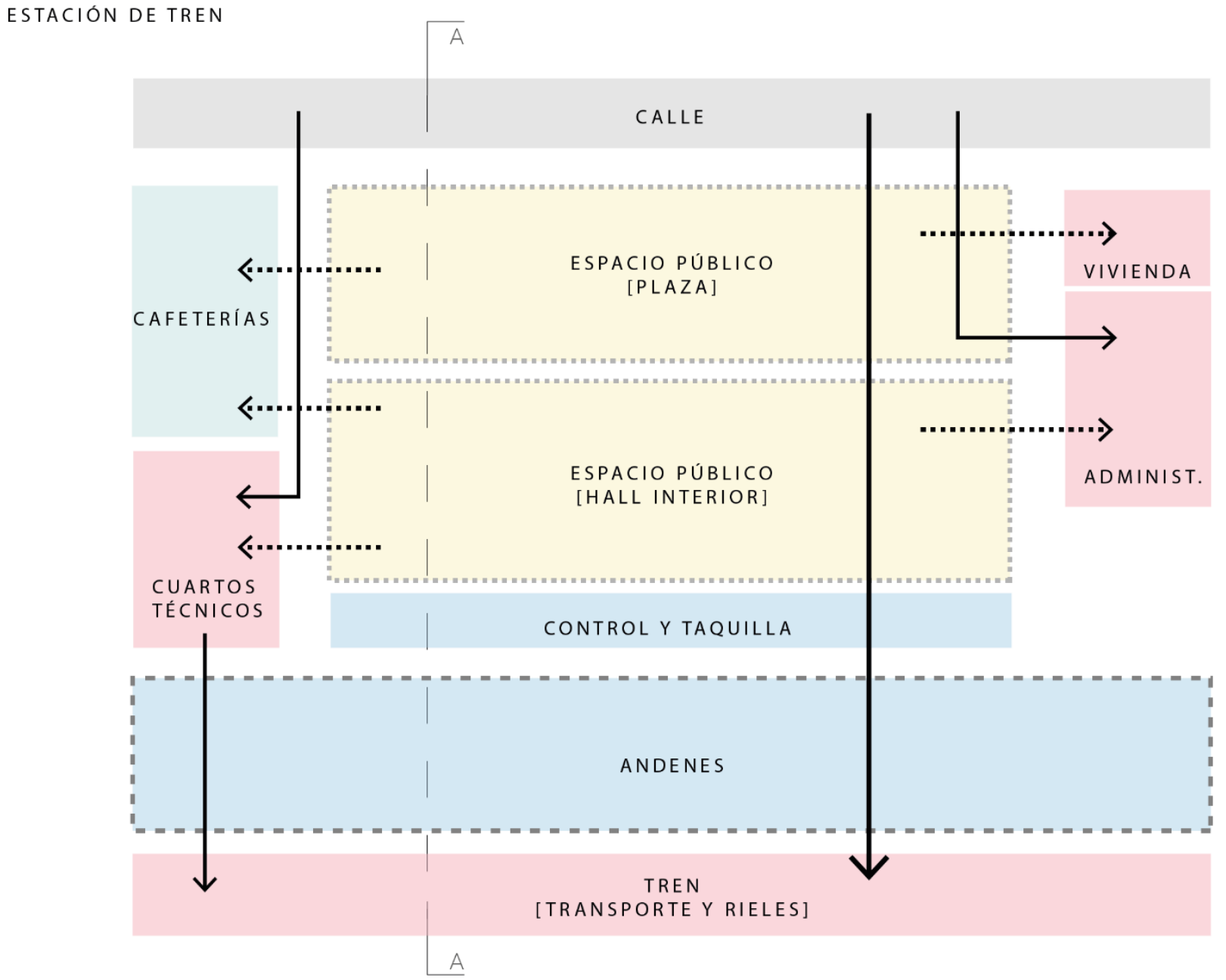

CÚPULA

TRANSITABLE.

NIVEL BUSES

$0.00 .$.

NIVEL ANDENES

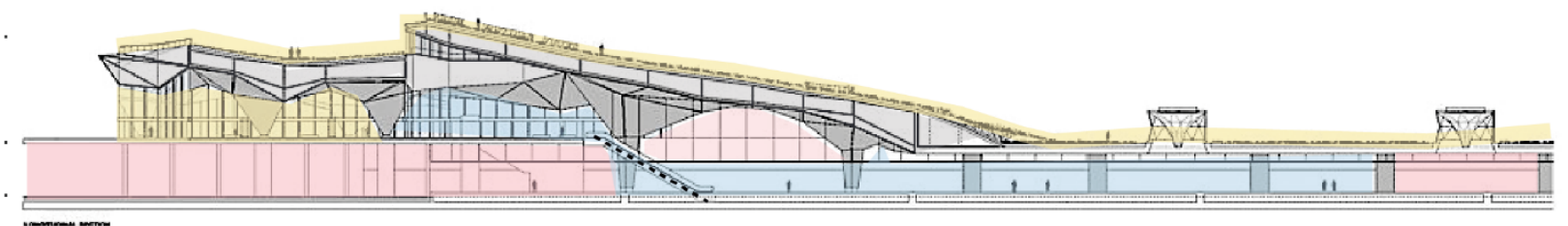

CORTE A-A 


\subsubsection{Organigrama de espacios}

INGRESO

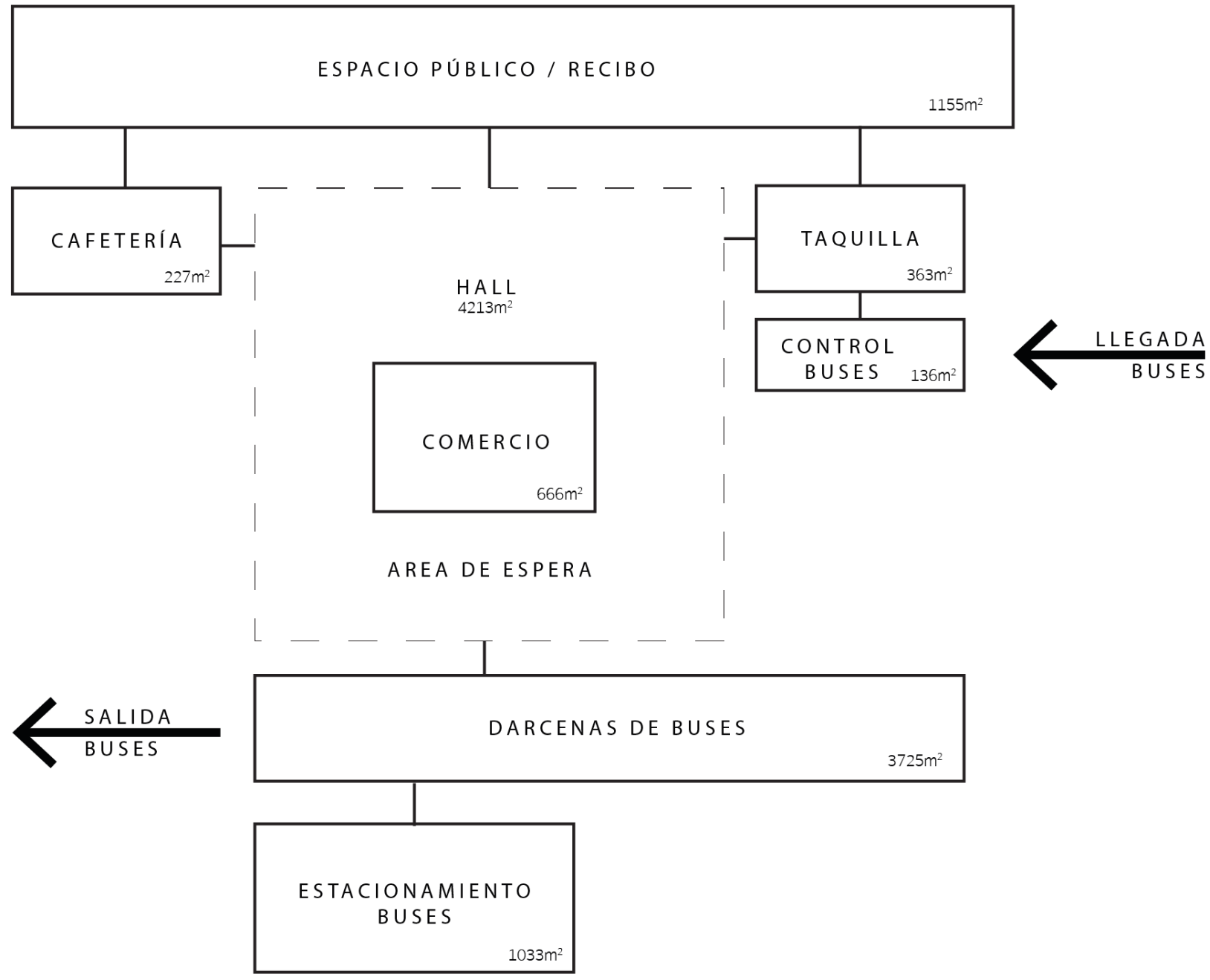




\subsubsection{Tipología Espacial}

1.- Según las vías existentes que rodean el terreno, las estaciones se emplazan una frente a la otra, con ambas puertas principales hacia la calle central (transversal). El resto del terreno es una gran plaza a nivel del suelo, totalmente pública.

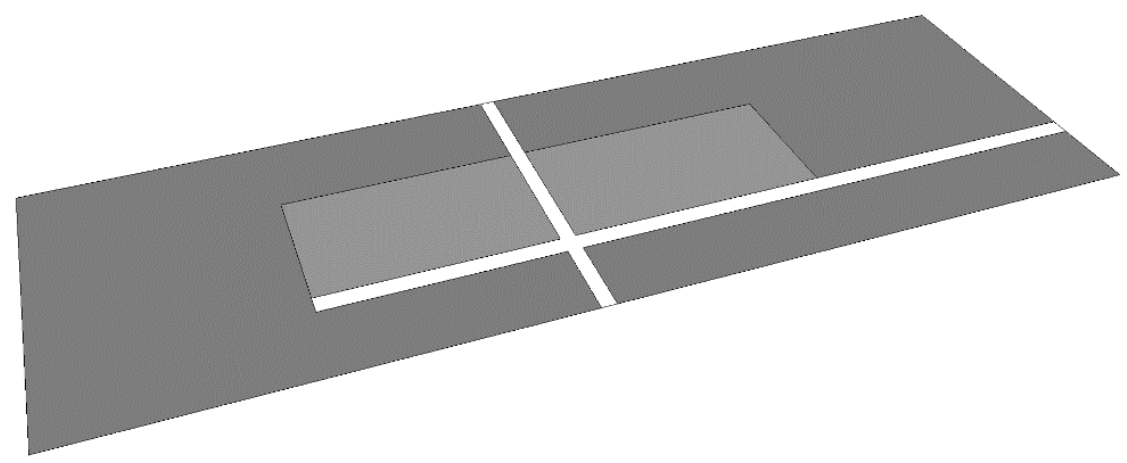

2.- Las vías internas de cada estación dependen de la función que cumplen. Las de autobús, rodean la estación a nivel del suelo. Sin embargo, la vía del tren es la que predomina sobre la estación de tren, pues el resto del programa gira en torno al soterramiento de los andenes.

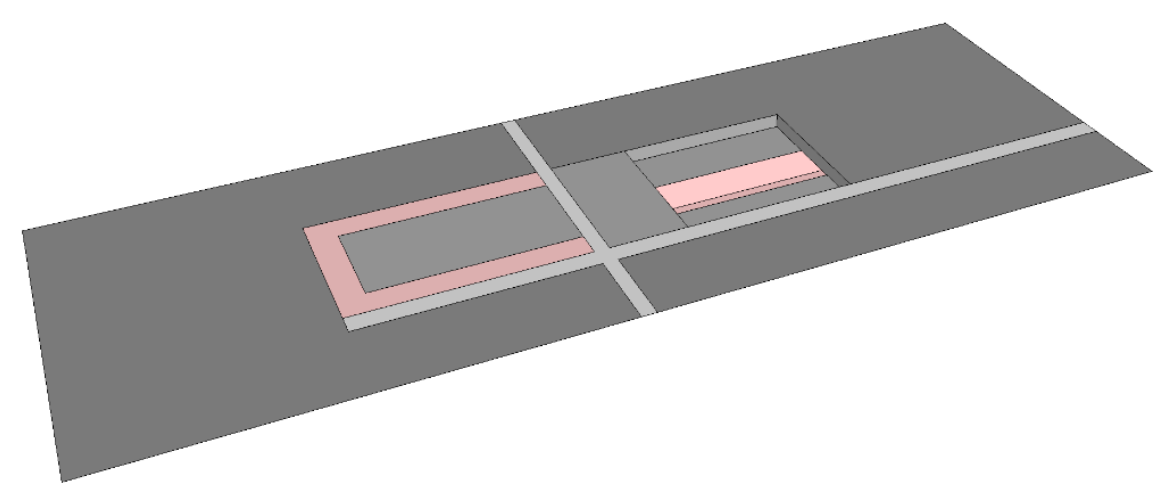

3.- Se implementan servicios complementarios (cafeterías y restaurantes) en los locales que dan a la calle, con una doble entrada, también hacia el interior de cada estación. 


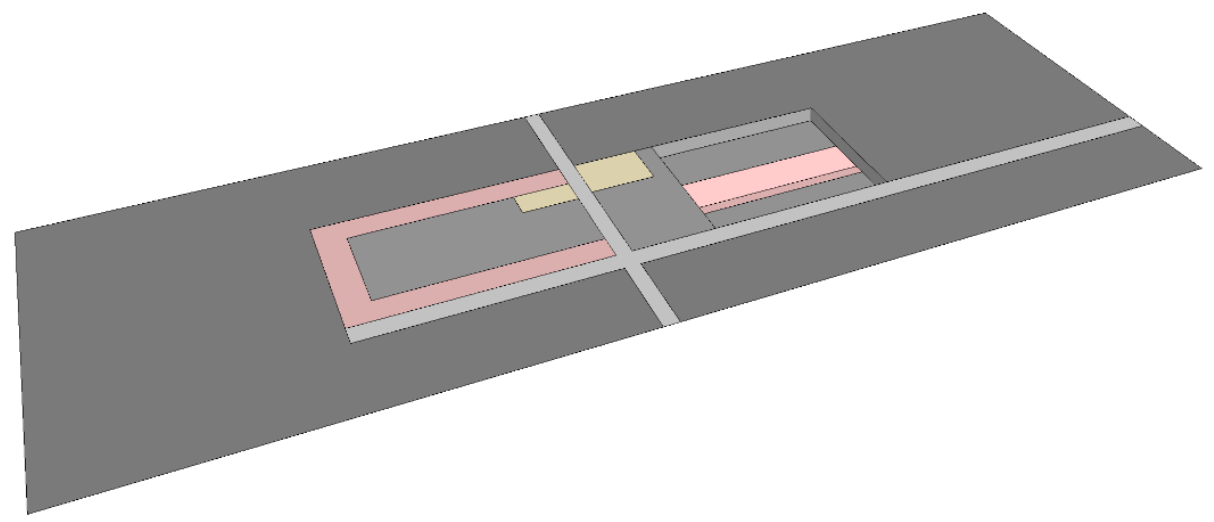

4.- Una cobertura metálica con estructura de tijerales cubre las estaciones simétricas y las conecta mediante una cúpula a la altura de la calle central.

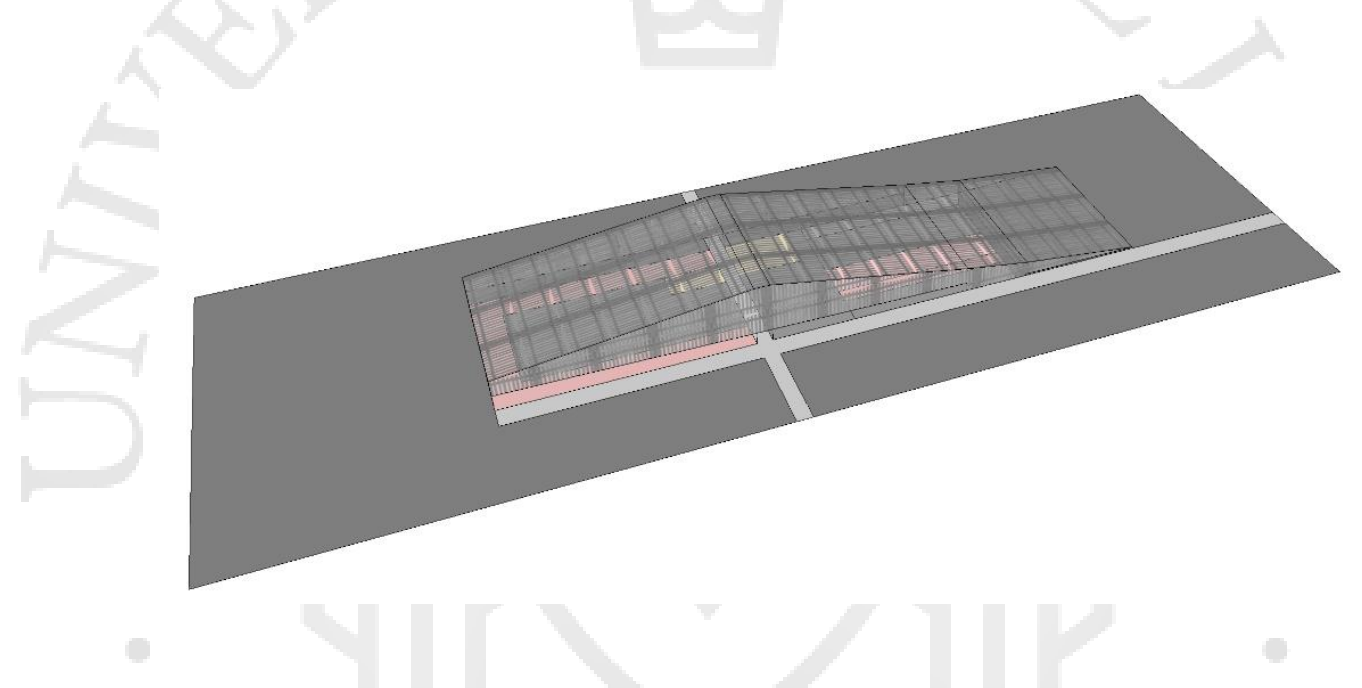

5.- La cúpula es transitable y forma parte de la continuidad de la plaza que se encuentra a nivel del suelo, de acceso y uso público. A esta tipología reciente se le suele llamar Landform Buildings.

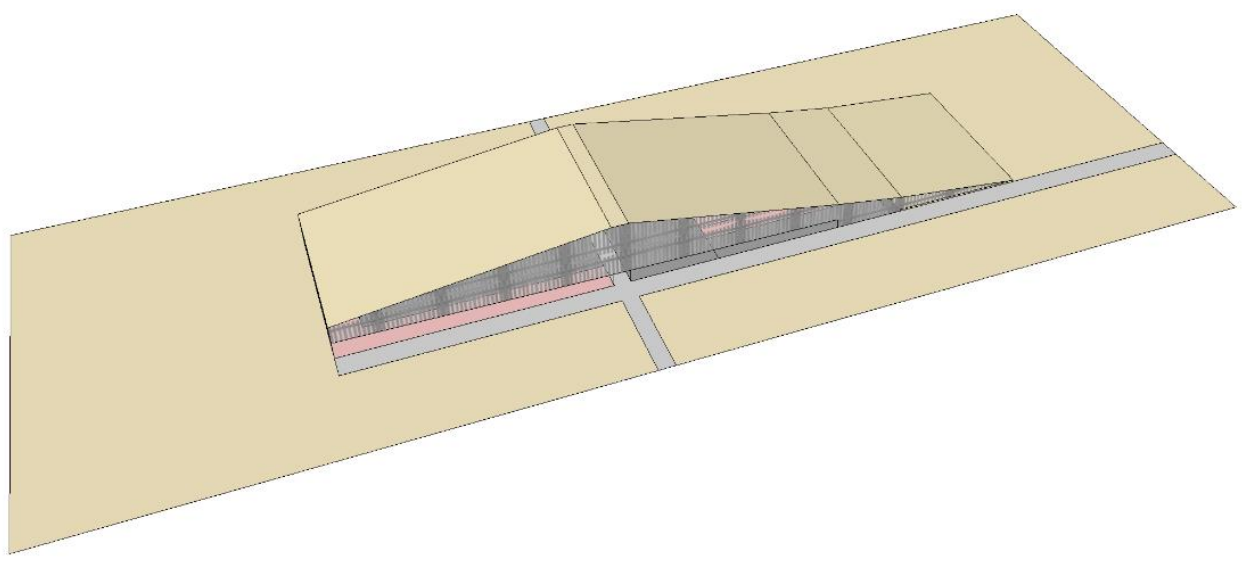




\subsubsection{Público-Privado}

La estación de Logroño propone un paralelismo sobre la relación entre los espacios públicos y privados y el área construida y el área libre. El 20\% del área del terreno está construida y es en esta área dónde están los espacios privados y semi privados.

El paso de lo público a lo privado permite que el flujo peatonal sea fluido, debido a que sus límites semi permeables logran que la transición sea ininterrumpida y continua. Se adjuntan esquemas a continuación.

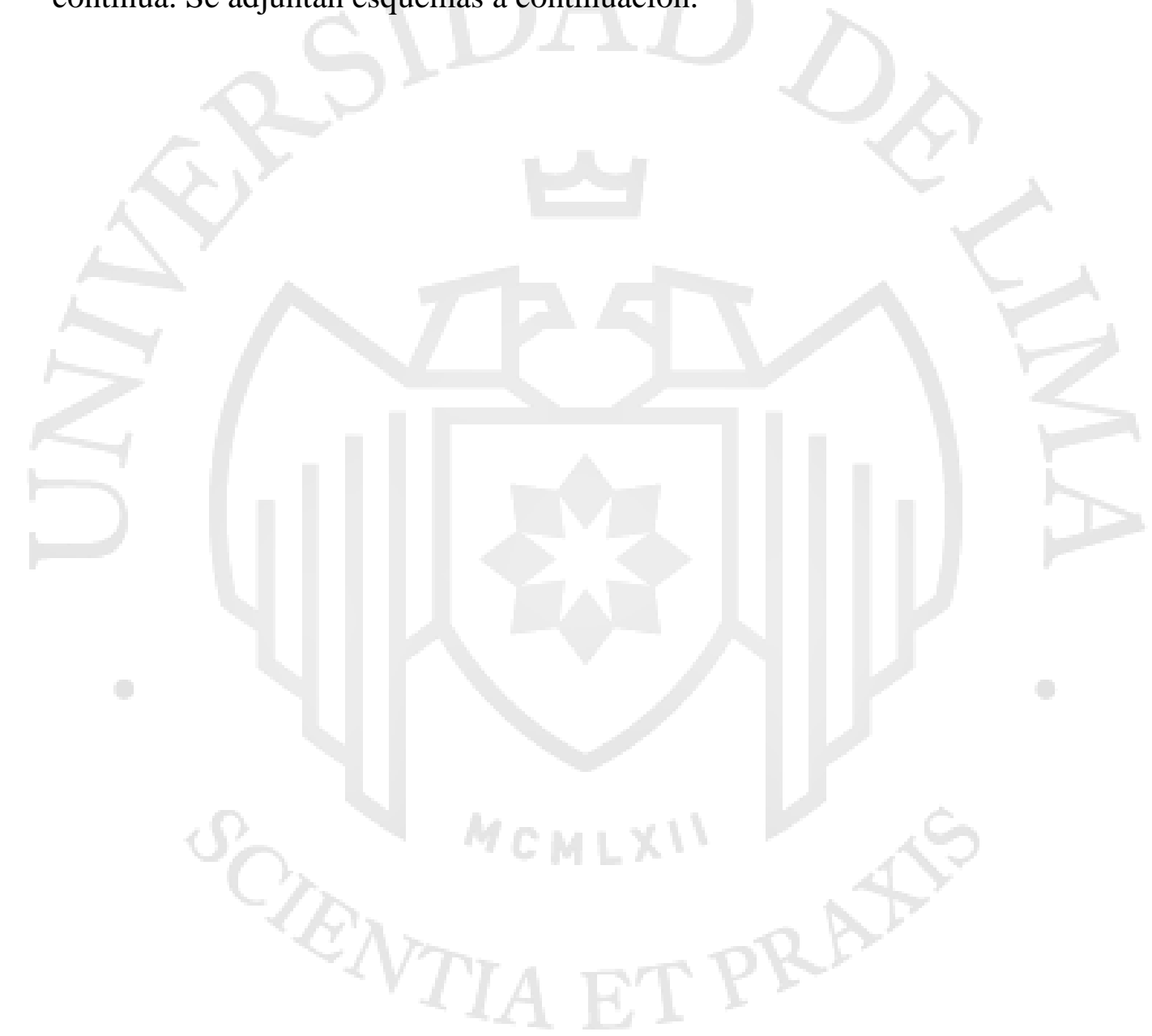



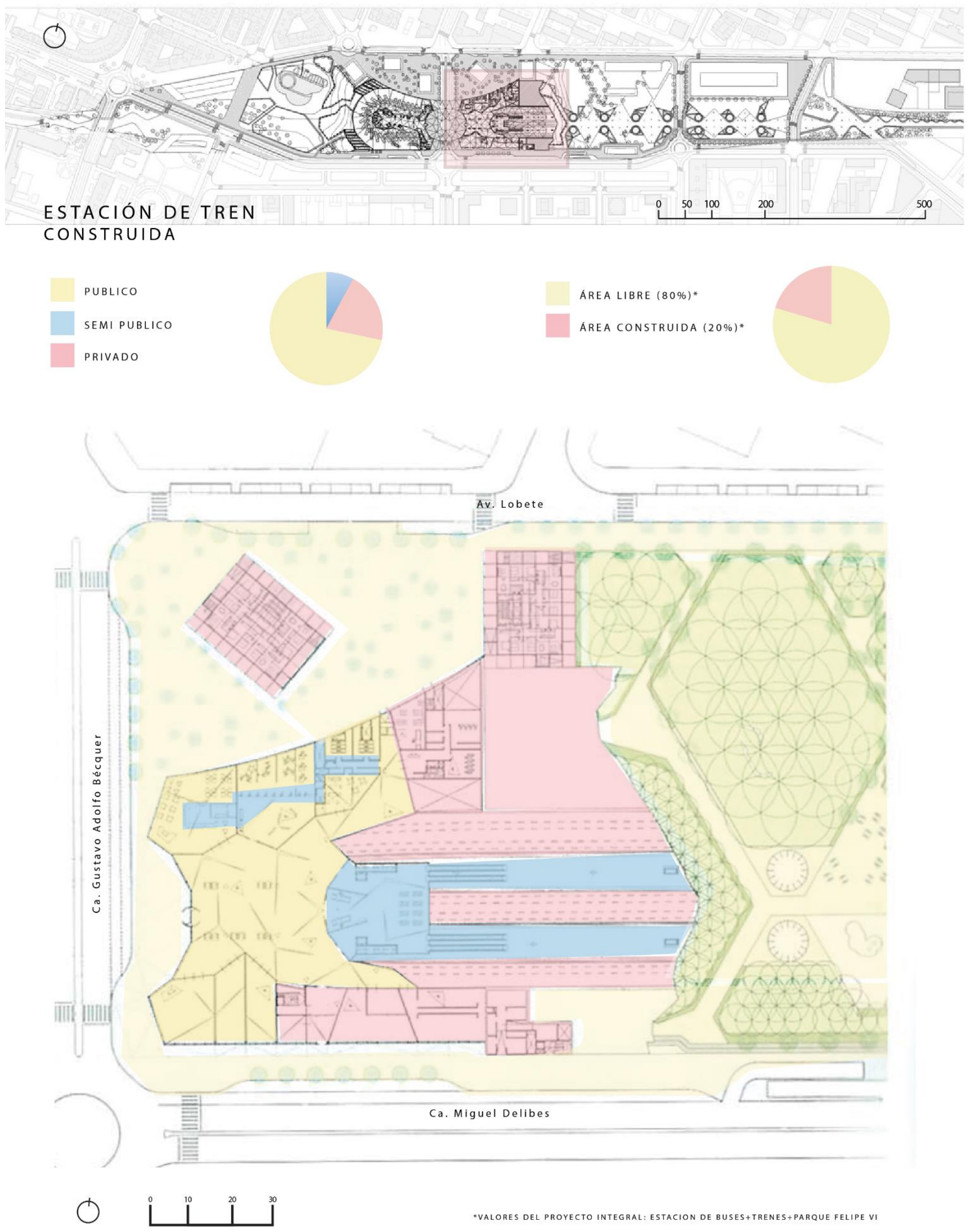


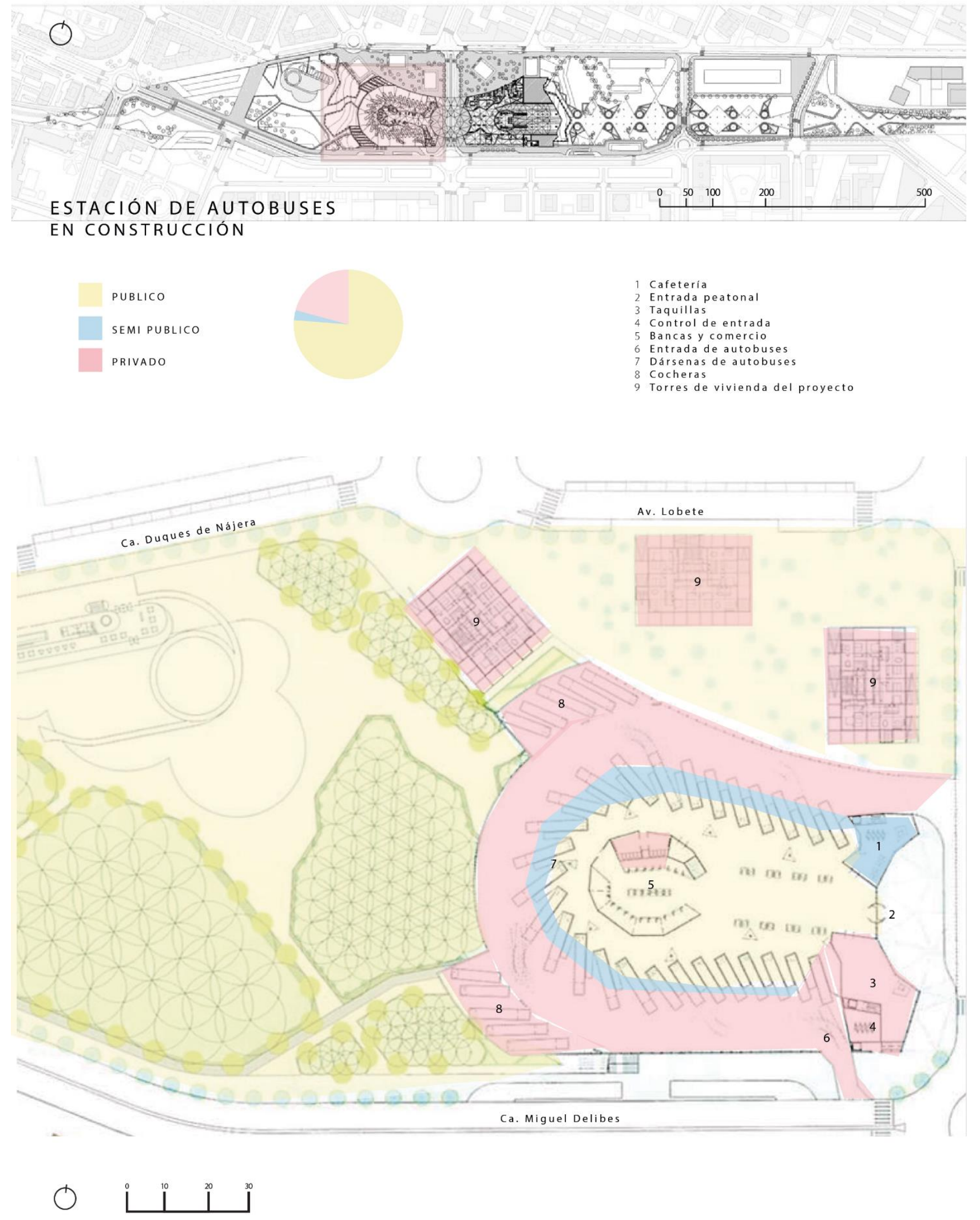




\subsubsection{Tecnología}

\subsubsection{Materiales y sistema constructivo}

Las dos estaciones de la Estación de Alta Velocidad de Logroño cuentan con una cubierta metálica y tijerales en forma de pliegues. Esta parte de una figura básica y varía según la necesidad del espacio y altura de techo.

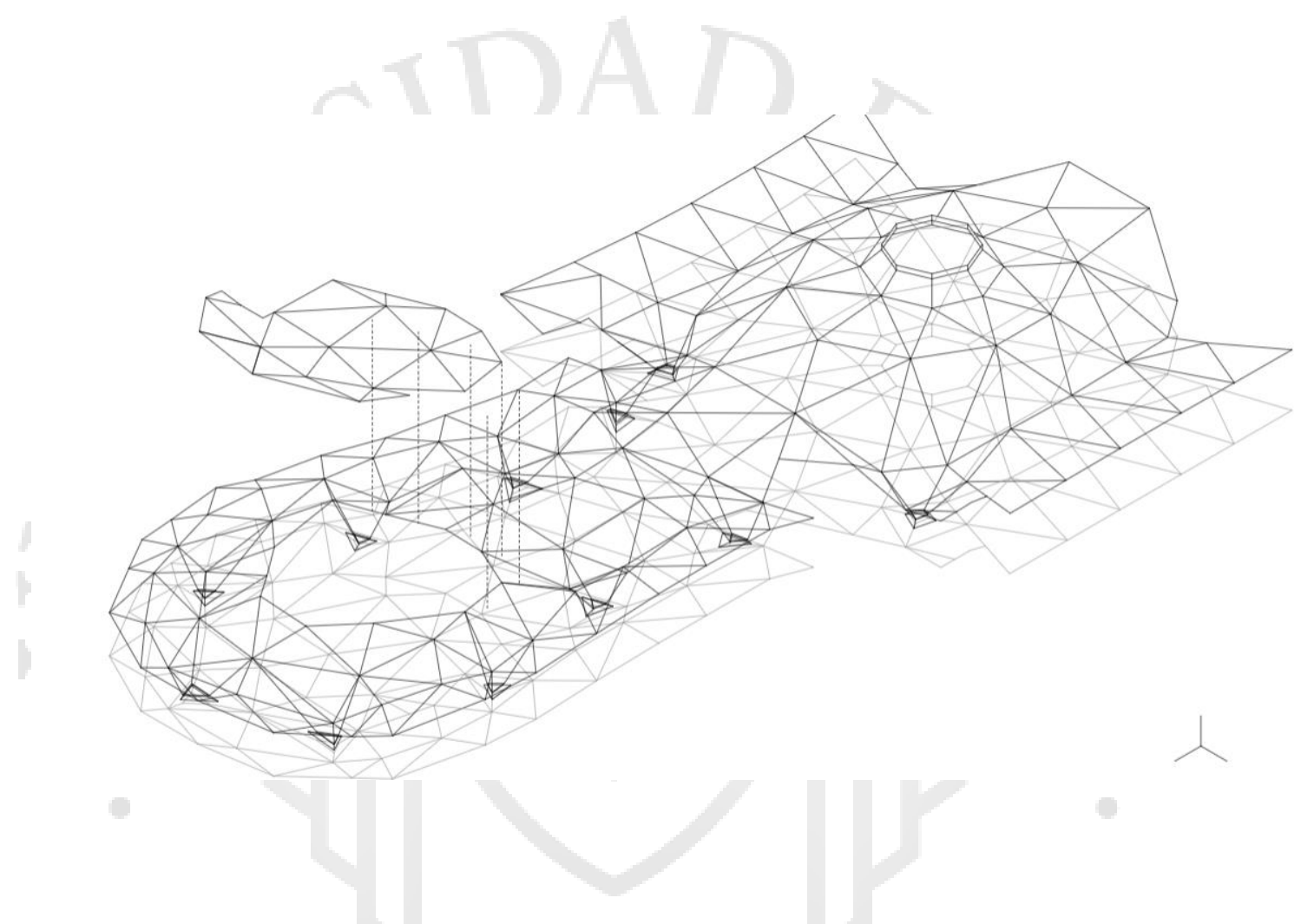

Con la finalidad de ser una estación de transferencia, la cúpula central pretende unir espacialmente ambas estaciones gemelas, formando el parque sobre la cubierta a un segundo nivel, con árboles y arbustos de diferentes especies.

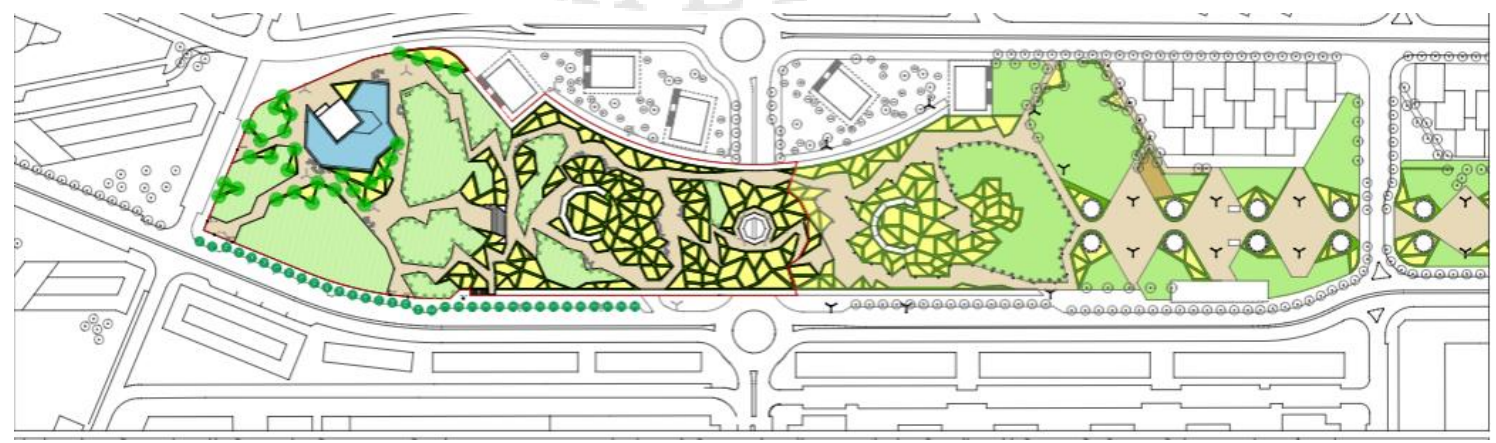

Fuente: (Rioja2, 2016) 

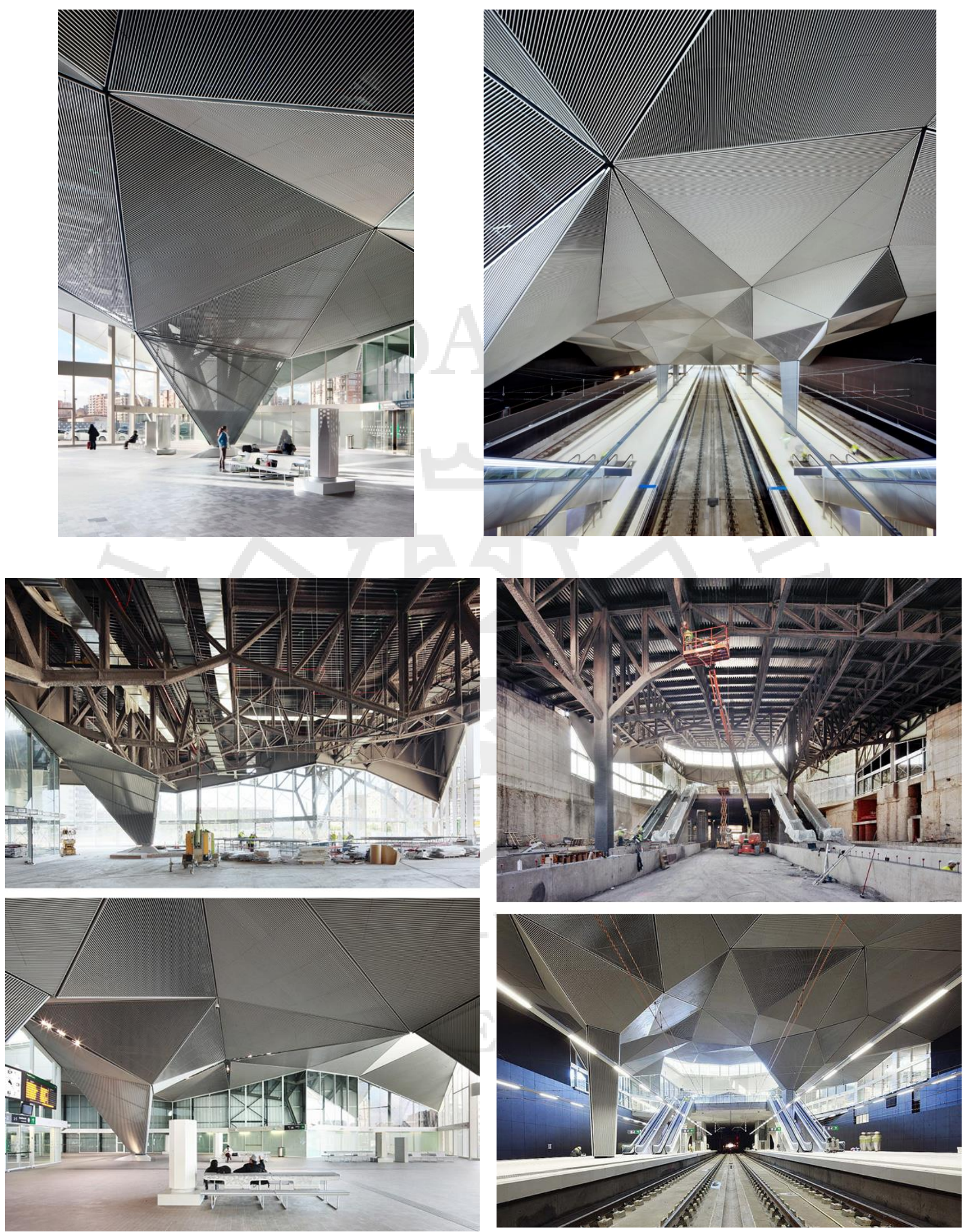

Imágenes: Estructura de tijerales y cobertura metálica en Hall y Andenes de la Estación de Tren. (Ábalos + Sentkiewicz, s.f.) 
La estación de autobuses que se construirá, contará con la gran cúpula conectora y un lucernario central para iluminar el interior.

Detalles constructivos: Fachada y entrada principal de la Estación de autobuses.

Fuente: (Rioja2, 2016); esquema de realización propia
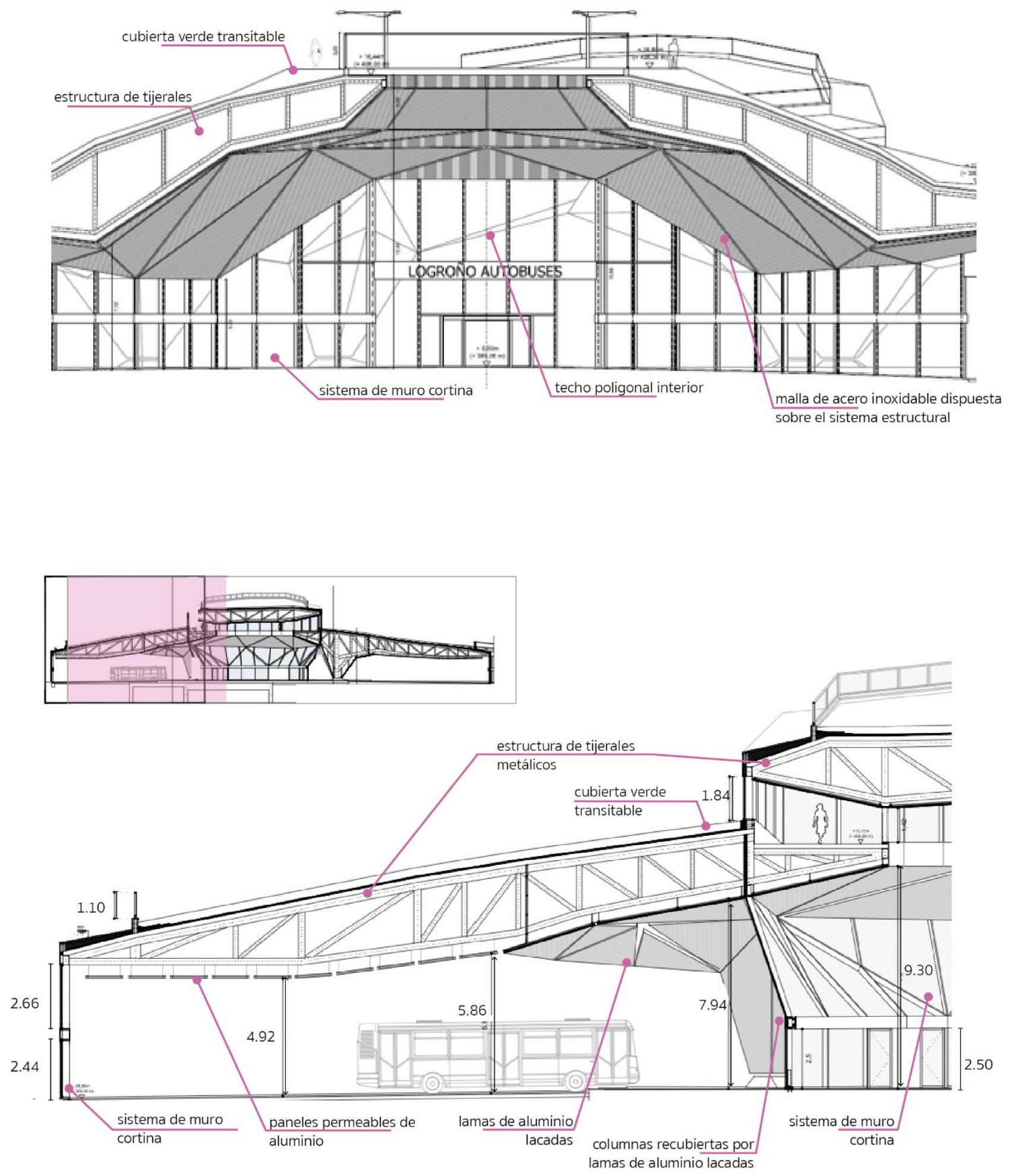


\subsubsection{Impacto ambiental}

En el contexto actual, donde existe una búsqueda constante de alternativas de producción de energía e infraestructura, los arquitectos de Ábalos+Sentkiewicz son llevados a producir un diseño termodinámico para la era de concientización ambiental. Esto es logrado mediante el reemplazo del típico modelo tectónico de estación por uno biotécnico: aquel que permite al arquitecto pensar en el edificio como organismos vivos en constante intercambio con el ambiente y su entorno. (Bojovic, 2013)

Para lograr esto existió, también, un intercambio de conocimientos entre especialistas que complementen la labor del arquitecto, además de redefinir el concepto de la profesión, positivamente, de ser una simple búsqueda de creación de espacios sin contexto.

En cuanto al diseño formal, la estación de trenes subterránea emerge al exterior mediante las zonas de acceso al proyecto y lucernarios que se conectan con la luz exterior del espacio público a nivel del suelo del Parque Felipe VI. Estos últimos son "pabellones poligonales que iluminan los andenes a través de unas aperturas circulares" (Gordon, 2012), complementados por un sistema de espejos y lograr introducir luz natural a la estación bajo la tierra.

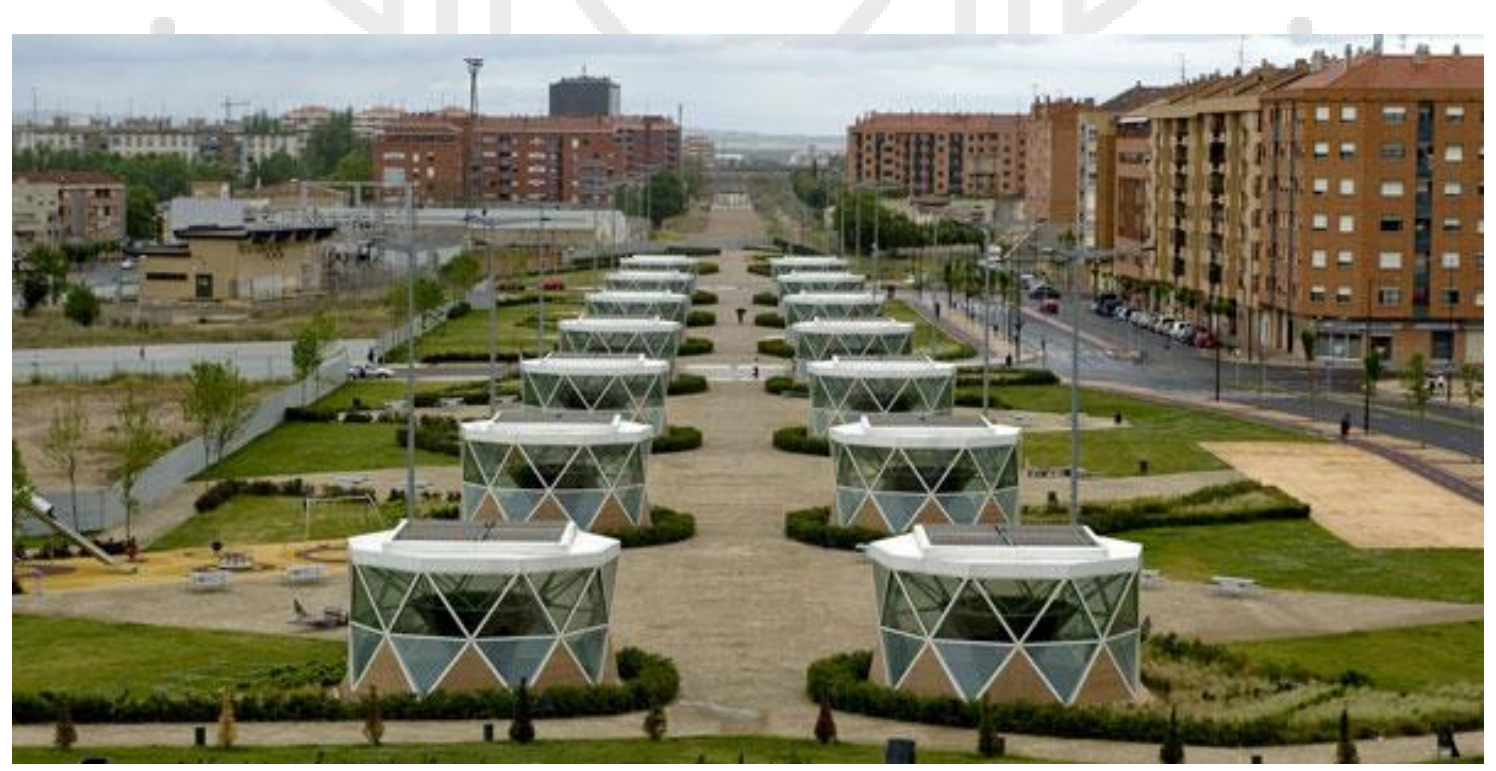

Imagen: teatinas vistas desde el Parque Felipe VI

Fuente: LIF2002 


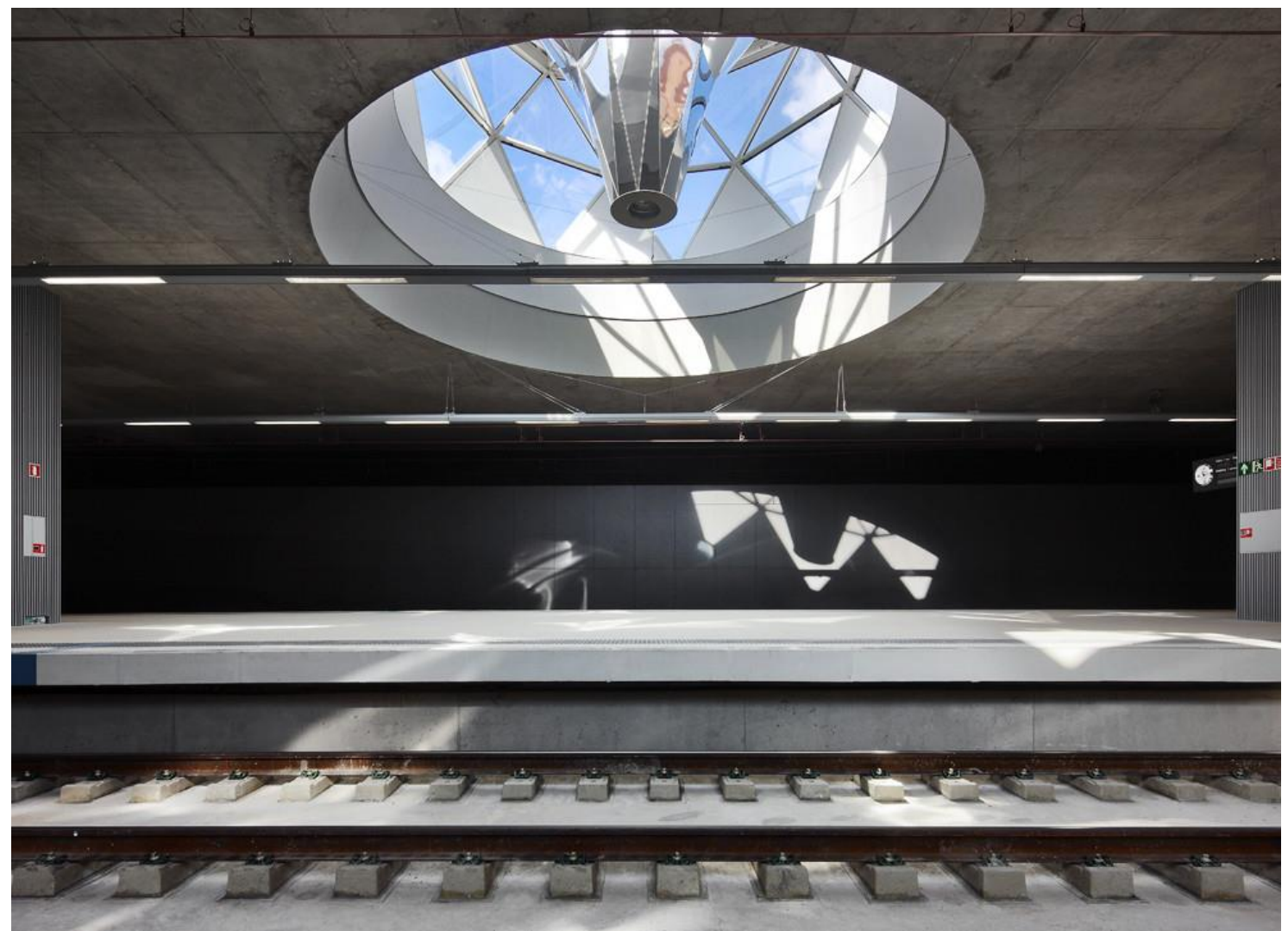

Imagen: teatinas y sistema de espejos desde el interior de la estación de trenes Fuente: (Ábalos + Sentkiewicz, s.f.)

Finalmente, el espacio público exterior es conformado por una colina artificial transitable y cubierta por diferentes especies verdes para contrarrestar parte de la contaminación que una estación de transporte supone.

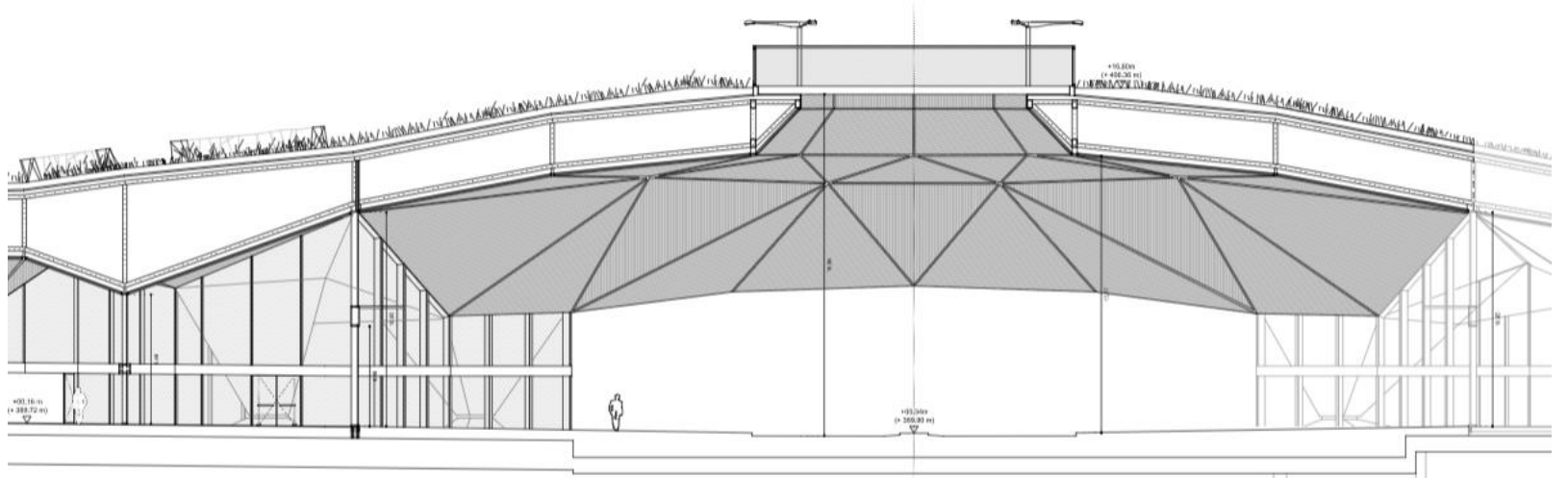

Plano: detalle de colina artificial ajardinada

(Rioja2, 2016; Ábalos + Sentkiewicz, s.f.) 


\subsubsection{Impacto social}

En Logroño existía un problema similar al de muchas ciudades atravesadas por una vía férrea: la división urbana en dos. Luego de la industrialización, las vías de este transporte se impusieron en espacios urbanos previamente consolidados, como un muro físico y social. Con la nueva estación, la capital de La Rioja, ha decidido llevar parte de las vías divisoras a un nivel subterráneo. Con este gesto, el proyecto consiguió unir el Norte y Sur de la ciudad, además de proveerla de un amplio espacio público y arborizado.

La estación actual de autobuses de Logroño ya "capitaliza las comunicaciones por carretera entre las poblaciones más importantes de la Comunidad Autónoma de La Rioja y localidades intermedias... y las capitales de otras Comunidades más próximas a su entorno o más importantes para las necesidades de los viajeros”. (La Rioja, 2011) Sin embargo, el proyecto fue definido por la alcaldesa de Logroño como "una nueva puerta de entrada a Logroño, a una ciudad moderna y competitiva" (La Rioja, 2011). La estación le ofrece a la comunidad una nueva imagen y servicios de calidad dentro de su programa. Además, aumenta la competitividad del entorno al incrementar las comunicaciones entre la comunidad y la intermodalidad de las mismas.

Finalmente, estación se convierte en la unión física de barrios anteriormente separados; se genera un nuevo centro en la capital riojana; y un ícono donde antes existía un espacio vial negativo a nivel urbano para la ciudad. 


\subsection{Estación de autobuses y biblioteca de Ronda (Málaga)}

\subsubsection{Historia}

\subsubsection{Información Del Proyecto}

- Arquitecto: Exit Architects.

- Estado de proyecto: Propuesta de concurso

- Año: 2012

- Sostenibilidad: Ecoproyecta.

- Paisajismo: Paraidesa.

- Software de análisis energético: Annabella Bebrens

- Arquitecto técnico: Alberto Palencia.

El proyecto fue una de las propuestas que llegaron a la etapa final del concurso organizado por el Ayuntamiento de Ronda en Málaga, España. El encargo fue una estación de Autobuses y Biblioteca de Ronda para reemplazar la estación Ronda que existe actualmente. Fue dirigida por Miguel García-Redondo, de Exit Architects.

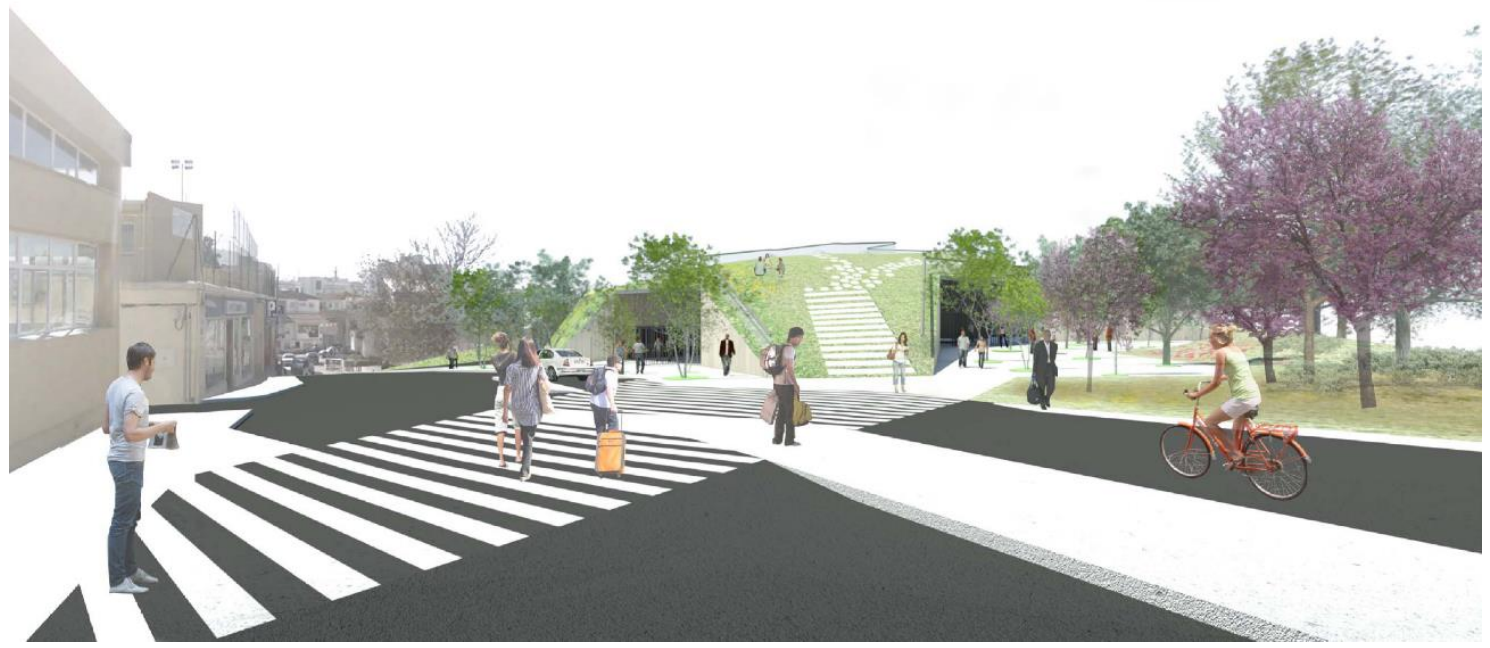

Fuente: Exit Architects 


\subsubsection{Toma De Partido}

Exit Architects presentó una propuesta bajo el nombre de "Cuentos en el andén". Actualmente, el terreno colinda con un instituto de secundaria, un centro de interpretación del mueble rodeño, una piscina climatizada y polígonos industriales. Partiendo de los servicios próximos, de la educación y sostenibilidad, el proyecto se emplaza en un solar cercano a la actual estación de Ronda, a menos de dos cuadras de distancia.

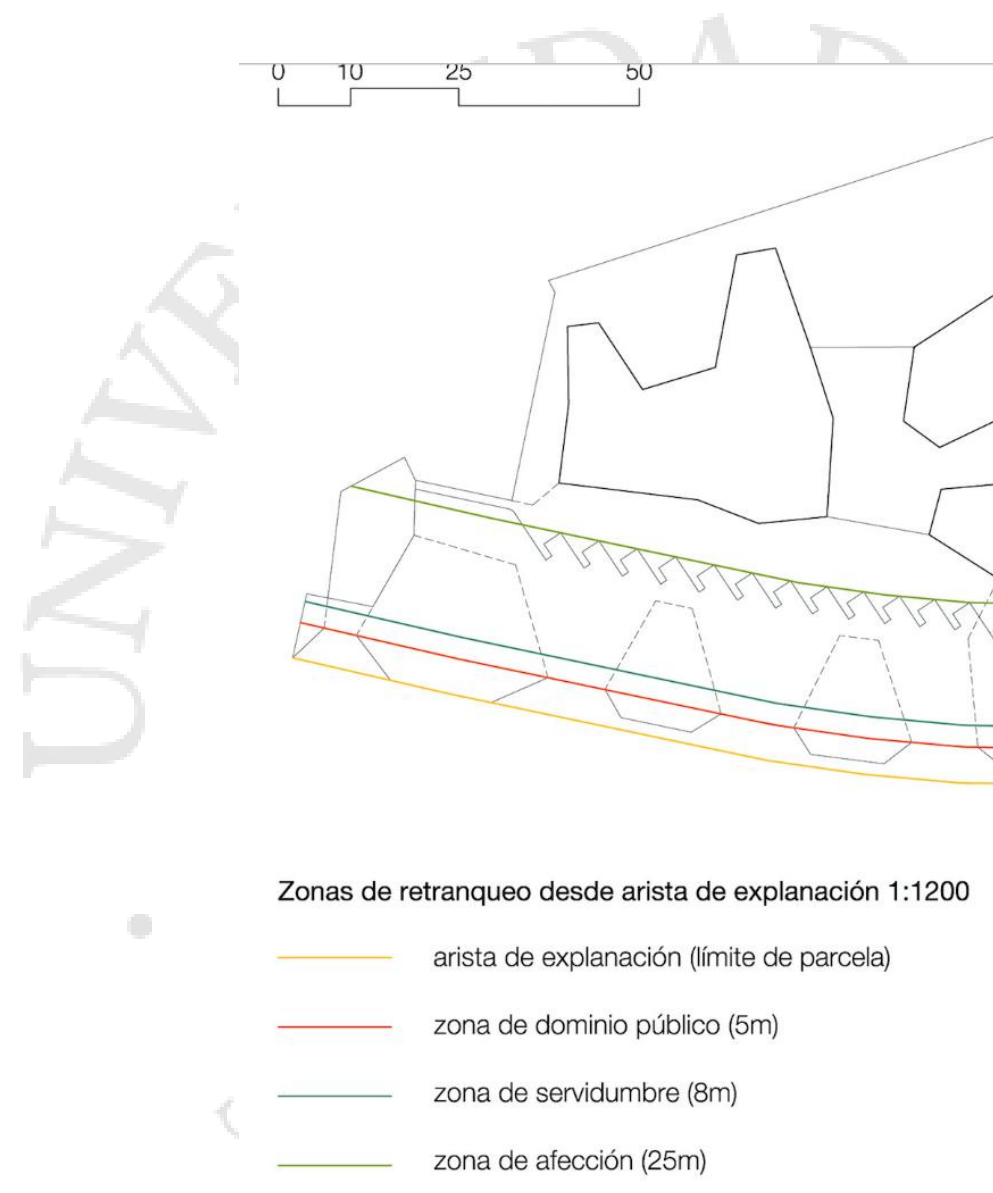

Como adicional al encargo, los arquitectos consideraron la adición de un tercer espacio a la dualidad estación biblioteca. Este sería un espacio verde y totalmente público. Es por ello, que, en lugar de considerarlo un factor negativo, se aprovechan los grandes árboles y vegetación del terreno que, además, ayudan a proteger la cubierta del edificio. De esta manera, se pretendía compensar la contaminación ambiental de una estación de buses y el tejido industrial aledaño.

Los apoyos de esta liviana cubierta sobre la tierra son invadidos por las plantas del entorno que ascienden sobre ella desdibujando el contorno de la misma, 
constituyendo de esta forma una sola entidad "cubierta-paisaje", e integrando todo el conjunto (estación-biblioteca-jardín) como una identidad única, proporcionando además un aislamiento natural y mayor inercia térmica que una cubierta convencional. (Ecoproyecta, 2013)
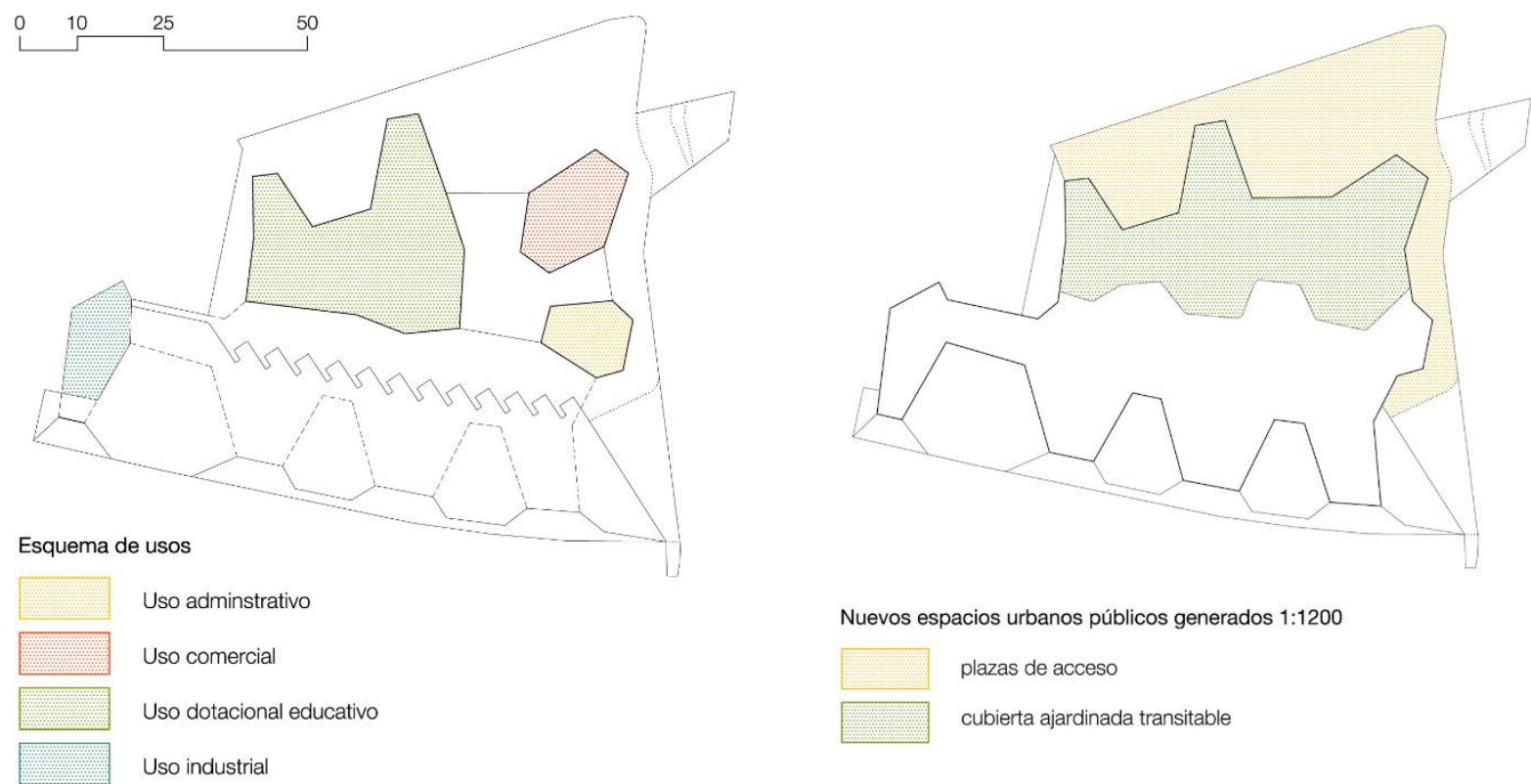

Nuevos espacios urbanos públicos generados 1:1200
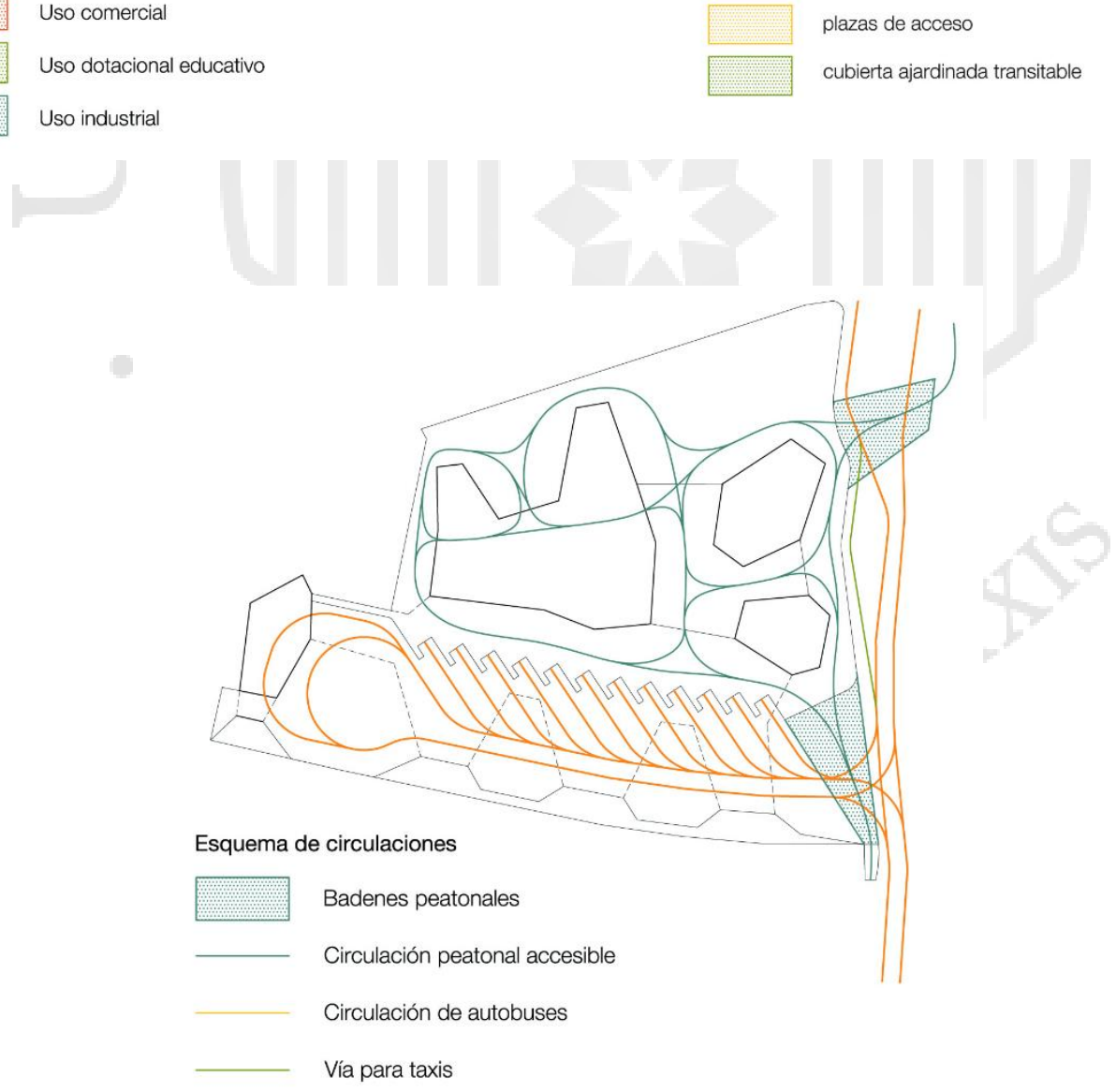

Fuente: Exit Architects 

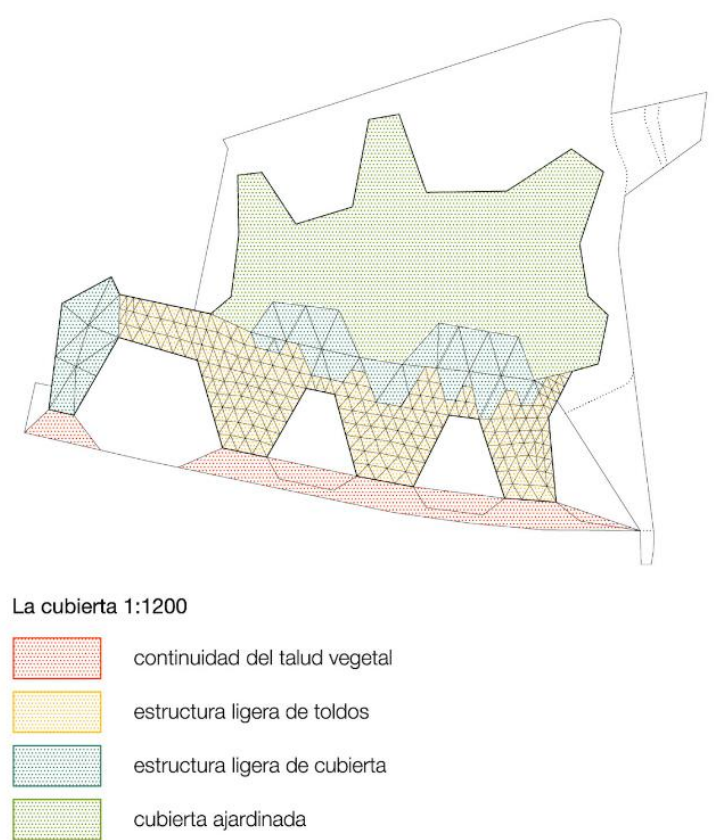

Finalmente, se entiende que la estación busca representar a nivel formal y funcional la dualidad de Biblioteca Estación adicionándole un parque y cubierta paisajista. Esto colabora al discurso de sostenibilidad y educación. El proyecto mantiene claro que hay una relación entre transporte público y lectura, pues facilita el acceso de la segunda y fomenta su uso durante tiempos de espera o viajes largos.

\subsubsection{Período histórico}

La ciudad de Ronda es el resultado de una fractura geológica en la tierra, está se genera por un tajo en el río Guadalevín. Pertenece a la comunidad autónoma de Andalucía en la provincia de Malaga en España.

Las vías de ingreso a la ciudad están rodeadas de paisajes naturales y son parte del atractivo turístico de la ciudad. Su primera línea de ferrocarril Bobadilla-Algeciras fue construida en 1890 y todavía opera en la ciudad.

En el 2012, frente al evidente crecimiento urbano, surge la necesidad de implementar en la ciudad una nueva estación de buses que conecte a los usuarios con las ciudades aledañas, así como reciba a la alta cantidad de turistas que la visitan. 


\subsubsection{Línea de tiempo}

Fuente: de realización propia

\section{0}

Se construye la red ferroviaria de Ronda

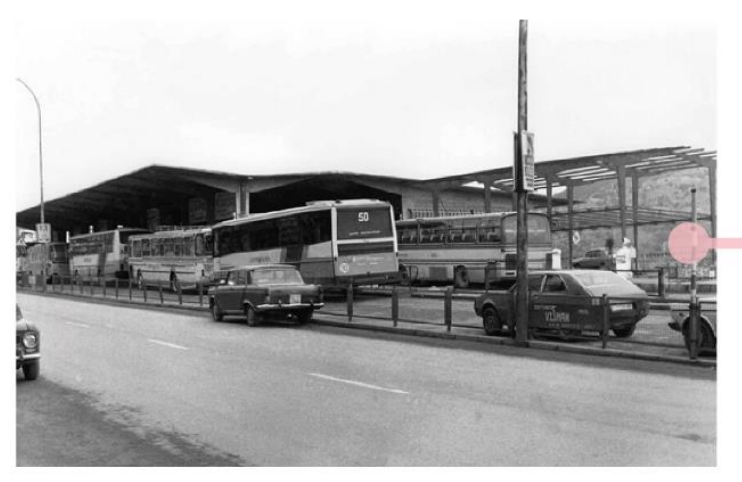

\section{2}

La estación de buses de Ronda comienza a tener problemas estructurales, donde el suelo cedía ante la carga de la edificación

\section{Octubre 2012}

El Ayuntamiento de Ronda convoca a un concurso de ideas para la nueva Estación de Autobuses y Biblioteca de Ronda, cerca a la estación del ferrocarril Ronda.

\section{3}

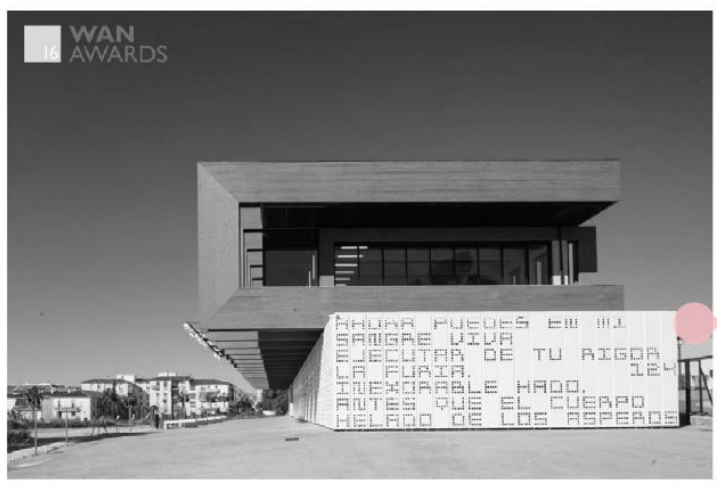

Gana el concurso el proyecto de Luis Angel Dominguez.

La propuesta de EXIT Architects consigue estar en la fase final pero no recibe mención.

El proyecto ganador es descalificado por inclumplir una base del concurso, meses después de ser anunciado

\section{$01 \mathrm{de}$ mayo 2013}

Se elige la propuesta de MMIT arquitectos.

\section{4}

Se adjudica la construcción del proyecto ganador a Lirola.

\section{julio 2015}

Inicia la demolición de equipamiento en los terrenos y posterior construcción del proyecto ganador

\section{2 de marzo 2016}

Inauguración de la Biblioteca Adolfo Suárez de Ronda según el diseño de MMIT Arquitectos

\section{6}

El proyecto de MMIT Arquitectos es finalista en los WAN Awards de Edificación civil. 


\subsubsection{Ubicación Y Relación Con EI Entorno}

\section{Plano: Ubicación de la Estación de Ronda}

Fuente: de realización propia
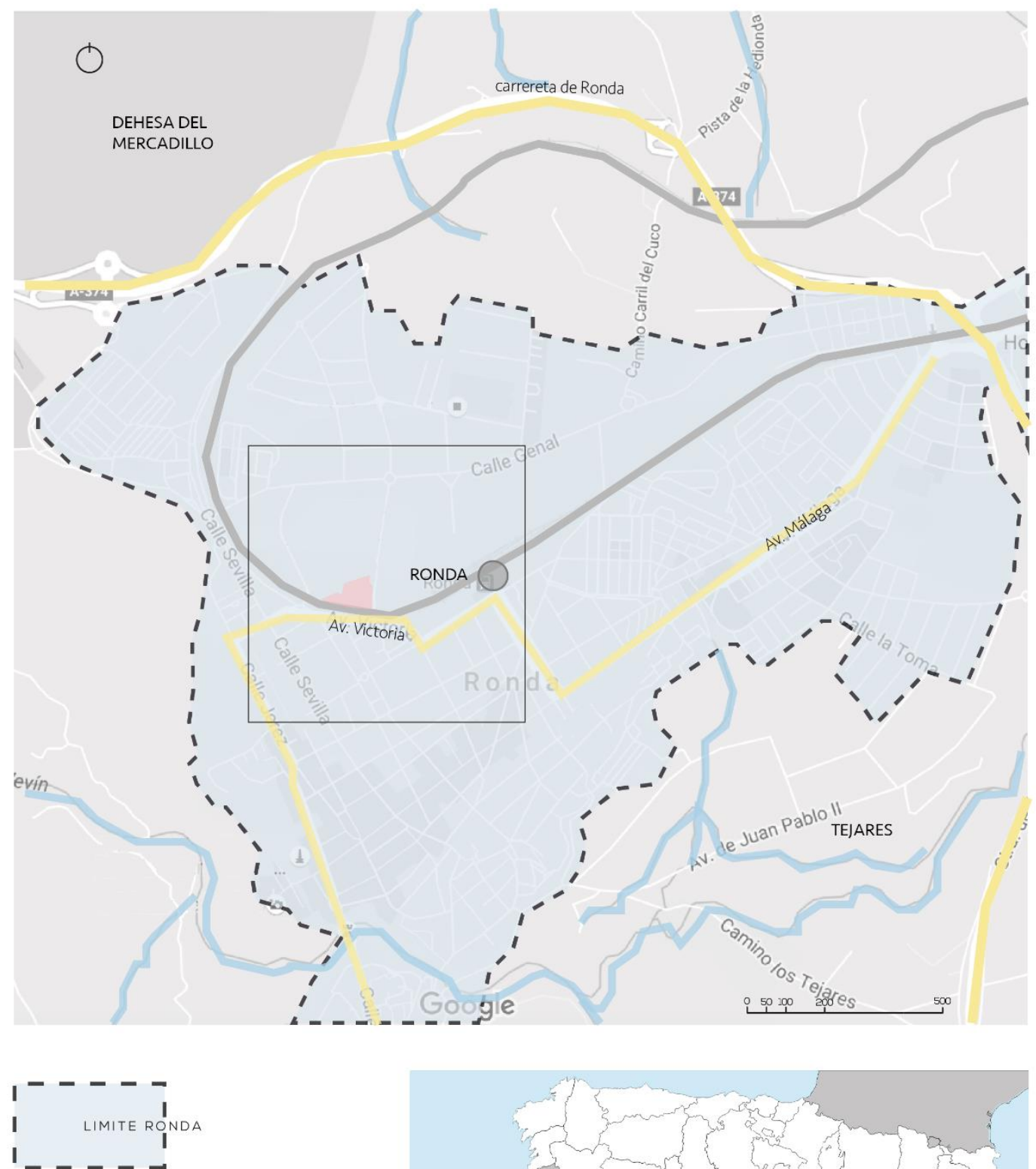

PRINCIPALES AUTOVIAS LINEA DE TREN

RIO GUADALEVIN (SUR) RIO GUADALCOBACIN (NORTE)

BIBLIOTECA-ESTACIÓN DE RONDA

ESTACIÓN DE TREN

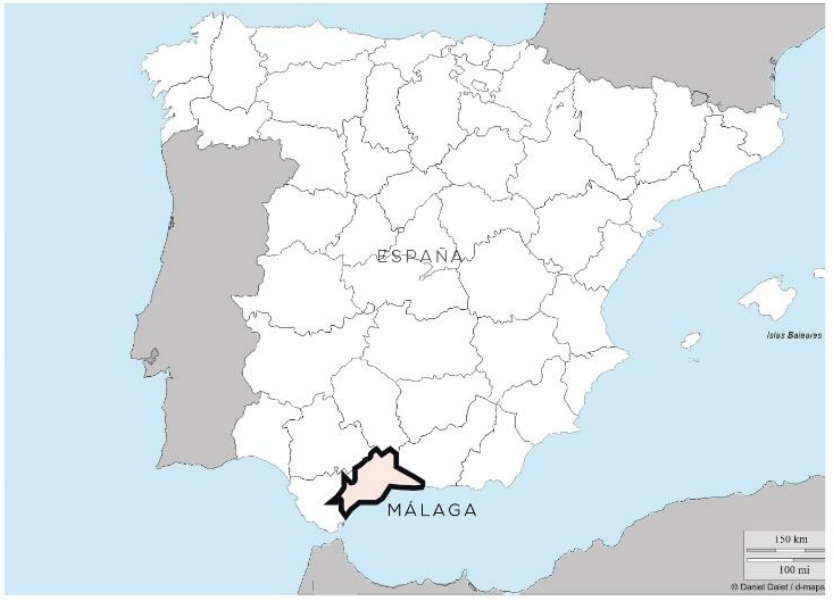




\section{Plano: Ubicación de la Estación de Ronda}

Fuente: de realización propia

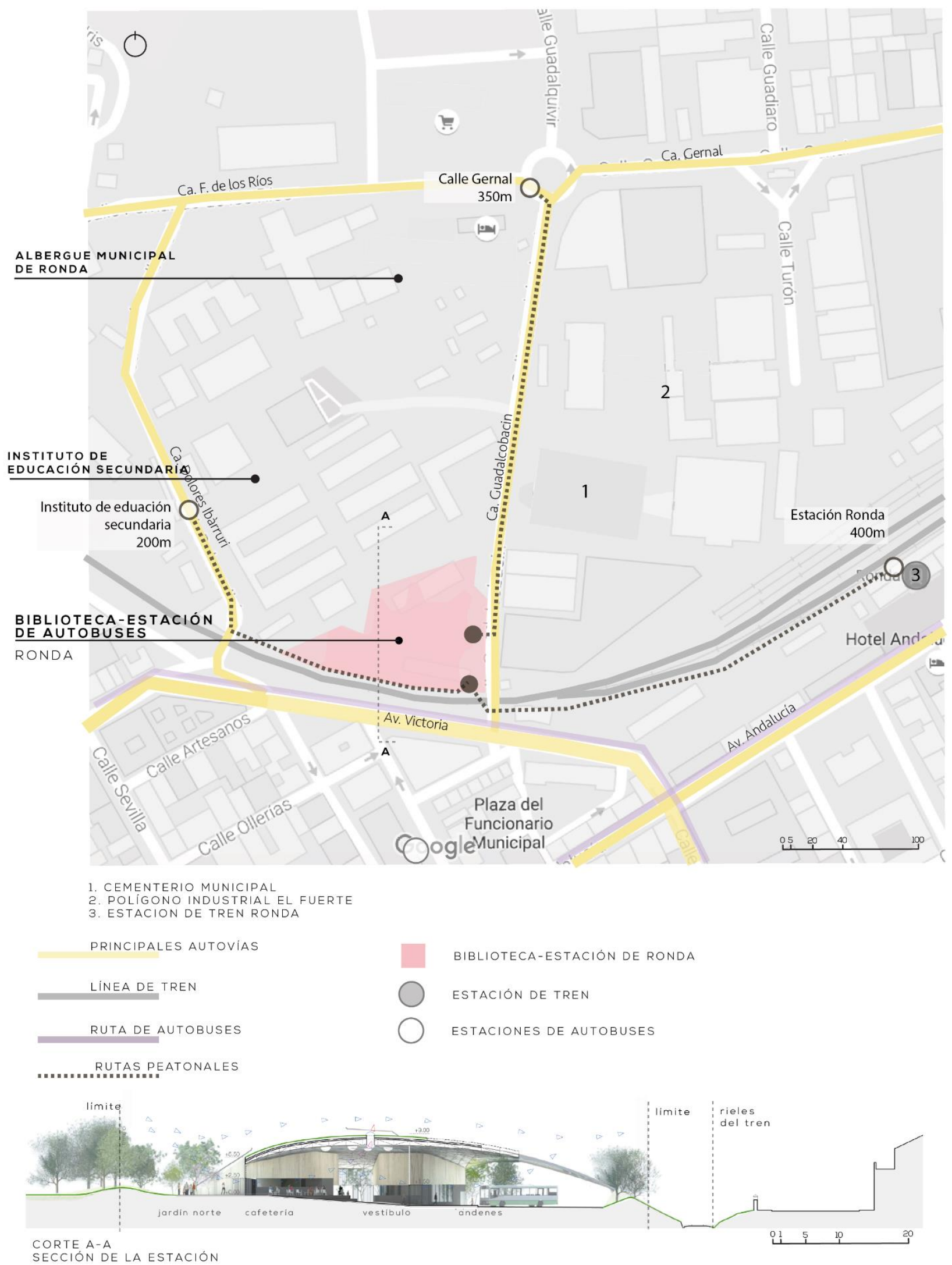




\subsubsection{Programa Y Relaciones Programáticas}

\section{Cuadro: Cuadro de áreas de la Estación de Ronda}

Fuente: de realización propia, a partir de planos (Exit Architects, 2012)

\begin{tabular}{|c|c|c|c|c|}
\hline AREAS & SUB AREAS & $\begin{array}{c}\text { SUPERFICE } \\
\mathrm{m} 2\end{array}$ & \begin{tabular}{|c|} 
AREA TOTAL \\
$\mathrm{m} 2$
\end{tabular} & $\%$ \\
\hline $\begin{array}{l}\text { ESTACION } \\
\text { DE BUSES }\end{array}$ & $\begin{array}{l}\text { Vestíbulo } \\
\text { Información } \\
\text { Expedición de boletos } \\
\text { Entrega de equipaje } \\
\text { Baños } \\
\text { Cafetería } \\
\text { Tienda } \\
\text { Administración } \\
\text { Dirección } \\
\text { Baños personal } \\
\text { Sala conductores } \\
\text { Baños conductores }\end{array}$ & $\begin{array}{r}340 \\
9 \\
23 \\
24 \\
53 \\
112 \\
33 \\
33 \\
19 \\
13 \\
15 \\
10\end{array}$ & 684 & 40.88 \\
\hline BIBLIOTECA & $\begin{array}{l}\text { Vestíbulo } \\
\text { Mostrador de préstamos } \\
\text { Mediateca y hemeroteca } \\
\text { Sala de usos múltiples } \\
\text { Baños } \\
\text { Depósito de limpieza } \\
\text { Depósito de libros } \\
\text { Dirección } \\
\text { Sala de reuniones } \\
\text { Baños personal } \\
\text { Vestíbulo } \\
\text { Sala de lectura } \\
\text { Espacios de trabajo en grupo } \\
\text { Espacios para la investigación } \\
\text { Espacios de estudio individual } \\
\text { Baños } \\
\text { Almacén }\end{array}$ & $\begin{array}{r}87 \\
19 \\
261 \\
109 \\
28 \\
4 \\
33 \\
19 \\
22 \\
20 \\
16 \\
217 \\
52 \\
41 \\
27 \\
16 \\
18\end{array}$ & 989 & 59.11 \\
\hline & & & 1673 & \\
\hline
\end{tabular}




\subsubsection{Aportes}

La estación de Autobuses y Biblioteca de Ronda, propuesta de EXIT Architects, aporta un sistema de ahorro de energía a la comunidad con el diseño logrado. En general, se proponía incorporar una producción basada en fuentes renovables utilizando $200 \mathrm{~m} 2$ de la cubierta verde, orientada al sur, que tuviese la capacidad de montar una "instalación fotovoltaica de autoconsumo con una potencia de $30 \mathrm{kWp}$. Esto equivale a unos 45000 kWh anuales" (Ecoproyecta, 2013). Esto significaría poder cubrir más del 50\% de la demanda energética del edificio, y cubrir la inversión en un plazo de 5 años. Además, la cubierta verde que se proyectó pretendía minimizar los efectos negativos que implica una estación de transporte.

La sostenibilidad del proyecto, también, se aplica en el uso de materiales. Se proponía utilizar madera con certificado de tala sostenible, sin perjudicar al medio ambiente por la construcción y necesidad de recursos del edificio. Asimismo, se pensó en la "reutilización del gran volumen de relleno que generará el movimiento de tierras para usos de jardinería y paisajismo; hormigón con áridos reciclados para cimentación

y soleras; acero con un alto porcentaje de reciclado en su fabricación; o el aislamiento térmico de corcho natural". (Ecoproyecta, 2013) 


\subsubsection{Tipología Espacial}

1.- El proyecto se emplaza al medio del terreno que, debido a la gran cantidad de árboles que presenta, envuelve al edificio en un bosque tupido. La forma, según los arquitectos, inicia respetando la naturaleza del espacio verde existente.

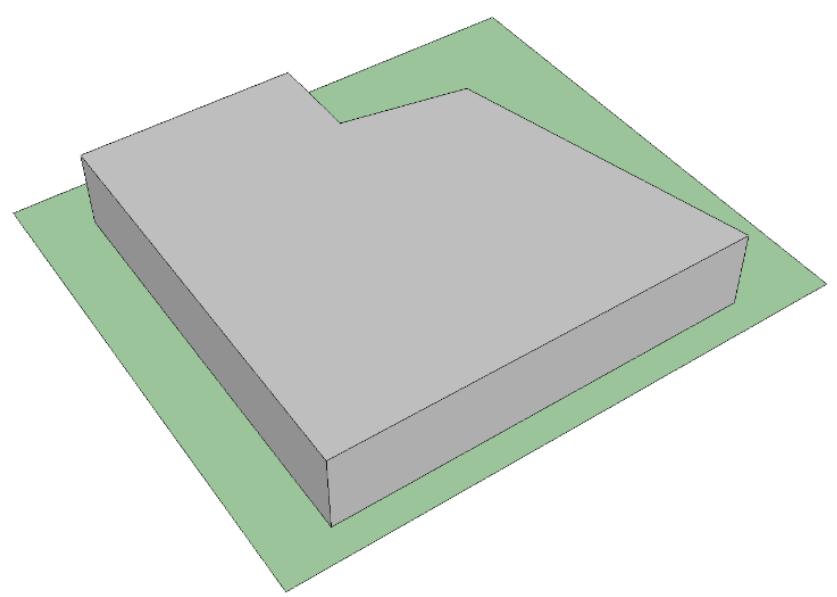

Fuente: Esquema de realización propia

2.- Las funciones se separan en el terreno según permeabilidad y nivel de privacidad. Aparece una vía de flujo peatonal y para autobuses que conecta el proyecto con la calle. El estacionamiento y paradero de buses recibe prioridad como plaza frente al programa (celeste)

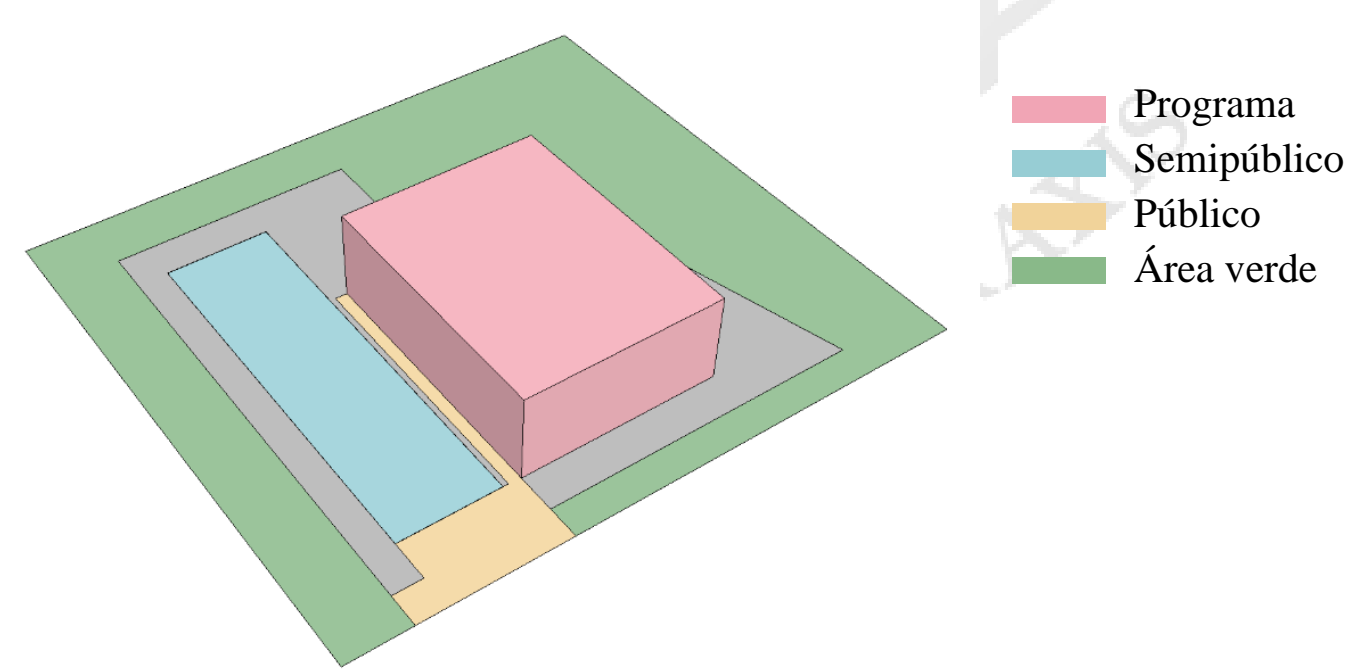

Fuente: Esquema de realización propia 
3.- El programa del edificio se entrelaza con el espacio público, permitiendo que la función de cada tramo interior active el exterior.

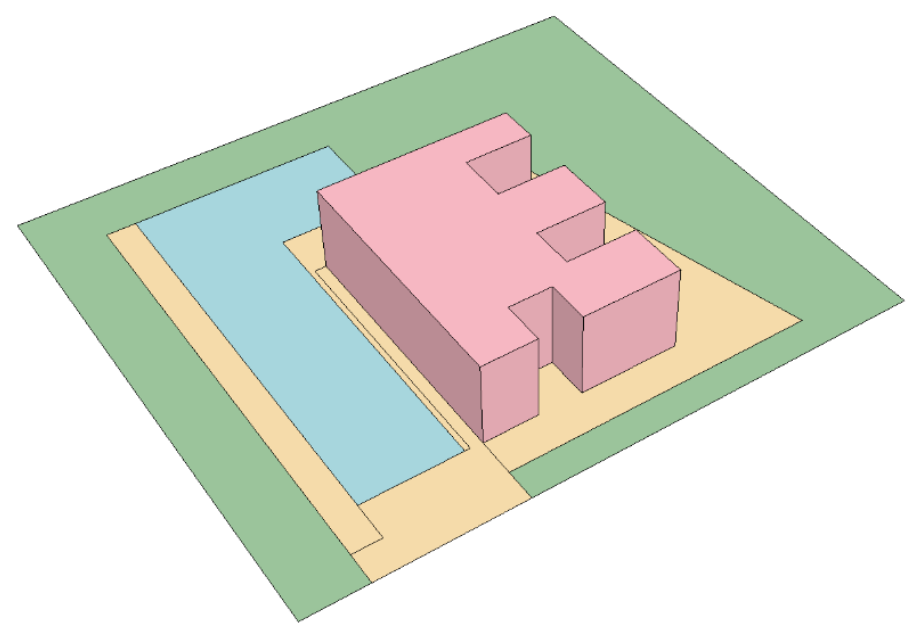

Programa

Semipúblico

Público

Área verde

4.- Hay una deformación de elementos, pero mantiene la mezcla espacial entre exterior e interior público.
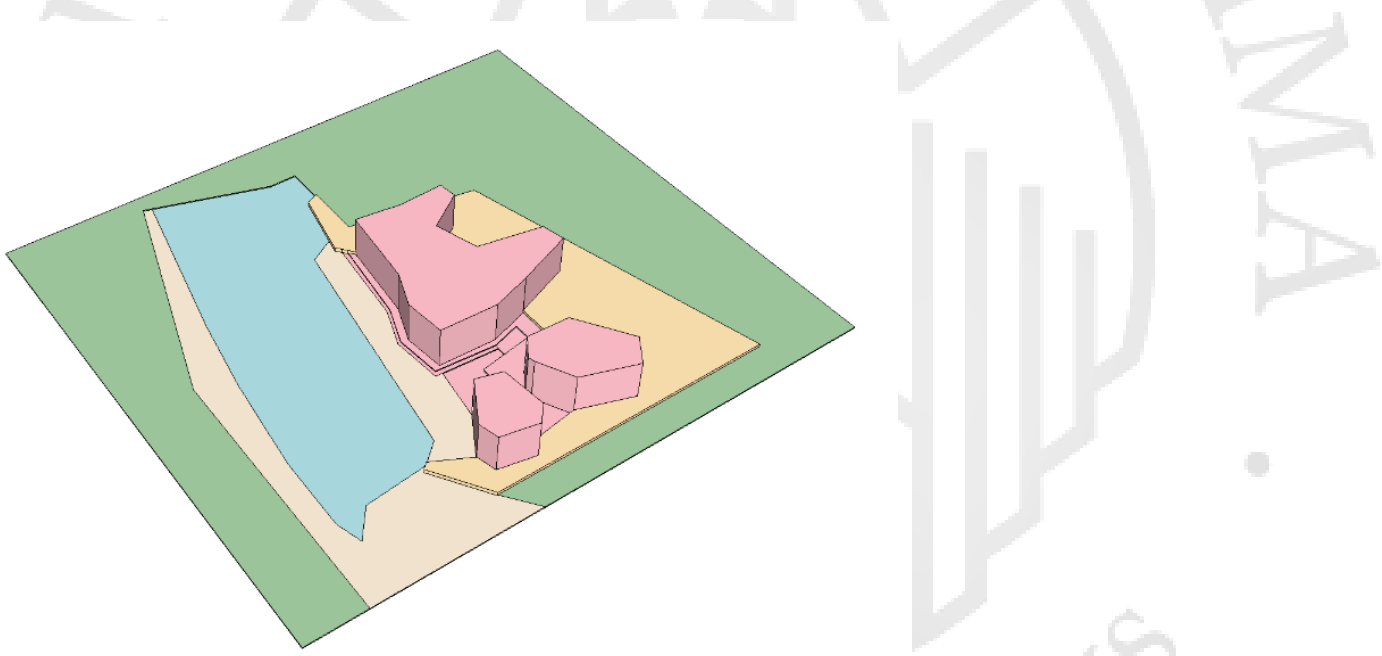

5.- Aparece una cubierta vegetal sobre el programa.

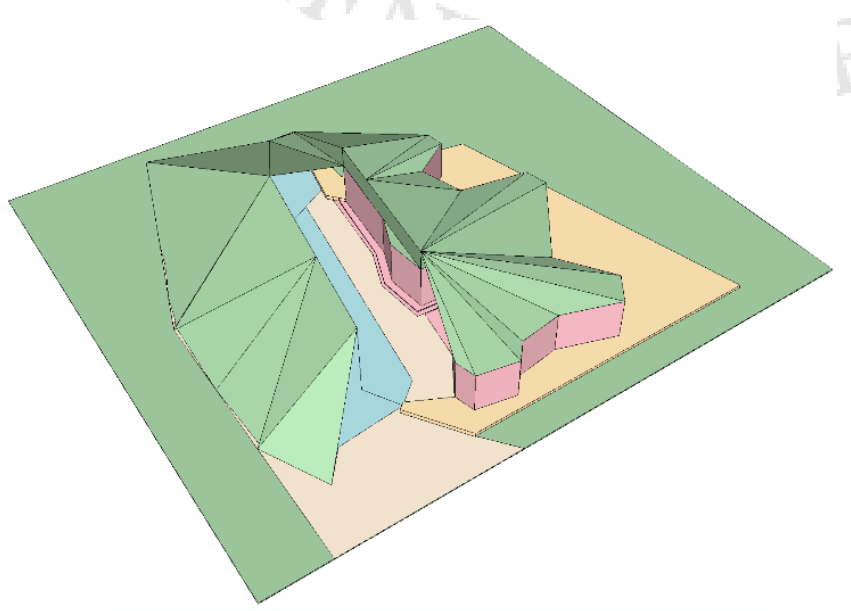




\subsubsection{Público-Privado}

La relación y flujo entre lo público y lo privado en la estación de buses de Ronda sigue un sistema claro: todos los bordes del terreno son espacios públicos de fácil acceso y libre flujo peatonal. Esto permite que el edificio se vuelva parte de la ciudad con facilidad.

\section{Plano: Primera planta}

Fuente: de realización propia, en base a planos de Exit Architects
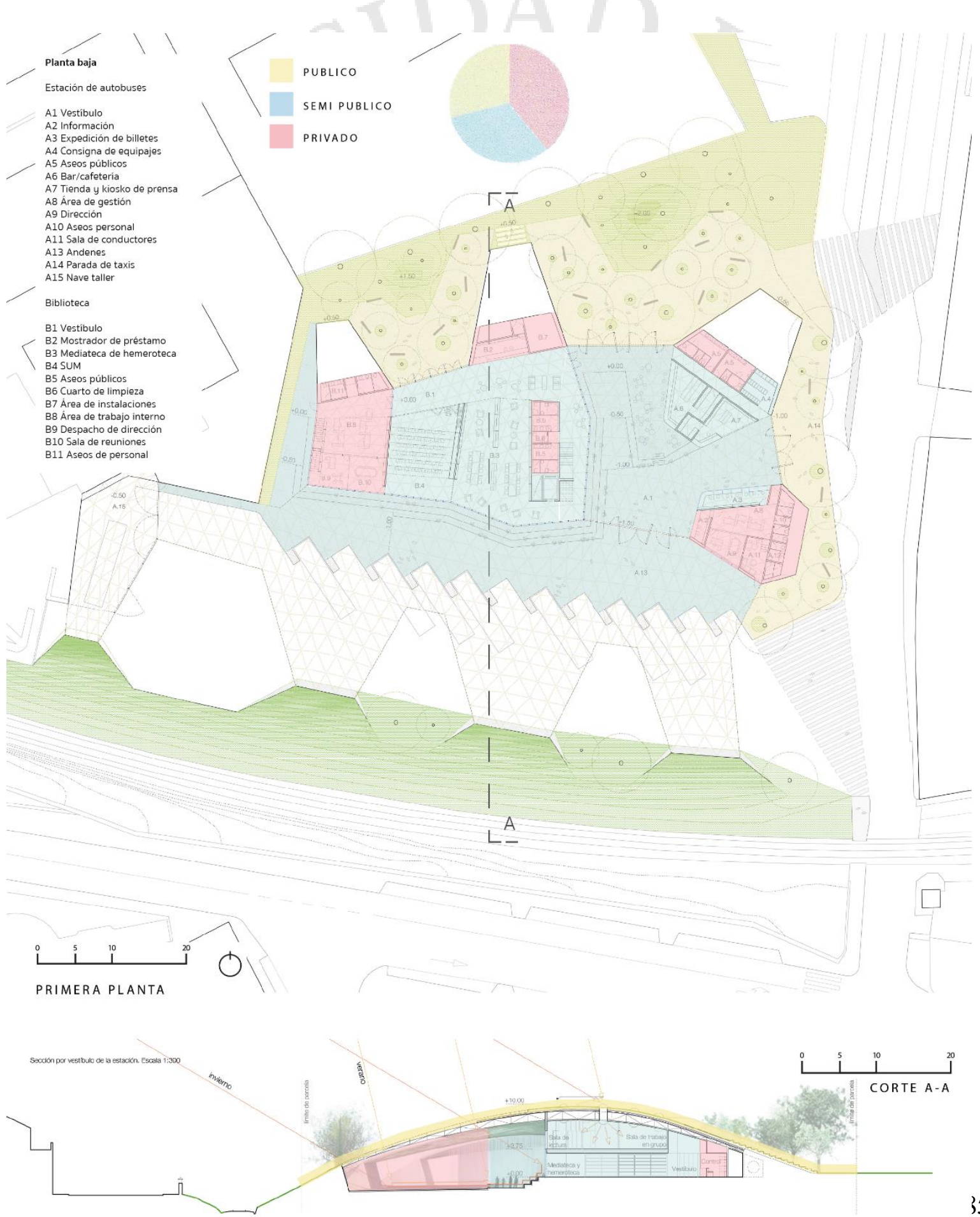


\section{Plano: Segunda planta}

Fuente: de realización propia, en base a planos de Exit Architects

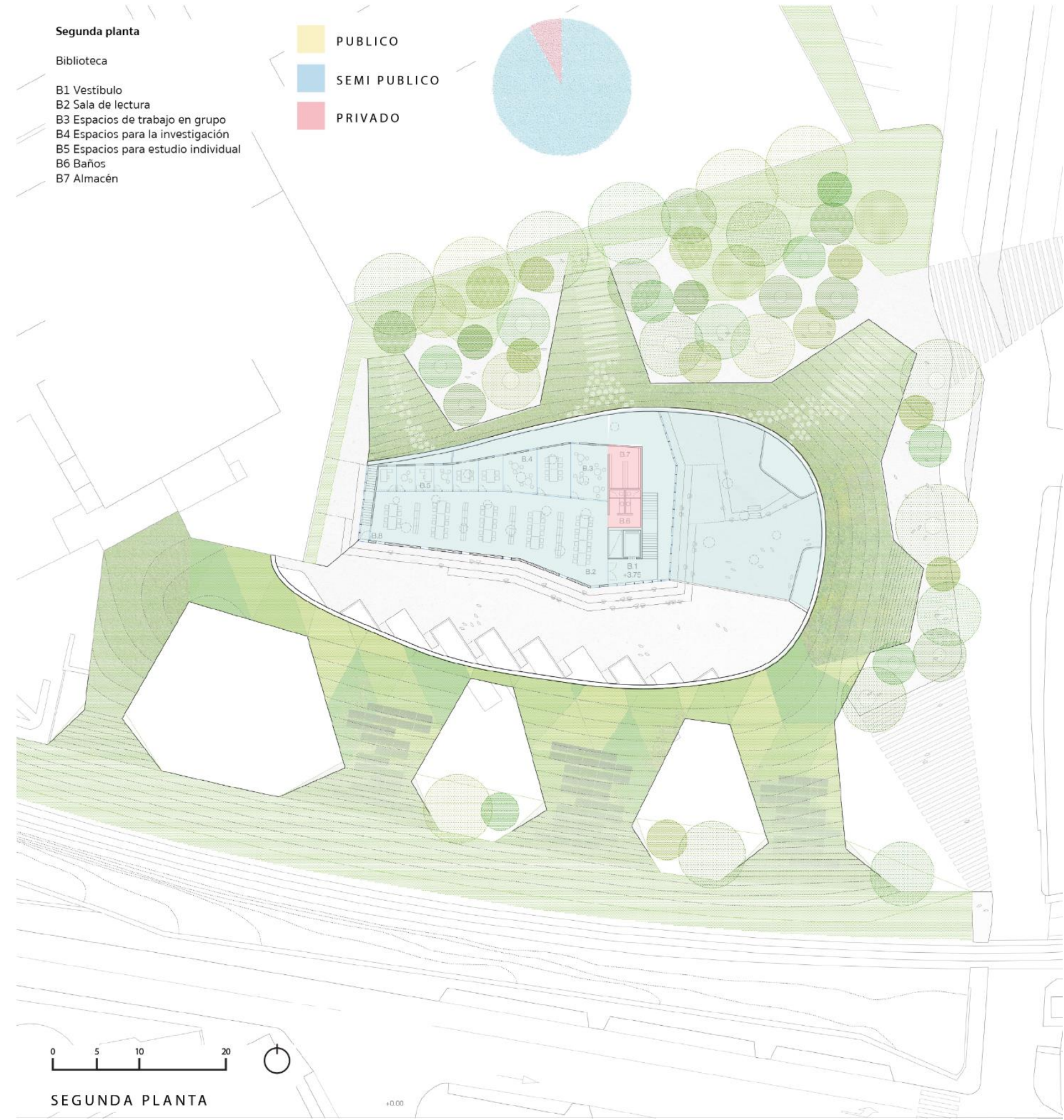

Los primeros límites de ingreso al edificio son permeables y conectan al usuario con espacios semi públicos, como halls de distribución o plazas interiores. Estos sirven como espacios intermedios del proyecto que articulan la relación entre los usuarios y los espacios cuyo acceso debe ser más controlado, pero que, sin embargo, siguen siendo 
públicos, como los andenes. Esto ayuda a controlar el acceso de peatones y usuarios en general, sin limitar su flujo y manteniendo el carácter público del edificio.

\subsubsection{Flujos del proyecto}

\section{Plano: primera planta}

Fuente: de realización propia, en base a planos de Exit Architects

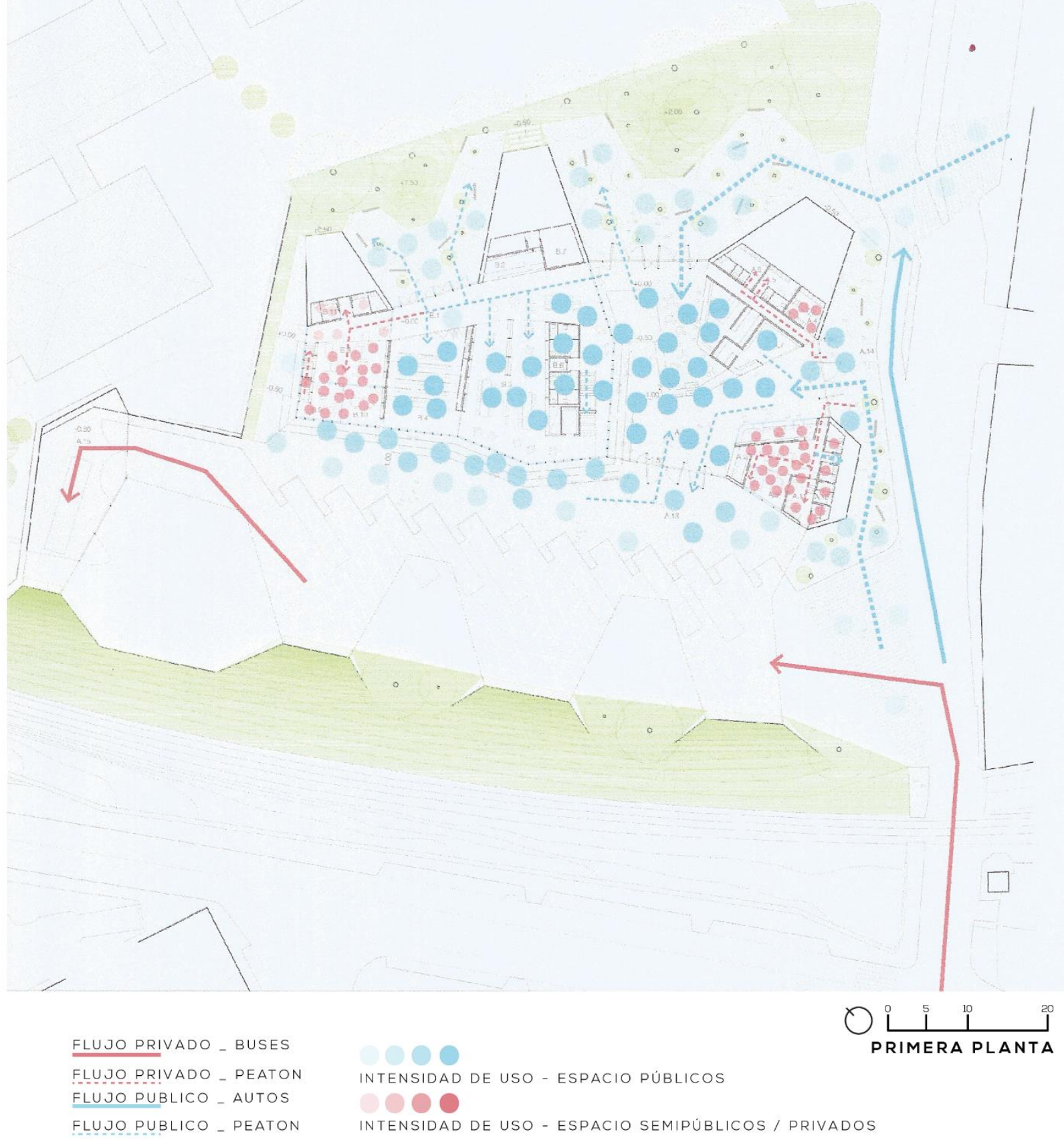




\section{Plano: Segunda planta}

Fuente: de realización propia, en base a planos de Exit Architects

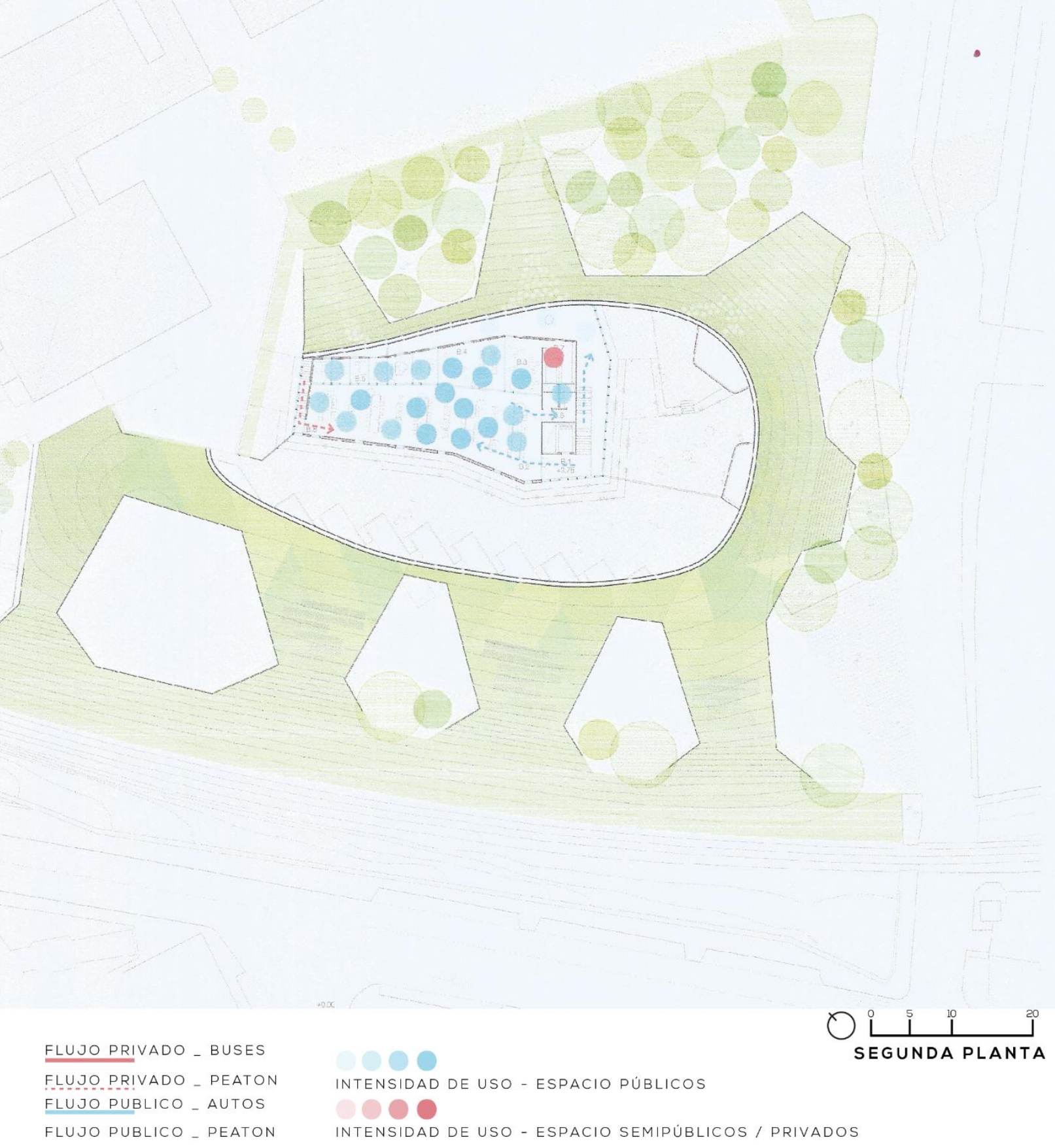




\section{Plano: cubierta}

Fuente: de realización propia, en base a planos de Exit Architects

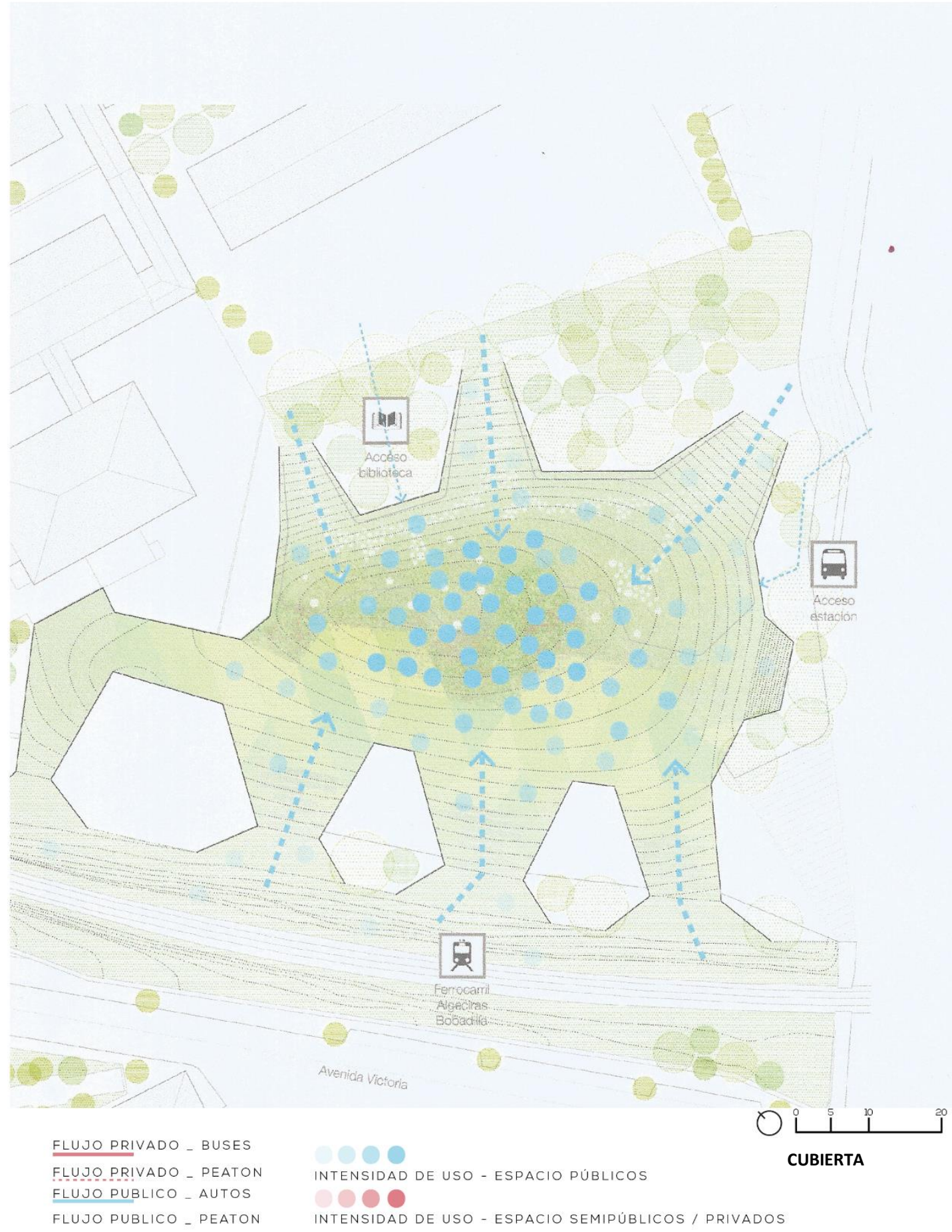




\subsubsection{Organigrama de espacios}

\section{Plano: organigrama primera planta}

Fuente: de realización propia, en base a planos de Exit Architects

PRIMERA PLANTA

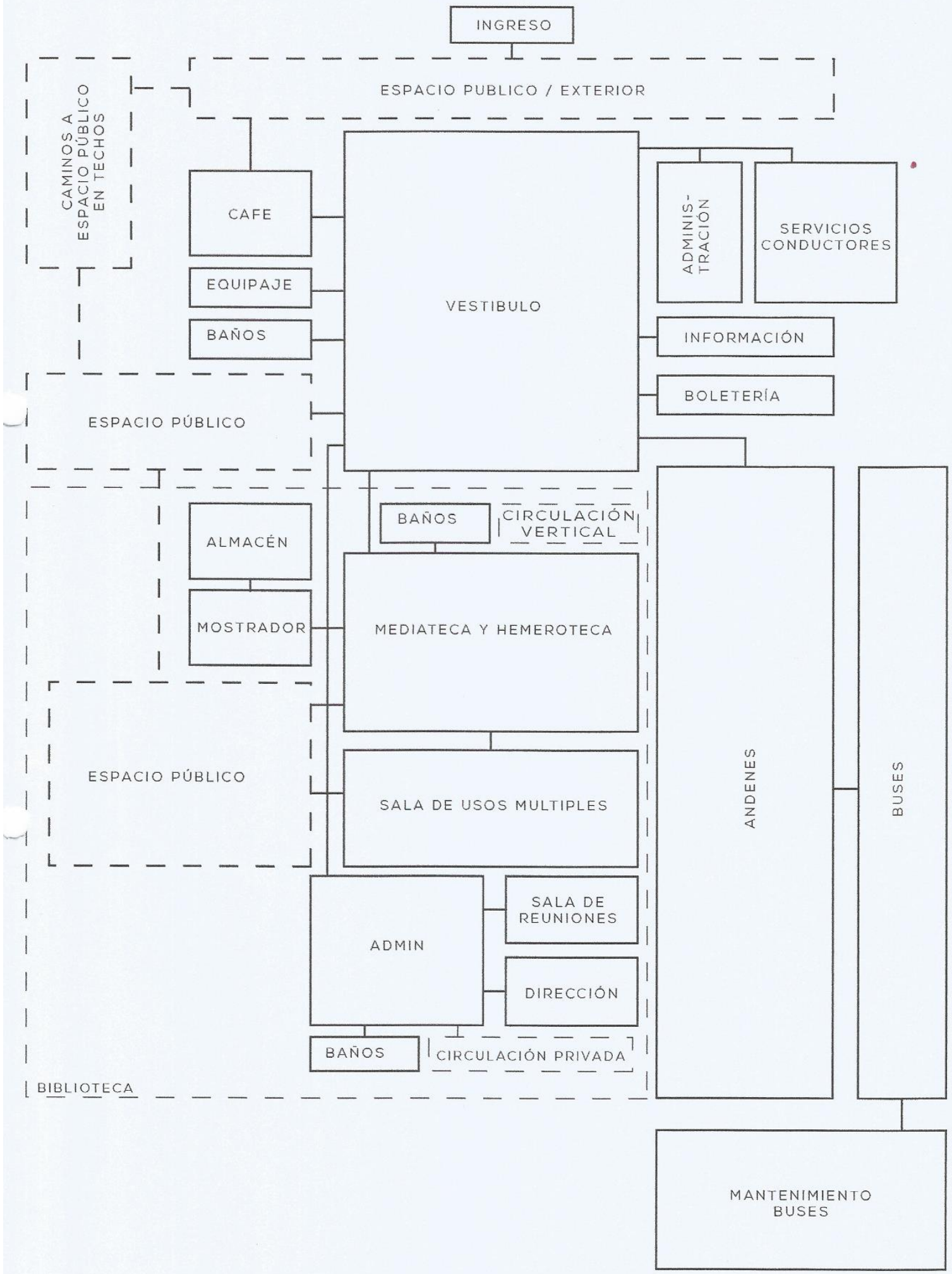




\section{Plano: organigrama segunda planta}

Fuente: de realización propia, en base a planos de Exit Architects

SEGUNDA PLANTA

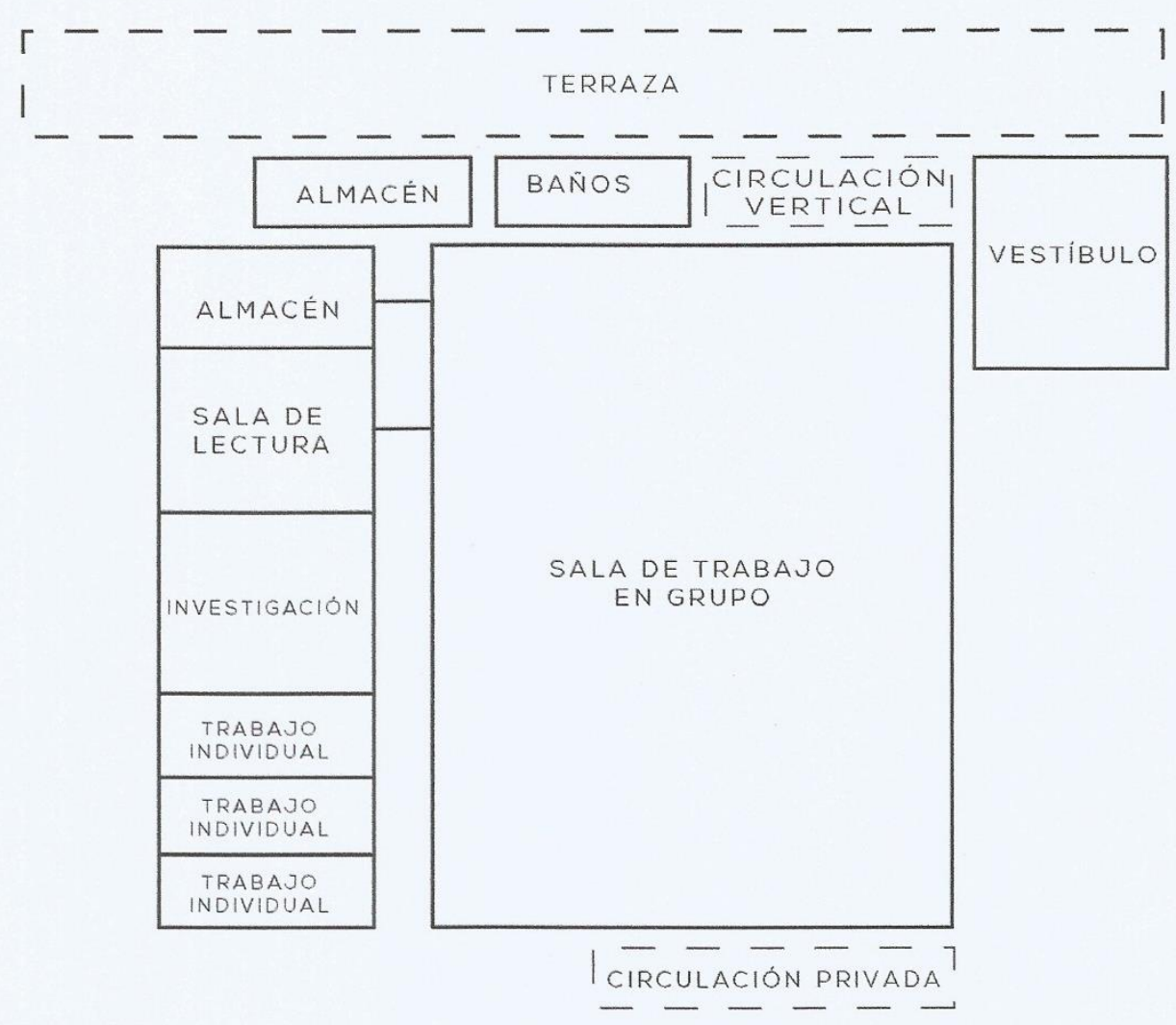




\subsubsection{Tecnología}

El proyecto se basa en la premisa de educación y transporte bajo un edificio de eficiencia energética. Es por eso que trabajan desde un inicio en asociación a Ecoproyecta $^{28}$, con quienes llegan a una propuesta que produce medidas de energía casi nulas. Sin embargo, las estrategias no sólo dependen de tecnología sino, también, de estrategias de orientación y paisajismo. (Ecoproyecta, 2013)

\subsubsection{Materiales}

El proyecto establece una serie de criterios medioambientales desde su inicio y, sus materiales de construcción son elegidos bajo esa premisa.

La cimentación y soleras de la propuesta son de hormigón con áridos reciclados; el acero para estructura, con un alto porcentaje de reciclado en su fabricación; madera con certificado de tala sostenible, de origen prioritariamente nacional; un sistema de toldos soportados por una estructura ligera para el confort térmico exterior.

La cubierta ajardinada tendría especies autóctonas y adaptadas para una baja demanda de agua para el riego. Finalmente, el volumen de relleno generado por el movimiento de tierras se utilizaría en dicha cubierta y los diseños de paisajismo del proyecto.

28 Ecoproyecta es una red colaborativa de profesionales relacionados con la construcción sostenible y el medio ambiente, y dedicada a la redacción de proyectos de arquitectura e ingeniería. Su actividad de diseño y búsqueda de soluciones está enfocada hacia la sostenibilidad aplicada a la construcción, los procesos productivos y la intervención en el medio, tanto urbano como rural. (Ecoproyecta) 


\subsubsection{Impacto ambiental}

\section{Medidas pasivas de ahorro energético}

- Espacio exterior ajardinado que permitirá regular la temperatura y humedad del entorno inmediato.

- Espacio atemperado, protegido por una cubierta.

- Sistemas bioclimáticos: ventilación natural y mecánica, sombreamiento y calentamiento puntual por radiación.

- Espacios climatizados, cerrados y tratados de manera convencional. Sin embargo, el uso de energía se ve amortiguado por el uso de otros sistemas que reducen la necesidad de acondicionar todos los ambientes.

- Cubierta vegetal, con el uso de corcho natural como aislante

- Aprovechamiento de la luz natural.

(Ecoproyecta, 2013)

\section{Medidas activas de ahorro energético}

Se propuso un sistema de gestión de alumbrado que permita apagar o prender las luces de ambientes según la luz natural en el mismo. Igualmente, se tomó en cuenta una gestión sostenible de agua que reutilice pluviales, aguas grises y ahorro en sanitarios.

El sistema de riego sería por goteo y de baja demanda, ya que las especies verdes propuestas son de bajo consumo de agua.

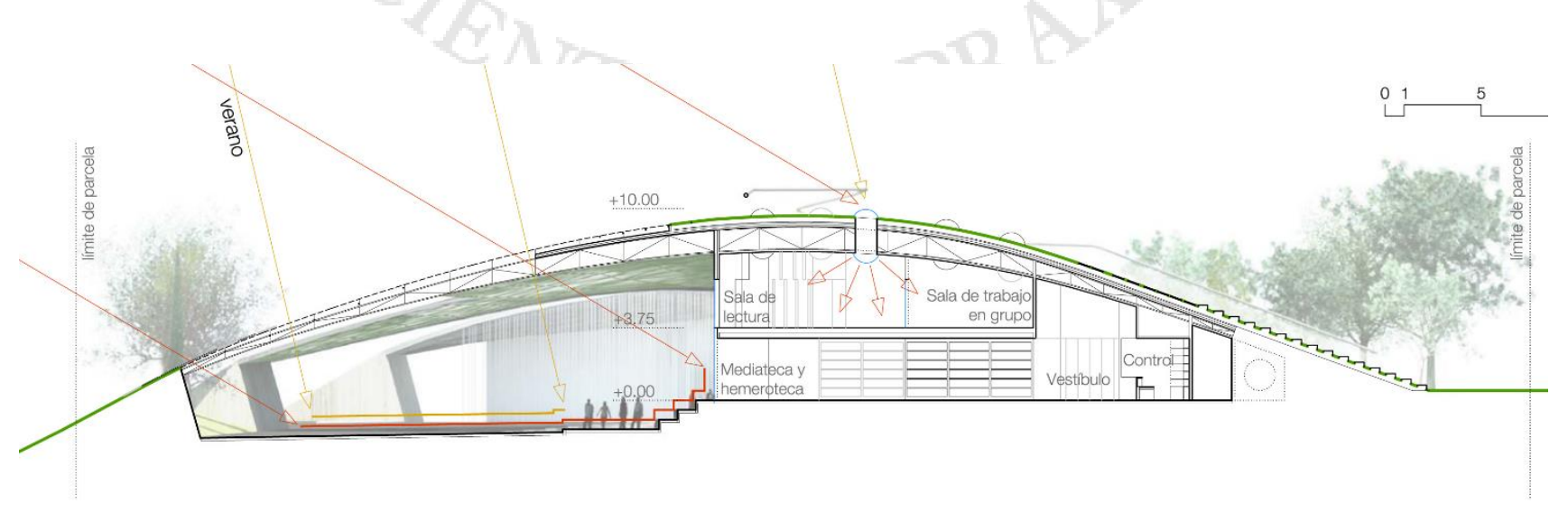




\section{Tablas: Consumos energéticos}

Fuente: Exit Architects, 2012

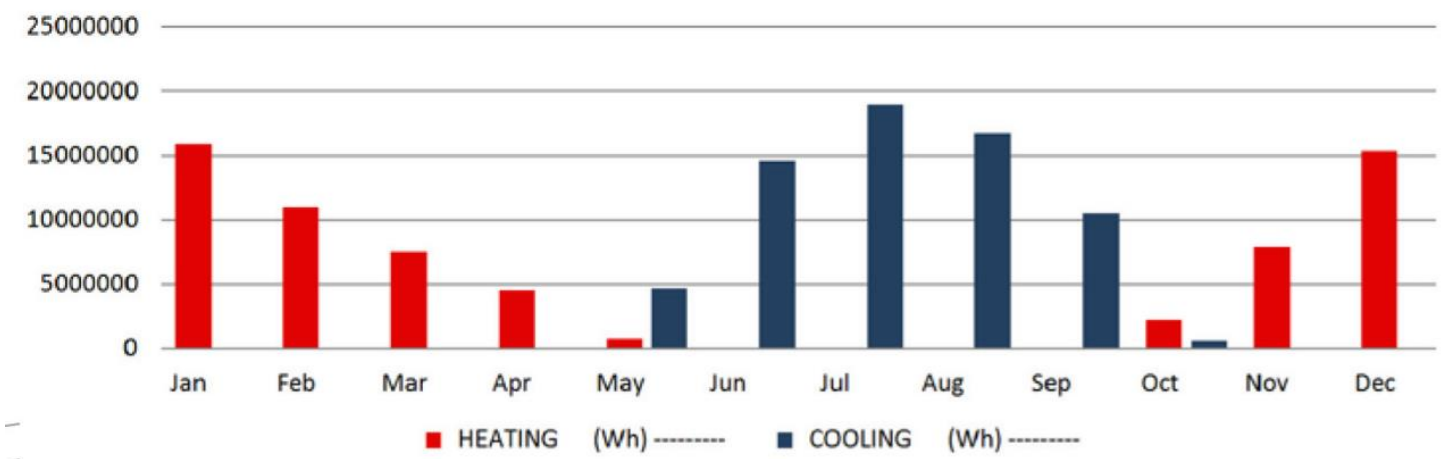

-Tabla de consumos energéticos mensuales de climatización en el supuesto de no utilización de estrategias bioclimáticas: cubierta vegetal, ventilación, uso de luz natural, creación de espacios atemperados, etc.

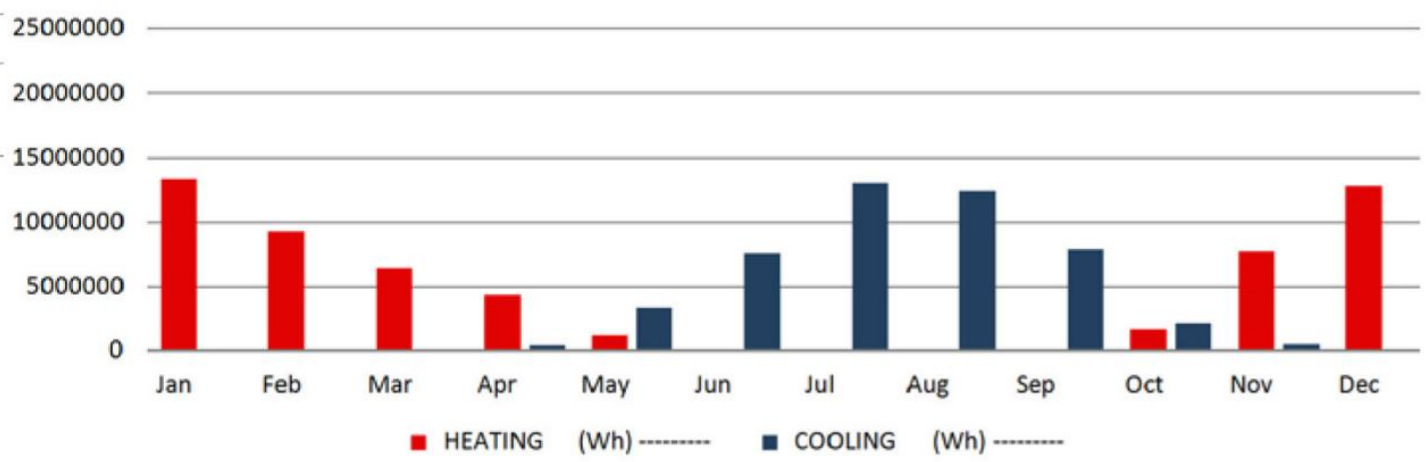

Tabla de consumos energéticos mensuales de la propuesta completa incluidas las medidas bioclimáticas antes descritas. Se puede apreciar un descenso general del consumo en torno al $25 \%$.

\section{Fachada principal del edificio y cubierta}

La cubierta ajardinada del edificio se propuso también para la fachada bajo la loma del tren. Ésta, un conjunto de toldos y los árboles del proyecto, dotarían a la calle y espacio público de confort térmico al aire libre.

El sistema de estructura es de tijerales metálicos que ayudan a dar la forma de loma natural y permiten la apertura de teatinas para iluminación natural cenital. 

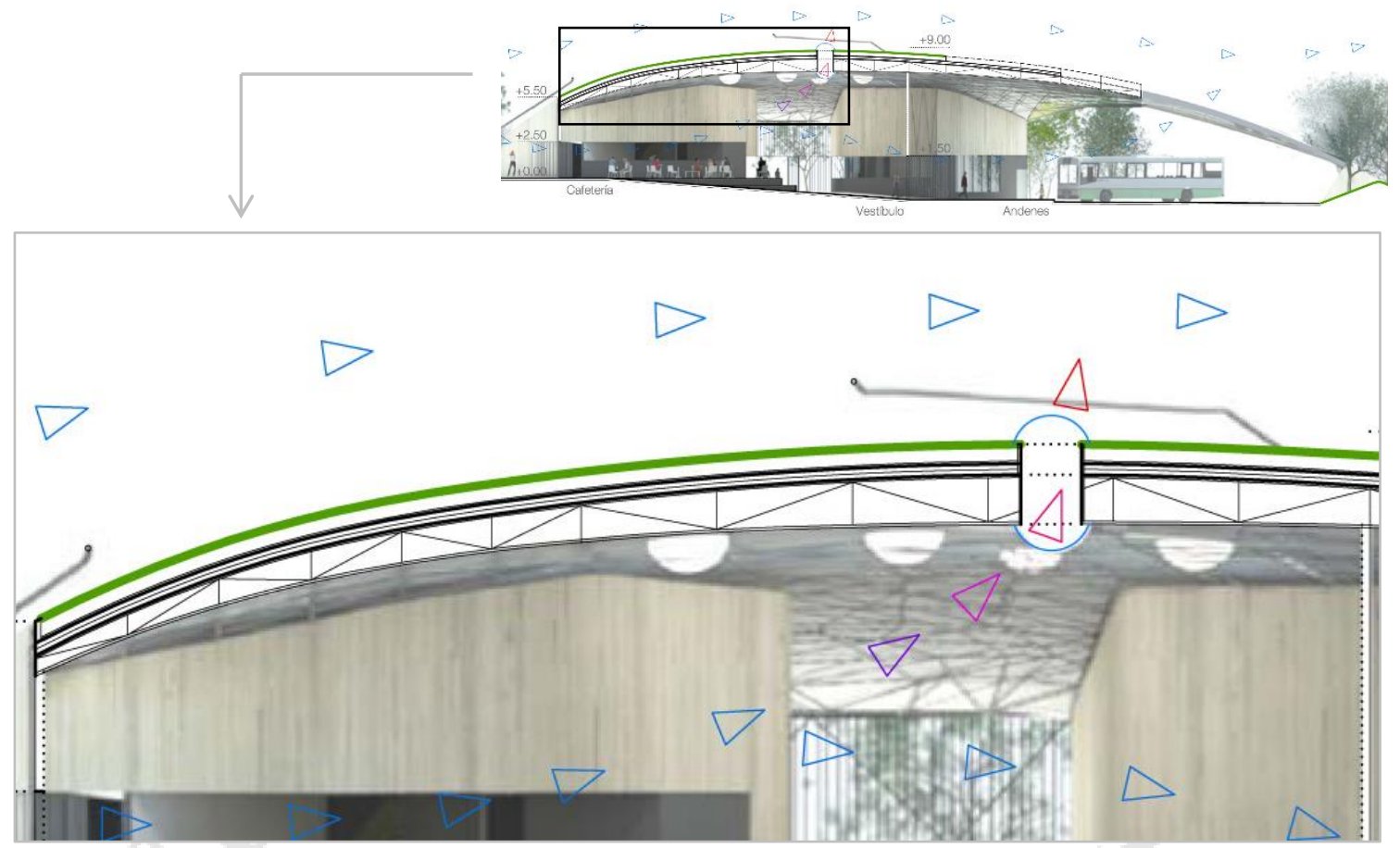

Fuente: (Exit Architects, 2012)

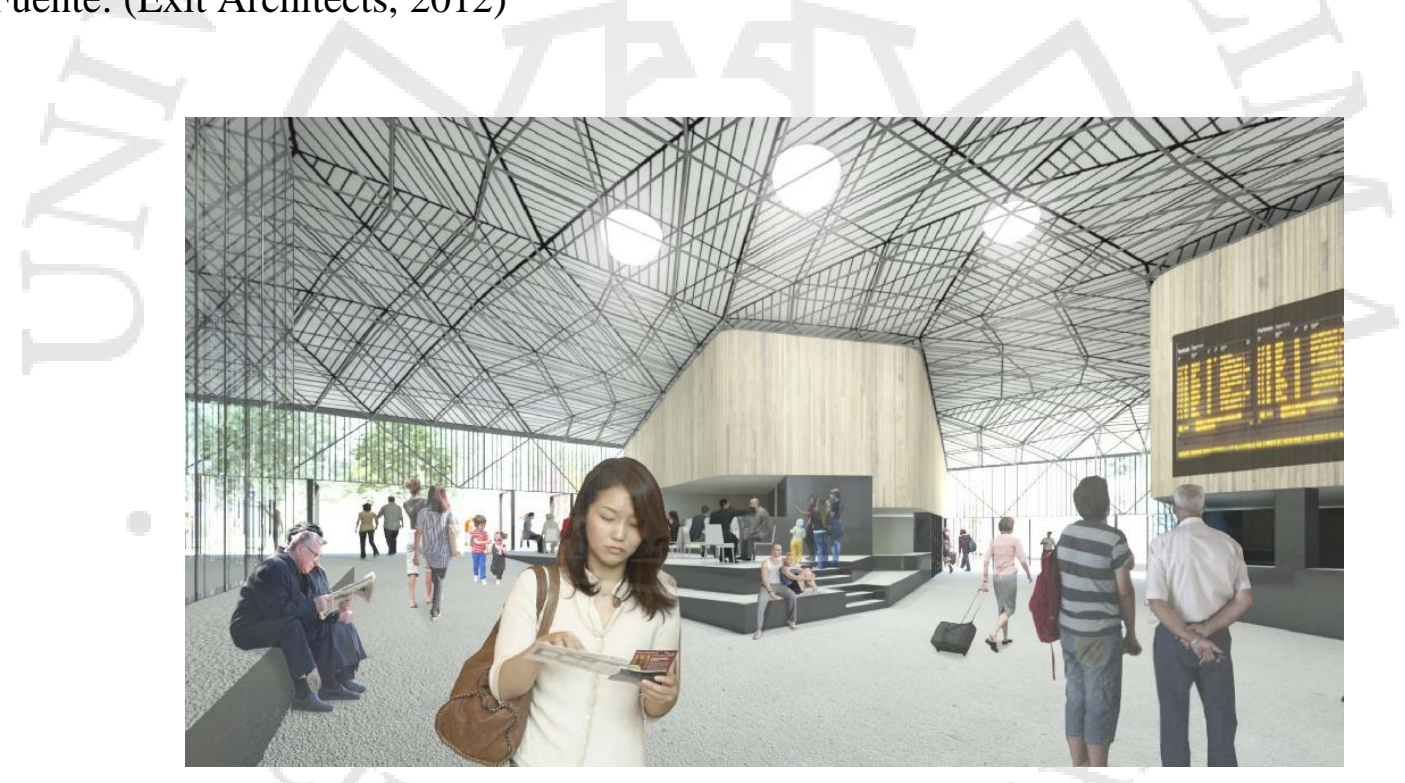

Fuente: (Exit Architects, 2012)

\section{Impacto social}

La propuesta de Exit Architects no fue construida, por lo cual, su impacto social no puede ser medido con precisión. Sin embargo, la Biblioteca Adolfo Suárez, construida por los arquitectos ganadores, se abrió en mayo de 2016 para dar servicio a más de 60000 personas, según la prensa de Málaga. 


\subsection{Centro Cultural Moravia}

\section{Historia}

\section{Información Técnica}

- Arquitecto: Rogelio Salmona

- Director de obra en Medellín: Marco Aurelio Montes Botero

- Equipo de diseño: Rogelio Salmona y María Elvira Madriñán

- Fecha de proyecto: 2006

- Fecha de finalización: 2008

- Cliente: Alcaldía De Medellín

- Ingeniero estructural: De Valdenebro Ingenieros Ltda.

- Áreas:

Área del Lote: 1.859 Mt. 2

Área Construida: $1.628 \mathrm{Mt} .2$

Áreas abiertas: $316 \mathrm{Mt} .2$

\section{Arquitecto del Proyecto: Rogelio Salmona}

El arquitecto Rogelio Salmona, nació en París (1929) pero creció en Bogotá,

Colombia. No terminó sus estudios de arquitectura en Universidad Nacional de Colombia, pero trabajó en Francia como colaborador en el Atelier de Le Corbusier durante una década. Fue candidato al premio Pritzker de arquitectura en el 2007. Ganó el premio Alvar Aalto en el 2003.

\subsubsection{Toma de partido}

El arquitecto entendió a Moravia como un sector de bajos recursos y una violenta historia, poblado por una comunidad conectada y solidaria.

Frente al encargo de diseñar un lugar que, "aglutine la vida comunitaria del barrio a través de actividades artísticas y creativas que incentivan la práctica de la música, el teatro, la danza, el cine y las artes plásticas” (web Rogelio), el arquitecto 
debió entender la identidad de Moravia, y al hacerlo descubrió que es un sector de bajos recursos y una historia violenta que está poblado por una comunidad conectada y solidaria.

Desde la arquitectura, se quiso "respetar [las] tradiciones urbanas, la diversidad existente, resaltar el paisaje y poner en evidencia el entorno" (terracota30); asimismo, se quiso reforzar el sentido comunitario y fomentar la participación social y la solidaridad. (arqa)

Se plantea estructurar los espacios sobre un eje central, que conecte los dos espacios más importantes del proyecto: el auditorio y el espacio público exterior. En el centro se proyecta un patio central, hundido para extender sus límites y conectarlo visualmente con los espacios más altos, y para controlar su privacidad desde el exterior. Por otro lado, se proponen superficies de ladrillo para acotar la escala de los espacios públicos, y se usan como una herramienta para interpretar las características de la arquitectura del lugar.

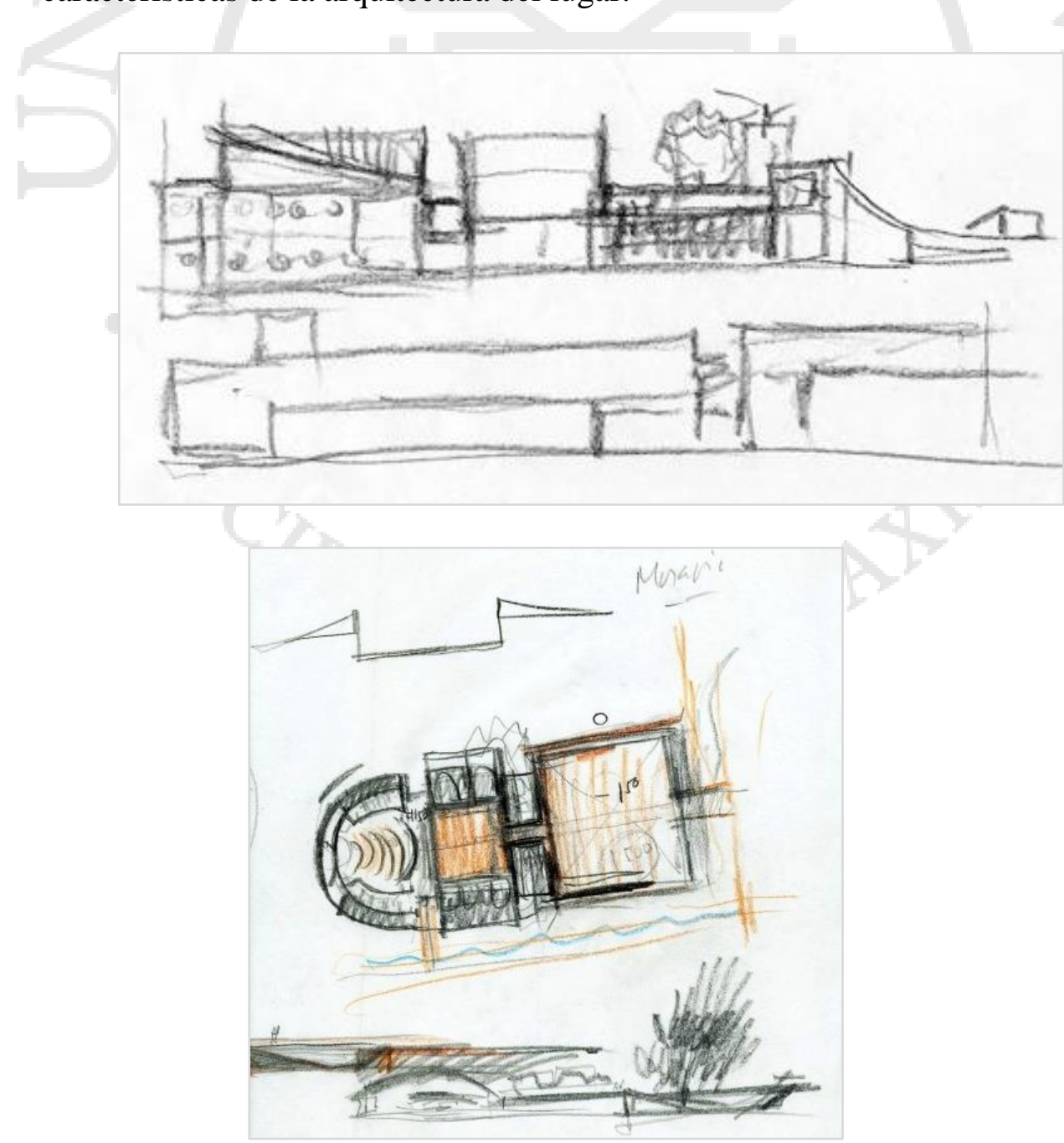




\subsubsection{Período histórico}

El Morro de Moravia es un sector de bajos recursos y violenta historia, este se comenzó a poblar a través de invasiones que iniciaron en 1990. Para mediados de la década de los 90, ya estaba medianamente poblado y para finales de la misma década e inicios de los 2000, el municipio de Medellín ya lo había identificado como un área con problemáticas sociales.

El plan de ordenamiento territorial propone en su plan parcial de intervención integral para Moravia invitar a la Universidad Nacional de Colombia a estudiar el sector y diagnosticar las condiciones físicas, medioambientales y sociales del barrio. Esto de desarrolla mediante asambleas barriales en las que se identificaron problemas y se propusieron planes de intervención.

Hacia el 2005, la secretaría de Cultura Ciudadana diseña una propuesta metodológica que indicó la necesidad de programas de capacitación artística y cultural como estrategia para lograr los cambios sociales necesarios. Así nace la idea de Casa de Cultura que luego evolucionaría a Centro de Desarrollo Cultural de Moravia.

Se invita al arquitecto Rogelio Salmona a visitar el lugar y desarrollar el diseño del edificio, que se comenzó a construir en el 2006, con la ayuda de los pobladores de la zona. En el 2008 se inaugura oficialmente el Centro de Desarrollo Cultura de Moravia. 


\subsubsection{Línea de tiempo}

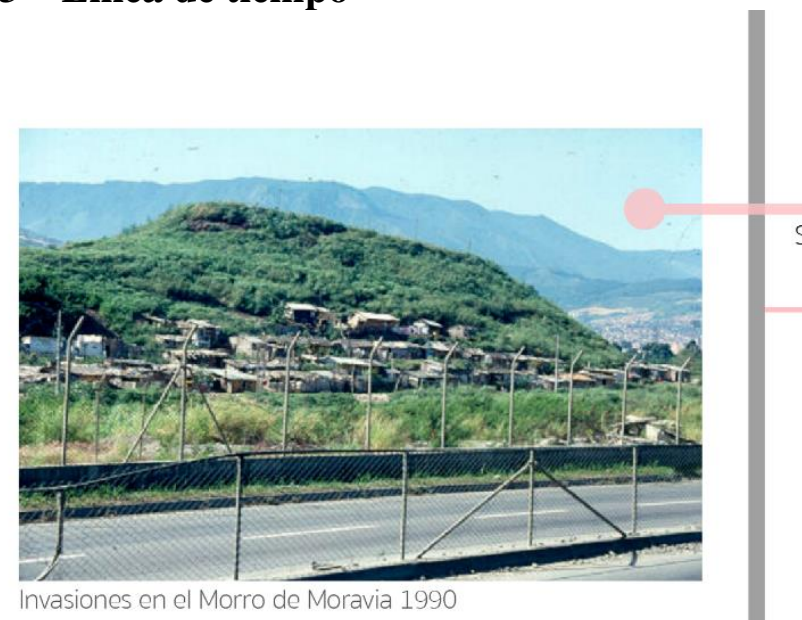

1990

Se inician invaciones en el Morro de Moravia

\section{$1999-2002$}

EI POT [Plan de Ordenamiento Territorial] propone la formulación de un Plan Parcial de Intervención Integral para Moravia

La Administración Municipal convoca la Universidad Nacional de Colombia para elaborar diagnósticos sobre las condiciones físicas, medioambientales y sociales del barrio.

Se llevan a cabo asamableas barriales para identificar problemas y proponer planes de intervención en conjunto con la comunidad.

\section{$2003-2005$}

Secretaría de Cultura Ciudadana [a través de programa Memoria y Patrimonio Cultural] diseña propuesta metodológica que incluyó: programas de capacitación artística y cultural.

Nace la idea de "Casa de Cultura" que evluciona a CDCM (Centro de Desarrollo Cultural de Moraiva)

Se acuerda, en conjunto con los pobladores, que el CDC se ubicará en la manzana 54, donde ubicará en la manzana 54 , donde se encontraba un botadero
municipal y se expropian y relocalizan en el mismo barrio las 150
viviendas que se encontraban ahí

Municipio de Medellín invita al arquitecto Rogelio Salmona a visitar el lugar y desarrollar el diseño del edificio.

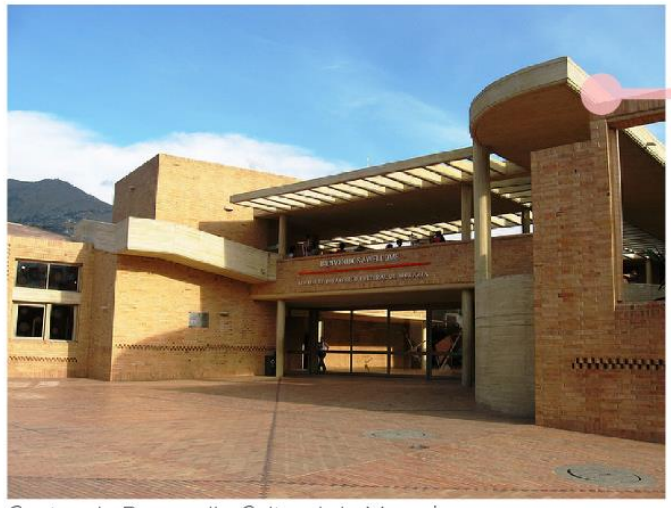

Centro de Desarrollo Cultural de Moravia

\section{8 - ACTUALIDAD}

El Centro de Desarrollo Cultural de Moravia, es parte de un sistema integrado de intervenciones urbanas del barrio. En el se realizan diversas activdades culturales que se alinean con el resto de intervenciones que se realizan en la zona.

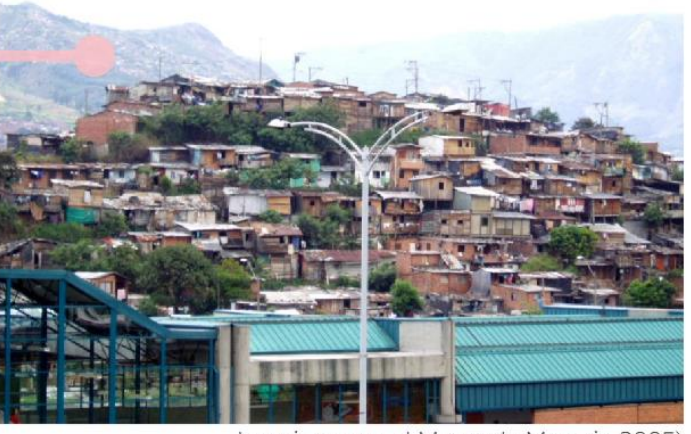

Invaciones en el Morro de Moravia 2005)

\section{$2006-2008$}

Inicia la construcción física de la obra con la ayuda de los pobladores de la zona.

La empresa Comfenalco Antioquia y la Administración Municipal se encanrgan de la gestión financiera para lograr la construccion del centro.

Comfenalco se encargar de la gestión del CDC.

Rogelio Salmona fallece y la obra queda encargada a su colega Marco Aurelio Montes botero

En el 2008 se inagura oficialmente el Centro de Desarrollo Cultural de Moravia en un homenaje a Rogelio Salmona.

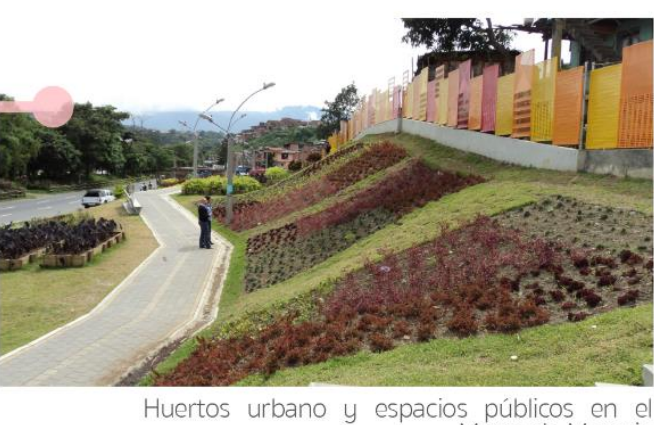

Morro de Mor e 


\subsubsection{Ubicación Y Relación Con El Entorno}

El Centro de Desarrollo Cultural Moravia (CDCM) se encuentra en el barrio de Moravia, en Aranjuez (Comuna 4) de la ciudad de Medellín en el departamento de Antioquia en Colombia. El proyecto está casi en el centro de la comuna y tiene una importante cercanía al Morro de Moravia y al Río de Medellín. (entorno 1 y entorno 2)

En la parte sur de la comuna 4, hay dos importantes estaciones de la línea uno del metro: La estación Universidad, ubicada frente a la Universidad de Antioquia; Y la estación Hospital, que está en la Fundación hospitalaria San Vicente De Paul. Asimismo, en la parte norte de la comuna, se encuentra la estación Caribe del mismo sistema de transporte. Desde la última, el acceso al CDCM es peatonal y breve. Por otro lado, se puede acceder al proyecto en auto particular por la Av. Carabobo, que conecta toda la comuna de norte a sur.

Dentro del barrio de Moravia, la ubicación del centro es estratégica. Se encuentra frente a la avenida más importante, en cercanía a dos importantes centros educativos del lugar y cerca al Morro de Moravia en el cual se encuentran los huertos urbanos que se han diseñado ahí como parte del proyecto de intervención urbana que implemento el CDCM. (Entorno 3 y 4 )

\section{Entorno inmediato}

En su entorno inmediato, al lado oeste se encuentra un jardín de niños de dos niveles; al este, la Av. Carabobo y una serie de edificios de uso mixto (vivienda y comercio) de entre cuatro y cinco niveles; en el norte pasa el una acequia que proviene del río Medellín; finalmente, al sur del CDCM hay edificios mixtos de cuatro y cinco niveles.

En su manzana, la arquitectura se centra hacia el interior, dejando veredas peatonales importantes en sus cuatro lados. Así mismo, hacia el norte, en una conexión visual con la acequia, se encuentra la fachada principal del proyecto en una importante plaza. 
En la cara que da a la Av. Carabobo, el edificio muestra su mayor altura debido a que se enfrenta a una calle amplia y a edificios igual de altos al otro lado; sin embargo, mantiene un volumen de menor altura para controlar la escala con la que se relaciona con esa calle y con los peatones de la misma. Por el otro lado, se enfrenta, en una calle más angosta y principalmente peatonal, con el jardín de niños y se contiene en su misma altura, generando una ligera tensión que fomenta la conexión y relación entre las actividades que se realizan en cada edificio.

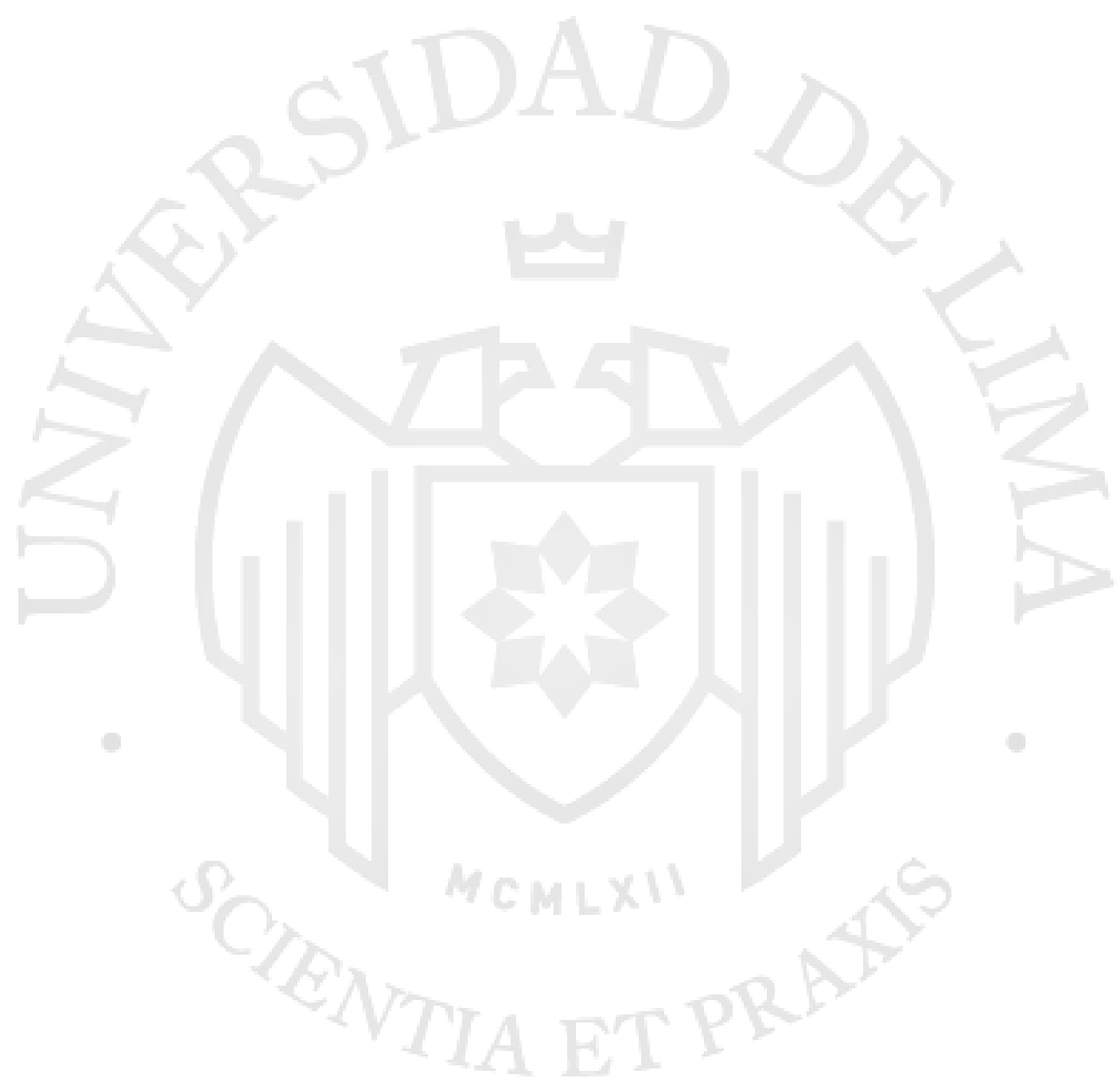




\section{Plano: Ubicación Macro}

Fuente: Realización propia, basado en planos de CDCM
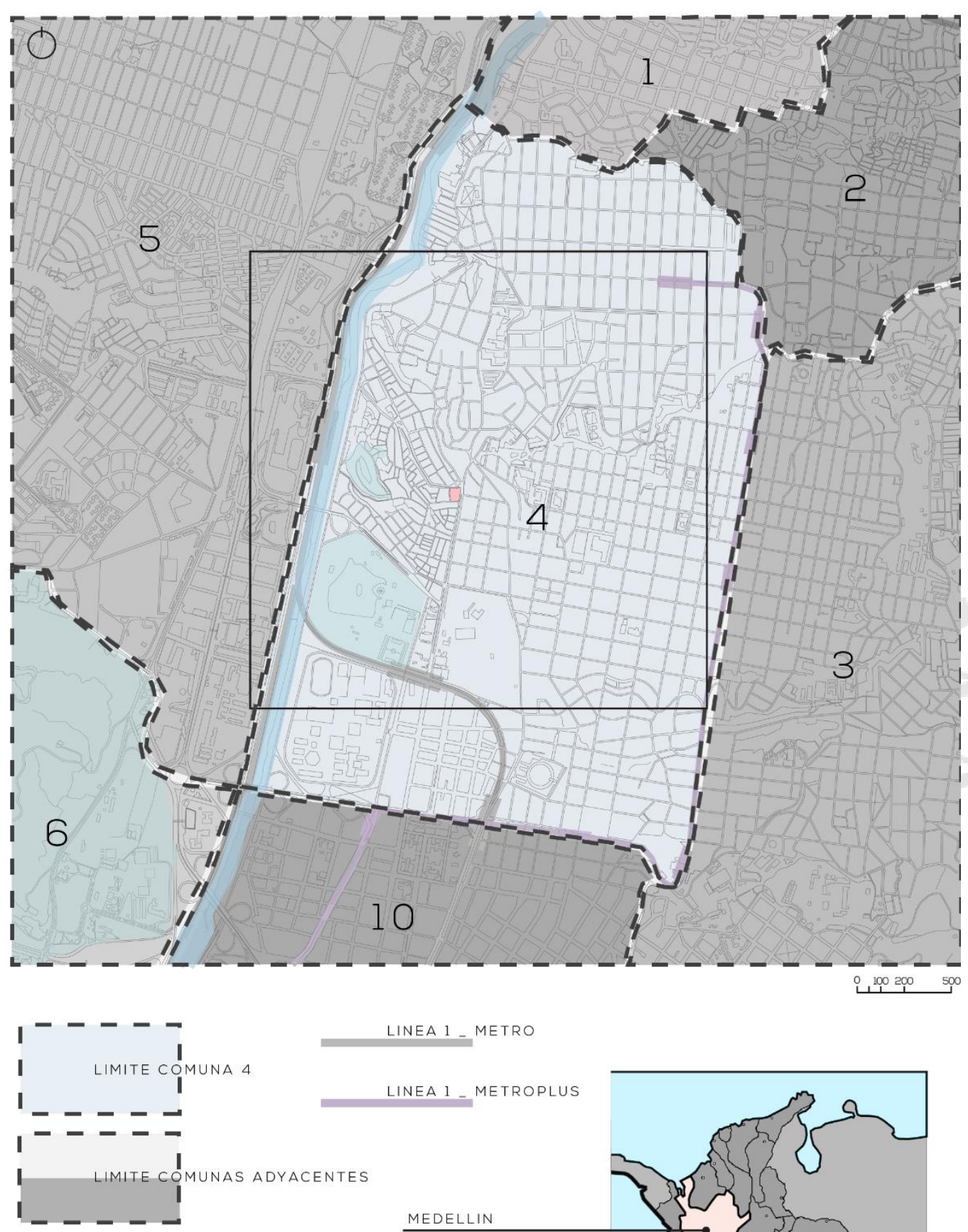

LINEA 1 - METRO

LINEA 1 _ METROPLUS

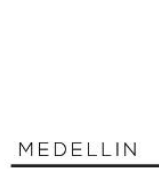




\section{Plano: Ubicación CDCM}

Fuente: Realización propia, basado en planos de CDCM
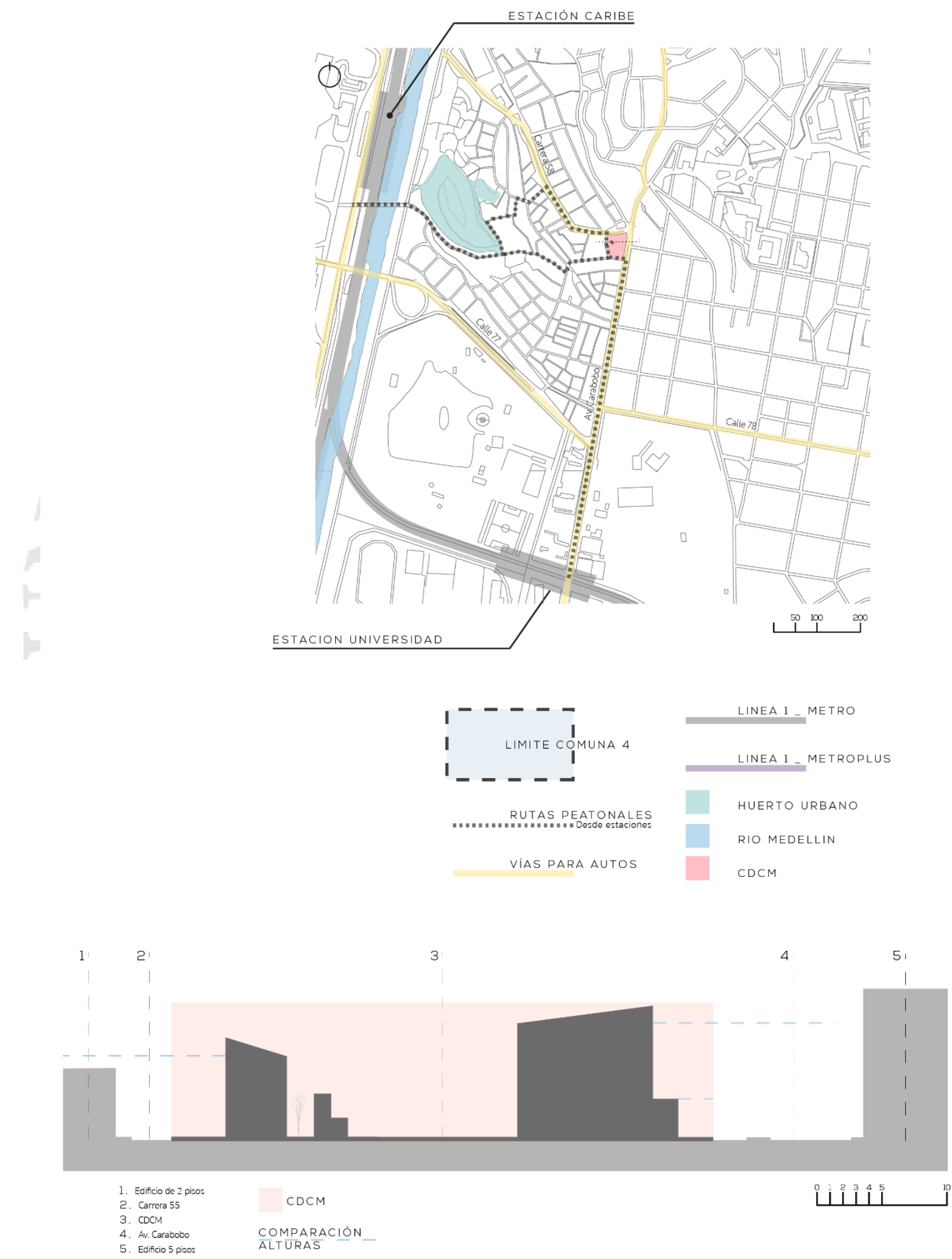


\section{Plano: Ubicación CDCM}

Fuente: Realización propia, basado en planos de CDCM

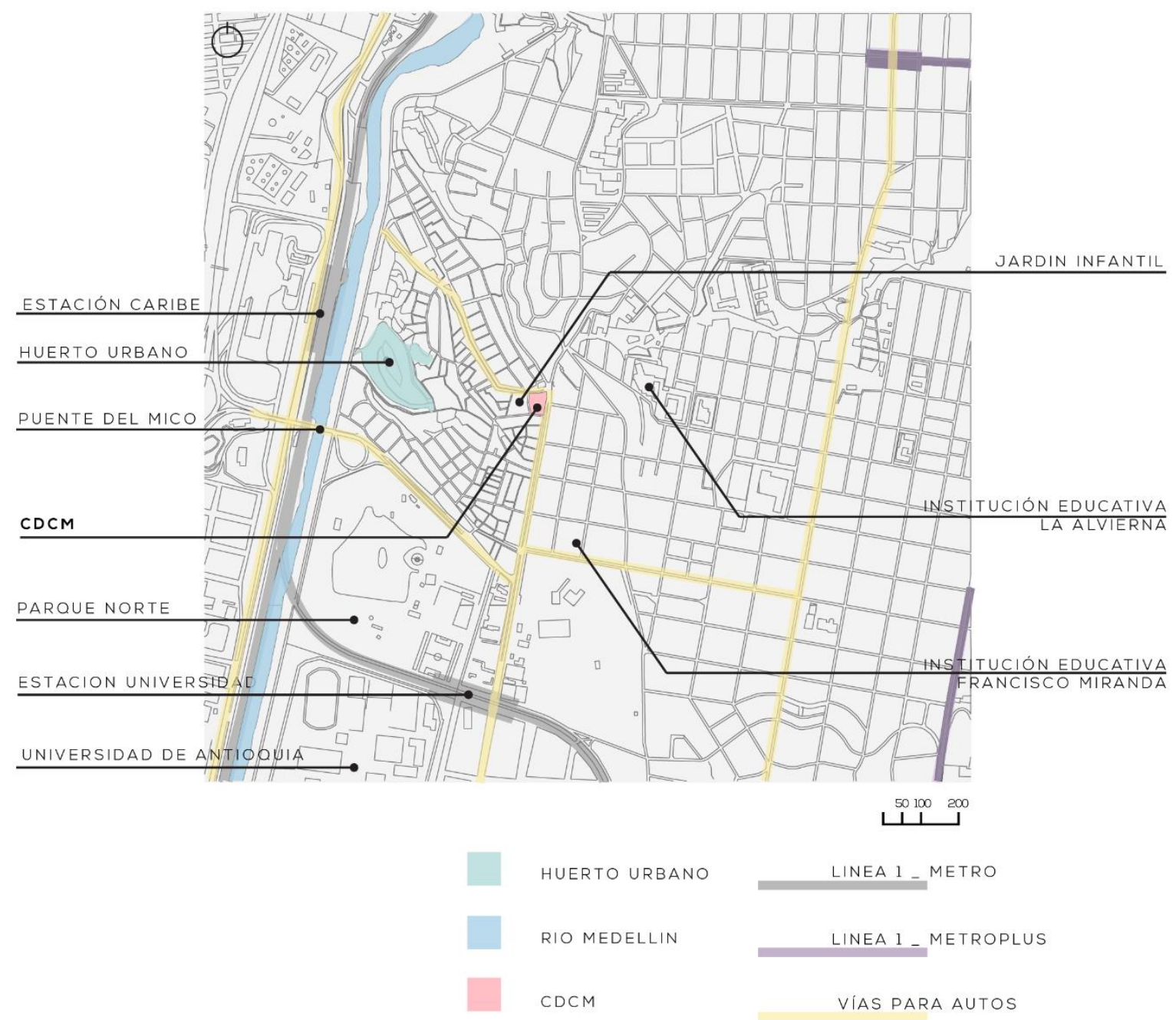




\subsubsection{Programa Y Relaciones Programáticas}

La composición general del proyecto se centra en torno al patio central. Todos los espacios de carácter semipúblico se conectan directamente con el patio. Asimismo, los espacios que requieren de mayor privacidad, o cuyas actividades están menos relacionadas con el espacio público y los usuarios en general, como la administración y el CEDEZO (Centro de desarrollo empresarial zonal), tienen accesos independientes del patio.

Por otro lado, el espacio más importante del proyecto: el auditorio, se encuentra al extremo opuesto del ingreso principal, de manera que obliga a los usuarios a atravesar el patio para llegar a el y así fomentar su uso.

Las conexiones verticales entre los espacios se dan de tres formas. Primero, a través de una rampa larga que mantiene una conexión visual con el patio central, y que funciona como una transición suave entre el espacio público y la calle y los espacio interiores del CDCM, como las aulas y la sala de exposiciones. El segundo tipo de conexión vertical, es una escalera que se encuentra en el punto intermedio entre el auditorio y las aulas, esta funciona como un eje de circulación vertical rápido que conecta los espacios semipúblicos. Finalmente, la tercera forma de conexión vertical es la más privada, se encuentra en dos espacios; primero, en las oficinas administrativas y el CEDEZO, como una circulación interna; y segundo, dentro del auditorio, como una forma de acceder al mezanine y a las salas de control de sistemas. Las circulaciones en la segunda planta, sirven como una herramienta de conexión visual y ayudan a darle al interior del edificio un carácter más permeable y público. 


\section{Cuadro: Cuadro de áreas del CDCM}

Fuente: de realización propia, a partir de planos

\begin{tabular}{|c|c|c|c|c|}
\hline AREAS & SUB AREAS & Superficie m2 & $\begin{array}{c}\text { AREA TOTAL } \\
\mathrm{m} 2 \\
\end{array}$ & $\%$ \\
\hline ESPACIO PUBLICO & $\begin{array}{l}\text { Espacio publico central } \\
\text { Espejo de agua } \\
\text { Espacios públicos } \\
\text { perimetrales } \\
\text { Jardín }\end{array}$ & $\begin{array}{r}164 \\
70 \\
640 \\
91\end{array}$ & 965 & 37.46 \\
\hline ADMINISTRACIÓN & $\begin{array}{l}\text { Oficinas } \\
\text { Cedazos }\end{array}$ & $\begin{array}{l}83 \\
46\end{array}$ & 129 & 5.01 \\
\hline AULAS LUDICAS & $\begin{array}{l}\text { Aula lúdica } \\
\text { Aula privada } \\
\text { Aula privada } \\
\text { Depósito }\end{array}$ & $\begin{array}{r}83 \\
9 \\
9 \\
6\end{array}$ & \multirow{3}{*}{323} & \multirow{3}{*}{12.54} \\
\hline $\begin{array}{c}\text { AULAS } \\
\text { CAPACITACIÓN }\end{array}$ & $\begin{array}{l}\text { Aula } 1 \\
\text { Aula } 2\end{array}$ & $\begin{array}{l}43 \\
43\end{array}$ & & \\
\hline AULAS & $\begin{array}{l}\text { Aula } 1 \\
\text { Aula } 2 \\
\text { Aula } 3 \\
\text { Aula } 4 \\
\text { Aula } 5 \\
\text { Aula } 6\end{array}$ & $\begin{array}{l}20 \\
20 \\
20 \\
20 \\
20 \\
30\end{array}$ & & \\
\hline Mezanine & Mezanine & 76 & 76 & 2.95 \\
\hline EXPOSICIONES & $\begin{array}{l}\text { Sala abierta principal } \\
\text { Sala secundaria } \\
\text { Sala cerrada }\end{array}$ & $\begin{array}{l}60 \\
40 \\
23\end{array}$ & 123 & 4.77 \\
\hline $\begin{array}{c}\text { SERVICIOS } \\
\text { COMPLEMENTARI } \\
\text { OS }\end{array}$ & $\begin{array}{l}\text { Cafetería } \\
\text { Cocina cafetería } \\
\text { Fotocopias } \\
\text { Baños } \\
\end{array}$ & $\begin{array}{l}35 \\
15 \\
23 \\
18 \\
\end{array}$ & 91 & 3.53 \\
\hline AUDITORIO & $\begin{array}{l}\text { Hall izquierdo } \\
\text { Hall derecho } \\
\text { Hall izquierdo - segundo } \\
\text { nivel } \\
\text { Hall derecho - segundo } \\
\text { nivel }\end{array}$ & $\begin{array}{l}14 \\
14 \\
14 \\
14\end{array}$ & 555 & 21.55 \\
\hline
\end{tabular}




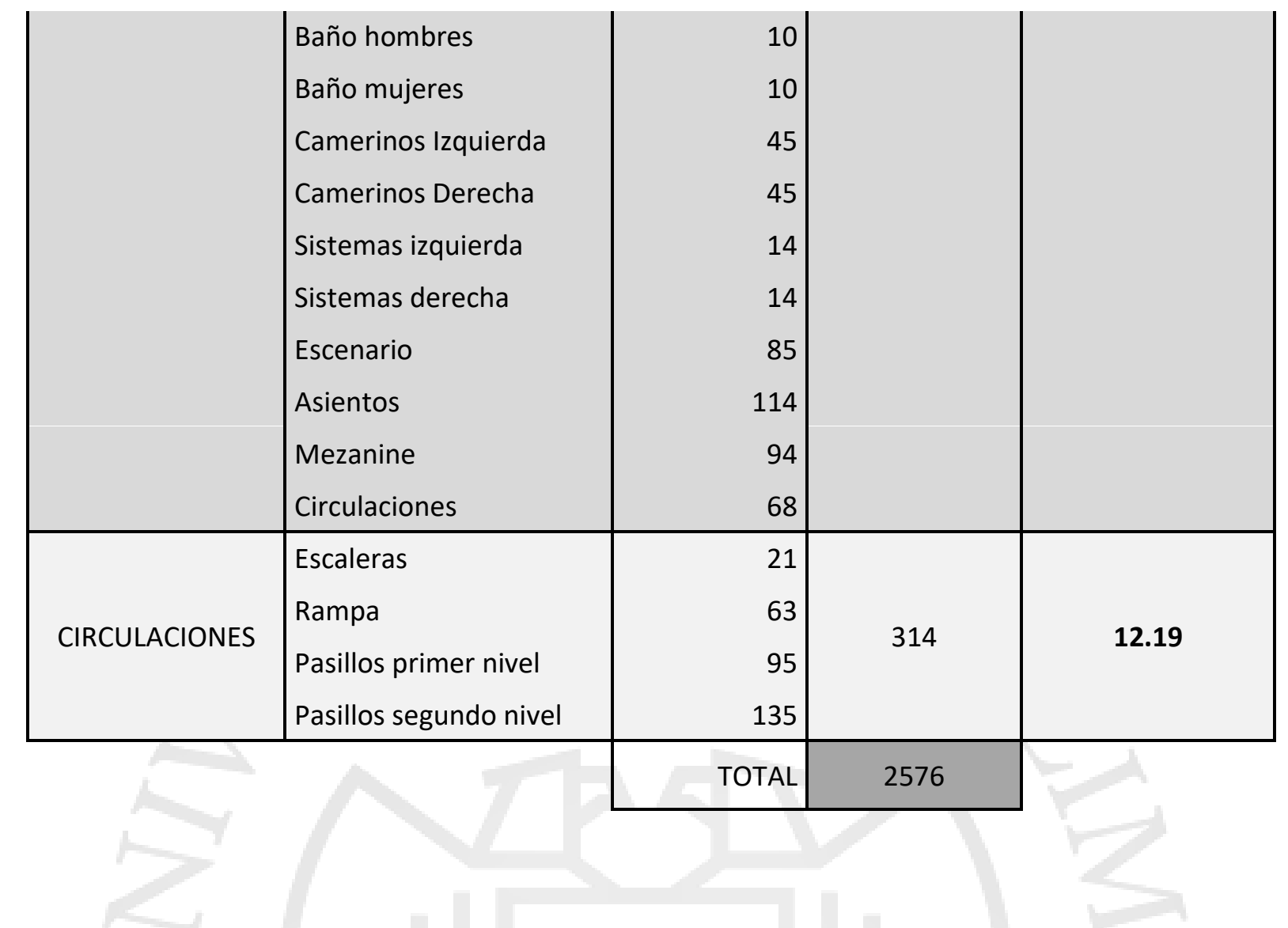

\subsubsection{Tipología Espacial}

En el diagrama 1, se puede ver que el primer gesto morfológico es el de separar los volúmenes hacia los extremos generando una plaza central, similar a la de la típica casa patio; así respondiendo a la idea de la casa del pueblo. También se genera agrupan los volúmenes hacia el medio del terreno, formando espacios abiertos en el perímetro.

Seguidamente, para lograr generar un segundo nivel de espacio publico, se genera una segunda apertura en el volumen de la izquierda, y se forma una plaza central secundaria que responde a los programas que se encuentran en los volúmenes que la contienen. Asimismo, se rompe la rigidez del perímetro ampliando el área de las veredas. (diagrama 2) 
Diagramas 1 y 2 (Fuente: de realización propia)
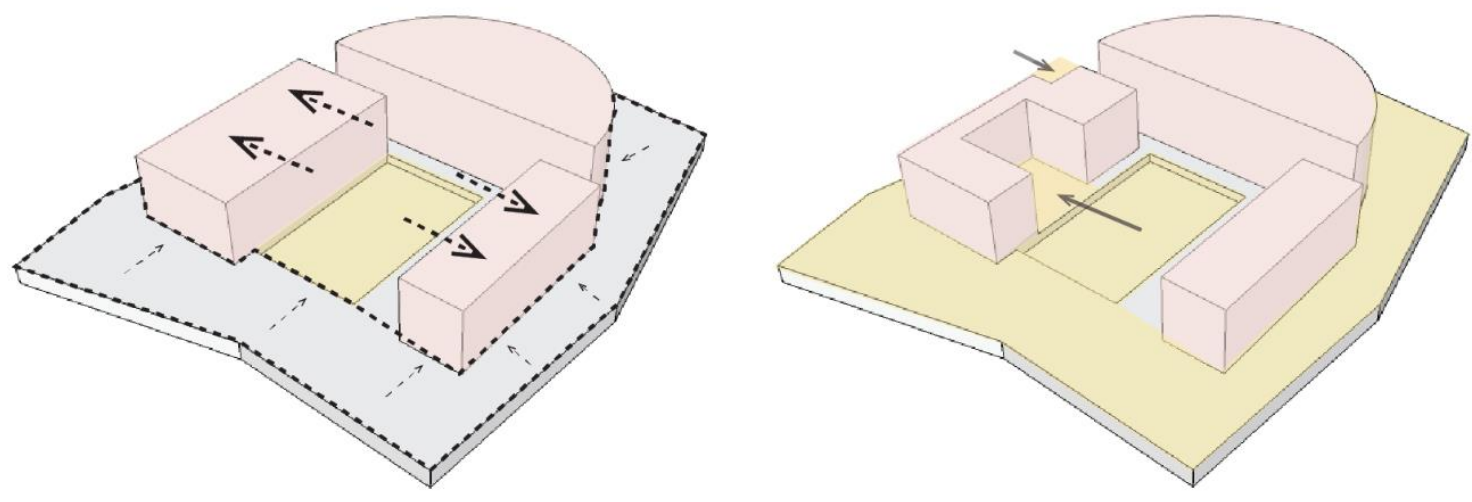

Se genera un quiebre en uno de los volúmenes que contienen el patio central para dirigir el flujo de los usuarios hacia el interior del proyecto. Además, se controlan las Alturas que dan hacia la calle para presentar hacia el exterior una escala mas accesible. (diagrama 3 )

Finalmente, la circulación se usa para controlar el espacio publico de la plaza central, así como, para generar conexiones visuales entre los dos niveles del proyecto. También se genera una terraza en el segundo nivel, mediante la cual la entrada al proyecto y a la plaza central, se convierte en un patio semi cubierto. (diagrama 4)

Diagramas 3 y 4 (Fuente: de realización propia)
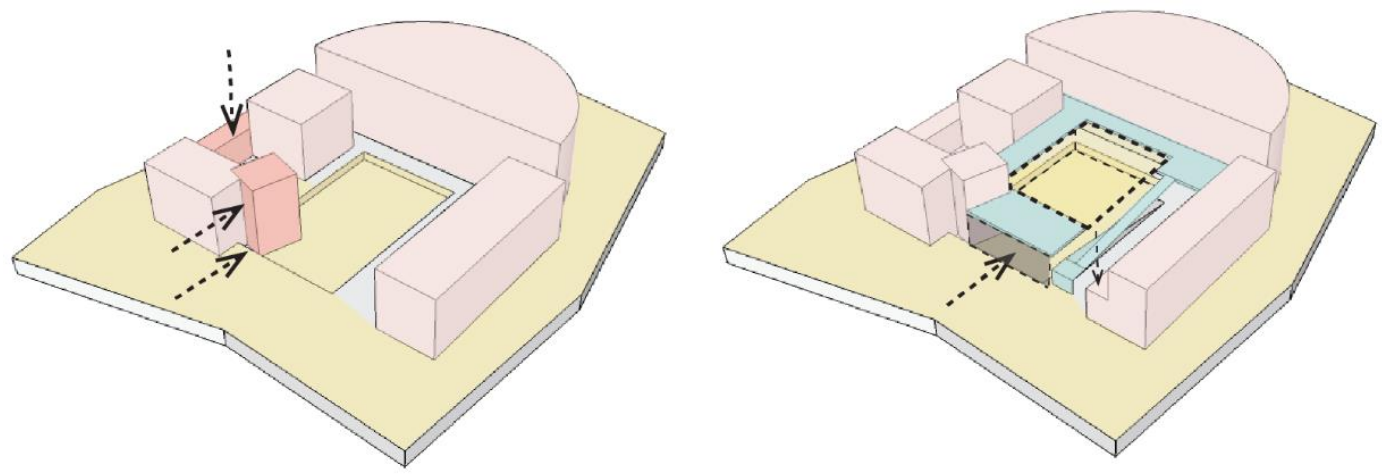


\subsubsection{Público-Privado}

Se entiende como público, aquello a lo que se tiene acceso sin pasar por ninguna barrera física. En la primera planta, se encuentra la mayor cantidad de espacios públicos y todos sirven como un nivel previo a un espacio más privado.

Los espacios semipúblicos, son aquellos que tienen cierto grado de privacidad, pues ya se encuentran contenidos dentro del edificio de cierta manera. Las amplias circulaciones de este proyecto funcionan como espacios semipúblicos, puesto que son accesibles a los usuarios en general, pero se encuentran dentro del edificio. Del mismo modo, las diversas aulas, la sala de exposición y el auditorio, a pesar de ser de uso público, se encuentran dentro de la arquitectura y bajo diferentes niveles de permeabilidad. La sala de exposiciones es visualmente impermeable, sin embargo, requiere que el usuario recorra la mayoría del edifico para llegar a ella. Contrariamente, las aulas del primer nivel, son altamente accesibles, pero su nivel de permeabilidad les da cierto grado de privacidad.

Finalmente, los espacios privados son aquellos que no son de uso público, entre ellos se encuentran las oficinas administrativas. Asimismo, estos espacios tienen ingreso separados, esto facilita su accesibilidad, pero formaliza su independencia del resto del programa del edifico.

Debido a que la mayoría de espacios en la primera planta son públicos, es en ella en la que se encuentra la mayor cantidad de flujo de usuarios. La plaza central, es el espacio de mayor confluencia de personas, no solo por su amplitud, sino por su ubicación. El auditorio, en ocasiones puede estar ocupado por muchos usuarios, sin embargo su uso no es tan típico como el de la plaza.

En las circulaciones del segundo nivel y la rampa, también se puede dar una considerable afluencia de usuarios debido a su fluida relación con la calle.

Por otro lado, los espacio semipúblicos interiores, como las aulas, la sala de exposición y el mezanine, también tienen un flujo de usuarios fluido y que varía según su uso. 


\section{Plano: primera planta}

Fuente: Realización propia, basado en planos de CDCM

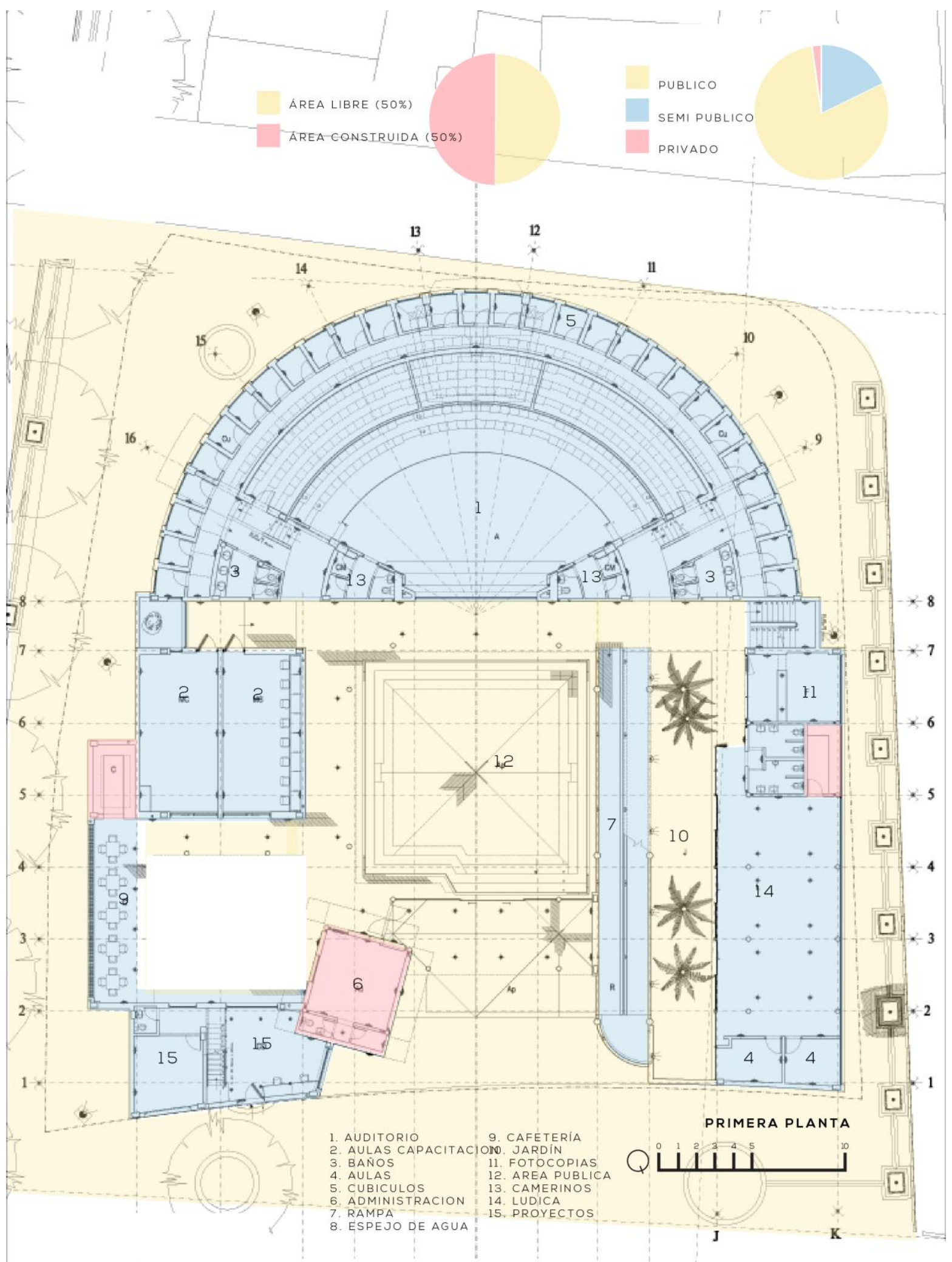




\section{Plano: segunda planta}

Fuente: Realización propia, basado en planos de CDCM

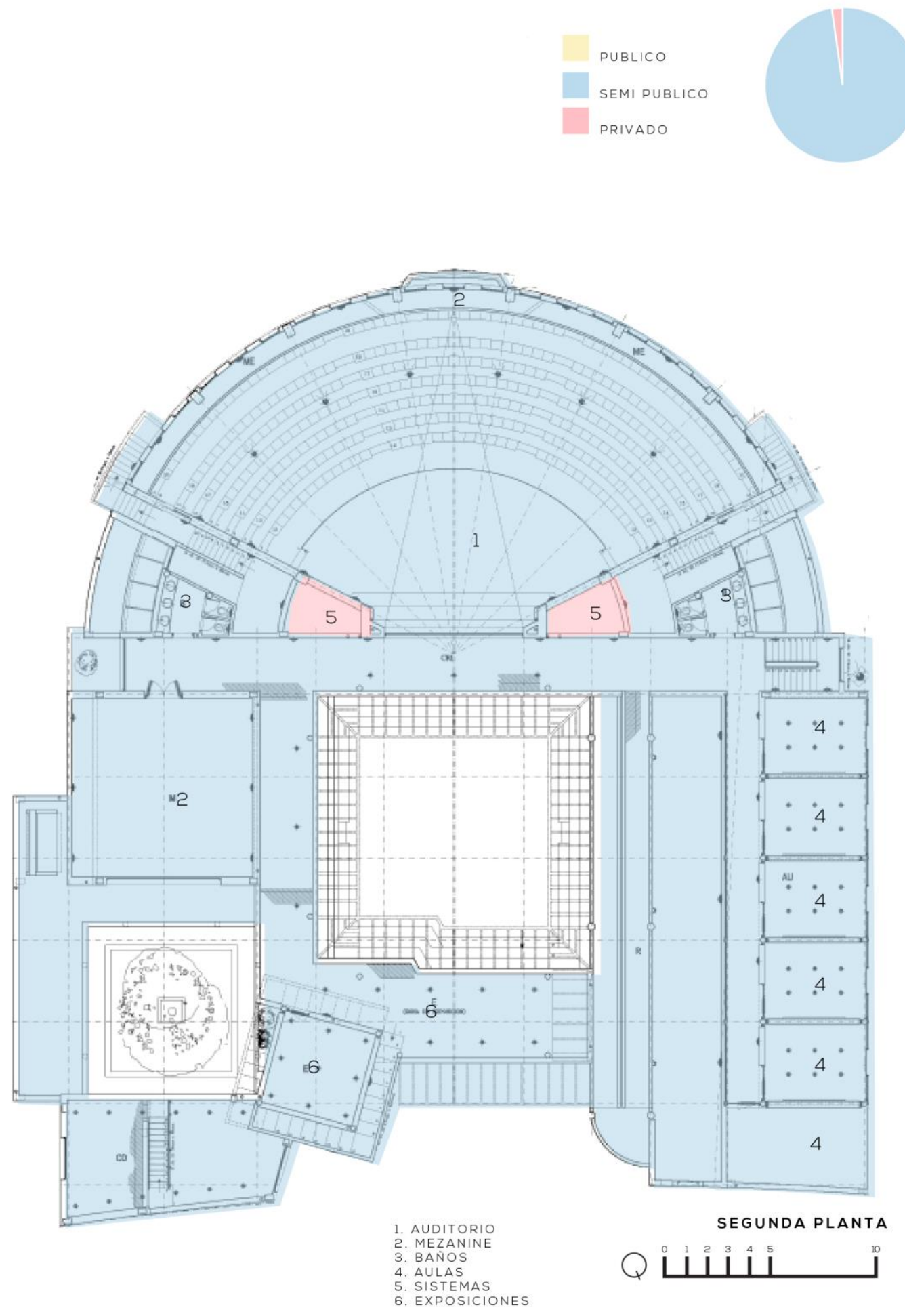




\subsubsection{Flujos del proyecto}

\section{Plano: primera planta}

Fuente: Realización propia, basado en planos de CDCM

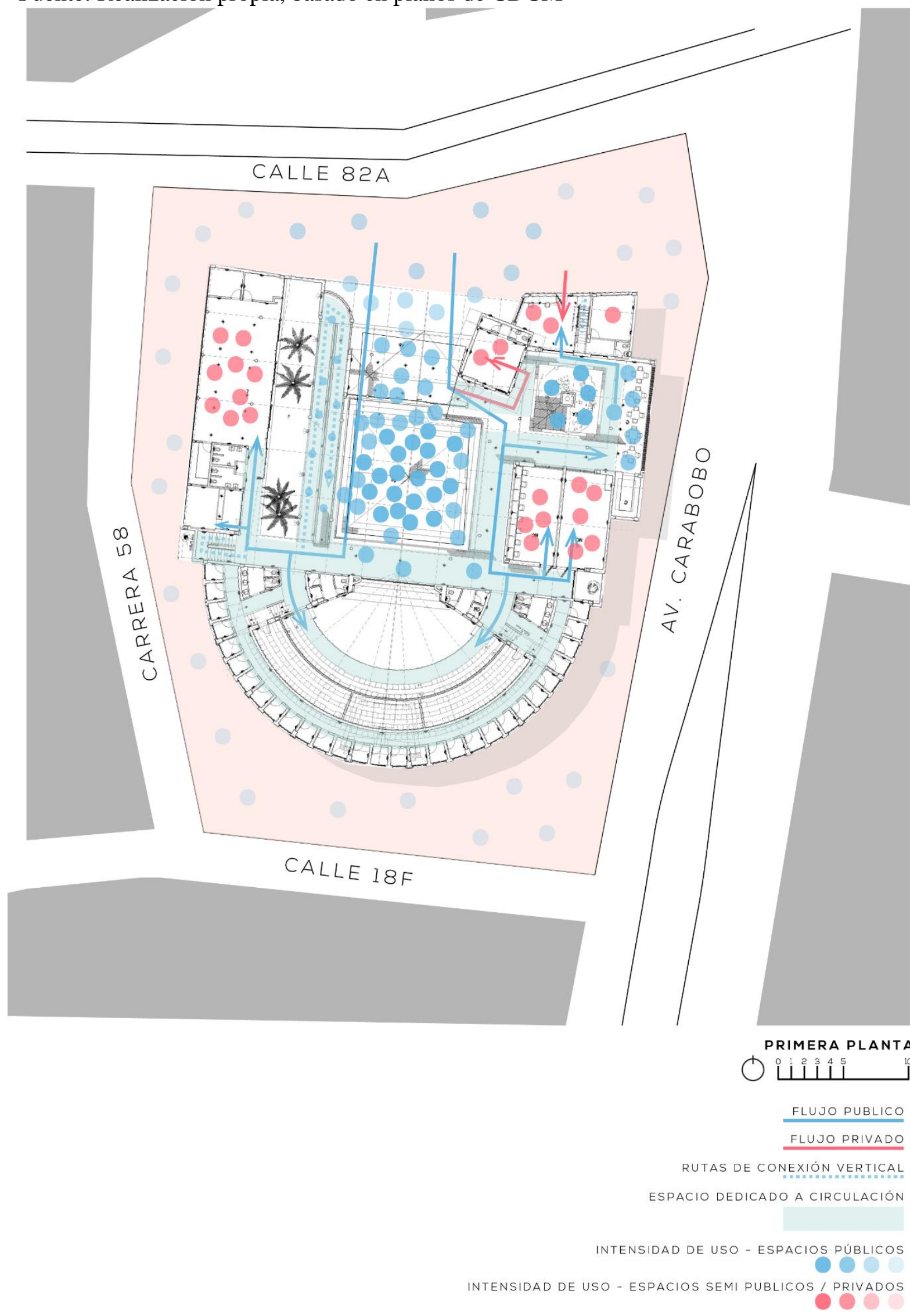




\section{Plano: segunda planta}

Fuente: Realización propia, basado en planos de CDCM
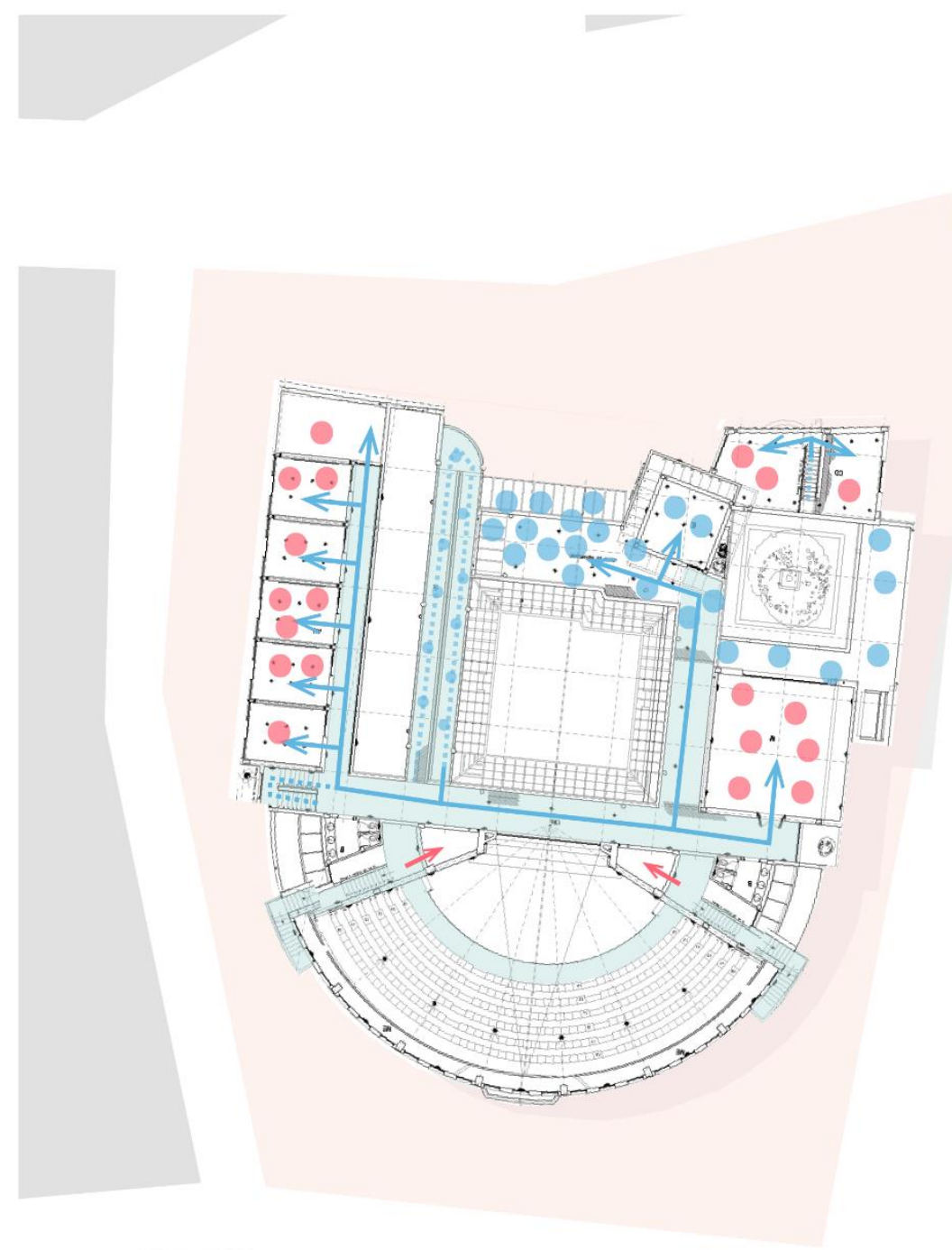


\subsubsection{Relaciones programáticas}
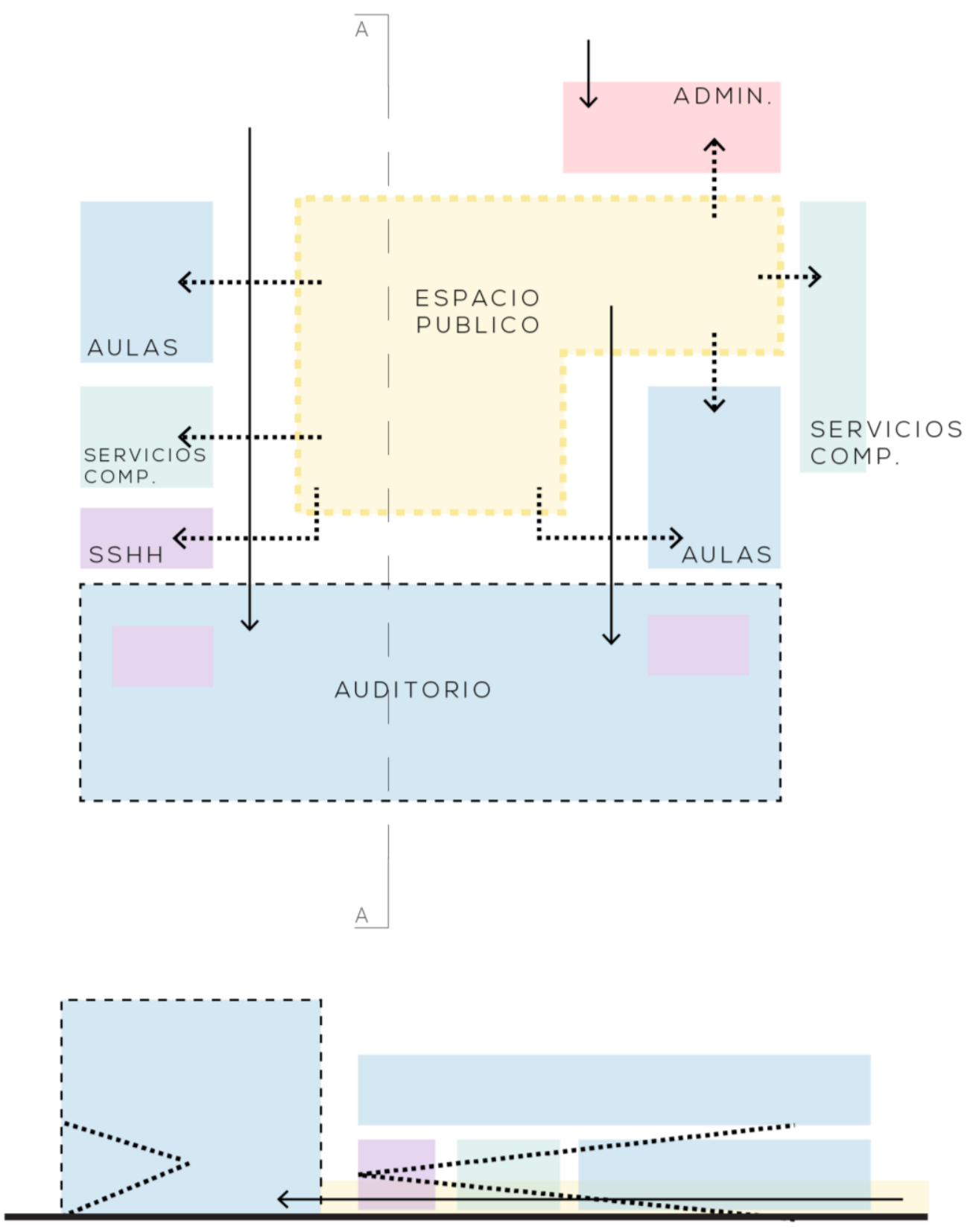

CORTE A-A 


\subsubsection{Organigrama de espacios}
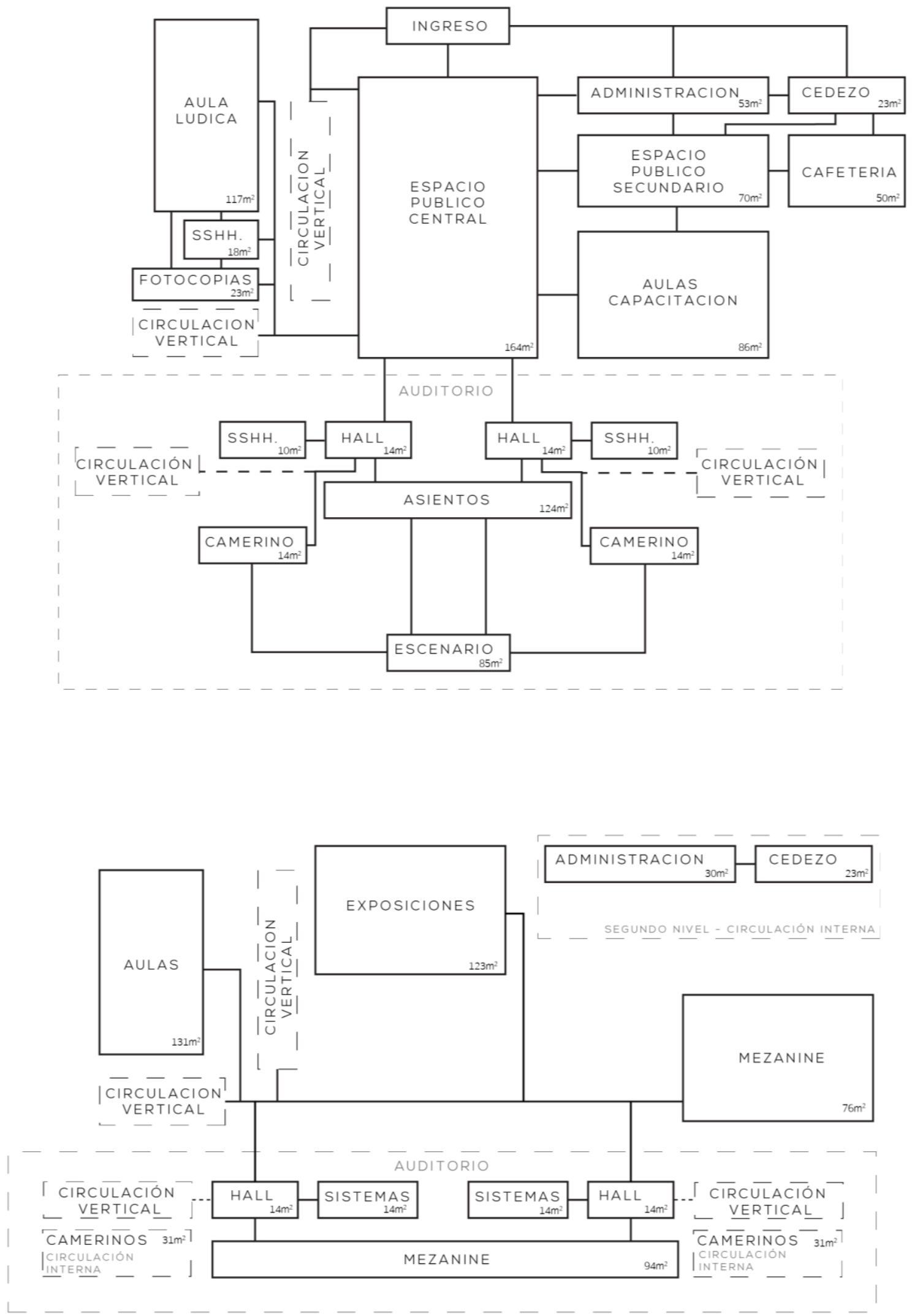


\subsubsection{Aportes}

El mayor aporte al entorno de Moravia fue el Jardín Urbano. Antiguamente fue un cerro de basura que recibió aproximadamente 1.5 millones de toneladas de desechos;100 toneladas diarias.

Debido al crecimiento urbano e industrial de Moravia, entre 1972 y 1984, se generó un cerro de 40 metros de altura en 7.5 hectáreas. Esto generó que, en 2001, más de 15 mil personas debieron convivir con plagas y desechos (Arcia, 2014). La población llegó a relacionarse con el montículo de desechos a través del oficio de reciclaje de diversos materiales. Llegaron a existir viviendas improvisadas en el terreno.
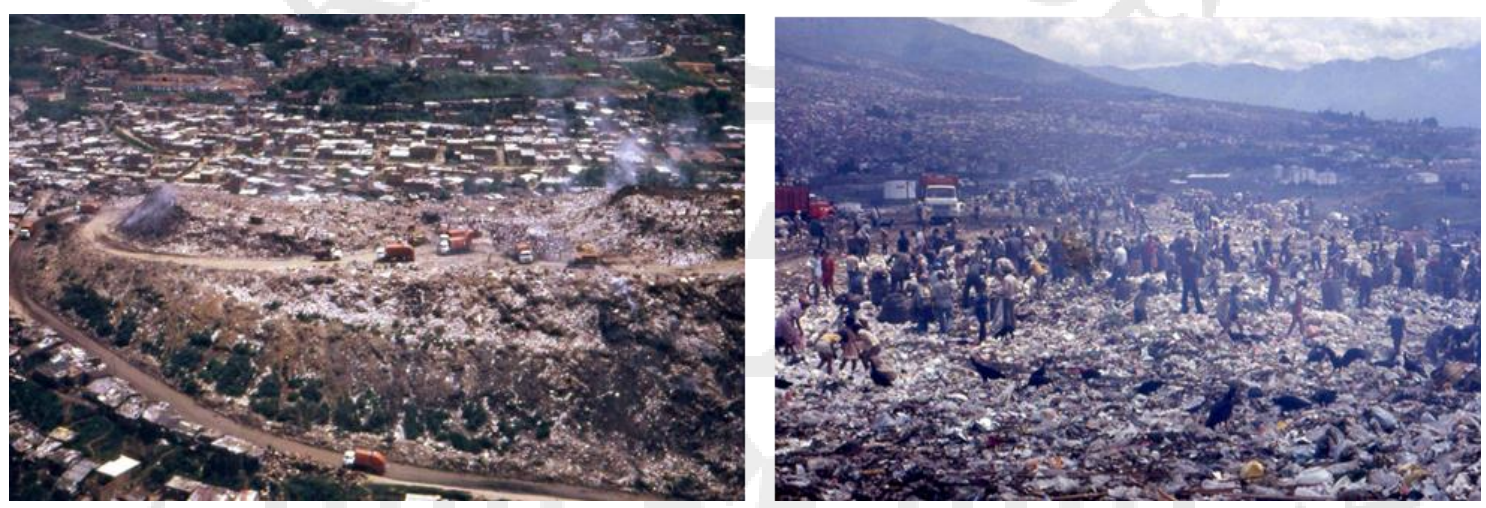

Imagen: Invasión y basural. Cerro de Moravia, 1982

Fuente: Jorge Melguizo Posada

Hubo, sin duda, una baja calidad de vida de los habitantes, con $0.37 \mathrm{~m} 2$ de espacio libre por persona, sin agua potable, exposición a riesgos geotécnicos y químicos. Mantuvo un alto nivel de violencia y desigualdad en comparación al resto de los barrios. Por ello, a partir del año 2000, inicia el Macroproyecto Urbano de Moravia y se trazan las principales líneas de acción para la renovación y recuperación de la zona.

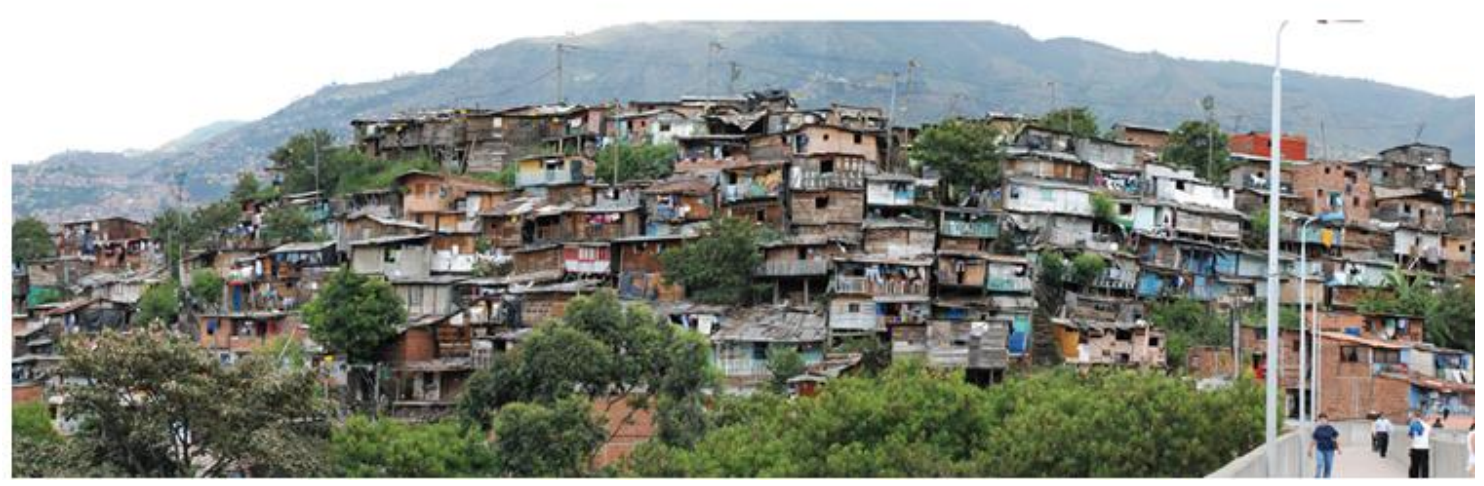




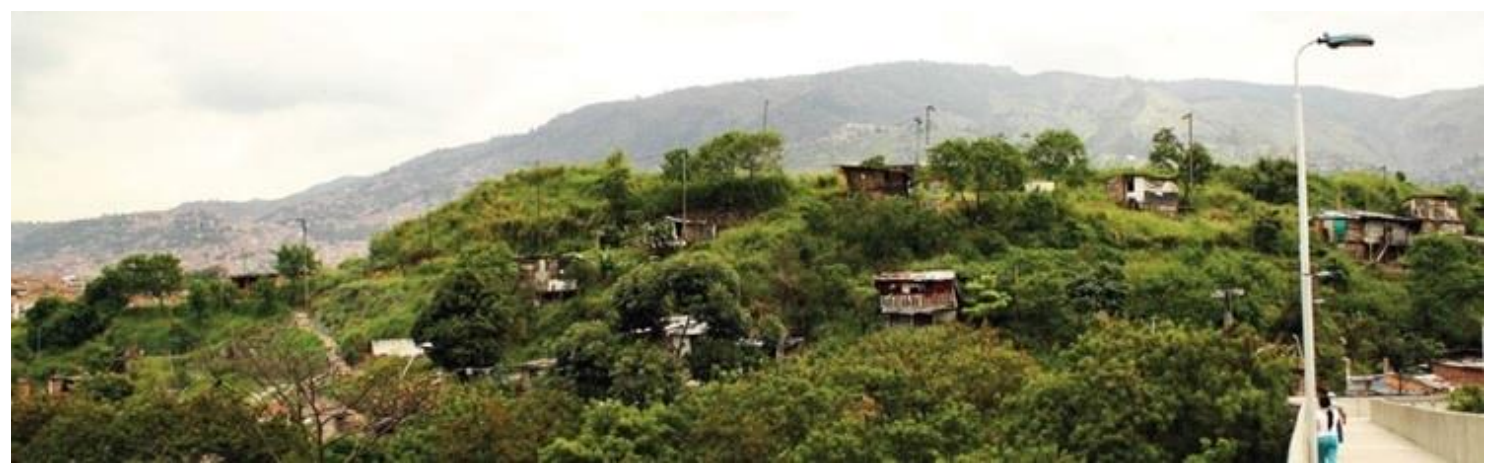

Imágenes: Arriba Foto panorámica Moravia, 2004; Abajo Foto panorámica Moravia, 2010.

Fuente: RECICLAR CIUDAD: Repensar la Transformación, hacia una Gestión Sostenible del Territorio

Dentro de los proyectos, se desarrollaron medidas para la regeneración del cerro.

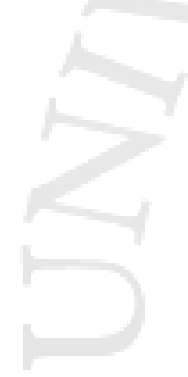

Estas medidas incluyeron el uso de sistemas naturales como los buffer strips y humedales construidos, implementados y probados en la planta piloto de tratamiento de lixiviados, cuyo objetivo era el manejo de las aguas contaminadas. Se desarrollaron intervenciones paisajísticas a través del programa de Jardines Comunitarios promovido por la Catedra UNESCO de Sostenibilidad (parcelas - de fitorremediación y biorremediación) para la extracción de metales pesados. En paralelo se construyeron espacios públicos y equipamientos comunitarios periféricos al cerro. Este conjunto de medidas aseguran no solo la recuperación y descontaminación de esta zona degrada, sino la sostenibilidad de las intervenciones. (Arcia, 2014)

Gracias a estas medidas, la intervención del cerro de Moravia es un referente a nivel internacional por la incorporación de tecnologías sostenibles y los procesos de participación social. 


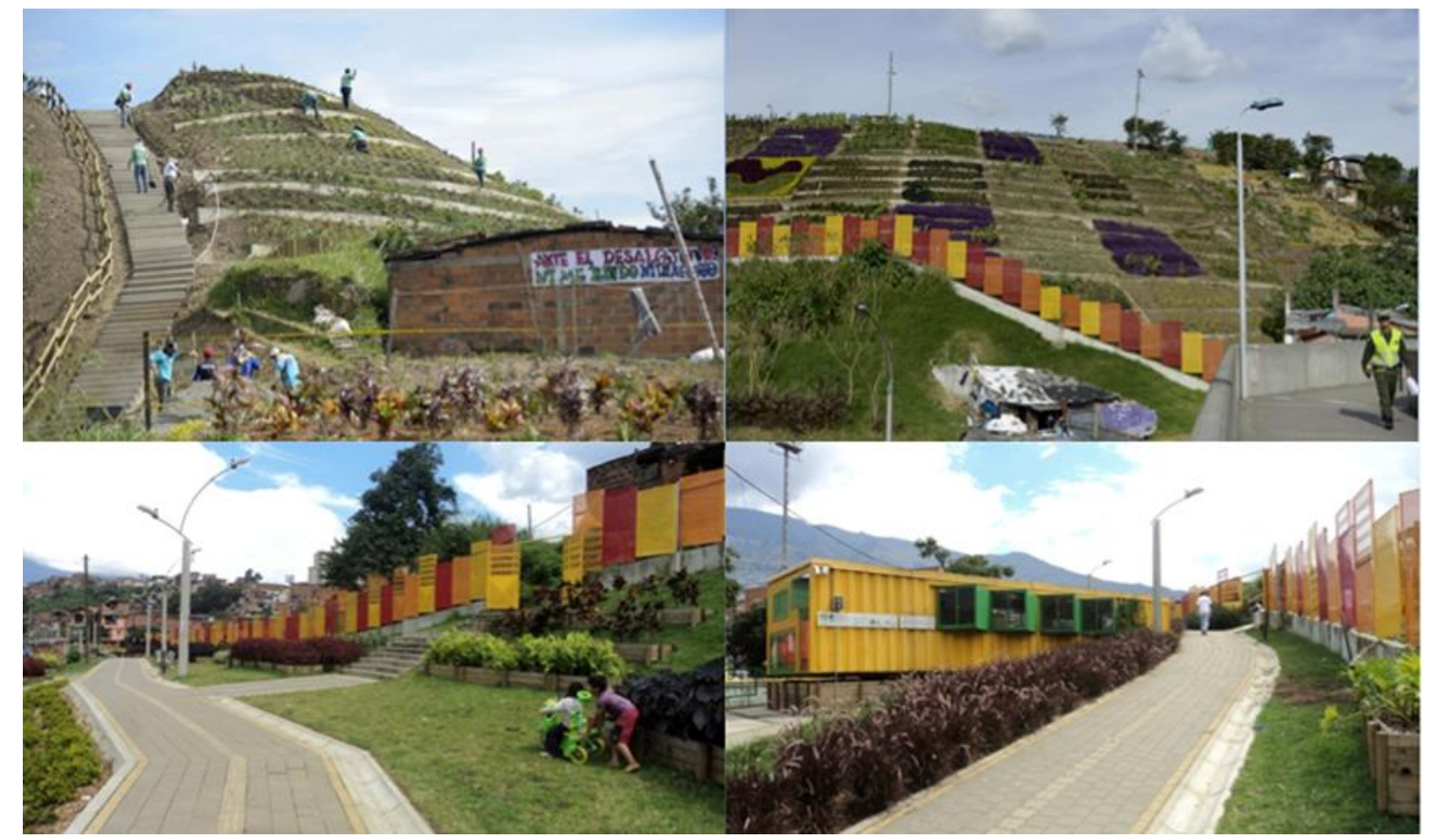

Imágenes: Cerro de Moravia como Jardín Urbano

Fuente: AFP

\subsubsection{Tecnología}
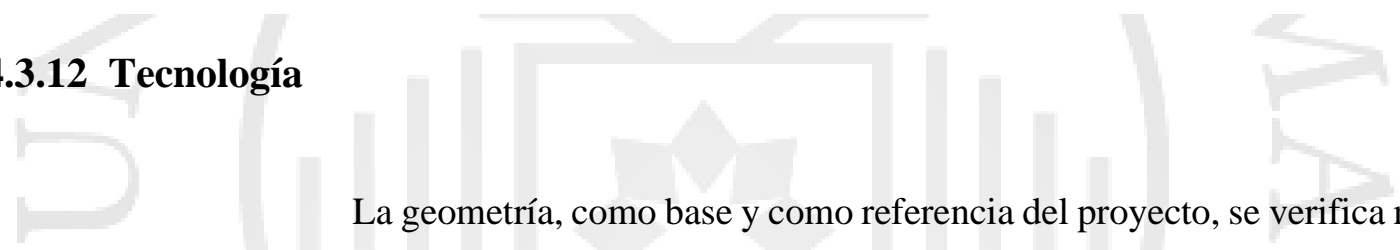

La geometría, como base y como referencia del proyecto, se verifica no solamente en la composición espacial sino en las técnicas constructivas. El uso del ladrillo, elemento icónico de la arquitectura colombiana y particularmente de Rogelio Salmona, demuestra su condición versátil y de detalle al combinarse de maneras diversas en diferentes situaciones de encuentro y terminaciones. Los dibujos controlados del piso que convergen en un punto central, las juntas que demarcan superficies diferentes, las esquinas en donde se encuentran dos paredes, o una y la cubierta, el muro curvo del anfiteatro que responde a condiciones acústicas de reverberación: ${ }^{-}$todas estas situaciones se diseñan individualmente y generan una marca propia y sutil para el sitio. (Martignoni, 2013)

Como parte de una técnica de integración social, los mismos usuarios fueron quienes construyeron el centro con diferentes amarres y disposición de ladrillos. Esto dependía del uso y función del espacio y el nivel de permeabilidad o privacidad que fuese necesario. 


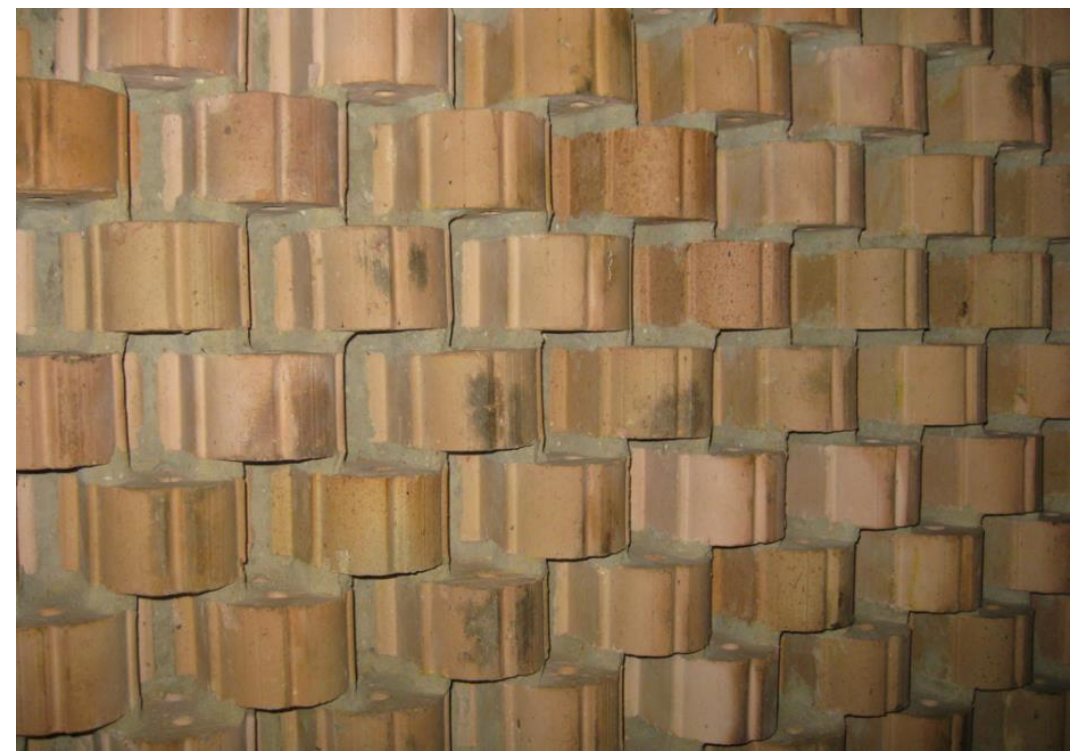

Fuente (Martignoni, 2013)
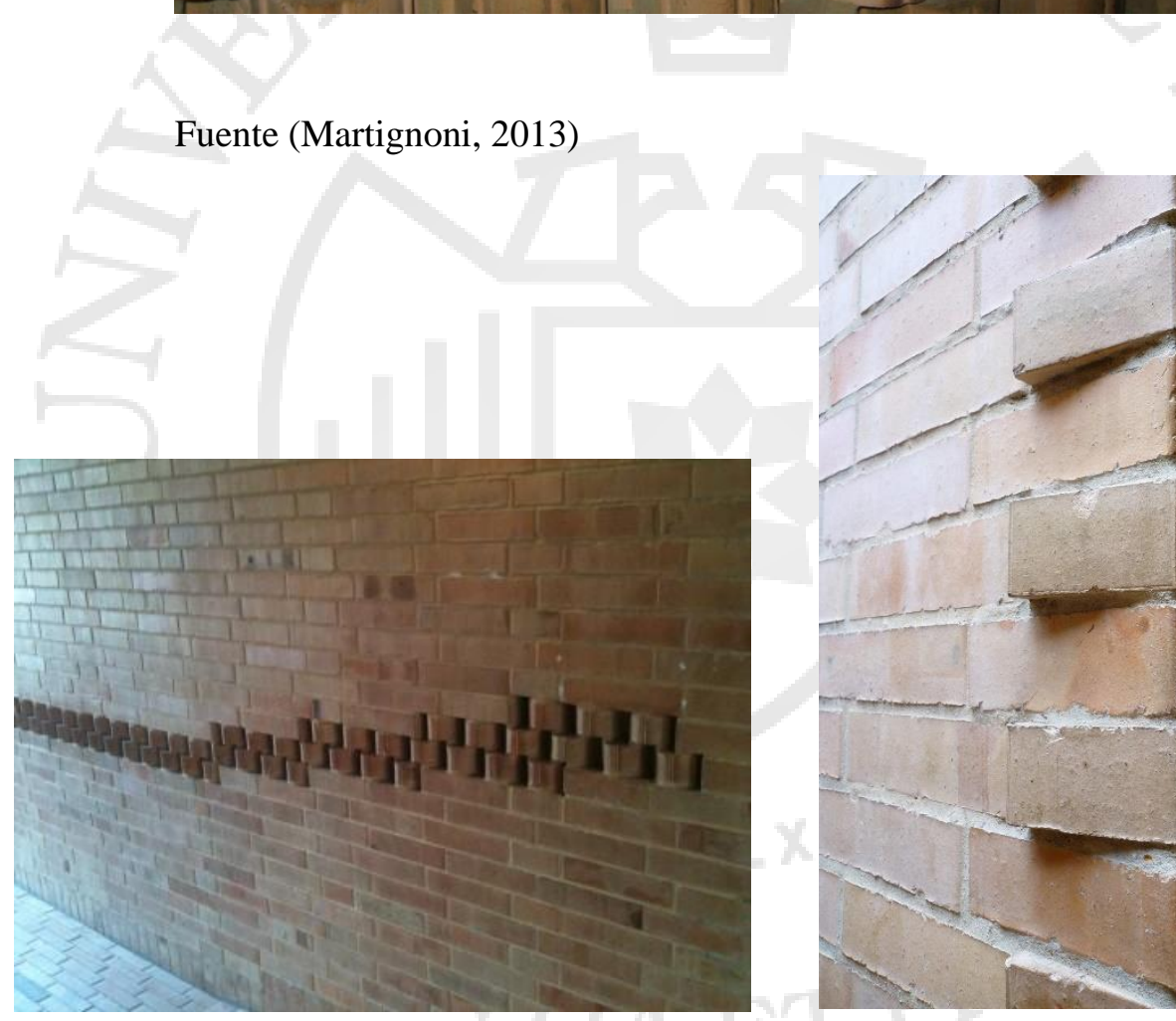

Celosías para ventilación y terminaciones de muros con amarres Fuente: Tectónica Blog.

En la planta, por otro lado, podemos determinar la presencia de un sistema porticado, donde las columnas se encuentran distanciadas sistémicamente según ambiente en el que se ubiquen. Esto quiere decir que, probablemente, el edificio tiene un sistema de construcciones separadas, técnica común para evitar problemas en sismos. 
Plano: Primera planta CDCM (Martignoni, 2013)

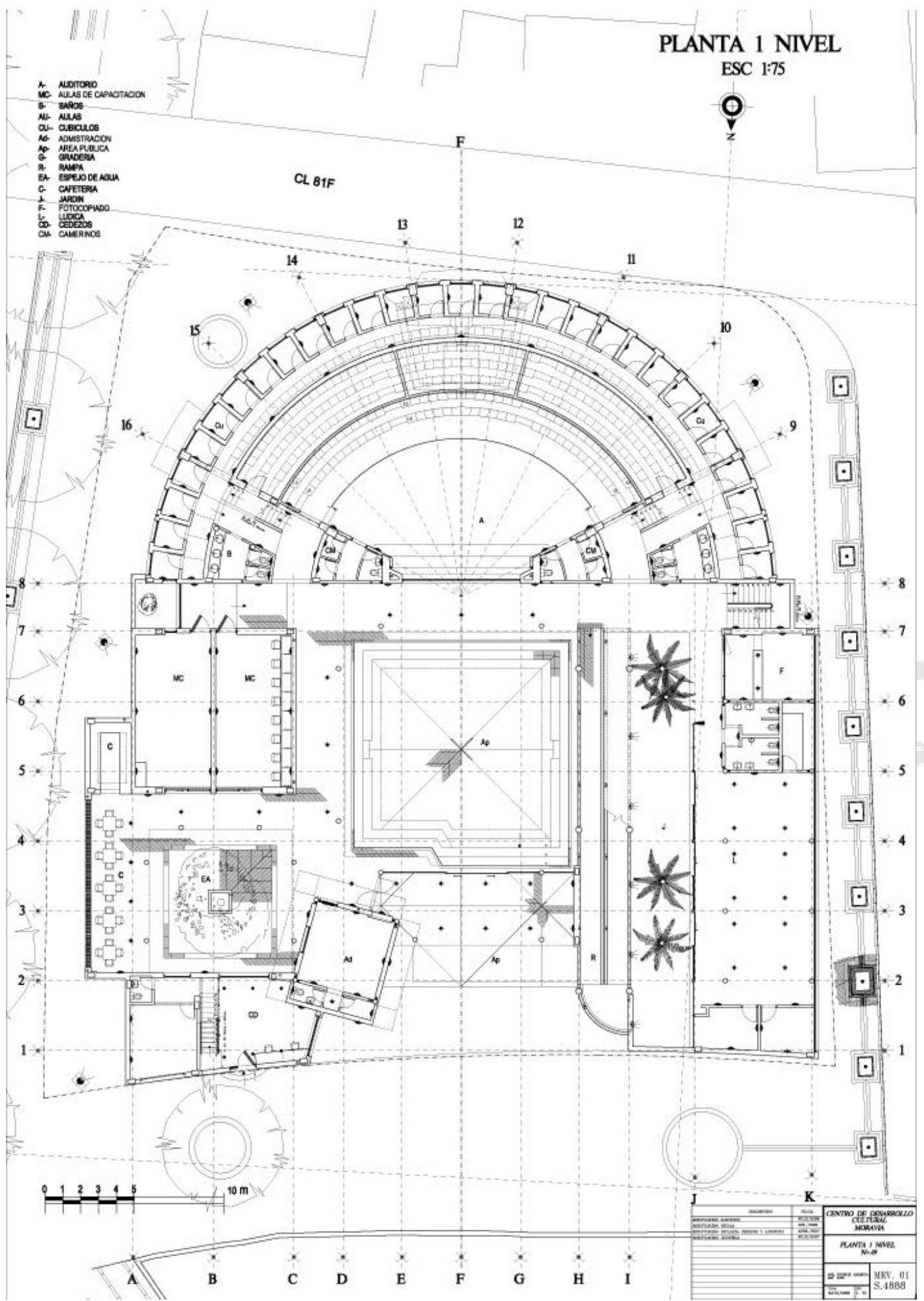

Por otro lado, la cubierta del techo se encuentra soportada por tijerales metálicos. Esto se ve, principalmente, en los techos con pendiente. 
Plano: Corte transversal CDCM (Martignoni, 2013)

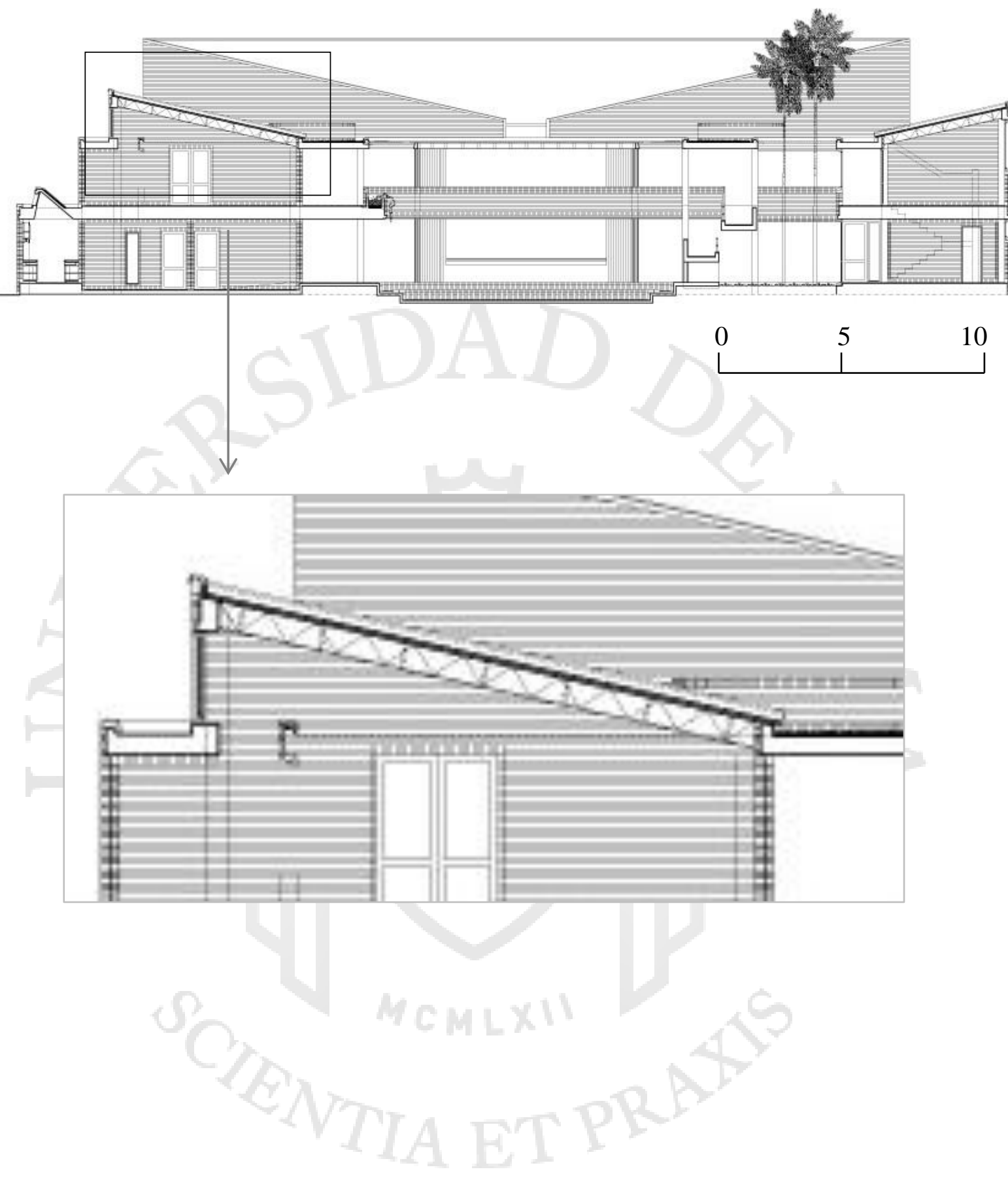


Plano: Detalle constructivo Patio Cafetería CDCM (Martignoni, 2013)

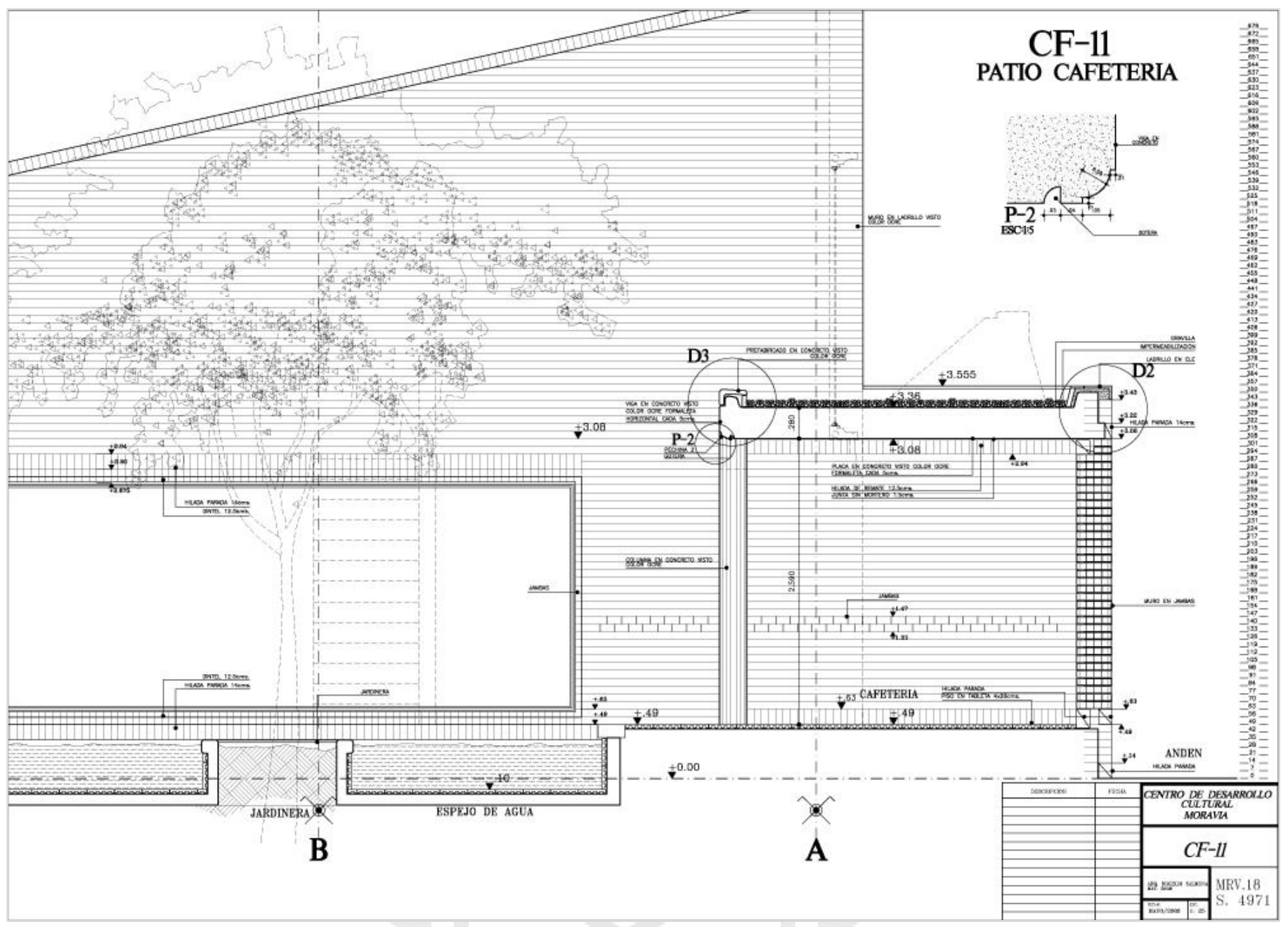


Plano: Detalle constructivo aula múltiple y cocina CDCM (Martignoni, 2013)

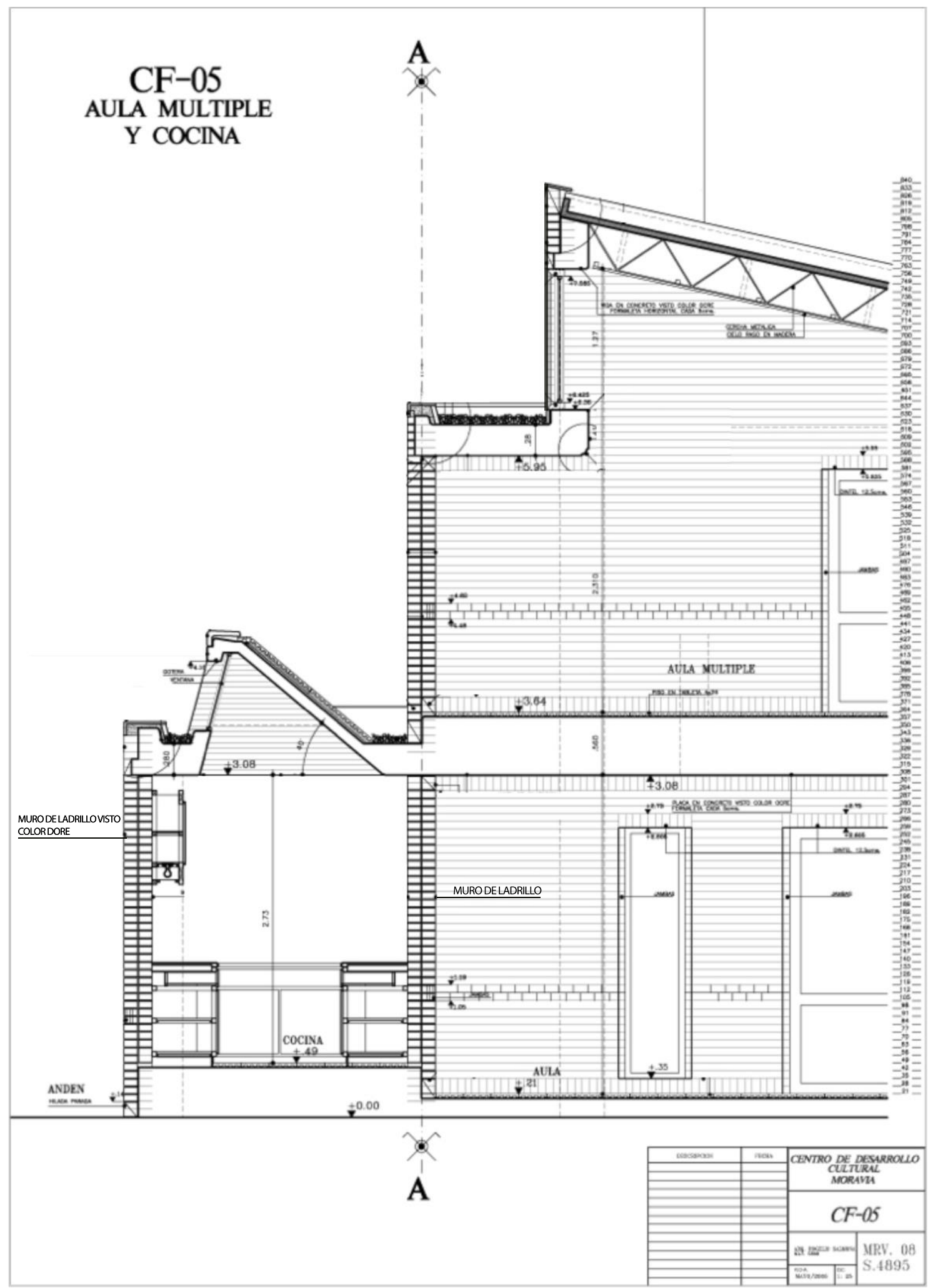




\subsubsection{Impacto Social}

El objetivo del CDCM en su entorno es generar cambio en los paradigmas sociales de sus habitantes. La construcción del centro es parte de un plan integrado de intervenciones que promueven la regeneración urbana del barrio de Moravia. Este plan tiene como objetivo general:

La mejora de las condiciones socioeconómicas y ambientales de los habitantes de Moravia y de su entorno, fortaleciendo el proceso participativo de la transformación urbana y disminuyendo los riesgos para la salud pública mediante el uso de tecnologías sostenibles para la descontaminación y la gestión integral y sostenible de zonas contaminadas. (Montoya, y otros, 2011)

Para que el CDCM logre el impacto social deseado, se plantearon tres principales lineamientos:

1. Línea social: aborda seis programas y trece proyectos.

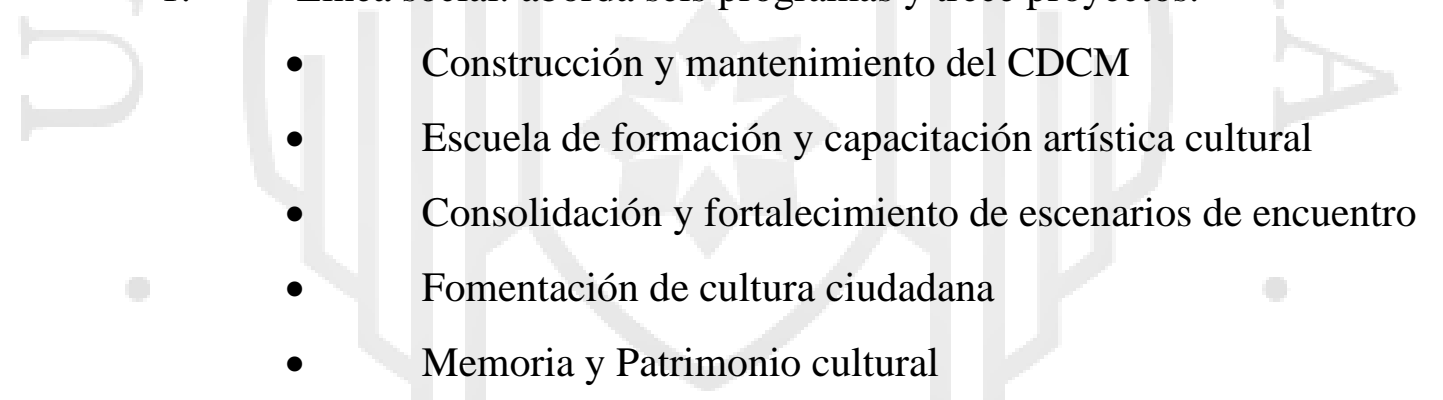

2. Línea ambiental:

- Un programa general de formación y educación ambiental en cinco proyectos.

3. Línea de desarrollo social: Contiene tres programas y siete proyectos - $\quad$ Escuela de artes y oficios

Las actividades culturales que se realizan en el centro, así como las actividades de regeneración urbana que se realizan en todo el barrio (y se planifican en el CDCM), han logrado su objetivo de generar importantes cambios en esa sociedad.

Los equipamientos culturales han servido como una herramienta para el fortalecimiento de la convivencia estos son espacios que permiten e incentivan las 
diversas expresiones de creatividad artística y cultural. Gracias a estas actividades, el CDCM se ha convertido en "la casa de todos", y sirve como un espacio para el intercambio cultural y el fortalecimiento de la identidad colectiva de la comunidad; de esta forma, generando vínculos importantes entre la cultura, la sociedad y la imagen del estado frente a las personas. (Echeverrí Cardona, 2012)

El intercambio cultural, ha generado una convivencia entre los actores ciudadanos y confianza en el conocer nuevas cosas y recibir información e ideas de actores ajenos al lugar.

Asimismo, a través de las acciones del Centro Cultural, al haberse convertido en un espacio neutro en la ciudad, se ha logrado fortalecer el ejercicio de formación ciudadana y de construcción de la ciudadanía. Esto ha cambiando los imaginarios sociales que antes dominaban la identidad del lugar.

El acceso a la producción de bienes cultura- les, la formación integral, la animación cultural y el acompañamiento identitario hacen parte de la propuesta y del modelo de gestión que con- vierten a este Centro Cultural en un espacio consecuente con la transformación cultural de la ciudad y referente de nuevas dinámicas para la convivencia comunitaria. (Echeverrí Cardona, 2012, pág. 14)

El CDCM, ha beneficiado a más de dos millones de usuarios de forma directa e indirecta. Se han realizado 14,000 actividades de índole cultural que fomentan la equidad, el desarrollo y la inclusión. 


\subsection{Estación de Autobuses Santa Pola}

\subsubsection{Historia}

\subsubsection{Información Técnica}

- Arquitectos: : iL

- Año: 2015

- Ubicación

- Arquitecto a cargo

- Área:isépi $6010.0 \mathrm{~m} 2$

- Fotografías: iLepipilippo Poli

- Proveedores: FERPAS

- Arquitecto Colaboradorispe: Luis Carreira (ArchDaily, 2016)

\subsubsection{Toma de partido}

Desde un inicio, el proyecto tenía la intención de solucionar el suelo existente en el límite entre la zona industrial y la urbana que se unen a través de la carretera de Elche. A manera de puerta urbana, la estación debía tener una fuerte identidad y ser considerada icónica o un hito. Se plantea un "conjunto edificado y urbanizado persiguiendo un tratamiento orgánico y homogéneo de todos sus elementos" (ArchDaily, 2016)

Dentro del terreno, se ubica a la Estación junto a la rotonda, de manera que sea visible desde cualquier ángulo de la calle. Volumétricamente, "se dispone de un gran plano de cubierta, que debe proporcionar gran cantidad de sombra y protección en los apeaderos, conformando de esta forma el elemento principal de la edificación" (ArchDaily, 2016) El volumen se compone por los servicios de la estación, como taquillas y salas de espera. 


\subsubsection{Ubicación}

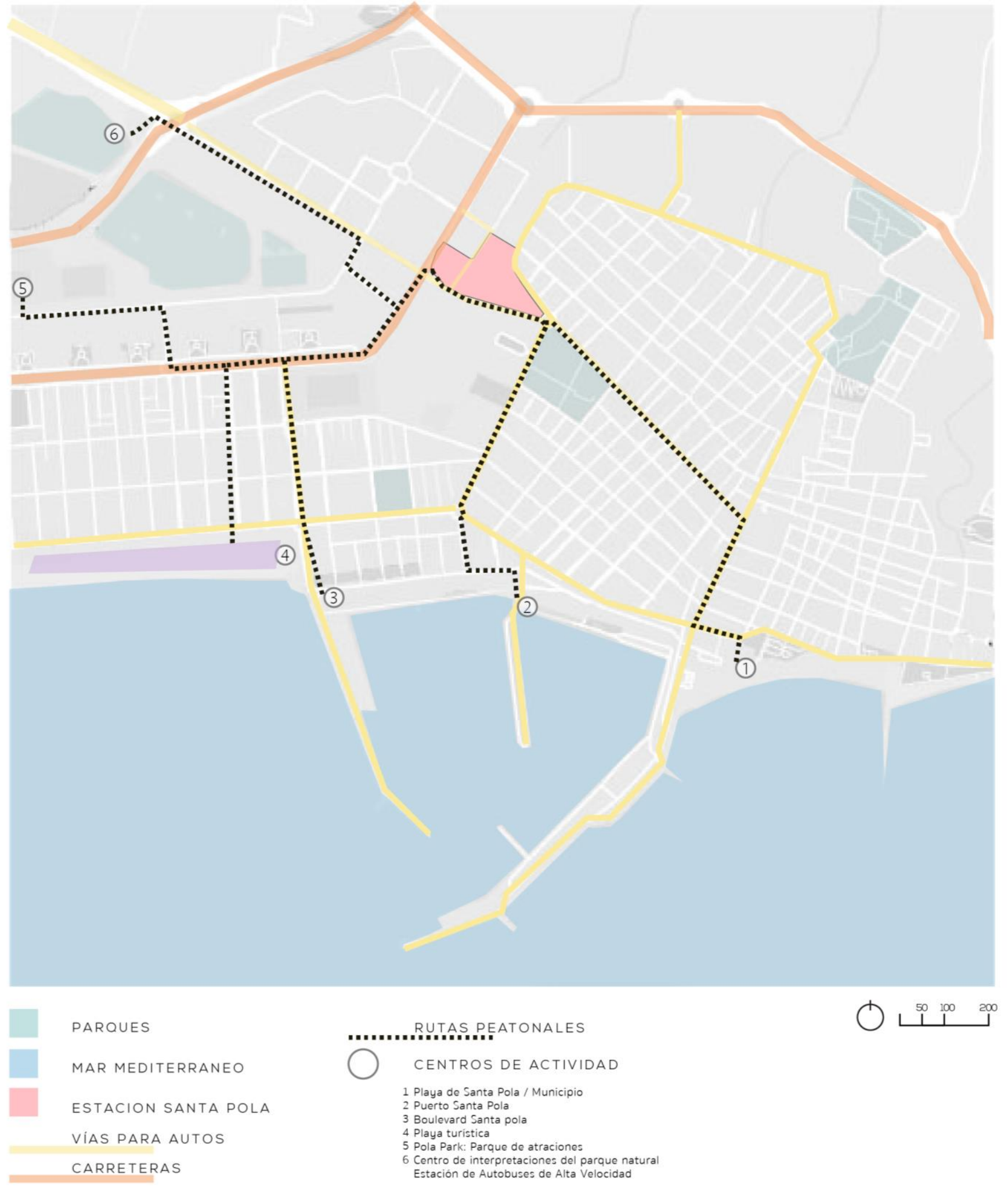




\subsubsection{Programa Y Relaciones Programáticas}

Cuadro 1.4.3.1: Cuadro de áreas de la Estación Santa Pola

Fuente: de realización propia, a partir de planos

\begin{tabular}{|c|c|c|c|c|}
\hline ÁREAS & SUB ÁREAS & $\begin{array}{c}\text { SUPERFICE } \\
\mathrm{m} 2\end{array}$ & $\begin{array}{c}\text { ÁREA TOTAL } \\
\mathrm{m} 2\end{array}$ & $\%$ \\
\hline $\begin{array}{c}\text { ESTACIÓN DE } \\
\text { BUSES }\end{array}$ & $\begin{array}{l}\text { Venta de boletos } \\
\text { Zona de espera interior } \\
\text { Baños } \\
\text { Tienda } \\
\text { Embarque } \\
\end{array}$ & $\begin{array}{r}101 \\
121 \\
39 \\
83 \\
284 \\
\end{array}$ & 628 & 6.44 \\
\hline ZONA COMERCIAL & $\begin{array}{l}\text { TIENDA } 1 \\
\text { TIENDA } 2\end{array}$ & $\begin{array}{r}300 \\
1300\end{array}$ & 1600 & 16.41 \\
\hline EXTERIORES & $\begin{array}{l}\text { ESTACIONAMIENTO } \\
\text { MANTENIMIENTO BUSES } \\
\text { ESTACIÓN DE SERVICIO }\end{array}$ & $\begin{array}{r}1680 \\
181 \\
547 \\
\end{array}$ & 2408 & 24.70 \\
\hline VIAS & $\begin{array}{l}\text { BUSES } \\
\text { INGRESO AUTOS } \\
\text { PARTICULARES } \\
\end{array}$ & $\begin{array}{l}982 \\
492\end{array}$ & 1474 & 15.12 \\
\hline CIRCULACIÓN & $\begin{array}{l}\text { PEATONAL INTERIOR } \\
\text { PEATONAL PERIMETRAL }\end{array}$ & $\begin{array}{r}204 \\
1887 \\
\end{array}$ & 2091 & 21.45 \\
\hline AREAS VERDES & $\begin{array}{l}\text { EXTERIORES } \\
\text { JARDIN INTERIOR }\end{array}$ & $\begin{array}{r}1313 \\
236 \\
\end{array}$ & 1549 & 15.89 \\
\hline
\end{tabular}




\subsubsection{Tipología}
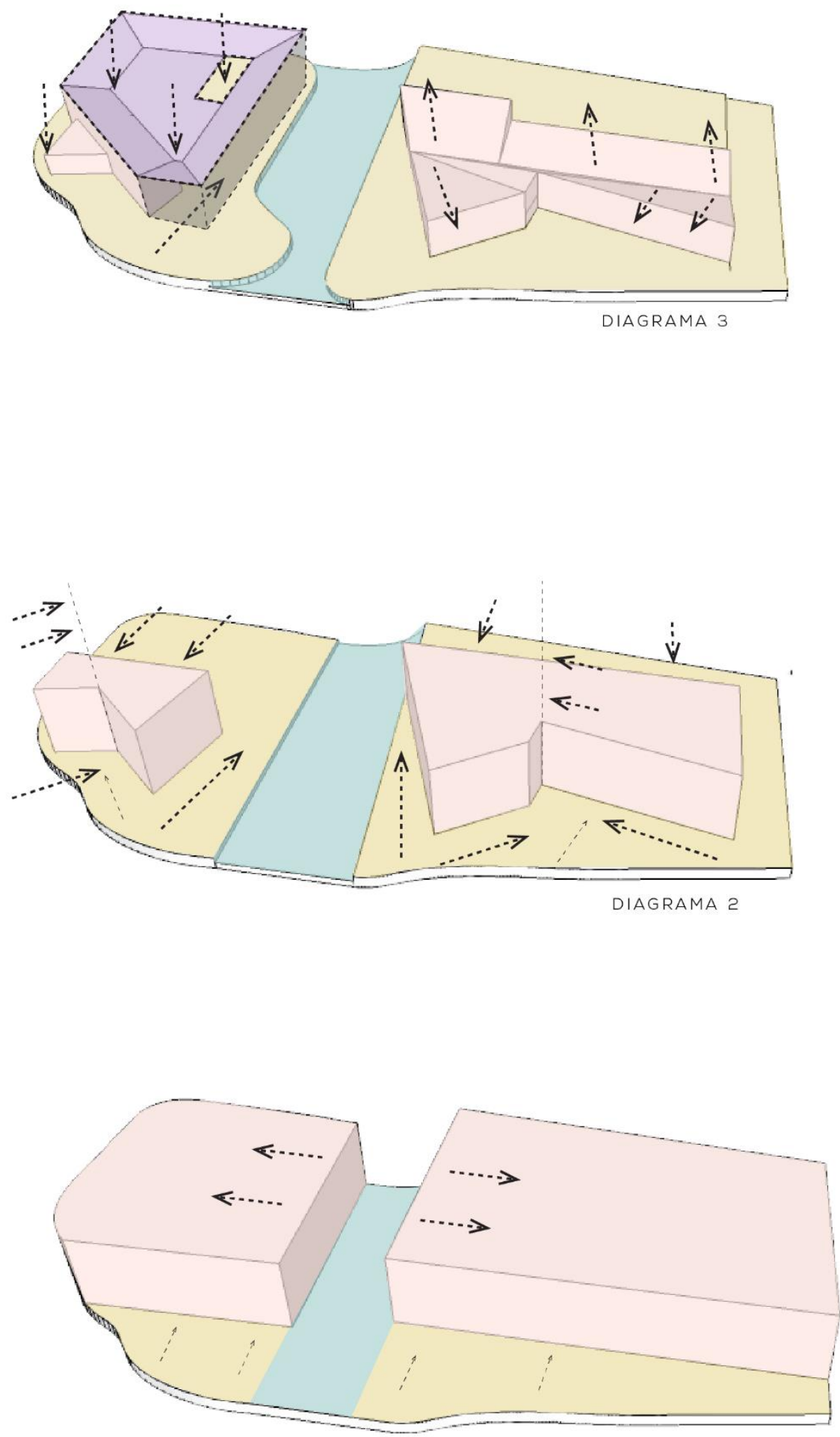

DIAGRAMA I 


\subsubsection{Público-privado}

Fuente: de elaboración propia, en base a planos de los arquitectos

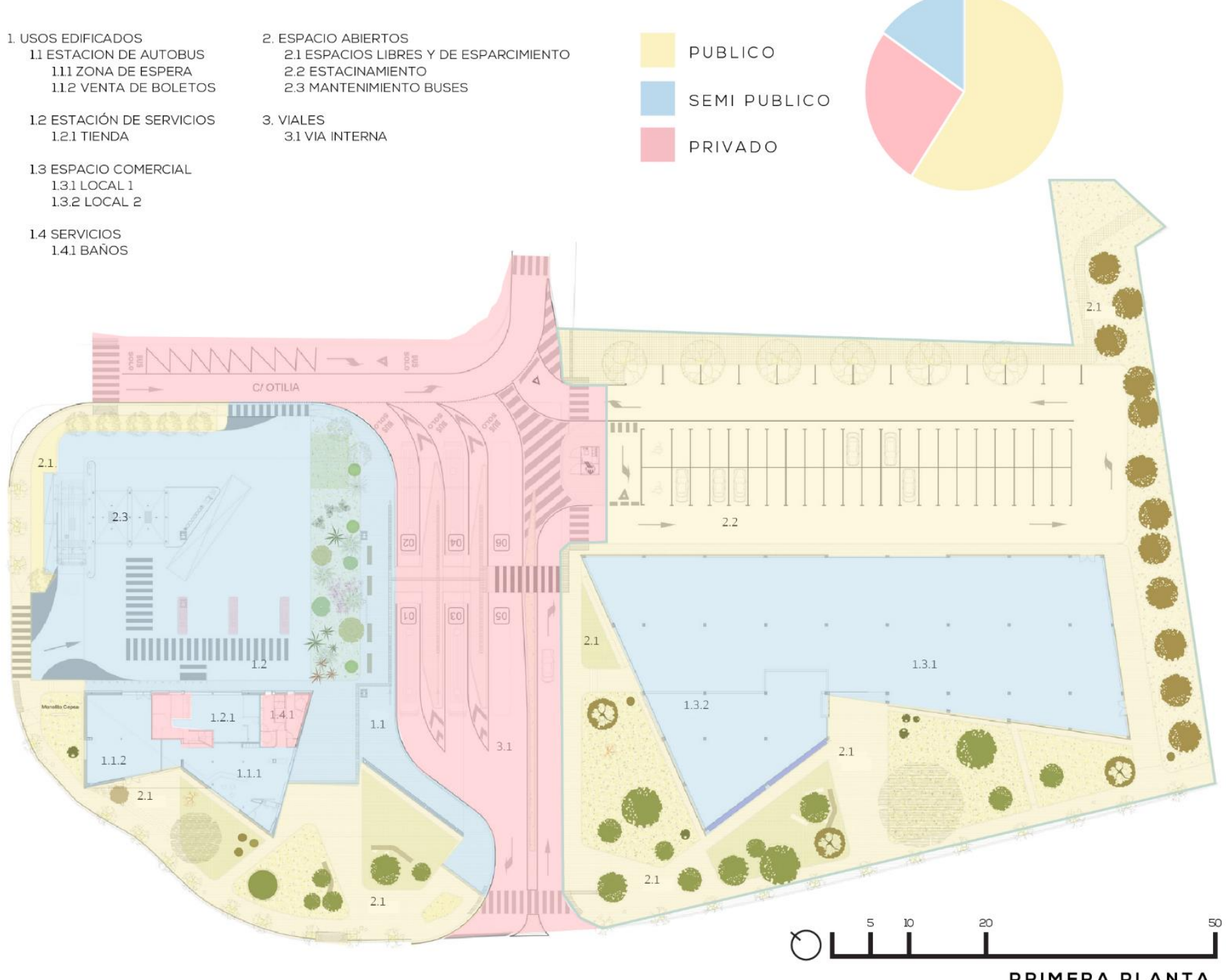

PRIMERA PLANTA
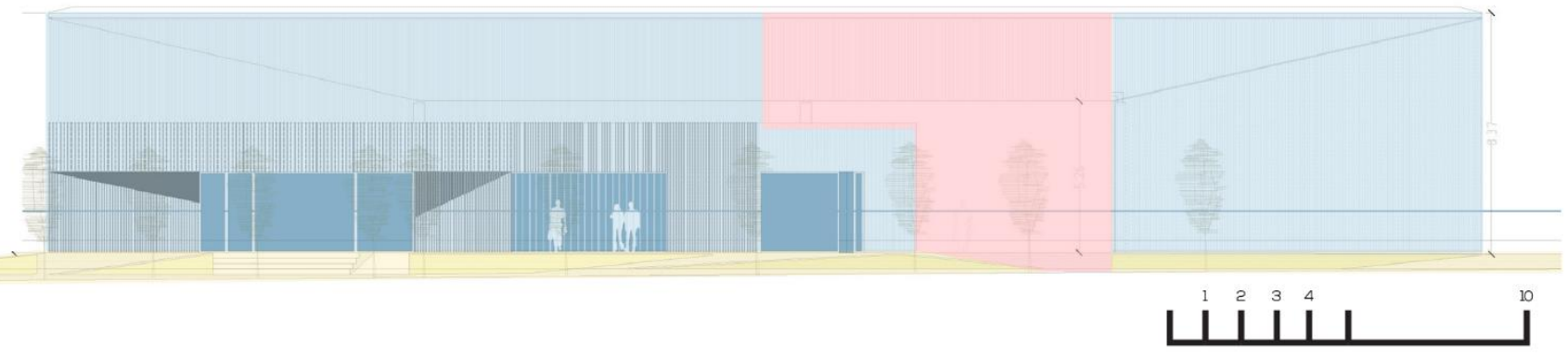


\subsubsection{Flujos de proyecto}

Fuente: de elaboración propia, en base a planos de los arquitectos
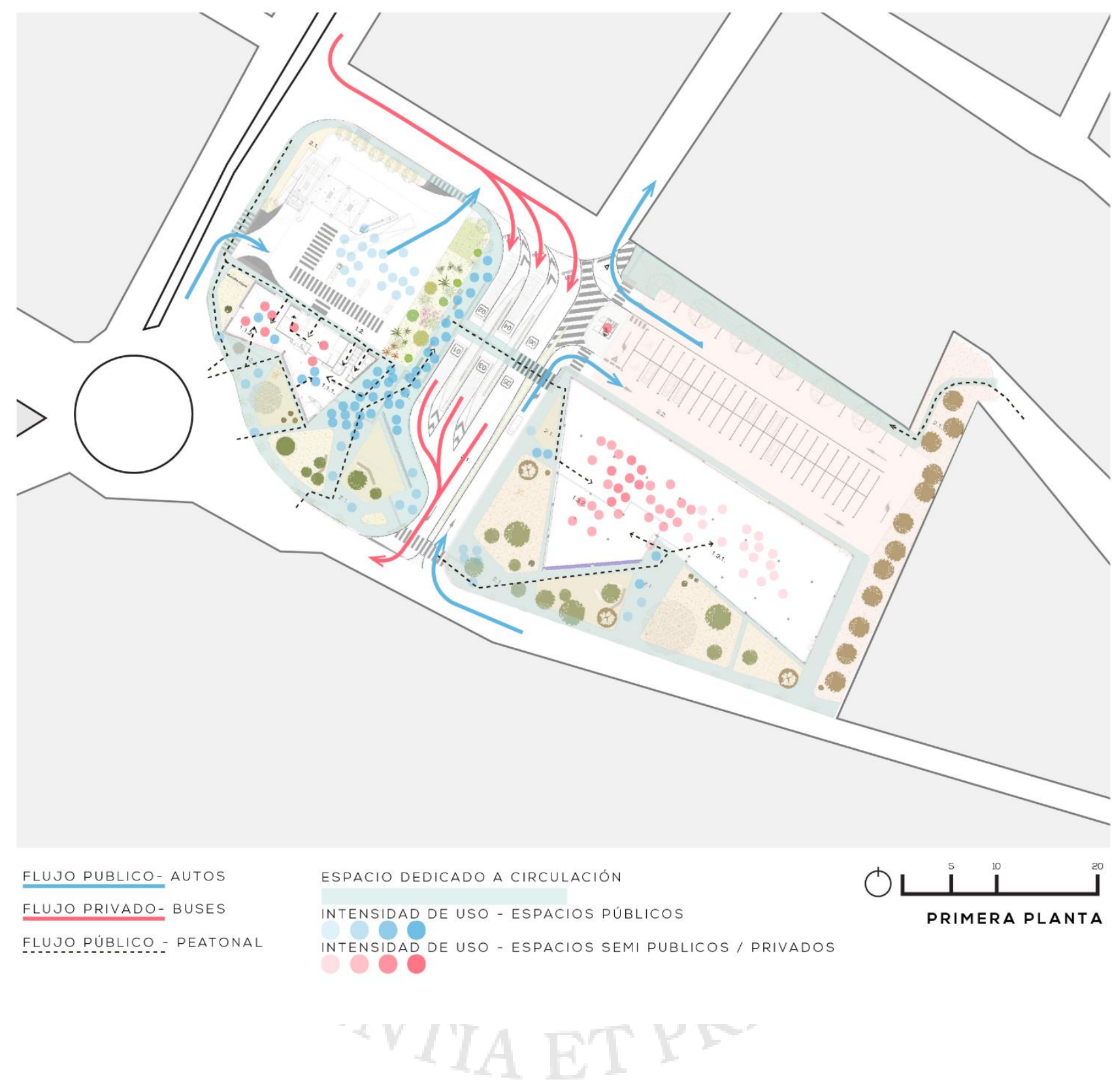


\subsubsection{Relaciones programáticas}

Fuente: de elaboración propia, en base a planos de los arquitectos

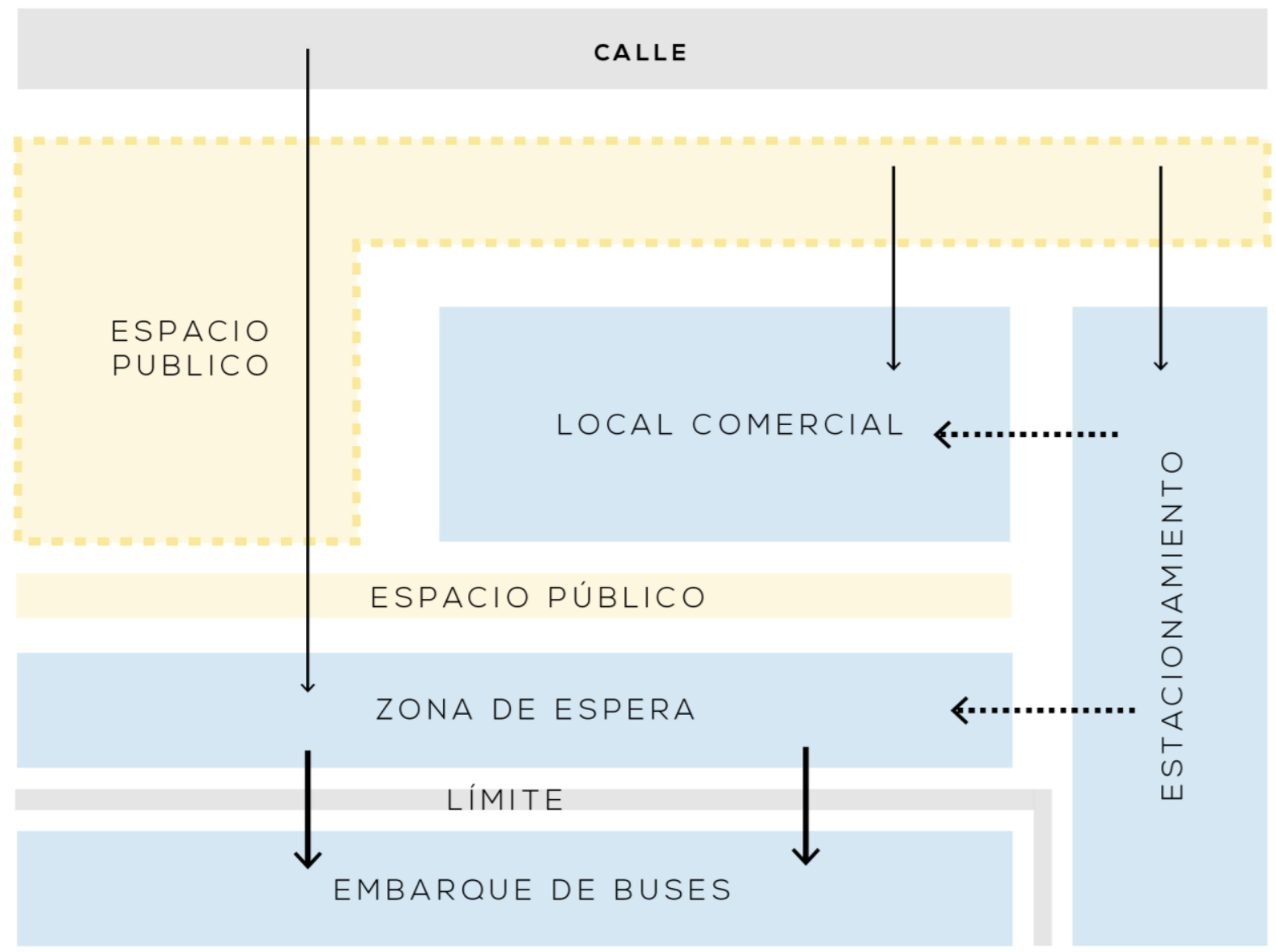

CALLE 


\subsubsection{Organigrama}

Fuente: de elaboración propia, en base a planos de los arquitectos

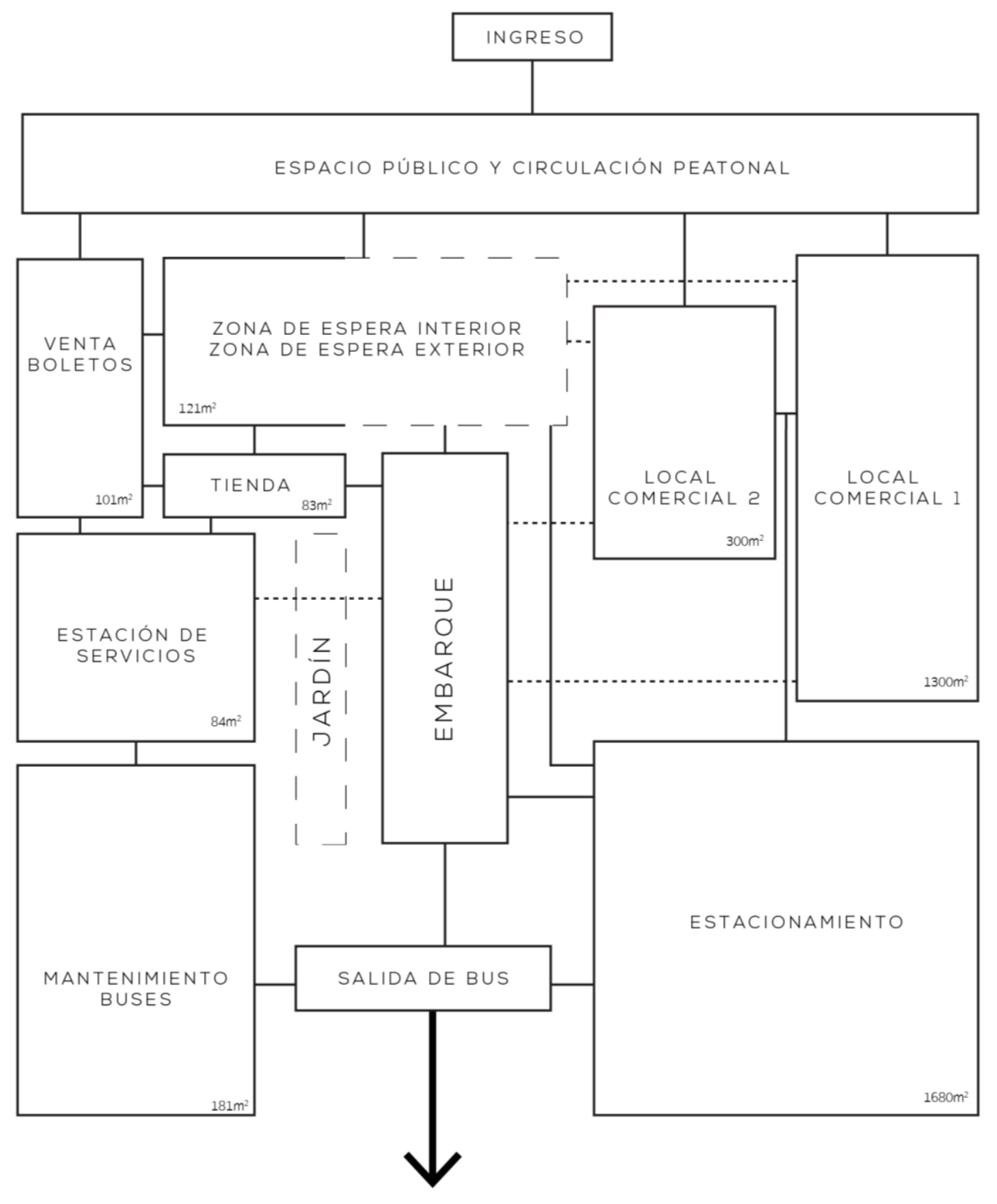




\subsubsection{Tecnología}

El sistema constructivo de la Estación de Santa Pola es porticado, con columnas evidentemente moduladas según el ambiente o espacio. En el área de tiendas, por ejemplo, hay un tipo de planta libre, estrategia común en edificios de uso comercial.

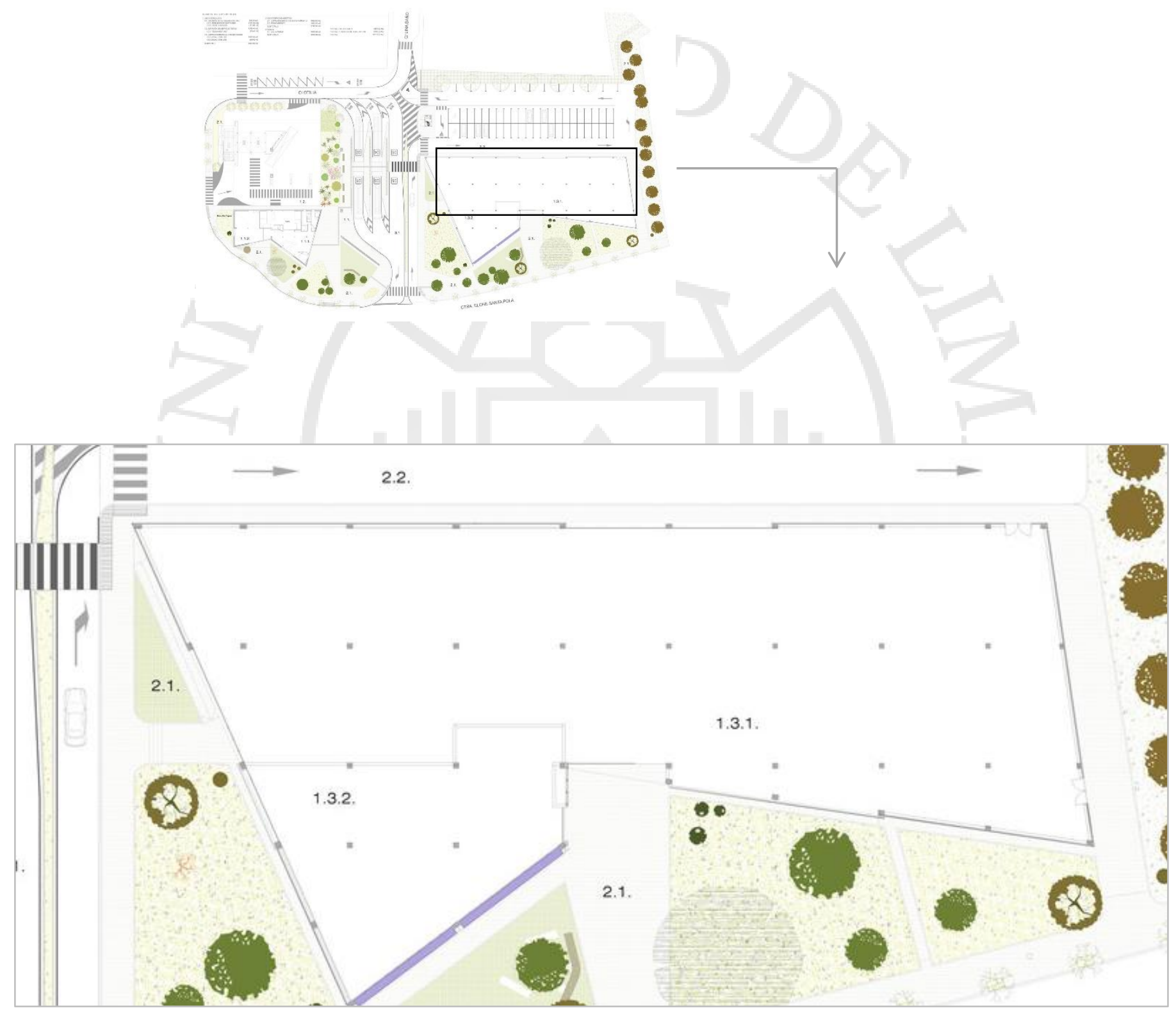

Fuente: (ArchDaily, 2016) 
El mismo sistema porticado se aplica en el resto del recinto, con columnas que cambian de modulación. Estas son posicionadas para soportar los amplios techos voladizos que la estación tiene. La cubierta es metálica.

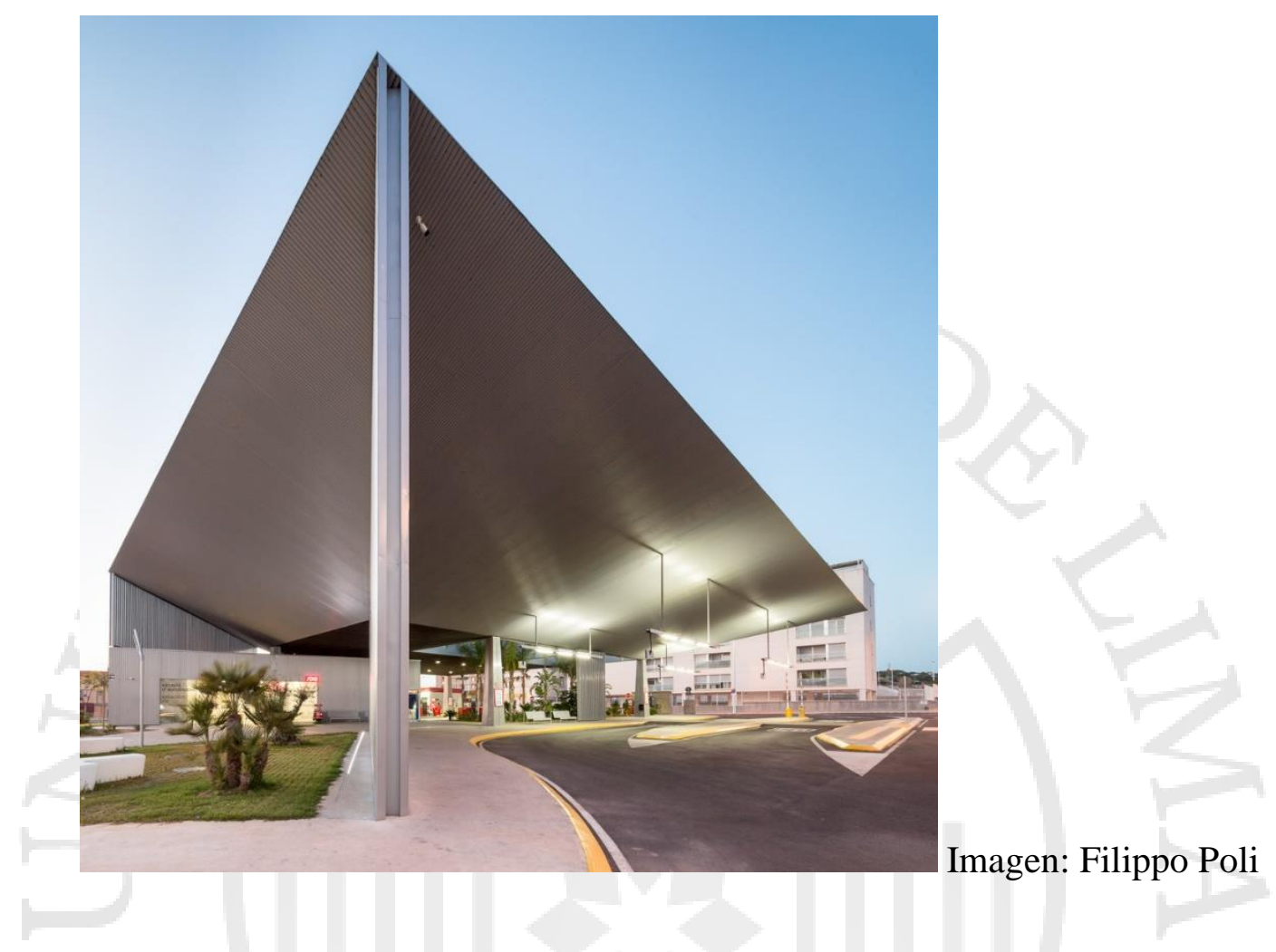

Además, existe una intención de levantar la cubierta para una mejor ventilación e iluminación naturales.

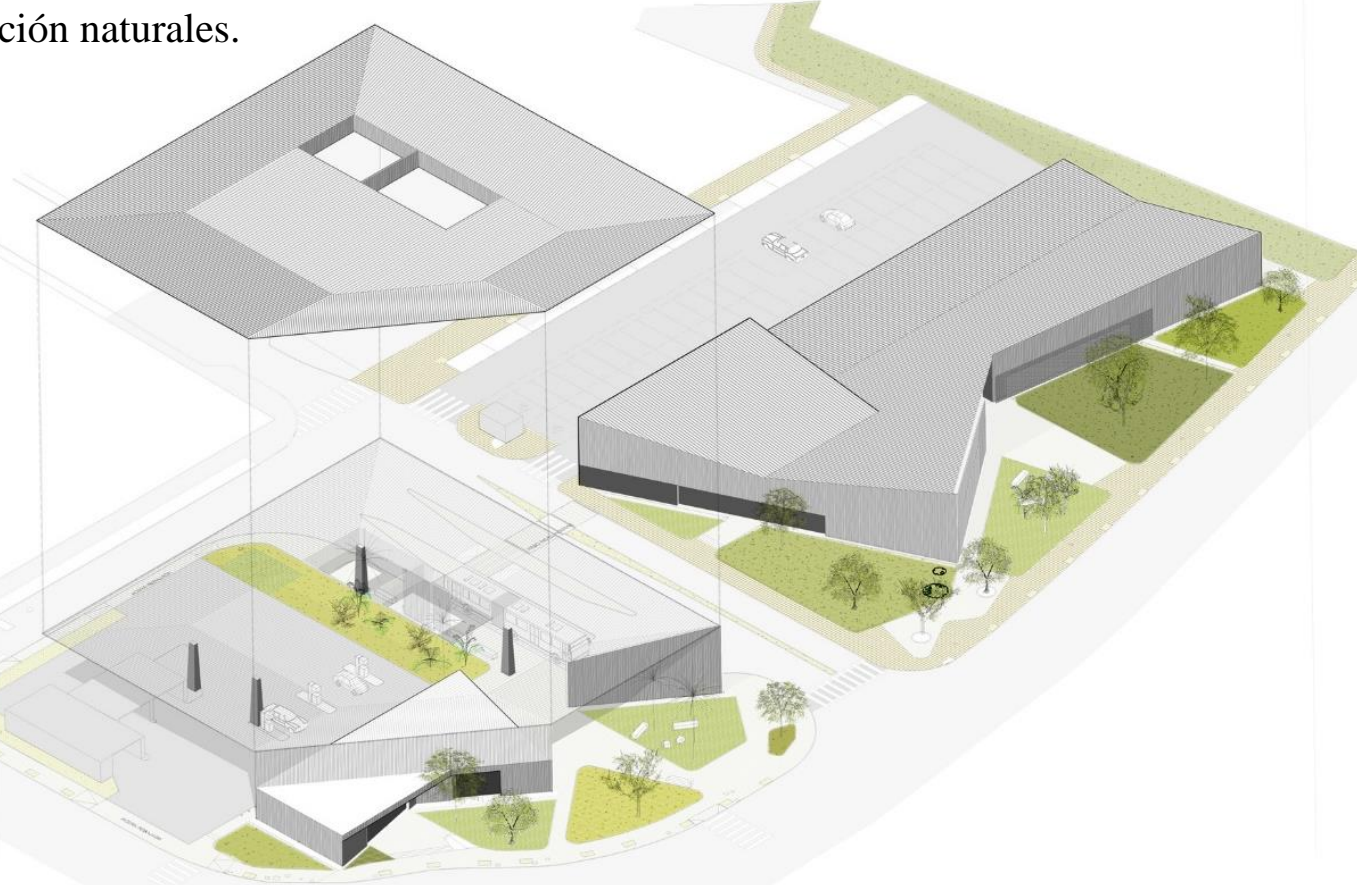

Fuente: (ArchDaily, 2016) 


\subsection{Estación del BRT Ecovía Casa de la Cultura, Quito.}

\subsubsection{Historia}

\subsubsection{Datos del proyecto}

- Año: 2001

- Propietario: Gobierno Metropolitano de Quito

- Estado: En funcionamiento

- Número de andenes: 1

- Número de vías: 1

- Plataformas: 1

\subsubsection{Toma de partido}

Luego de la eficacia en fase de construcción y operación del sistema de transporte Trolebús, el Municipio del Distrito Metropolitano de Quito decide que el uso de carriles exclusivos para los sistemas de transporte masivos es efectivo para contrarrestar el tiempo de viaje, espera y congestión vehicular en las vías principales de la ciudad. Ecovía es uno de los Sistemas Troncales de la Red Integrada de Transporte de Quito, Ecuador. (SANCHEZ ELIZALDE, 2014)

Ecovía está constituida principalmente por la red de Seis de Diciembre-Marín, que recorre desde la Avenida Río Coca hasta el playón de La Marín. Seis de Diciembre es una línea de integración con el sistema Trolebús y más de 15 líneas alimentadoras. Por lo tanto, un pasajero puede recorrer la mayor parte de vías de la ciudad con un solo pasaje. (Mogollón, 2006)

Los corredores atraviesan área urbana y optimizan su uso con diferentes estaciones: paraderos, intermodales, de transferencia, etc. La estación Casa de la Cultura es una parada de doble vía en una zona con gran cantidad de equipamientos urbanos culturales, de salud y educación. 


\subsubsection{Línea de tiempo}

Bajo el contexto de una ciudad caótica por un transporte deficiente y los problemas que esto traía a la ciudad, Quito aplica al programa de las Naciones Unidad para el Desarrollo (PNUD) de implementación de un sistema de transporte. Con el aporte de técnicos de diferentes nacionalidades, se coincidió en que lo más apropiado para controlar y racionalizar el transporte en Quito era la implementación del Trole. (Empresa pública Metropolitana de Transporte de pasajeros, 2016) Este medio de transporte fue elegido por encima del tren ligero y monorriel. Una de las características decisivas fueron las plataformas de ingreso a nivel del piso de los buses.

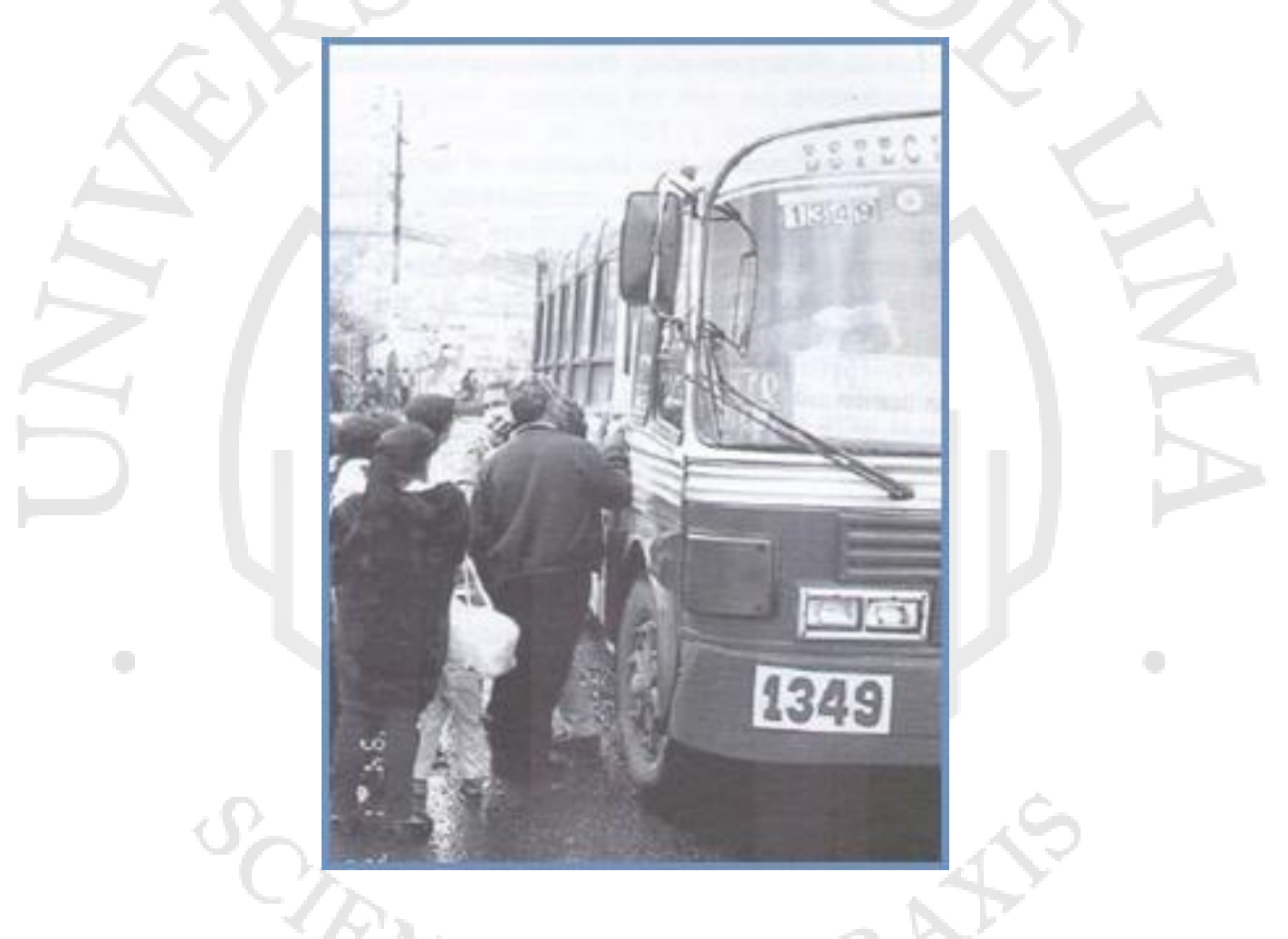

Imagen: Transporte previo al Trolebús (Empresa pública Metropolitana de Transporte de pasajeros, 2016)

En 1990 inicia el proyecto Trolebús como parte del Plan Maestro de Transporte de la década. En 1992, el plan se encontraba desarrollado y listo para su ejecución. Se necesitó conseguir un financiamiento que permita planificar, regular y organizar el transporte y tránsito en la ciudad; así como crear la Unidad de Planificación y Gestión de Transporte, la responsable por gestionar dichos problemas. (Empresa pública Metropolitana de Transporte de pasajeros, 2016) 
El 17 de noviembre de 1995 se crea la Unidad Descentralizada para la Gestión y Operación del Trolebús mediante la resolución No. 048. Esta era la encargada del servicio brindado mediante el sistema de Trolebuses. El 24 de octubre del mismo año llega el bus prototipo, recibido por el pueblo como señal de progreso. Durante la primera quincena de diciembre de 1995 arriban 13 unidades más. Es así como, el 17 de diciembre, se inaugura el primer tramo entre la Estación Sur El Recreo y la calle Esmeraldas con 14 buses.

El 19 de marzo de 1996 entra en füncionamiento la segunda etapa del Trolebús, con 32 unidades. Pasó de transportar 50000 personas en la primera etapa a 90000 en la segunda.

En 1999 se concesiona a 8 empresas que recorren la vía de 6 de diciembre y se constituye la Ecovía, por donde pasarían buses de transito rápido y baja emisión de gases.

El 21 de diciembre del 2000 se inaugura la tercera etapa, con 54 vehículos y 120000 pasajeros transportados.

En 2001 se inauguran las primeras estaciones de la Ecovía, como la Estación Casa de la Cultura. En 2005 se implementa la segunda etapa. 


\subsubsection{Ubicación y Relación con el Entorno}

Plano 4.5.2.1

Fuente: de elaboración propia, en base a planos del ayuntamiento

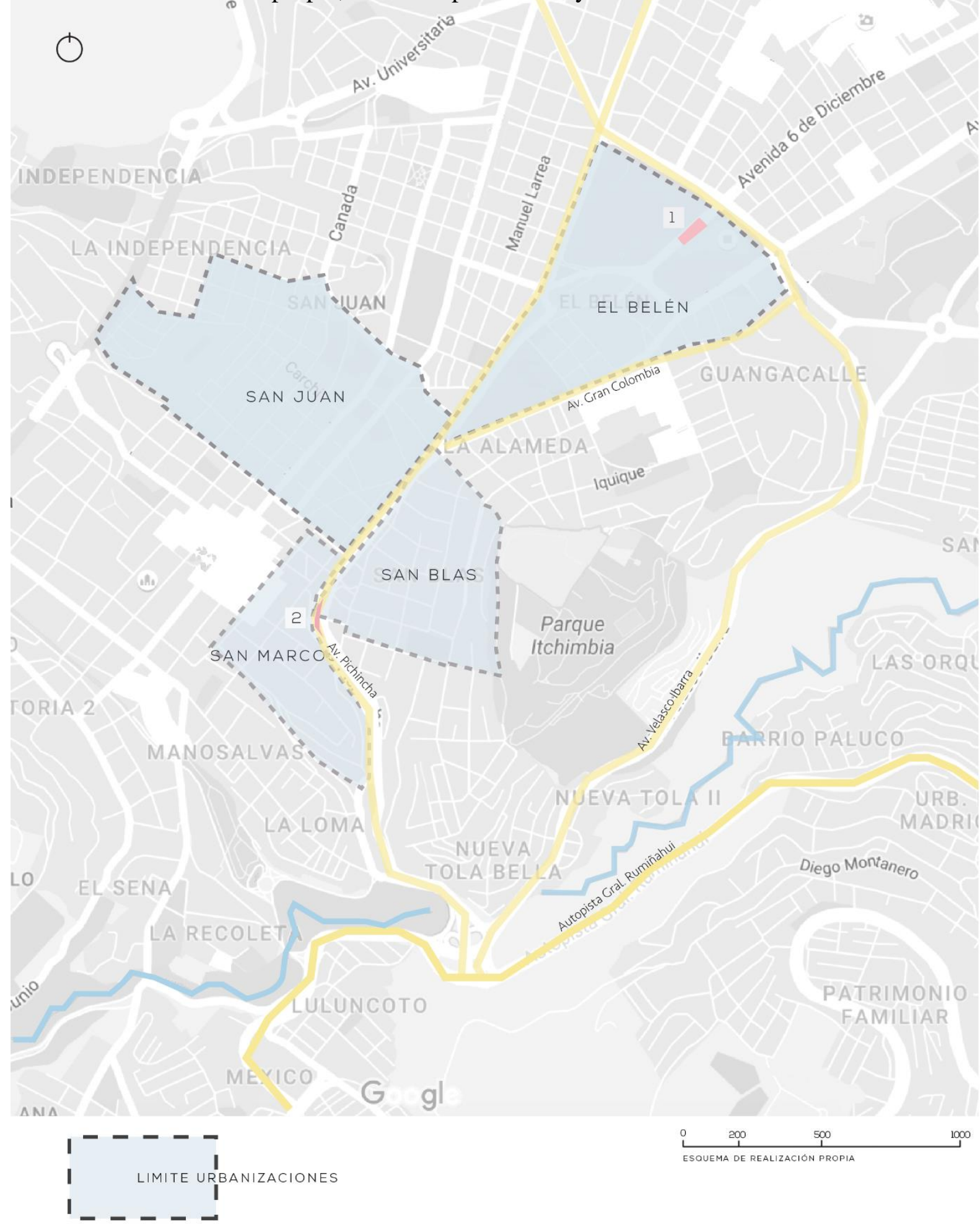

PRINCIPALES AUTOVIAS

RIO MACHÁNGARA

ESTACIONES

1. ESTACIÓN CASA DE LA CULTURA

2. ESTACIÓN EL PLAYÓN DE MARÍN CENTRAL 
Plano 4.5.2.1

Fuente: de elaboración propia, en base a planos del ayuntamiento

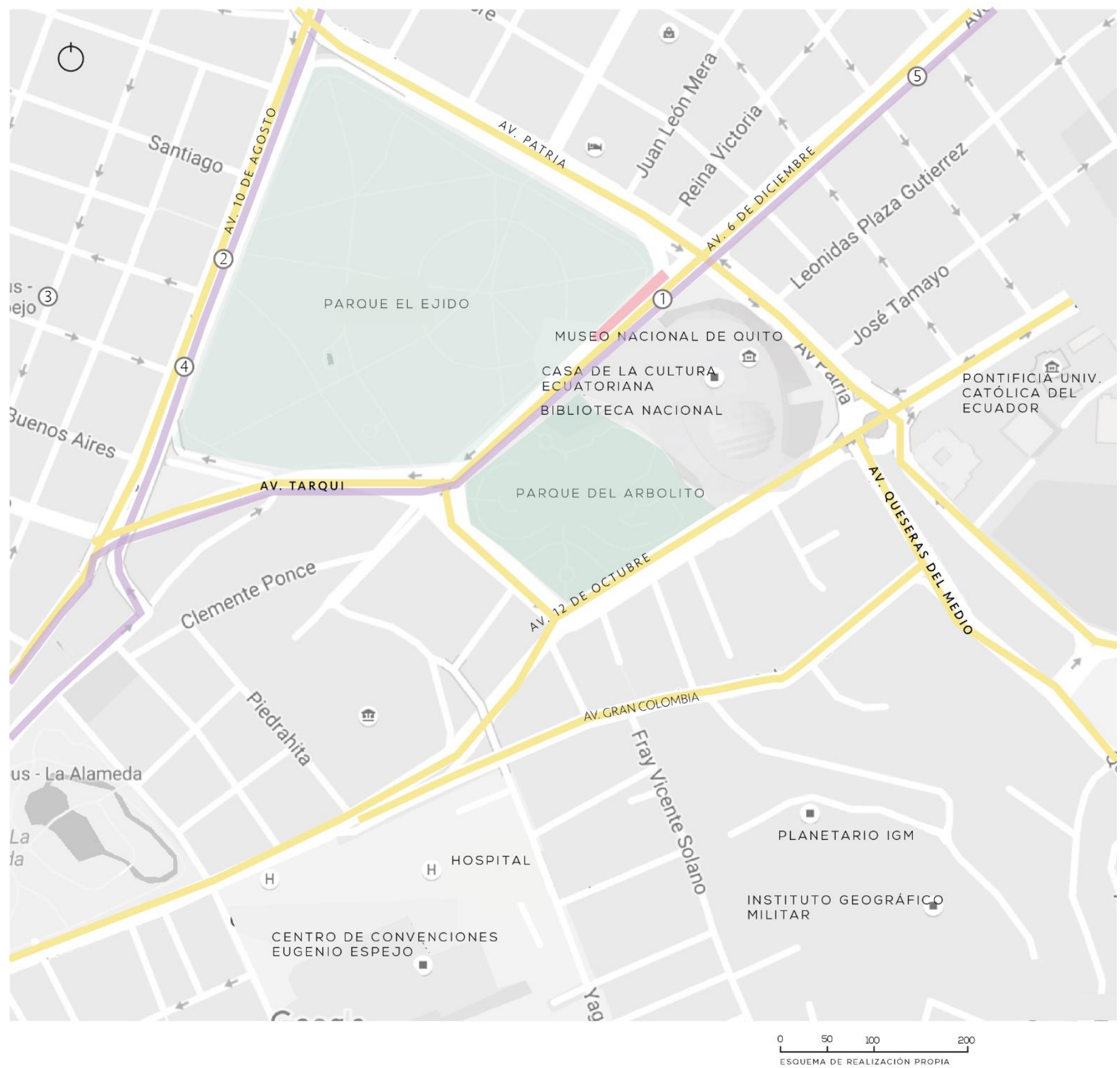

PRINCIPALES AUTOVIAS

RUTA DE AUTOBUSES

ESTACIÓN CASA DE LA CULTURA

(estaciones de autobuses

1 Ecovia - Casa de la Cultura

2 Trolebus-El Ejido

3 Av. América

4 Av. 10 de Agosto

5 Trolebus-Mariscal 


\subsubsection{Programa y relaciones programáticas}

\subsubsection{Relaciones programáticas}

Fuente: de elaboración propia, en base a planos del ayuntamiento

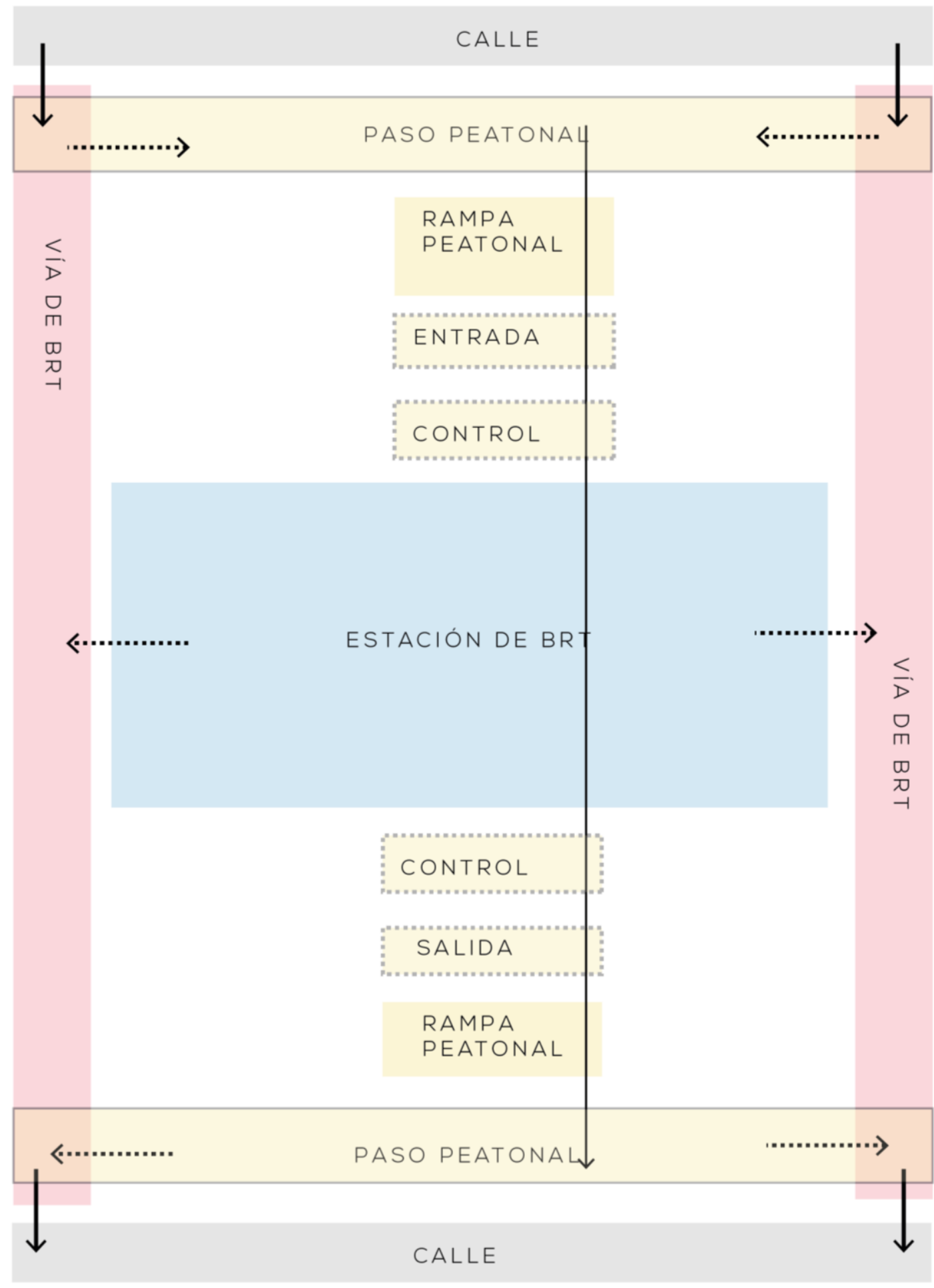




\subsubsection{Tipología espacial}

La tipología de la estación de la Cultura de la Ecovía, es estación de paso de BRT de Troncal de uso institucional (Rodriguez \& Vergel Tovar, 2013). Esto quiere decir que, la estación, se ubica y atiende a diversos usos institucionales como Bibliotecas, escuelas, universidades, teatros, hospitales, iglesias y todos los centros recreativos no orientados al sistema de transporte de BRT.

La estación se sitúa al centro de las vías de doble sentido de la Avenida, elevada aproximadamente $1.00 \mathrm{~m}$ sobre el nivel del suelo. La entrada a ambos lados provoca que el flujo dentro de la estación sea lineal.

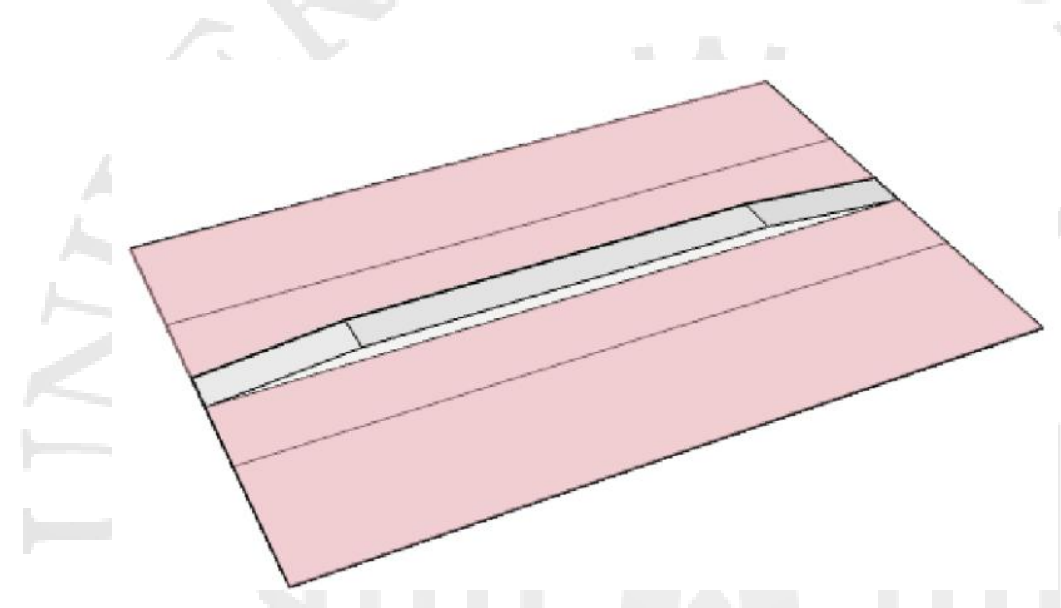

El emplazamiento de la estructura cumple con los radios y espacios necesarios para el flujo y espera de usuarios.

Formalmente, es una estación de estructura en arco, con total visual al exterior desde su interior.

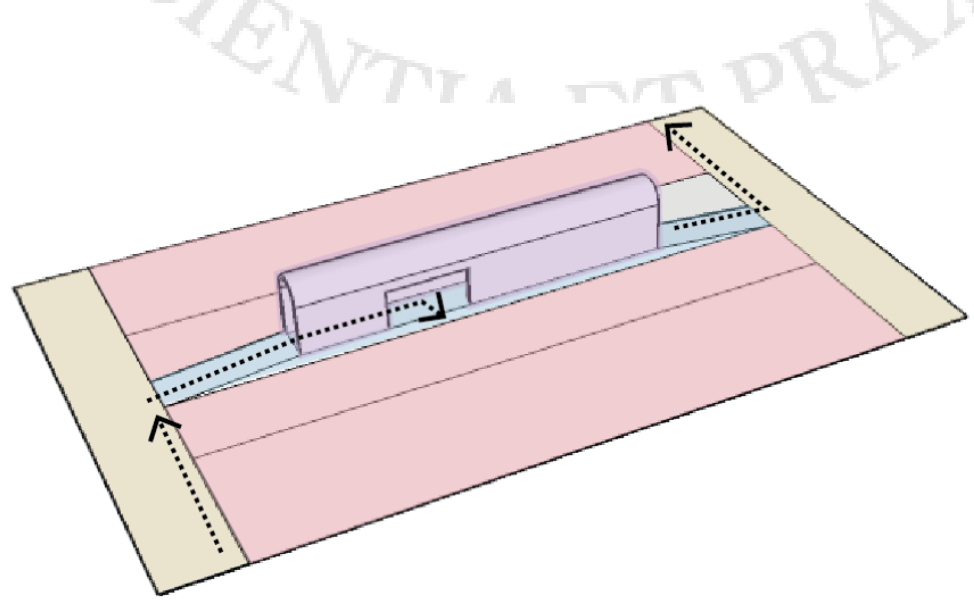




\subsubsection{Público Privado}

Fuente: de elaboración propia, en base a planos del ayuntamiento

PUBLICO

SEMI PUBLICO

PRIVADO

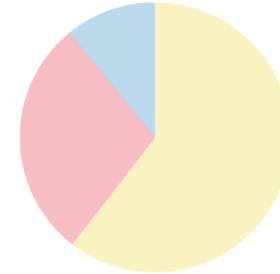

0
ÁREA LIBRE (89\%)*

ÁREA CONSTRUIDA (11\%)

a.<smiles>C1CCCC1</smiles>

PARQUE EL EJIDO

o ' CONTROL
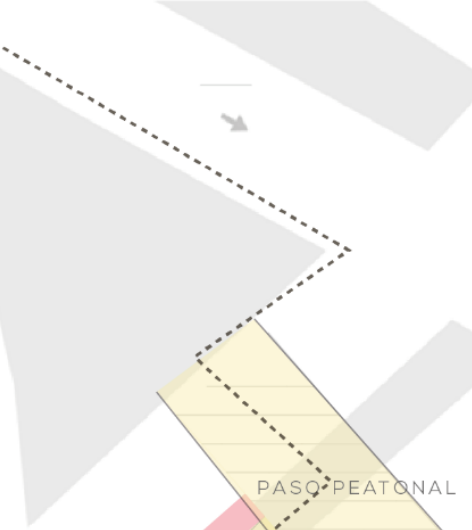

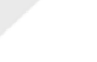
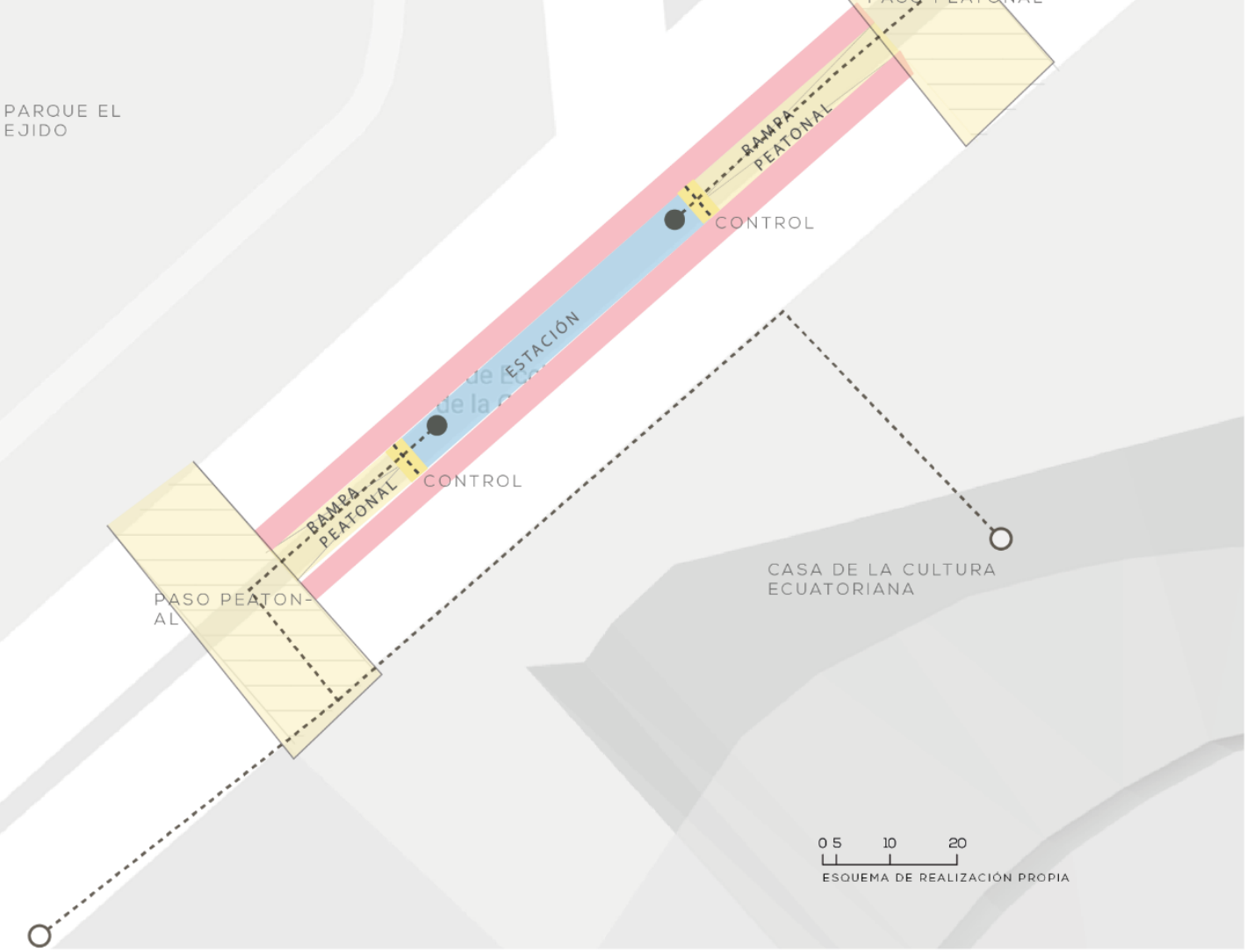


\subsubsection{Flujo del proyecto}

Fuente: de elaboración propia, en base a planos del ayuntamiento

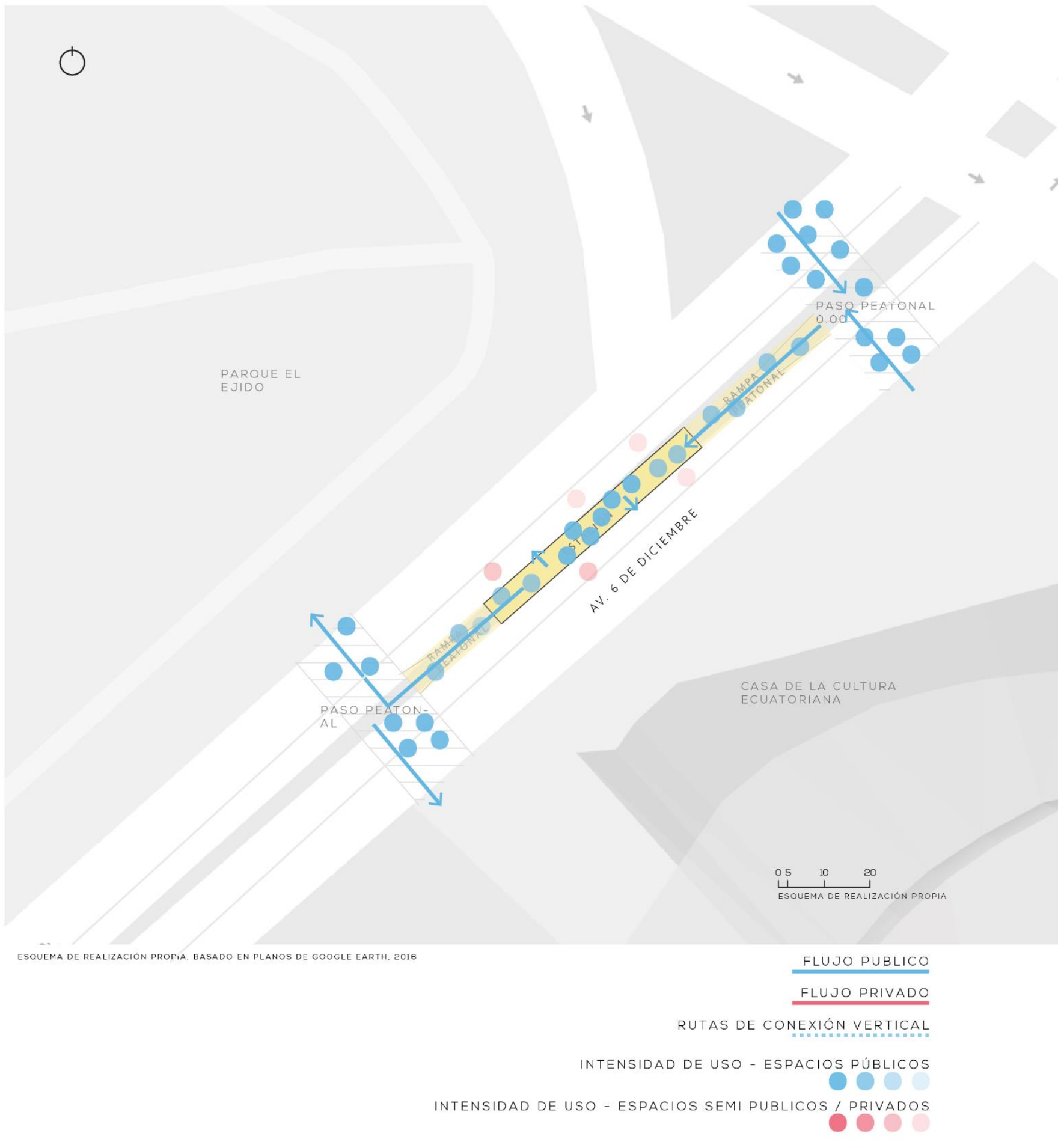




\subsubsection{Tecnología}

Actualmente, la Empresa Metropolitana de Movilidad y Obras Públicas (EPMMOP) es la encargada de la infraestructura vial, incluyendo a las estaciones. Se encuentran en un proyecto de desmontaje y modernización de 44 estaciones del Trolebús en Quito desde finales del 2015. El proceso que se lleva a cabo, será similar o igual para las estaciones de la Ecovía, por lo que lo tomaremos como referencia. (Alcaldía de Quito, 2015)

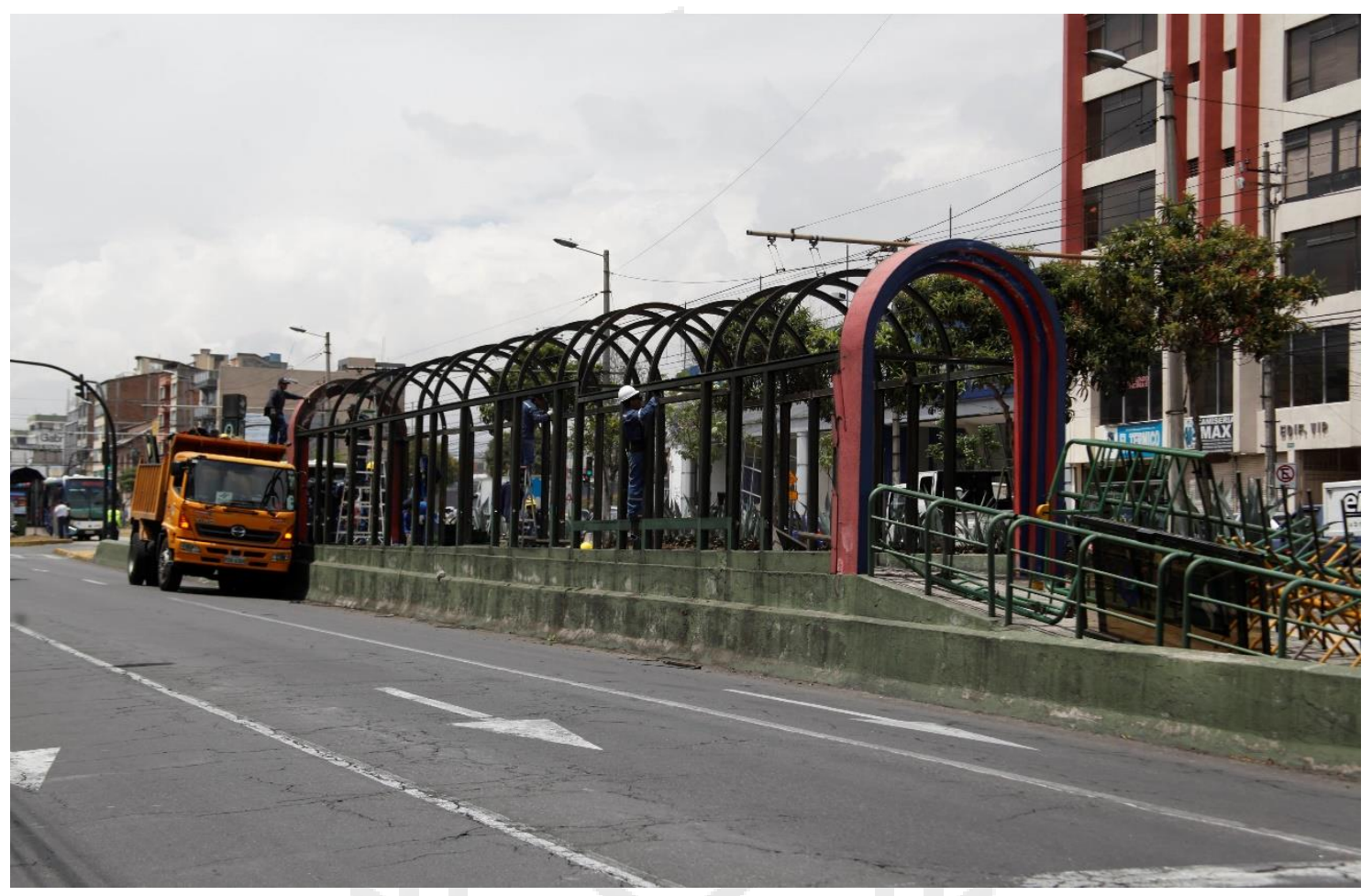

Imagen: Desmontaje Parada Marina Jesús Trolebús (Alcaldía de Quito, 2015)

Las actuales paradas de Trolebús y Ecovía se encuentran en un carril central, sobre cimientos de concreto y barandas simples de fierro. La estructura de la estación consiste en un conjunto de arcos metálicos con amarres intermedios. Los vanos laterales son de vidrio templado entre estructuras y la cubierta varía por estaciones, pero suele ser metálica.

El piso de la cabina de estación es de hormigón poroso

Sin embargo, la refacción de estaciones pretende ser amigable con todos los ciudadanos y el medio ambiente mediante el uso de la tecnología en materiales y sistemas. 


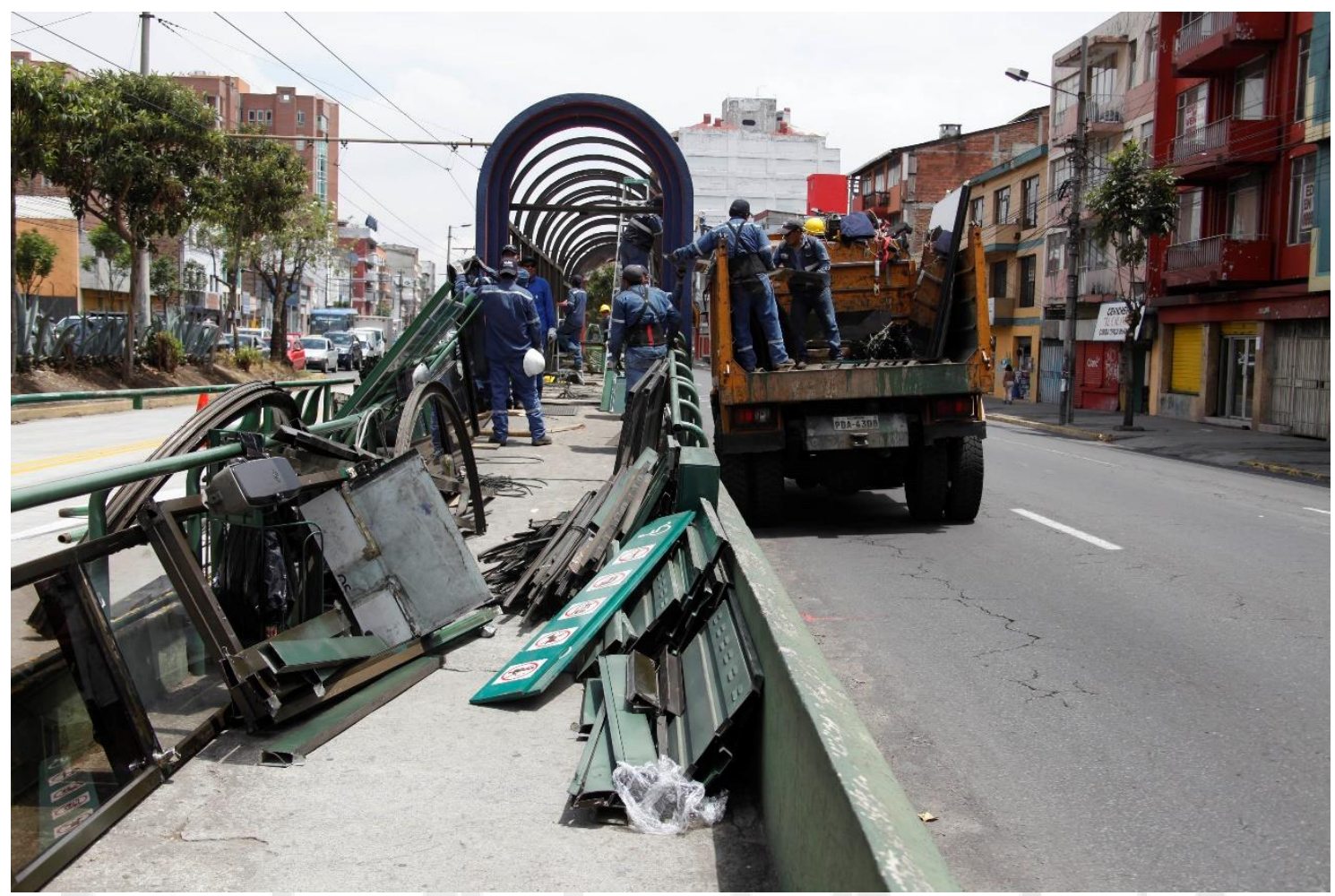

Imagen: Estación Trolebús (Alcaldía de Quito, 2015)

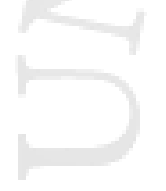

Aportamos al ornato de la ciudad son una réplica [sic.] del diseño de la parada Plaza del Teatro que posee iluminación led, tendrá techo verde con plantas, canalización de distribución de agua cristales transparentes y cámaras de video vigilancia para mayor seguridad, paradas inclusivas y universales con adhesivos podo táctiles para favorecer a las personas con discapacidad visual.

También tendrán pasamanos de doble altura, sistema de internet gratuito wifi y adaptables a las 80 nuevas unidades biarticuladas que el Municipio está adquiriendo actualmente. (Alcaldía de Quito, 2015)

La EPMMOP ejecutará cambios que ayudarán con problemas de visibilidad e iluminación que muchas veces vuelven peligrosa una estación. Se maximizará el espacio y las estaciones serán más transparentes con el nuevo sistema de mamparas. (Alcaldía de Quito, 2015) 
Además, se ejecutarán guías podo táctiles de fibra de carbono para personas con discapacidad visual, así como mobiliario cómodo y apto para quienes lo necesiten.

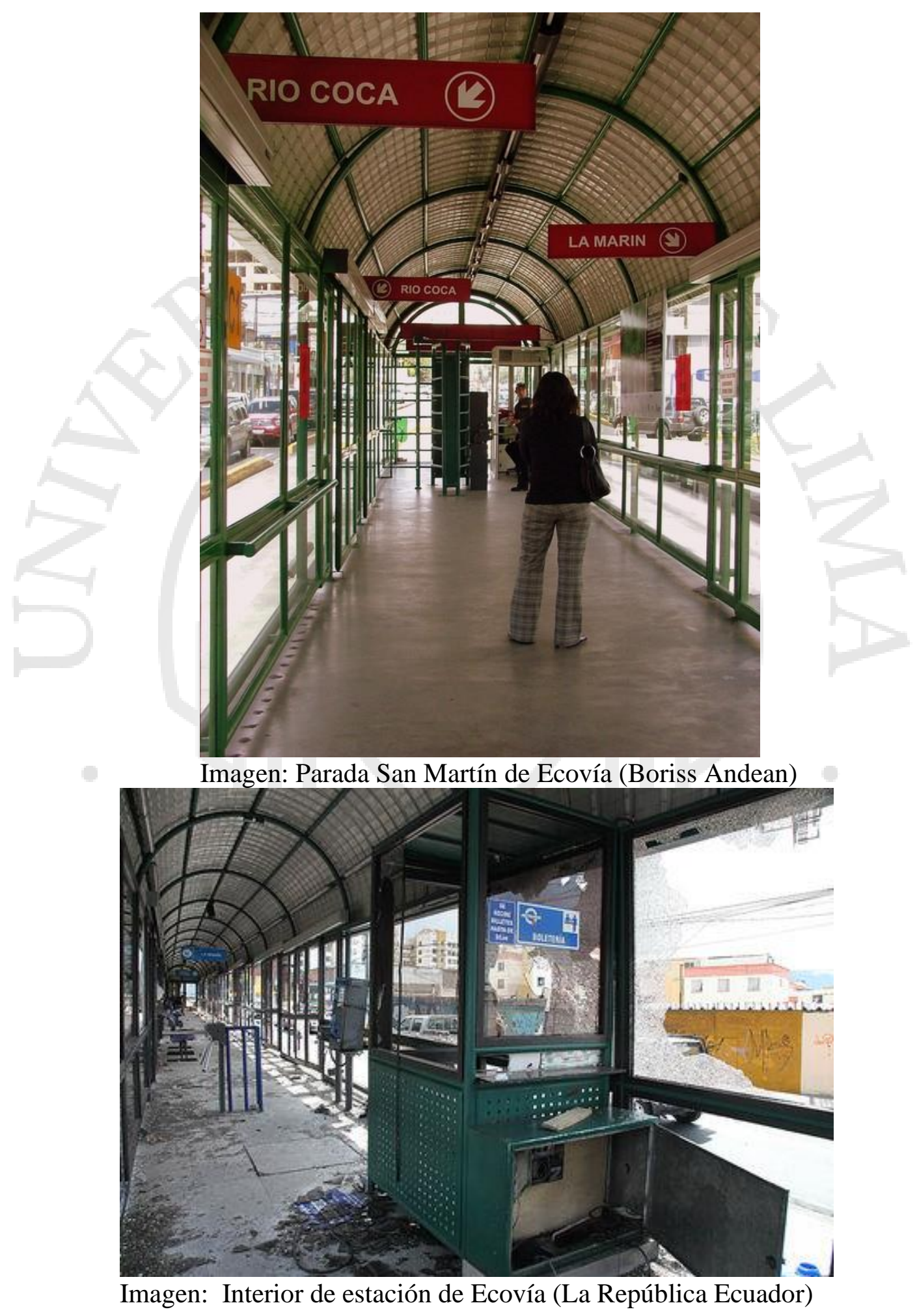




\subsubsection{Impacto Social}

La estación Casa de la Cultura de la Ecovía se encuentra en un nodo, como dice su nombre, cultural. Dentro de un radio de 300 metros de distancia, abarca el Parque el Arbolito y los equipamientos culturales dentro del mismo: La Casa de la Cultura Ecuatoriana, el Museo Nacional de Quito, El Ágora y la Biblioteca Nacional Del Ecuador Eugenio Espejo. También se encuentra adyacente al parque El Ejido. Al tener dos parques, uno a cada lado de la vía, la estación cumple con la función de dar prioridad al peatón. Conectar dos espacios públicos amplios a través de una vía de BRT es una cuestión que no debe olvidar velocidades menores a las del bus, como la de los ciudadanos.

Su tamaño no perjudica el ancho de las vías, pues, las vías del BRT solo mantienen la berma central durante el emplazamiento de la estación. Pasándola, las vías del bus se juntan, sin desperdiciar espacio central que ningún peatón puede aprovechar.

Por otro lado, dentro de un radio de influencia de menos de 500 metros se conecta con varias estaciones de Trolebús y, una a mayor distancia, se encuentra una estación del Metrobús, otros sistemas de transporte de Quito. Si bien no es una estación central ni intermodal, los pasajeros pueden conectar tramos de diferentes sistemas de transporte cerca de esta Estación.

4.5.7.1 Radio de influencia

La estación de Logroño, gracias a su ubicación, sirve como un elemento articulador, que la conecta desde el centro hacia el norte, sur, este y oeste.

Esta estación tiene proyección de atender entre 75,000 y 80,000 usuarios por día, en la ciudad de Logroño que tiene una población estimada de 150,876 personas según el Instituto Nacional de Estadística de España al 2016. La estación influencia a más de 50\% de la ciudad. (Google Inc., Instituto Nacional de Estadística, 2018) (Universidad Politécnica de Madrid, 2015) 


\section{Esquema: Radio de influencia}

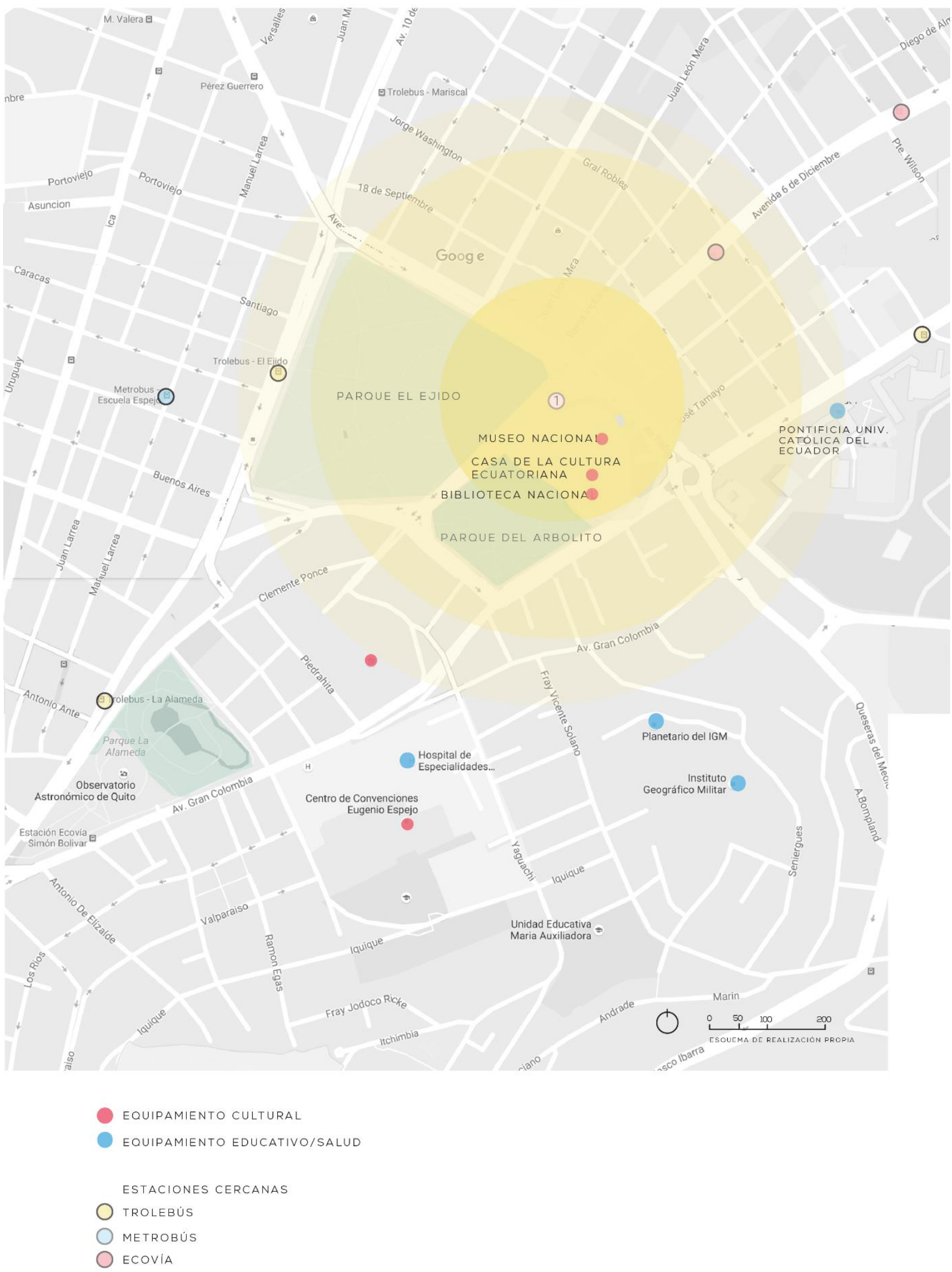




\subsection{Centro Cultural Gabriela Mistral, Santiago de Chile.}

\subsubsection{Historia}

\subsubsection{Datos del proyecto}

- Arquitecto: CFA Cristián Fernández Arquitectos

CFA arquitectos Lateral, arquitectura \& diseño. Cristián Fernández E., Christian Yutronic, Sebastián Baraona R., Loreto Figueroa A.

- Estado: Construido y en funcionamiento (Primera Etapa)

- Año de proyecto: 2009-2011

- Ingeniería: Luis Soler P.

- Colaboradores: Hernán Vergara H., Marcelo Fernández, Nicolás Olate V., Hernán Vergara, Nicolás Carbone, Juan Pablo Aguilera, Rodrigo Herrera, Eduardo Cid, Sebastián Bravo, Sebastián Medina, Ximena Conejeros, Irene Escobar, Ricardo Álvarez, Sebastián Bórquez, Rodrigo Carrión.

- Especialistas: Mecánica de Suelos: Geofun - Ingeniería Acústica: Thiele \& Sommerhoff - Iluminación: Douglas Leonard Lighting · Proyecto Eléctrico: Luis Farías - Instalaciones Sanitarias: Enrique Montoya - Ingeniería Eficiencia Energética: Cero Energías · Escenotecnia: Ramón López y Enrique Bordolini . Climatización: M \& R · Accesibilidad Universal: Proyecto Accesible

- Superficie Construida: $18.000 \mathrm{~m} 2$ aprox.

(Yutronic, s.f.)

\subsubsection{Toma de partido}

Los arquitectos inician el proceso de creación del Centro Cultural GM a partir de su entorno, pues hacía muchos años que no se relacionaba con la porción de ciudad que lo rodeaba. Sus oportunidades de espacio público para brindar al barrio fueron fundamental para el diseño. 
Nuestra estrategia de proyecto nos llevó a definir cuáles eran sus posibilidades para la ciudad y luego el edificio simplemente se amoldó a un diseño urbano que a nuestro entender re-fundaba la relación del lugar con su contexto convirtiéndose en exactamente todo lo contrario de lo que es hoy. En esa dirección las palabras de Jean Nouvel nos hicieron mucho sentido: "Un edificio contemporáneo en un sitio o proyecto existente es exitoso en la medida en que es capaz de realzar lo que lo rodea al mismo tiempo que se realza con lo que lo rodea". (Yutronic, s.f.)

Sin embargo, la propuesta técnico-expresiva parte del proyecto original ${ }^{29}$, reinventando los espacios y cualidades arquitectónicas según el nuevo programa cultural y público.

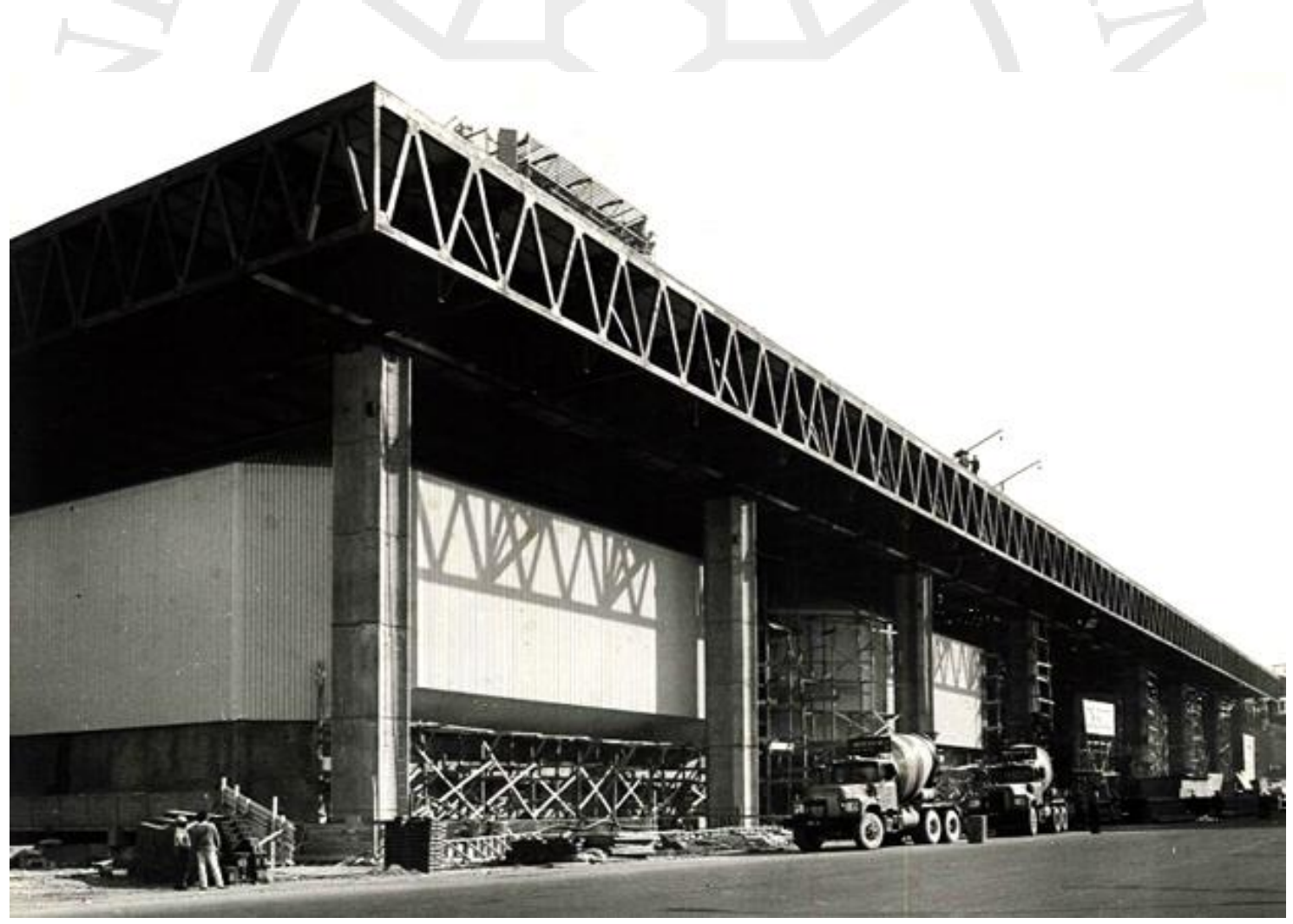

Fuente Fotografías Edificio Diego Portales: GAM

${ }^{29}$ Edificio Diego Portales, que sirvió de sustituto al Palacio de la Moneda cuando se incendió. Sin embargo, el mismo edificio sufrió un incendio también. 
Las principales ideas que rescatamos son cuatro, pero se pueden fundir en un único concepto de "transparencia". Estas son: la apertura hacia la ciudad y sus relaciones urbanas a través de una gran cubierta con volúmenes sueltos bajo ella; la creación de nuevo espacio público; la apertura del edificio a la comunidad con la incorporación de programa comunitario como comedores públicos; y la legitimación del proyecto a través de la incorporación de la mayor cantidad de agentes sociales en la configuración de un nuevo referente. (Yutronic, s.f.)
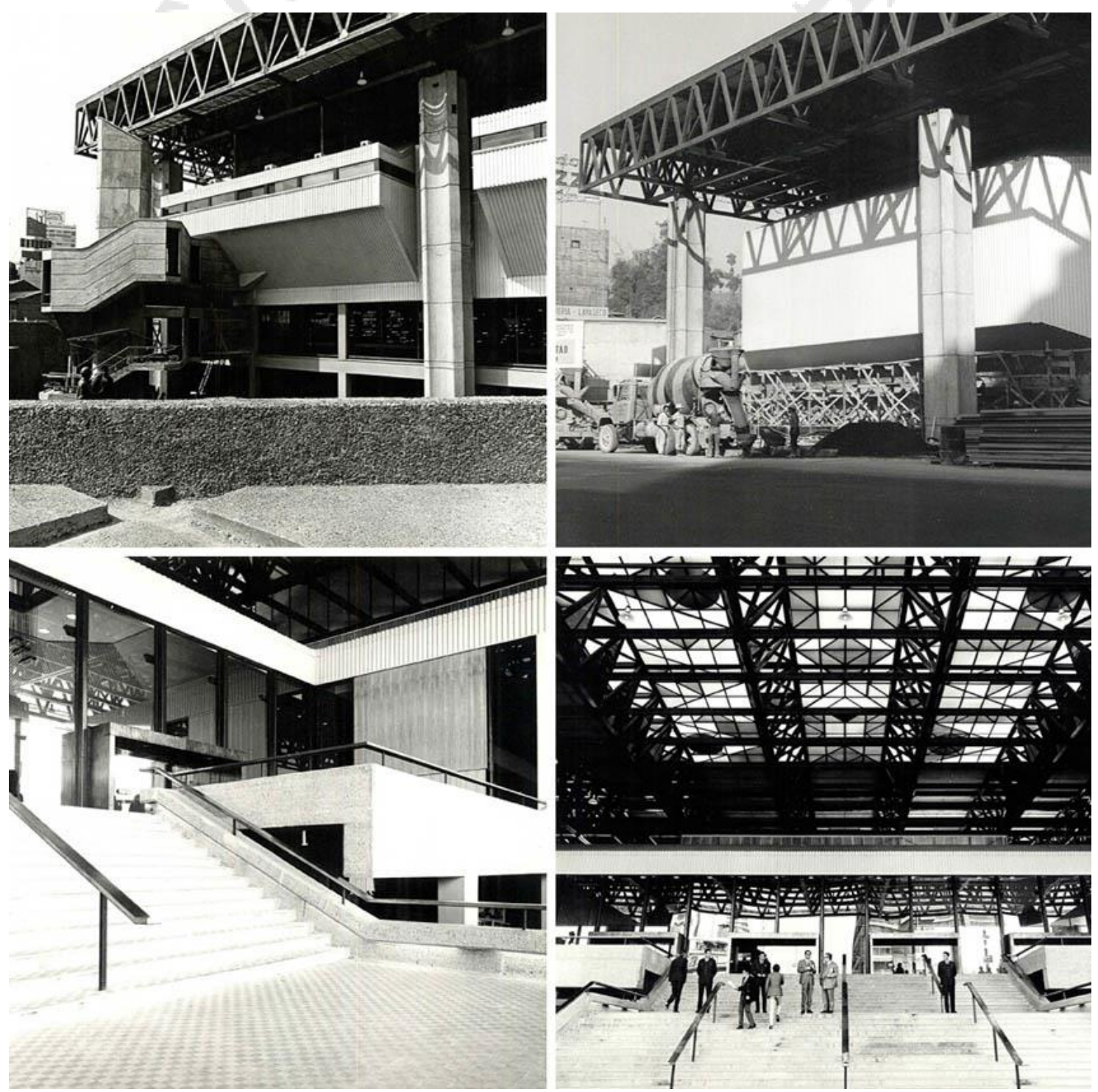

Fuente Fotografías Edificio Diego Portales: GAM 


\subsubsection{Línea de tiempo}

En 1972 fue construido en 275 días para la reunión de la Tercera Conferencia Mundial de Comercio y Desarrollo de las Naciones Unidas (UNCTAD III) durante el gobierno del presidente Salvador Allende. Su periodo como centro cultural Gabriela Mistral luego de eso fue breve, pues, tras el incendio del Palacio de la Moneda, debió ser la nueva sede. Esto produjo que se vea impermeabilizado y le de la espalda al barrio donde se emplazaba. Más, adelante, fue sede del Ministerio de Defensa y se le llamó edificio Diego Portales

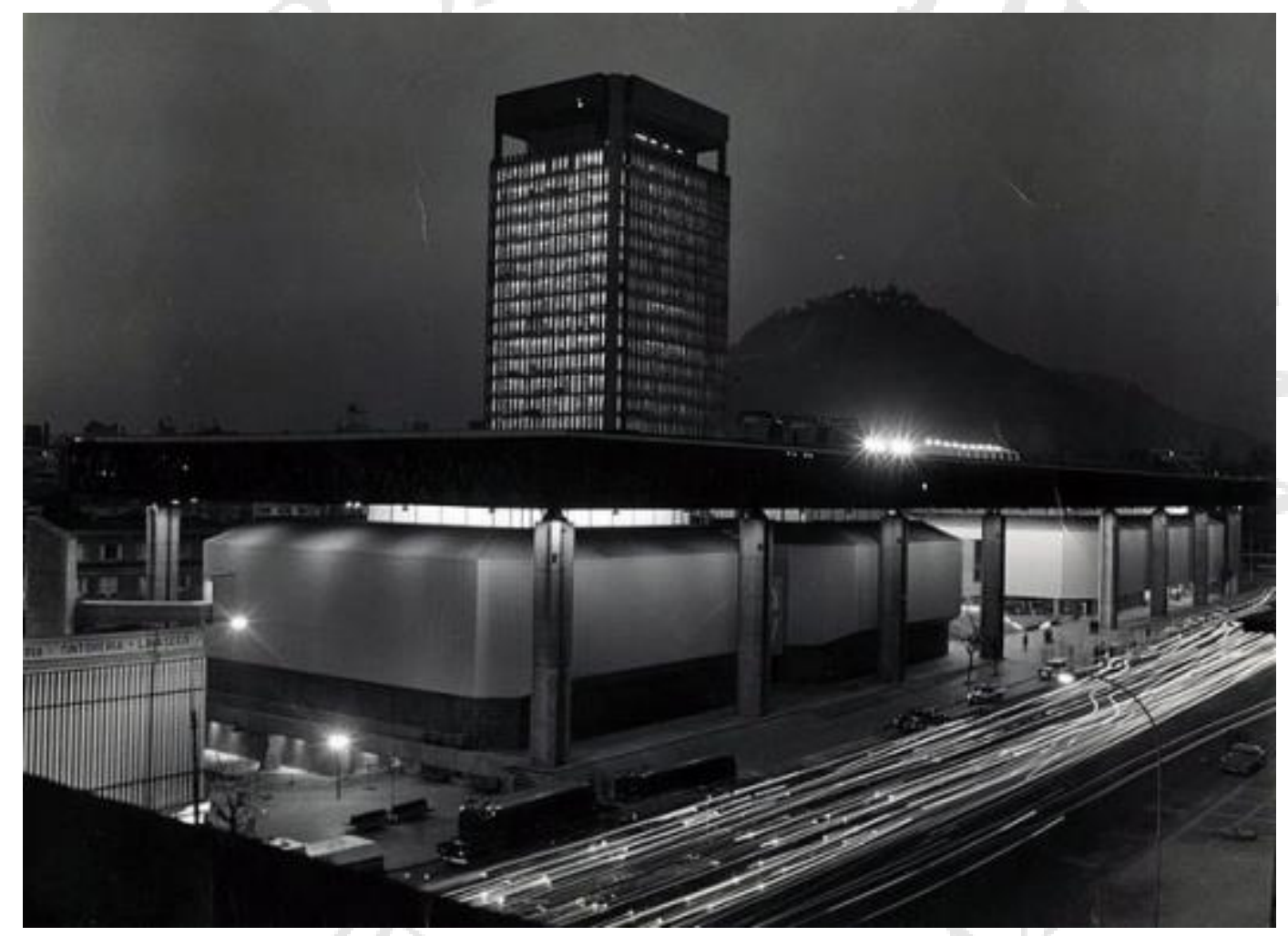

Vista nocturna del Edificio UNCTAD III, Santiago-1972. Fuente: Min. Relaciones Exteriores de Chile

Sin embargo, en 2006, un incendio comprometió la estructura del edificio y el gobierno replanteó las funciones del Ministerio de Defensa. Así, regresó a ser el Centro Cultural Gabriela Mistral.

En 2009 se inicia la construcción del nuevo centro, a cargo de Lateral. 


\subsubsection{Ubicación y relación con el entorno}

\section{Plano 4.6.2.1 Ubicación}

Fuente: de elaboración propia, en base a planos del GAM

MUSEO DE ARTES VISUALES

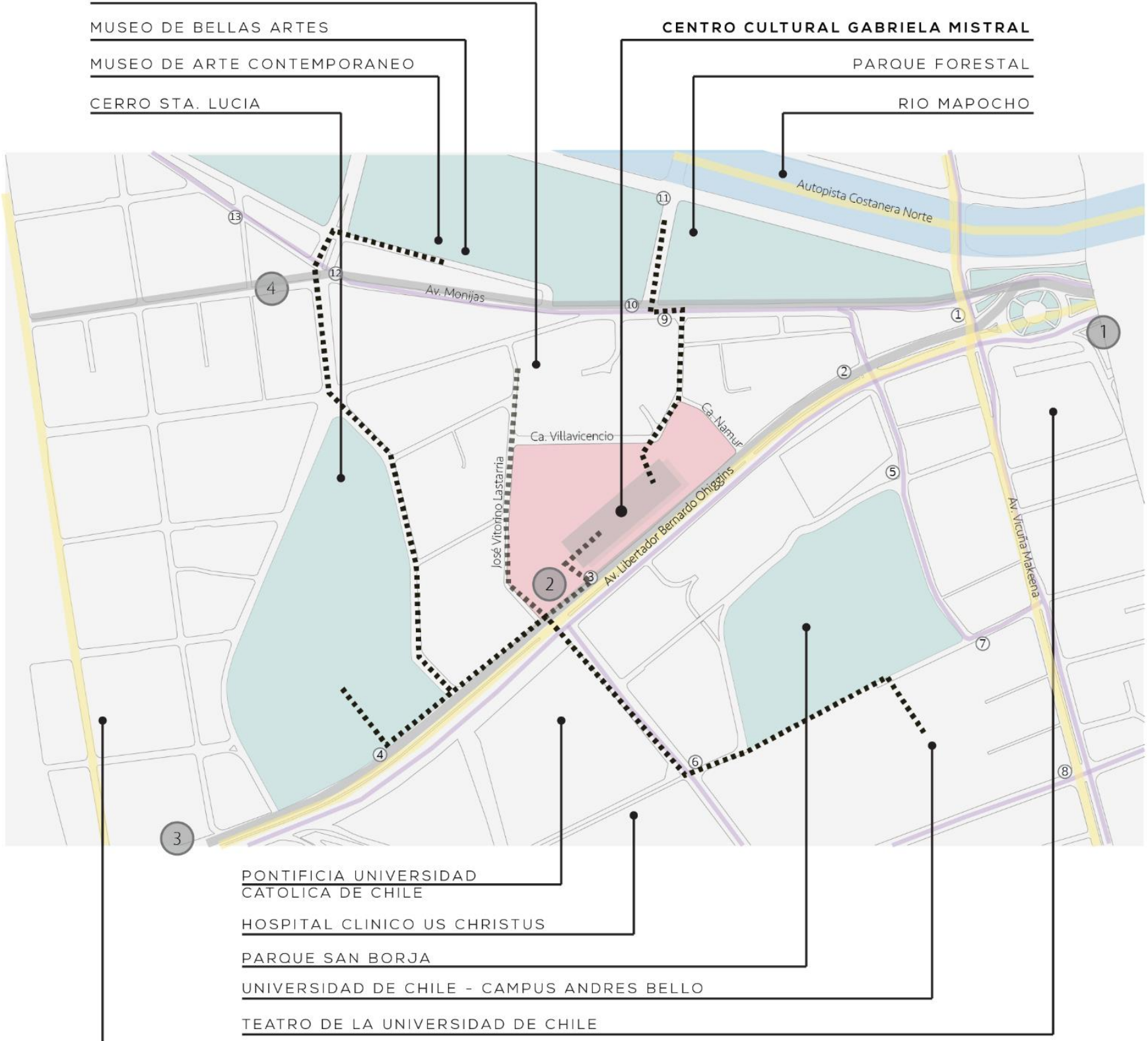

TEATRO MUNICIPAL DE SANTIAGO

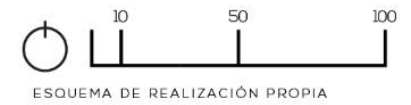

PRINCIPALES AUTOVIAS

LÍNEA DE TREN

RUTA DE AUTOBUSES

RUTAS PEATONALES

RIO MACHOPO

CENTRO CULTURLA

ESTACIONES DE AUTOBUSES

PA384 _ Plaza Italia

2 PA343 - Plaza Italia

3 PA42P - Universidad Católica

4 PA69P2 Universidad Católica

5 PAl71 - Universidad Catolica

6 PA715 _ Portugal

PA420 _ Diagonal Paraguay

8 PAl72 - Parque Bustamante

9 PA4OP - Parque Forestal

10 PA274 _ Parque Forestal

11 PA410 _ Puente Purisima

12 PA395 - Bellas Artes

13 PA260 - Miraflores 


\section{Plano 4.6.2.2 Ubicación inmediata}

Fuente: de elaboración propia, en base a planos del GAM
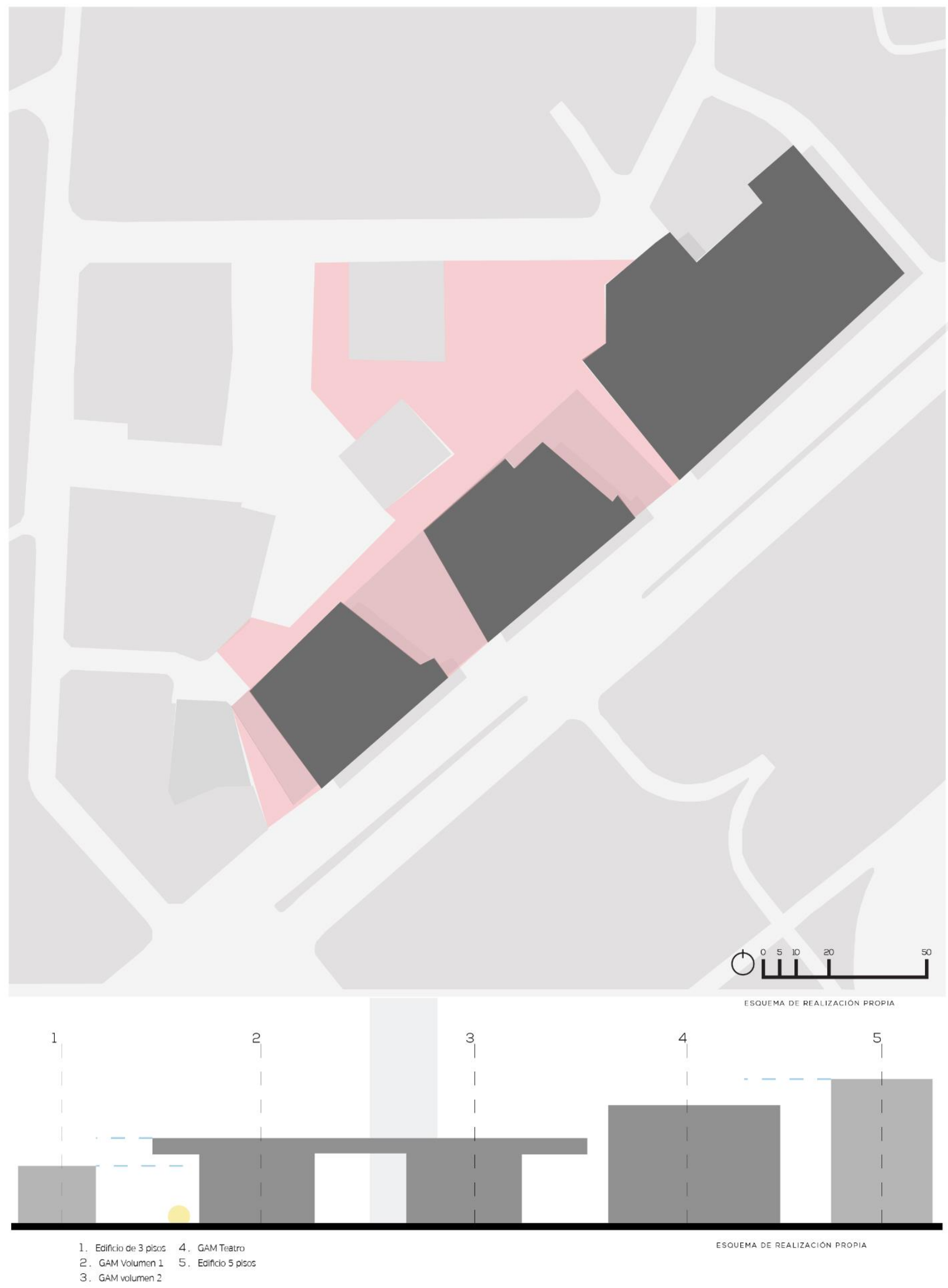


\subsubsection{Programa y relaciones programáticas}

Cuadro 4.6.2.1 Cuadro de áreas

Fuente: de realización personal, basado en planos de Lateral

\begin{tabular}{|c|c|c|c|c|}
\hline AREAS & SUB AREAS & $\begin{array}{c}\text { SUPERFICE } \\
\text { m2 }\end{array}$ & $\begin{array}{c}\text { AREA } \\
\text { TOTAL m2 }\end{array}$ & $\%$ \\
\hline $\begin{array}{l}\text { ESPACIO } \\
\text { PUBLICO }\end{array}$ & $\begin{array}{l}\text { Planta baja } \\
\text { Primer nivel } 1 \\
\text { SSHH } \\
\text { hall } \\
\text { Información }\end{array}$ & $\begin{array}{r}927 \\
4124 \\
54 \\
633 \\
68\end{array}$ & 5806 & 32.69 \\
\hline AUDITORIO & $\begin{array}{l}\text { Escenario } \\
\text { Sala de ensaño } \\
\text { Hall } \\
\text { SSHH } \\
\text { Vestuarios } \\
\text { Almacenes } \\
\text { Hall } \\
\text { Butacas } \\
\text { SSHH } \\
\text { Backstage } \\
\text { Hall } \\
\text { Butacas } \\
\text { SSHH } \\
\text { Tramoya } \\
\text { Butacas } \\
\text { Sistemas }\end{array}$ & \begin{tabular}{r|r}
867 \\
413 \\
266 \\
52 \\
514 \\
358 \\
460 \\
495 \\
152 \\
845 \\
306 \\
190 \\
43 \\
547 \\
190 \\
58
\end{tabular} & 5756 & 32.40 \\
\hline COMERCIO & $\begin{array}{l}\text { Comercio } 1 \\
\text { Comercio } 2 \\
\text { Comercio } 3 \\
\text { Comercio } 4 \\
\text { Comercio } 5\end{array}$ & $\begin{array}{l}160 \\
180 \\
234 \\
145 \\
160 \\
\end{array}$ & 879 & 4.948 \\
\hline ADMINISTRACION & $\begin{array}{l}\text { SSHH } \\
\text { Área de trabajo }\end{array}$ & $\begin{array}{r}54 \\
407 \\
\end{array}$ & 461 & 2.595 \\
\hline GALERIA & SSHH & 38 & 852 & 4.796 \\
\hline
\end{tabular}




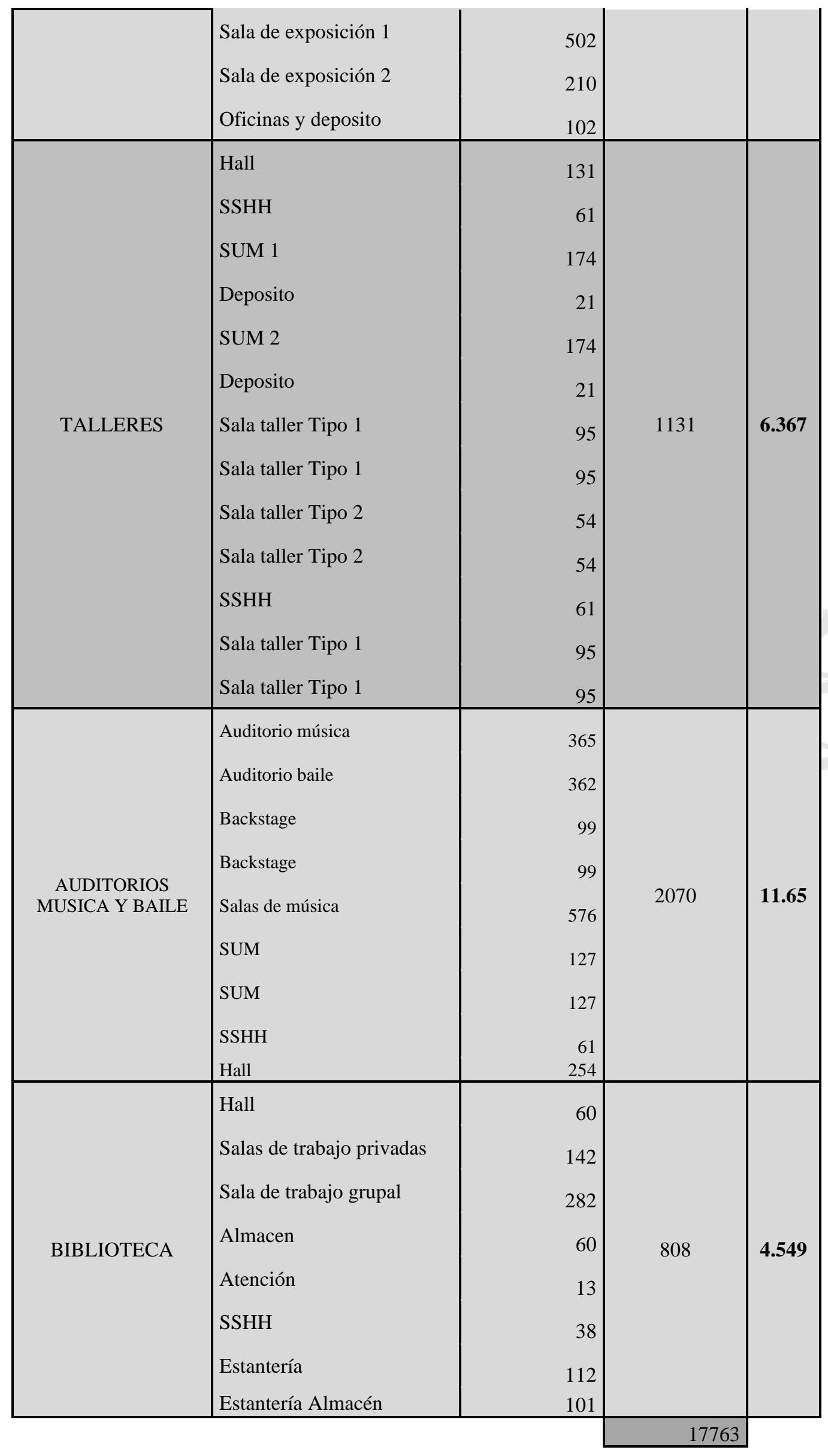




\subsubsection{Tipología espacial}

El Centro Cultural Gabriela Mistral tiene la tipología de un volumen permeable y pasante a través de parte de la primera planta. Los programas se ubican alrededor del espacio abierto.

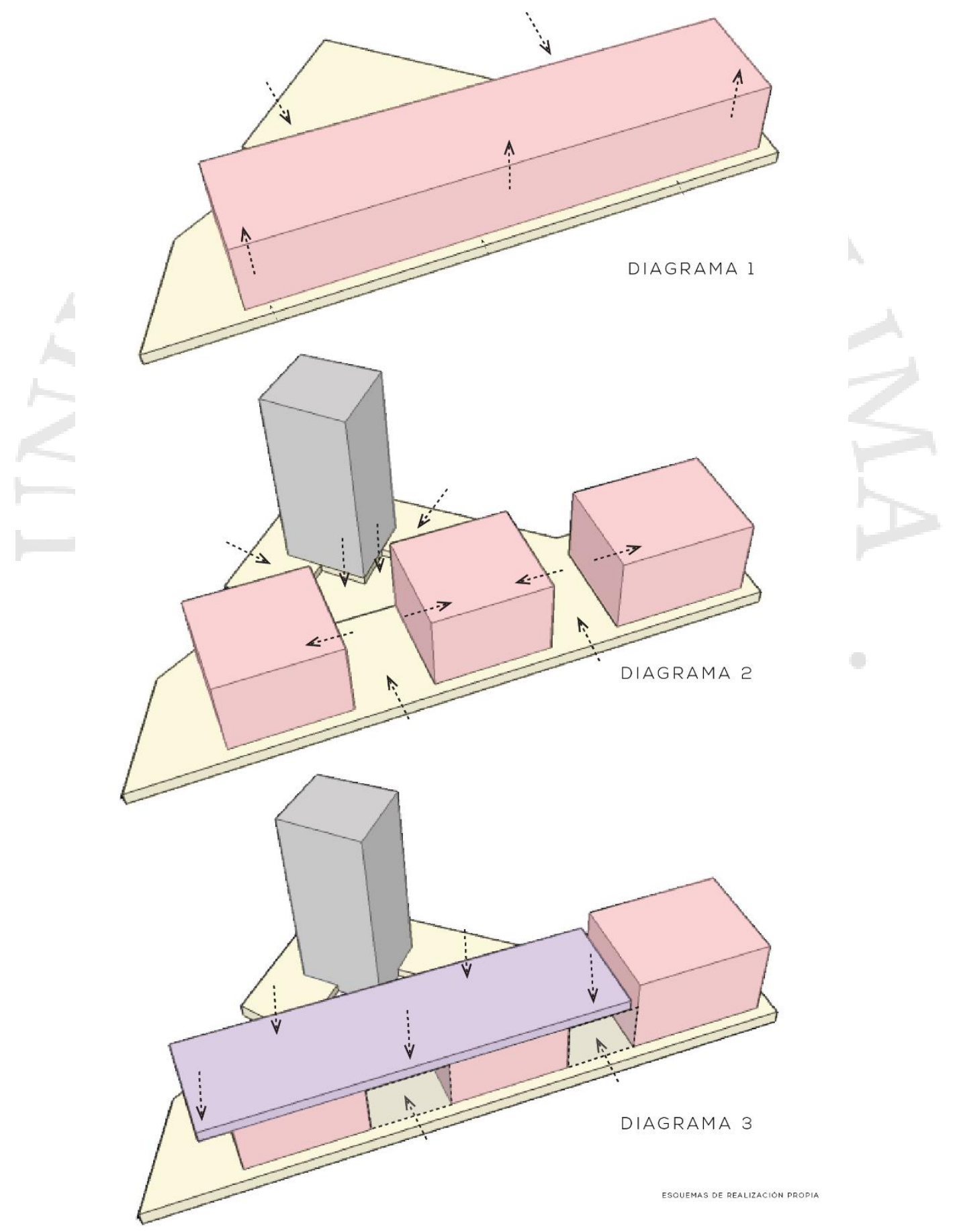




\subsubsection{Público Privado}

Fuente: de elaboración propia, en base a planos del GAM
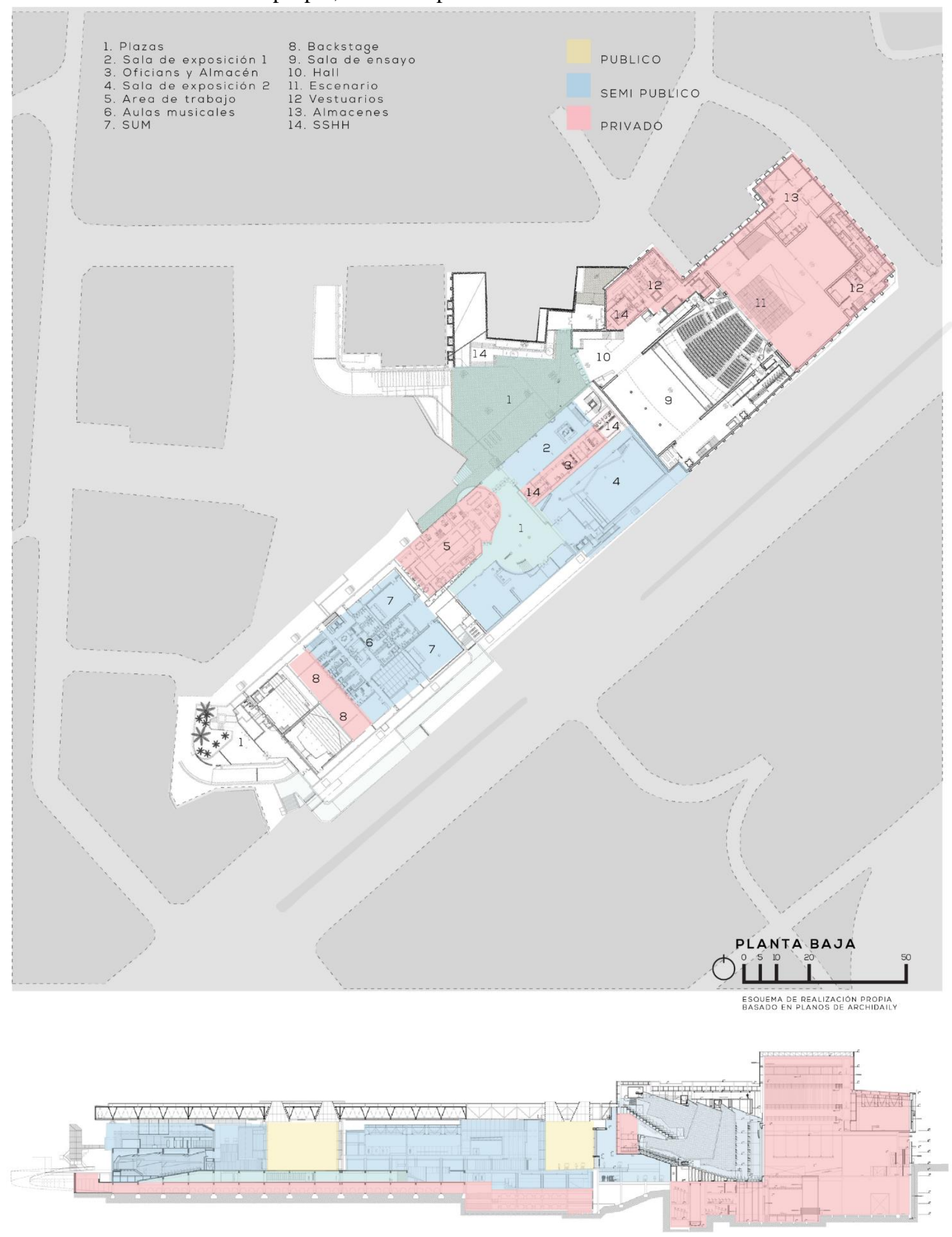
Fuente: de elaboración propia, en base a planos del GAM

$$
\begin{aligned}
& \text { 1. Plazas } \\
& \text { 2. Hall } \\
& \text { 3. Comercio } \\
& \text { 4. Auditorio } \\
& \text { 5. SsHH } \\
& \text { 6. Butacas } \\
& \text { 7. Backstage } \\
& \text { 8. Vestuarios }
\end{aligned}
$$

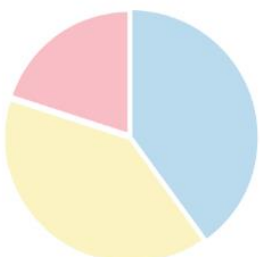

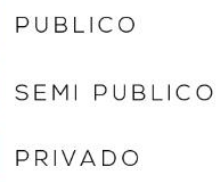

ANÁLISIS INCLUYE A TODAS LAS PLANTAS

$\sqrt{4}$ 8 $1^{35}$ 3
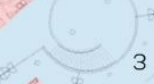
Fuente: de elaboración propia, en base a planos del GAM
1. Hall
2. SUM
3. Taller
5. SSHH
6. Butacas
7. Sistemas

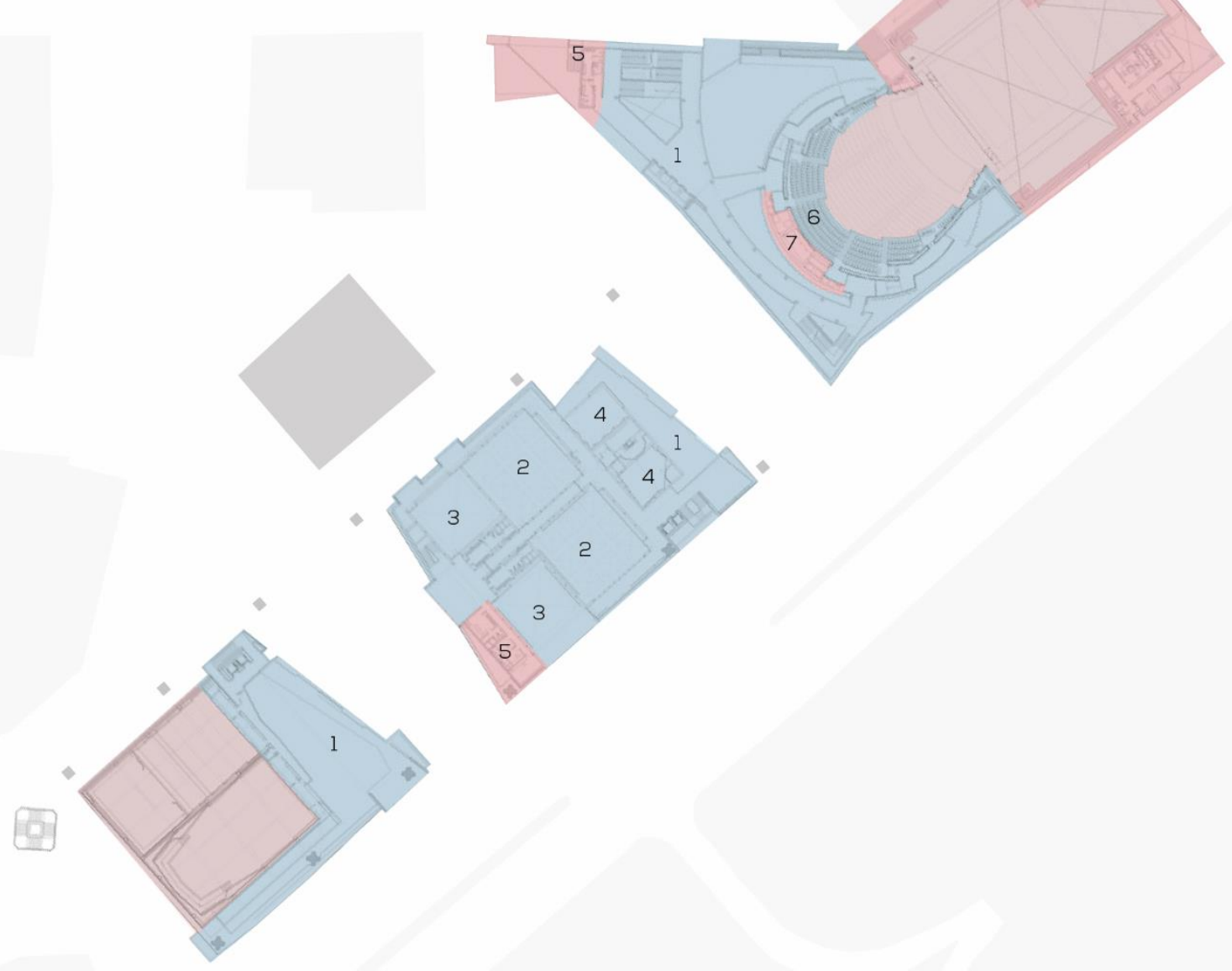

SEGUNDA PLANTA

${ }^{\circ} \mathrm{LI}^{5} \mathrm{~L}^{10}$

ESOUEMA DE REALIZACIÓN PROPIA
BASADO EN PLANOS DE ARCHIDAILY 


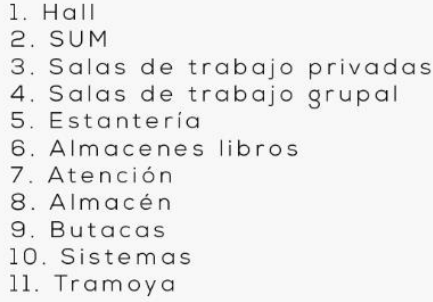

11. Tramoya

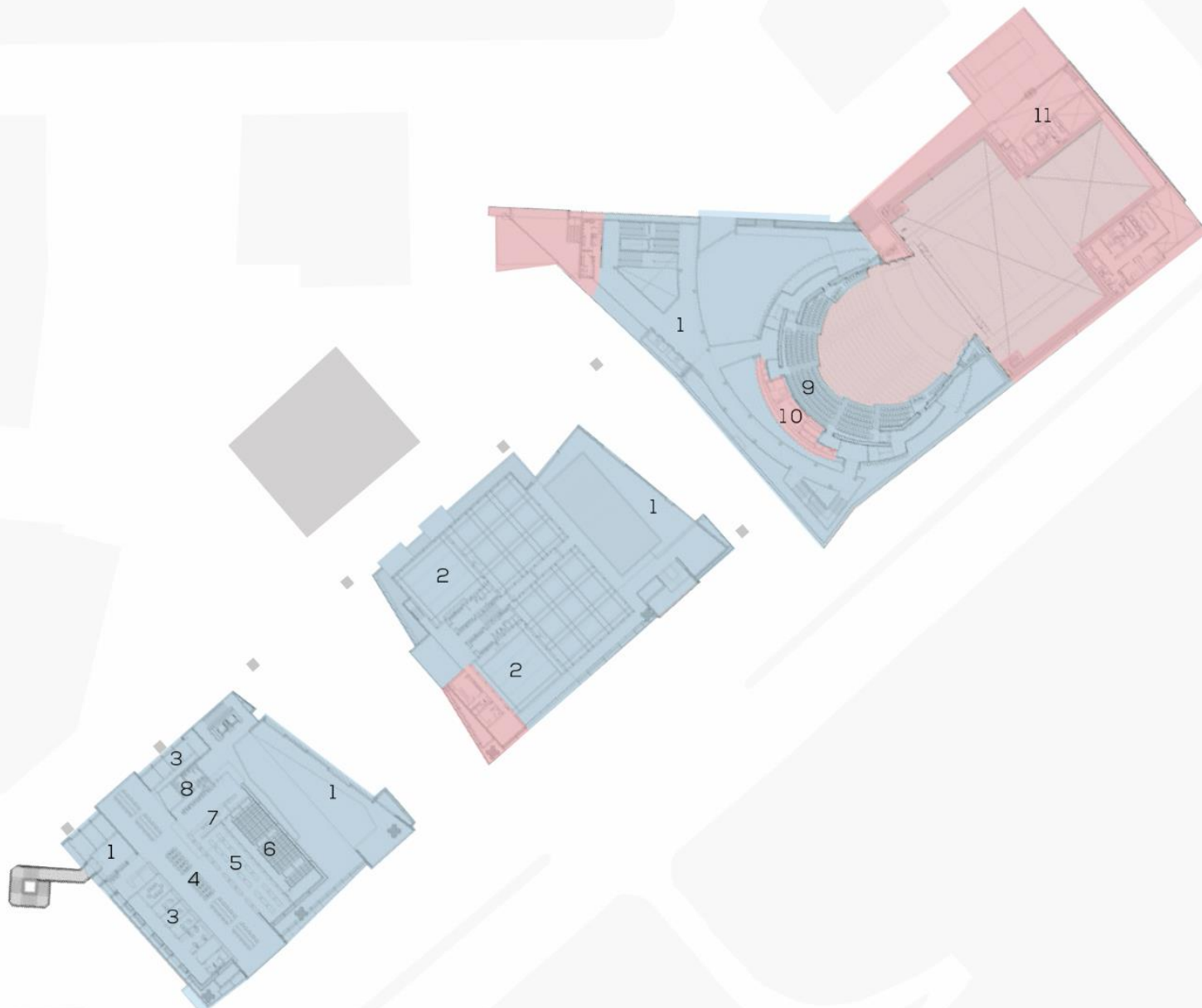

TERCERA PLANTA

$O \mathrm{~L}^{5}{ }^{10}{ }^{20}$

ESOUEMA DE REALIZACION PROPIA
BASADO EN PLANOS DE ARCHIDALY 


\subsubsection{Flujos del proyecto}

Fuente: de elaboración propia, en base a planos del GAM

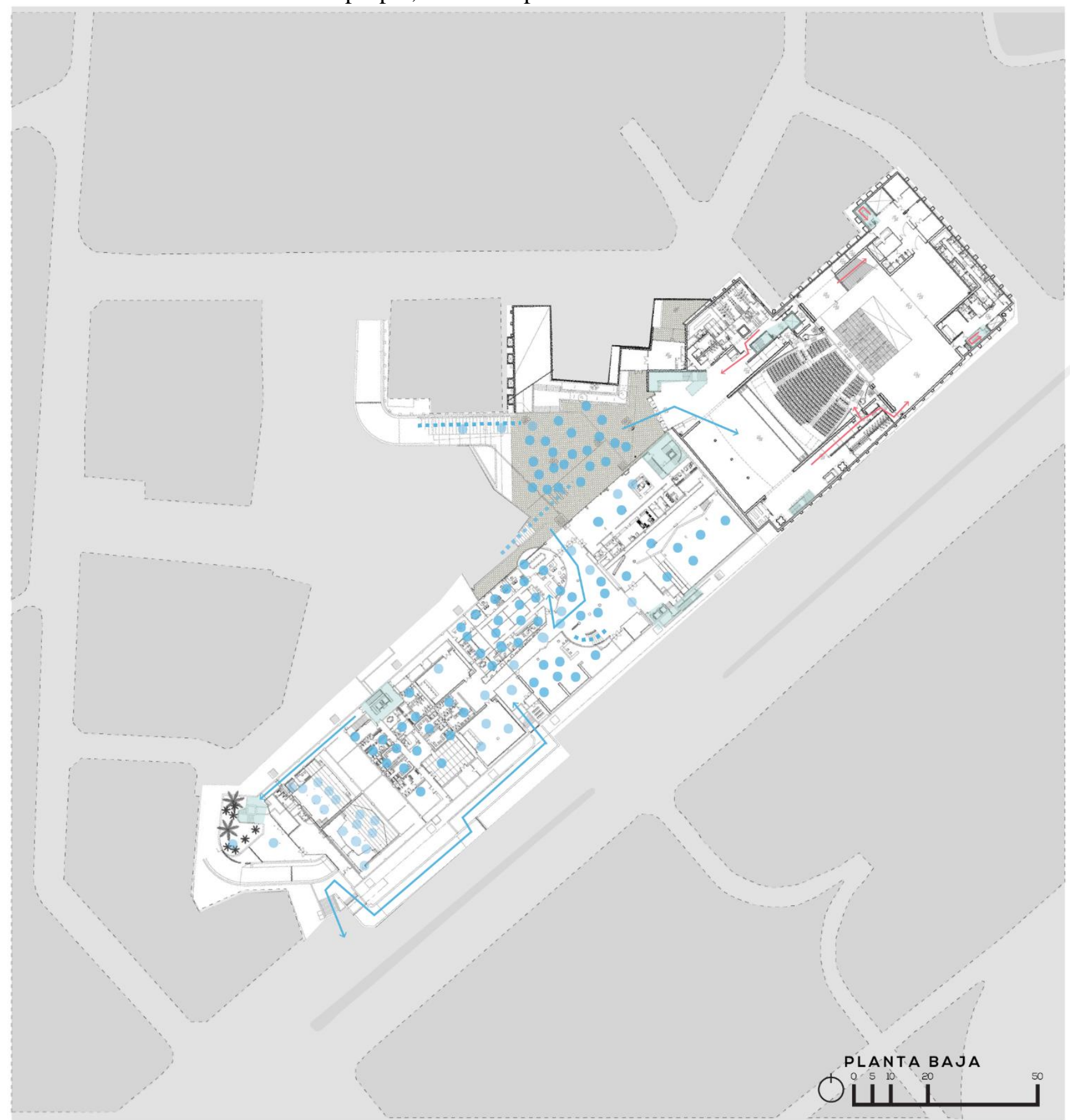

ESOUEMA DE REALIZACION PROPIA
BASADO EN PLANOS DE ARCHIDALY

FLUJO PUBLICO

FLUJO PRIVADO

RUTAS DE INGRESO PEATONAL

CIRCULACIONES VERTICALES 
Fuente: de elaboración propia, en base a planos del GAM

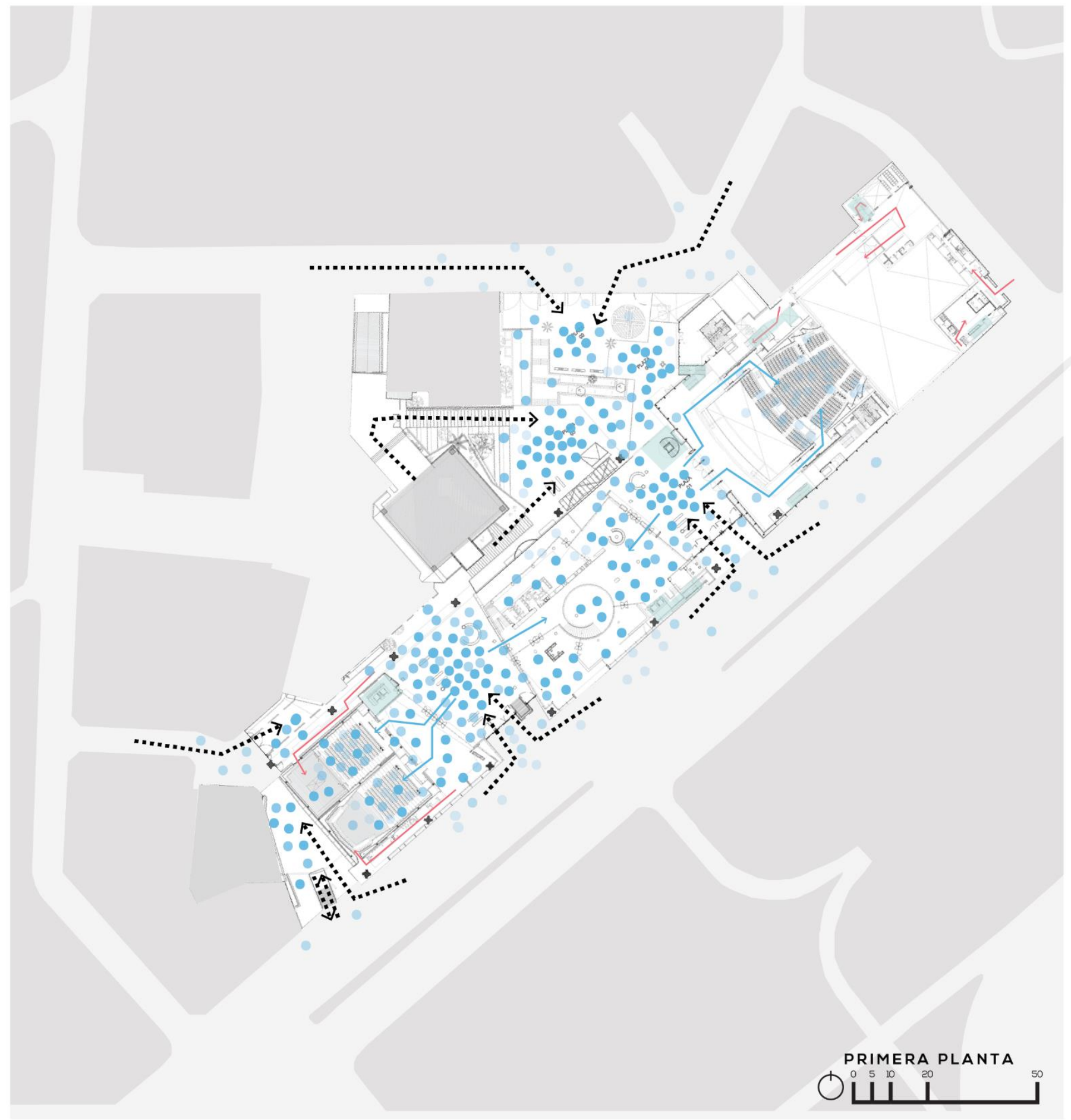

ESQUEMA DE REALLZACION PROPIA
BASADO EN PLANOS DE ARCHIDAILY

FLUJO PUBLICO

FLUJO PRIVADO

RUTAS DE INGRESO PEATONAL

CIRCULACIONES VERTICALES 
Fuente: de elaboración propia, en base a planos del GAM
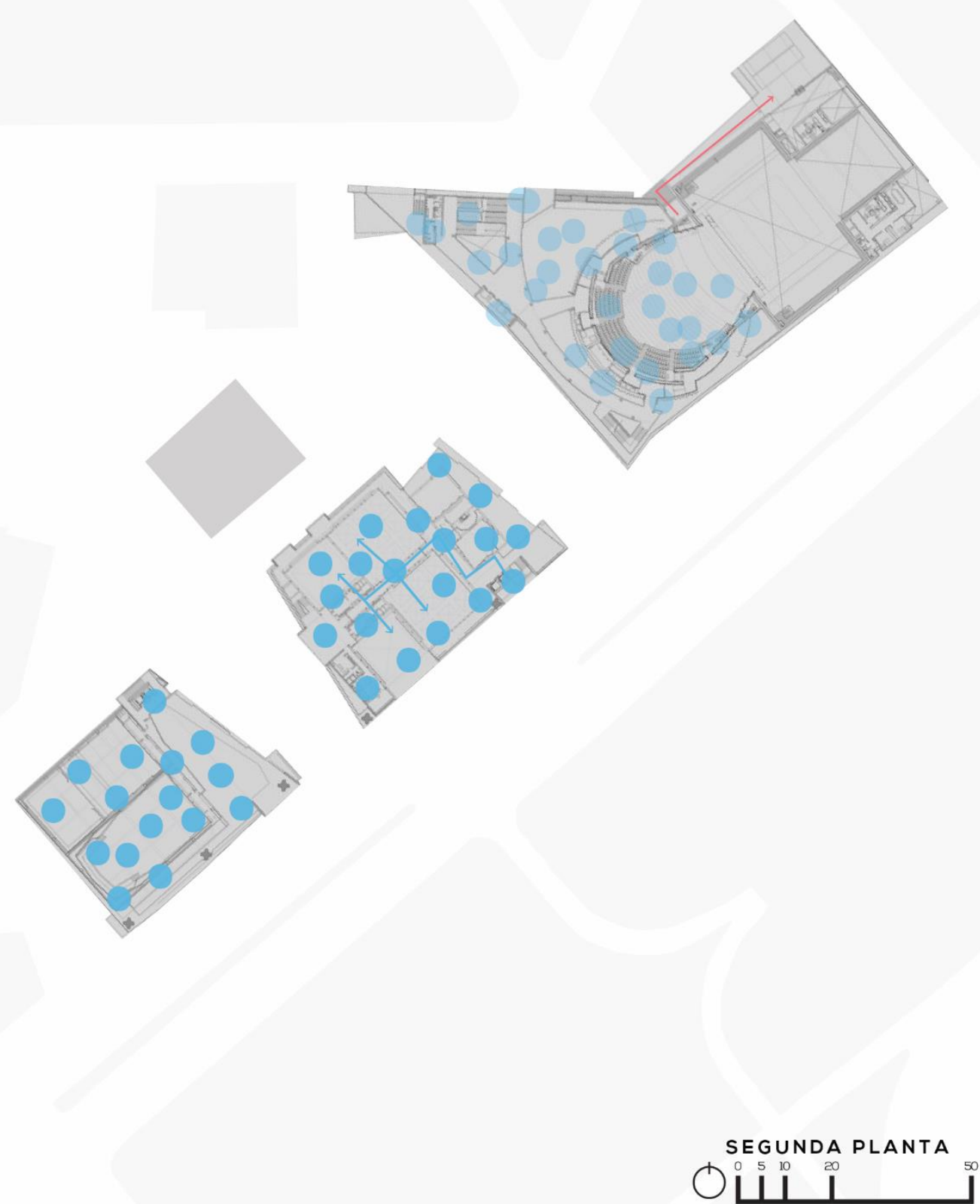

ESQUEMA DE REALIZACION PROPIA
BASADO EN PLANOS DE ARCHIDAILY

FLUJO PUBLICO

FLUJO PRIVADO

RUTAS DE INGRESO PEATONAL

CIRCULACIONES VERTICALES 
Fuente: de elaboración propia, en base a planos del GAM

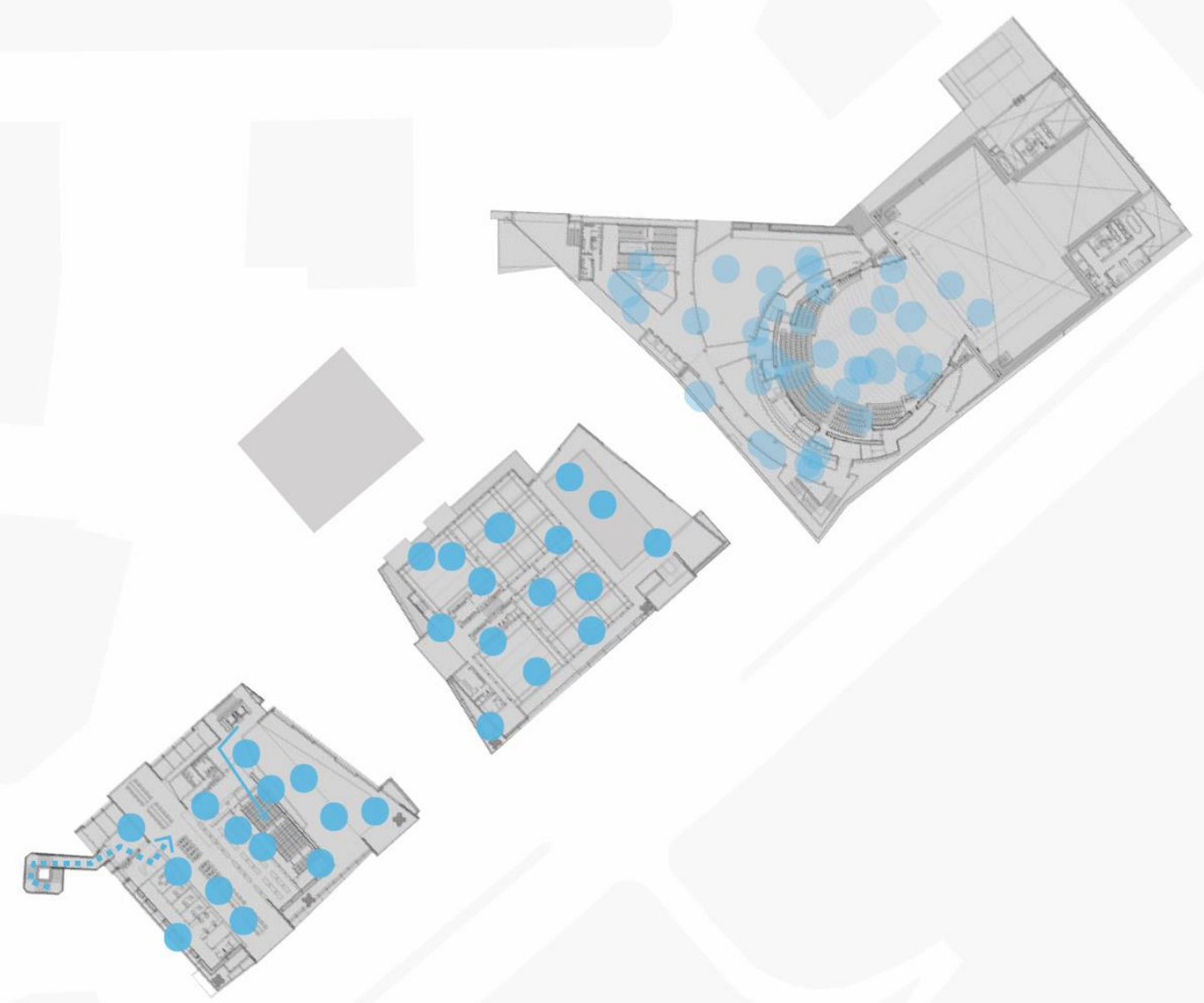

لـ

ESOUEMA DE REALLZACION PROPIA
BASADO EN PLANOS DE ARCHIDAILY

FLUJO PUBLICO

FLUJO PRIVADO

RUTAS DE INGRESO PEATONAL

CIRCULACIONES VERTICALES

INTENSIDAD DE USO - ESPACIOS PÚBLICOS 


\subsubsection{Relaciones programáticas}

Fuente: de elaboración propia, en base a planos del GAM
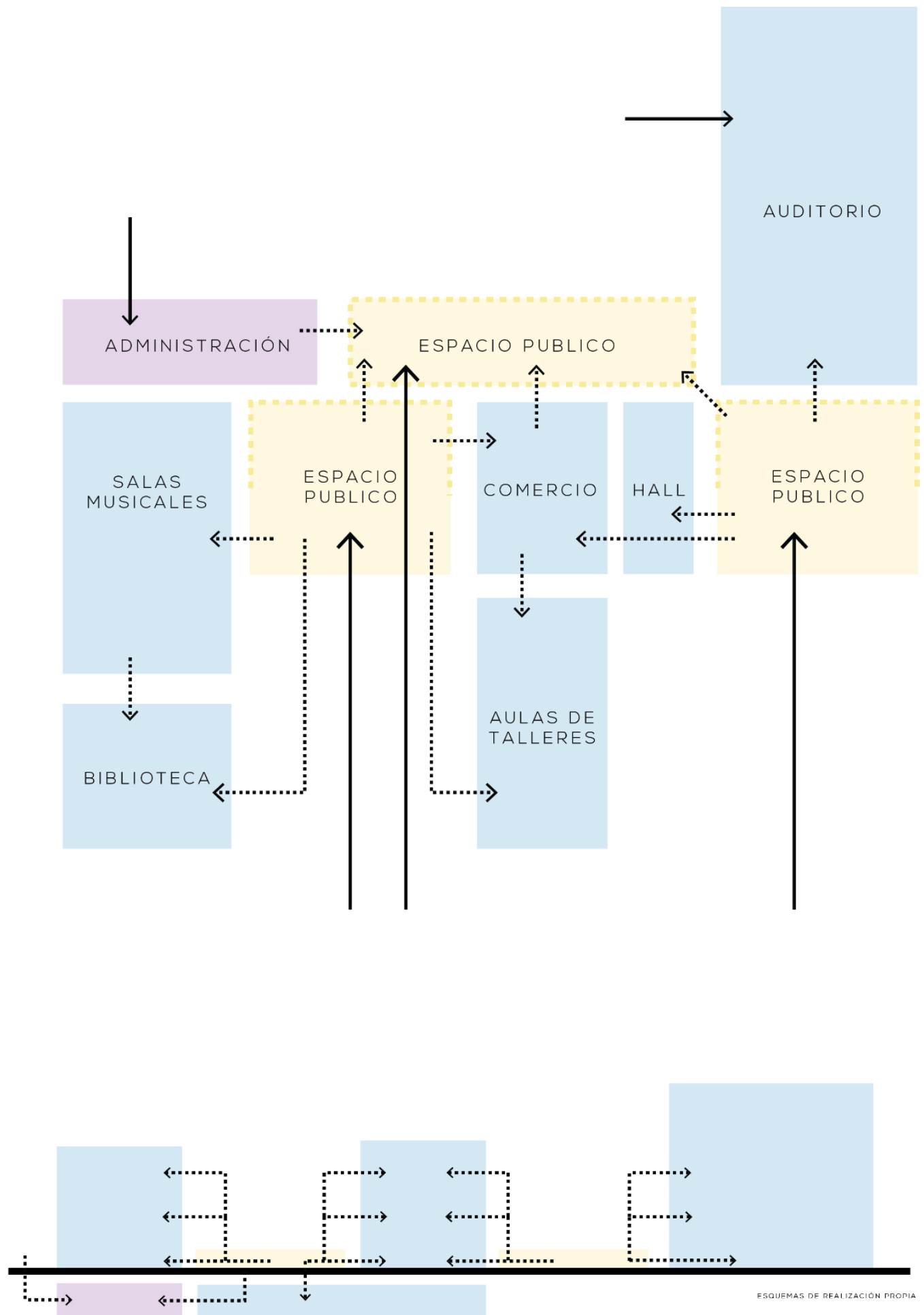


\subsubsection{Organigrama de espacios}

Fuente: de elaboración propia, en base a planos del GAM

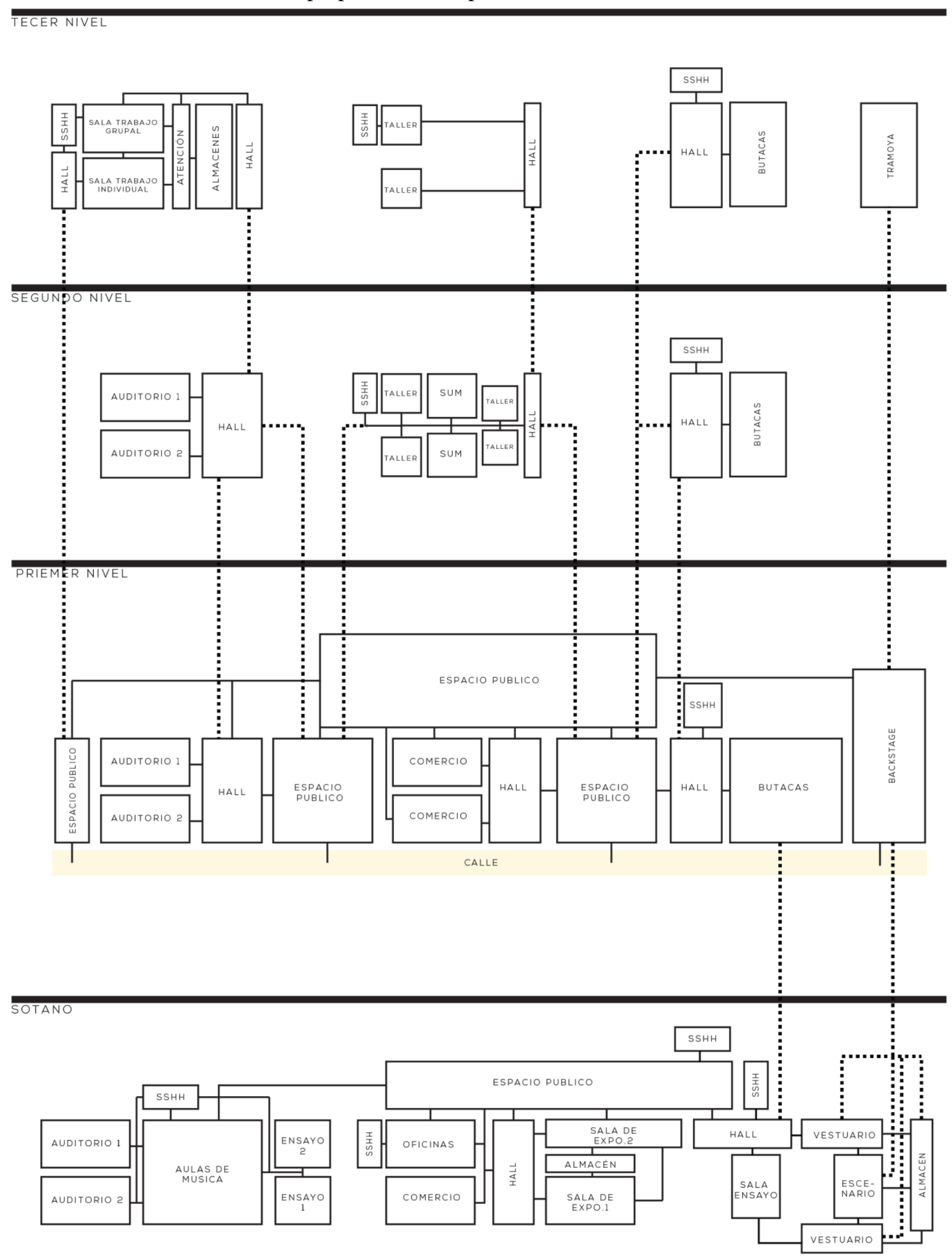




\subsubsection{Tecnología}

Los arquitectos del nuevo Centro Cultural Gabriela Mistral, posterior al último incendio, decidieron rescatar cinco principales elementos arquitectónicos y constructivos. Estos fueron: el uso del acero corten, el hormigón armado a la vista, el cristal, el acero y la madera. (Yutronic, s.f.) Además, cada uno de los materiales debía mostrarse al límite de su expresividad, sin aplicaciones ficticias ni tratamientos que negaran la naturaleza de cada uno de ellos.

El acero corten fue el material que, con la expresividad, demostró una unión entre pasado, presente y futuro para los diseñadores. Estuvo presente en el edificio original y se le llevó a la fachada, cielo y pavimento en el nuevo proyecto. Este material tuvo variaciones en textura: se utilizó perforado, liso, plegado y natural. (Yutronic, s.f.)

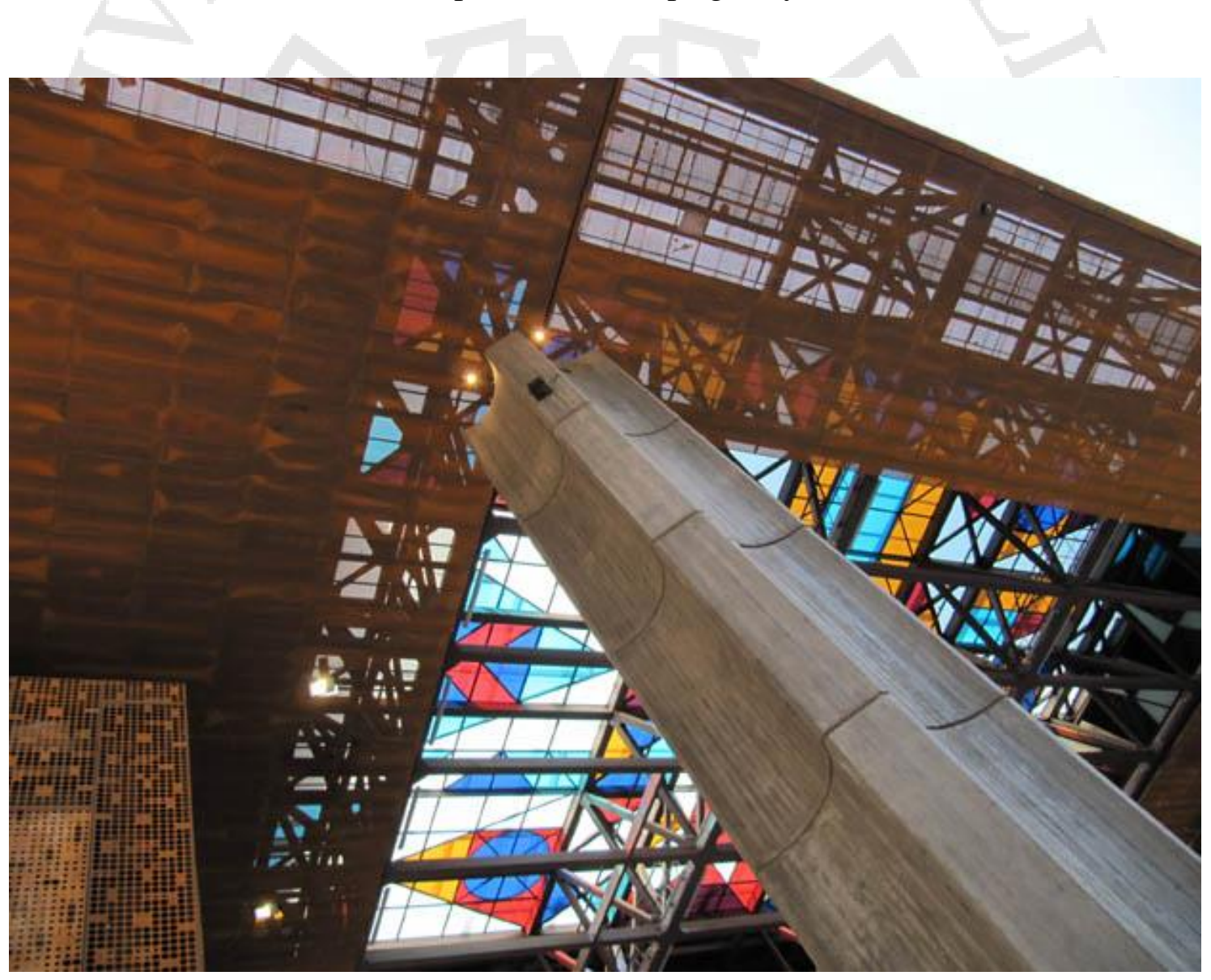

Fuente: Arquitectura en acero

Las fachadas muestran al acero corten en conjunto con cristal de muros cortina y grandes ventanas siguiendo dos juegos básicos de modulación y varios secundarios. 
Los dos básicos son: el acero corten perforado es la piel del edificio que trata de cubrirlo todo, pero cuando existe un programa al interior que merece ser visto desde el exterior éste se interrumpe dejando aparecer un volumen de cristal que devela un interior fascinante. Es el caso de la Sala de Ensayo de Danza, la Sala de lectura de la Biblioteca y de algunos halles del edificio. El segundo juego es que la aparición de las cajas de cristal deforma la piel de acero corten produciendo pliegues en ésta que cambian totalmente la forma en que la luz cae sobre las fachadas. Combinando estos dos juegos se crea un curioso tipo de espontaneidad en el diseño que nos permite romper con la idea de 'caja' y aspirar a futuras relecturas. (Yutronic, s.f.)

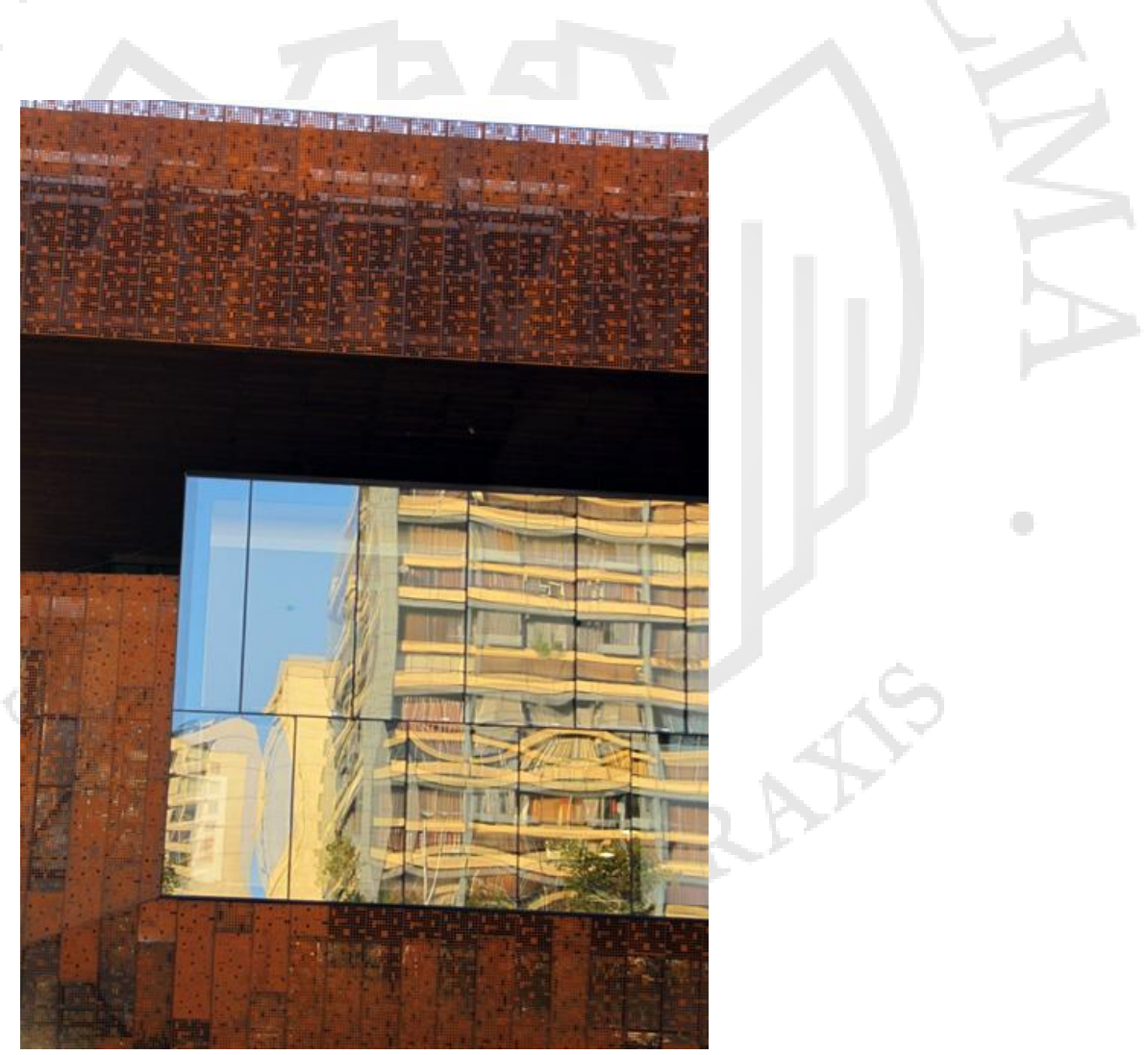

Imagen: Fachada (Yutronic, s.f.) 

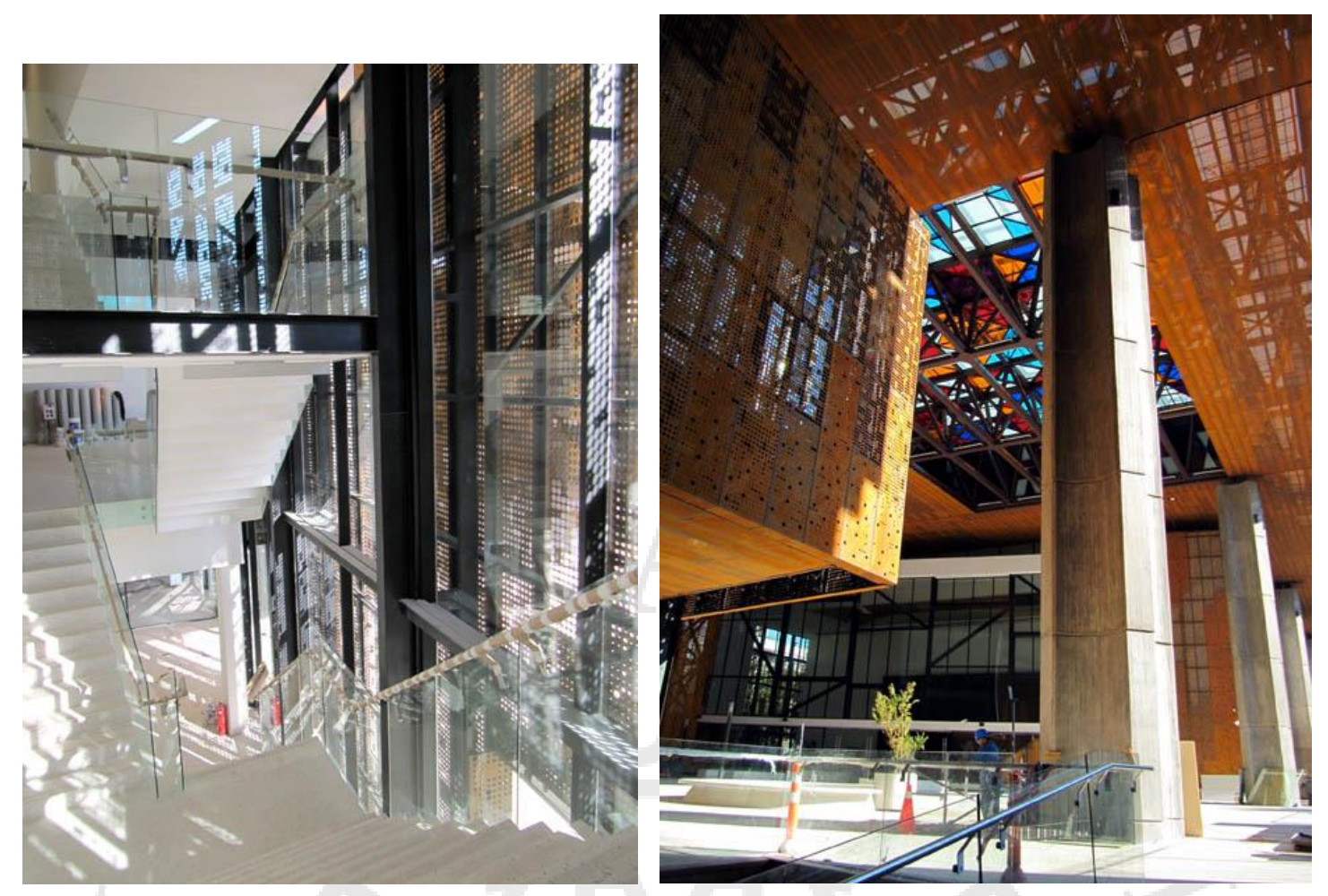

Fuente: Arquitectura en acero

Se ha utilizado el mismo pavimento en todo el proyecto, con aplicaciones de acero corten en franjas de $10 \times 120 \mathrm{~cm}$. aleatoriamente.

Se ha instalado equipos acústicos y escenográficos técnicos de alta tecnología. Cada sala fue tratada independientemente para un mejor funcionamiento acústico dependiendo de las necesidades. La Sala de Música tiene un "diseño de iplanos inclinados y con quiebres que son capaces de generar una llegada correcta del sonido a todas las ubicaciones" (Villamil, 2011) Las butacas son de un material orgánico que absorben el sonido. En el caso de la Sala de Danza, los acabados son más sobrios y oscuros. Esta sala y la de teatro cuentan con puentes de iluminación, varas para escenografía y puentes de luces. Asimismo, los escenarios cuentan con sistemas motorizados para cambios de escenografía. 


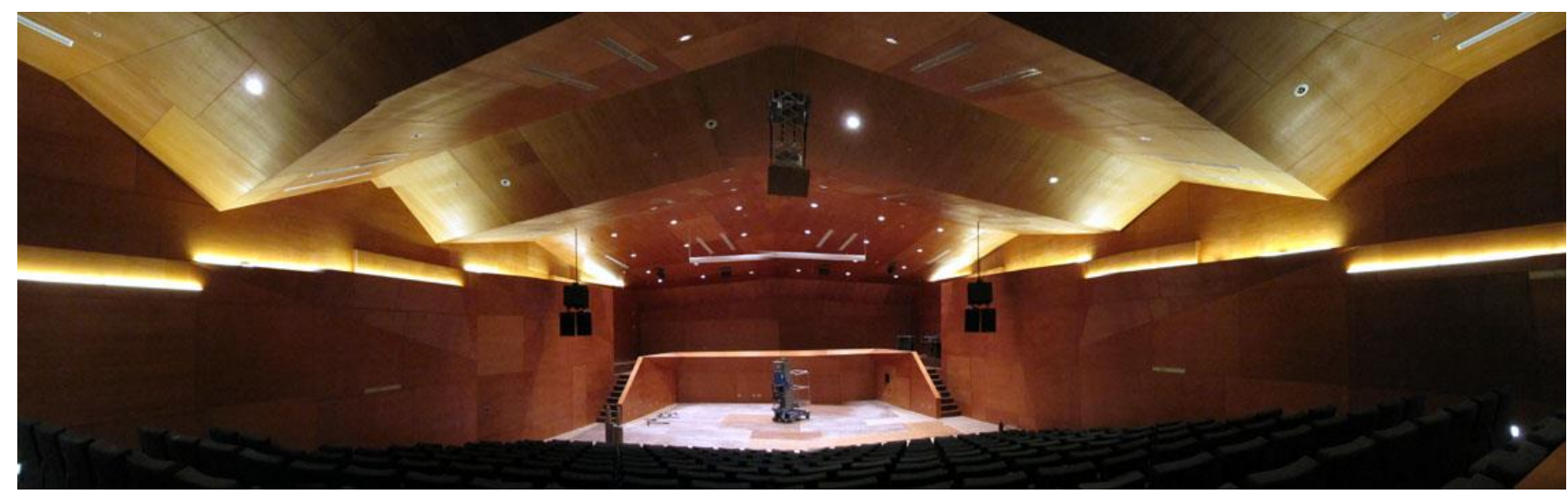

Fuente: Yutronic

\subsubsection{Impacto Social}

El edificio del actual Centro Cultural tiene una carga histórica que los arquitectos tuvieron que afrontar desde su entorno. Esto se debe a que, siempre estuvo cerrado a la ciudad, sin brindar un espacio público de calidad y utilizado como edificios de instituciones sin carácter social (Como el Palacio de la Moneda).

Es por ello, que el proyecto "asume la responsabilidad de rescatar la memoria fragmentada de un edificio que ha enfrentado herméticamente la avenida principal de Santiago de Chile durante las últimas cuatro décadas" (Yutronic, s.f.). Es un edificio de carga negativa para muchos ciudadanos, por representar un mal recuerdo y acontecimientos de un periodo complicado.

Luego del incendio, algunas obras de arte fueron rescatadas y aún permanece parte del diseño original. Sin embargo, la reinvención del edificio como espacio por y para el público se logra gracias a la visibilidad controlada y una 'traslucidez sugerente'. Así, se mantiene el nivel de privacidad sin negar la conexión con el entorno ni la entrada de la gente. A la nueva fachada perforada se le considera un 'regalo' para el tramo de la avenida a la que el edificio le dio la espalda por tantos años.

Además, el diseño se integra visualmente con el barrio posterior. Finalmente, el edificio se relaciona con el espacio donde fue construido y levantado. A través de los 
materiales, se vincula con el pasado, reinventando las experiencias con un nuevo programa público. Esto genera que se reemplace la imagen negativa y cerrada del antiguo edificio, dando la bienvenida a los ciudadanos.

"Chile tiene poco patrimonio histórico. Es un país joven que ha sido afectado por los terremotos. Este edificio tiene una corta historia, pero una altísima significación. No lo quisimos demoler, hacer desaparecer o disfrazar de otra cosa", dice Cristian Fernández (Villamil, 2011)

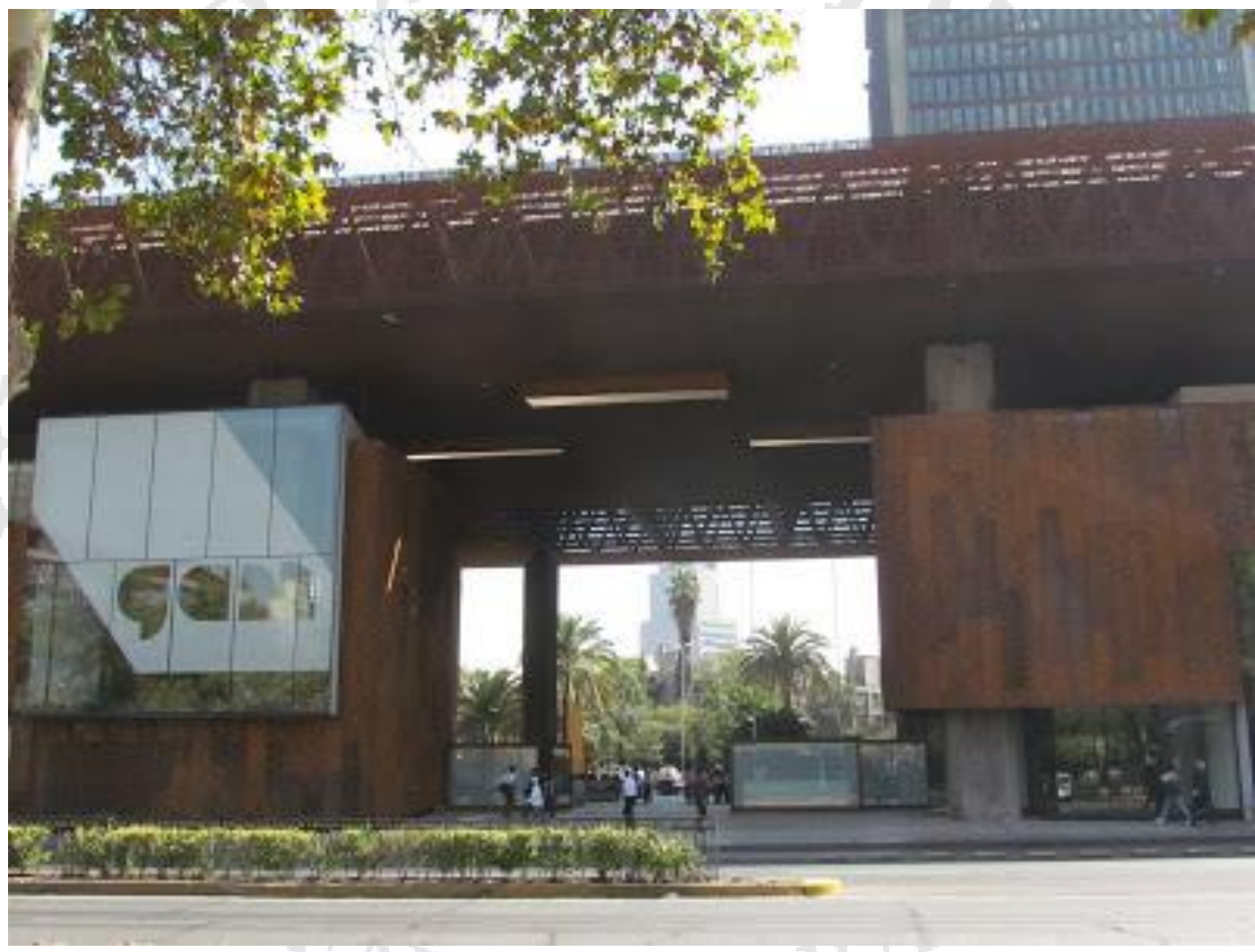

Fuente: Villamil, 2011

Finalmente, el GAM tiene un aporte programático. Tiene diversas actividades enfocadas a todo el público y ofrece espacios para el desarrollo de quienes se dedican profesionalmente a las actividades artísticas. 


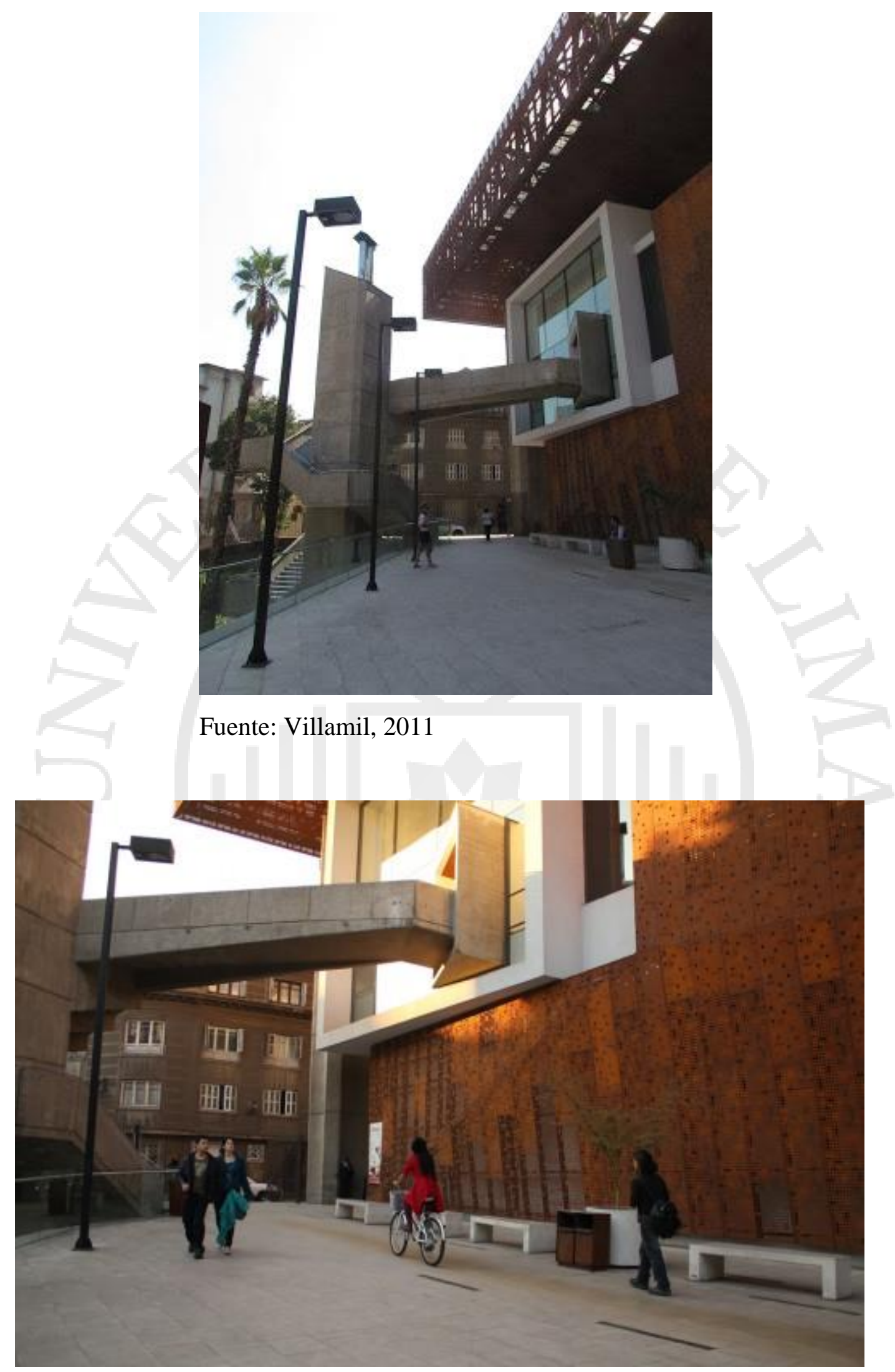

GAM hacia el barrio Lastarria. Fuente: Plataforma Urbana. 


\subsection{Plaza Elíptica, Madrid}

\subsubsection{Historia}

\subsubsection{Datos del proyecto}

- Adjudicación: U.T.E. formada por las empresas TRN, Ingeniería y Planificación de Infraestructuras, SA y GTT, Ingeniería y Tratamiento del Agua SA.

- Costo: 41, 76 millones de euros sufragados mediante la financiación privada de una concesión administrativa para la construcción y explotación del intercambiador a la Sociedad Mercantil formada por las empresas Sacyr, Castromil y Transportes La Unión por un período de 35 años.

\subsubsection{Toma de partido}

El primero principio para el diseño de la estación de autobuses en la plaza elíptica, fue recibir a los usuarios que llegaban al terreno desde los tres principales ejes. Estos ejes funcionan son de carácter distribuidor porque conectan la zona con el centro del casco urbano de Madrid. Hacen conexiones en dirección Norte-Sur, Oeste-este y NoresteSureste.

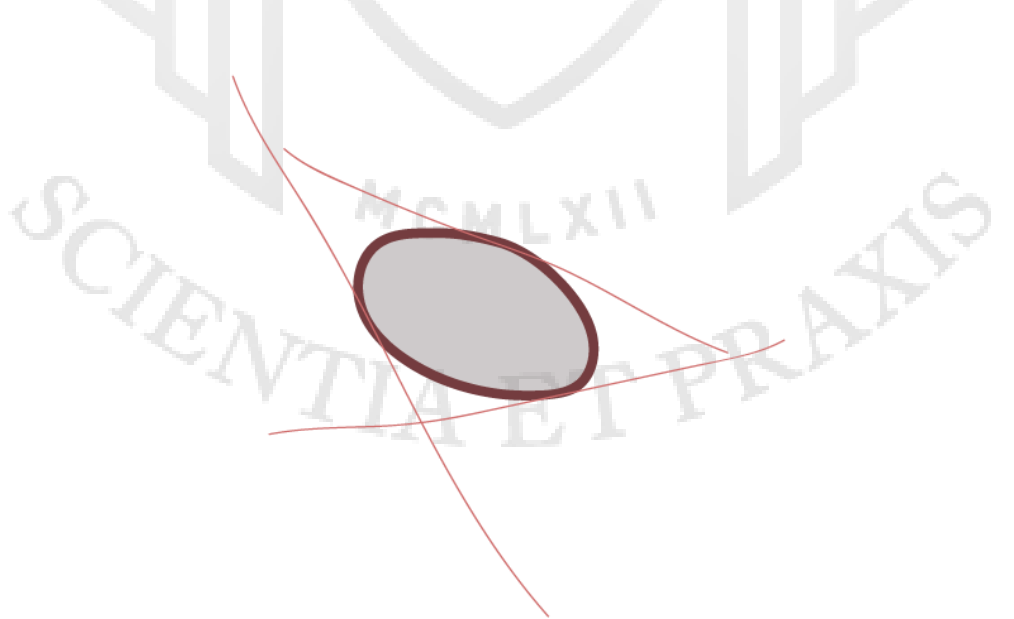

Este primer trazado, sirvió para indicar los potenciales ingresos o recibos de usuarios. 
El área del terreno, y la envergadura del proyecto exigieron que se desarrollara ocupando niveles subterráneos, de esa forma, la distribución estaría centralizada y por lo tanto sería organizada, y en ese sentido fácil de transitar por los usuarios.

Así, se plantea imitar la forma elíptica de una glorieta que ya existía en el terreno, y generar vías que giran en torno a esta, de esa forma, al elipse funciona como el espacio distribuidor de las dársenas y el espacio público para los usuarios.

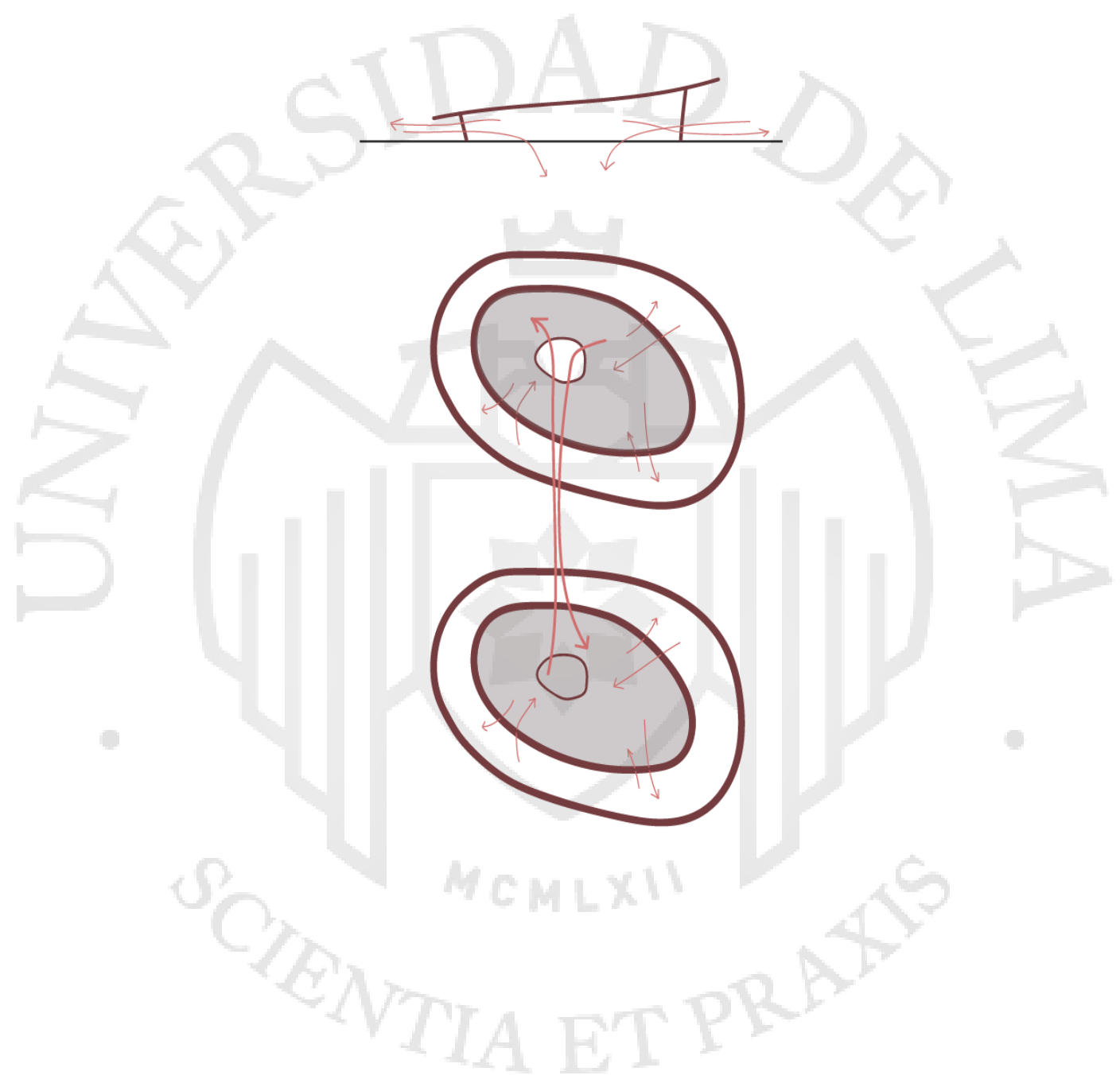




\subsubsection{Ubicación y relación con el entorno}
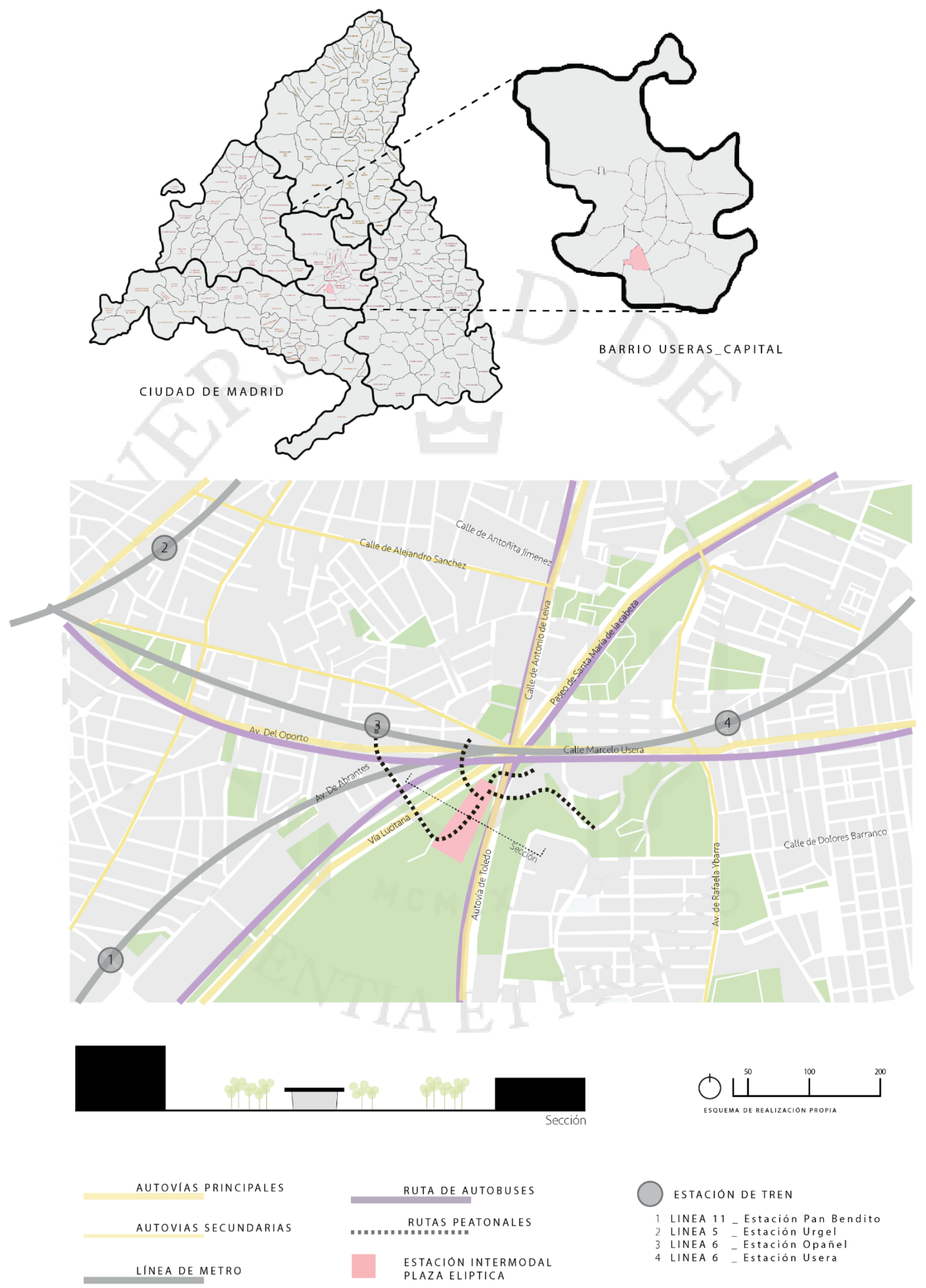

3 LINEA 6 - Estación Opañel

4 LINEA 6 - Estación Usera 


\subsubsection{Programa y relaciones programáticas}

El proyecto consta de 3 niveles subterráneos, a los que se ingresa por una gran portada dentro de espacio público. La planta de tipología triangular mantiene programa dentro de la 'isla', con las vías de circulación constante de buses alrededor. En total, existen 10 dársenas de embarque por planta, rodeando a un gran espacio semipúblico.

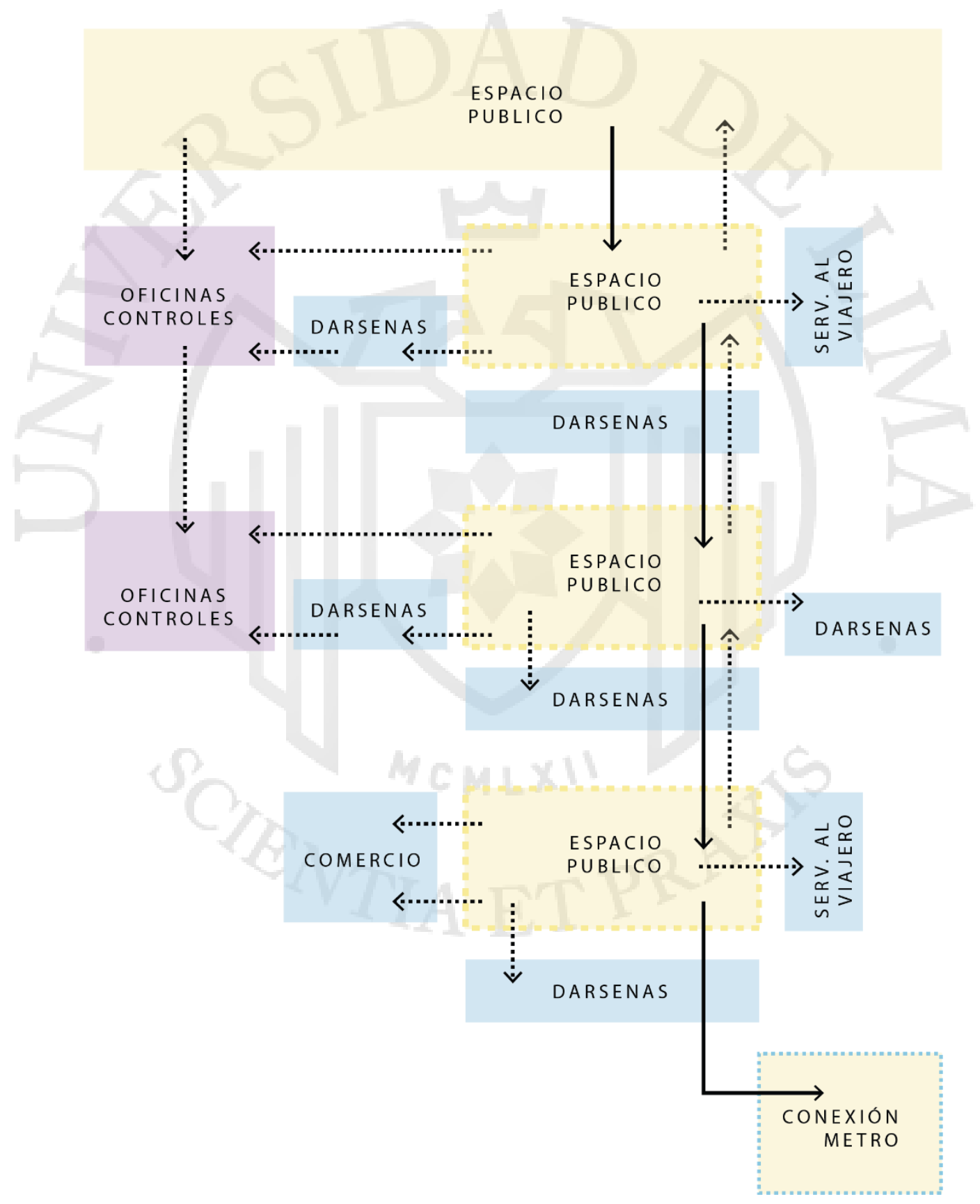


En todo momento se consideró importante movilizar el flujo de pasajeros. Por ello, diversas estrategias se generaron en los espacios. Una de ellas es un segundo núcleo de circulaciones que conecta a los viajeros con la vía del Metro. Otra estrategia es priorizar el espacio para los viajeros que bajan de los buses a intercambiar de transporte.

\section{Imagen: Entrada a Nivel 0 (Lanik)}
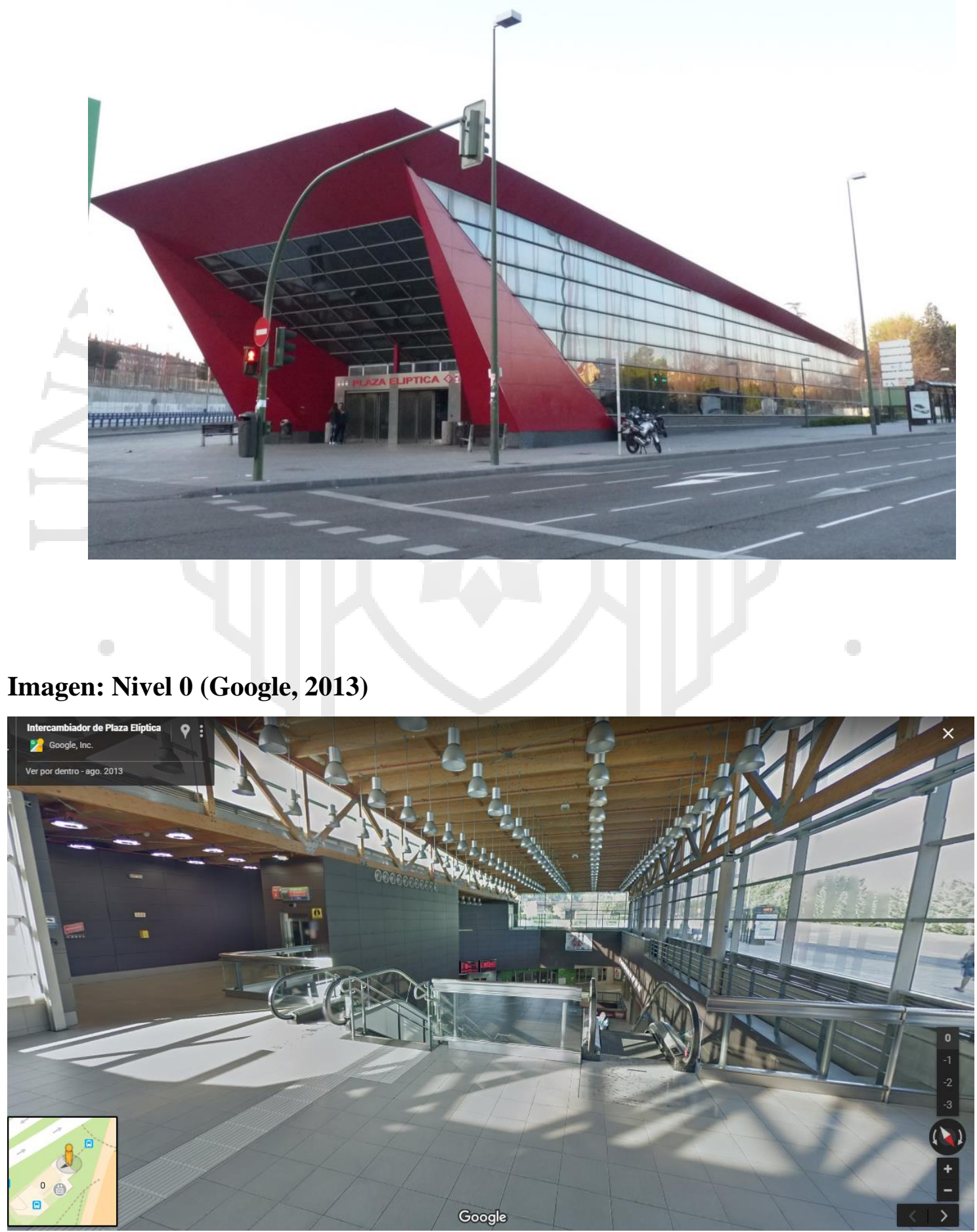
Imagen: Nivel -1 (Google, 2013)

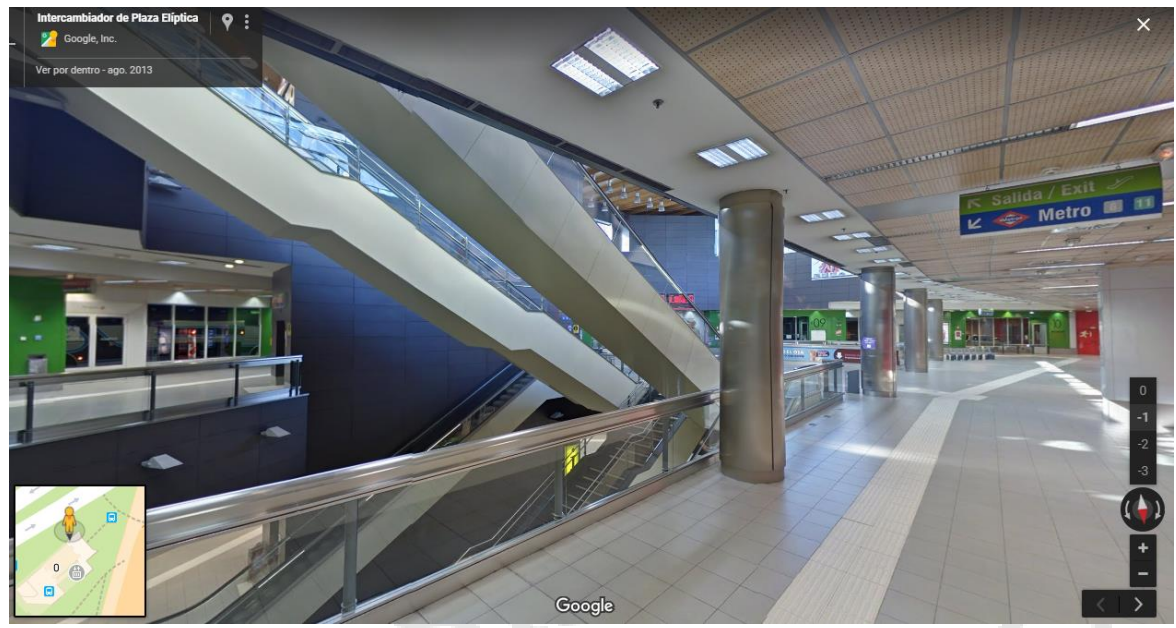

Imagen: Nivel -1 (Google, 2013)

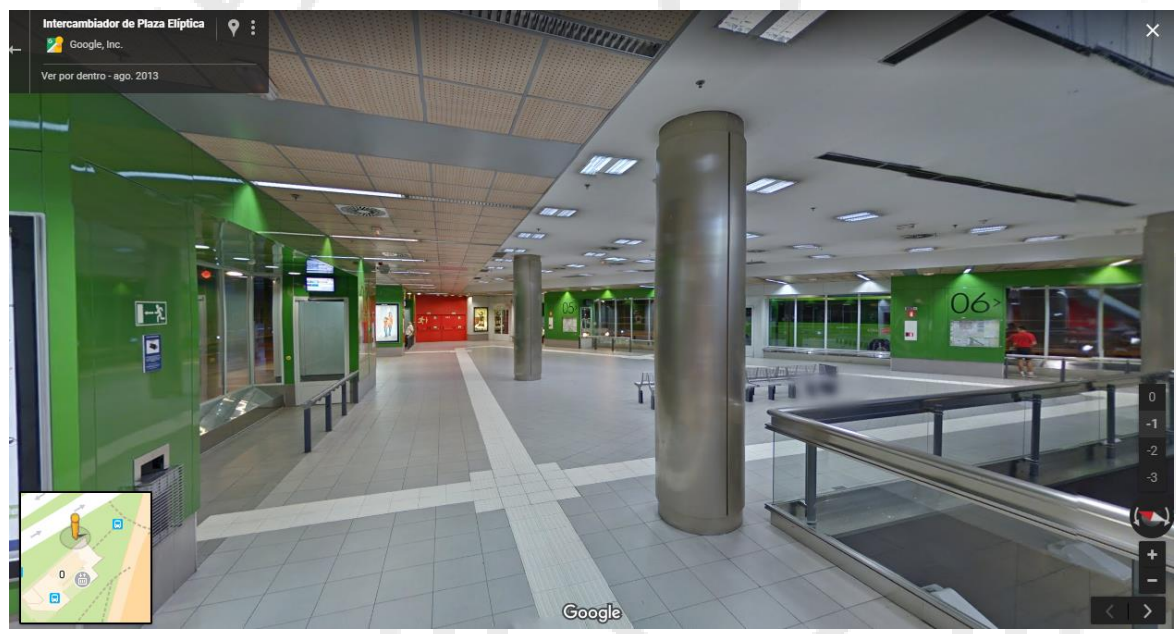

Imagen: Control (Ayuntamiento de Madrid)

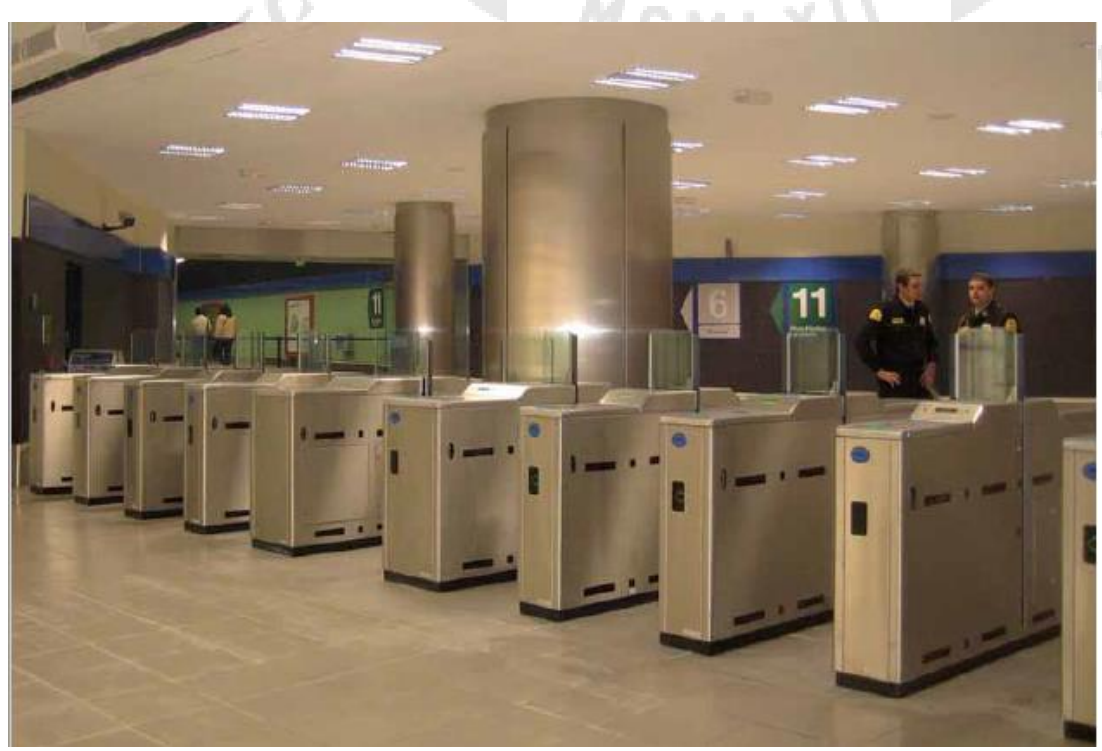


Imagen: Nivel -2 (Google, 2013)
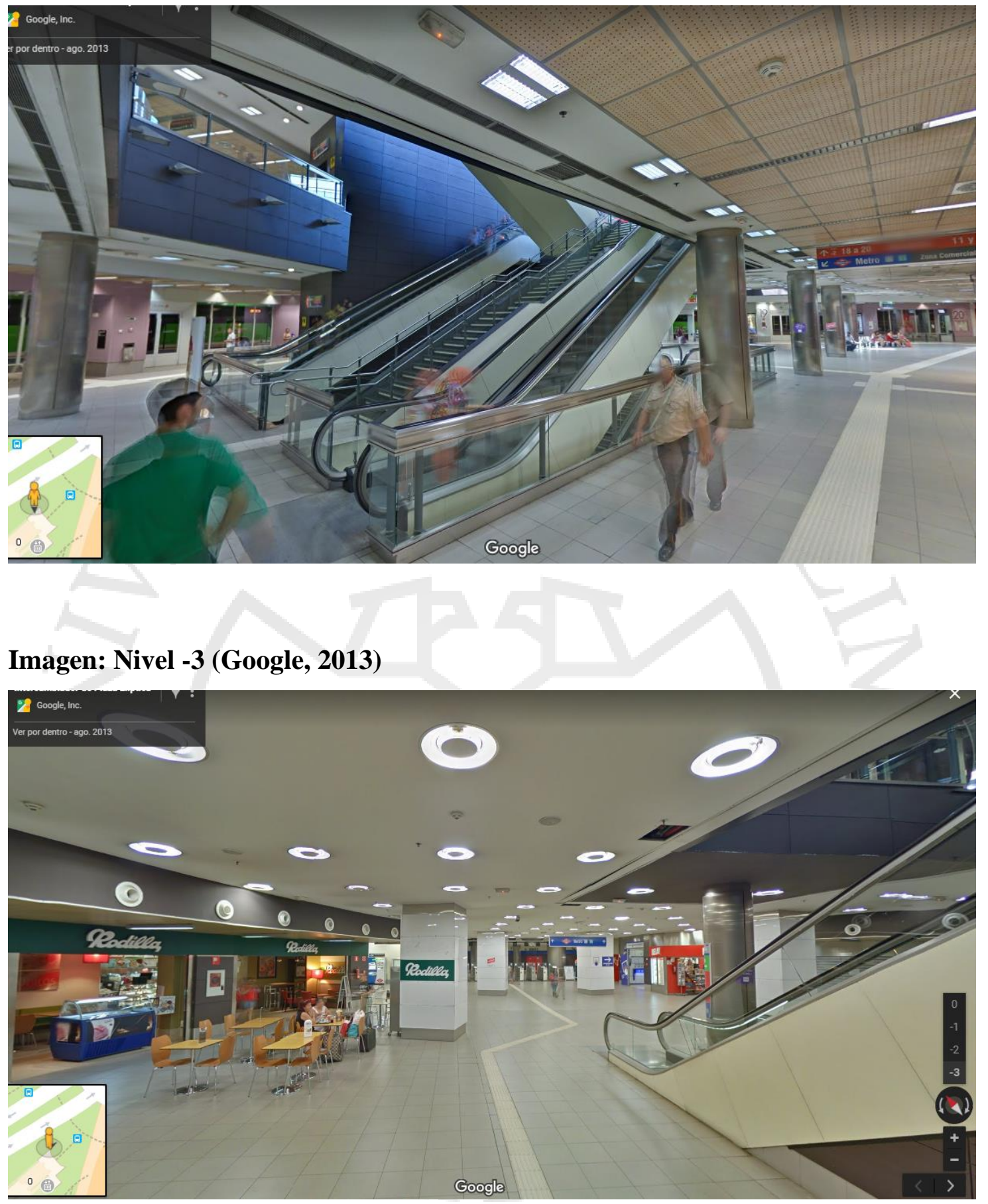


\subsubsection{Tipología espacial}

El primer gesto morfológico en el proyecto, es el de levantar un espacio de la plaza en el nivel de la calle, y generar un vació en el interior. Este gesto logra hacer un único volumen ligero y aislado en el nivel 0.00 , y genera un vacío con su forma hacia el interior del terrero.

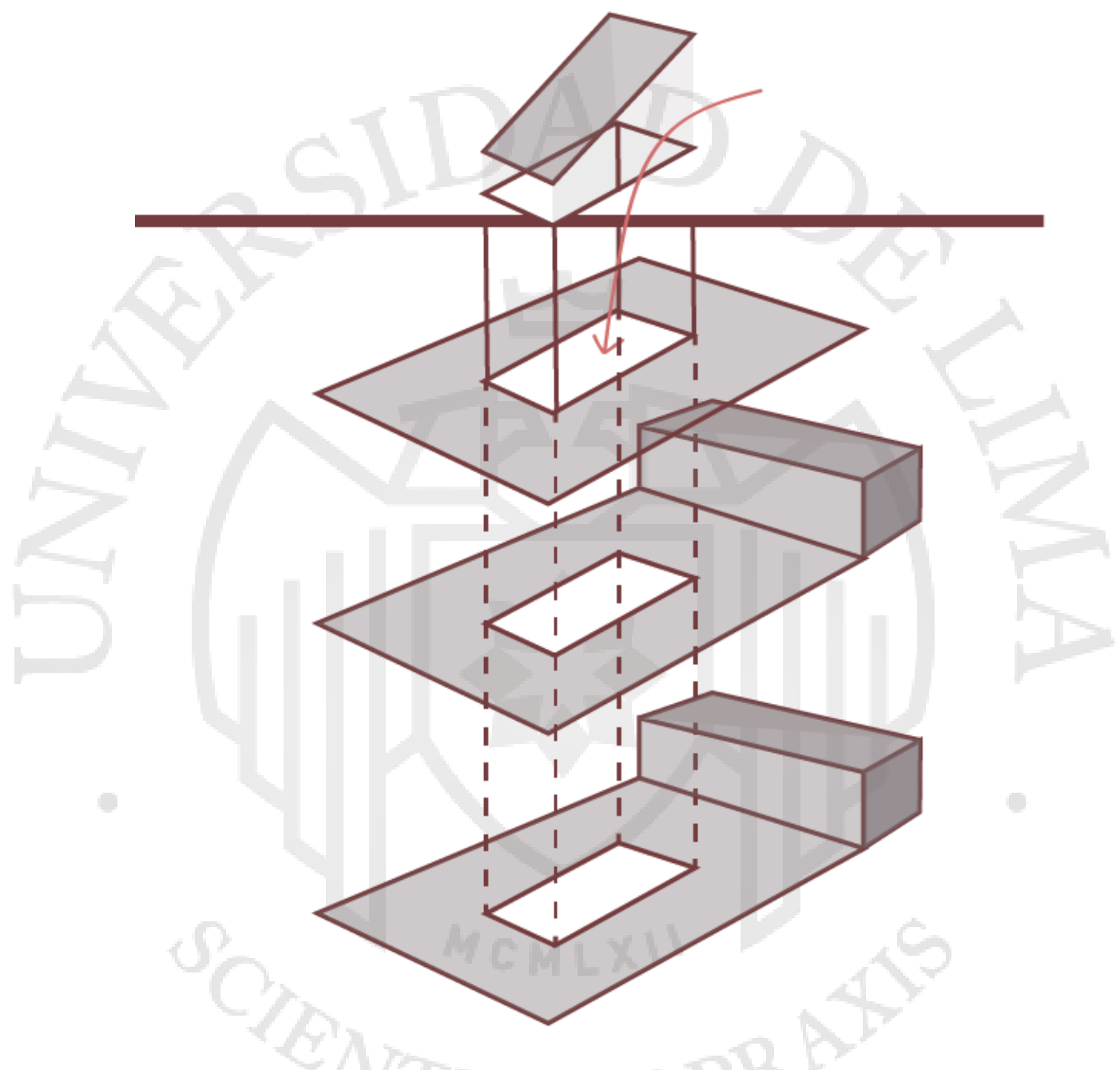

Seguidamente, se expande en los niveles subterráneos el vacío, para ocupar ahí los programas privados del proyecto y las vías, generando un espejo de lo que sucede en el nivel de la ciudad: un espacio público que es rodeado por las vías de los autos y buses.

Finalmente, se esconden los espacios más privados y de servicios, en un lateral canalizado e interconectado entre sí, pero desconectado de las actividades que realizarán los usuarios. 


\subsubsection{Público Privado}

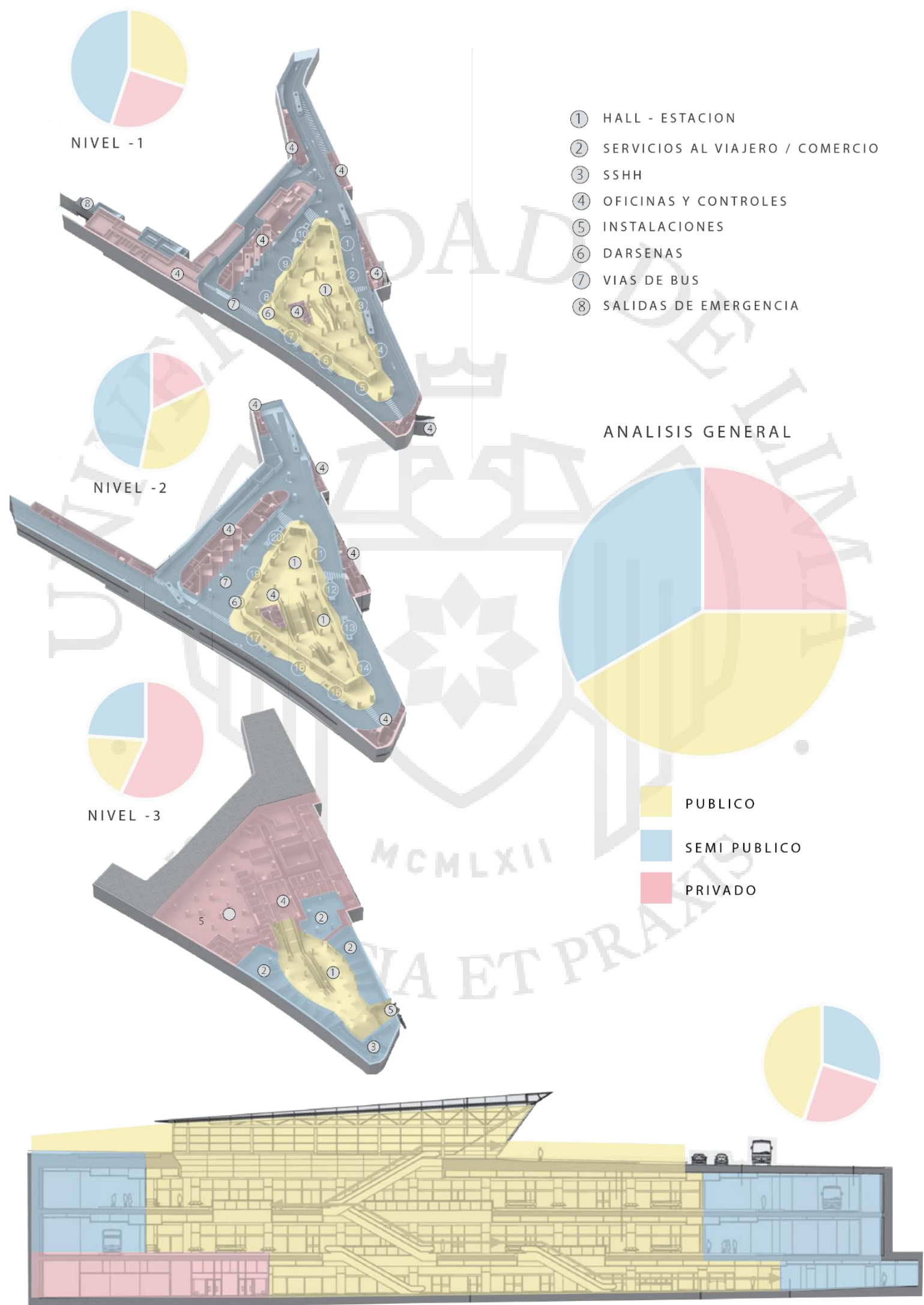




\subsubsection{Flujos del proyecto}

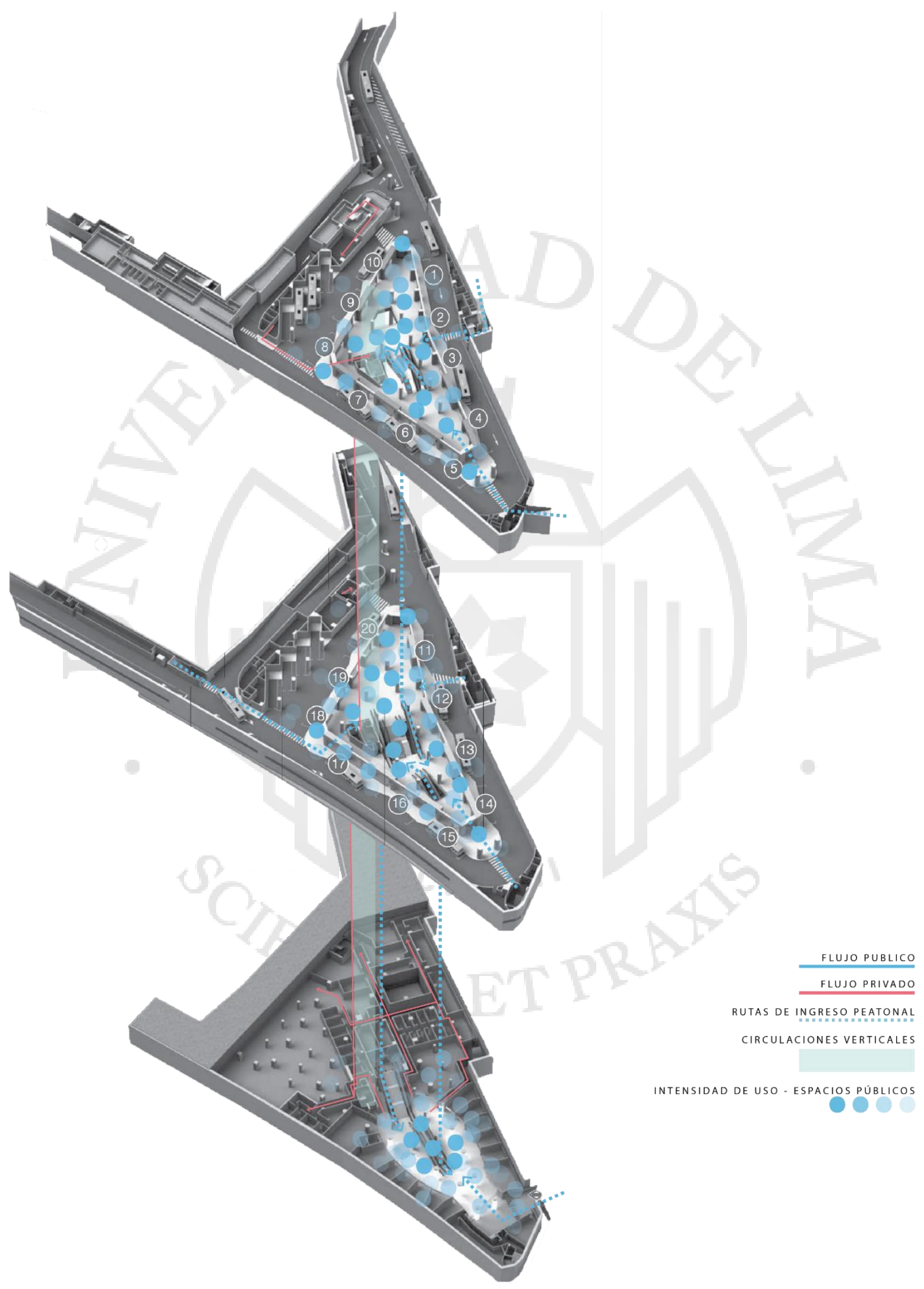




\subsubsection{Organigrama de espacios}

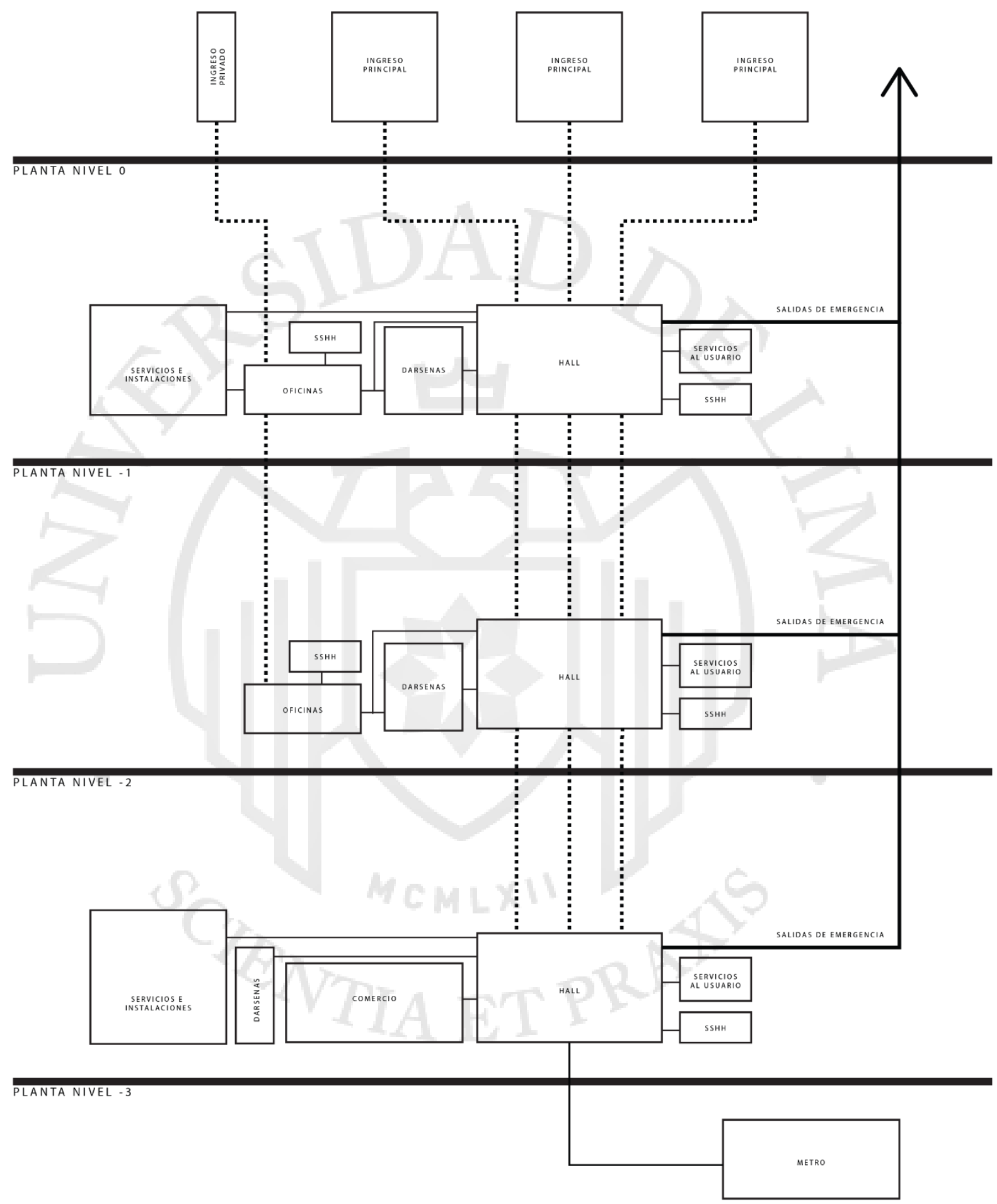




\subsubsection{Tecnología}

El sistema constructivo consta de pilotes laterales perimetrales, pilares principales, y el alternado de excavación de sótanos y construcción de losa maciza. Esta ultima fue proyectada en hormigón armado por las cargas de peso que recibiría y la resistencia al fuego que debe mantener.

A nivel de escaleras, se resuelven mediante losas de $35 \mathrm{~cm}$ de ancho de hormigón armado.

Los túneles que se debieron hacer, consisten en muros de pilotes arriostrados en cabeza a manera de pantallas laterales, losas superiores y solera de cimentación. Los pilotes del proyecto tienen $0.60,0.80,1.00$, o 1.20 de diámetro.

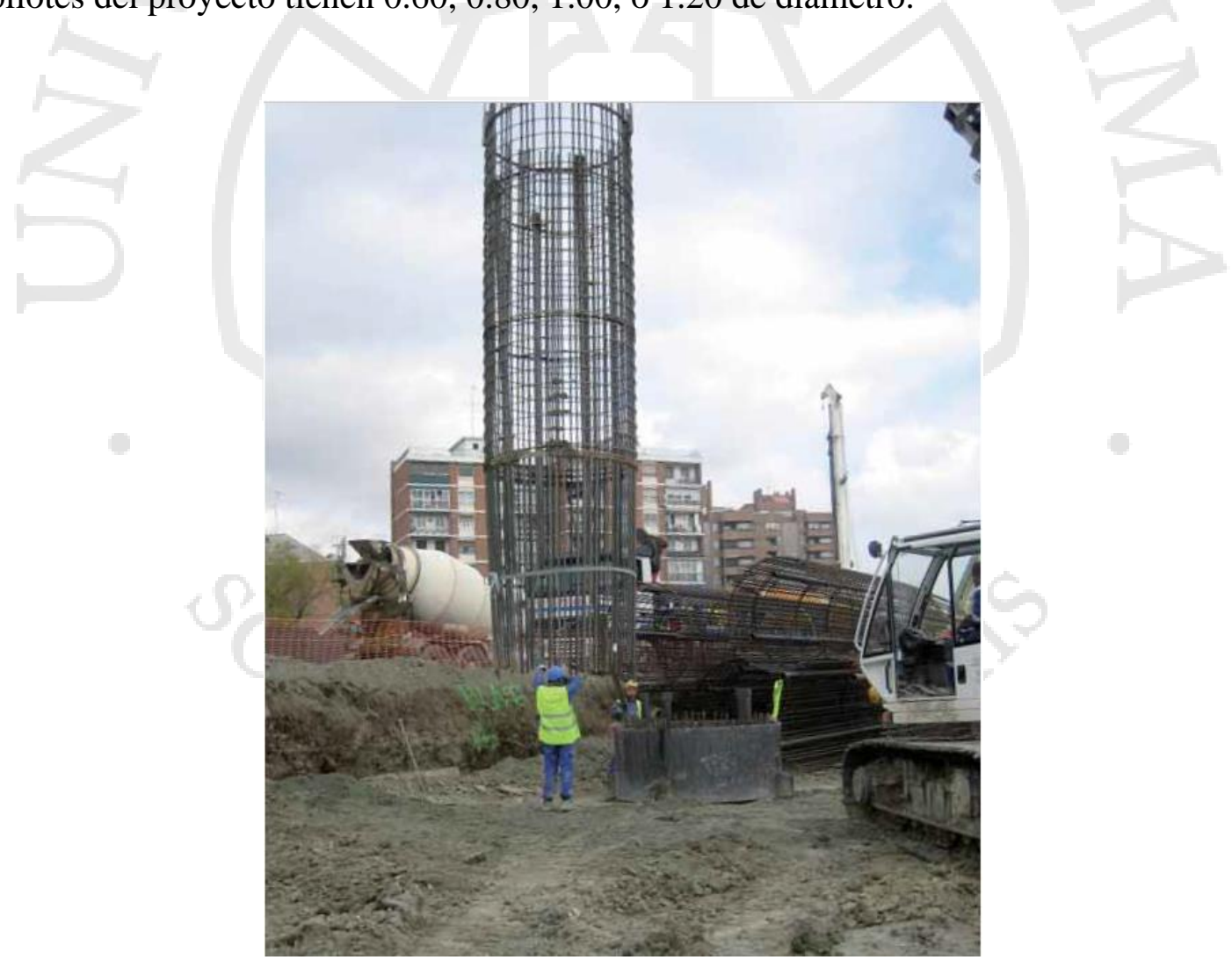

Armadura de cimentación - Pilotes. Fuente: (Ayuntamiento de Madrid) 


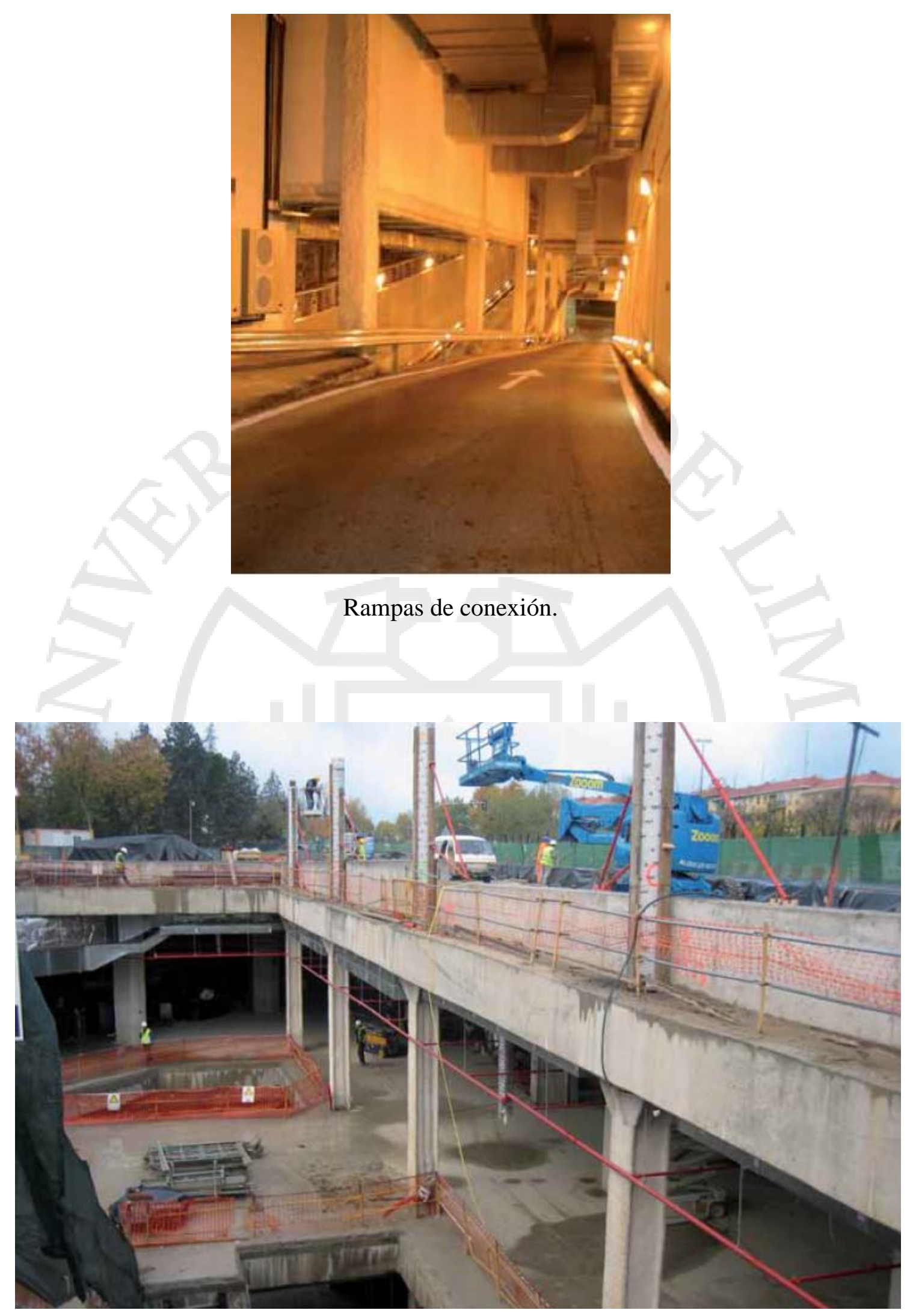




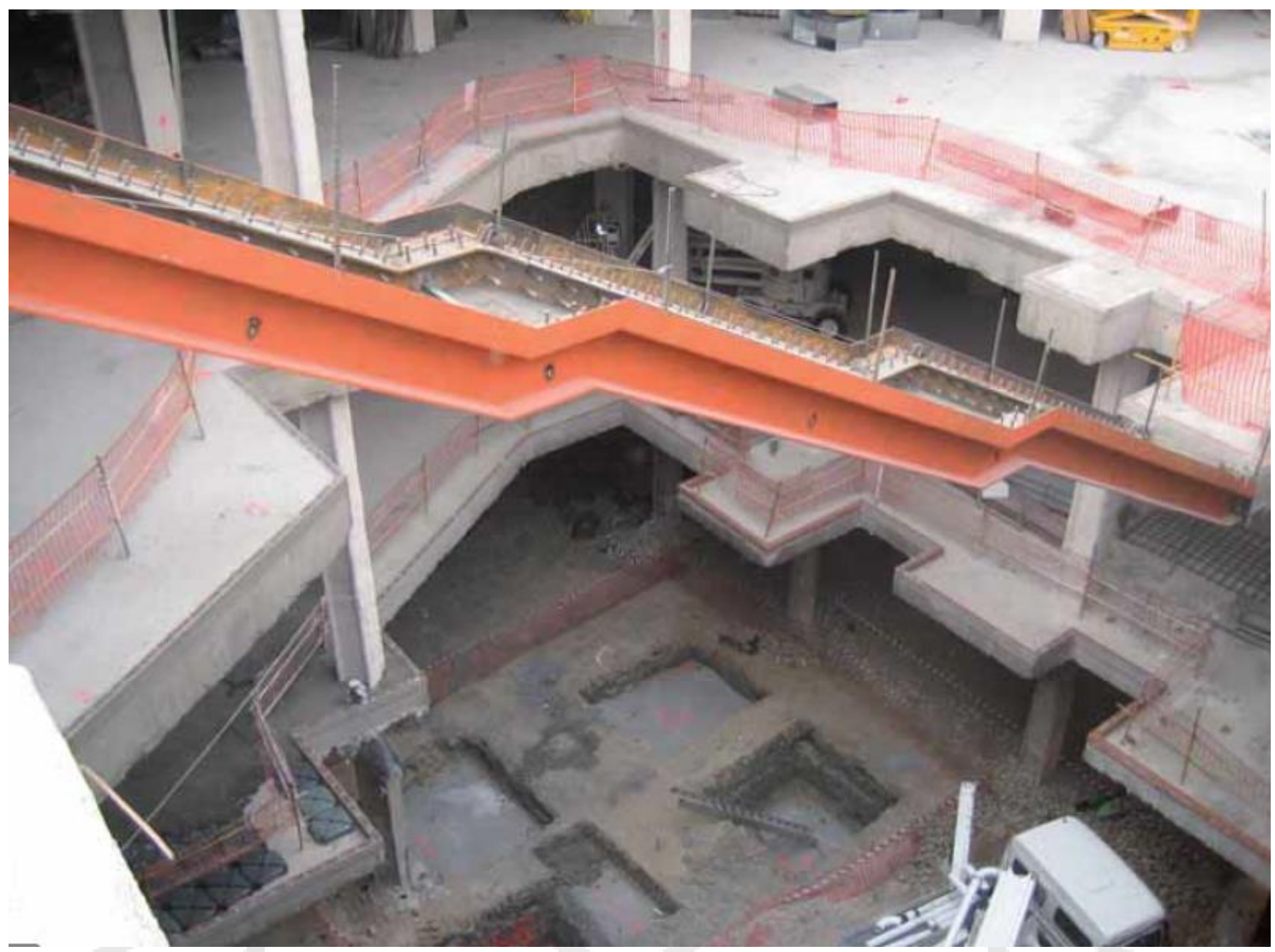

Losa de sótanos y de escalera. Fuente: (Ayuntamiento de Madrid)

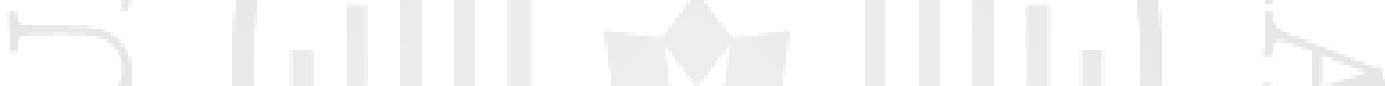

En cuanto a estrategias, se destaca la iluminación planeada. Esta incide en difuminar la percepción desde el interior de la estación hacia las dársenas de abordaje y las vías del bus. Con esto, y una cómoda espacialidad, se fuera a las esperas siempre dentro de la zona de viajeros y no generar colas en las puertas de abordaje.

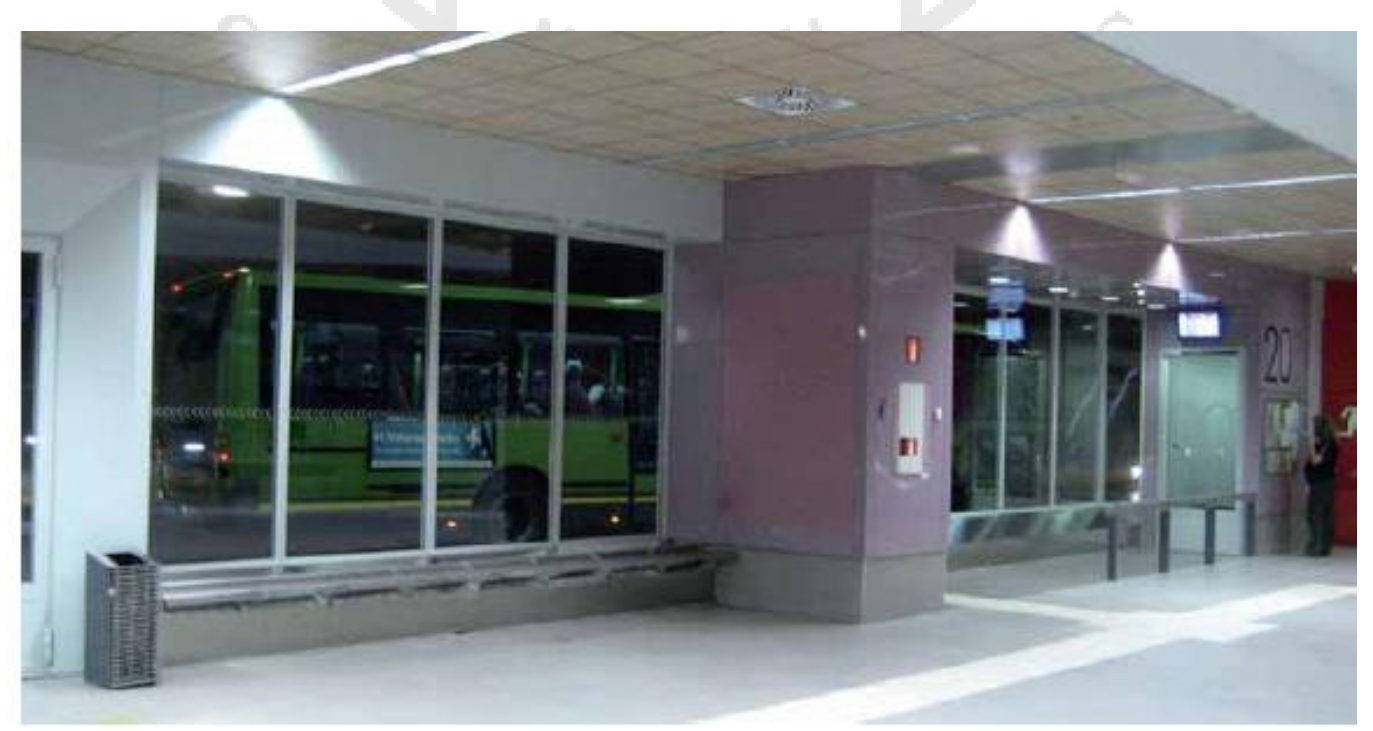

Mamparas en zona de abordaje. Fuente: (Ayuntamiento de Madrid) 
Cuadro resumen y características a tomar de referencia:

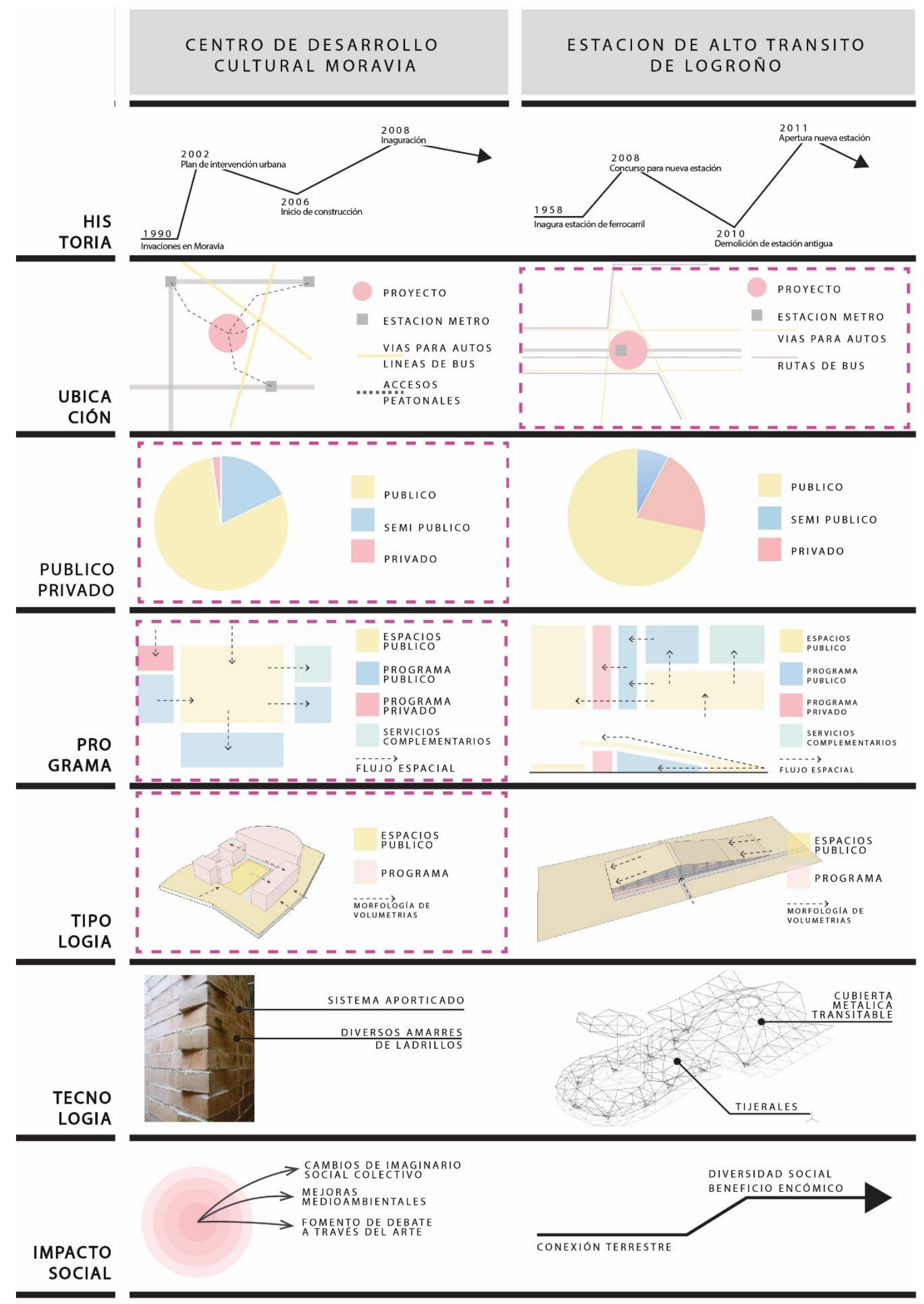


CENTRO CULTURAL

GABRIELA MISTRAL
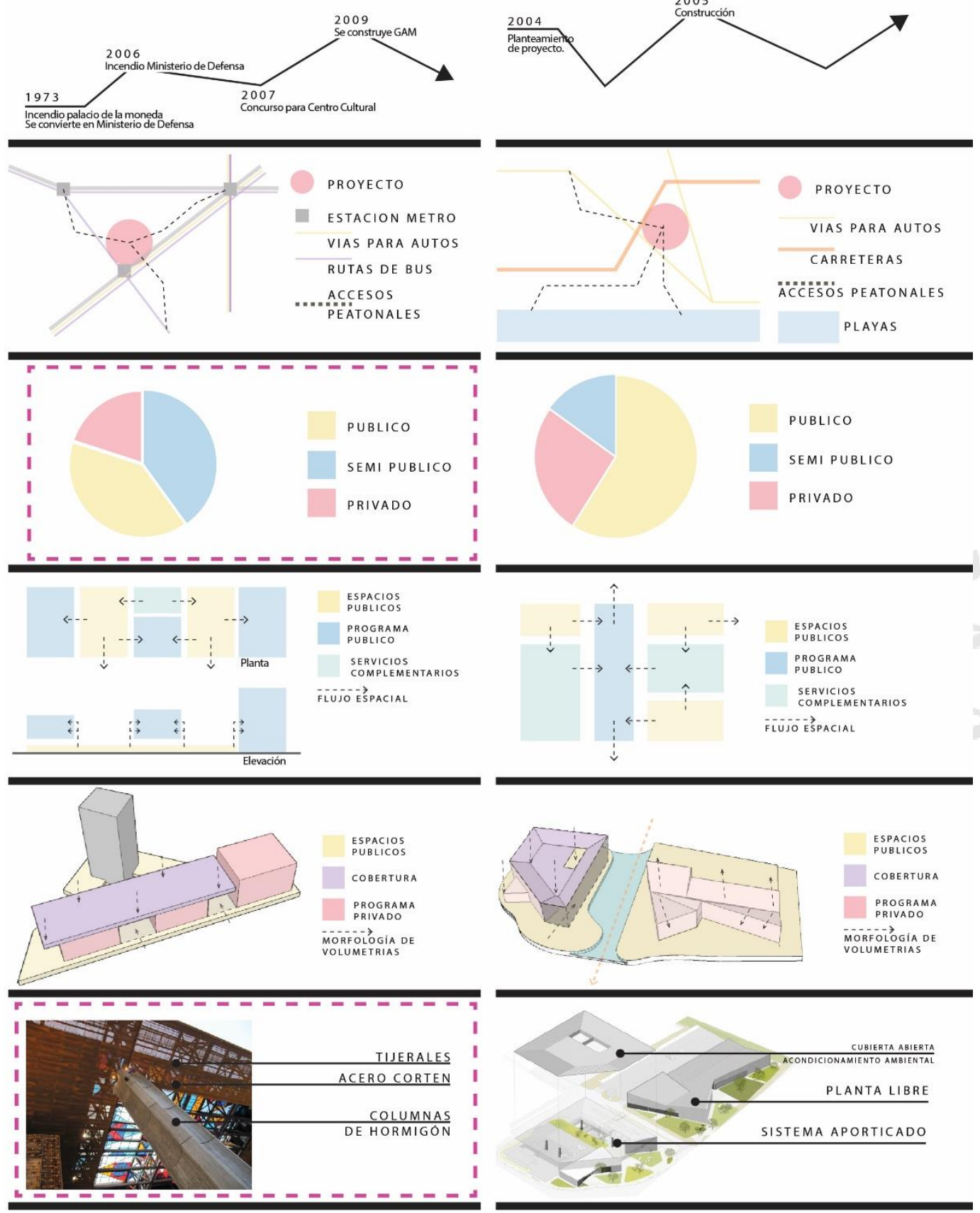

PLAYAS

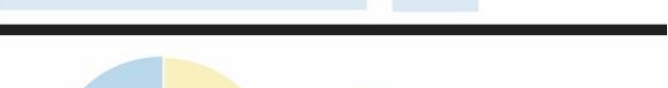

UBLICO

SEMI PUBLICO

PRIVADO

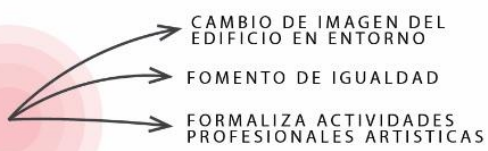


BIBLIOTECA Y ESTACIÓN DE BUSES DE RONDA
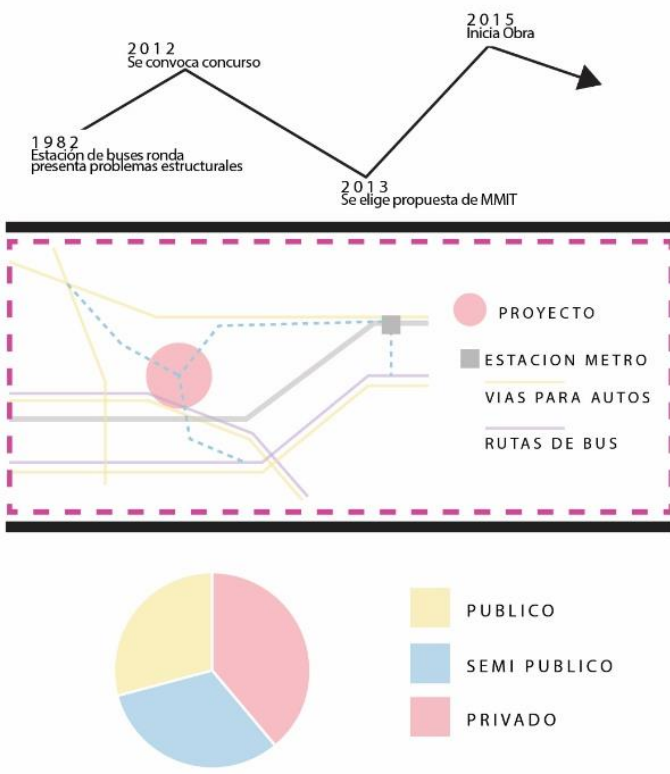

\section{PUBLICO \\ SEMI PUBLICO \\ PRIVADO}

ESTACIÓN CASA

DE LA CULTURA
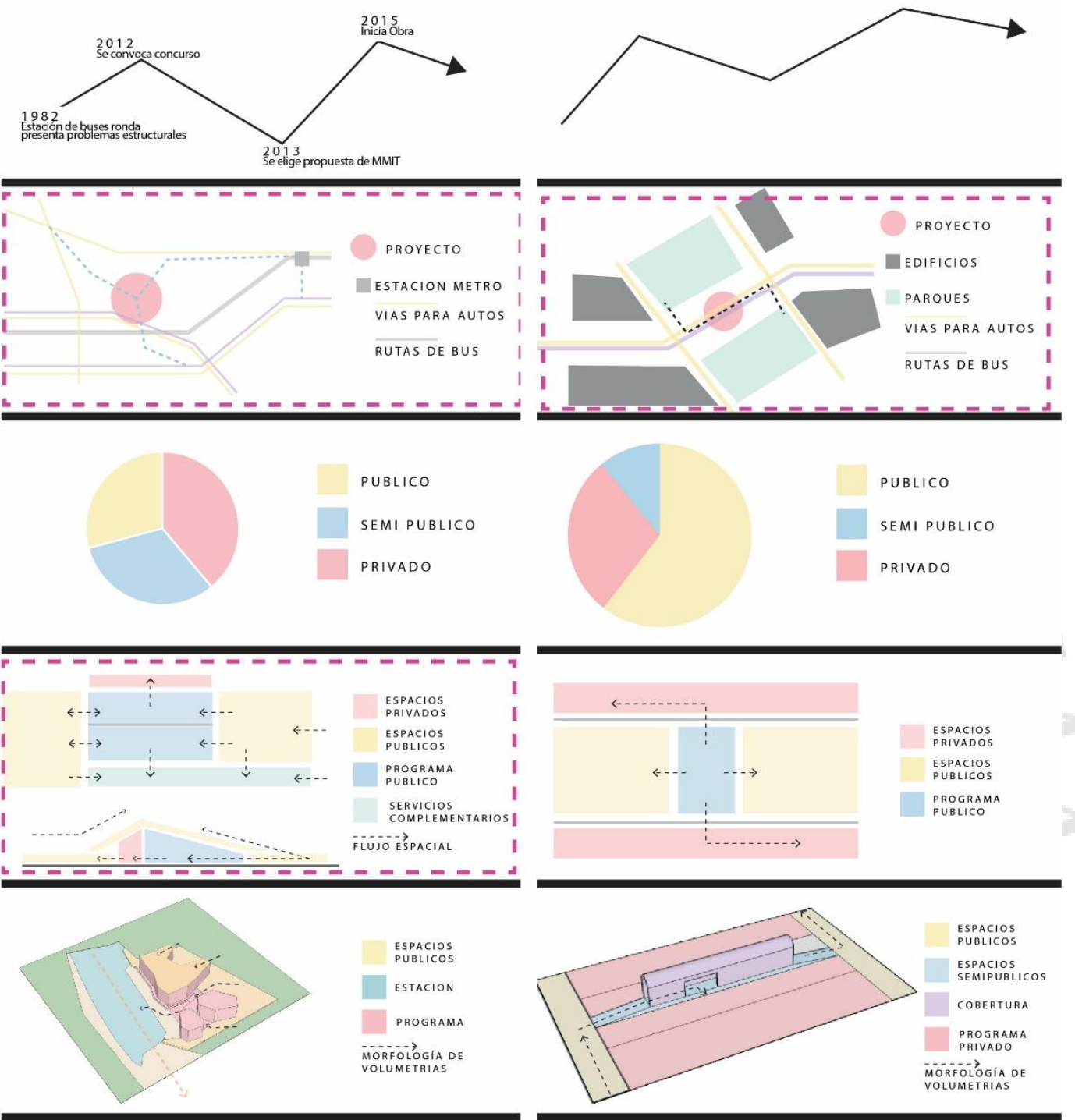

PUBLICO

SEMI PUBLICO

PRIVADO
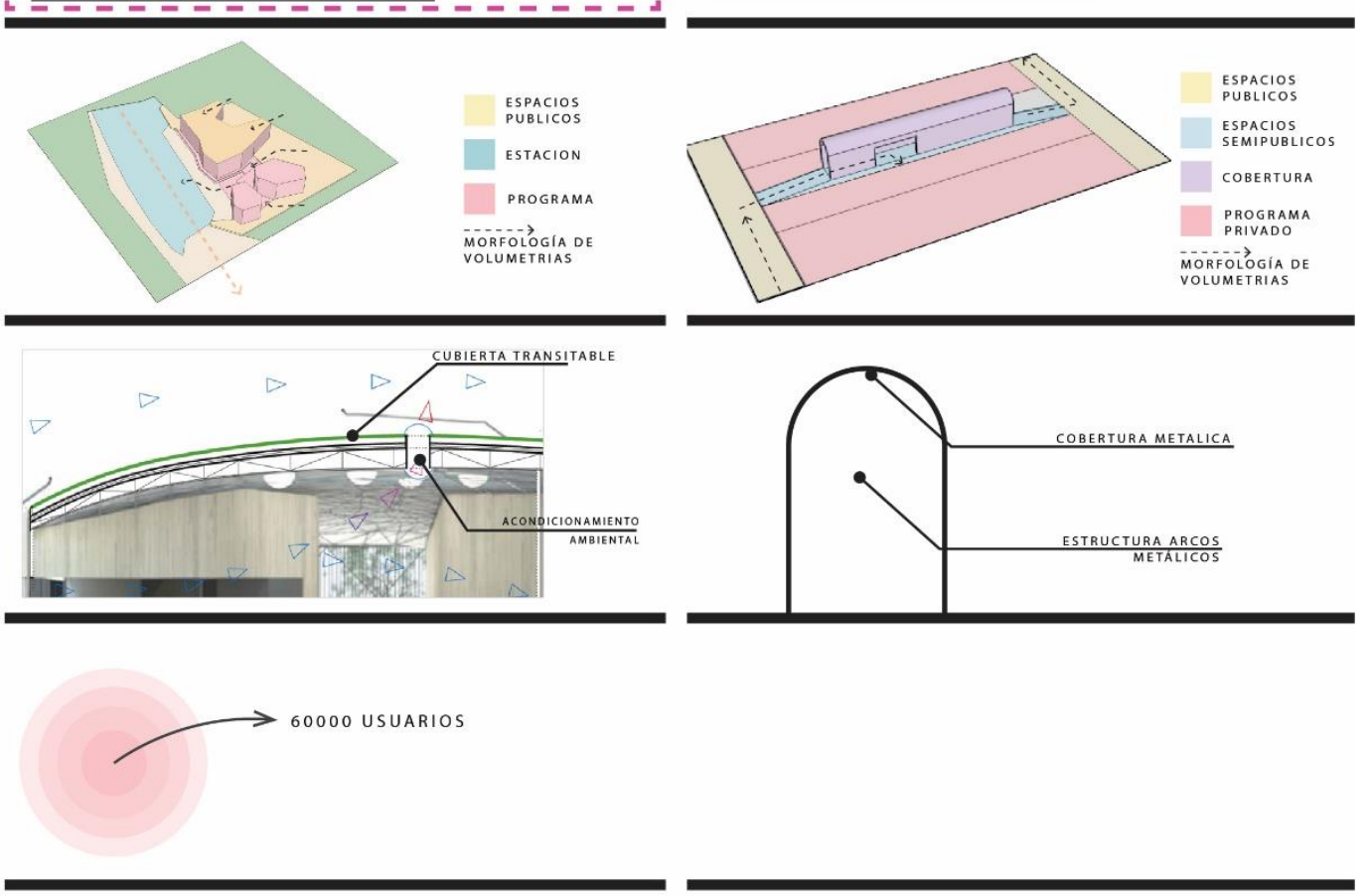


\section{CAPÍTULO V \\ MARCO CONTEXTUAL}

\subsection{Criterios para la elección de terreno}

El Centro Cultural y estación tendrá, como fin principal, cohesionar y animar espacios autónomos separados por las vías del Metropolitano. Sin embargo, la división urbana a nivel del suelo es un patrón repetitivo a lo largo de la ruta de dicho transporte público en Lima Metropolitana. Es por ello que se evaluará la vía del Metropolitano enfocándonos en las estaciones, con el fin de decidir cuál es el terreno y la estación del más adecuados y para el emplazamiento de la propuesta, y que necesitan de un mayor nivel de atención e intervención.

Los criterios utilizados determinan qué tan factible es la intervención en un espacio, según la condición de su entorno. El más importante, es que la vía se encuentre a nivel del suelo de la ciudad. Aquellas estaciones ubicadas en la Vía Expresa tienen requerimientos diferentes al Centro Cultural que se busca proponer, pues, la vía seguirá siendo un factor físico de división urbana.

El segundo criterio, se refiere a encontrar terrenos disponibles, vacíos urbanos o espacios de pocos pisos aledaños a una estación del Metropolitano. Luego de evaluar referentes internacionales, el programa de Centro Cultural tiene, aproximadamente, $80 \%$ de área libre. Para completar dicho requerimiento es importante que los terrenos tengan, al menos, 5000m2. Además, la estación debe ser de tipología de parada, no central, intermodal, ni final. Este criterio se debe a, que, en las grandes estaciones, la vía del Metropolitano es interrumpida o terminada.

Asimismo, el terreno aledaño a la estación, no puede encontrarse en un zona declarada Monumental o espacios Industriales de la ciudad. Lo primero, es un factor que limitaría el diseño y emplazamiento del programa. Lo segundo, traería consecuencias de contaminación auditiva, visual o ambiental a la futura propuesta cultural. Dentro de una zona de usos mixtos, la industria pesada no es considerada equipamiento urbano. 
Finalmente, el criterio de cultura determinará qué estaciones se encuentran en zonas de carácter cultural con potencial a explorar y aquellas en barrios que carecen de equipamiento cultural. En ambos casos, un Centro Cultural pretenderá mejorar la calidad de vida mediante la su programa y emplazamiento.

Luego de una primera elección de posibles terrenos y estaciones, se aplicarán nuevas variables. A través de éstas, se compararán los tres terrenos elegidos y serán evaluados mediante la Escala de Likert, un método de encuesta psicométrico que, en base a una calificación por subtemas, proporciona una calificación acumulada.

\subsubsection{Estaciones del Metropolitano}

El Metropolitano cuenta con 38 estaciones entre paradas, estación central y finales a los extremos norte y sur. Sin embargo, bajo los criterios previamente mencionados, la mayor parte no forman parte de potenciales locaciones para desarrollar el proyecto.

$\mathrm{Al}$ año 2013, las estaciones presentaban un flujo diario de pasajeros similar, a excepción de los extremos.

Cuadro: Afluencia diaria de pasajeros por estación (Carbajal López, Aragón Casas, \& Dávila Cajahuanca, 2013)

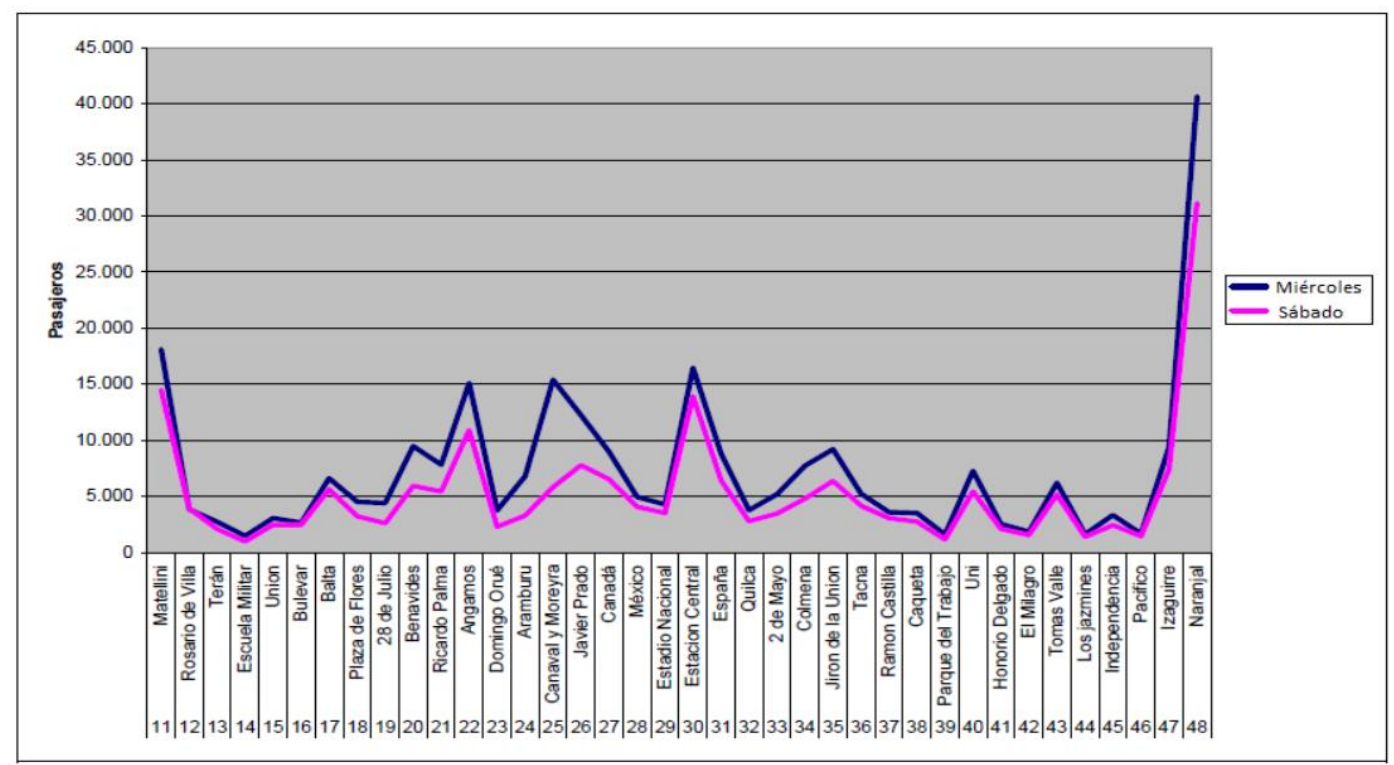


METROPOLITANO

VIAS | ESTACIONES

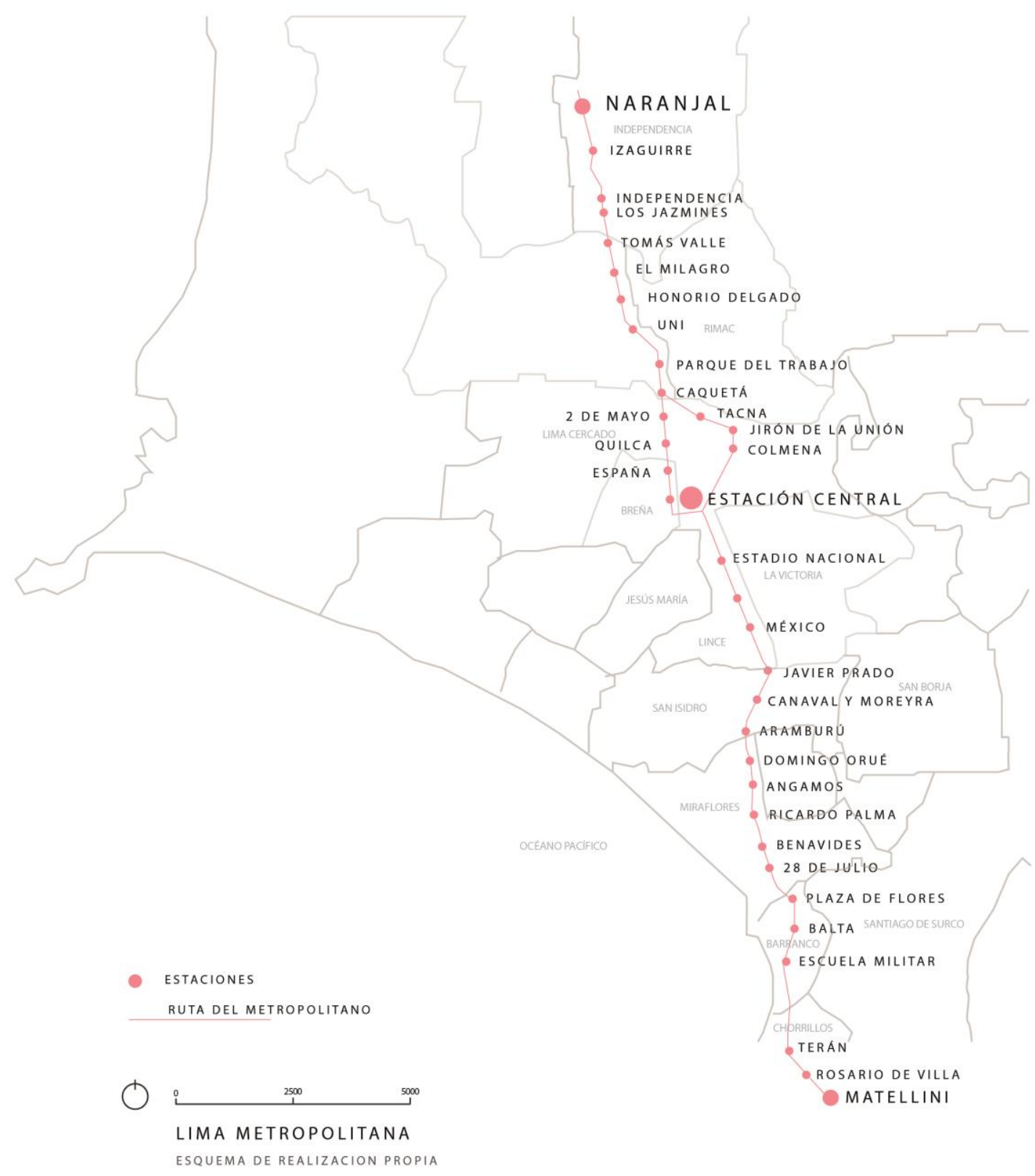


METROPOLITANO

CRITERIOS DE ELECCIÓN

ESTACION Y VIA DEL METROPOLITANO FUERA DE LA VIA EXPRESA, A NIVEL DEL SUELO.

TERRENOS DE MAS DE 5000 M 2 ALEDAÑOS A LA ESTACION.

LA VIA DEL METROPOLITANO GENERA DOS ESPACIOS AUTONOMOS.

ESTACION TIPO PLATAFORMA DE PARADA

FUERA DE ZONA MONUMENTAL

FUERA DE ZONA INDUSTRIAL

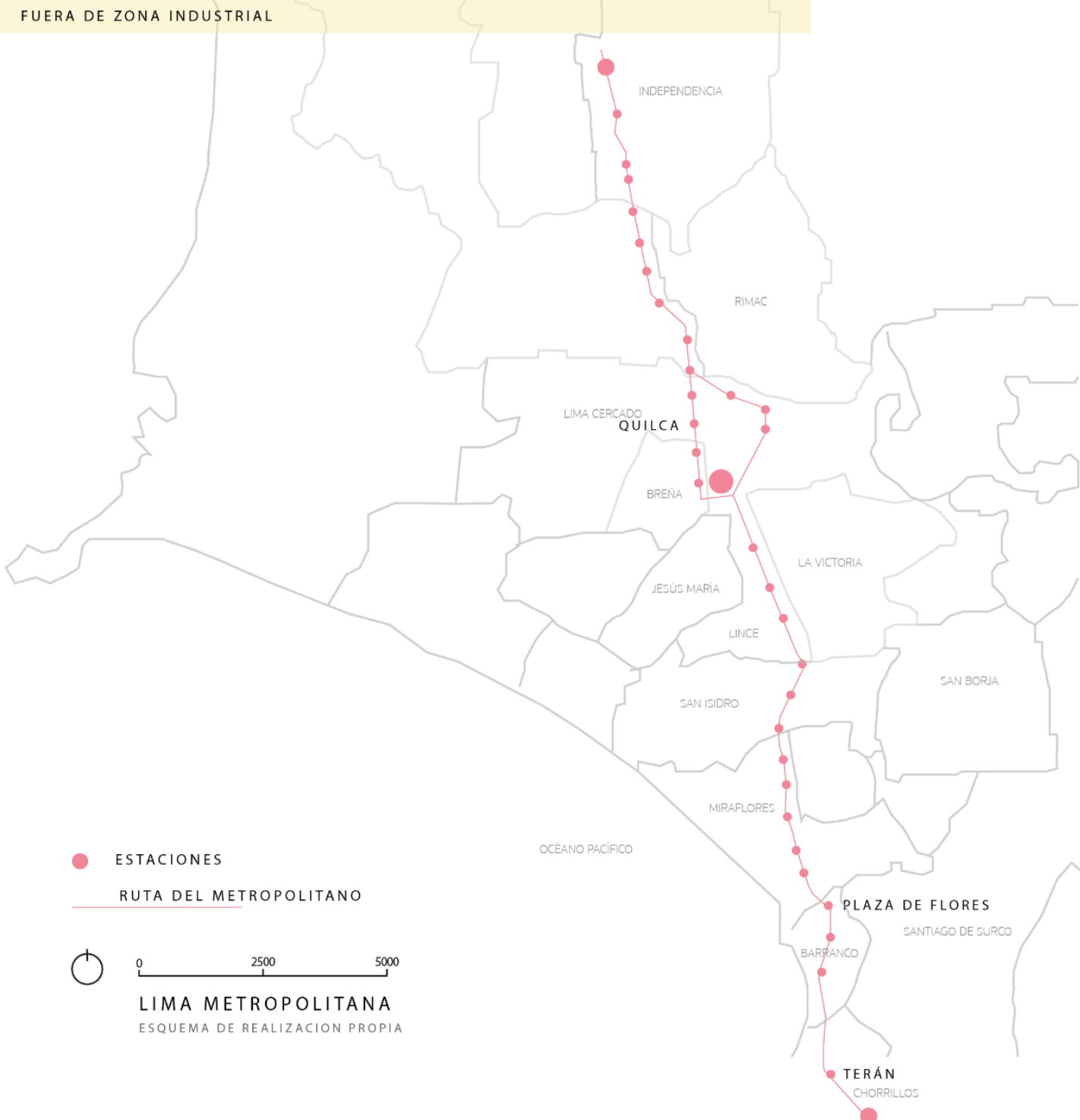


Es así que, finalmente, son posibles locaciones: Estación Quilca, en Lima Cercado; Estación Plaza de Flores, en Barranco; y Estación Terán, en Chorrillos. La mayor parte de estaciones del Norte, no cumplen con el criterio de 'no ser zona industrial'. Las que se encuentran al Centro, no tienen terrenos disponibles adecuados, o son Zona Monumental.

\subsubsection{Criterios de evaluación y Escala de Likert}

\section{Criterio 1: Área del terreno}

El proyecto buscará un amplio espacio de permanencia y esparcimiento para el peatón. $\mathrm{Al}$ menos, el terreno deberá tener $5000 \mathrm{~m} 2$ y estar capacitado para un área libre mayor al 50\%. Además, el equipamiento urbano debe ser de escala distrital pero permitirse albergar a público metropolitano, pues la estación facilitará la llegada en transporte público de toda la ciudad. Por lo tanto, se dará una mayor puntuación al terreno con mayor área disponible.

\section{Criterio 2: Usos de suelo}

El uso actual de los suelos dependerá de la zonificación que las municipalidades hayan planteado. Mientras la zonificación y uso actual sea de recreación, recibirá mayor puntuación, ya que existirán menos problemas al proponer el proyecto.

\section{Criterio 3: Morfología}

Es importante un terreno con frente amplio hacia la vía más conflictiva (Vía del Metropolitano), de manera que se produzca la mayor conexión visual y física entre las actividades del Centro y los usuarios del Metropolitano; con la menor cantidad posible de vecinos.

\section{Criterio 4: Accesibilidad peatonal}

Al ser un terreno para proyectar ciudad peatonal, las bermas y pistas deben estar acondicionadas para los transeúntes. Esto, a su vez, genera que haya gente en la calle, aumentando el flujo peatonal, usuarios de Metropolitano y de diversos equipamientos. 
Criterio 5: Vías de acceso

Al buscar que el equipamiento forme parte de un sistema Metropolitano, es necesario que la estación y el terreno se encuentren físicamente conectados entre sí. Además, deben existir grandes vías alternas de transporte que lleguen al espacio. Por lo tanto, a menor distancia entre la vía del Metropolitano y el terreno, mayor puntaje; así como también, a menor cantidad de vías de acceso de transporte al terreno, menor puntaje.

\section{Criterio 6: Percepción}

En este criterio, la puntuación es inversa, pues, es importante encontrar el lugar con mayor necesidad de intervención. Mientras exista una imagen más clara de la fragmentación urbana y consecuencias de ello, el puntaje será mayor.

\section{Criterio 7: Consideraciones ambientales}

Las condiciones climáticas y de contaminación ambiental influirán en el proyecto. Al ser Lima una ciudad, gran parte del tiempo, nublada, se buscará el terreno con mayor período de asoleamiento al año y mejores condiciones climáticas.

\section{Criterio 8: Infraestructura y servicios}

La puntuación dependerá de la dotación de agua, desagüe y energía o alumbrado público existente. Esto se debe a que, a mejores condiciones en la zona, el terreno y futuro proyecto tendrá una mejor calidad de infraestructura y servicios también. Sin ellos, podrían existir problemas en construcción, instalaciones y un presupuesto poco ventajoso.

\section{Criterio 9: Riesgos}

Los riesgos se refieren a aquellos factores fuera del alcance de los proyectistas. Ejemplos son: problemas legales con el terreno, calidad de suelo y vulnerabilidad ante desastres naturales. A menor riesgo, mejor puntuación.

Criterio 10: Características de construcción de la zona

Se busca repotenciar un radio urbano en la zona aledaña al terreno y aumentar el valor del suelo en la medida de lo posible. Por ello, la puntuación en este criterio depende del potencial crecimiento público y privado del entorno según su patrón actual. 
Criterio 11: Equipamiento próximo

Es importante tener en cuenta los equipamientos existentes, de manera que se pueda evaluar la posible generación de un polo urbano de servicios. Sin embargo, depende del tipo que sea, pues buscamos generar un centro de servicios variados. A mayor variedad, mayor puntuación.

Criterio 12: Uso actual del terreno

Si un terreno está actualmente ocupado, obtendrá una baja calificación, pues, los requerimientos y problemática al reemplazar usos podrían generar conflictos sociales o urbanos. A menor uso de terreno o mayor deterioro de infraestructura, mayor puntuación.

Criterio 13: Usuarios de la estación del Metropolitano adyacente

Como factor influyente, tenemos a la cantidad de viajes por cada estación adyacente al terreno. La documentación de personas que utilizan dicha estación actualmente como plataforma de embarque o desembarque por otros motivos, nos facilitará una proyección de usuarios que necesiten un espacio de permanencia y recreación dentro del proyecto. A mayor número de personas que usen la estación, mejor puntuación. El promedio a alcanzar es de 5000 personas diariamente.

Criterio 14: División urbana que provoca

Este criterio es aquel que señala la prioridad de terreno a intervenir según el problema urbano que causa el Metropolitano en la zona. Las vías pueden dividir dos zonas urbanas a menor, intermedia o mayor escala. De esto dependerá la puntuación: a mayor división, mayor puntuación. Es importante conocer el terreno más fragmentado social y físicamente por las vías del Metropolitano y su estación.

Criterio 15: Espacios de permanencia peatonal

Este criterio también es de calificación inversa: A menor cantidad de espacios de permanencia en el entorno del terreno, mayor calificación. Esto responde, una vez más, a priorizar los terrenos según necesidad de intervención urbana. 


\subsection{Estación Terán, Chorrillos.}

La Estación Terán se encuentra en el distrito de Chorrillos, entre las estaciones Escuela Militar y Rosario de Villa, al Sur de Lima Metropolitana.

La salida y cruce peatonal desde la estación a las calles próximas tiene el largo de una sola pista vehicular y es regulado por un semáforo y cruce peatonal a desnivel. En ese caso, la distancia es medida en 02 minutos como máximo desde la salida de la estación.

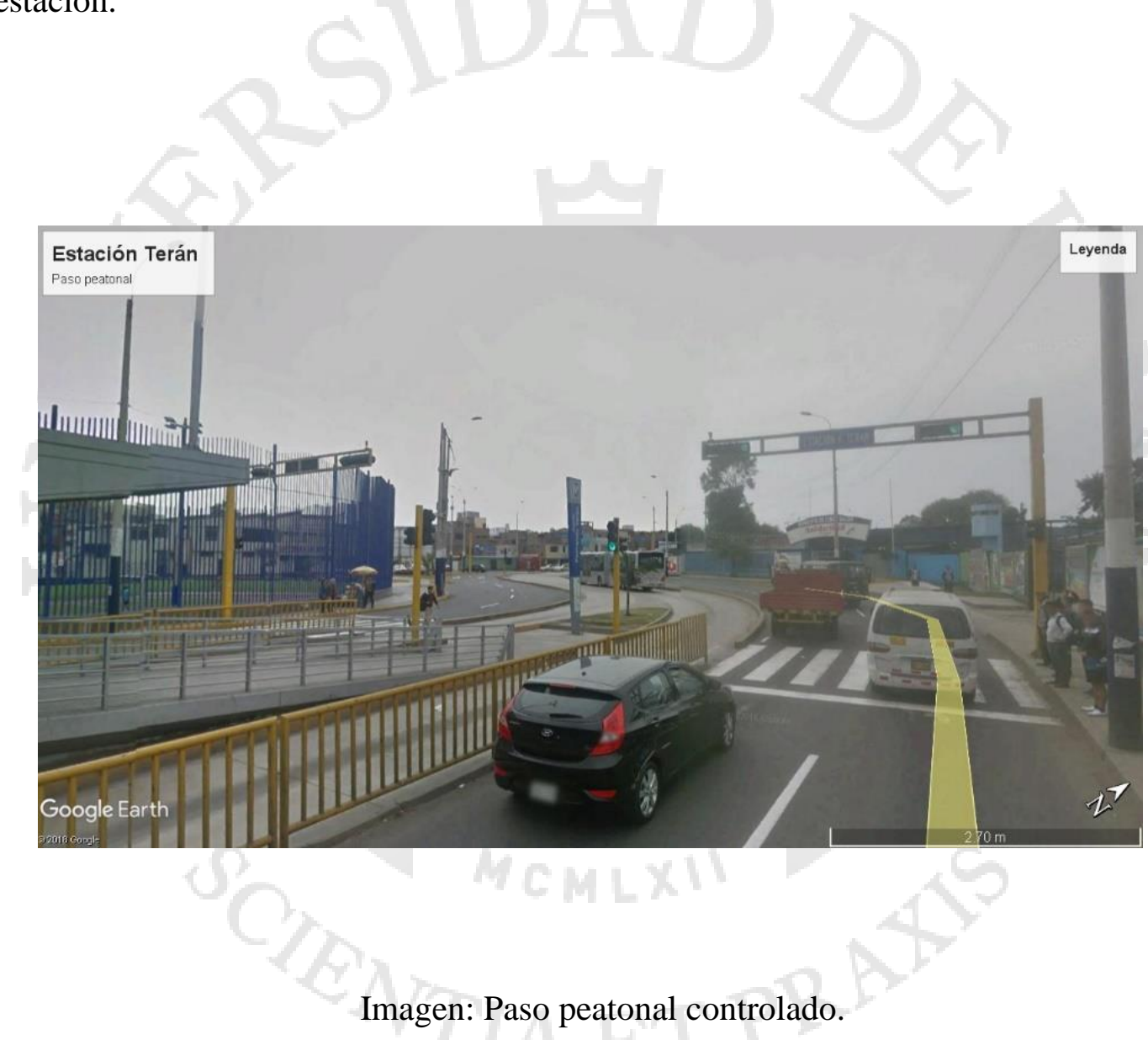




\section{ESTACIÓN TERÁN}

VIAS ACCESIBILIDAD

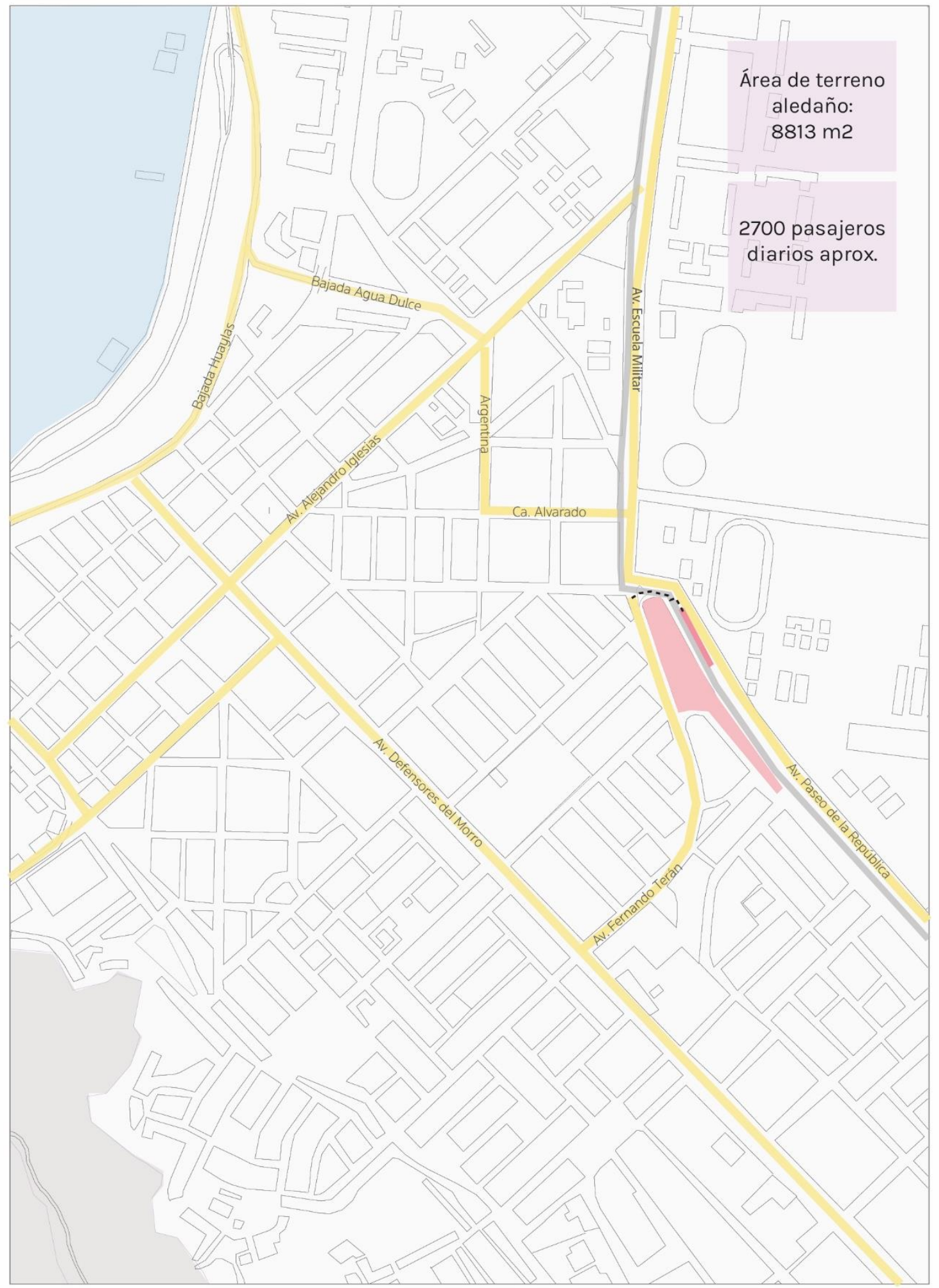

VIAS PRINCIPALES

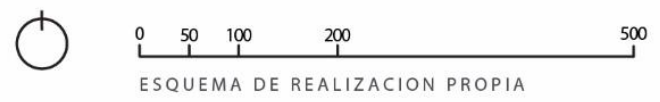

VIA DEL METROPOLITANO

RUTA PEATONAL ( $2 \mathrm{~min}$ )

OCÉANO PACÍFICO

ESTACIÓN TERÁN - TERRENO 
ESTACIÓN TERÁN

EQUIPAMIENTO
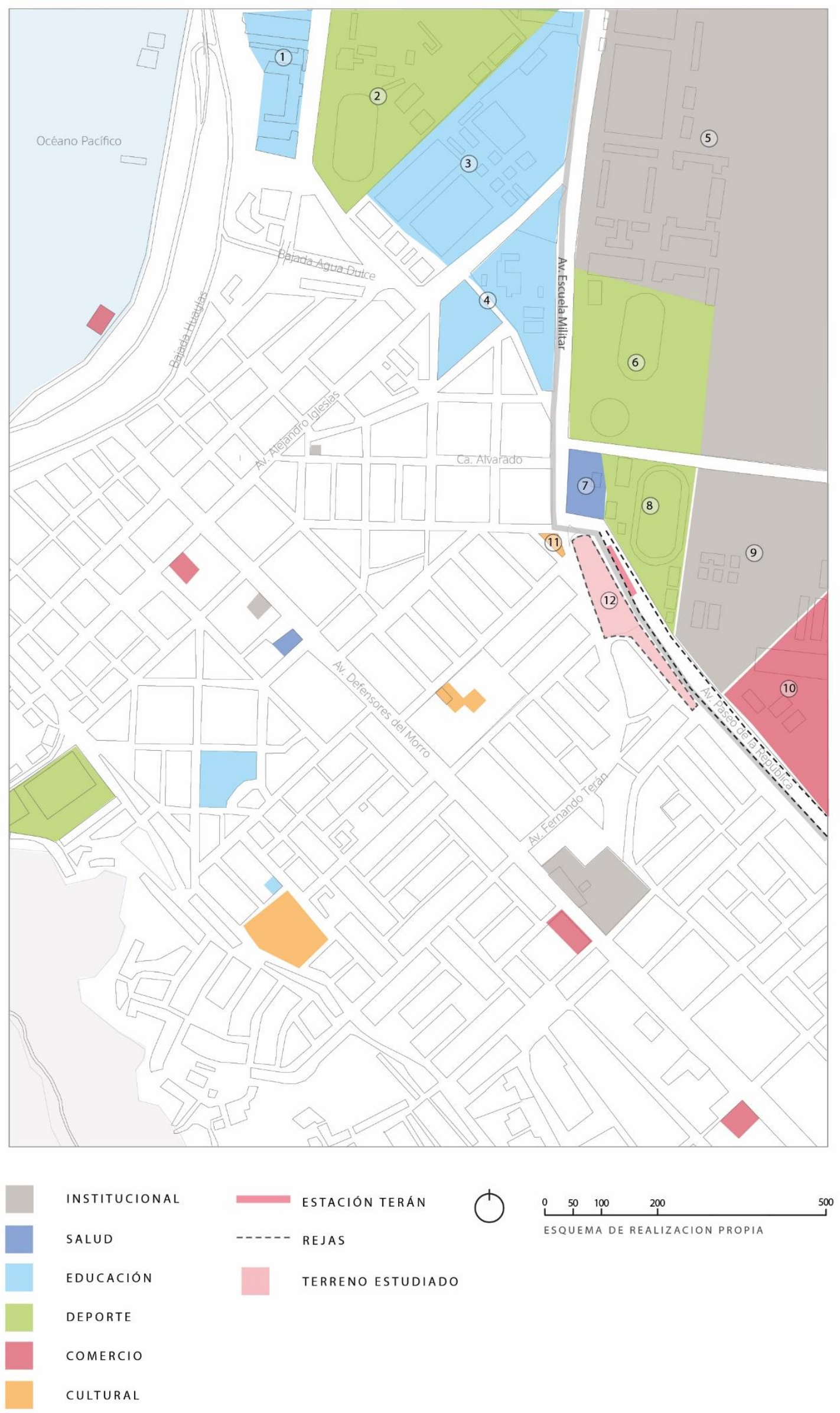
En este caso, el perfil de vía cuenta con espacio suficiente para la estación, automóviles y peatones. Su función no genera un límite físico, como en otras estaciones del Metropolitano. Sin embargo, el enrejado de la vía del bus y del equipamiento aledaño, genera espacios autónomos y de diferente uso. Por un lado, es residencial bajo y, por otro lado, hay todo tipo de equipamiento.

A pesar de que la zona no cuenta con muchos espacios culturales, se encuentra activada por un centro comercial, estadios, espacios deportivos y religiosos, etc. Estos son espacios de esparcimiento público y privado:

(1) Centro Educativo Sagrado Corazón Chalet / Escuela de baile

(2) Pedro Ruiz Gallo

(3) Círculo Militar de Chorrillos

(4) Colegio Emilio Soyer / IE Brigida Silvia de Ochoa

(5) Escuela Militar de Chorrillos

(6) Estadio Municipal A.V. / Coliseo M.C.

(7) Hospital de la Solidaridad

(8) Estadio Municipal C.A

(9) COEDE

(10) C.C. Plaza Lima Sur

(11) Polideportivo / Skatepark

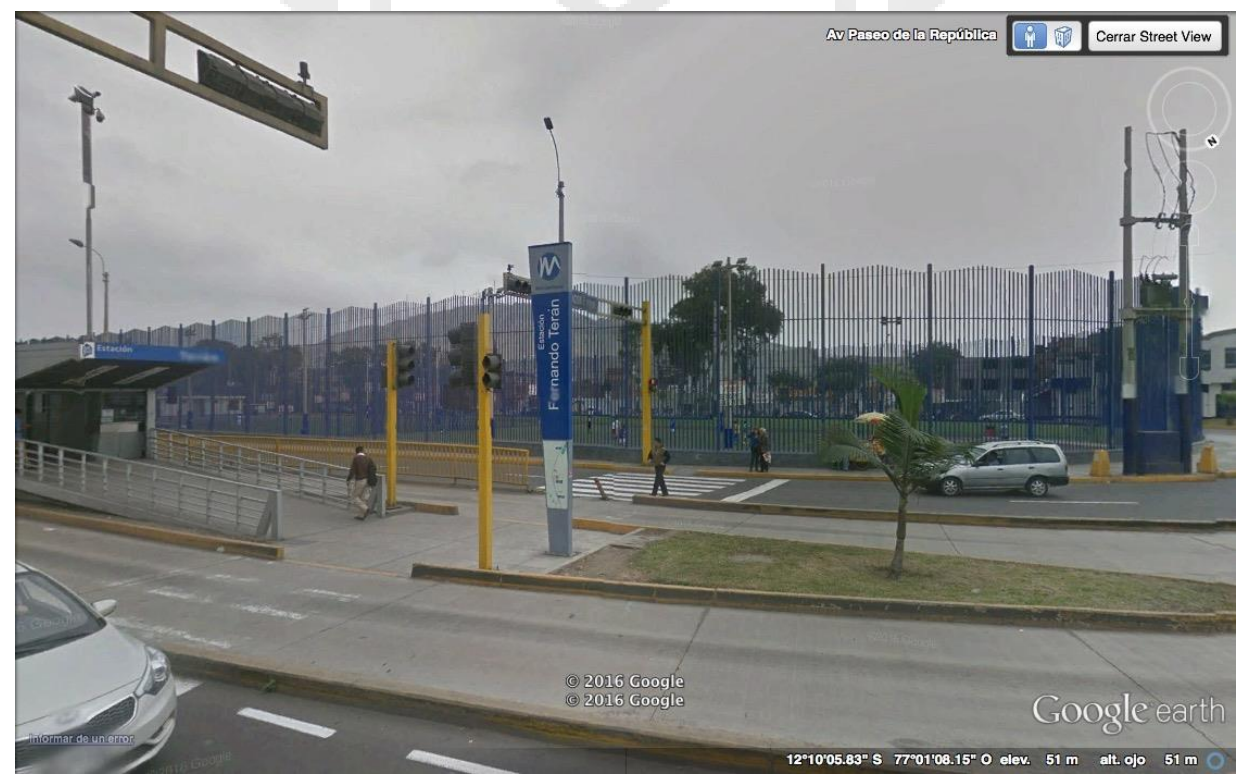

Imagen: Entrada a estación y polideportivo aledaño. 
La estación de considera objeto de estudio, porque cuenta con las características que el proyecto busca. Entre ellos, se encuentra aledaña a un gran terreno de equipamiento deportivo público, pero en condiciones que no favorecen al peatón ni al perfil urbano. Está completamente enrejado y controlado, siendo útil solo para quien desarrolla actividades deportivas dentro. No es un espacio para la ciudad.

La zona residencial cercana al mar tiene un crecimiento inmobiliario mayor al resto de la zona. En ella se desarrollan edificios multifamiliares dirigidos a NSE A-B. Cerca al Morro Solar, existen aún residencias antiguas en material rudimentario como adobe y quincha. Coincidentemente, el NSE de esta zona es menor.

La Estación Terán colinda, por el oeste con edificaciones de material noble y por el este, con el Centro Comercial Plaza Lima Sur y la Escuela Militar.

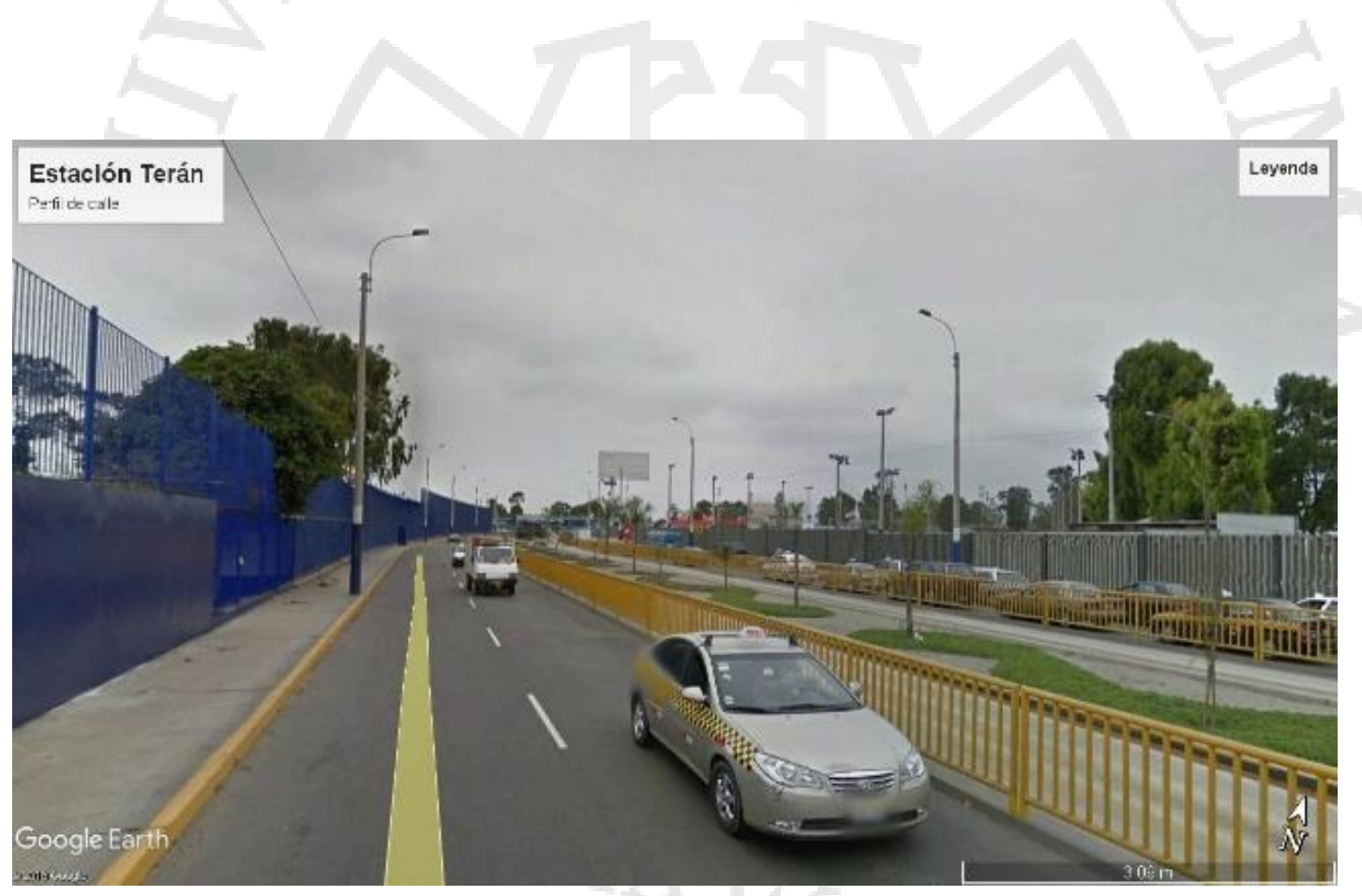

Imagen: Perfil de vías y enrejado. 
ESTACIÓN TERÁN

DIVISIÓN URBANA

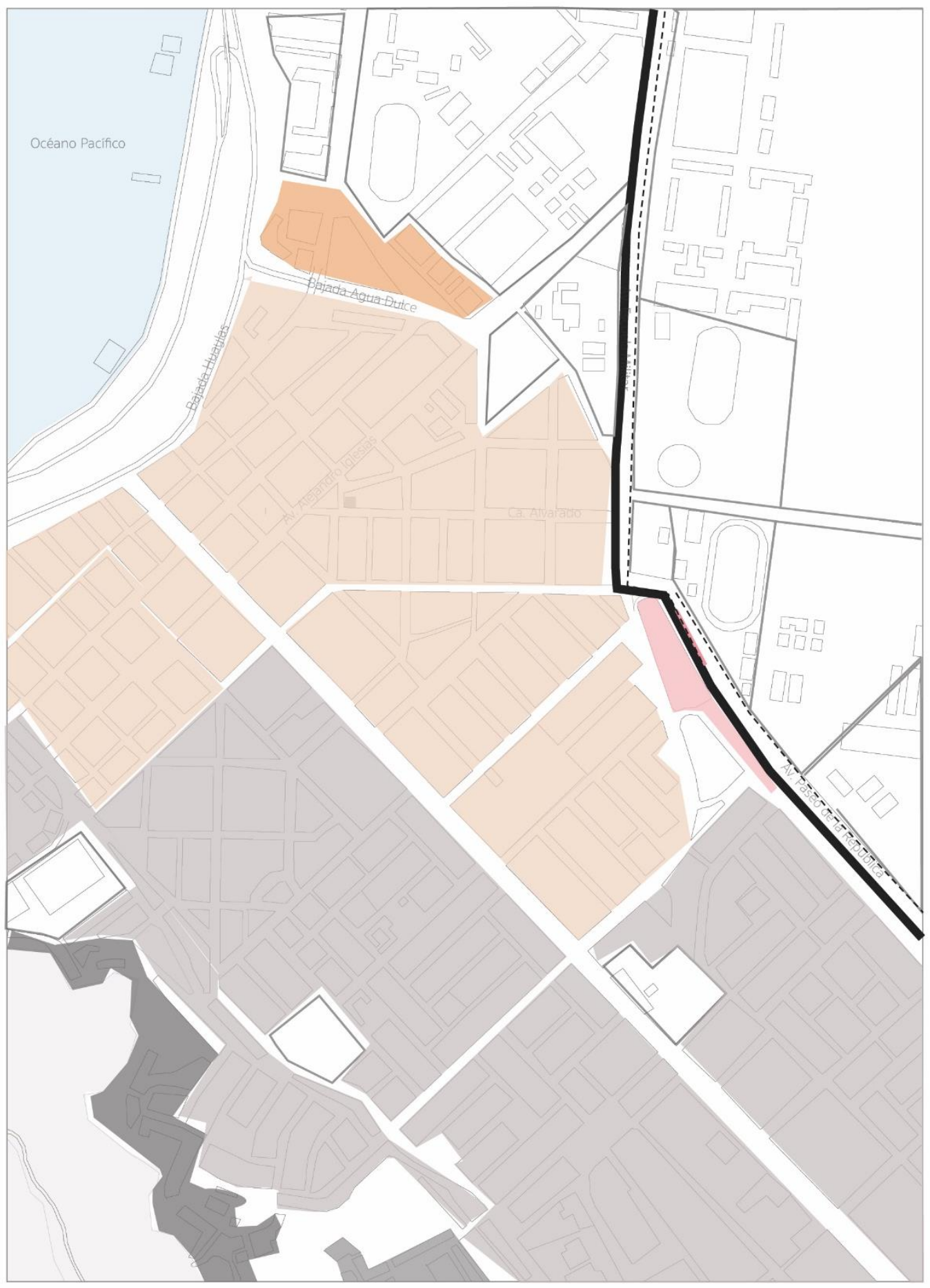

ESTADO DE CONSTRUCCIONES

ESQUEMA DE REALIZACION PROPIA 


\subsection{Estación Quilca, Lima Cercado.}

La estación Quila se encuentra en el Cercado de Lima, al centro de la ciudad. Algunas edificaciones en el distrito tienen valor monumental.

Además de recibir a la vía del Metropolitano, la Avenida Alfonso Ugarte recibe a la ruta del Sistema Integrado de Transporte (SIT), un sistema de buses que recorre la ciudad por corredores preferenciales.

Al igual que en la estación Terán, la ruta peatonal entre veredas es de 2 minutos, regulado por un semáforo y paso de cebra peatonal.

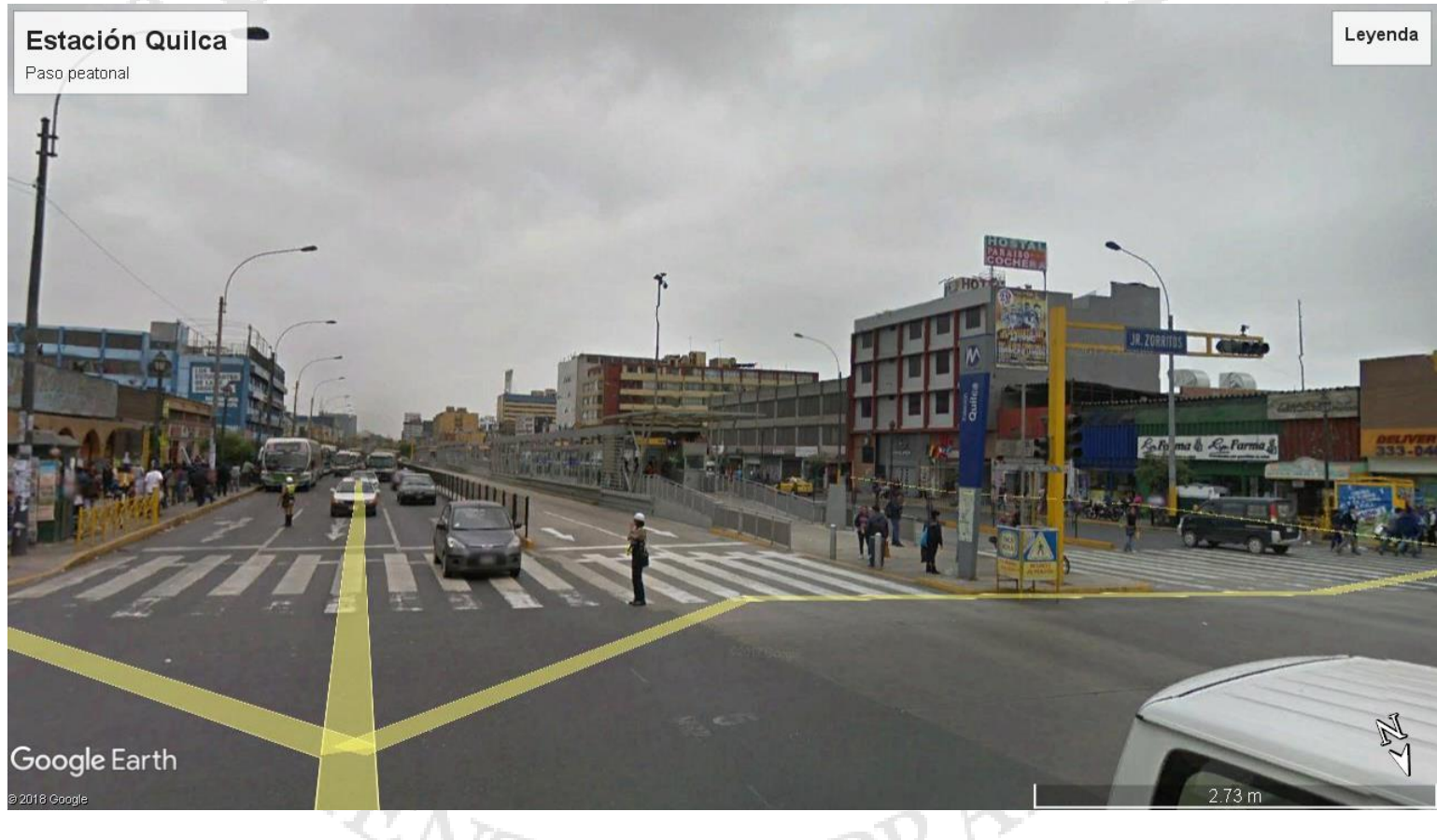

Imagen: Paso peatonal controlado. 
ESTACIÓN QUILCA

VIAS ACCESIBILIDAD

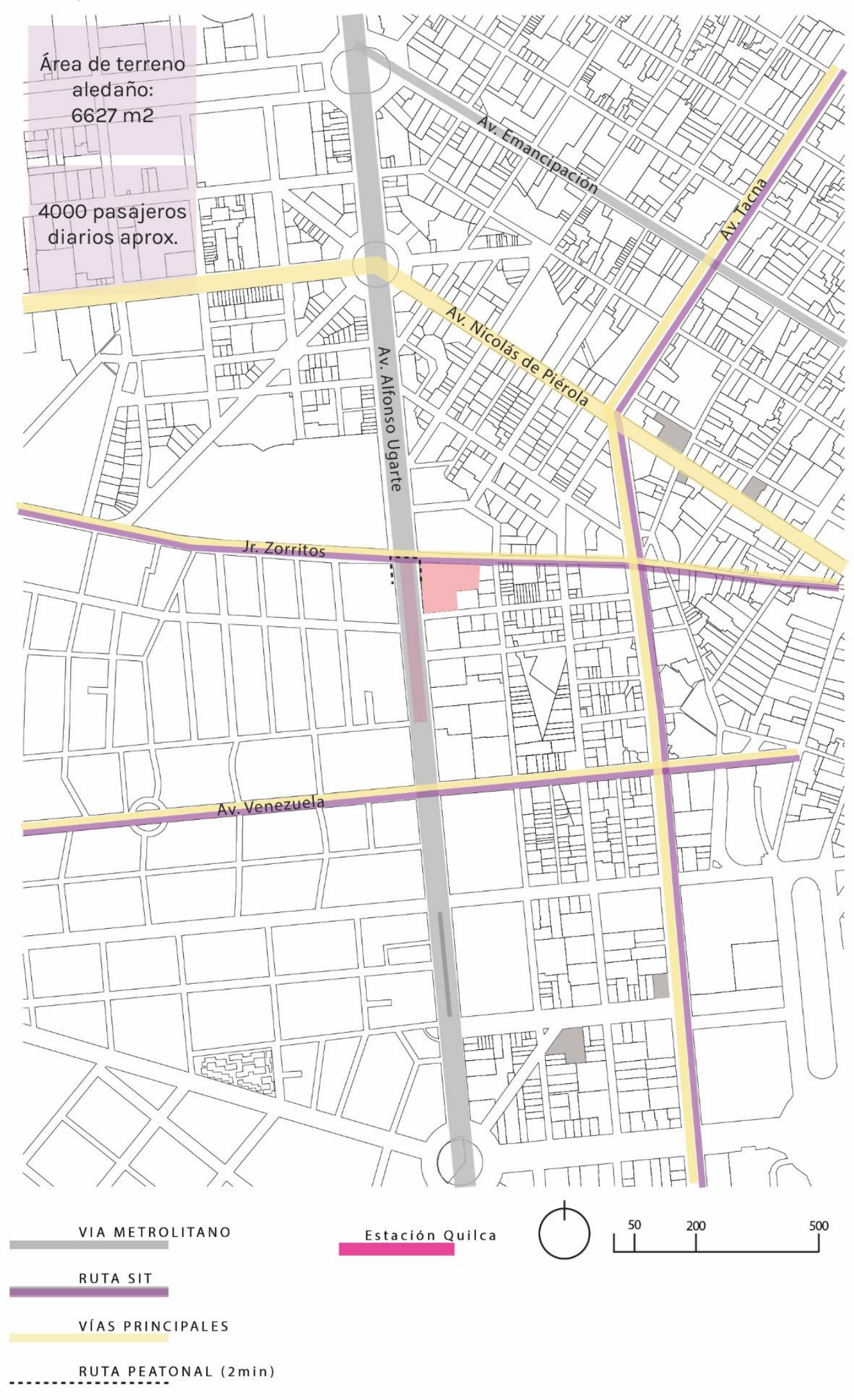



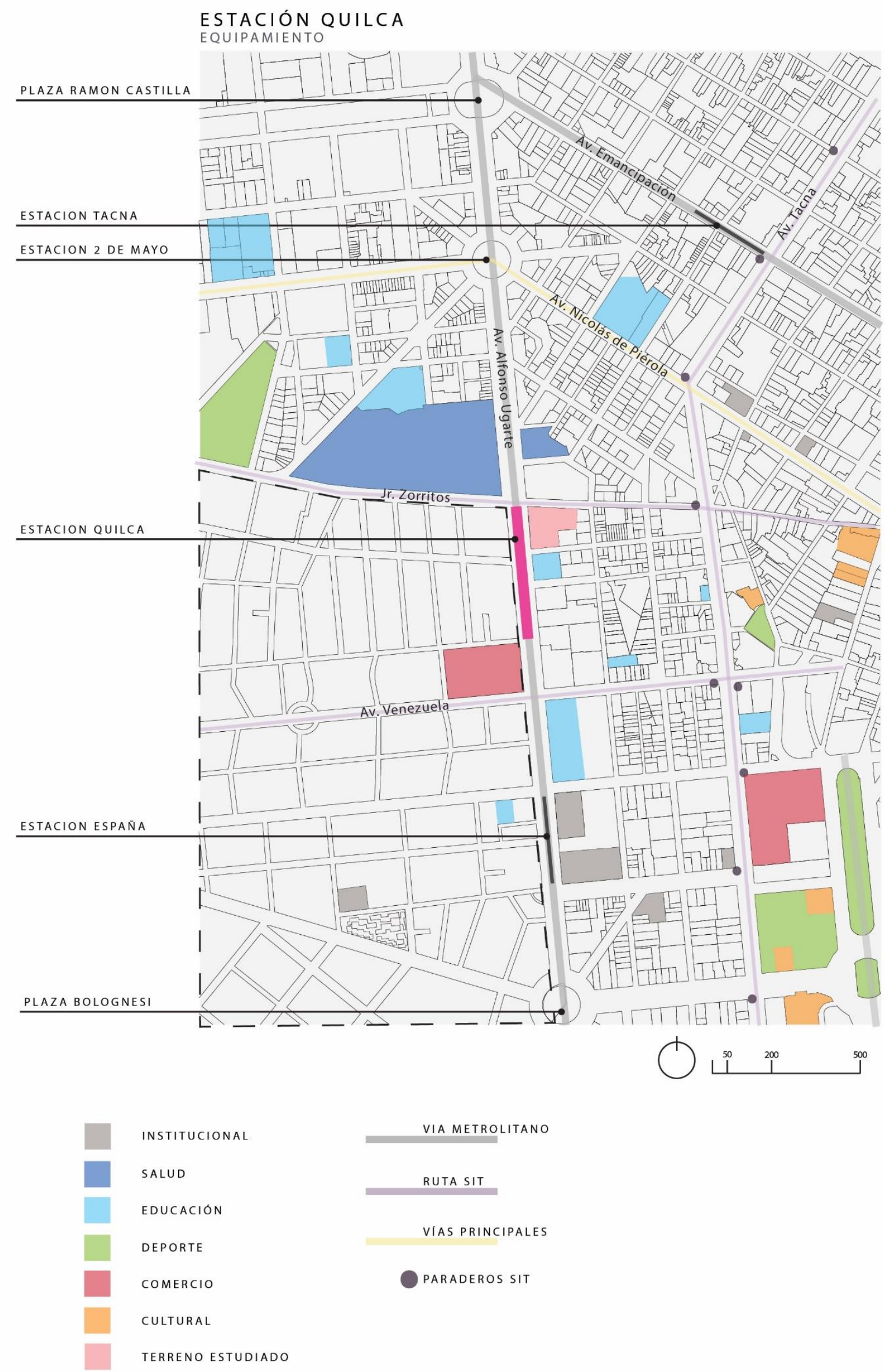
ESTACIÓN QUILCA

ESPACIO PÚBLICO

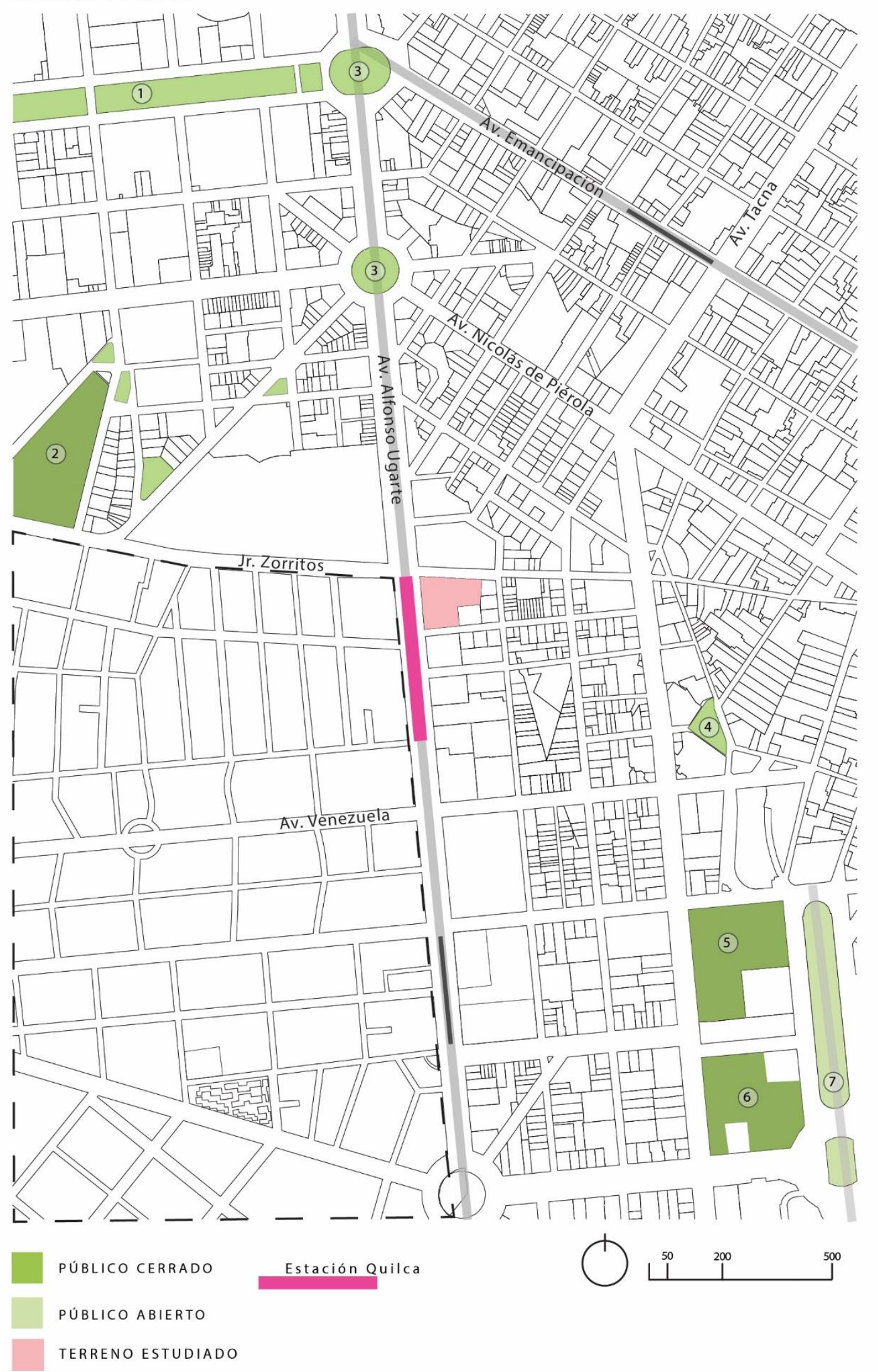


En la zona de estudio existen espacios públicos abiertos, constantemente en mantenimiento por la municipalidad de Lima y con áreas verdes. Sin embargo, la ubicación de todos ellos no es propicio para el uso del peatón común. Todos se encuentran en óvalos, o entre vías rápidas, impidiendo la fácil entrada. Es el caso de

( 1 ) Alameda de las Malvinas

( 3 ) Plaza Ramón Castilla / Plaza Dos de Mayo

( 7 ) Paseo de los Héroes Navales

Por otro lado, el Estadio Lolo Fernandez (2) y el parque Juana Alarco de Dammert (6) se encuentran limitados por rejas.

La Estación Quila se encuentra en el límite de Cercado de Lima y Breña. A pesar de ser administraciones diferentes, ambos bordes se asemejan en equipamiento, edificaciones y problemática social.

Según el Plan de Seguridad Local Ciudadana 2016 del Cercado de Lima, la mayor parte de violencia en la zona se relaciona a la portabilidad de armas, en su mayoría robadas. Además, según el Mapa del Crimen de Lima (Observatorio de Criminalidad del Ministerio Público, 2016), la mayor parte de casos se refieren a la violencia familiar y problemática dentro del hogar. 


\subsection{Estación Plaza de Flores, Barranco.}

ESTACIÓN PLAZA DE FLORES

VÍAS | ACCESIBILIDAD

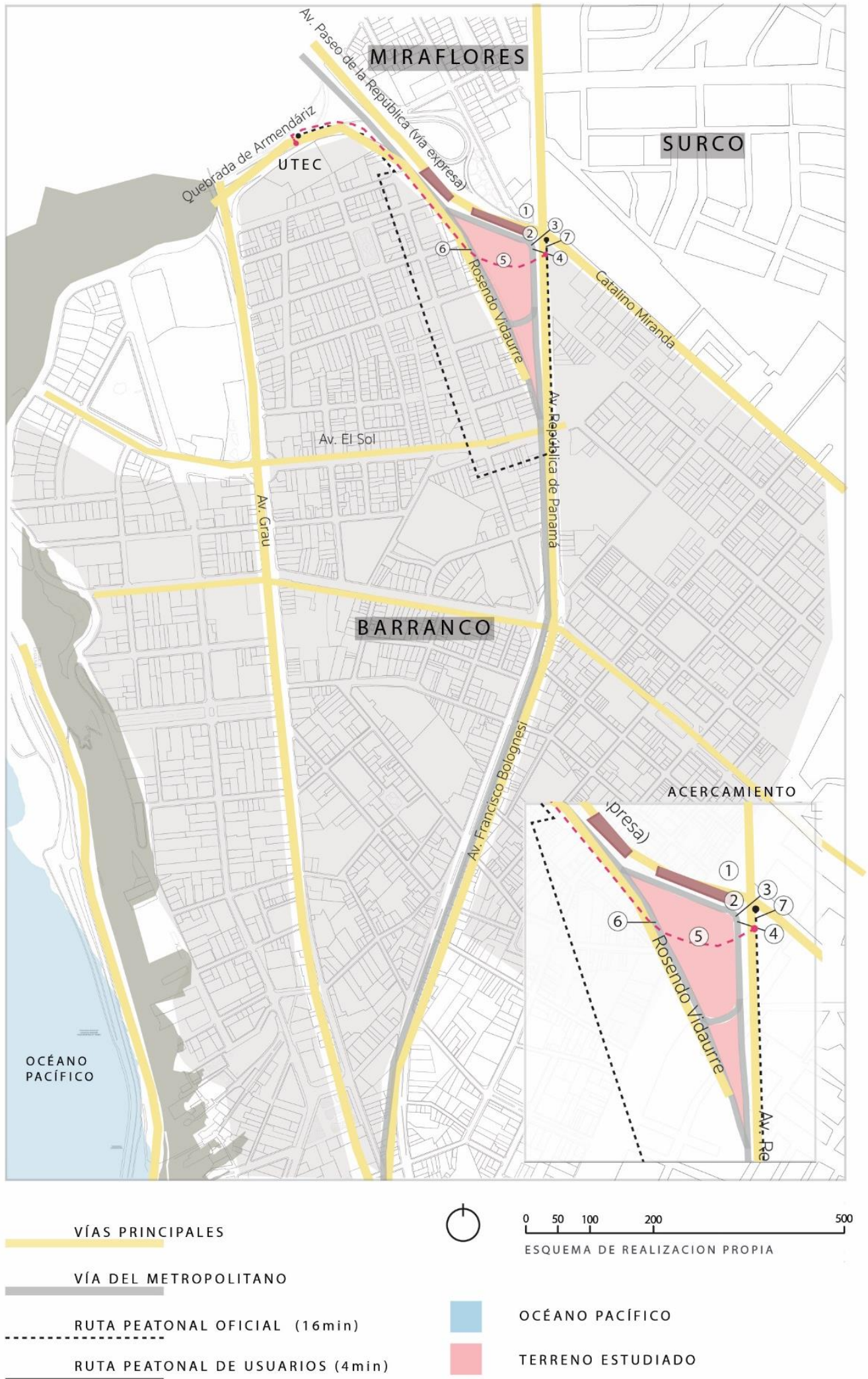


El tránsito peatonal alrededor de la estación se complica en Barranco. El usuario que viene desde Miraflores, debe cruzar un puente peatonal de varios tramos, llegara una vereda próxima a una vía rápida, y surcar a través de estrechas veredas con postes y semáforos.

El terreno podría funcionar como recibidor y activador de un paso peatonal obligado.

Tránsito de Miraflores a Barranco:

(1)

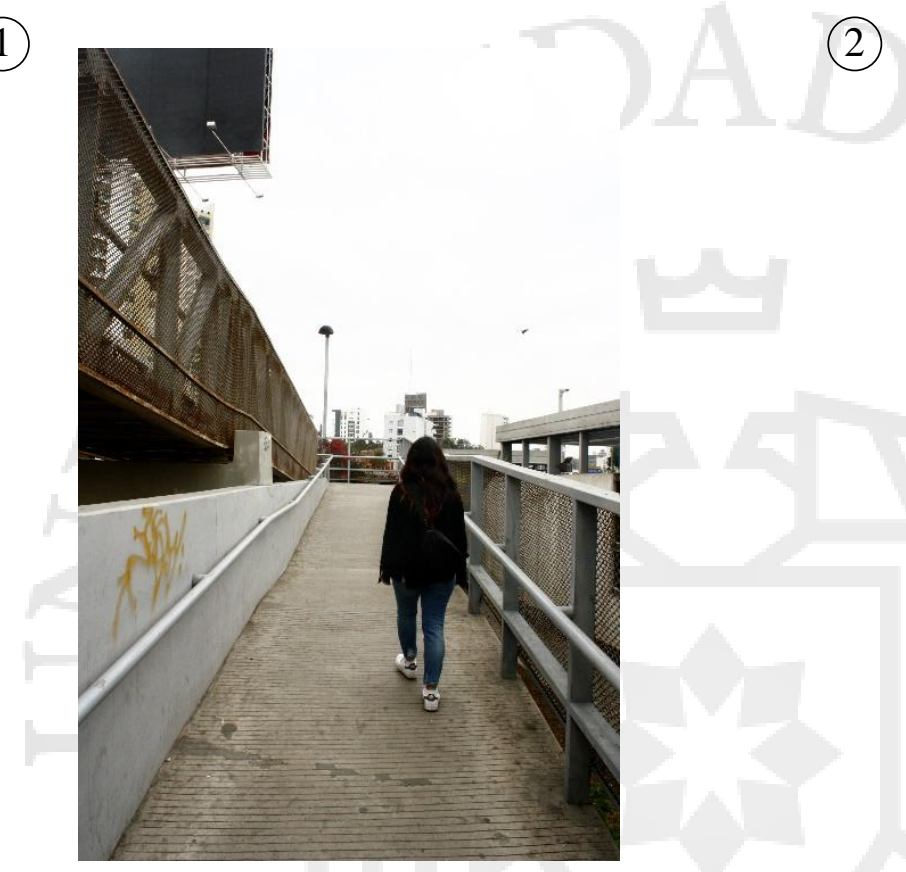

(3)

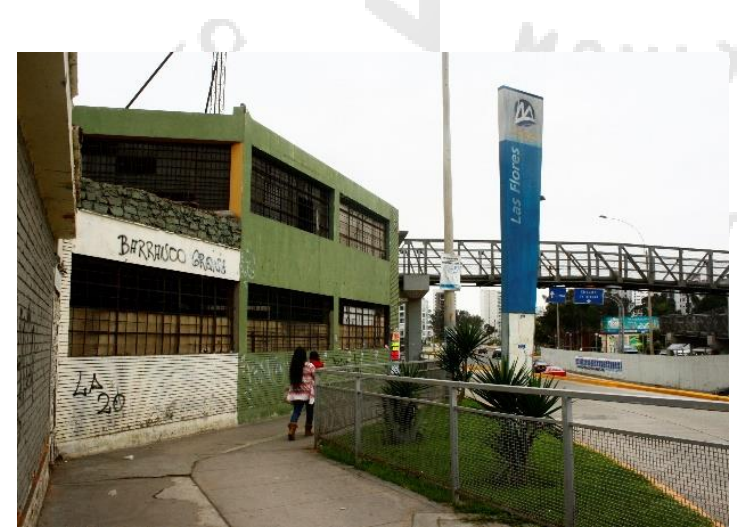

(2)

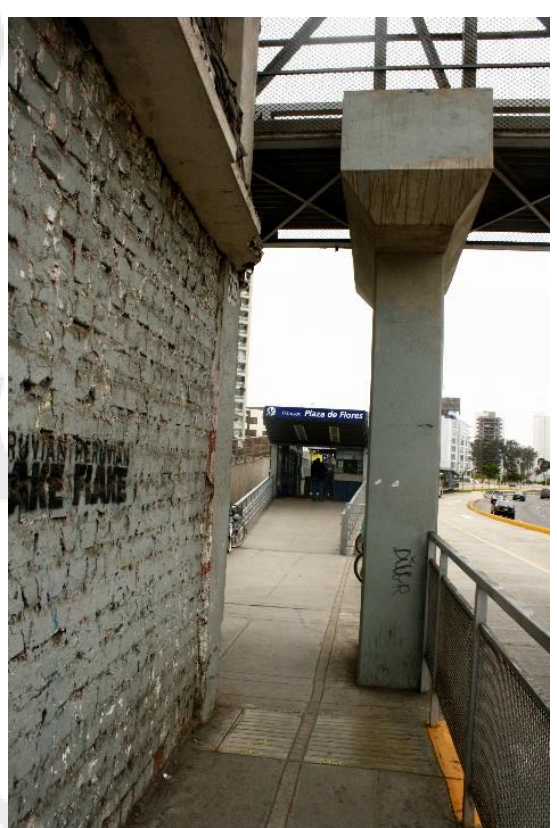

(4)

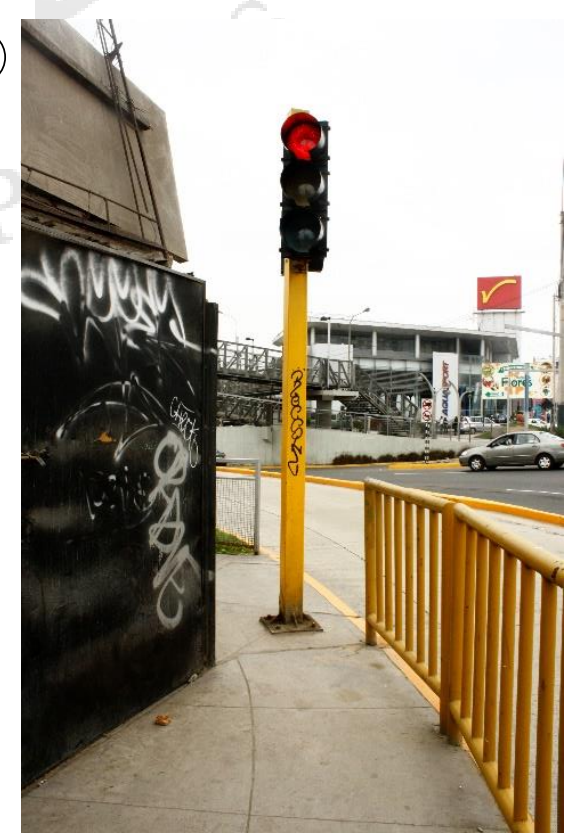


(5)

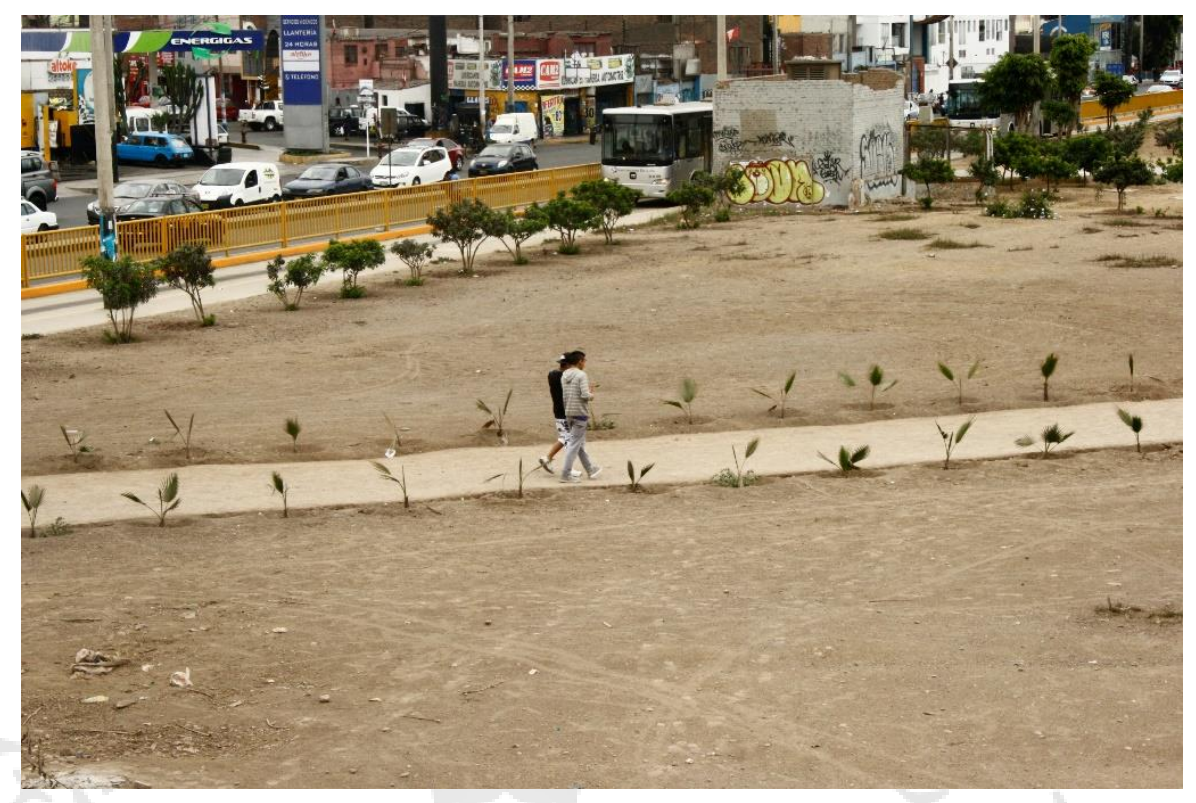

6
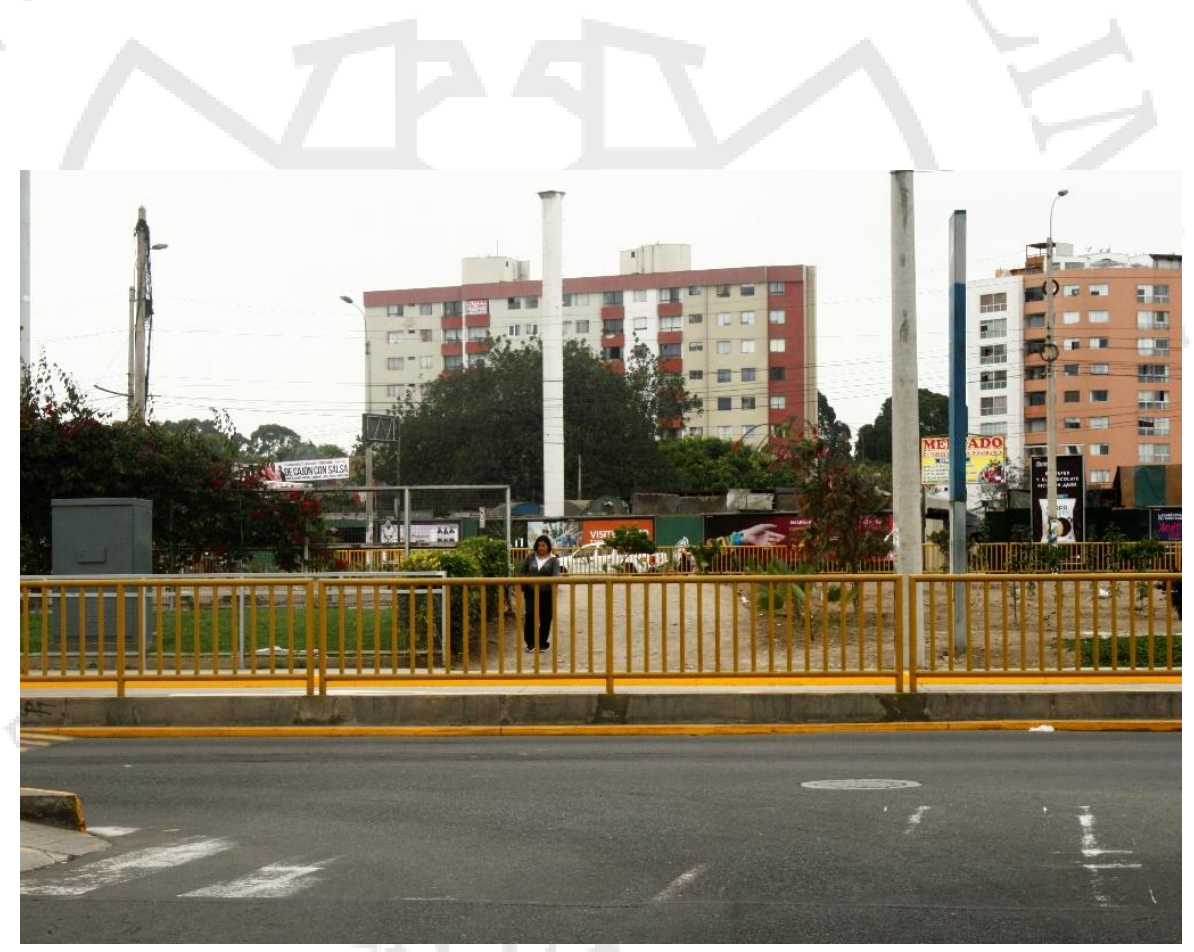
Tránsito de la Zona 3 de Barranco a la Zona 2:

(7)

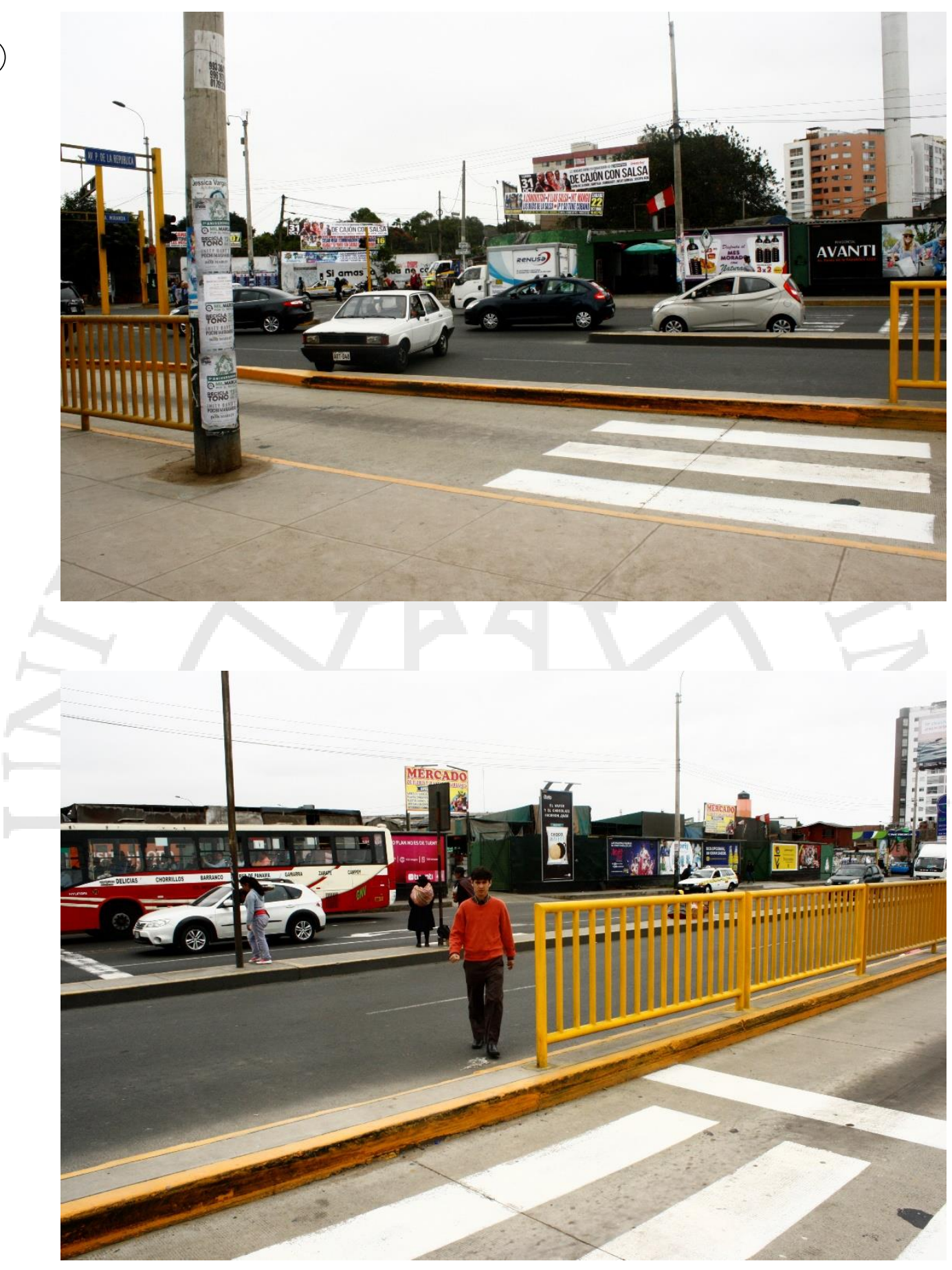


ESTACIÓN PLAZA DE FLORES

EQUIPAMIENTO

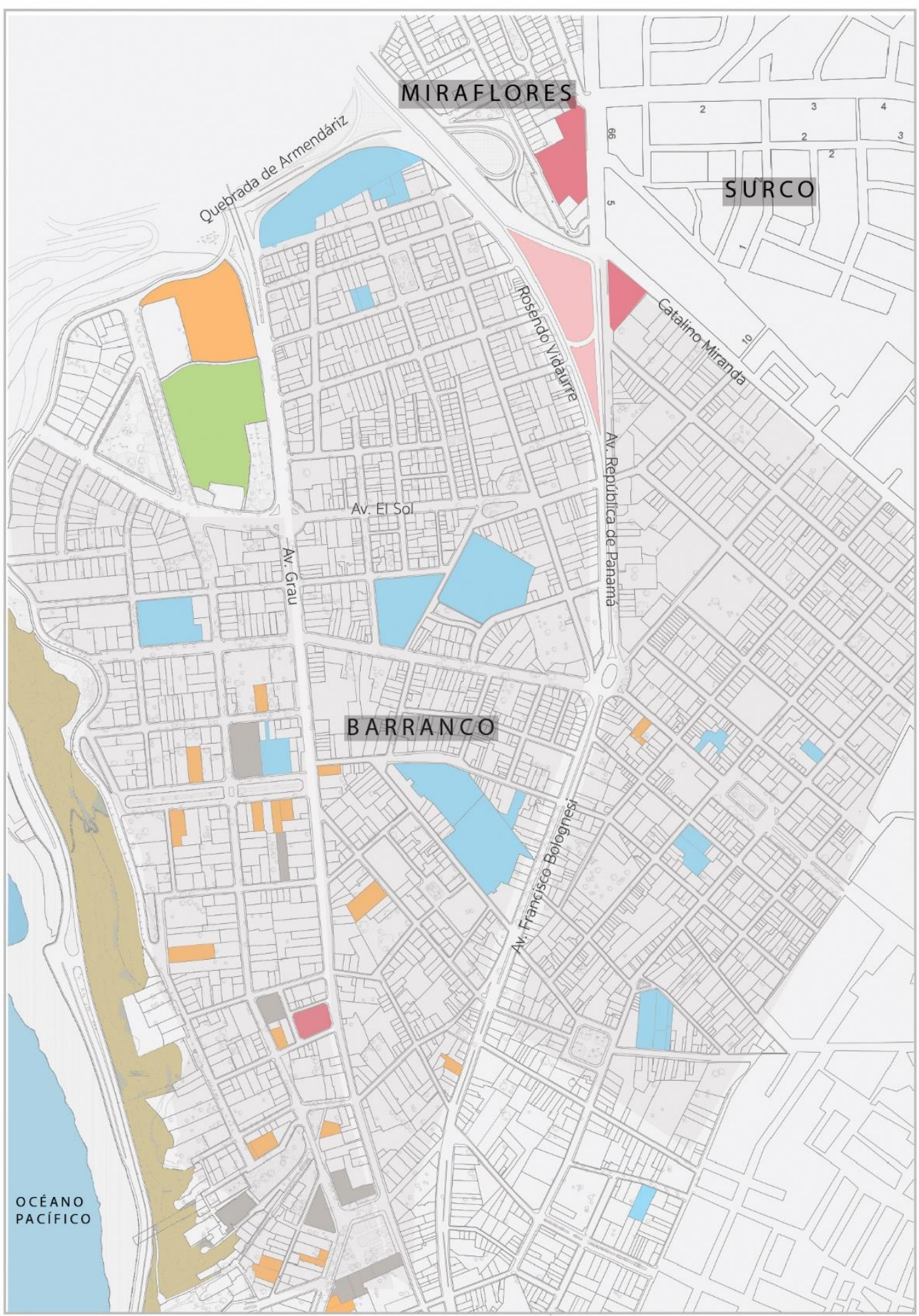

INSTITUCIONAL

EDUCACION

DEPORTE

COMERCIO AGRUPADO

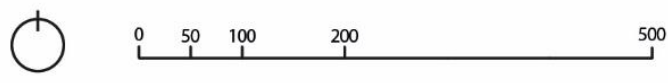

CULTURAL

ACANTILADO

TERRENO ESTUDIADO 
En el plano general, se observa un número elevado de servicios y equipamiento en la zona cerca al mar, en comparación a las demás zonas en estudio.

El plano toma en cuenta como Equipamiento comercial a mercados y agrupaciones de comercio. Sin embargo, alrededor de las Avenidas principales, existe una creciente oferta de servicios comerciales. La naturaleza de éstos varía según su ubicación.

En la Avenida San Martin, encontramos tiendas especializadas en vida saludable, vestimenta exclusiva, cafés, bares y restaurantes. En este caso, las actividades de la avenida son de paseo y opcionales.

Aunque la Avenida Grau también cuenta con restaurantes y bares, predominan los establecimientos de actividad obligatoria. Acá, se encuentran las entidades financieras, mercados, supermercados y librerías.

La Avenida Bolognesi y vía del Metropolitano, tiene una menor oferta de servicios para actividades opcionales. Cerca y alrededor al Terreno de estudio, existen talleres de mecánica, gasolineras, bodegas y pequeños restaurantes, que suelen atender a los trabajadores del área.

Hacia uno de los extremos del terreno, República de Panamá, se encuentra el mercado Polvos Verdes, de plantas y flores ornamentales.

Entre Grau y Bolognesi, se encuentran las entidades educativas más grandes de la zona de estudio.

Las Avenidas Catalino Miranda y Balta, ofrecen algunas bodegas, bares y servicios automotrices. Los demás espacios son residenciales. Alrededor de estas Avenidas, también encontramos entidades educativas estatales. Sin embargo, no se ofrece alguna actividad recreativa o de disfrute cerca a ellas.

Finalmente, en Miraflores se encuentra Plaza de Flores, uno de los mercados de flores y plantas más importantes de Lima, que hace 10 años se ubicaba en el terreno de estudio y debió ser reubicado por las autoridades. 
Este mercado y Polvos Verdes mantenían una conexión visual, divididos por la Avenida República de Panamá. Sin embargo, luego de reubicar Plaza de Flores, la conexión es complicada y a través de los limitados espacios de tránsito peatonal previamente mencionados. Sería adecuado, presentar una conexión física que mantenga la identidad de este espacio de Lima.

Por lo tanto, encontramos que, en las áreas cercanas al Oeste, la oferta de servicios y equipamiento de actividades opcionales es mayor al de la zona Este estudiada.

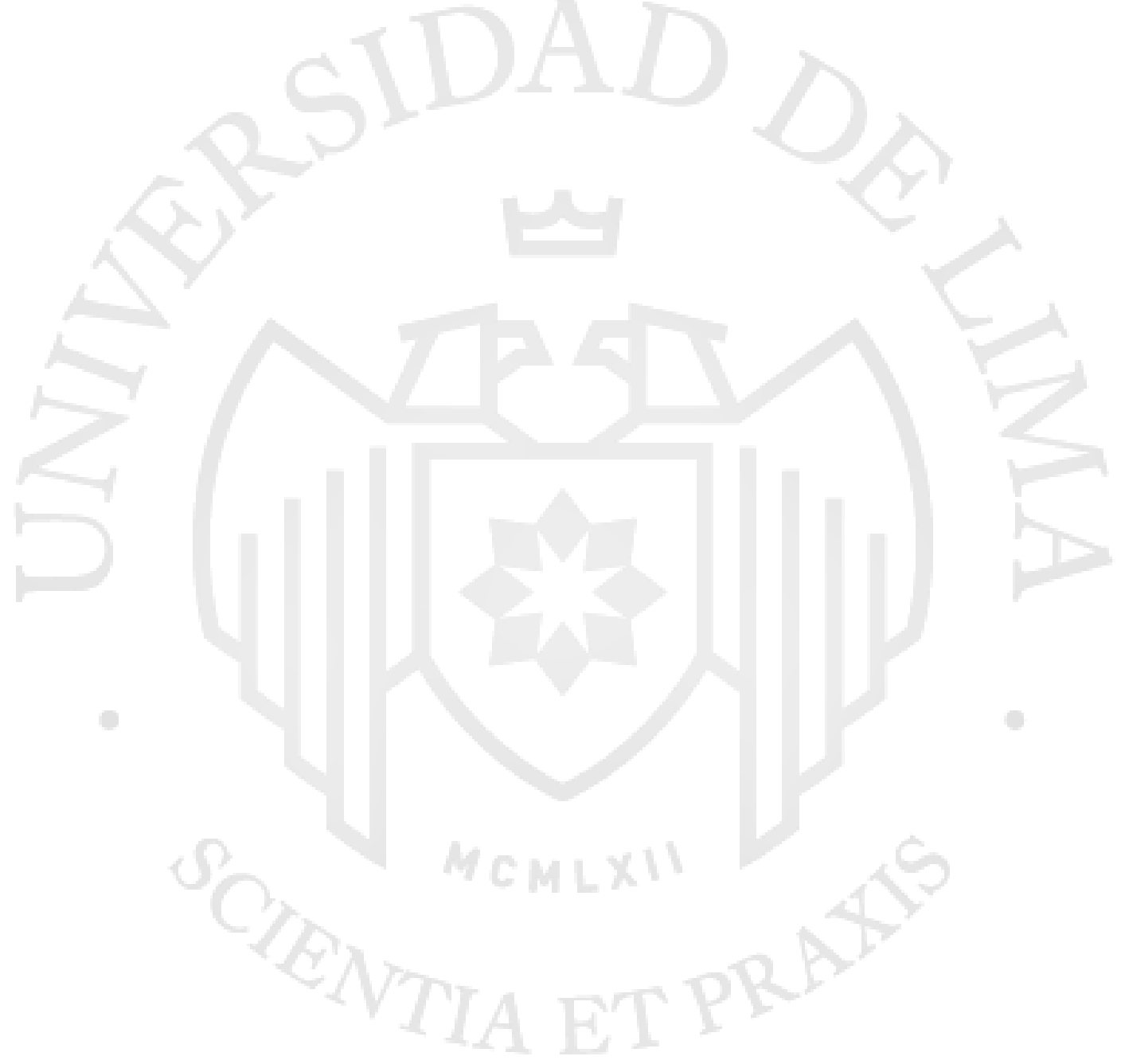


ESTACIÓN PLAZA DE FLORES

ESPACIO PÚBLICO

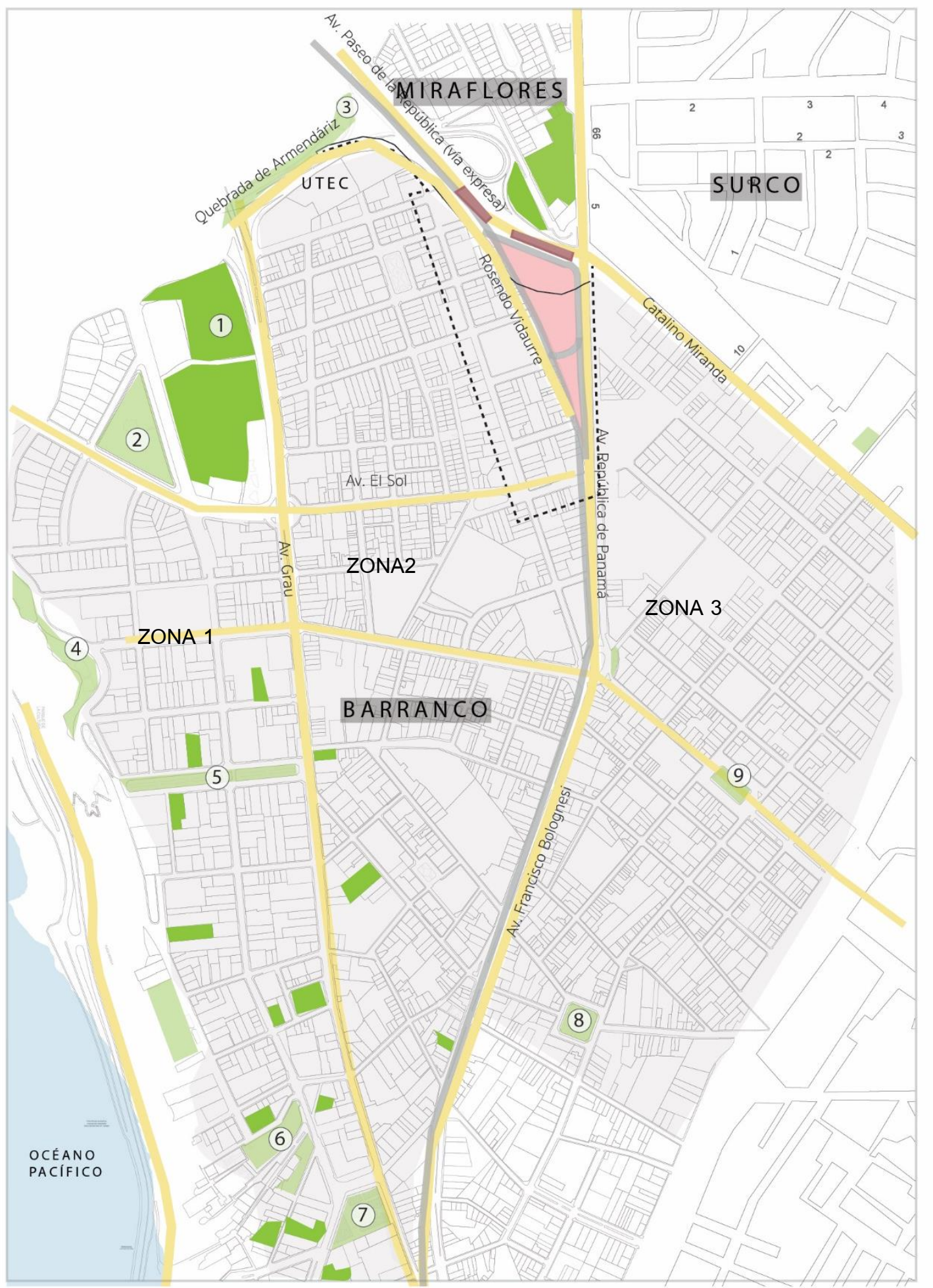

PÚBLICO CERRADO

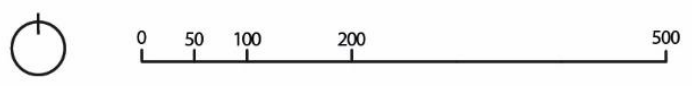

Museos, Centros, Estadios

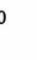

PÚBLICO ABIERTO

Plazas, Parques, Malecones

TERRENO DE ESTUDIO 
Al igual que el equipamiento, el espacio público abierto o físicamente cerrado, se concentra en la zona oeste de estudio. En la llamada Zona 3 de Barranco, solo se ofrece dos plazas secas a la gente.

A continuación, los principales espacios públicos:

(1) Museo de Arte Contemporáneo, MAC: Espacio exterior verde y abierto al público. Sin embargo, funciona según el horario del museo.

(2) Parque de Los Héroes: Parque público y abierto, remodelado en el 2018.

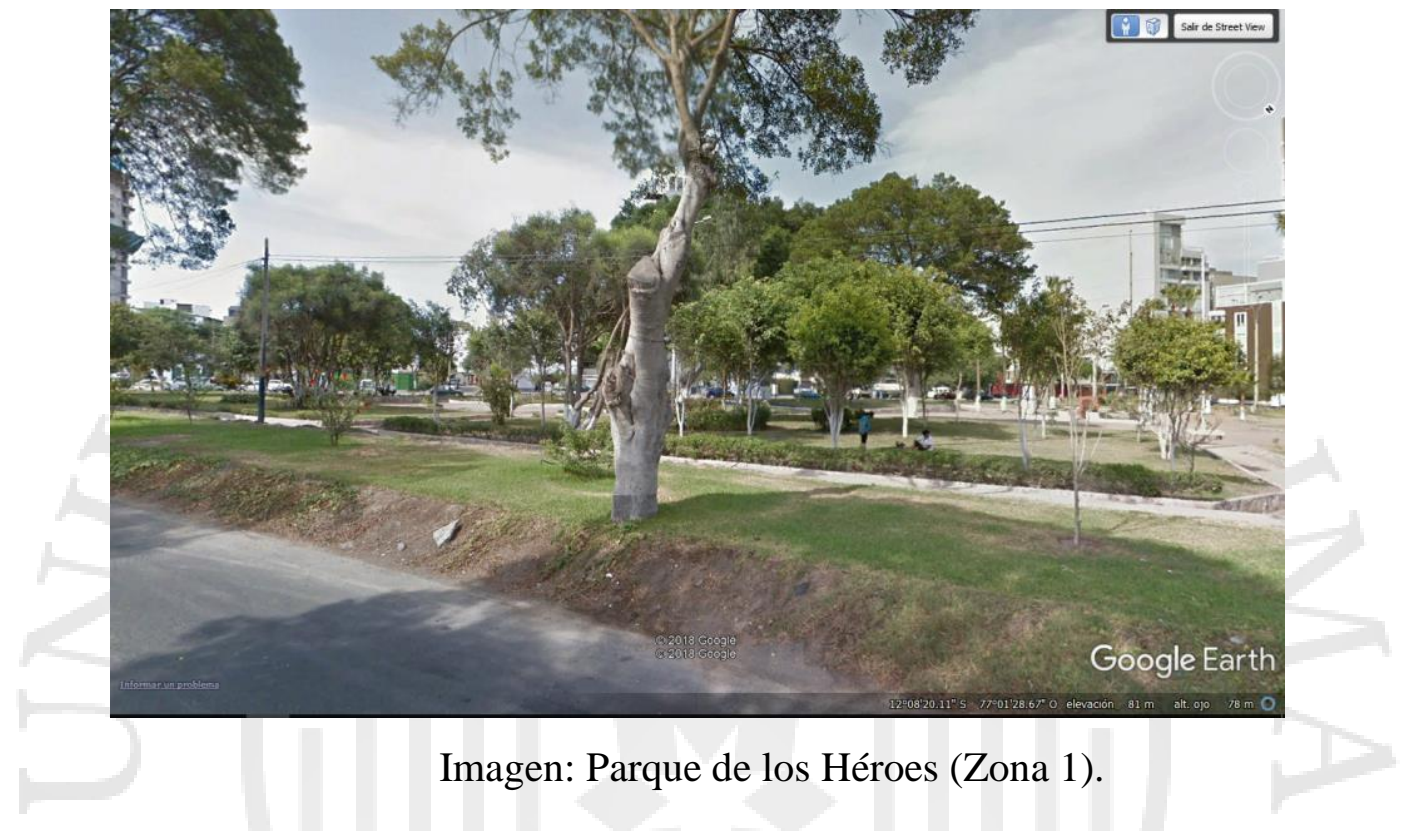

(3) Bajada de Armendáriz: Bajada a las playas y parte del Malecón de Miraflores. Tiene espacios peatonales.

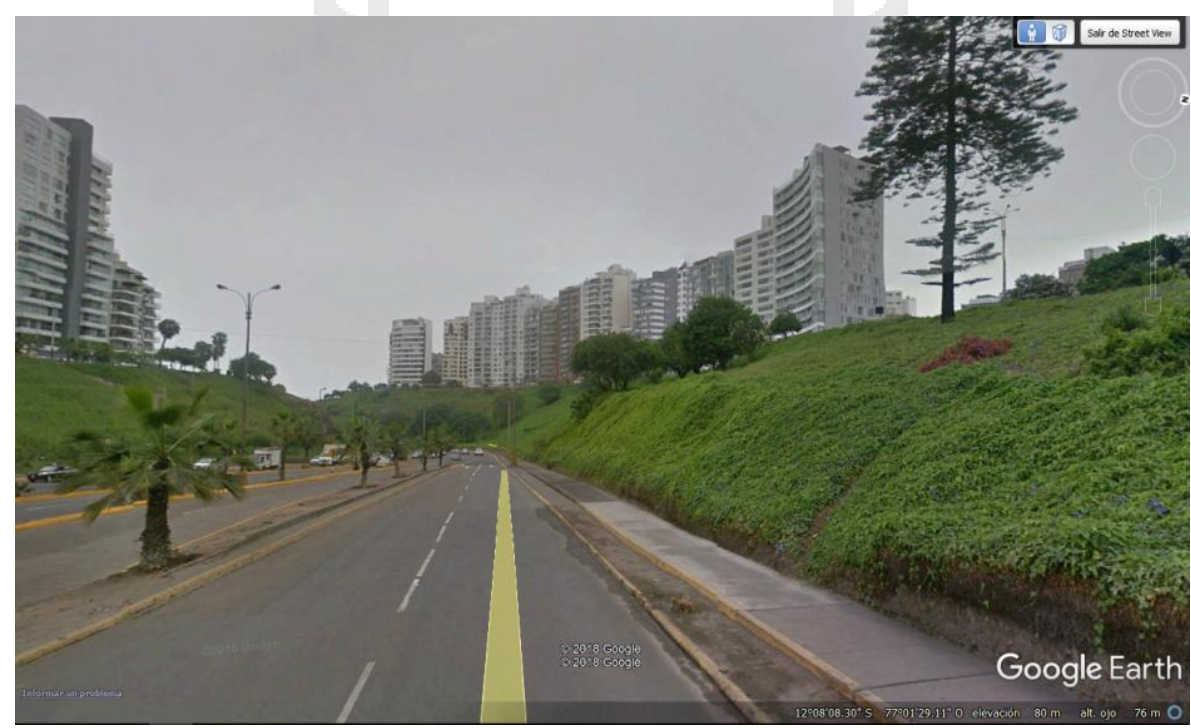


(4) Malecón Paúl Harris / Souza: Parques abiertos de actividades recreativas mixtas.

Se reproducen de manera similar a lo largo del malecón de Barranco.

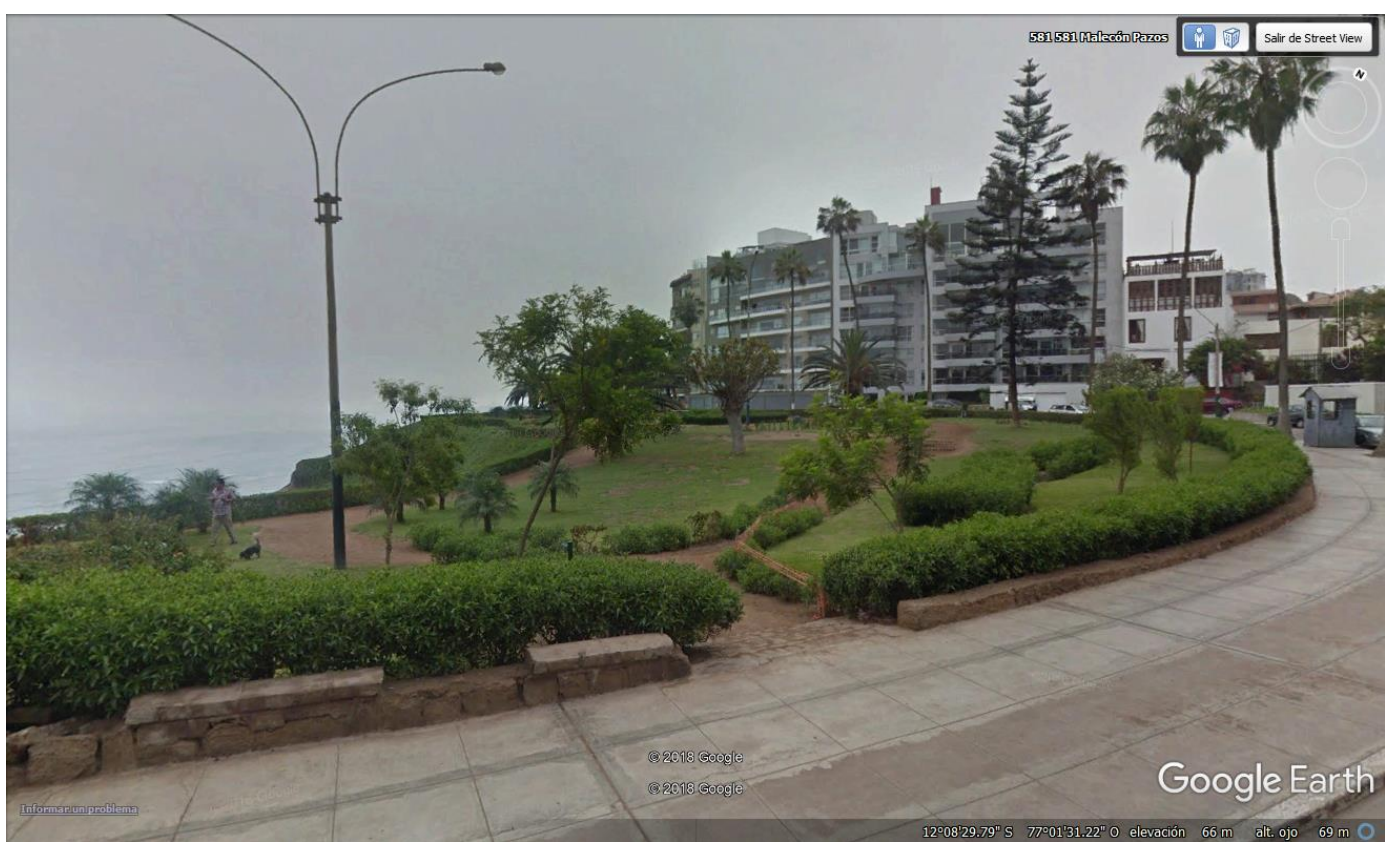

(5) Paseo Saénz Peña: Espacio de paseo abierto al público. Alberga varios espacios culturales y centros de labores.

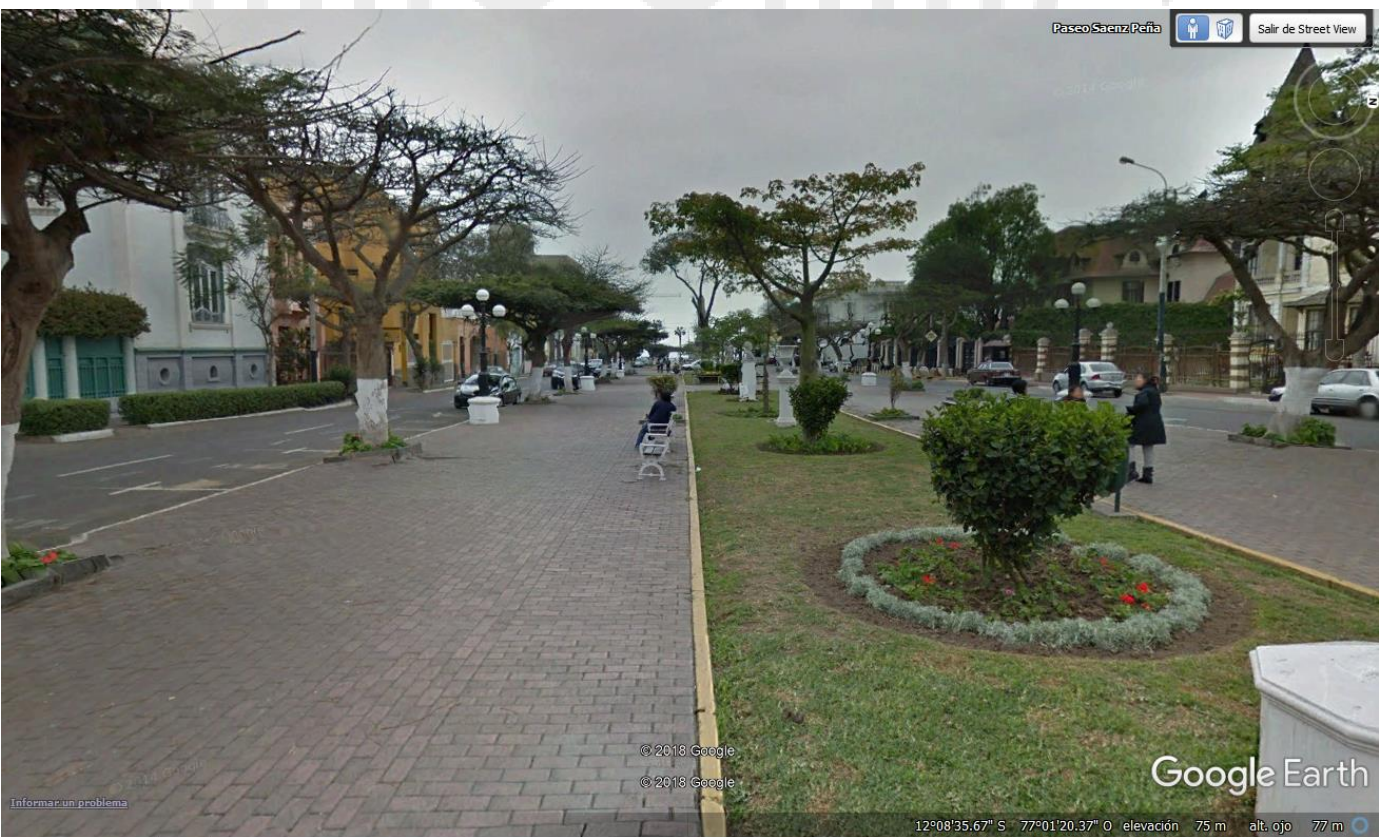


(6) Bajada de Baños: Vía antigua que se dirige a la playa desde Barranco. Rodeada de árboles de la misma edad y espacios verdes abiertos, donde se reúnen carros de comida ambulantes. Además, ofrece bares y restaurantes importantes a su alrededor.

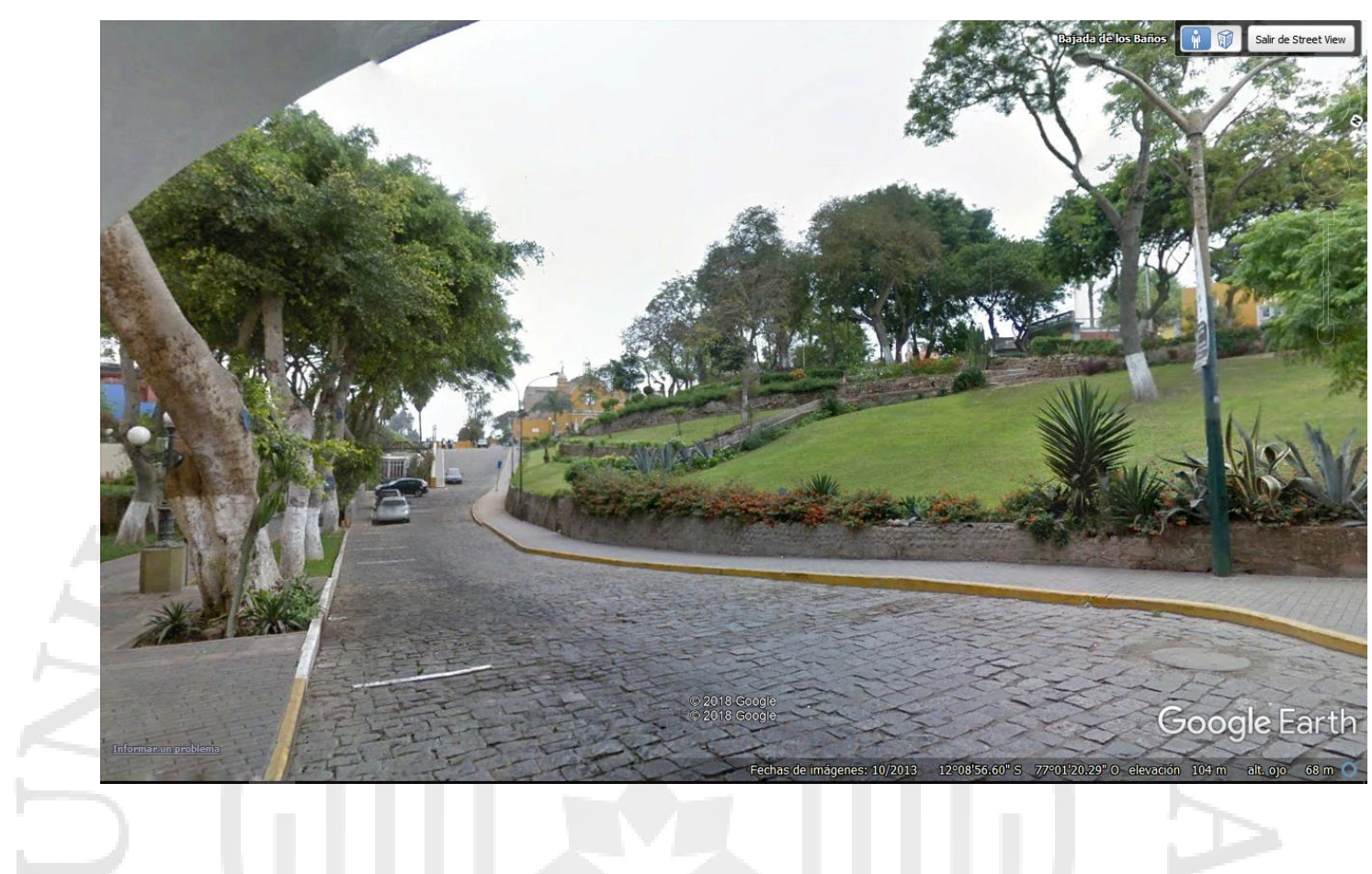

(7) Parque de Barranco: Plaza del distrito, con iglesia, biblioteca, municipalidad, restaurantes y bares a su alrededor.

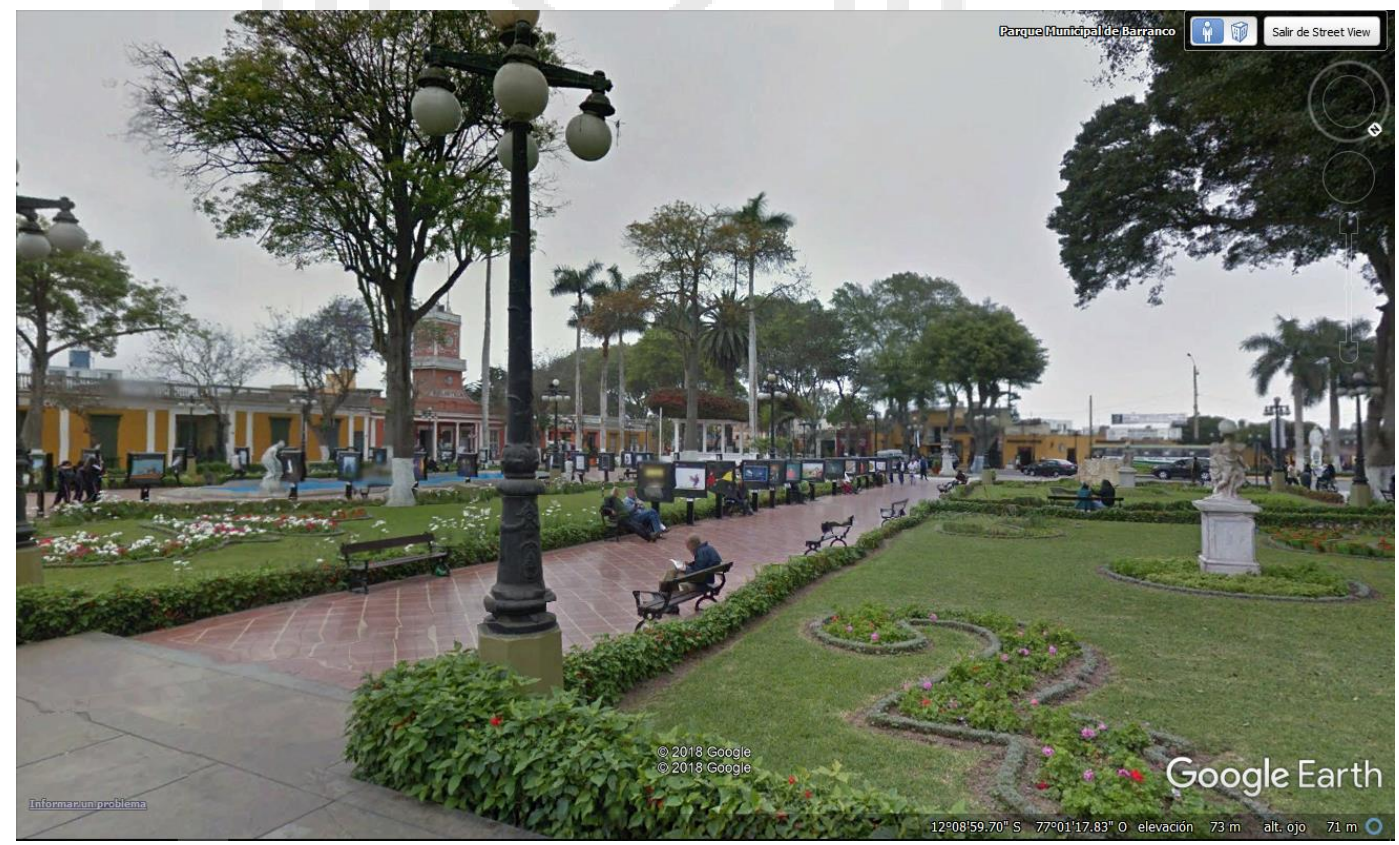


(8) Plaza Raimondi: Plaza cercada, de acceso público peatonal. Se limita el uso del área verde, solo permitiendo que los asistentes observen. No está permitido pisar el jardín.

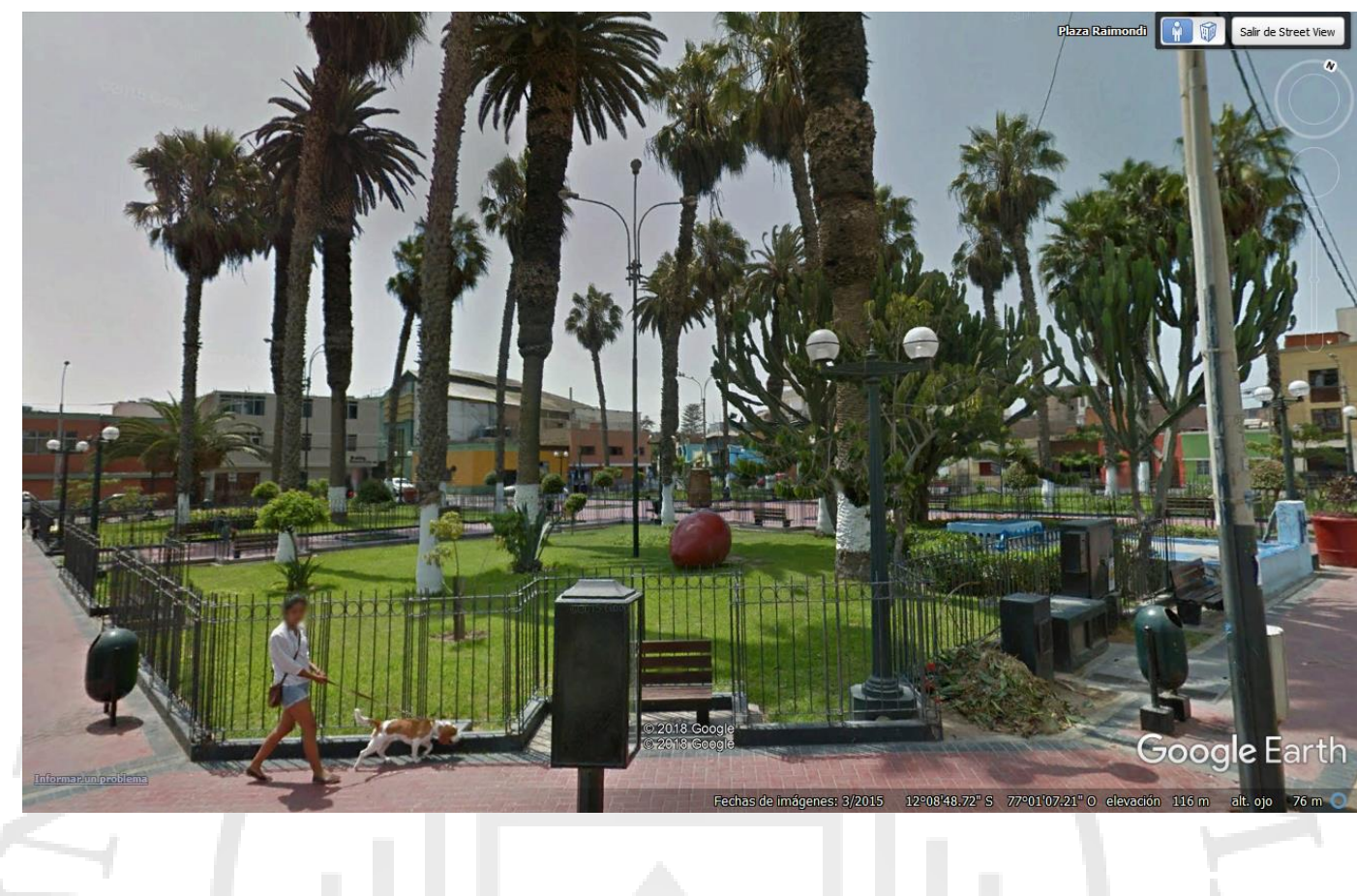

(9) Plaza Butters: Plaza seca cercada, donde no se permite utilizar el área verde.

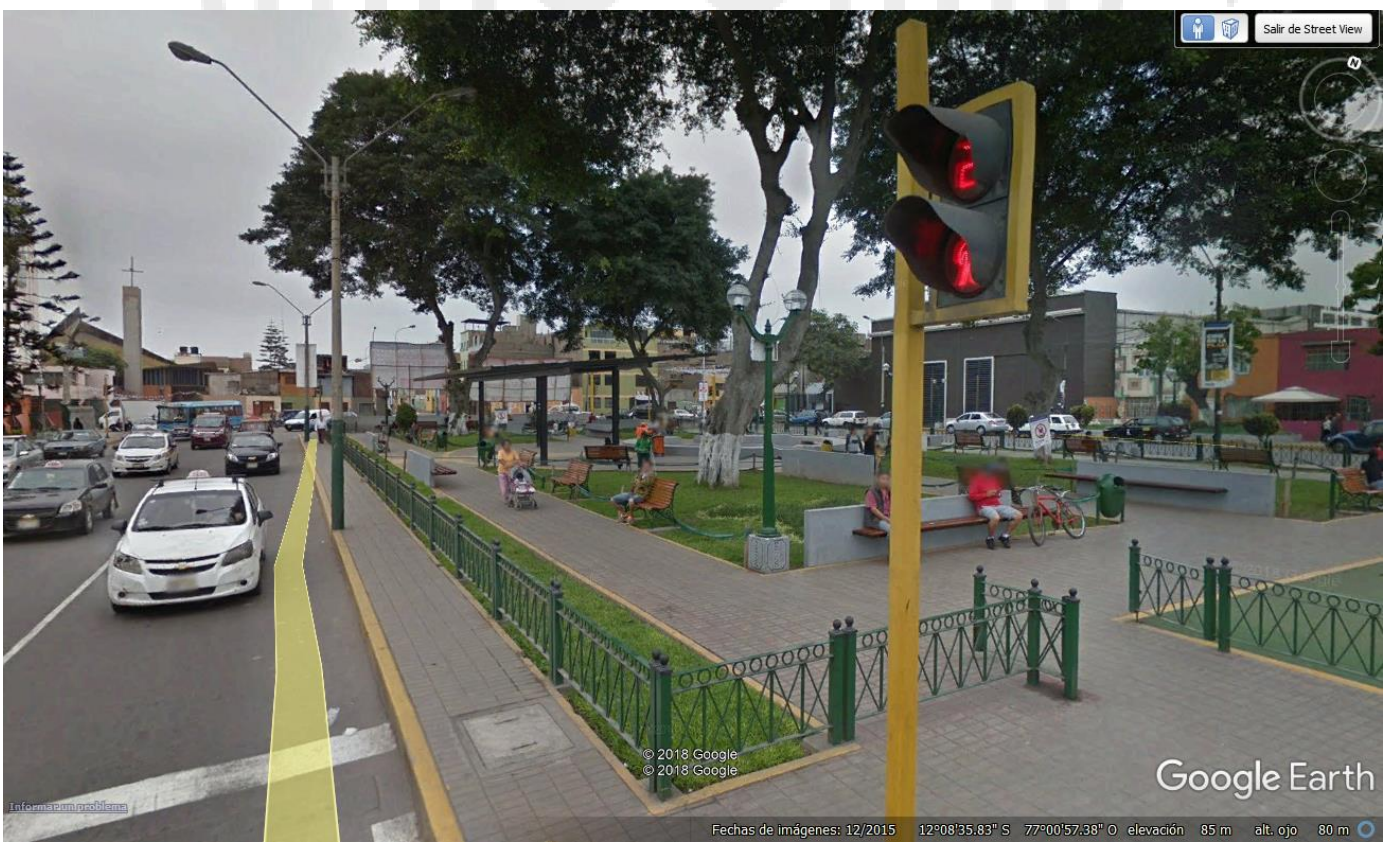

Imagen: Plaza Butters (Avenida Balta) 
ESTACIÓN PLAZA DE FLORES

DIVISIÓN URBANA

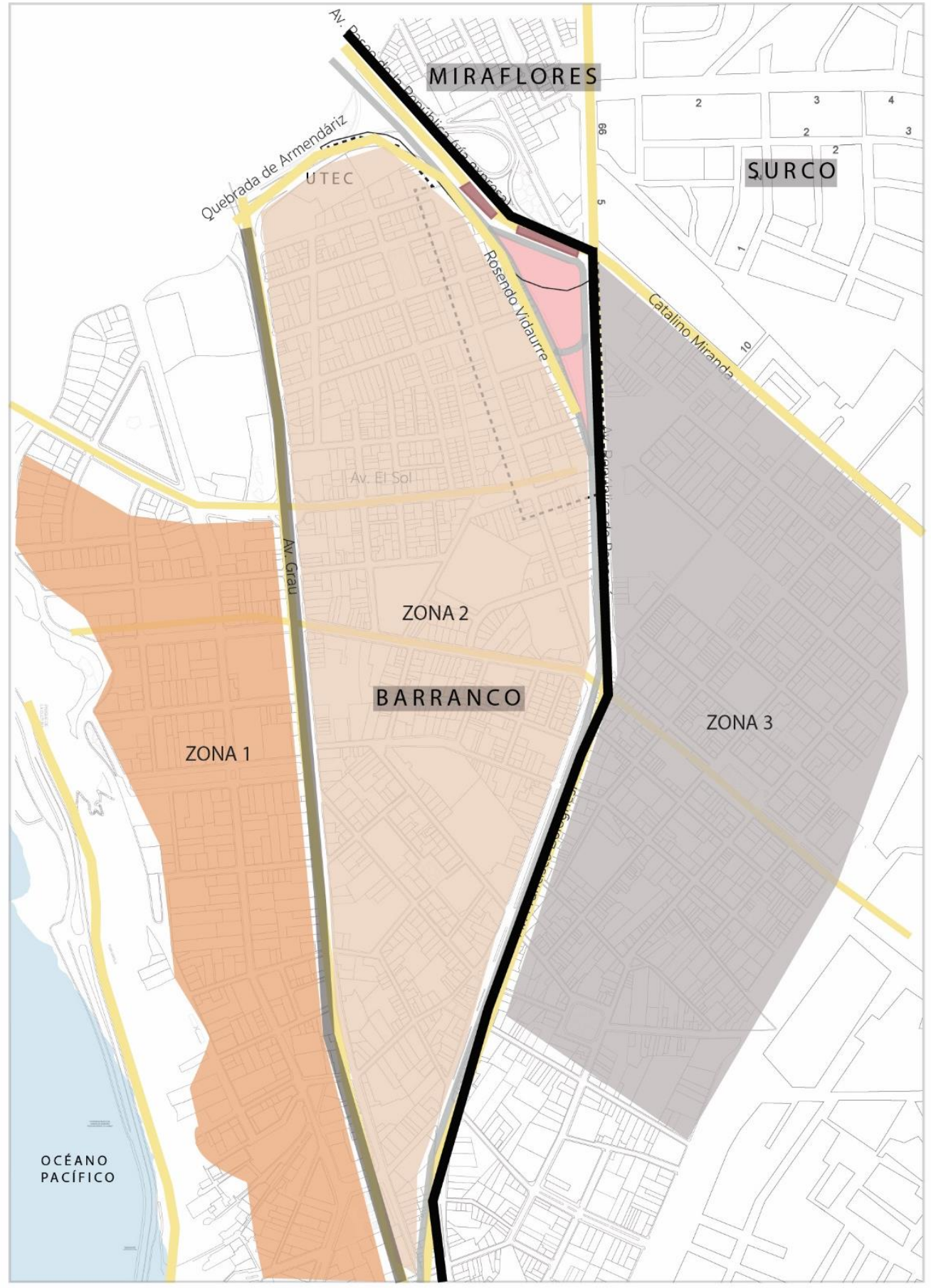

ZONAS POR NSE | ESTADO DE EDIFICACIONES

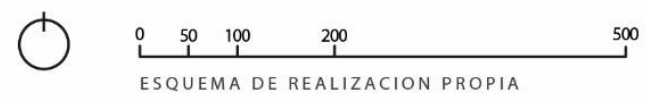

ESQUEMA DE REALIZACION PROPIA 
ESTACIÓN PLAZA DE FLORES

RED DE ESPACIOS CULTURALES

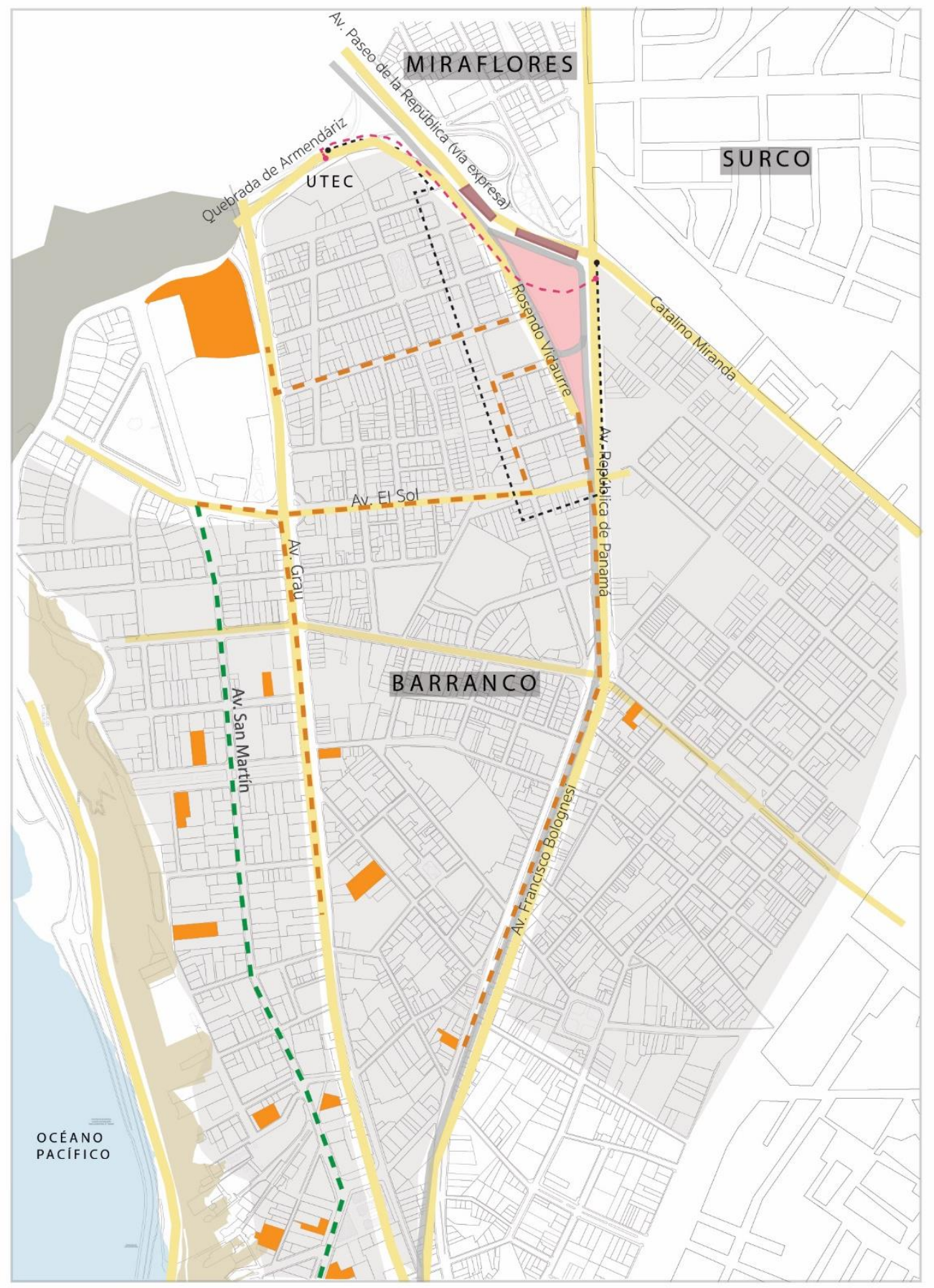

- - - RECORRIDO PEATONAL ACTIVADO

- - - RECORRIDO PEATONAL POR MEJORAR

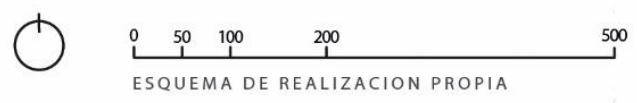

VIAS PRINCIPALES

VÍA DEL METROPOLITANO

RUTA PEATONAL OFICIAL (16min)

RUTA PEATONAL DE USUARIOS (4 min)

TERRENO ESTUDIADO

ESTACIÓN 
Barranco cuenta con 338 bienes y servicios de carácter cultural y 141 con potencial para ser complementado. $26 \%$ de ellos se disponen a artes plásticas y visuales, $16 \%$ artes escénicas, y $12 \%$ centros culturales. Lo restante es de carácter patrimonial.

El 96\% de los servicios culturales son de inversión privada. El restante 4\% es gestionado por la Municipalidad de Barranco, con planes a futuro de incrementar dicha cifra. Se ha ofrecido eventos y servicios culturales regularmente para posicionar el distrito como el más importante del circuito de la cultura local. Sin embargo, existe una desarticulación entre la Municipalidad y los actores de Barranco.

Dentro de seguridad del distrito, los problemas más comunes son aquellos de convivencia y problemas en la calle. El primer problema es el alcoholismo callejero, seguido por el consumo de drogas y el pandillaje (Comisaría de Barranco, 2015)

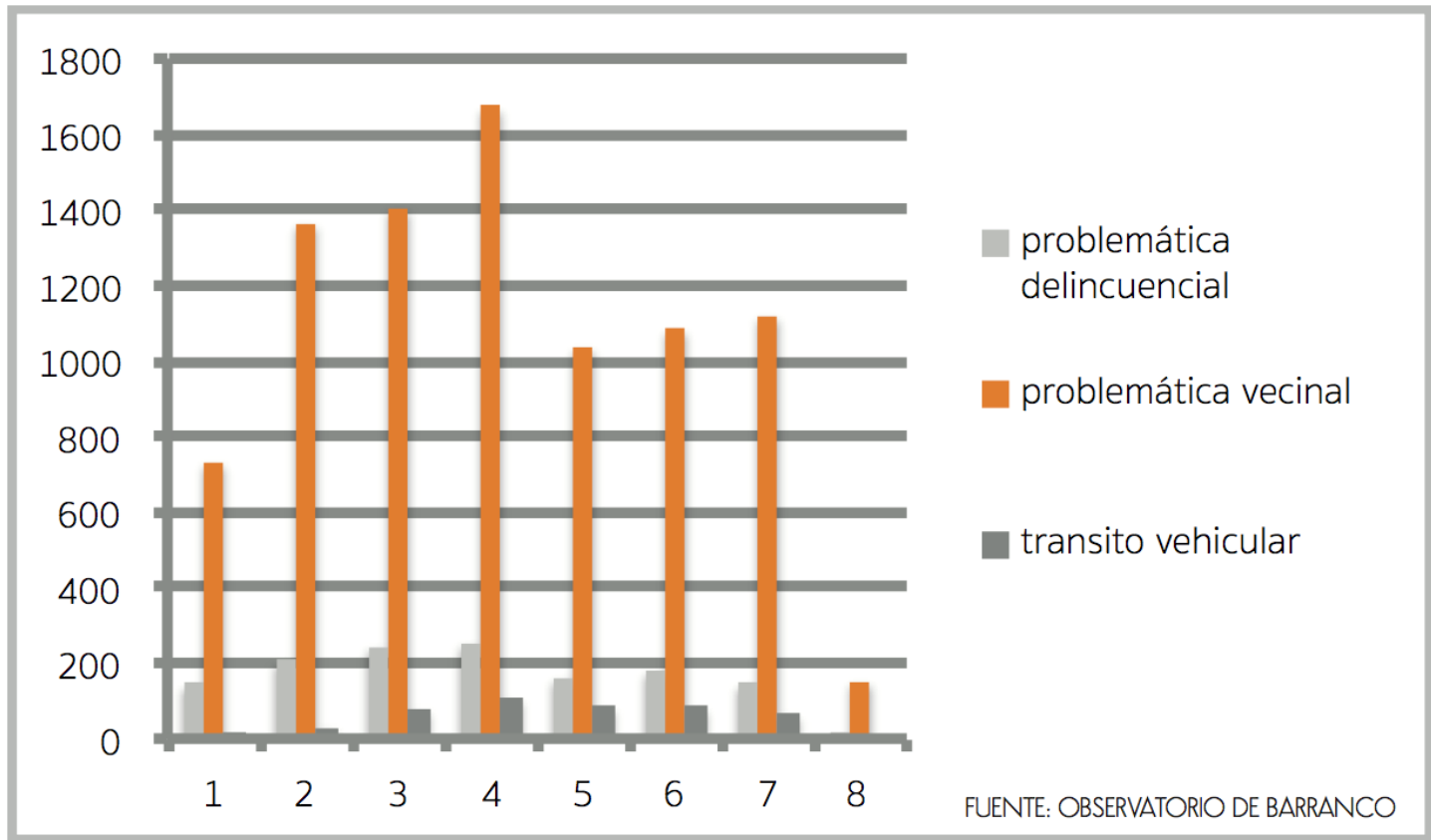

Otro problema es la división social entre las Zonas 1, 2 y 3 del distrito. Esto genera una exclusión social preocupante dentro de un mismo espacio político.

La implementación del Plan de Cultura de Barranco 2016 -2021 constituye una oportunidad clave para aportar a la reducción de la delincuencia y violencia desde el arte y la cultura; tomando en cuenta además que el Plan Local de Seguridad Ciudadana incluye el concepto de convivencia y la ejecución de 
actividades culturales como parte de sus estrategias. $\mathrm{Y}$ así mismo es una oportunidad para generar espacios de encuentro e intercambio en los espacios públicos que aporten a la integración vecinal. (Municipalidad de Barranco, 2015)

La Municipalidad, también, dispone de espacios públicos para el desarrollo de planes culturales que descentralicen el servicio de la Zona 1. Sin embargo, estos espacios no cuentan con la infraestructura básica para la implementación cultural que se requiere.

Los lineamientos recientes de Barranco en función a la cultura han sido organizados mediante la Agenda 21 del distrito. Es un plan basado en la Agenda Cultural de la UNESCO, que busca un desarrollo sostenible de los servicios y bienes culturales. Además, se recalca la importancia de que los actores y habitantes sean incluidos en la creación e implementación de dicho plan.

Estos planes requieren de un espacio de desarrollo. Sin embargo, los espacios públicos que pertenecen a la Municipalidad de Barranco pertenecen a la Zona Monumental del Distrito. Por eso, se requiere de nuevos espacios donde implementar los planes culturales. 

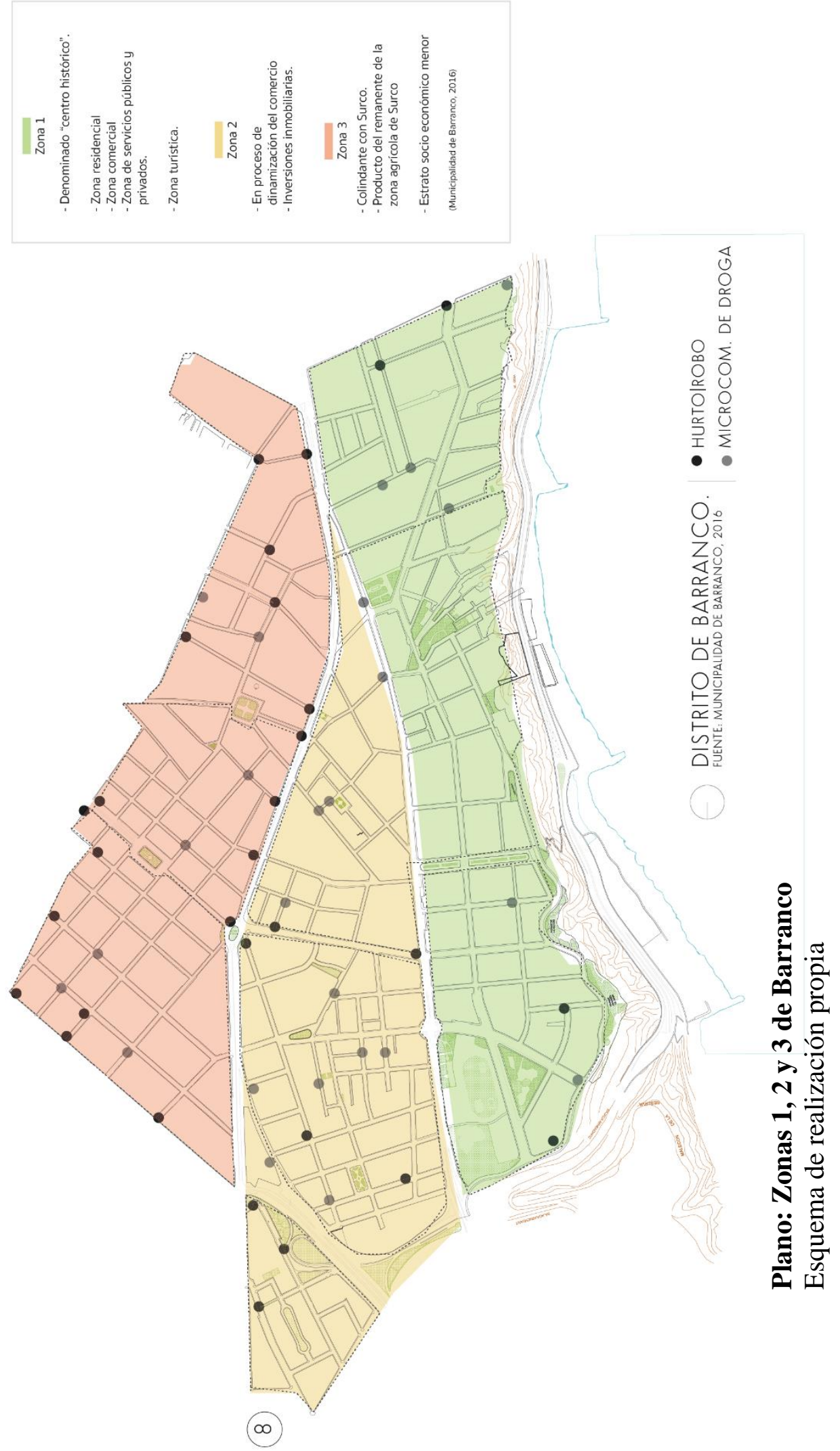


\subsection{Cuadro comparativo}

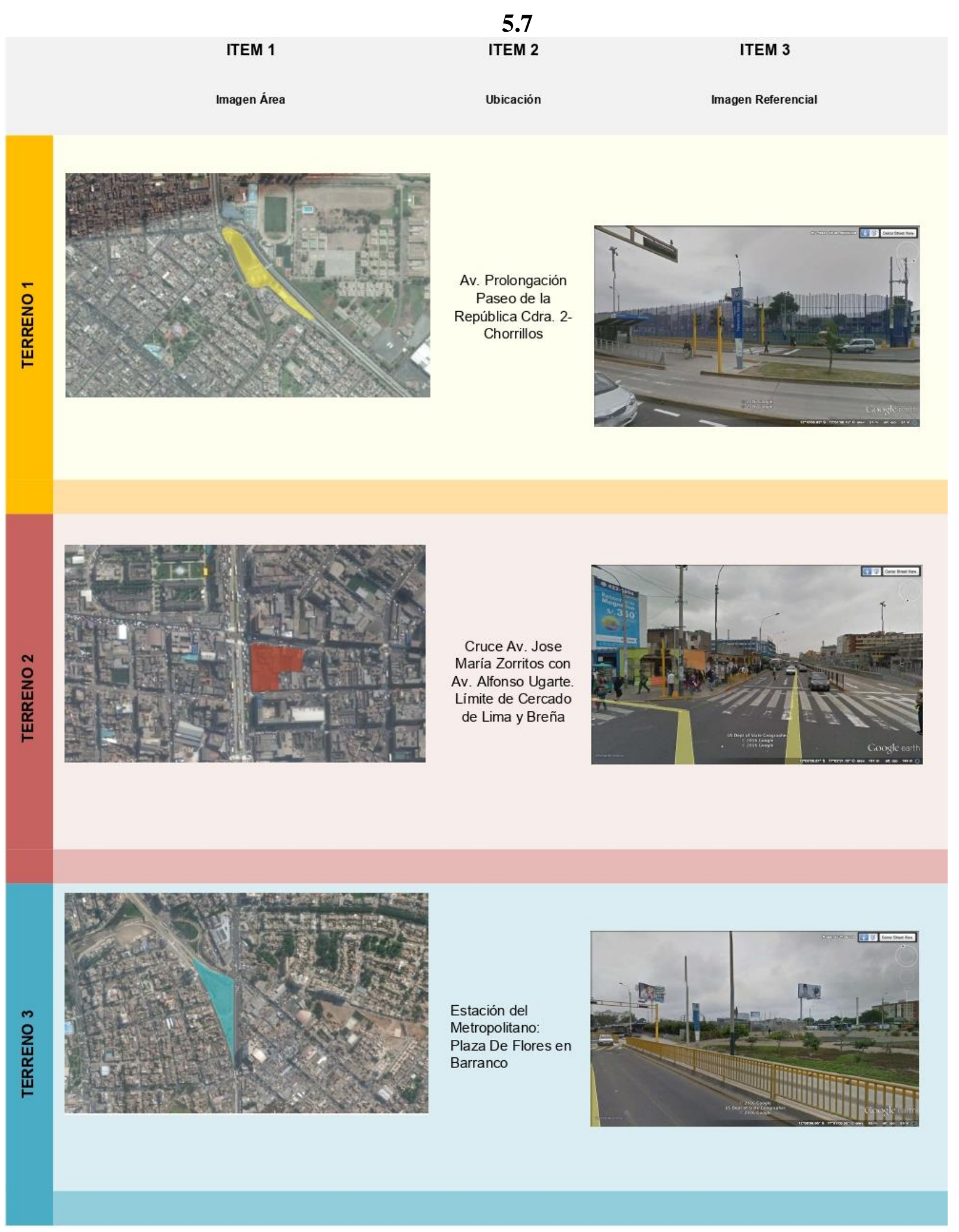




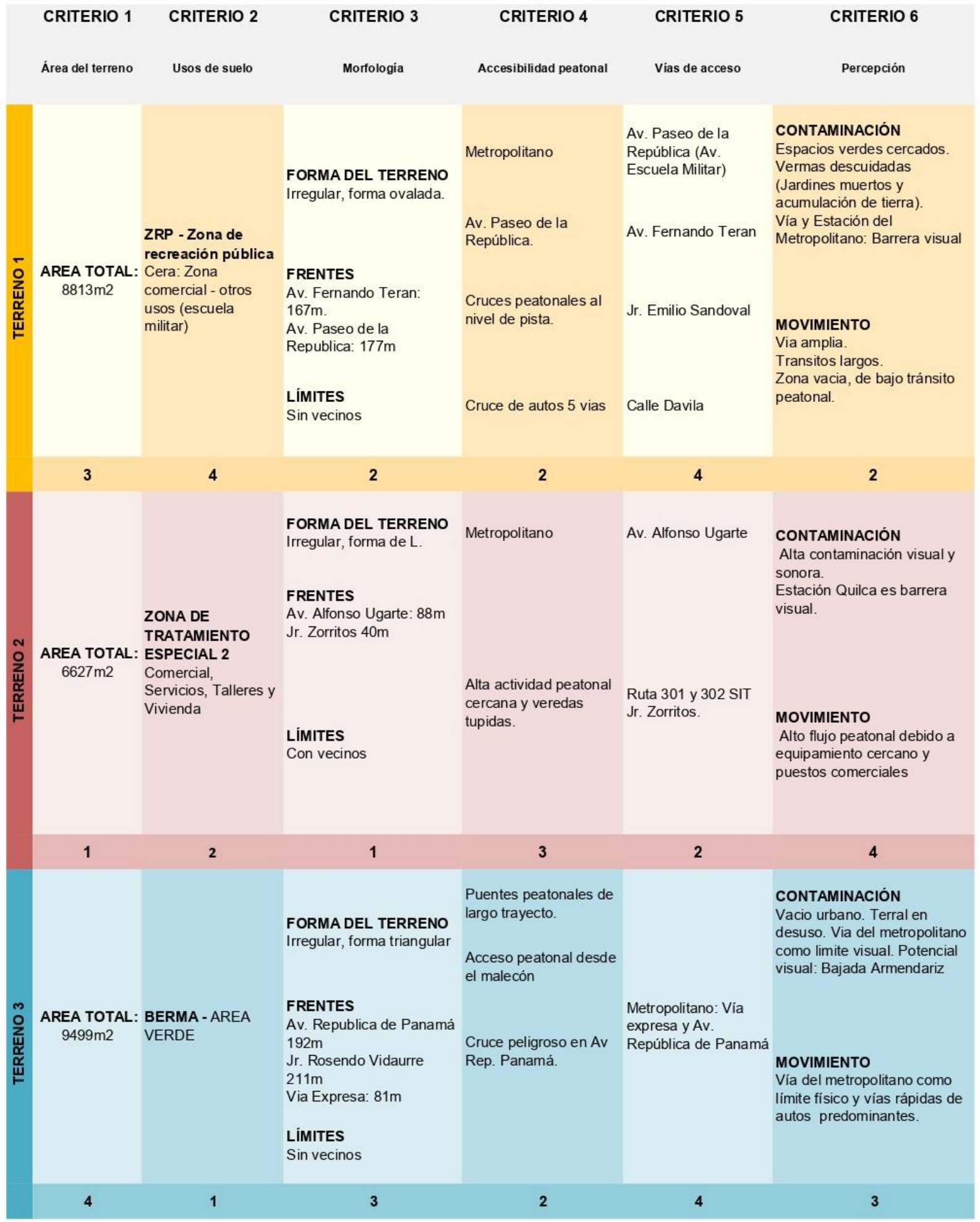




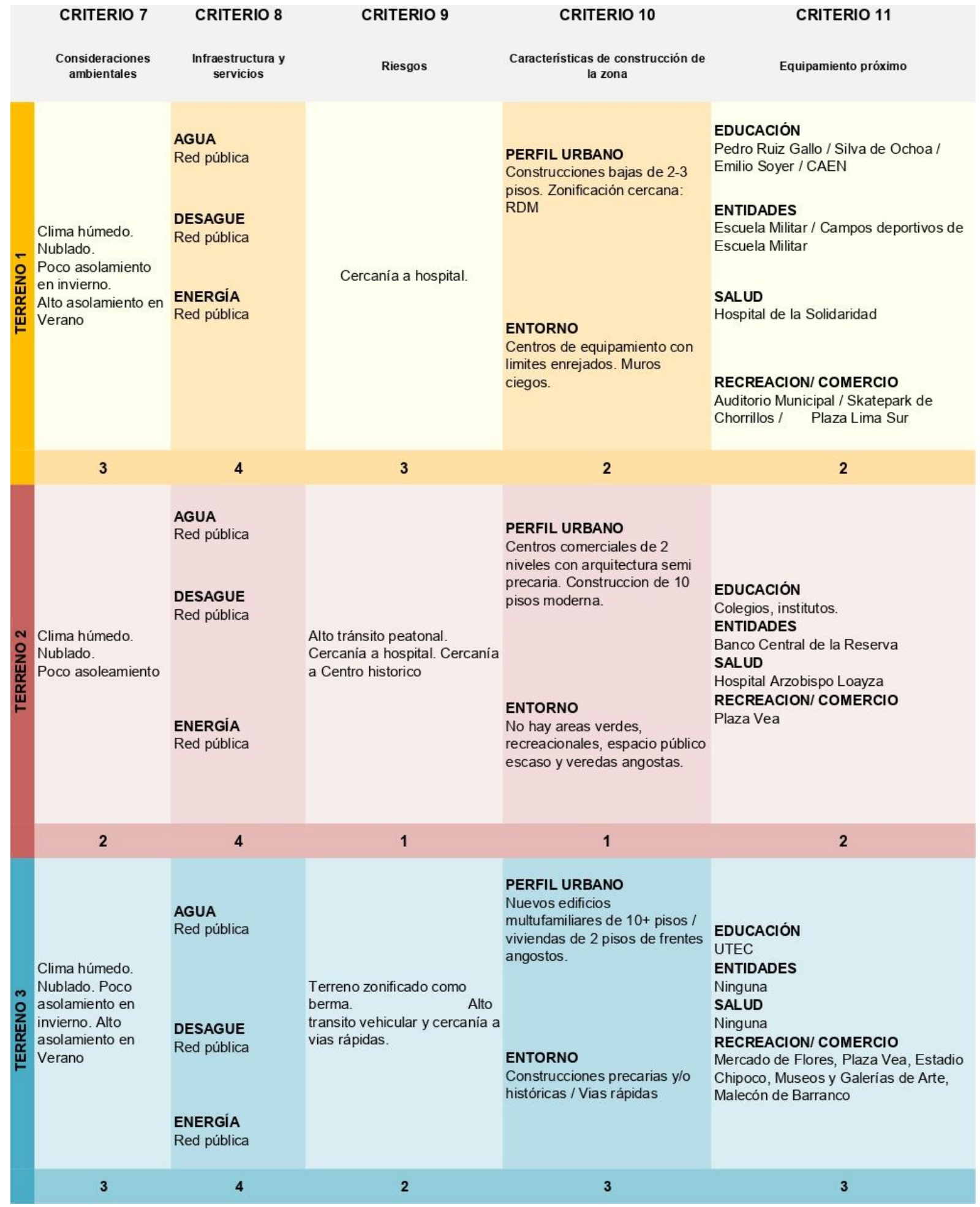




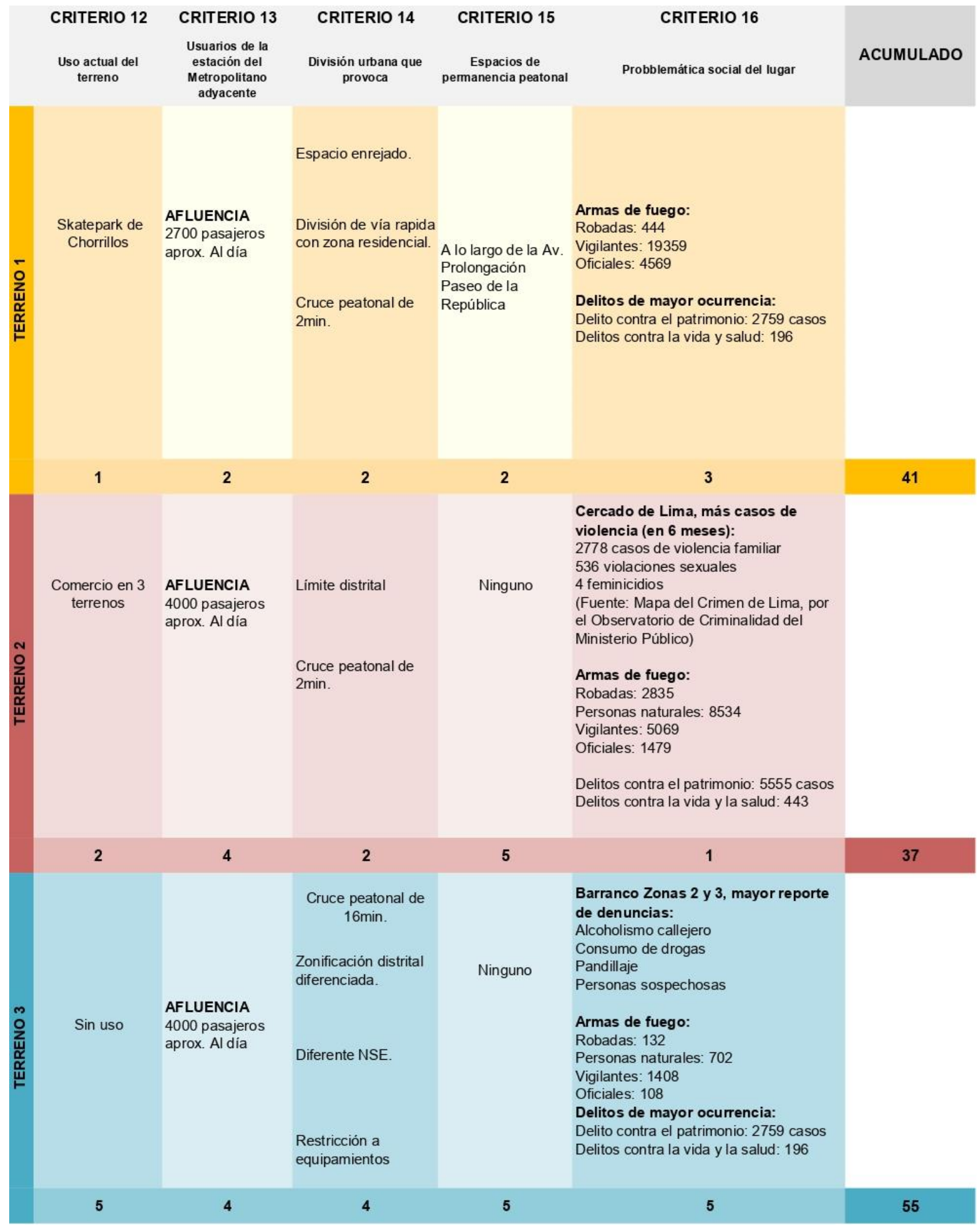

Fuentes:

Instituto Metropolitano de Planificación (Mapas de Cobertura de Servicios)

Carbajal López, Aragón Casas, Dávila Cajahuanca. OPTIMIZACIÓN BASADA EN SIMULACIÓN EN UN SISTEMA DE TRÁNSITO PÚBLICO MASIVO Comité de seguridad ciudadana de Chorrillos / Ficha Informativa de Seguridad ciudadana de Chorrillos

Ficha informativa de Seguridad Ciudadana del Cercado de Lima

Reportes de la Gerencia de Seguridad Ciudadana de la Municipalidad de Barranco

Comité de seguridad ciudadana de Barranco / Ficha informativa de Seguridad ciudadana de Barranco 


\subsection{Conclusiones de elección de terreno}

Luego de evaluar estaciones a lo largo de la vía del Metropolitano y terrenos colindantes mediante la escala de Likert, el espacio de la Estación Plaza de Flores de Barranco obtuvo una puntuación superior por 12 puntos.

En área de terreno, es el de mayor espacio disponible para emplazamiento, frente a los demás, con 9499m2. Sin embargo, en el criterio 2, uso de suelo, obtiene la menor puntuación. Esto se debe a que su uso es de Berma central y está dispuesto a ser área verde del Metropolitano. Por lo tanto, los parámetros urbanísticos del terreno no existen como tal, y el cambio de zonificación llevará más tiempo.

En Morfología, predomina que su frente más amplio colinde con la vía del Metropolitano y, además, no tenga vecinos. Lo mismo ocurre en el terreno de Chorrillos, mientras en Quilca, los lotes colindantes podrían suponer limitación de programa y accesos. Esta última, tiene mejores accesos peatonales y, si bien podrían no estar-totalmente resueltos, existe vida peatonal en este espacio de la ciudad. Sin embargo, las vías de acceso para el terreno en Quilca se limitan a la Avenida Alfonso Ugarte y una calle lateral. Mientras, los terrenos en Chorrillos y Barranco se encuentran entre avenidas importantes y consideradas metropolitanas.

La percepción en los tres terrenos fue puntuada inversamente. Por ello, el de mayor puntaje es Quilca, pues, el entorno es consolidado y denso a nivel urbano, con gran cantidad de transeúntes y contaminación visual. Por otro lado, el espacio en Terán es el único con ciertas áreas verdes visibles que atenúan el problema.

En equipamiento próximo, encontramos un empate de variedad de servicios y usos entre Terán y Plaza de Flores. Sin embargo, el primero se encuentra cerca de un espacio militar, lo cual puede ser negativo para un centro de esparcimiento público como el que se quiere proponer.

Finalmente, se ha encontrado que la división urbana y social en los tres terrenos, no necesariamente ha sido causada por las vías del Metropolitano. Es el caso de Quilca, cuyos problemas sociales son iguales tanto en el Cercado de Lima como en Breña. La 
violencia que presenta se debe a factores internos al hogar, a diferencia de Barranco, cuya problemática se refiere a convivencia y patrones de comportamiento en la calle.

Es probable que, en Quilca, el equipamiento adecuado sea de otra índole. Pero, según las teorías estudiadas, un Centro Cultural resuelve mejor las problemáticas sociales referentes a la convivencia, drogas y alcoholismo.

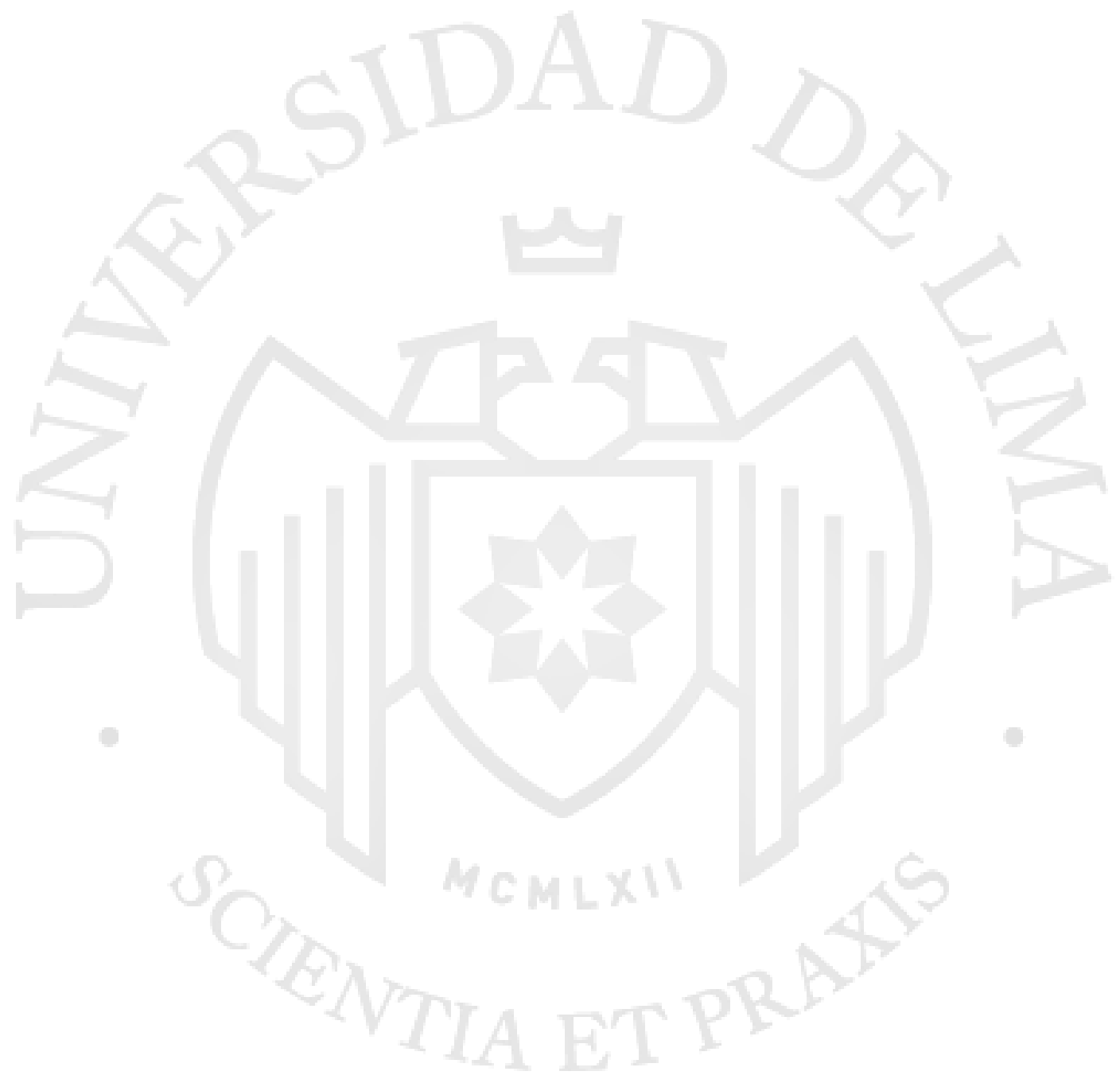




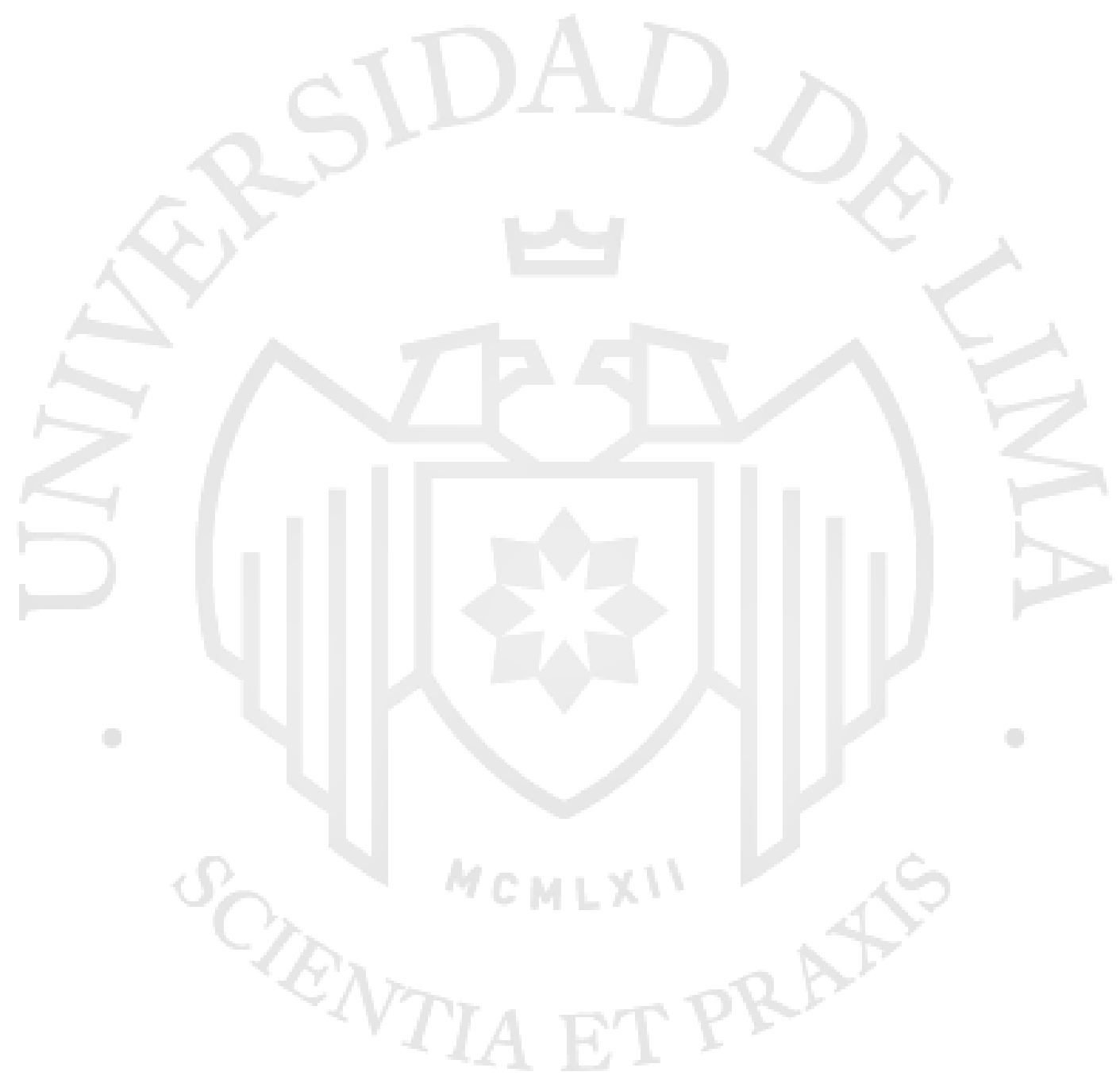




\section{CAPITULO VII}

\section{Proyecto}

\subsection{Antecedentes}

\subsubsection{Vía Expresa Sur y Plaza de Intercambio 360 del Metropolitano.}

En el año 2013, durante la gestión de Susana Villarán, se entregó la concesión de la construcción de ampliación de la Vía Expresa Paseo de la República a la constructora Graña y Montero, con el consorcio de Vía Expresa Sur (VES). A continuación, se menciona información recolectada en las oficinas de Graña y Montero, luego de una reunión con el Ingeniero Jean Flores Bazán, de GMI Ingenieros Consultores.

La VES requerirá de una inversión de 20 millones de dólares en $4.6 \mathrm{~km} \mathrm{y}$ facilitaría el tránsito motorizado desde el distrito de Barranco hasta la existente Panamericana Sur, y pasando por 4 distritos: Barranco, Surco, y San Juan de Miraflores. Sin embargo, los predios por donde se proyecta la construcción están ocupados por colegios, instituciones militares y viviendas. Se calcula que 300 predios con dueño legítimo deberán ser expropiados, y unos 400 de invasiones, reubicados.

Por esta razón, el proyecto que debió ser inaugurado en la segunda mitad del 2018, aún no comienza a construirse.

Mapa: Ampliación de la Vía Expresa Paseo de la República (en naranja). (Google Maps)

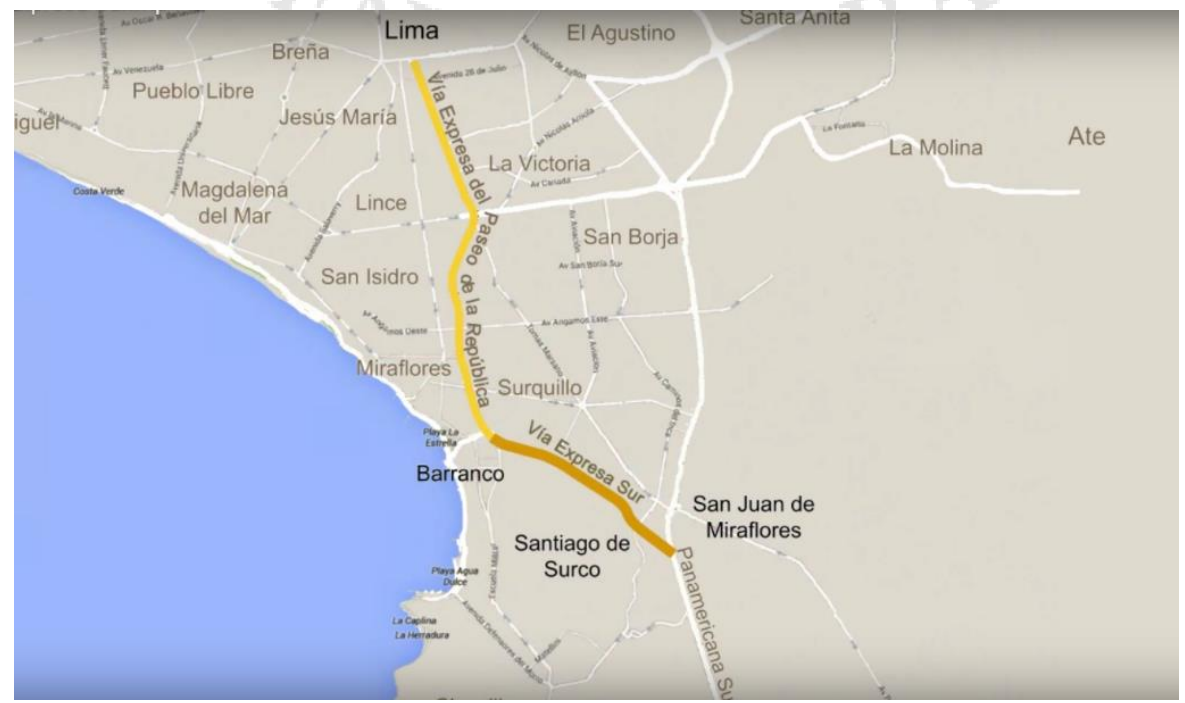




\subsubsection{Extractos del Expediente técnico.}

Los planos técnicos de la VES comprenden la construcción de tramos, estudios de suelos y detalles estructurales. Dentro del diseño, se ha considerado un espacio libre para el tránsito del Metropolitano actual y la proyección a futuro. Además de los 6 carriles de autos a desnivel, 4 auxiliares a nivel y carriles exclusivos para el Metropolitano a todo lo largo, el proyecto tendrá puentes vehiculares y dos óvalos a desnivel. Al llegar a la Panamericana Sur en San Juan de Miraflores, existirá un intercambio en varios niveles.

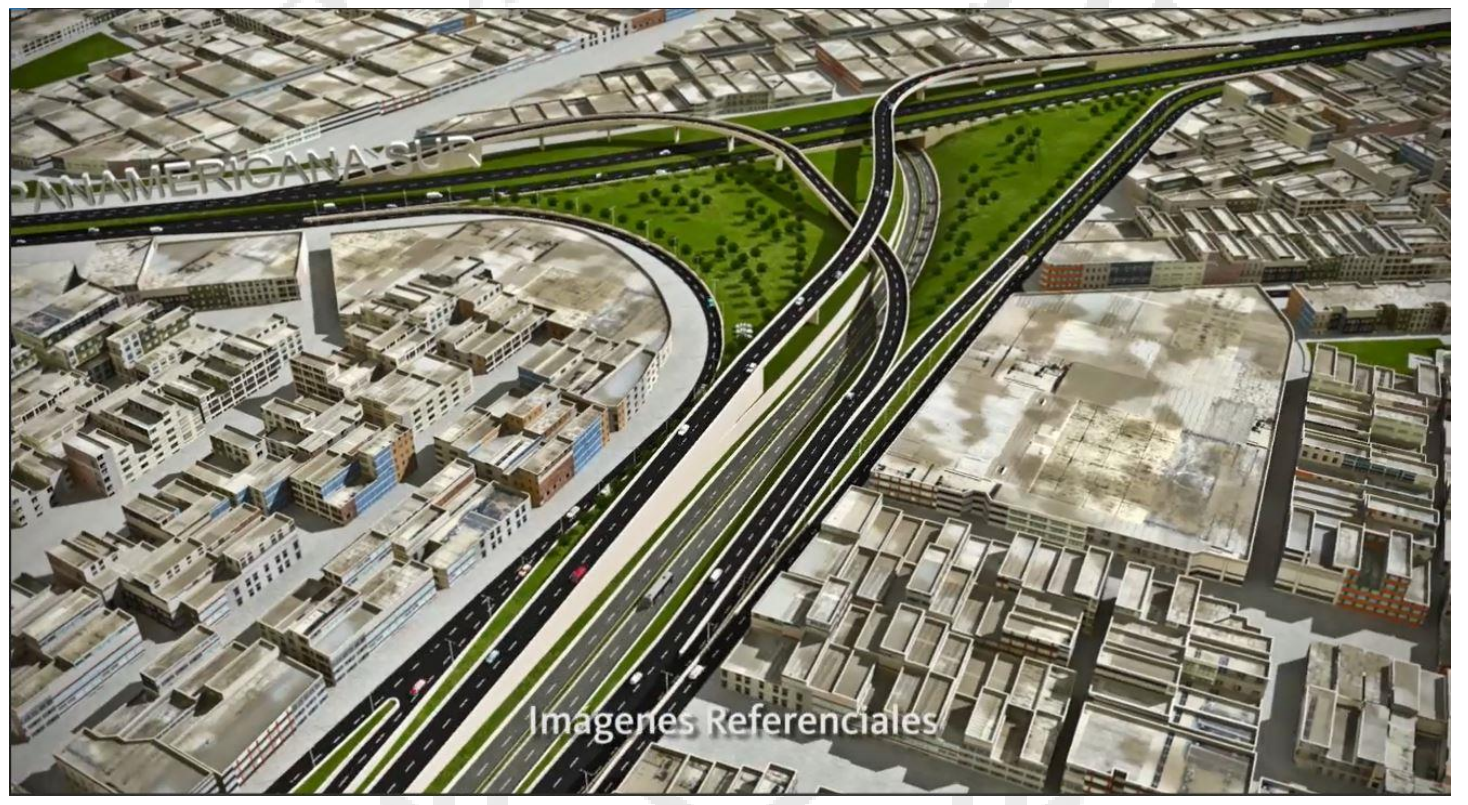

Imagen VES: Intercambio vial en la Panamericana Sur (final de concesión). Fuente: Video VES (2015)

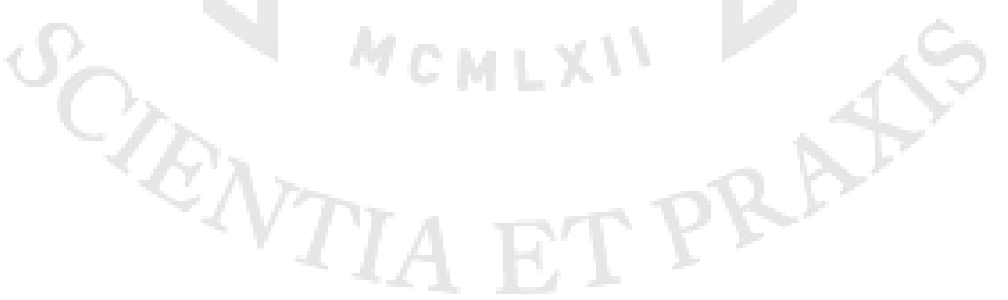




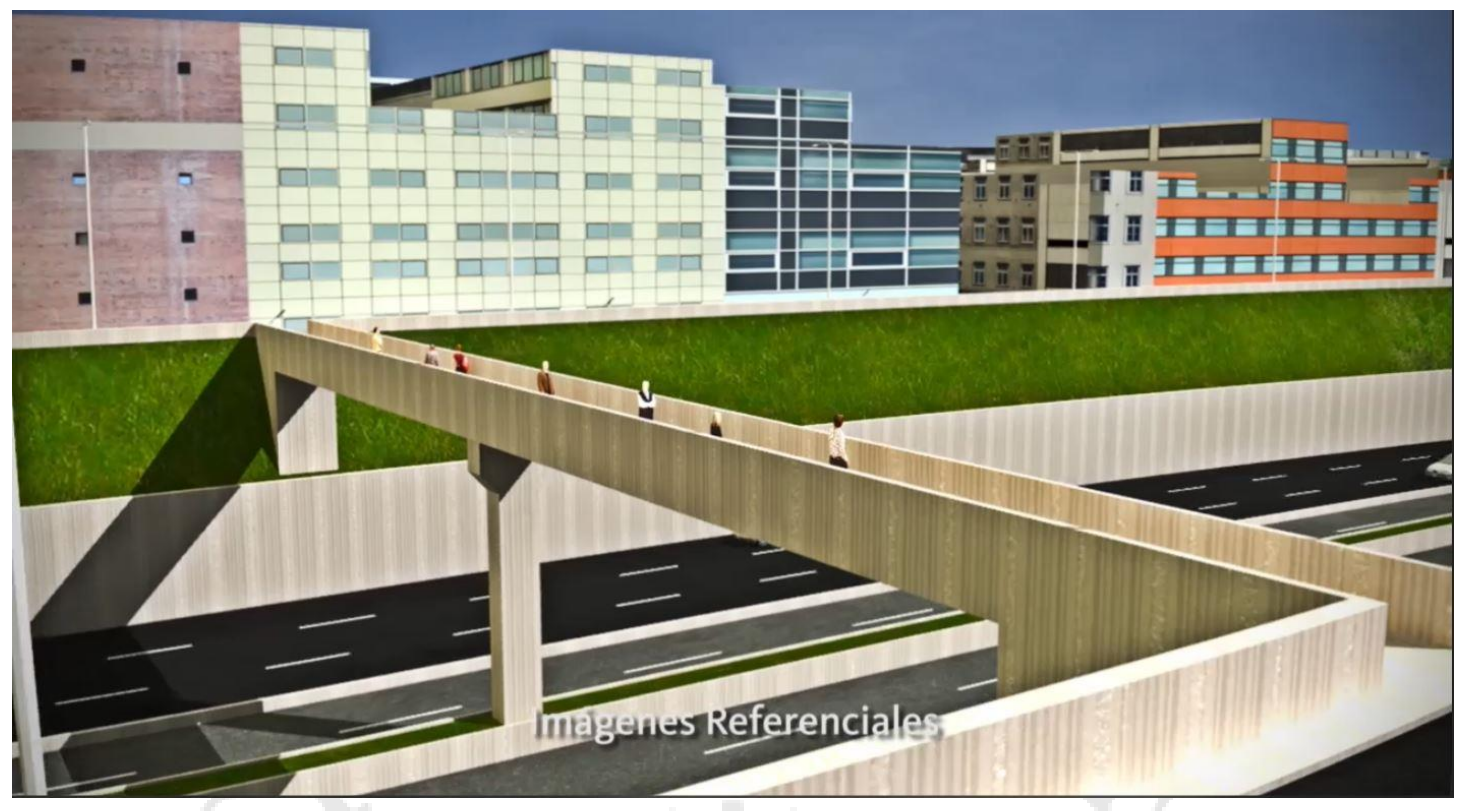

Imagen VES: Existirán 03 puentes exclusivamente peatonales en los 4.6km. Fuente: Video VES (2015)

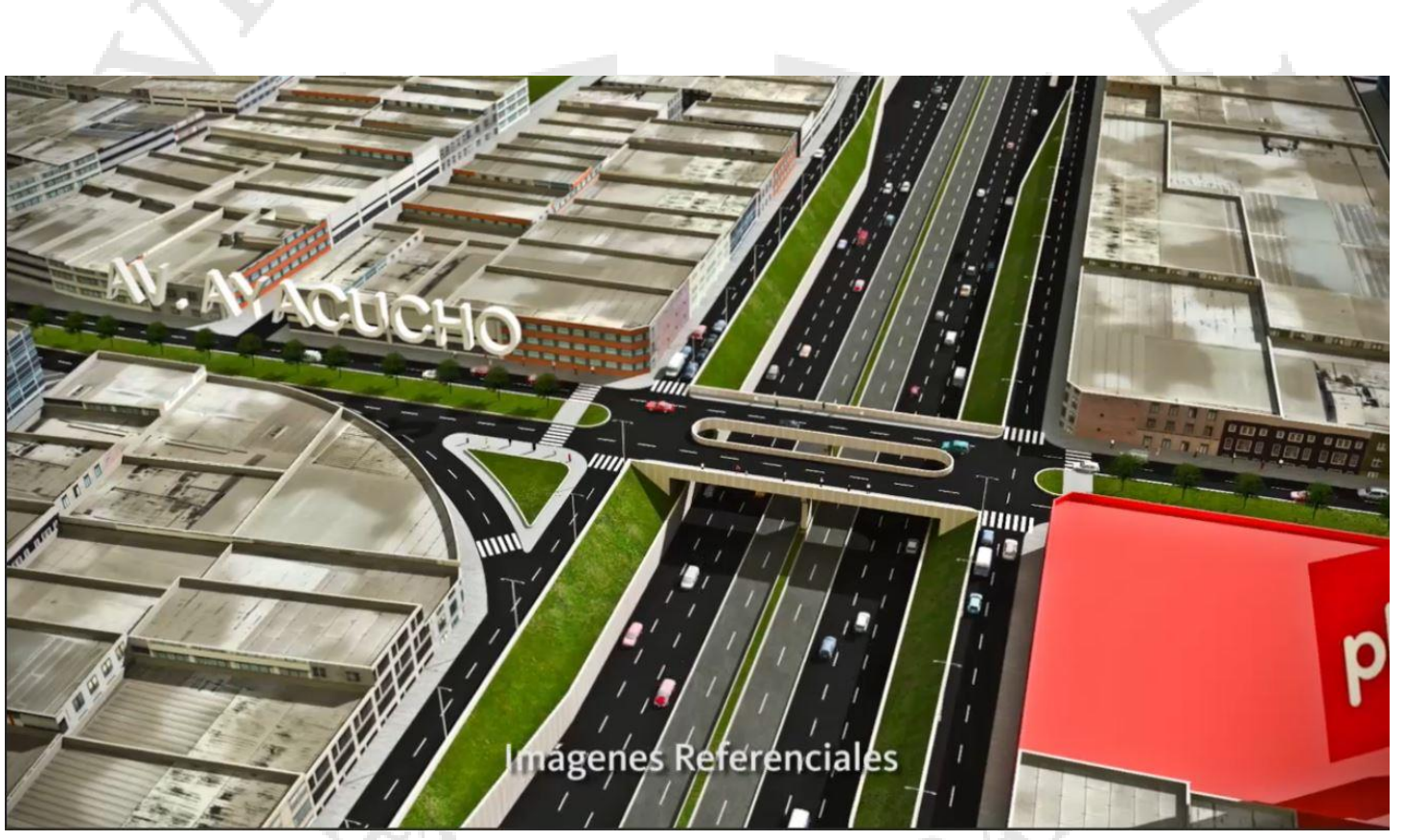

Imagen VES: Puente a desnivel en Avenida Ayacucho. Fuente: Video VES (2015) 


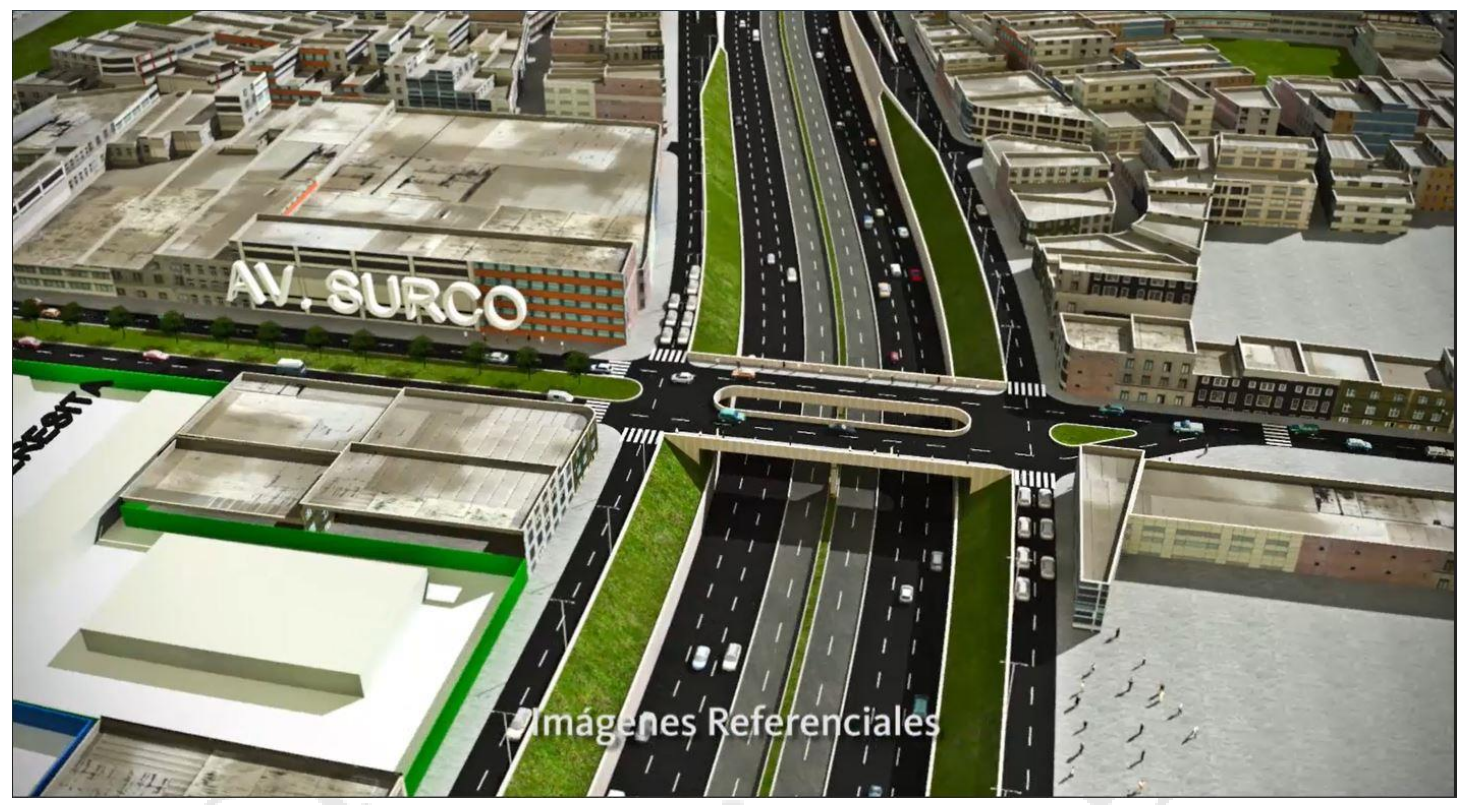

Imagen VES: Puente de autos a desnivel en Avenida Surco. Fuente: Video VES (2015)
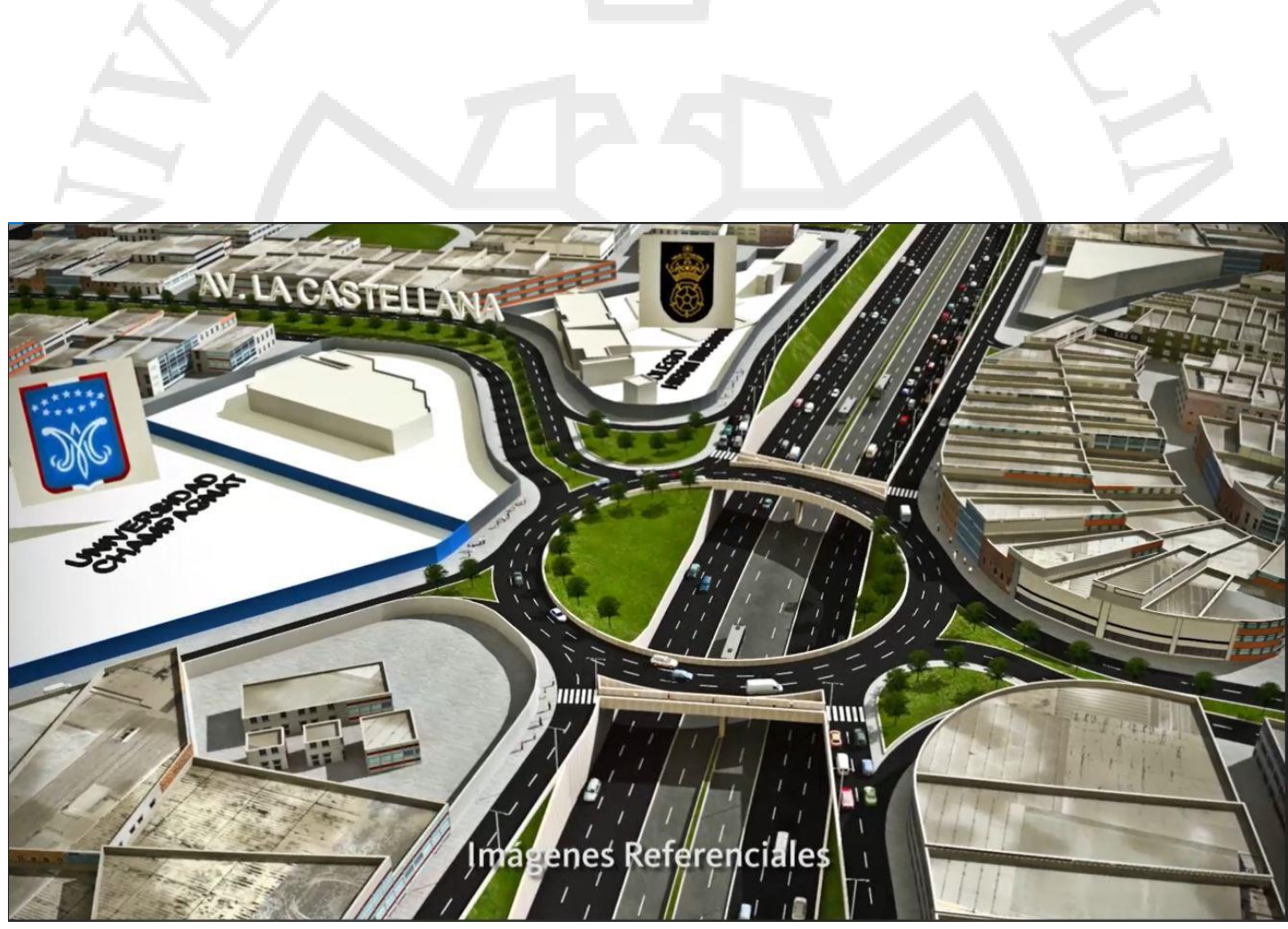

Imagen VES: Óvalo de autos a desnivel en Avenida La Castellana. Fuente: Video VES (2015) 


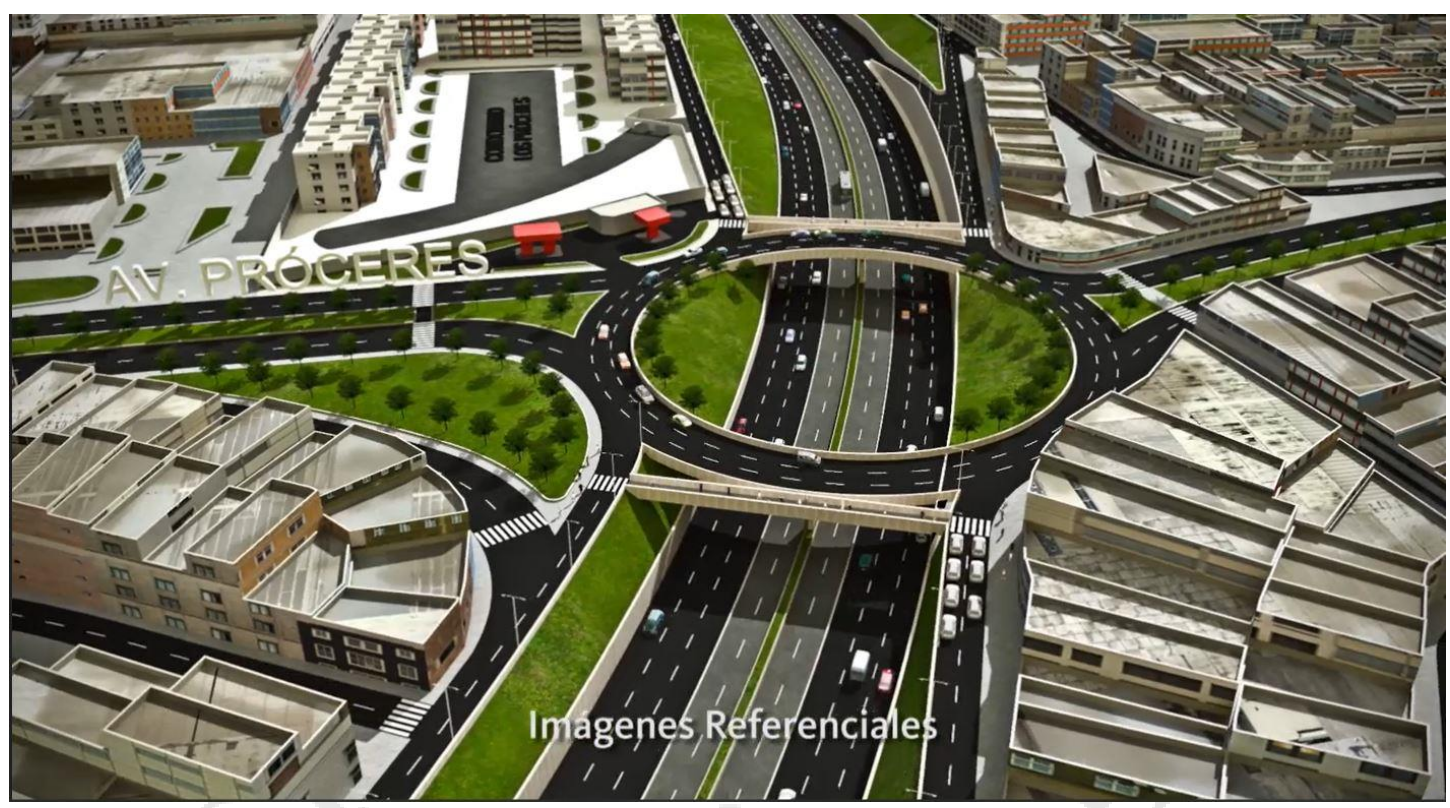

Imagen VES: Óvalo a desnivel en Avenida Próceres. Fuente: Video VES (2015)
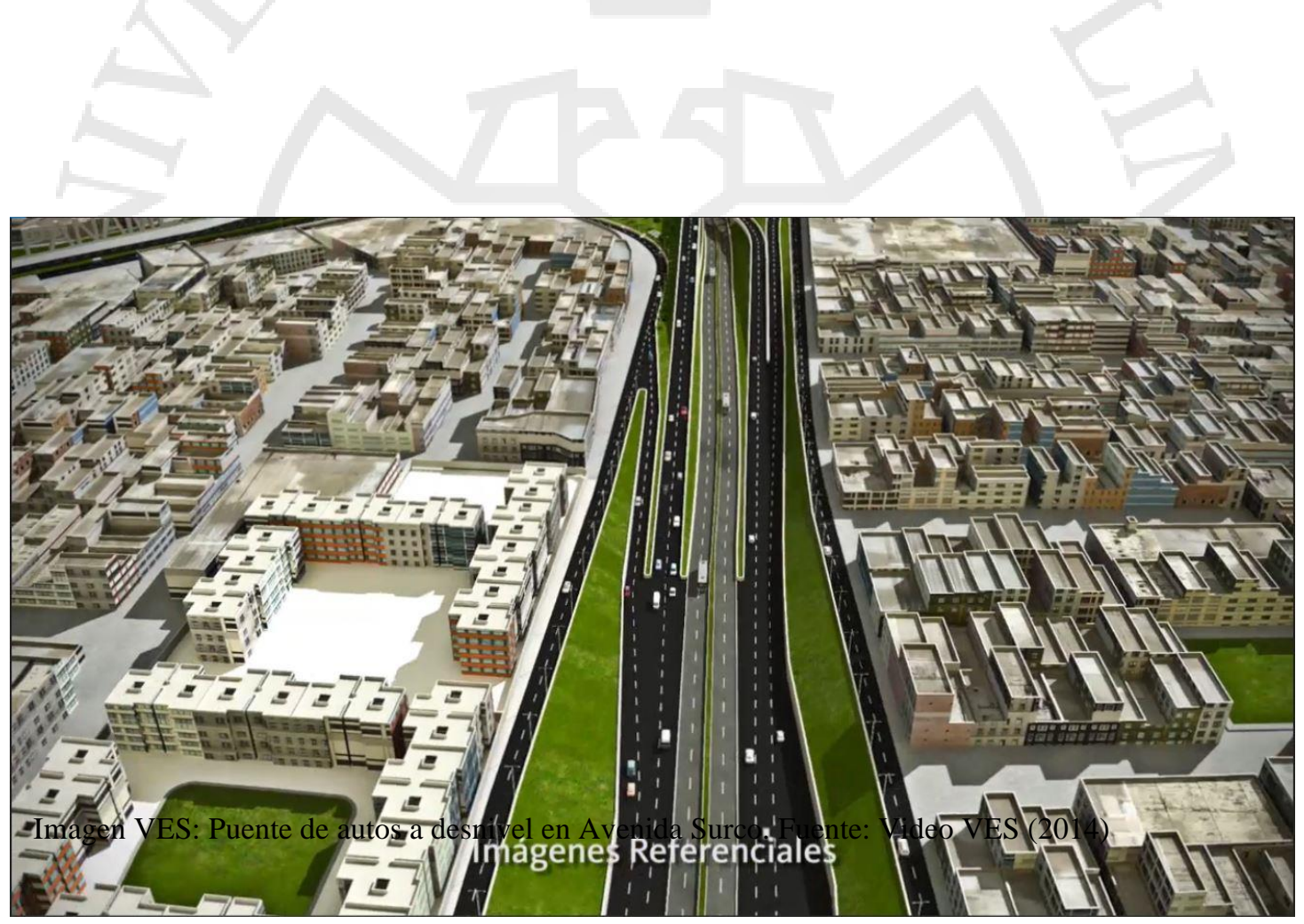

Imagen VES: Perfil vial típico. Fuente: Video VES (2015) 


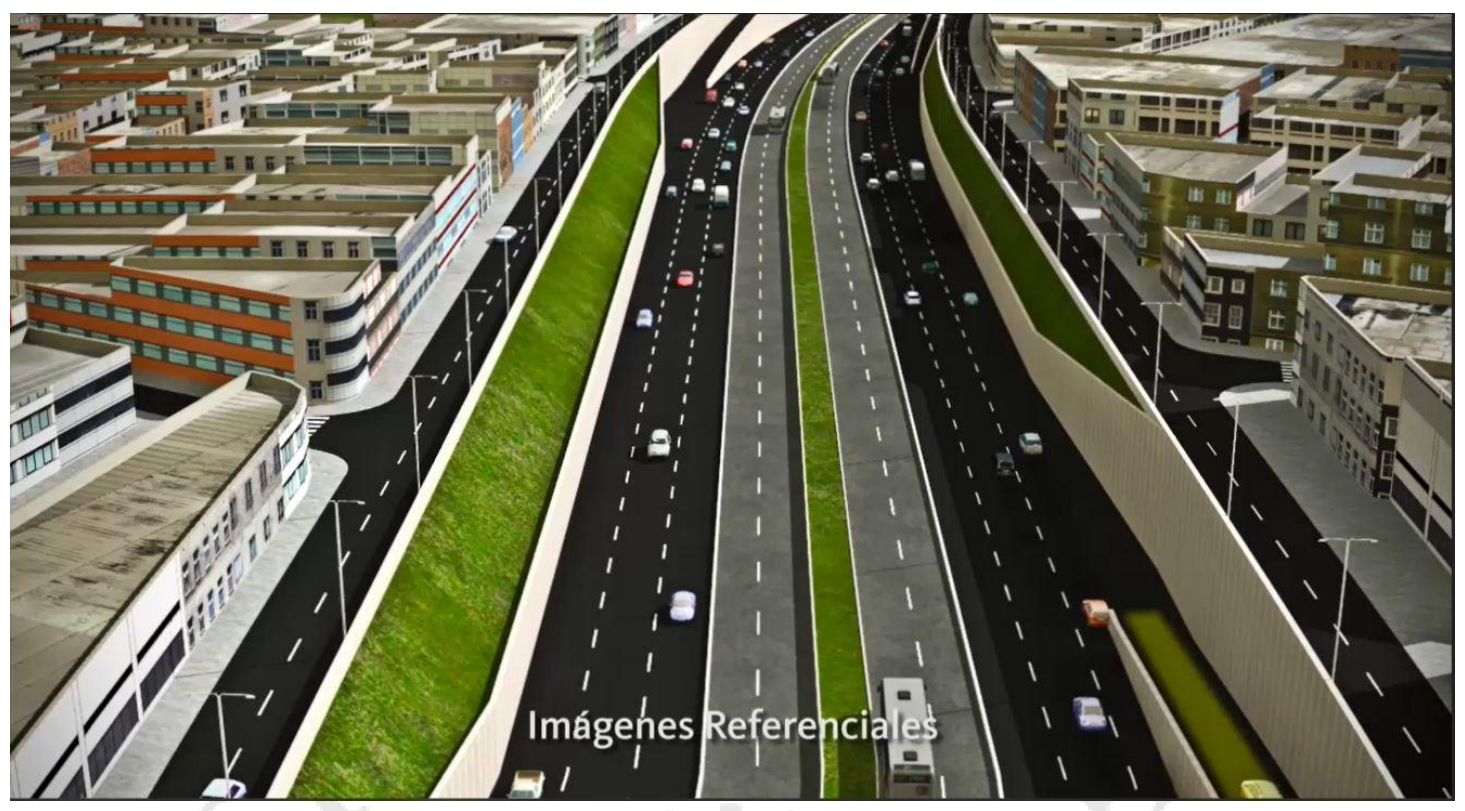

Imagen VES: Perfil vial típico. Tendrá 11 rampas de autos. Fuente: Video VES (2015)

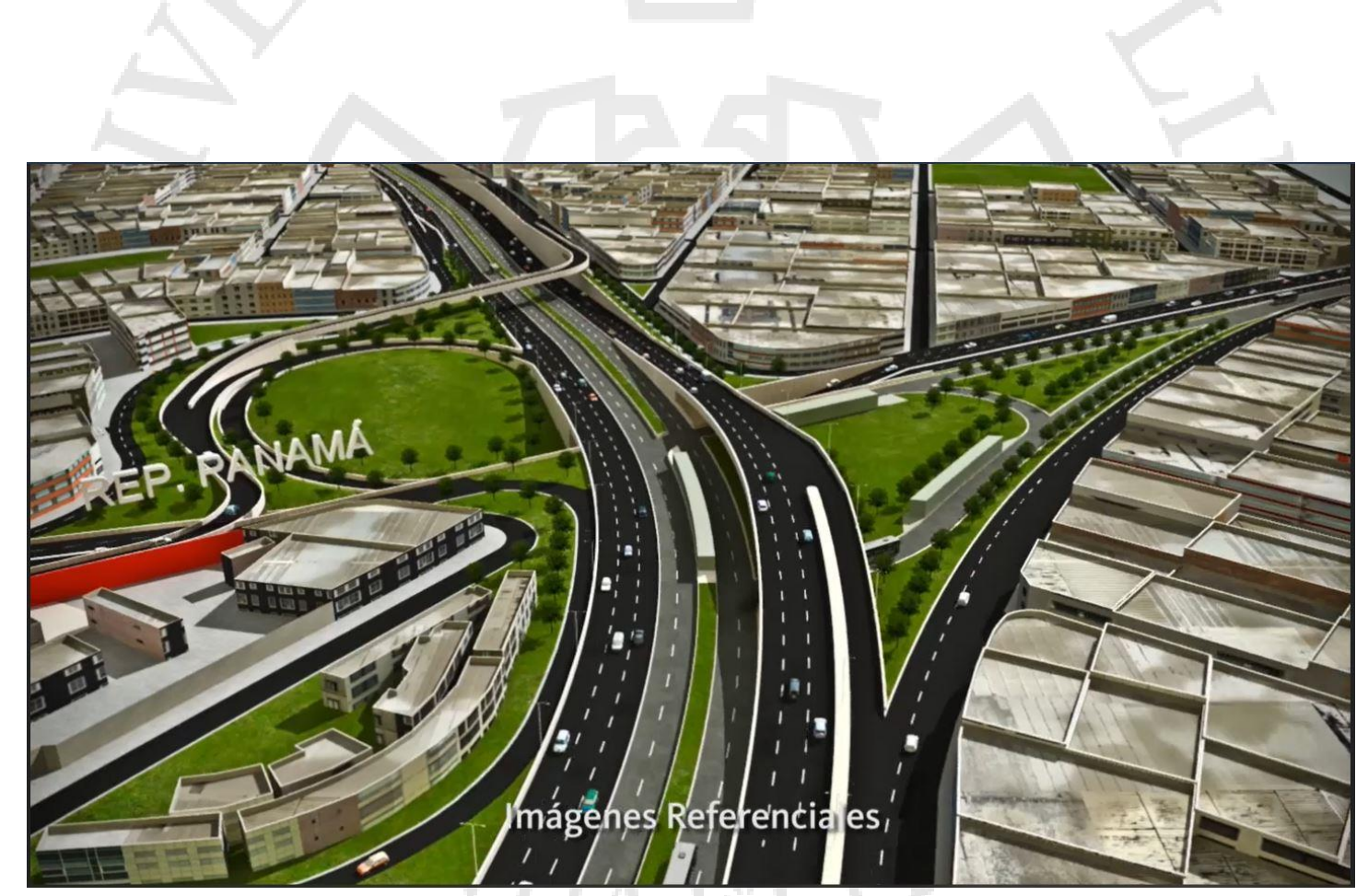

Imagen VES: Intercambio vial en Barranco y Plaza 360 de Transferencia, vista desde Miraflores. Fuente: Video VES (2015) 


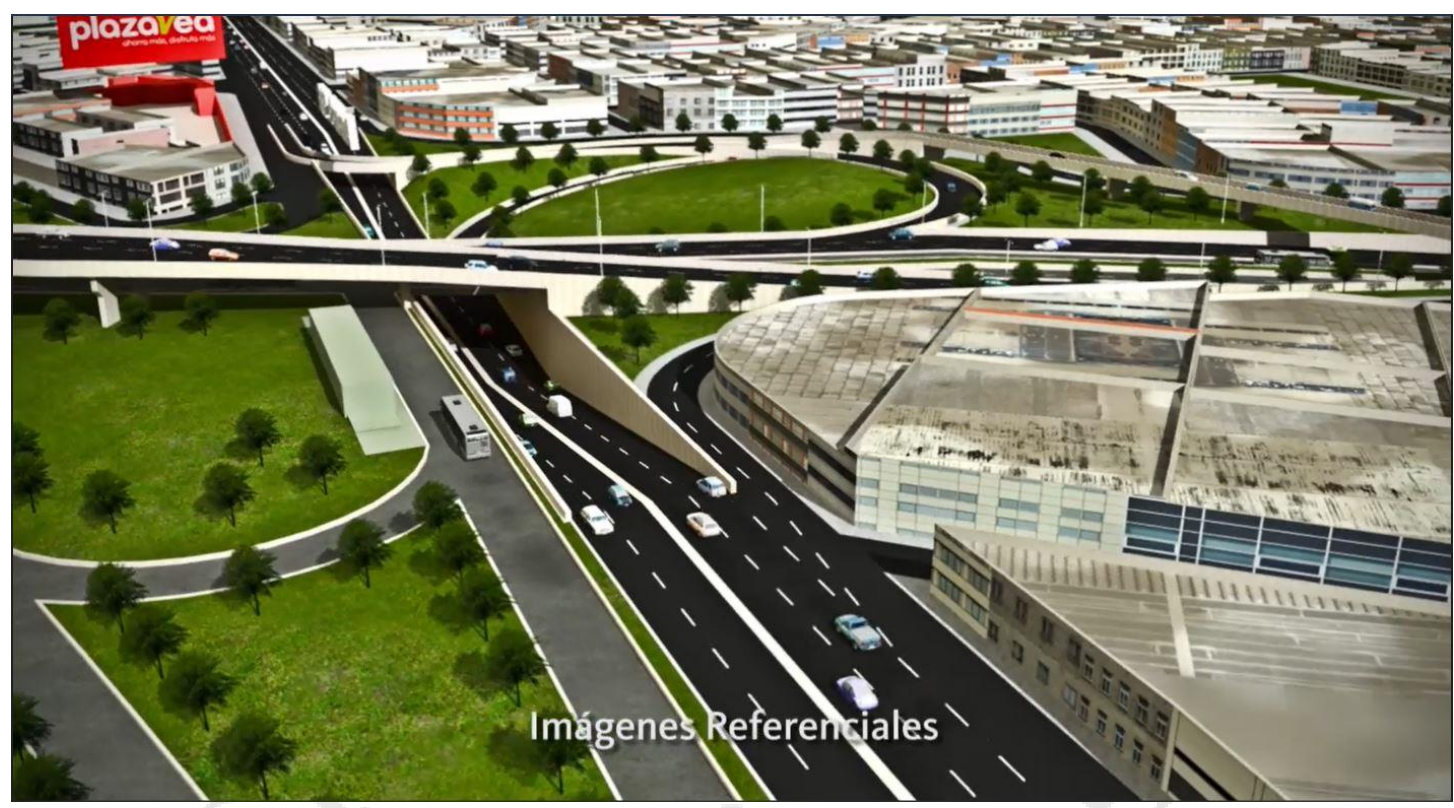

Imagen VES: Intercambio vial en Barranco y Plaza 360 de Transferencia, vista desde Barranco (inicio de concesión). Fuente: Video VES (2015)

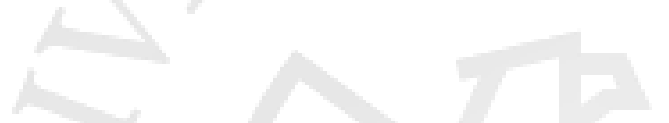

En la Estación Plaza de Flores, la Municipalidad de Lima ha considerado una Estación Plaza 360 de Transferencia del Metropolitano, cuya implementación no es de conocimiento público, pero existe referencialmente en los planos de Graña y Montero.

La Estación Plaza 360 de Transferencia consiste en dársenas alrededor del terreno aledaño a la actual Estación Plaza de Flores en Barranco. El diseño interno aún es desconocido, pero el espacio que abarca es de $74.00 \mathrm{~m}$ x $163.00 \mathrm{~m}$ aproximadamente. Aún sin conocer la estación, el plan general no da espacio al peatón ni a sus cruces a través de las vías.

Asimismo, los planos técnicos de las vías de la VES, presentan estudios viales y estructurales completos, proyectando vías que atraviesan entre Barranco, Surco y Miraflores, sin evaluar cruces peatonales y puentes. La escala del esquema siempre es a nivel macro.

Las vías de la VES atravesarán el terreno de estudio a desnivel y a nivel, expropiando una parte del espacio. En el siguiente extracto de plano, las vías en celeste son aquellas que aún no existen o serán modificadas para el tramo concesionado. 


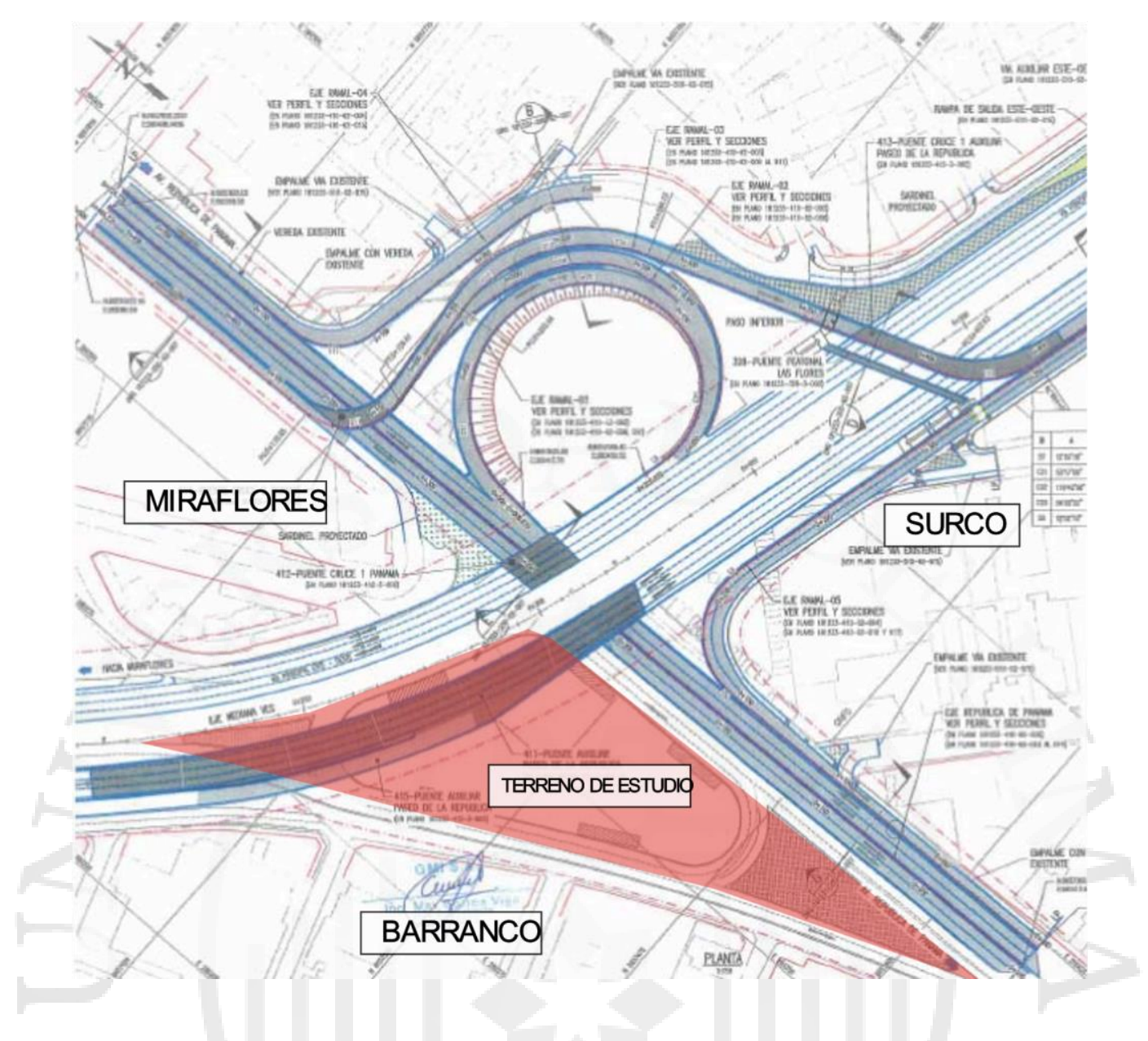

La ampliación se consideró desde la construcción de Paseo de la República, hace más de 45 años y el nuevo proyecto mantiene la misma lógica y orden, donde el auto mantenía prioridad sobre el peatón. El diseño de la VES, por lo tanto, no contempla el escenario actual, donde el peatón queda minimizado en espacios de veredas que comprenden menos de 1/3 de los espacios para el auto. En el presente trabajo, consideramos que un estudio vial aprobado no es suficiente para el proyecto que 'beneficiaría a 200 millones de limeños' ${ }^{30}$ siempre y cuando sean dueños de un auto.

Dentro del expediente técnico del proyecto, encontramos los cruces peatonales considerados como típicos a la altura de las 'orejas' del intercambio vial en Barranco. No se observan divisiones físicas entre vía rápida y cruce peatonal, ni reductores de velocidad. Incluso, en una de ellas no se proyecta la señal de Pare.

\footnotetext{
${ }^{30}$ Extracto del video promocional de la Vía Expresa Sur en su página web. Los realizadores no especifican a qué limeños se incluye. Sin embargo, asumimos que es un cálculo de quienes utilizarían las vías.
} 

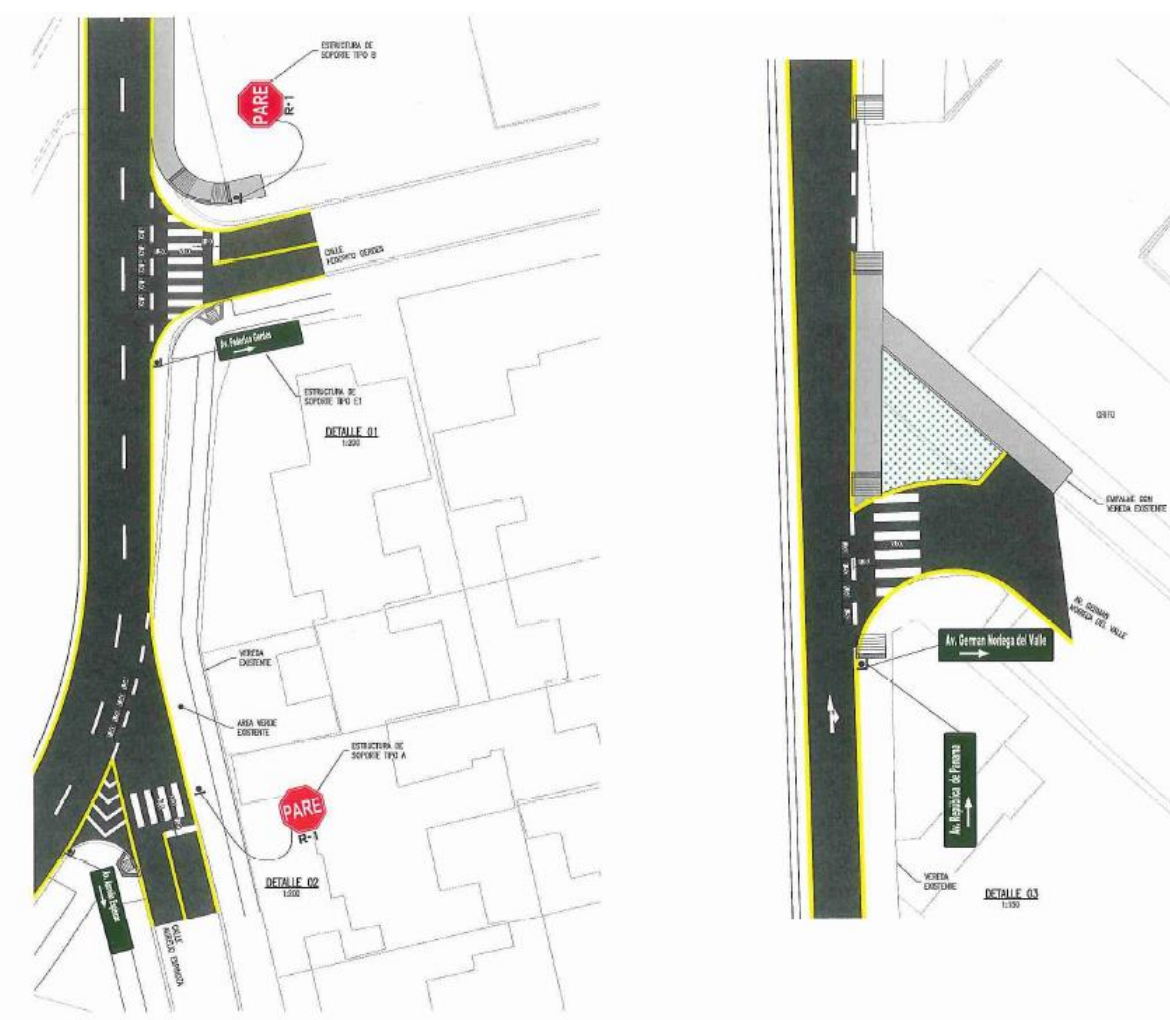

Esquemas de paso peatonal. Fuente: (Concesionaria Vía Expresa SUR S.A., 2015)

Si bien el Centro Cultural proyectado en este trabajo no busca que se elimine el proyecto de Graña y Montero, espera mitigar el impacto de una obra metropolitana que no contempla la escala humana en ninguna de sus páginas. Se intentará proveer soluciones alternativas que mantendrán cierta escala barrial en algunos puntos de la intervención vial. Por lo tanto, es necesario delimitar y especificar que, el presente trabajo no incluye a las vías rápidas ni del Metropolitano como parte del proyecto final. Sin embargo, se brindarán soluciones a nivel anteproyecto para sustentar la factibilidad del espacio utilizado por el Centro Cultural y su plaza pública. 


\subsection{Proyecto}

\subsubsection{Relación con la Vía Expresa Sur}

El proyecto de la Vía Expresa Sur, proyecta vías aéreas y subterráneas que interfieren con el terreno de estudio. La ampliación de vía existe como la tercera etapa, desde su planteamiento en 1858, para conectar el Cercado de Lima con Chorrillos. Sin embargo, no fue hasta el año 2014 que se publicaron las imágenes del plan de construcción vial.

Actualmente, y bajo el concepto del proyecto del Centro Cultural de Barranco, se plantea minimizar el impacto de la disposición de vías a la altura de la Estación Plaza las Flores del Metropolitano. Las vías aéreas y subterráneas generaran, a nivel peatonal, un mayor impacto en la división de espacios autónomos, dificultando (aún más) el libre tránsito a pie.

Como hemos observado, las consideraciones peatonales del expediente se limitan a cruces de cebra a nivel, y algunos sin semáforo. Más allá de ese punto, el terreno vacío seguiría siendo un espacio desaprovechado como berma central de Grass inutilizable. La nueva estación mantiene un emplazamiento similar al que existe. El anillo vial para el intercambio de rutas de buses abarca todo el terreno $\mathrm{y}$, hasta los planos observados, mantiene las estaciones del mismo tamaño y sin servicios o espacios complementarios.

Es a partir de eso, que el Proyecto del Centro Cultural de Barranco en Estación Plaza las Flores del Metropolitano, plantea una opción que, además de no perjudicar al peatón, aporte más espacio libre y público a la ciudad.

Es importante recordar que se deben brindar espacios saludables y sostenibles para que sean considerados de calidad. Para aprovechar el terreno libre, se debe garantizar la seguridad del usuario, y es por ello por lo que las vías rápidas en by-pass y a nivel del suelo, se replantean a nivel anteproyecto.

Según el planteamiento del proyecto, el Metropolitano se mantiene en el subsuelo al pasar por Barranco, como ocurre en la Vía Expresa Paseo de la República. 
A pesar de que el servicio de BRT debe ser económico, también debe contemplar una serie de factores que garanticen su funcionamiento dentro de una ciudad consolidada. Y el Metropolitano, en muchos espacios de Lima, no cumple con mantener las secciones de vías y espacios peatonales del Manual del BRT. Es por ello por lo que se considera necesario priorizar el beneficio urbano y social, frente al gasto económico que implica mantener un BRT en el subsuelo.

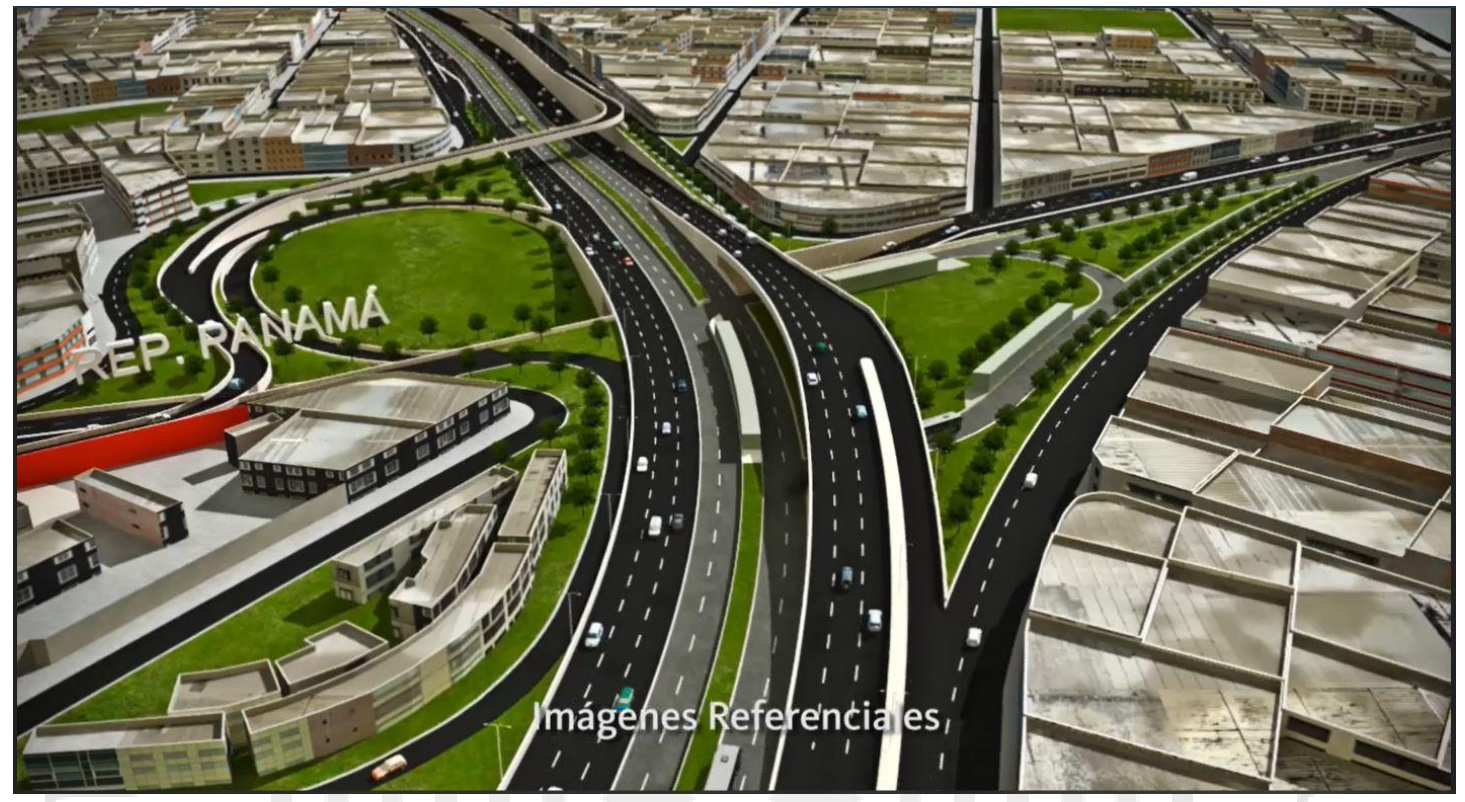

Imagen VES: Intercambio vial en Barranco y Plaza 360 de Transferencia, vista desde Miraflores. Fuente: Video VES (2015)

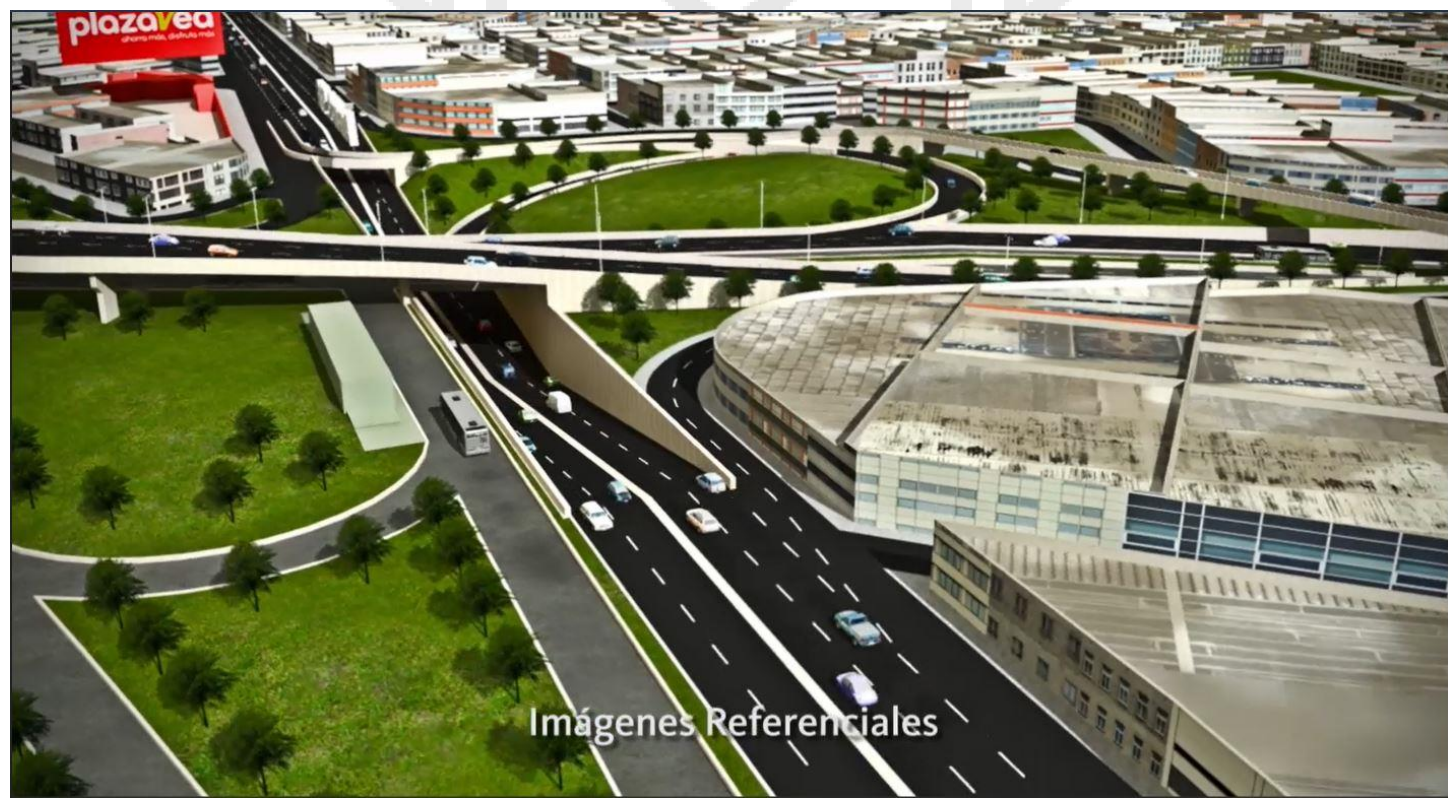

Imagen VES: Intercambio vial en Barranco y Plaza 360 de Transferencia, vista desde Barranco (inicio de concesión). Fuente: Video VES (2015) 
El siguiente gráfico especifica las vías, rutas y direcciones planteadas según el proyecto de la Vía Expresa Sur:

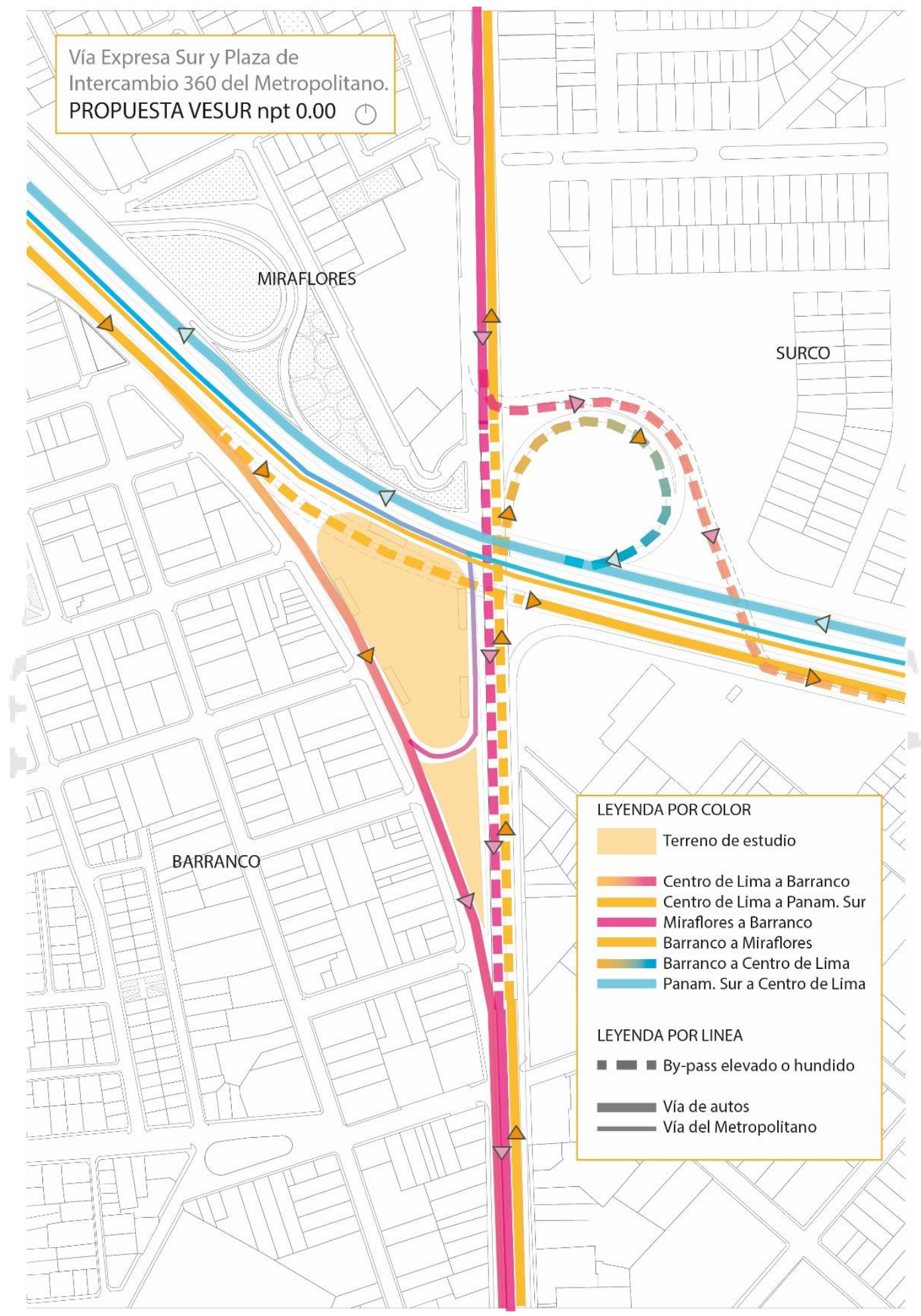

Esquema de realización propia 
Con el Metropolitano fuera de la superficie, no es necesario elevar Paseo de la República y abarca dos carriles del terreno a nivel del suelo. Finalmente, el by-pass de República de Panamá, será techado, dejando un carril auxiliar para que los autos en sentido Barranco-Panamericana Sur puedan recorrer.

En los siguientes gráficos, se muestra el planteamiento preliminar de vías y sus sentidos para el CCB, teniendo en cuenta el nivel +0.00 , el by-pass subterráneo y las vías del Metropolitano alrededor de la estación en el nivel -9.00.

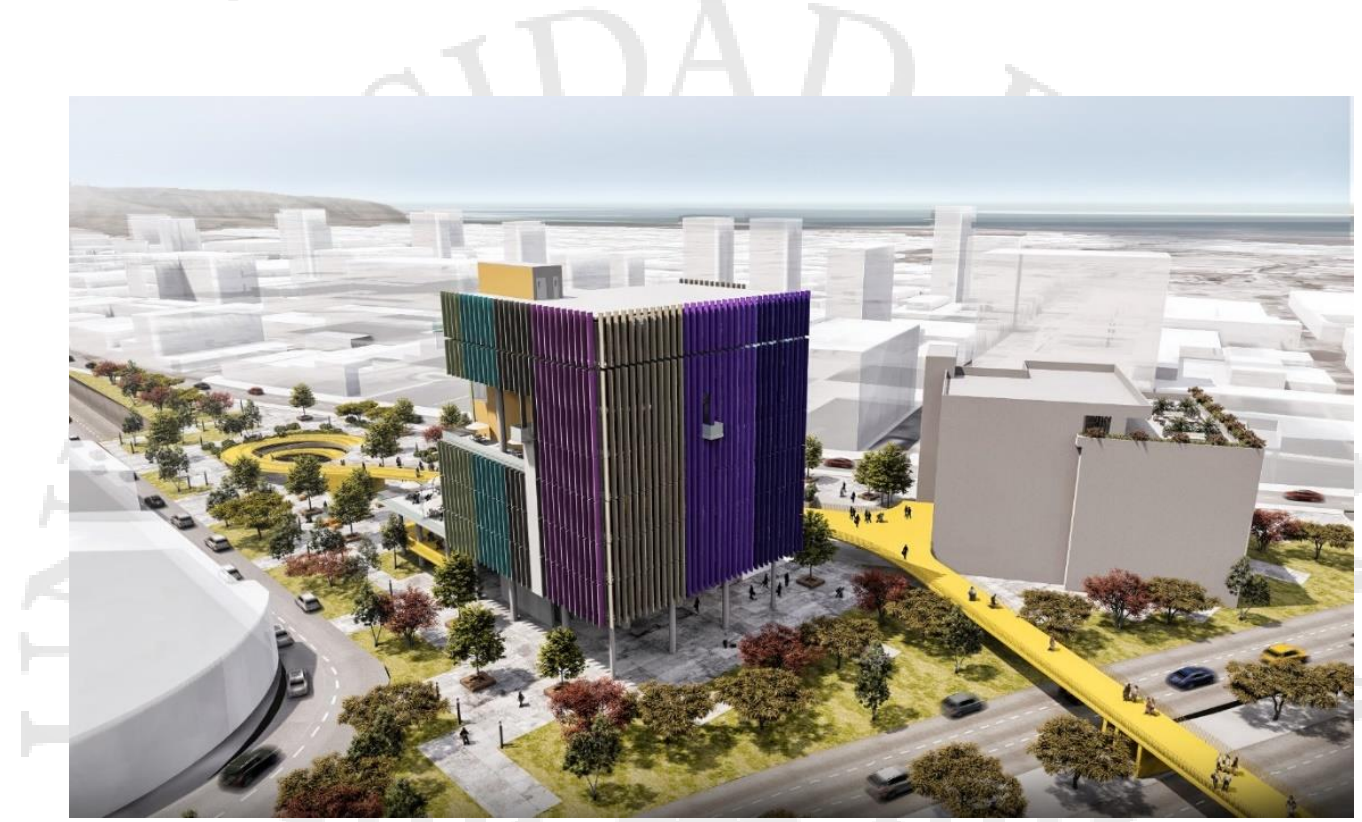

Imagen: Vista de las vías desde Surco.

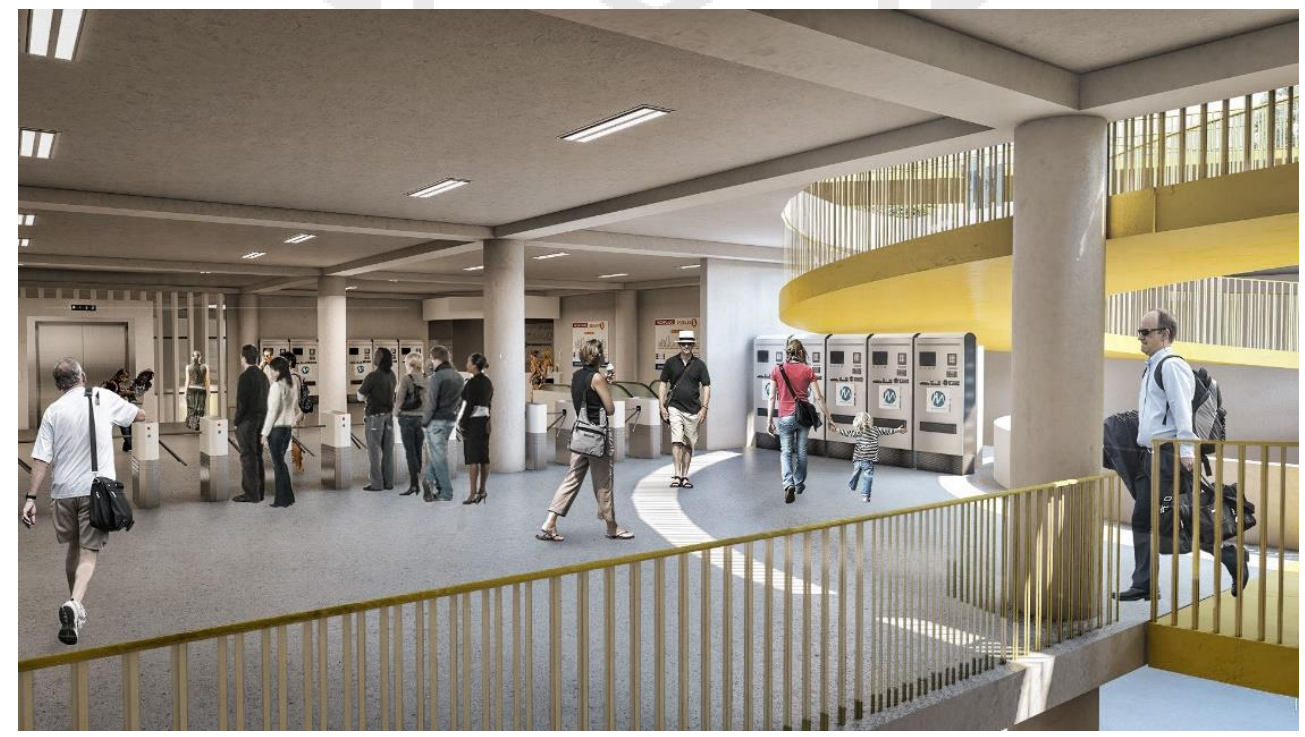

Imagen: Mezanine de distribución del Metropolitano, planteada a nivel anteproyecto por el CCB. 


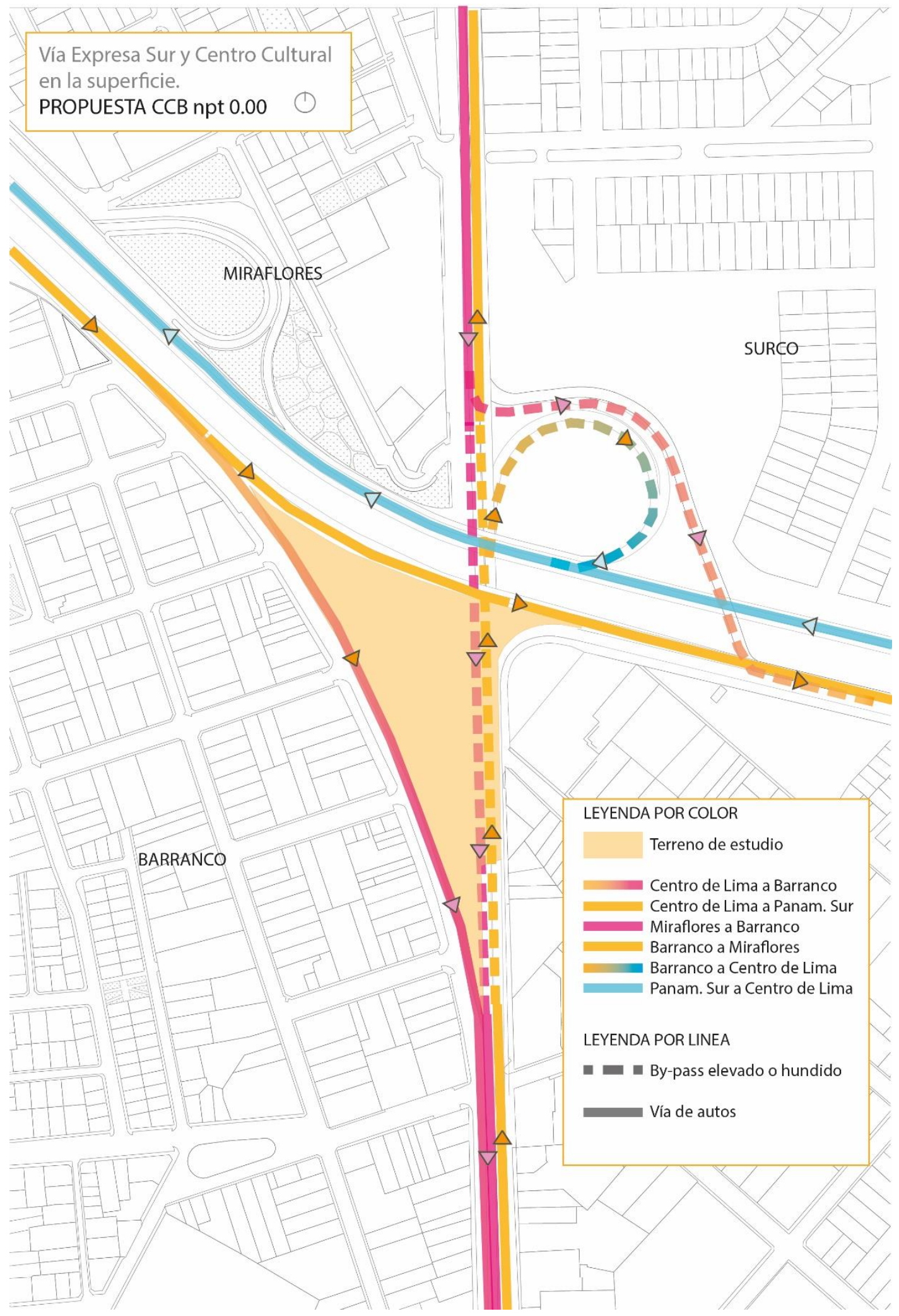

Esquema de realización propia 
Plaza Subterránea de

Intercambio 360 del Metropolitano.

PROPUESTA CCB npt -9.00

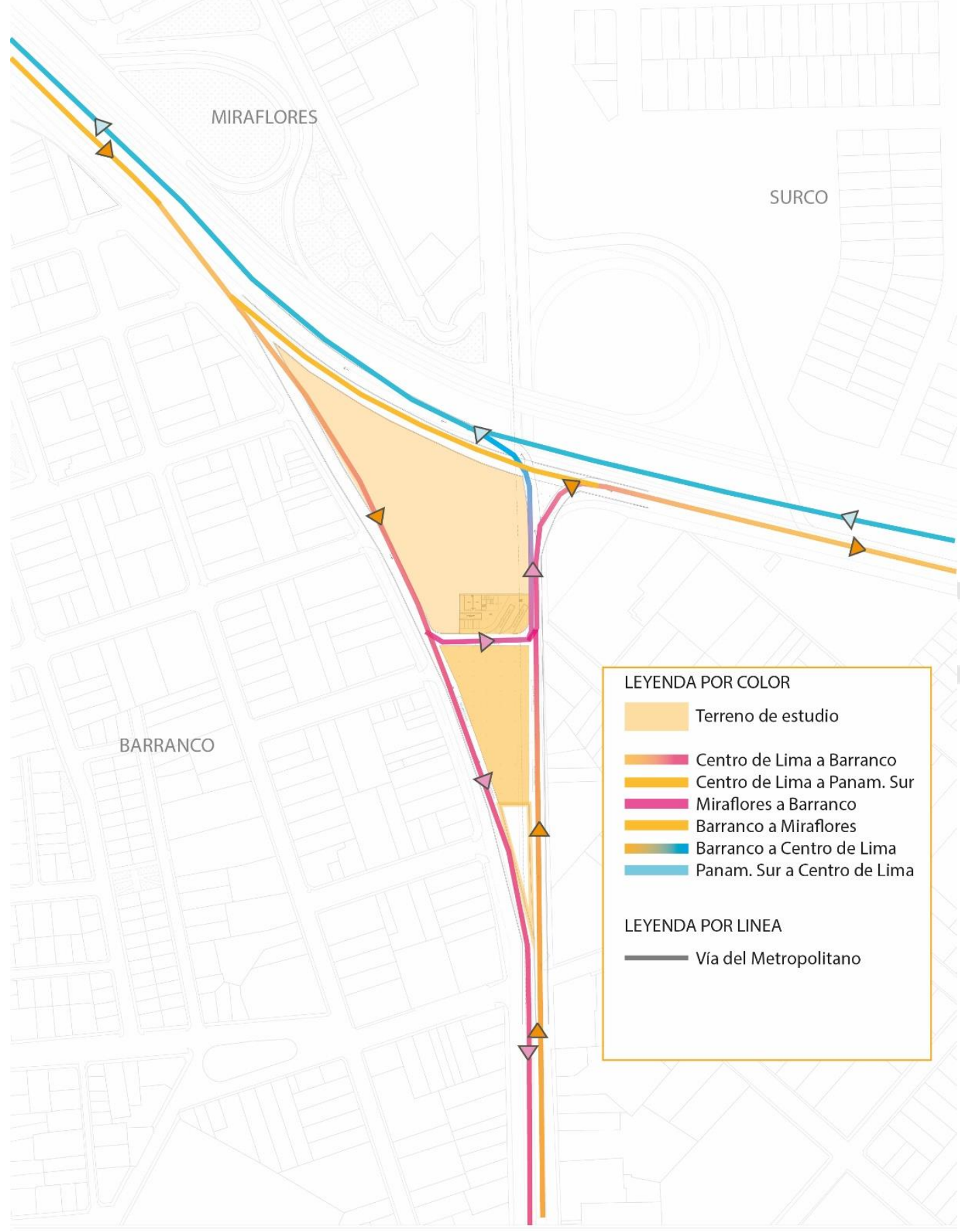

Esquema de realización propia 
Con este planteamiento, comprobamos que el Metropolitano no se mantiene bajo los lineamientos de un BRT. Al ser un sistema de transporte económico, no debe generar costos altos en infraestructura vial y costo social, impidiendo el libre tránsito peatonal. Por ejemplo, la vía elevada no muestra el paso peatonal hacia las estaciones ni precisa un plan de Miraflores a Barranco a través de la Vía Expresa Paseo de la República. De igual manera, la vía subterránea de República de Panamá no muestra un cruce peatonal hasta 3 cuadras antes de la estación.

El nuevo planteamiento de vías responde al objetivo del proyecto, de cohesionar espacios físicos separados por los límites de la Vía del Metropolitano y el actual vacío urbano. Paseo de la República a Nivel del suelo deja de obstruir visualmente el límite de Miraflores y Barranco. Y al techar República de Panamá, mantiene la continuidad urbana.

\subsubsection{Toma de partido}

El CCB se emplaza en un vacío urbano que funciona como límite virtual entre 3 distritos y no aporta a la ciudad. Además, los límites físicos de la vía del Metropolitano, dividen barrios que difieren en NSE y carecen de oportunidades positivas para aprovechar la ciudad por la falta de equipamiento urbano y espacios públicos (ver láminas 01, 02, 03, 13).

El proyecto se presenta con un alto nivel de permeabilidad y considera al peatón en cada momento, convirtiendo el límite del vacío urbano y vías en un espacio compartido (ver láminas 14 y 15). La plaza es un espacio público físico intermedio que cohesiona físicamente los 4 espacios autónomos: las zonas 2 y 3 de Barranco, y Miraflores y Surco. Con claros pasos peatonales a nivel de la vereda y recibos peatonales, el trazado respeta las vías existentes y las reúne al centro del proyecto, para que el peatón pueda continuar su camino sin ser interrumpido por límites físicos.

Los límites virtuales más importantes para combatir son aquellos que generan diferencias sociales y económicas. En este caso, la ciudad se ha fragmentado espacios de ganadores y perdedores, como menciona De Mattos. Principalmente, el CCB se construye como equipamiento que beneficia a varios sectores socioeconómicos, pero, 
sobre todo a aquellos que carecen de oportunidad y accesibilidad a los espacios culturales privados.

Incluso, dentro del proyecto, se busca minimizar los límites de público y privado. Mediante estrategias de diseño y gestión de los edificios, los usuarios pueden acceder a la mayor parte de espacios y entender que un equipamiento público es, precisamente, del público (ver láminas 17 y 19).

Como la fragmentación urbana viene, casi siempre, acompañada de la fragmentación social, es importante que el CCB sea una herramienta para que todos puedan ejercer sus derechos, aprovechar sus habilidades y tomar ventaja de las oportunidades que se encuentran en su medio.

Por lo tanto, el proyecto aprovecha los ángulos de una trama urbana interrumpida y se emplaza dando la fachada a todas las zonas autónomas fragmentadas por las vías metropolitanas (ver lámina 17). Así, el edificio, su plaza y el puente-rampa, reiteran que son accesibles y públicos para todos.

El CCB, la plaza y el puente son elementos articuladores; cada uno con el propósito de cohesionar la ciudad a niveles micro y macro, pero siempre priorizando al ciudadano peatón.

A partir del análisis de referentes y competencia local, se determina el programa y los espacios que lo albergarán. Ambos edificios terminan siendo la unión de varios bloques programáticos y con áreas definidas según la necesidad de cada actividad a realizarse. La altura de los edificios es el resultado del conjunto de espacios necesarios para atender al público objetivo.

La plaza, por otro lado, está planteada como un respiro al crecimiento inmobiliario que se espera a futuro alrededor del terreno. Mantenerla a nivel 0.00, es para aliviar el perfil urbano que se proyecta. 


\subsubsection{Programa}

El anteproyecto está compuesto por 3 elementos: Una plaza pública, una estación del Metropolitano, y un Centro Cultural. Los tres, conversan para brindar un espacio de accesibilidad a la exploración artística y a la movilidad. A nivel proyecto, se desarrollará el Centro Cultural y su emplazamiento sobre el terreno.

La estación Plaza de Flores responde a un proyecto pre-dimensionado, propuesto por la Municipalidad de Lima como una Estación de Transferencia. Sin embargo, el presente trabajo modifica la principal toma de partido, y la vuelve una estación subterránea. Si bien el Metropolitano es un BRT con el beneficio de ser económico, no cuenta con una sección de vía que se acomode al sistema instaurado en la zona; Barranco cuenta con veredas peatonales que también son bermas de autos.

El Centro Cultural cuenta con dos edificios: El Tótem y El Monolito. Ambos conversan visualmente en todas sus plantas y, físicamente, en el segundo nivel, con un nuevo estrato comercial en el puente peatonal.

Los edificios muestran personalidades opuestas pero relacionadas por el color y las actividades de expresión cultural. El Monolito es cerrado y perenne; constantemente esperando al usuario externo y ofreciendo programas artísticos. Cuenta con programa de exposición artístico, teatral, y gastronómico. En él, el usuario se acomoda a un espacio estereotómico enteramente público y espera ser definido por el edificio.

En El Tótem, ocurre lo contrario: el usuario hace al edificio. Los programas que ofrece se llevan a cabo exclusivamente gracias a la vida de los interesados. Las aulas y talleres se llenan por artistas que encuentran un espacio donde desarrollarse. Es un edificio de carácter tectónico y flexible en todas sus plantas. Quien lo ocupa, define la función.

Ambos edificios conforman una red de servicios y programas orientados a la formación y consumo de arte, en todas las formas posibles. Los acompaña la plaza, espacio de encuentro público entre los peatones que atraviesan y los que pasean. Se plantean espacios de plaza seca, otros de naturaleza xerófita y algunos de parque con 
Grass. El propósito es utilizar la menor cantidad de agua posible en el mantenimiento, proveyendo de espacios de carácter diferente, y de calidad.

\subsubsection{Análisis de espacios público-privado}

A continuación, se muestran esquemas del programa del proyecto, según su condición pública, privada o semipública. Los espacios públicos, son aquellos que permanecen abiertos las 24 horas del día, a disposición del usuario; los privados son los que albergan funciones administrativas y de operaciones internas; y los semipúblicos son aquellos de uso común o con cierta condición de entrada.

En todas las plantas de los edificios se prioriza el espacio semipúblico, que es más amplio, iluminado y ventilado. Se intenta tener el menor espacio privado posible, pues es importante que las funciones de administración del CCB no se limiten a algunos pocos. Los usuarios deben sentir la pertenencia al programa, su funcionamiento y su comunidad.

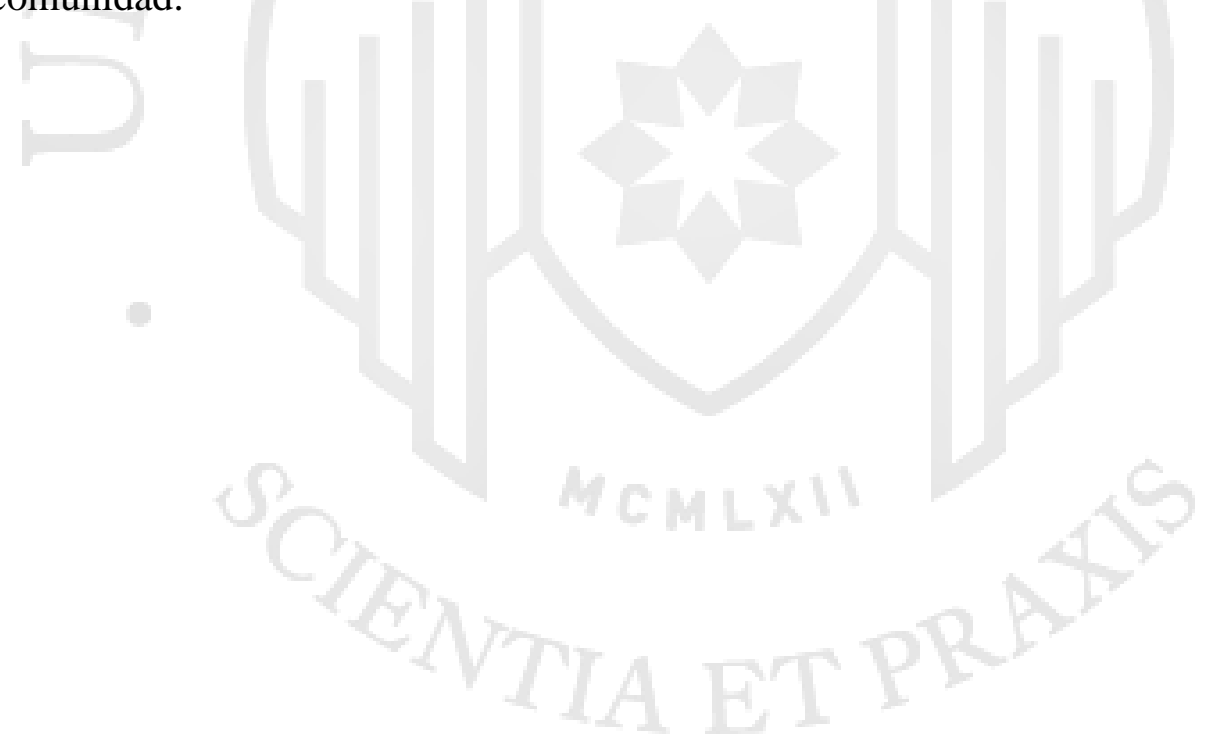




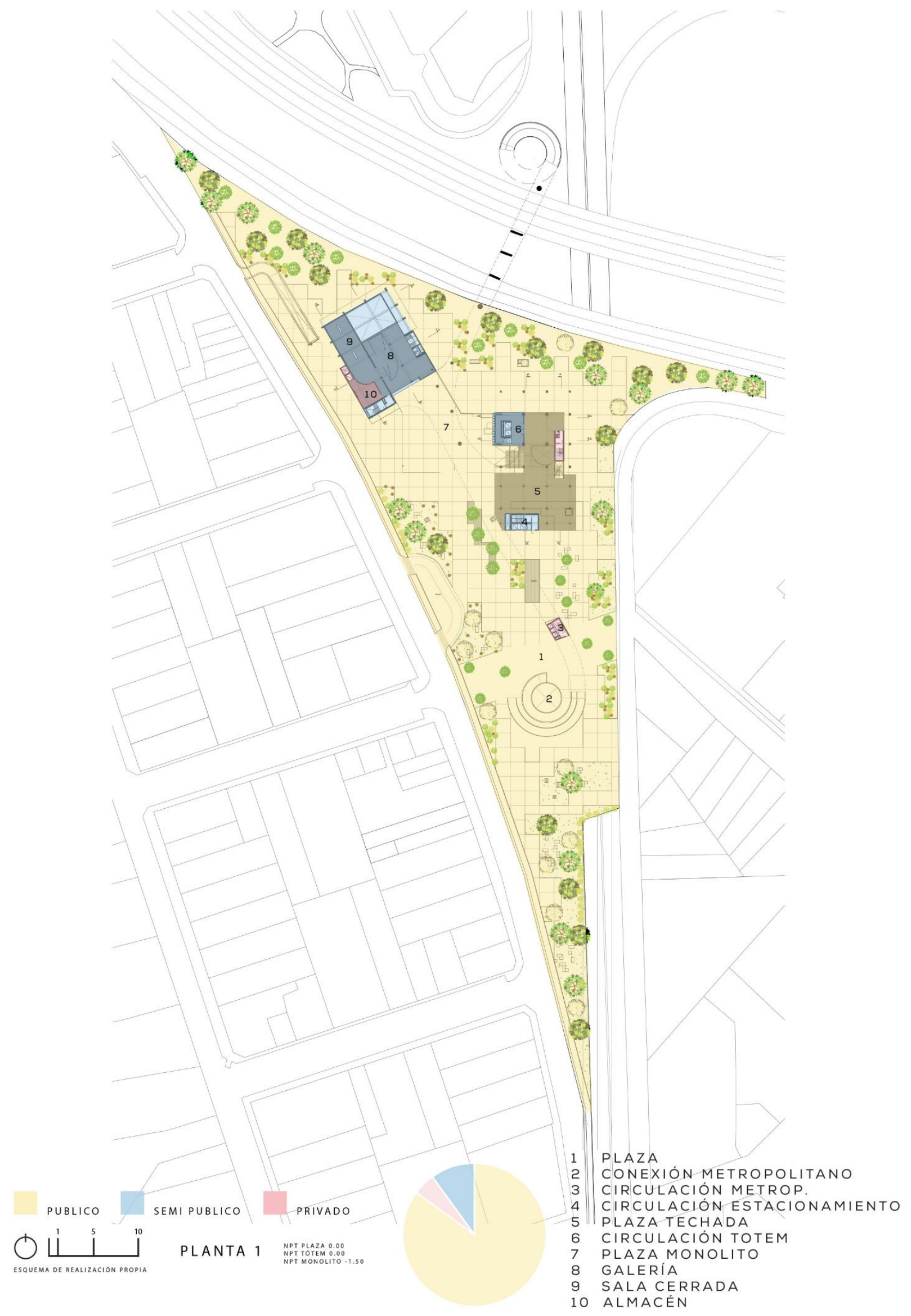



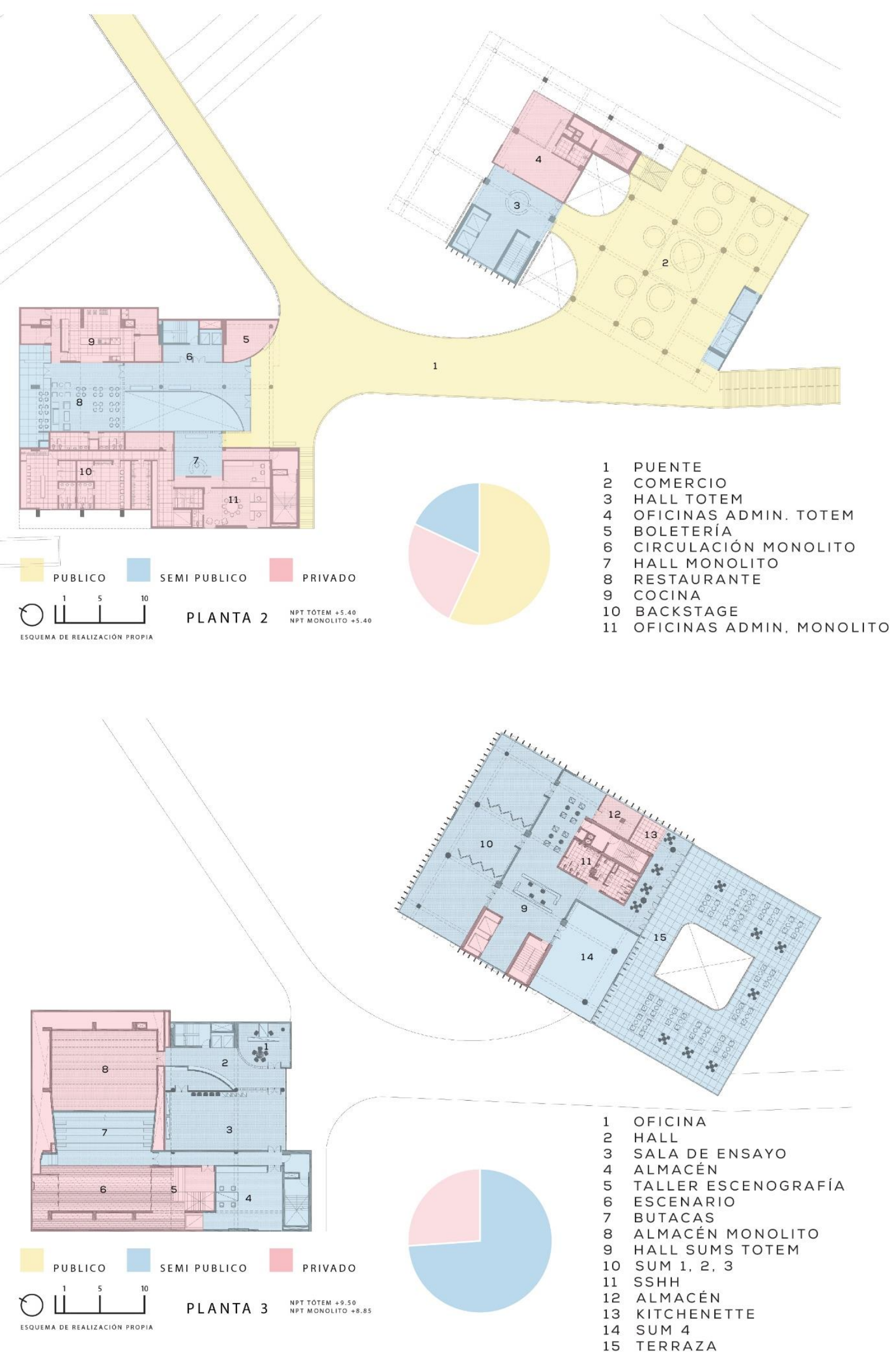

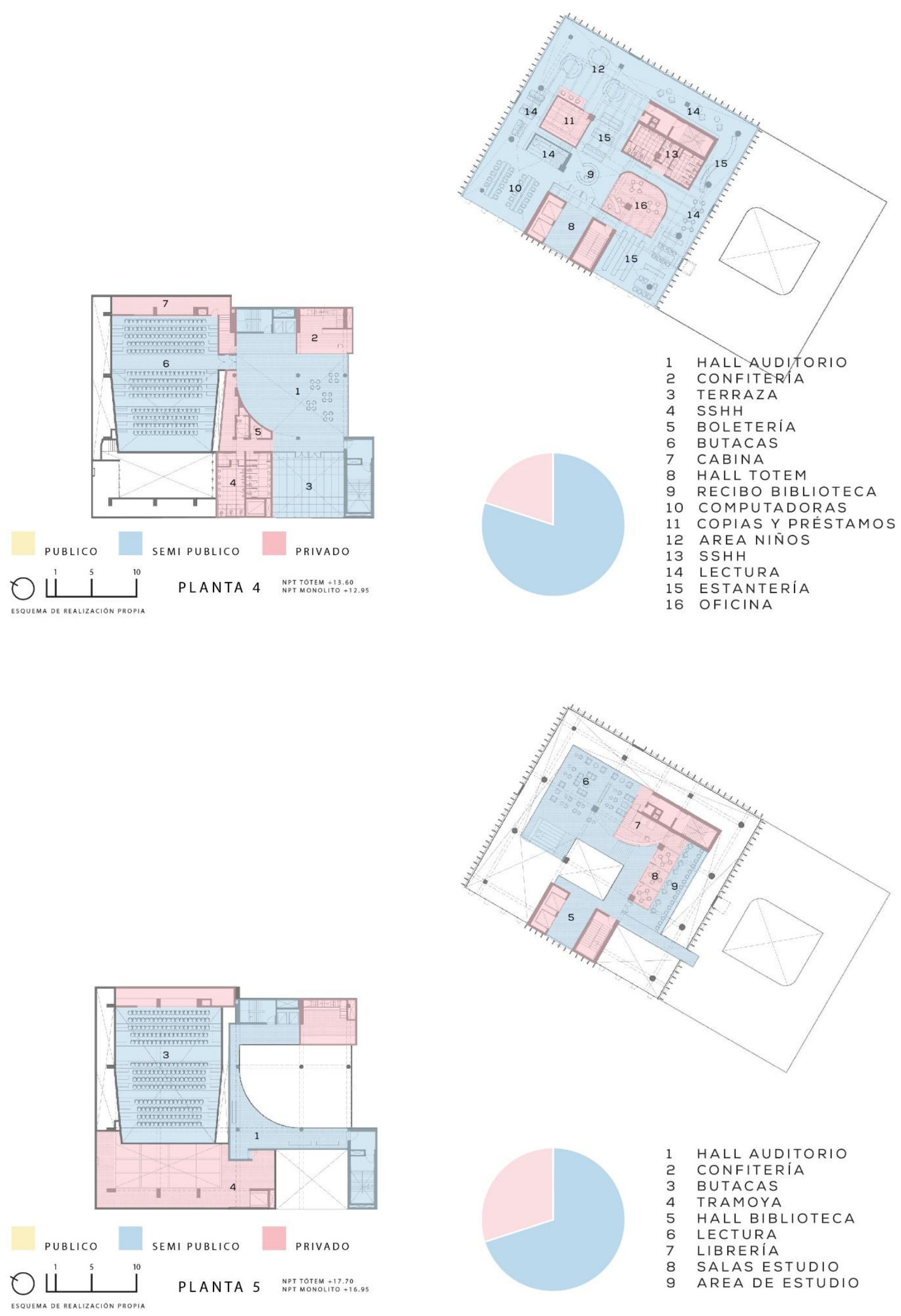

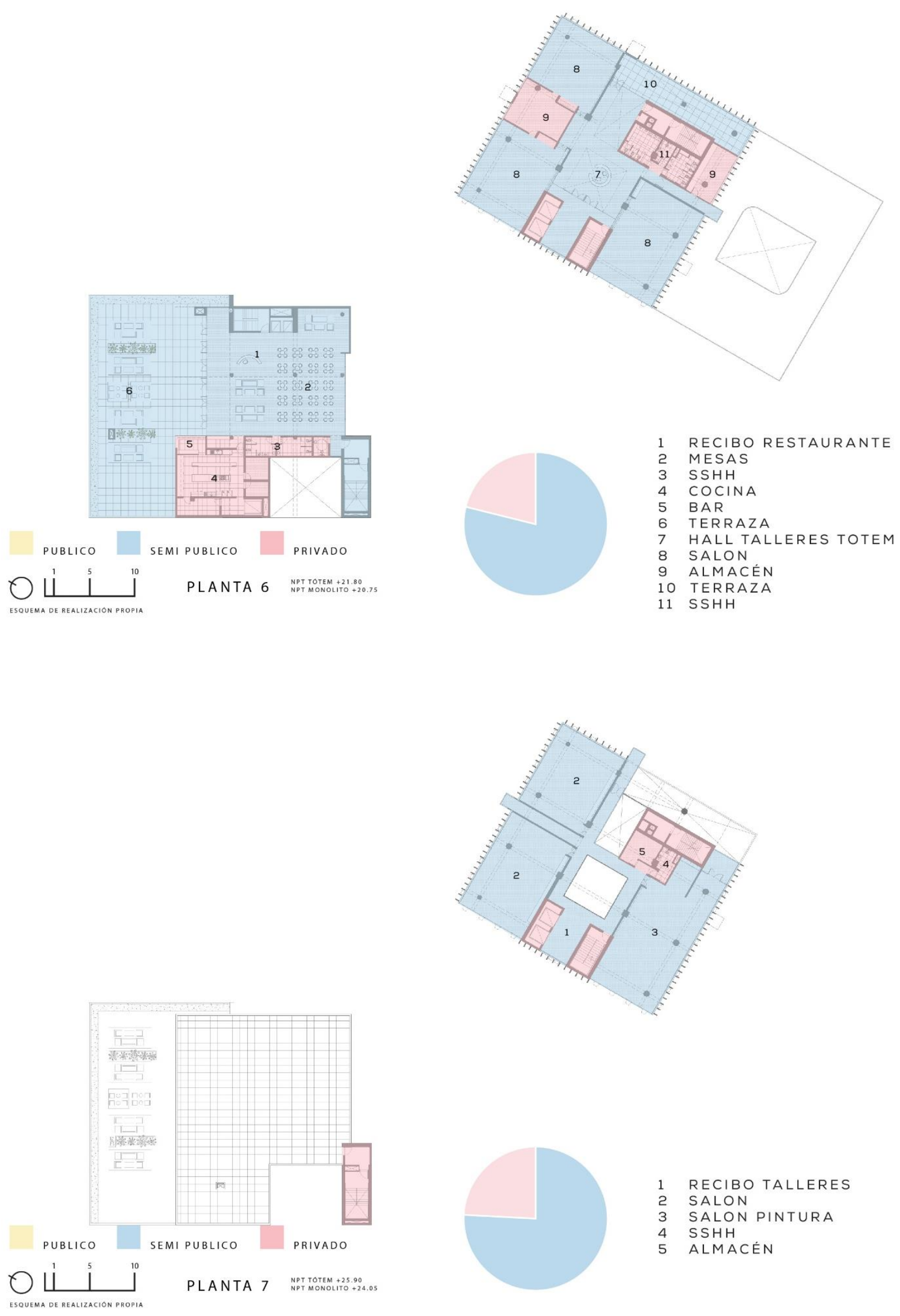

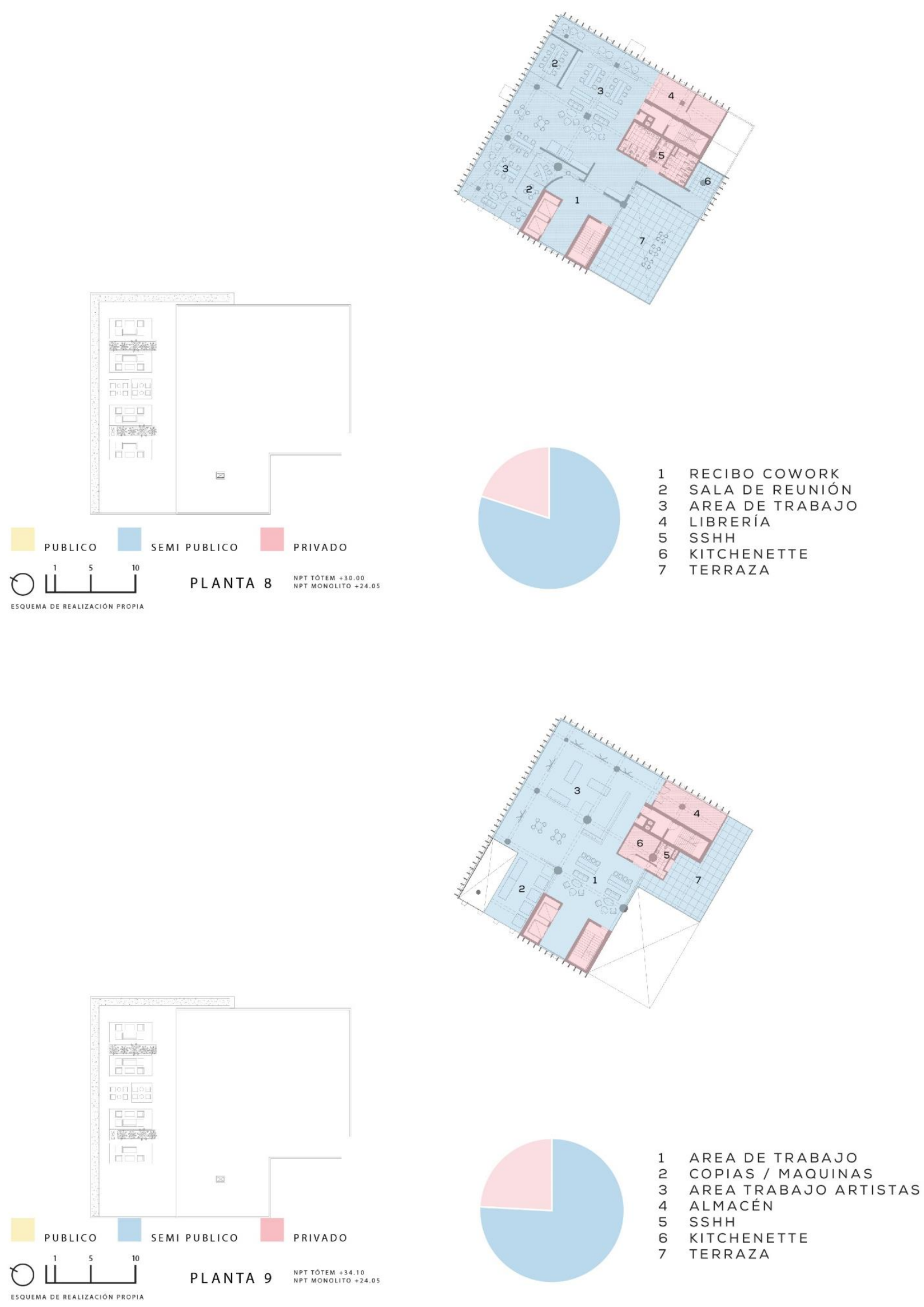


\subsubsection{Análisis de flujos}

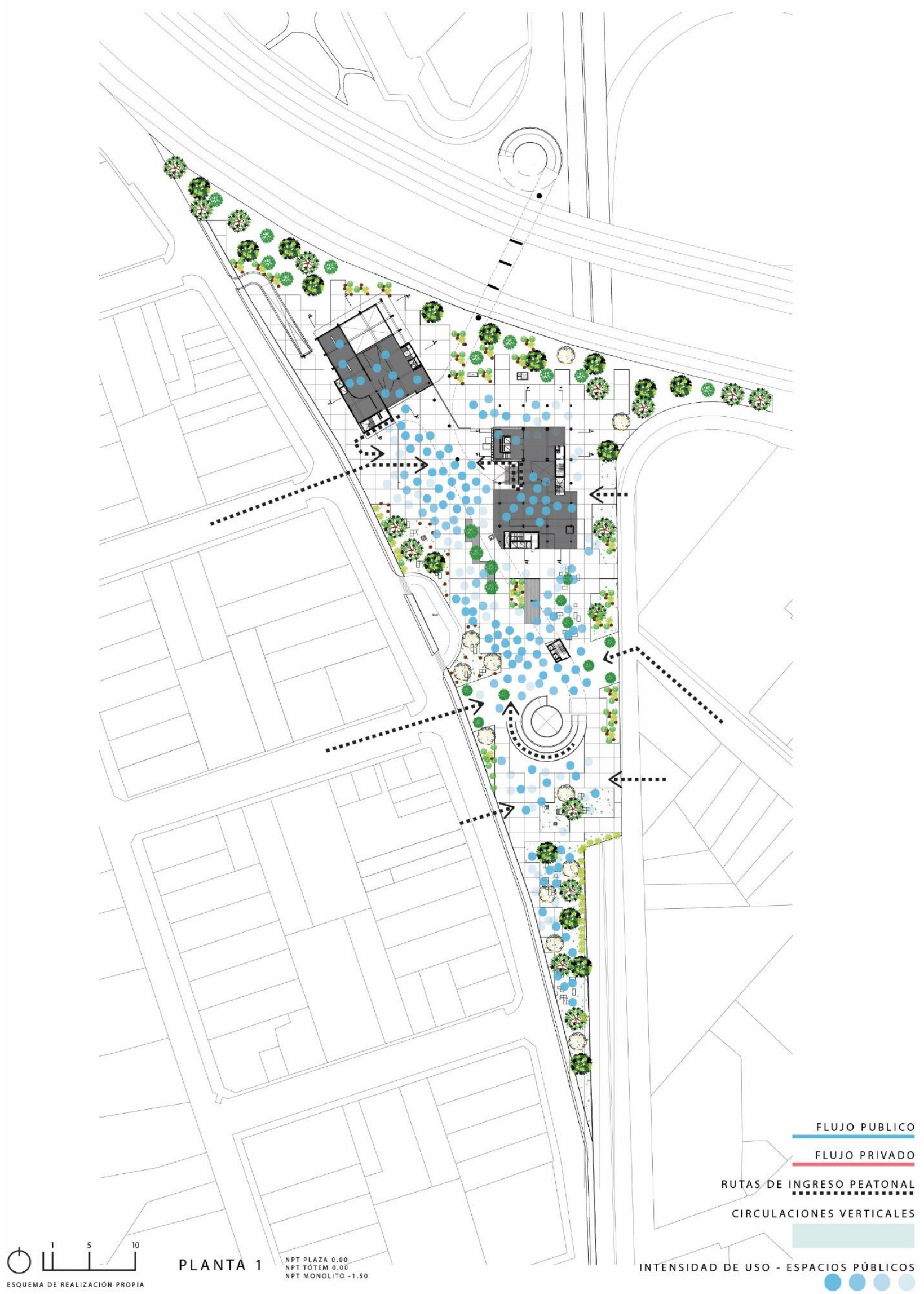


En el caso de la Plaza pública, los flujos son proyecciones de las vías del entorno y del cruce del puente desde Miraflores. Al llegar a la plaza, es importante que cada una de las vías encuentre un recibo, principalmente aquellas que desembocan cerca al edificio y a la bajada a la estación. No son solo espacios de tránsito, si no, el usuario debe tener la oportunidad de sentarse a descansar, observar y compartir.

En el estrato comercial del segundo nivel, se tiene en cuenta el flujo de usuarios que van directamente a consumir y aquellos usuarios de paso. Ambos confluyen al centro del puente y, por ello, debe funcionar también como un recibo amplio y con entradas claras hacia los espacios o a la bajada de la rampa.

El edificio Monolito mantiene sus espacios privados en bloque hacia uno o dos de sus bordes, y el espacio de flujo público se concentra en espacios limpios y enteros, donde el recorrido se limita a un solo sentido. Sin embargo, el Tótem tiene espacios privados repartidos en núcleos centrales dispersos. El usuario debe recorrer alrededor de ellos, y controla su recorrido.

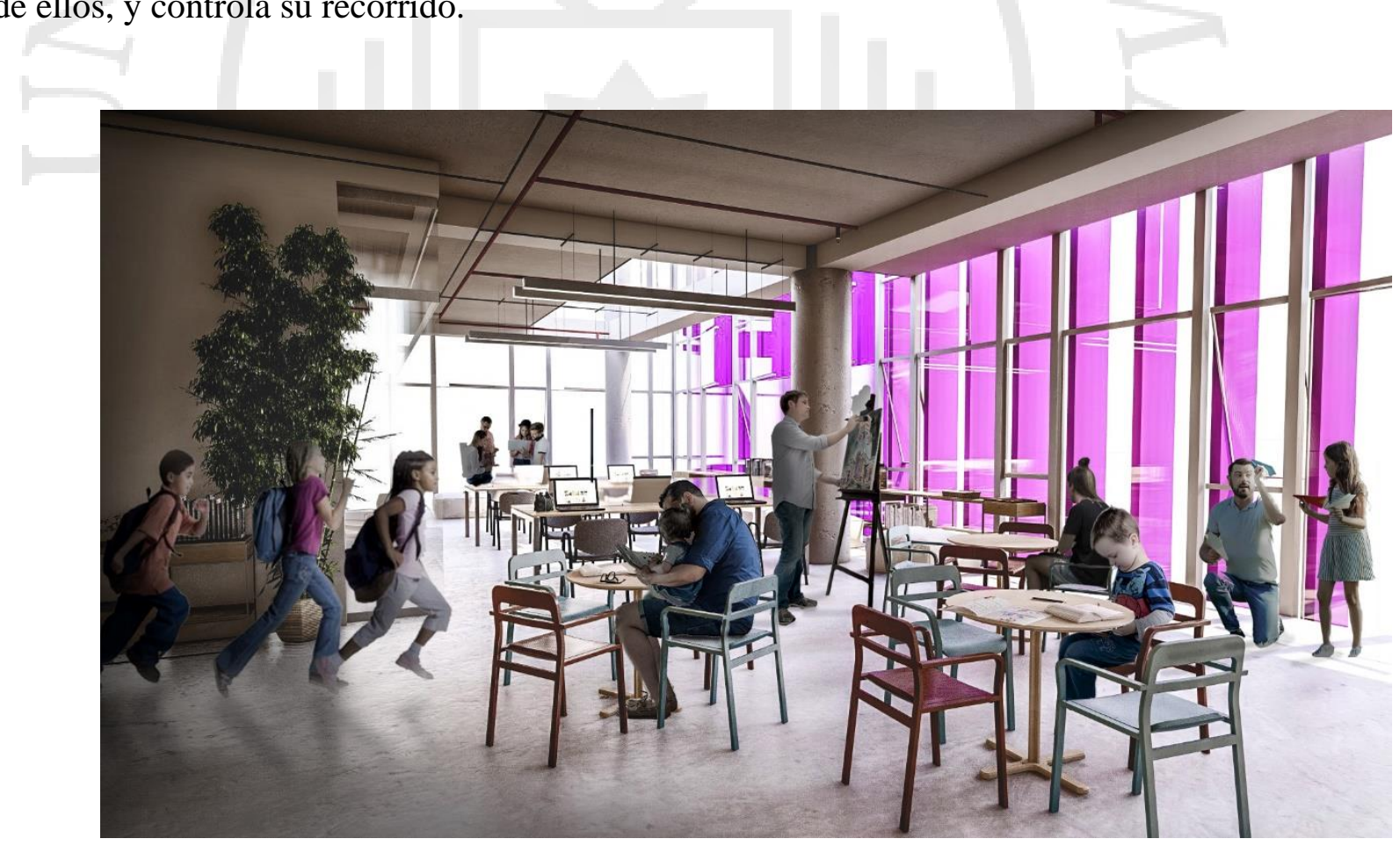

Imagen: Co-working, espacios abiertos y versátiles en el Tótem 


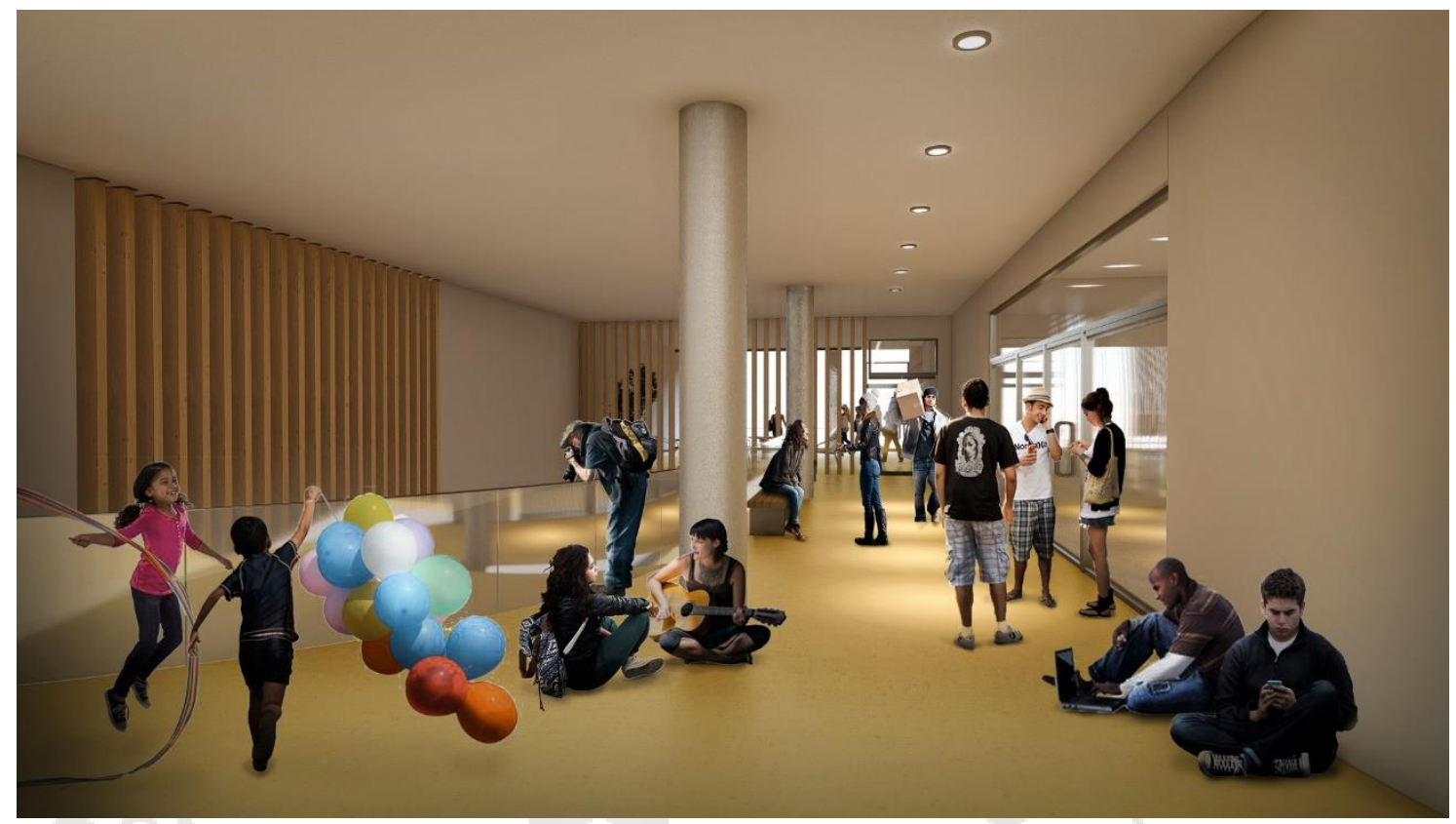

Imagen: Estrato Comercial, espacios controlados y direccionados en el

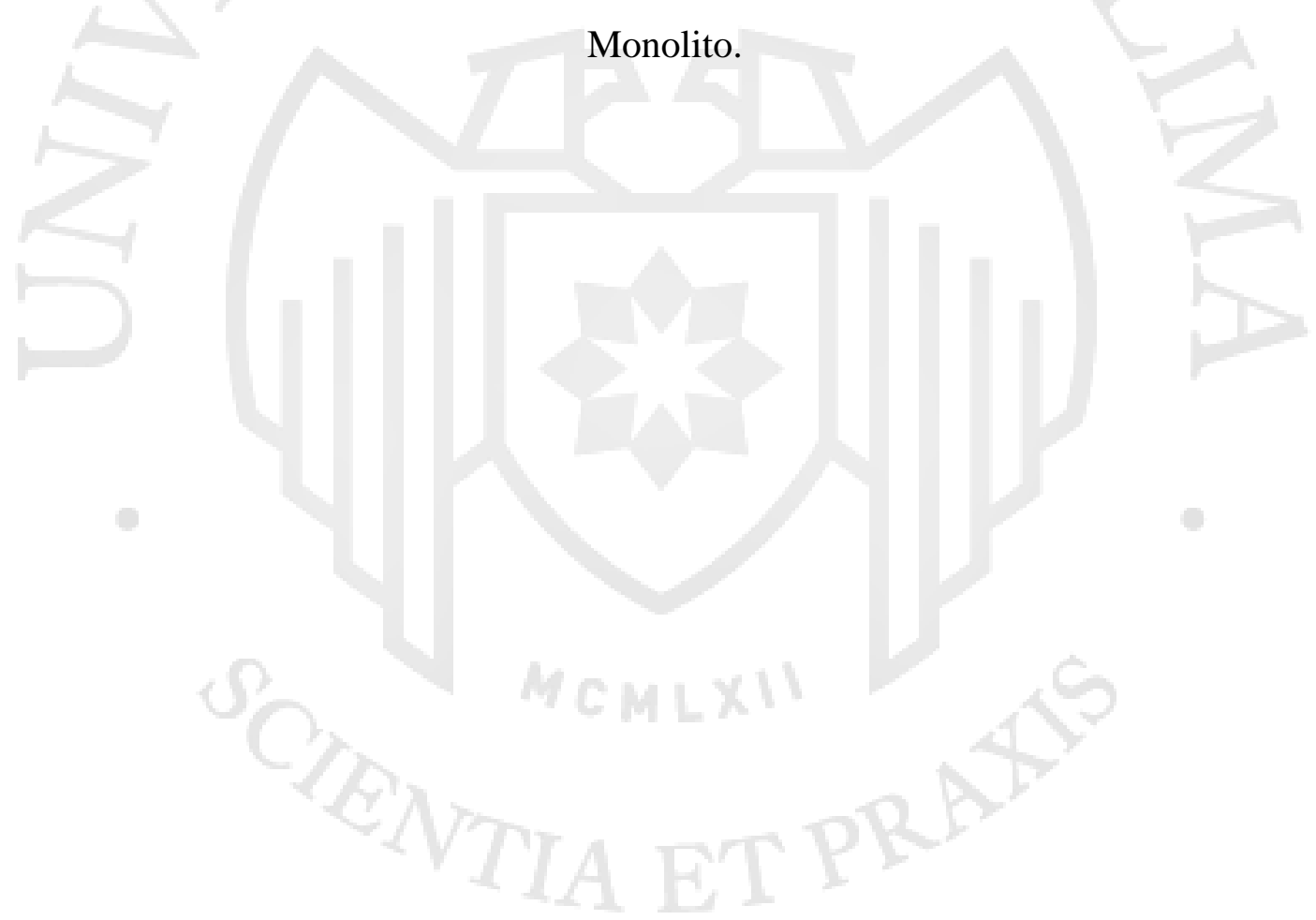




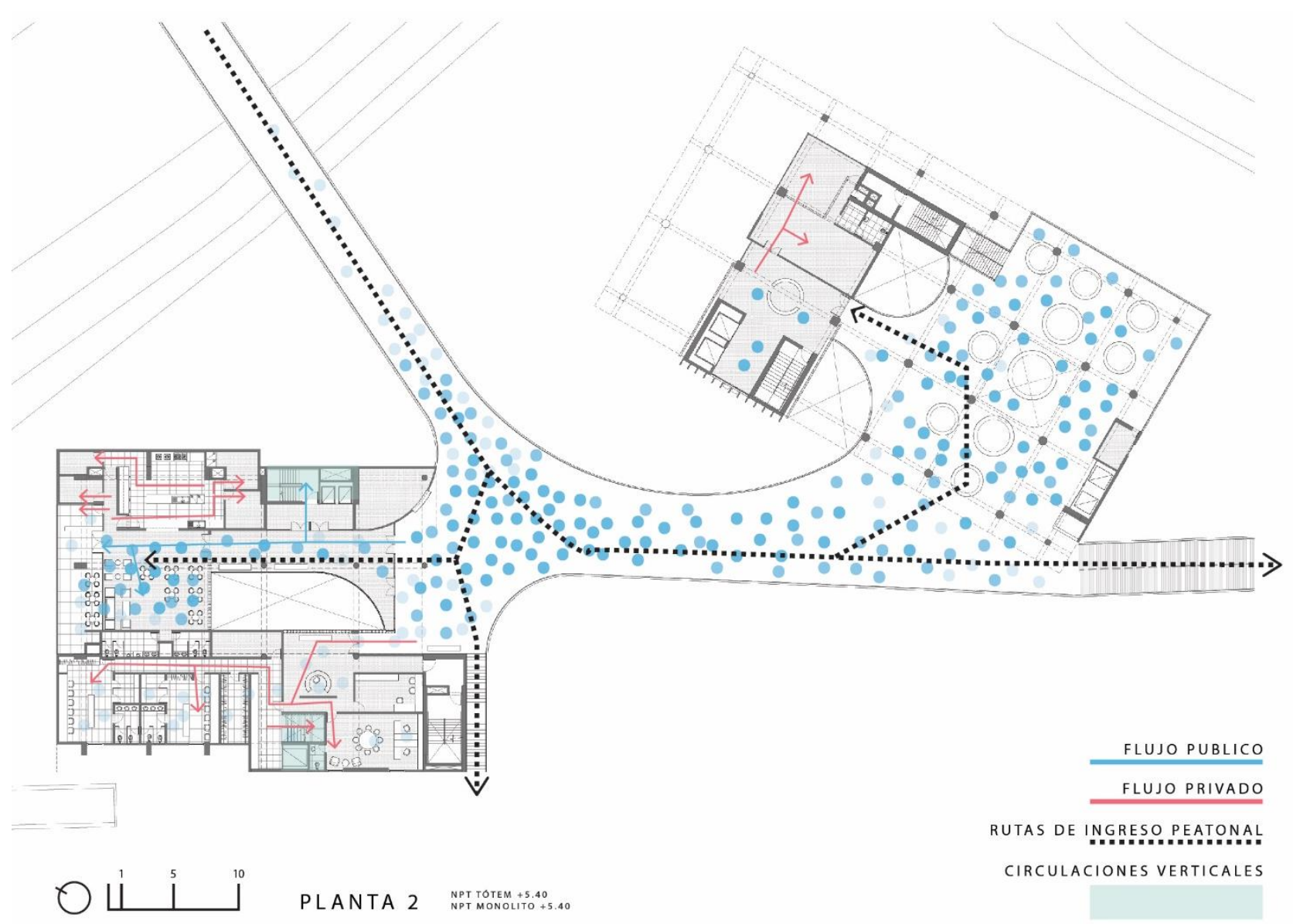

INTENSIDAD DE USO - ESPACIOS PÚBLICOS ESQUEMA DE REALIZACION PROPIA

(1)

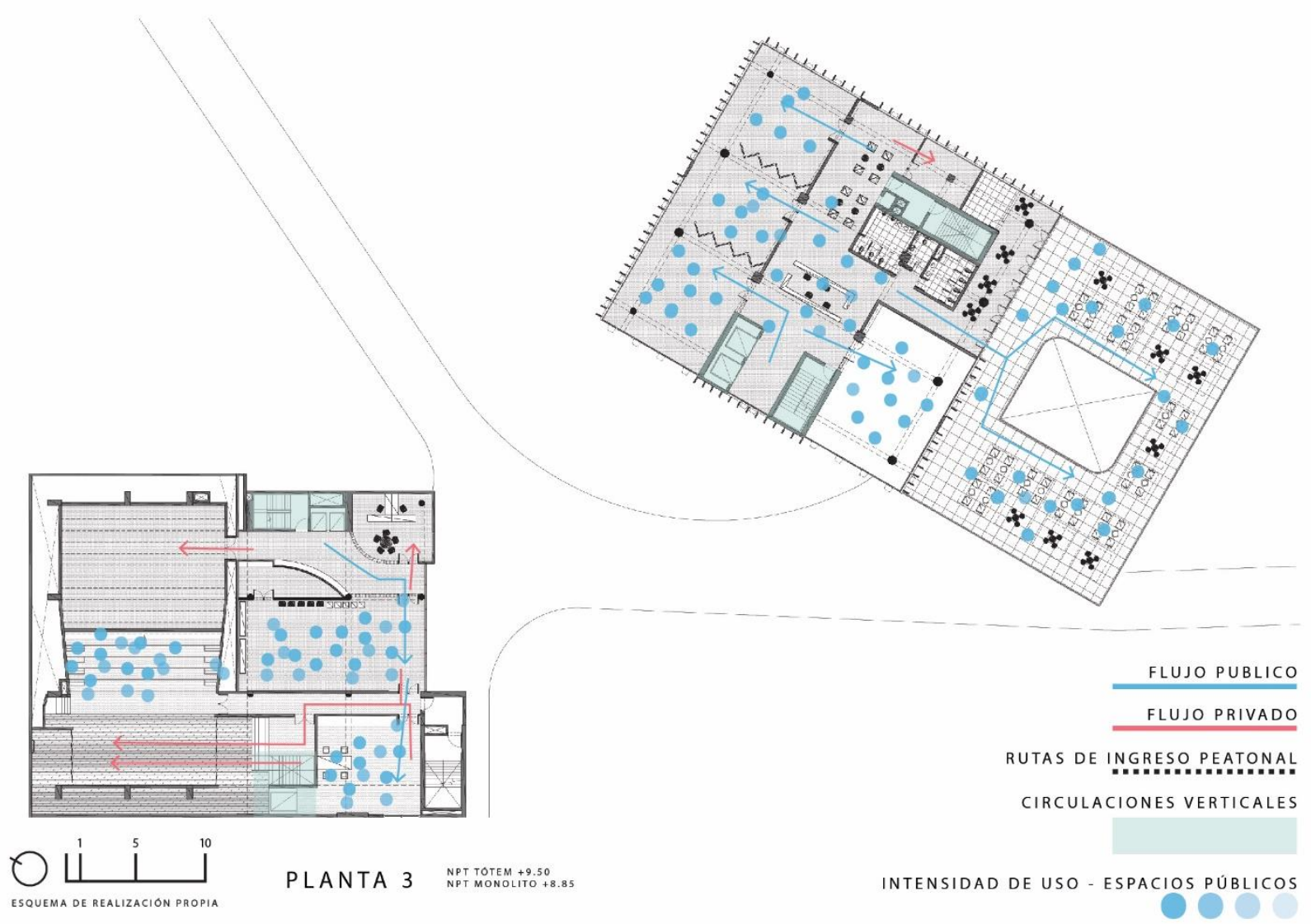




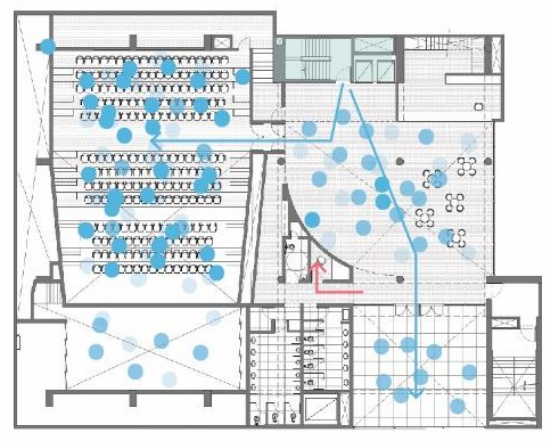

$\bigcirc \bigsqcup_{\text {ESQUEMA DE REALIZACION PROPIA }}^{5}$

PLANTA $4 \quad \begin{aligned} & \text { NPT TOTEM }+13.60 \\ & \text { NPT MONOLITO }+12.95\end{aligned}$
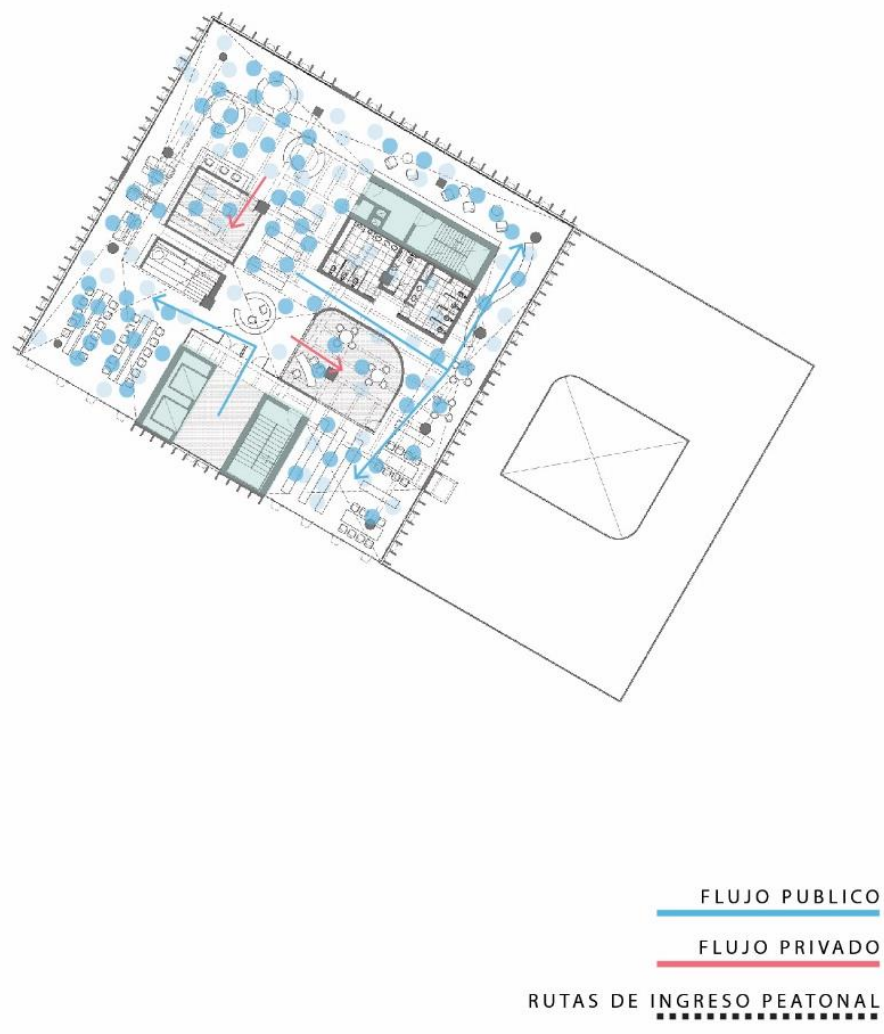

CIRCULACIONES VERTICALES

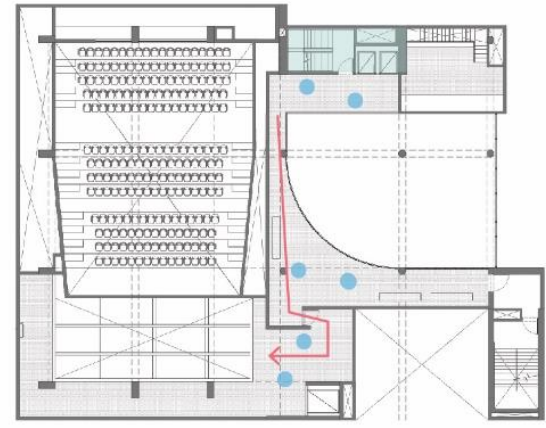

$\left.0 \bigsqcup^{1}\right|^{10}$

PLANTA $5 \quad \begin{gathered}\text { NPT TOTEM }+17.70 \\ \text { NPT MONOLITO }+16.95\end{gathered}$

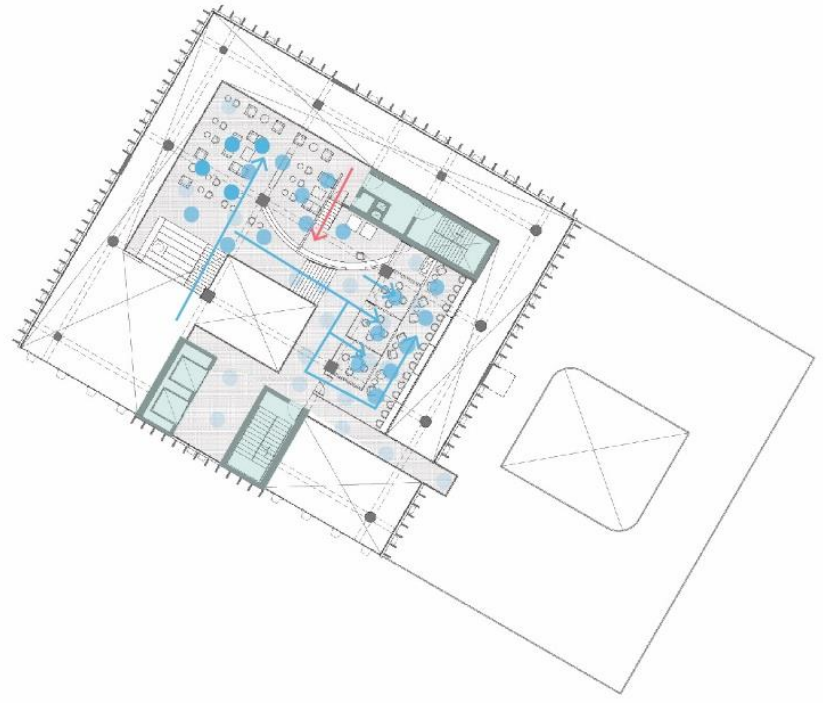

FLUJO PUBLICO

FLUJO PRIVADO

RUTAS DE INGRESO PEATONAL

CIRCULACIONES VERTICALES

INTENSIDAD DE USO - ESPACIOS PÚBLICOS 


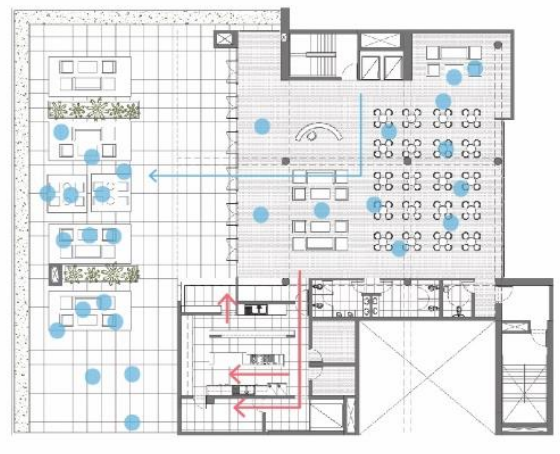

$\left.0 \amalg^{1}\right|^{10}$ ESQUema de REALIZACIÓN Propia

PLANTA $6 \quad \begin{gathered}\text { NPT TOTEM }+21.80 \\ \text { NPT MONOLITO }+20.75\end{gathered}$
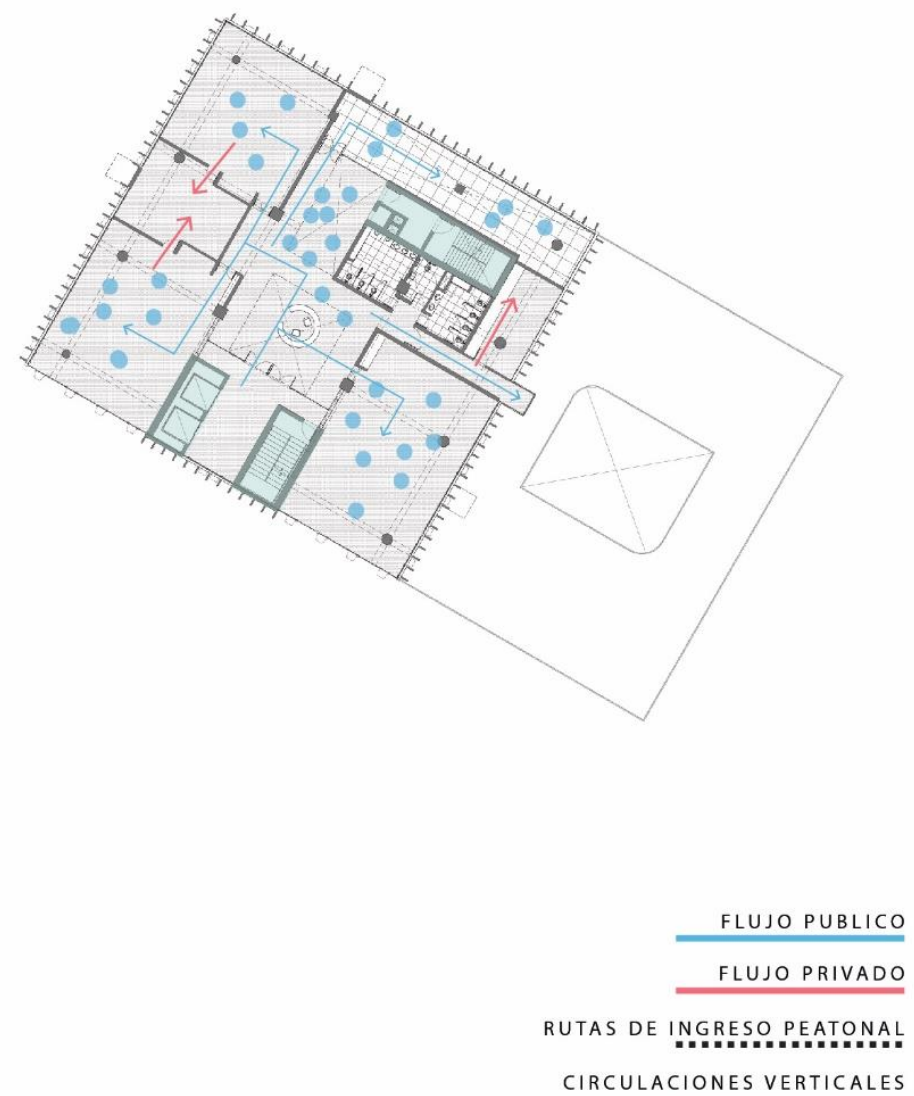

INTENSIDAD DE USO - ESPACIOS PÚBLICOS (1) 10

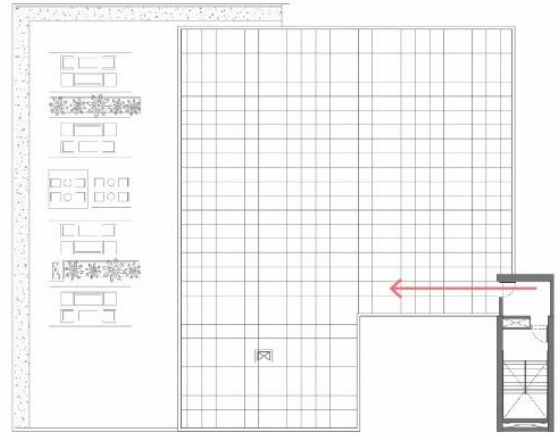

$\left.0 \amalg^{1}\right|^{10}$

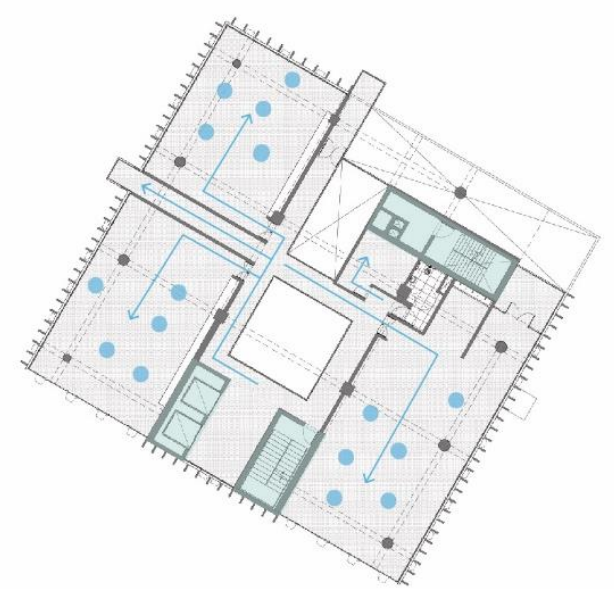

RUTAS DE INGRESO PEATONAL CIRCULACIONES VERTICALES 

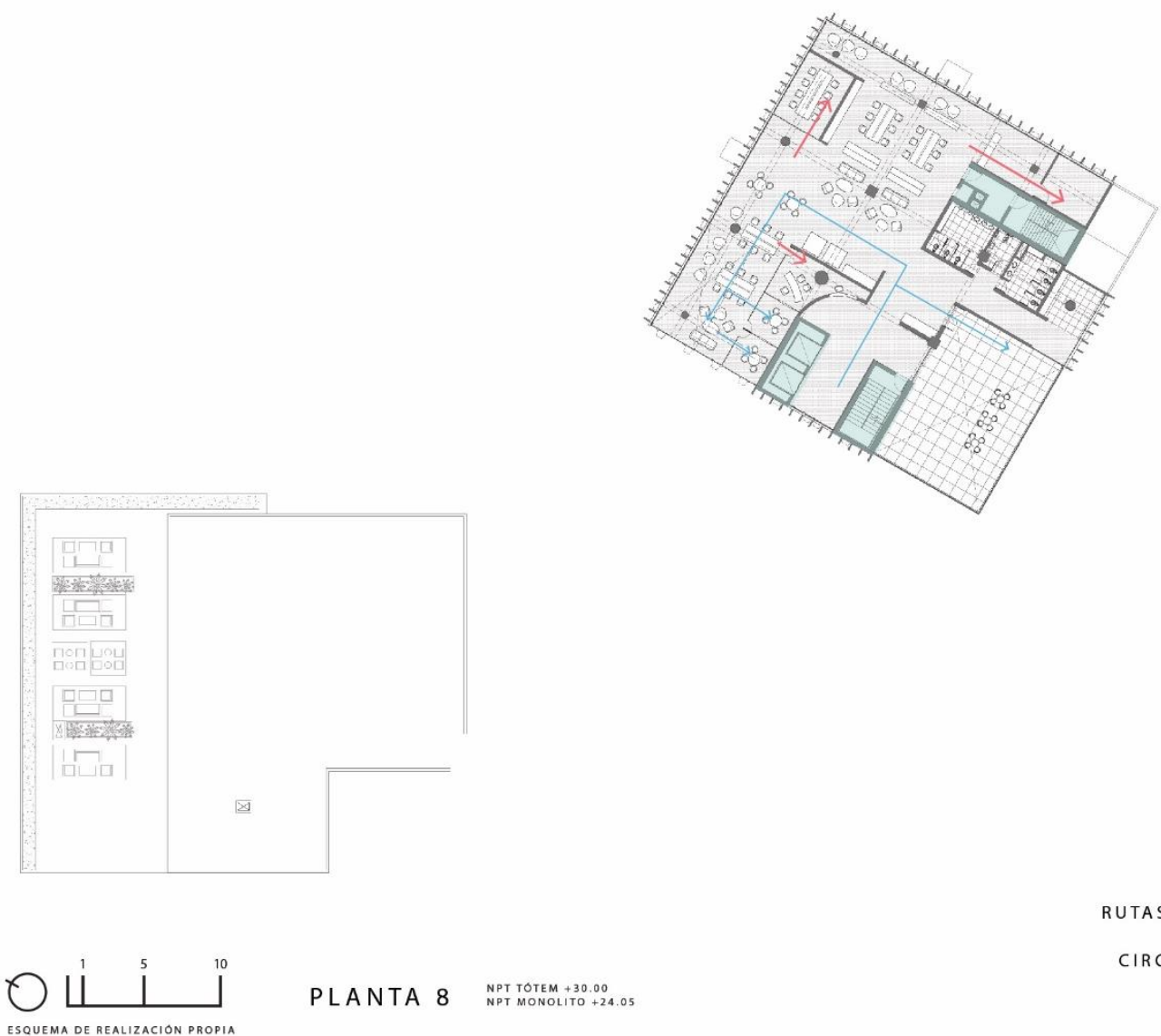

PLANTA $8 \quad \begin{gathered}\text { NPT TOTEM }+30.00 \\ \text { NPT MONOLITO }+24.05\end{gathered}$
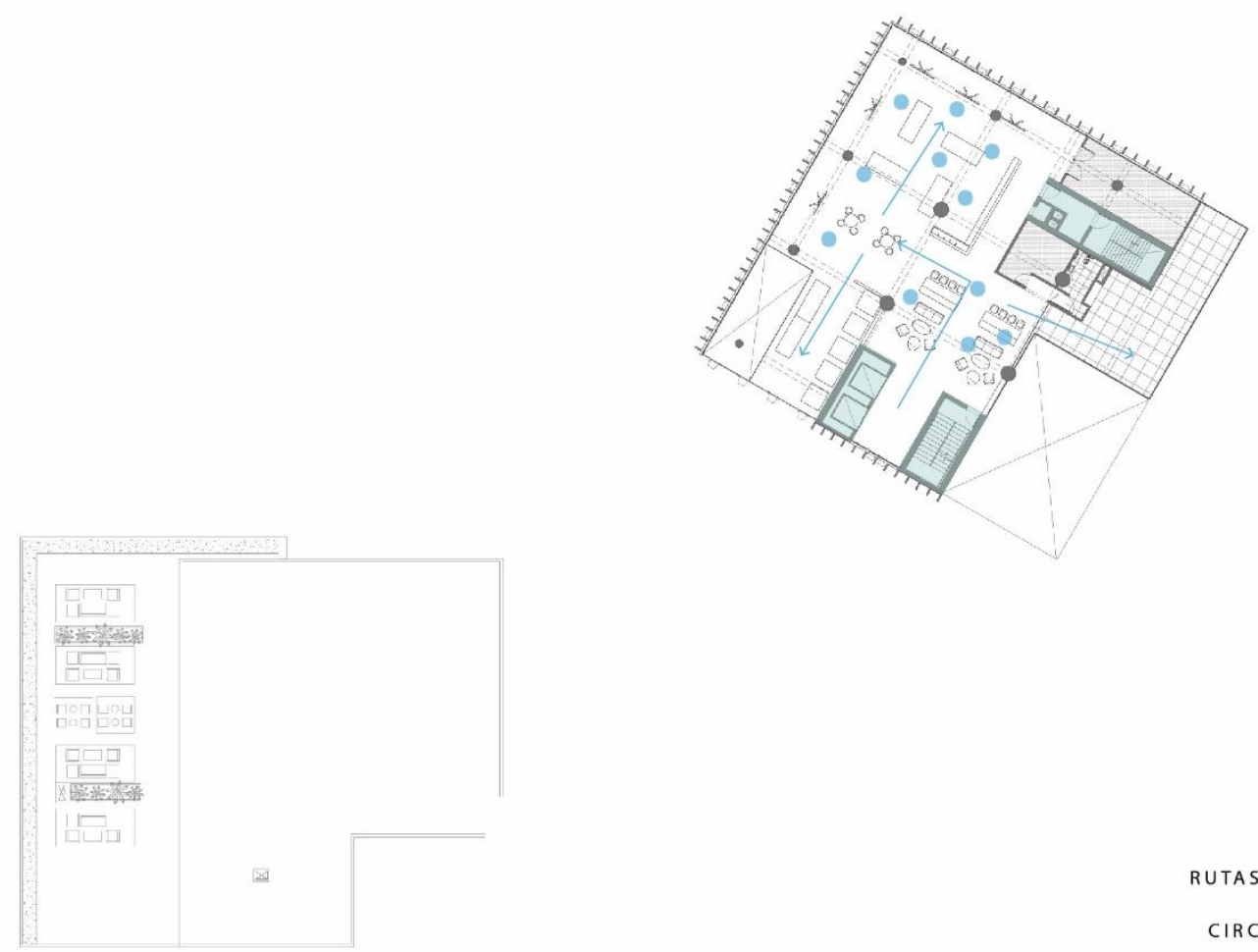

FLUJO PUBLICO FLUJO PRIVADO RUTAS DE INGRESO PEATONAL CIRCULACIONES VERTICALES

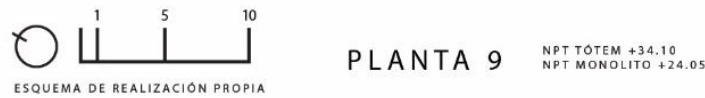




\subsubsection{Acabados y materialidad}

El Centro Cultural, tiene como una de sus premisas, ser un espacio flexible, cómodo, y que forme parte del imaginario colectivo. Para ello, el usuario debe identificar los edificios y espacios como propios.

A excepción de la fachada del Tótem, los acabados considerados son estándar. Los muros interiores serán entregados en concreto, tarrajeados y con pintura látex blanca.

Los pisos tienen 03 tipos de acabado: los pisos de salones, recibos, y espacios en general, se han propuesto en cemento pulido color Platinum; el estrato comercial y todo el puente, se consideró en cemento pulido pigmentado en color Topacio; y, los $\mathrm{SSHH}$, tienen porcelanato Gris oscuro, de formato $60 \times 60 \mathrm{~cm}$.

En general, el propósito de los acabados es ser intervenidos. El Centro Cultural, estará constantemente exponiendo obras de arte e ideas de sus artistas, no solo en los espacios destinados para ello. Los pasillos, aulas y fachadas del Monolito tendrán la oportunidad de cambiar según la temporada artística o coyuntural.

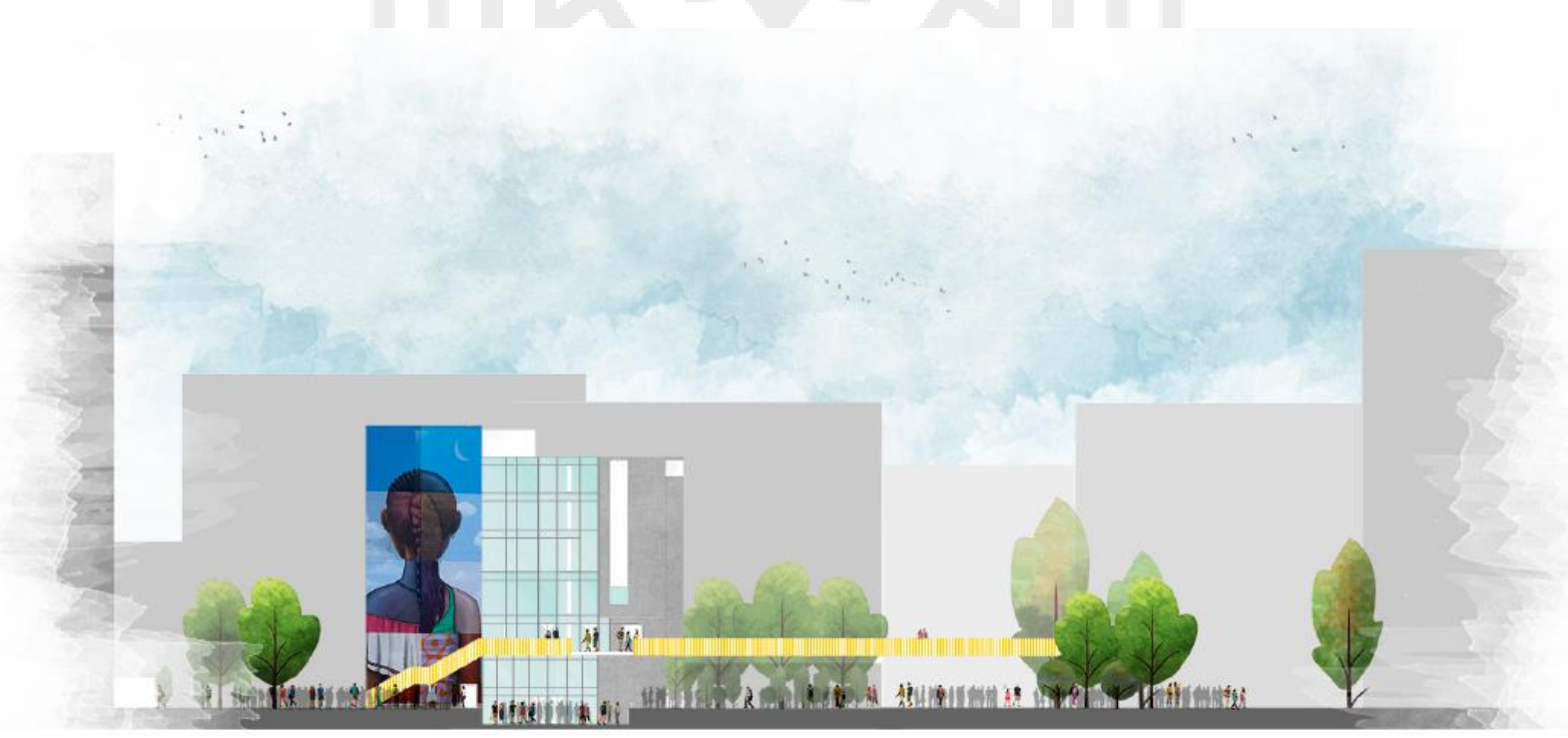

Elevación del Monolito, con una de las fachadas intervenidas 
Con esta propuesta, el usuario impone algunas de sus ideas y visiones sobre el edificio. Proponer espacios internos con colores, materiales o formas, implica que el usuario se acomode a un espacio previamente definido.

La fachada del Tótem es vidriada por los espacios de estudio y aprendizaje que contiene. Sin embargo, para limitar el paso de la luz solar directa, se propusieron lamas verticales. Estas permiten un mayor porcentaje de iluminación a lo largo del día que las horizontales, y una apropiada modulación de ventanas para la ventilación cruzada.

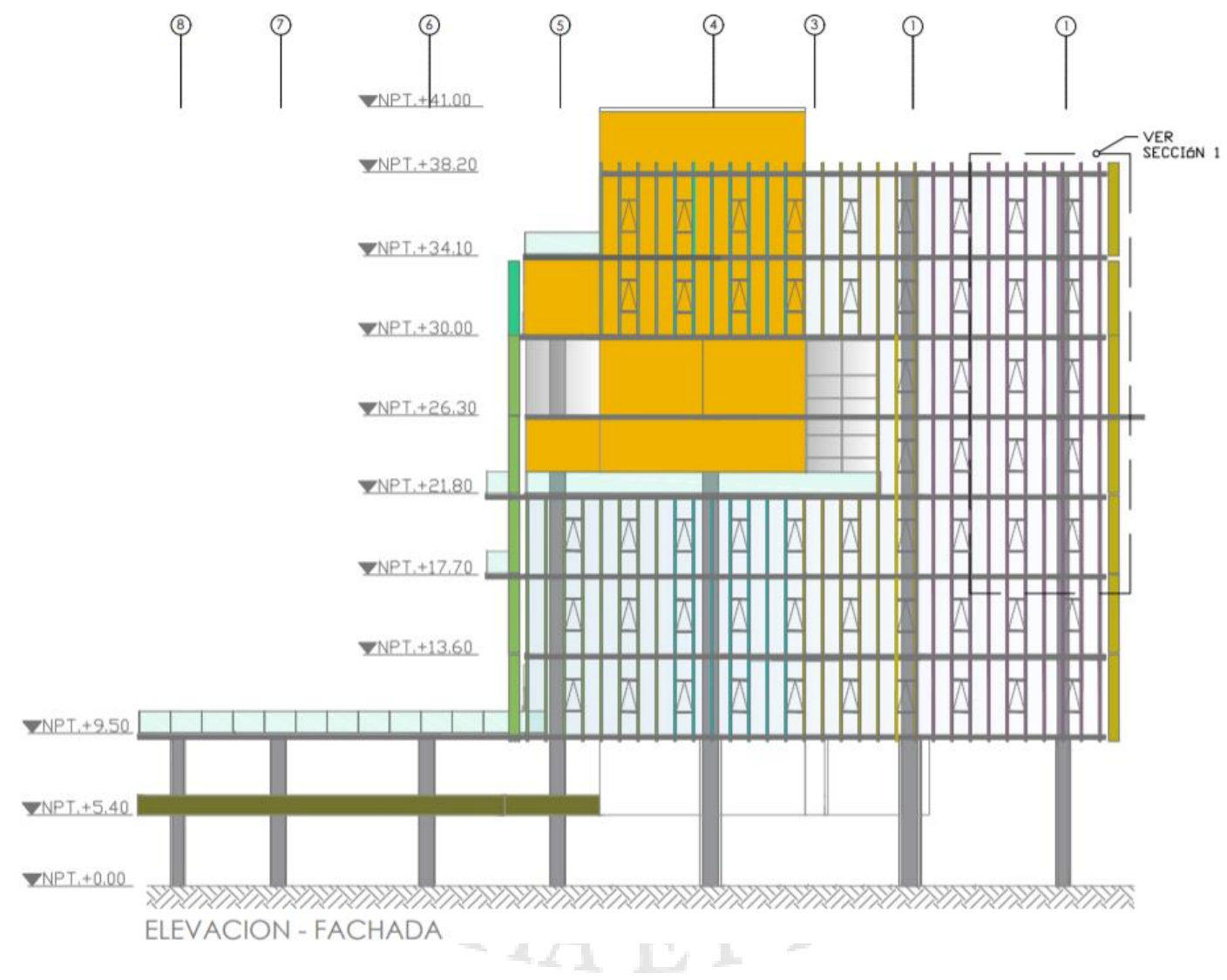




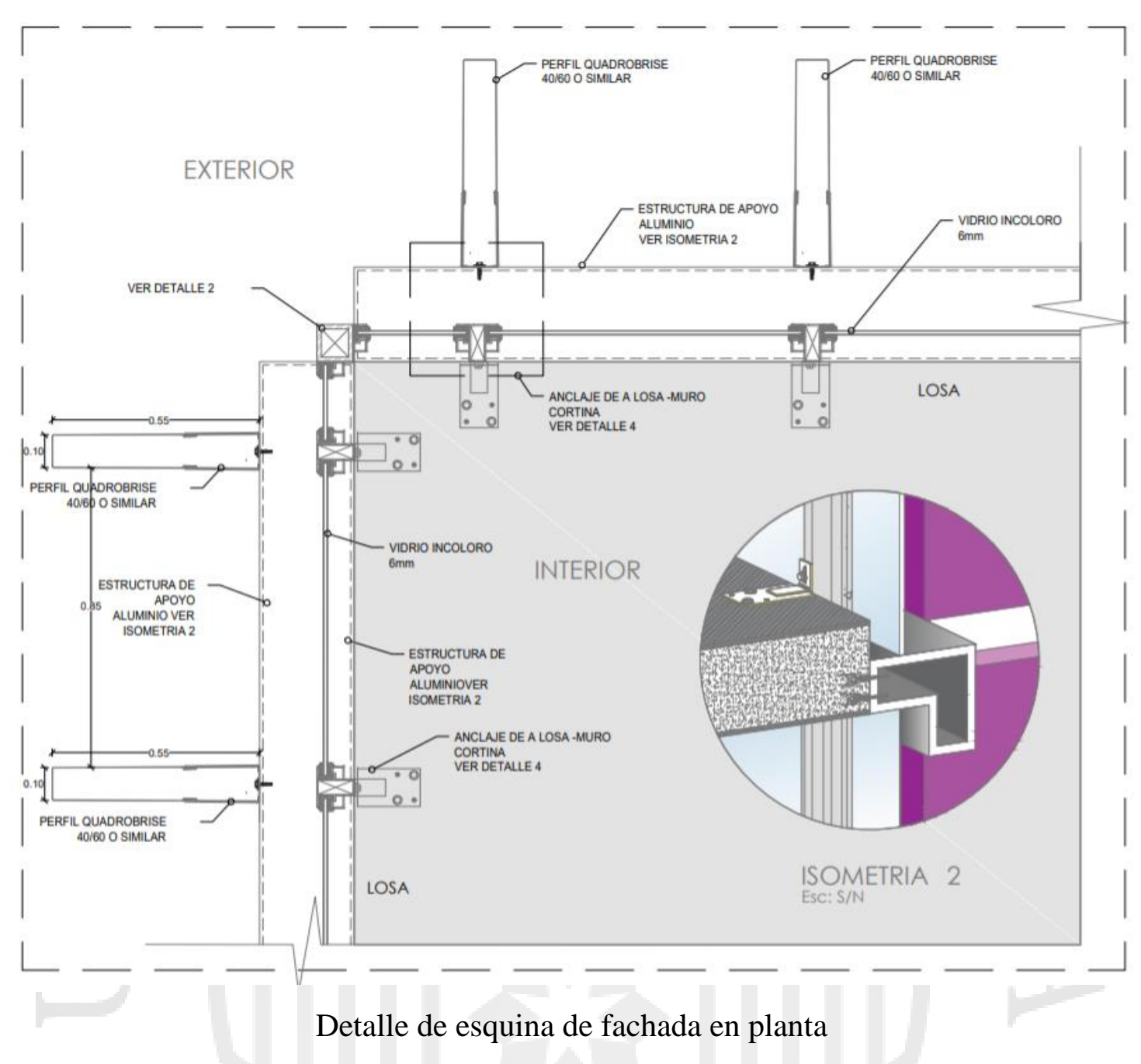

El color de las lamas estuvo inspirado en las fachadas coloridas del Barranco antiguo, aun presente en la Zona 3 y parte de la Zona 2 del distrito. Se eligieron los tonos fríos, para contrastar con el puente amarillo.

El puente, finalmente, tiene varias razones de ser amarillo. La primera es que, al intervenir en una vía rápida metropolitana, debe ser visible bajo cualquier condición. Y, la segunda razón es que, los colores oficiales de Lima Metropolitana son el Amarillo Oro y el Azul Oscuro para infraestructura pública. 


\subsubsection{Paisaje}

El paisaje planteado, utiliza especies que requieren poca agua (no necesariamente endémicas) pero son aquellas que nos rodean desde la colonia y hasta ahora se conservan mejor en Lima (ver lámina 05 y plot plan). Son los árboles más antiguos de la ciudad y no es gratuito. Se debe tomar en cuenta siempre al entorno en el que nos emplazamos, y Lima está clasificada como desierto por su poca precipitación anual y ausencia de aguas dulces fluyentes además de algunas acequias incaicas.

En arbustos y herbáceas se aplica el mismo concepto, con especies que no requieren más que de la humedad limeña y de un mantenimiento mínimo, que consiste en podar aquellas que perjudiquen el libre tránsito peatonal. Se les acomoda en espacios cerrados y a manera de islas y macizos, para que tengan un libre desarrollo, crecimiento y reproducción.

Este concepto, además, busca educar en este espacio, sobre el paisajismo ideal en Lima. Es importante derribar ideas preconcebidas de estética, donde se introducen especies que requieren constante riego y mantenimiento en áreas públicas. Existen espacios de césped paspalum (de los que menos consume agua) para los espacios de esparcimiento y que vayan a ser transitados. No se trata de negar el uso de las especies que requieren agua, si no, de ubicarlas apropiadamente. Todas las demás áreas, que no serán utilizadas por el peatón, tendrán cubre suelos (como la aptemia) o gravilla y cáscara de pino para proteger el suelo de la erosión y evitar que la tierra se convierta en charcos de barro.

Se intenta que el usuario reconozca las especies como las adecuadas para la ciudad, y sobre todo para el espacio público, rompiendo ideas preconcebidas. Se debe reconocer al paisaje como lo propio, lo limeño, de la comunidad y lo que más le beneficie con espacios funcionales, propios de Lima, verdes y de bajo mantenimiento.

El mobiliario urbano comprende bancas de usos diferentes (ver plano DE-04). Una, es la banca permanente, que se ubica estratégicamente bajo Meijos alrededor de la plaza. Su superficie amplia permite que el usuario pueda sentarse o echarse. La banca móvil, es la que lleva el color del espacio público del edificio al paisaje. Con el mismo 
amarillo del estrato comercial, las bancas resaltan entre las gramíneas. La intención de que sea móvil, es poder acomodar espacios según el requerimiento de cada usuario.

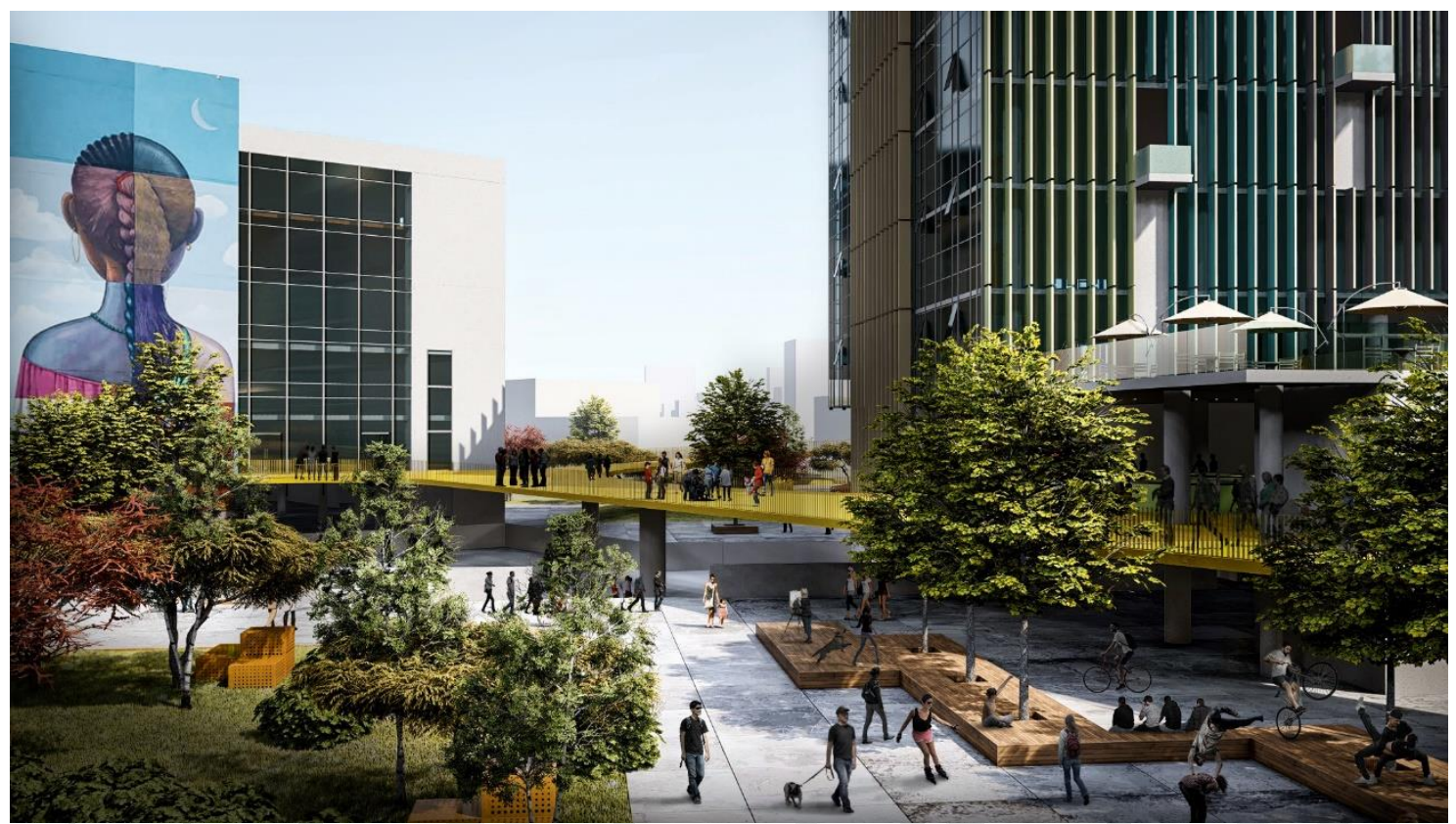

Imagen: Vista de la plaza a nivel de la rampa.

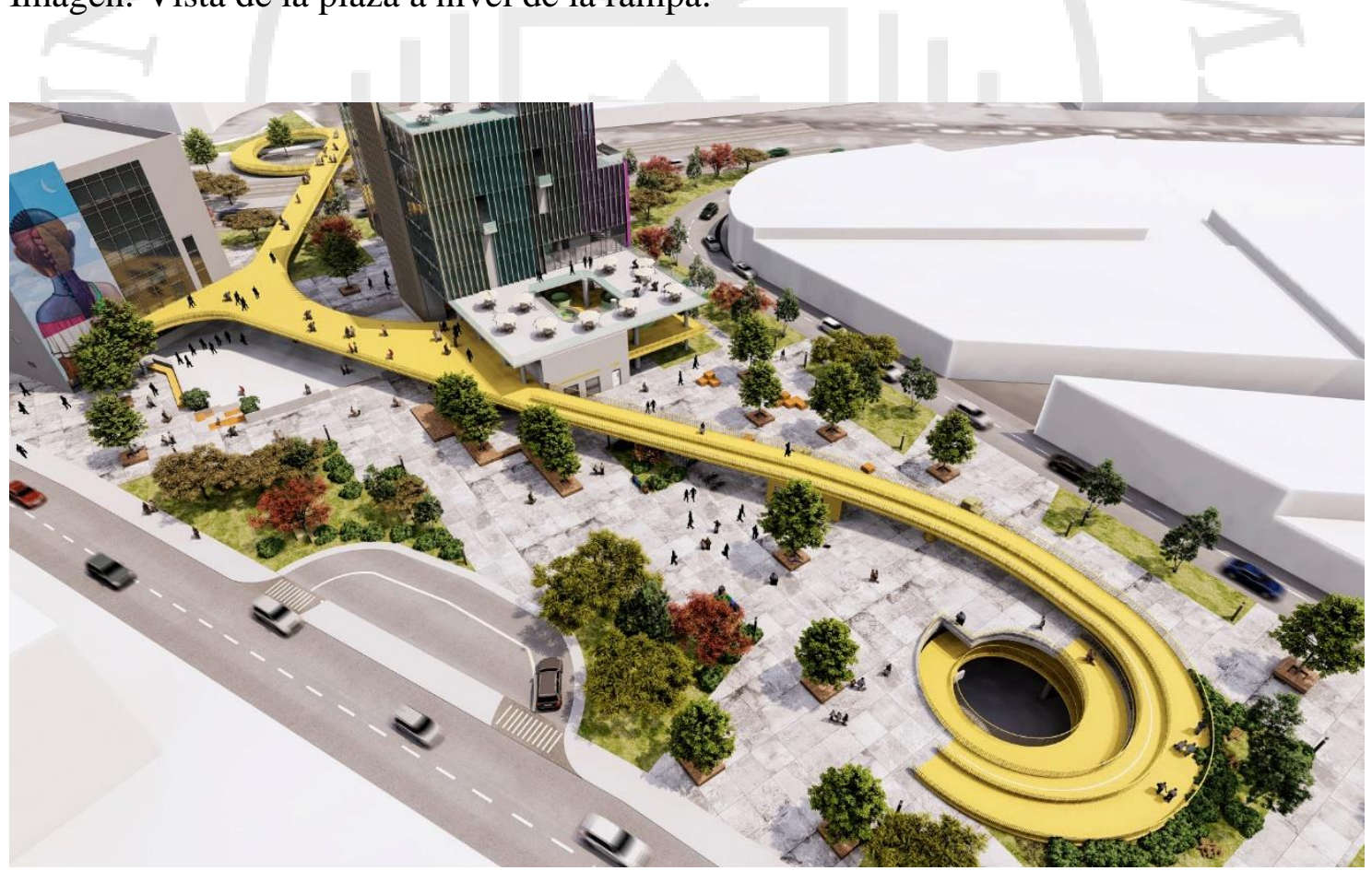

Imagen: Vista aérea de la plaza y rampa. 


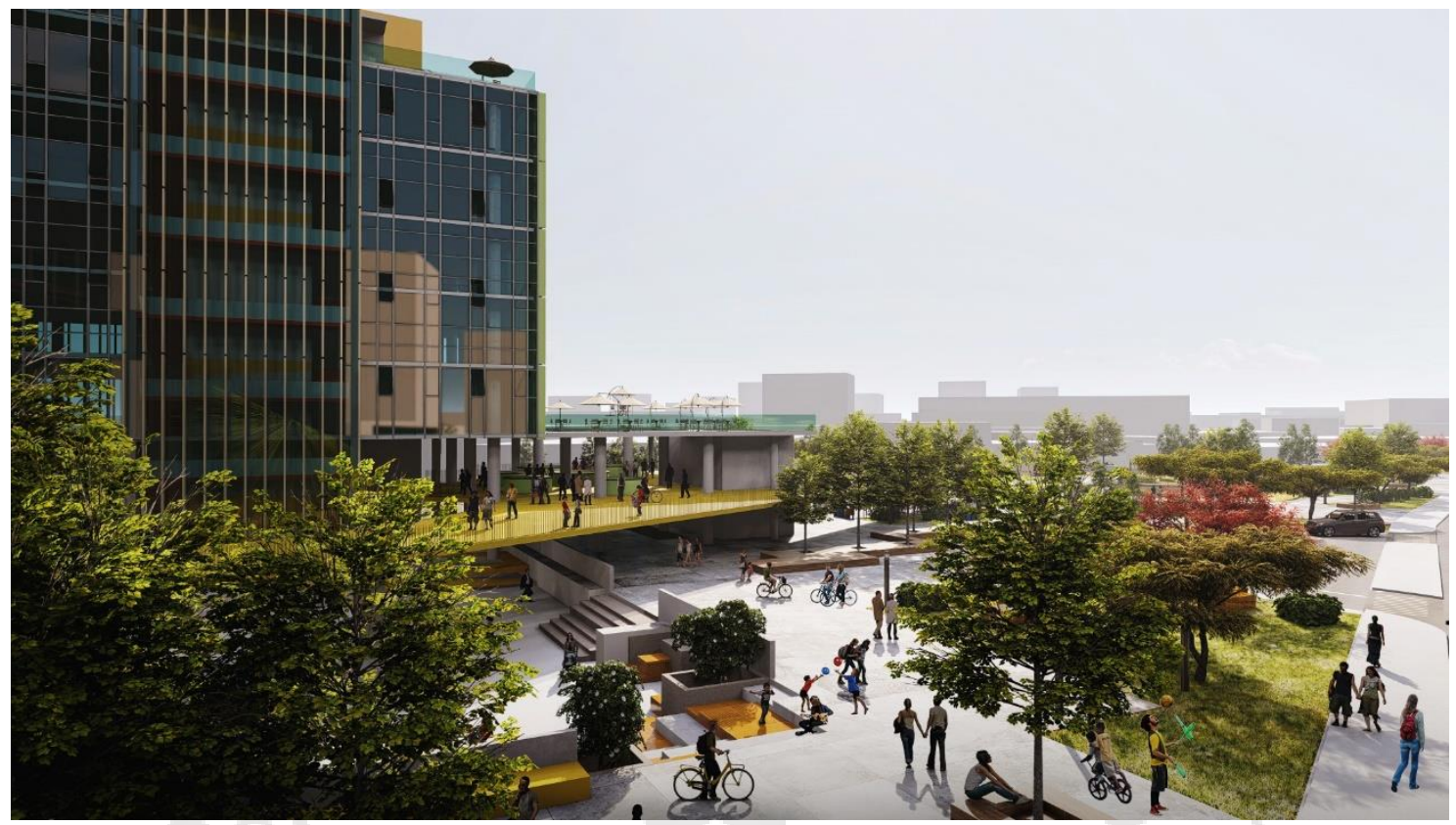

Imagen: vista de la plaza desde el Hall del auditorio.

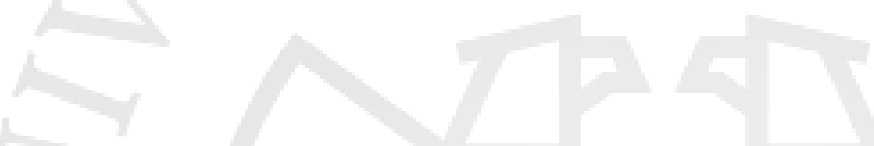

\subsubsection{Centro Cultural como animador urbano}

Como se ha mencionado previamente, un animador:

Puede definirse como un estímulo mental, físico y emotivo, que, en un sector determinado, incita a la gente a iniciar una gama de experiencias que los permita expandirse y expresar su personalidad y desarrollar en ellas el sentimiento de pertenecer a una comunidad sobre la cual pueden ejercer cierta influencia. (Chacón Blanco, 2010)

El concepto de animador urbano ha sido adoptado para el proyecto, para nombrar el impacto que el CCB tendrá sobre los usuarios y la ciudad. No se puede diferenciar lo social de físico, porque ambos conceptos deben ir de la mano al plantear espacios y programas públicos de calidad. Es por ello, que ambos se unen en el concepto "urbano", palabra que se refiere y resume a la ciudad.

El CCB busca, precisamente, proveer las herramientas necesarias al entorno para desarrollarse social y físicamente. 
A nivel físico, el CCB cohesiona físicamente tres distritos divididos por vías rápidas, ahora contemplando la escala humana de los usuarios. Provee de espacios versátiles, con y sin sombra; espacios de paso y espacios de descanso; espacios saludables y protegidos del entorno vial. Los edificios, por su lado, tienen espacios amplios, ventilados, iluminados y limpios donde se desarrollan actividades físicas y académicas.

La disposición física del proyecto, trae consigo influencias positivas en el imaginario colectivo y la forma de usar los espacios abiertos y cerrados. Los espacios versátiles, el programa y la actividad cultural educativa del CCB, pretende que el vacío urbano actual se convierta en un punto de encuentro para los limeños y la comunidad del entorno inmediato, que actualmente se encuentra desconectada aunque pertenezca a un mismo distrito.

Formar parte de un espacio público saludable, y de programas-sociales en comunidad, fomentan el desarrollo del imaginario colectivo, quien toma conciencia de que la ciudad le pertenece.

La plaza es un espacio que anima, principalmente, los espacios físicos. Es la costura física entre los barrios autónomos y prioriza el paso y recibo de peatones. Los edificios serán los animadores sociales, albergando al amplio programa que promueve la identidad artística y cultural del proyecto. Ambos, cumplen funciones compartidas a nivel urbano. Es importante que se le considere al proyecto integral como una intención de hacer arquitectura con un radio de influencia mayor a su terreno.

Finalmente, el proyecto elevará el costo del suelo de su entorno porque, a partir de la modernidad, es raro encontrar un espacio vacío en el área urbana de Lima Metropolitana. Y, más aún, en un entorno céntrico y con tantas oportunidades de impulsar un desarrollo positivo. El terreno de estudio, contará con accesos para automóviles, proximidad a una estación de transporte público y ciclovías. Pero principalmente, accesos, cruces y recibos peatonales que brinden confort al ciudadano de a pie.

Se ha comprobado mediante algunos casos de ejemplo, que es posible desarrollar comunidades gracias al arte y la cultura. Además, dicho desarrollo vendrá acompañado de una activa vida urbana diurna y nocturna que aporta a la seguridad y comodidad del entorno. 
El edificio del CCB y la plaza pública serán animadores urbanos para alcanzar la óptima convivencia vecinal, proveer espacios y programas educativo-culturales y promover la vida saludable en sociedad. Al ser un espacio de educación, recreación y punto de encuentro con identidad, el proyecto influencia más allá de sus límites físicos, a manera de acupuntura urbana. Habrá un mayor grado de interacción social y estimulará una serie de eventos positivos en la comunidad, pero también en la ciudad.

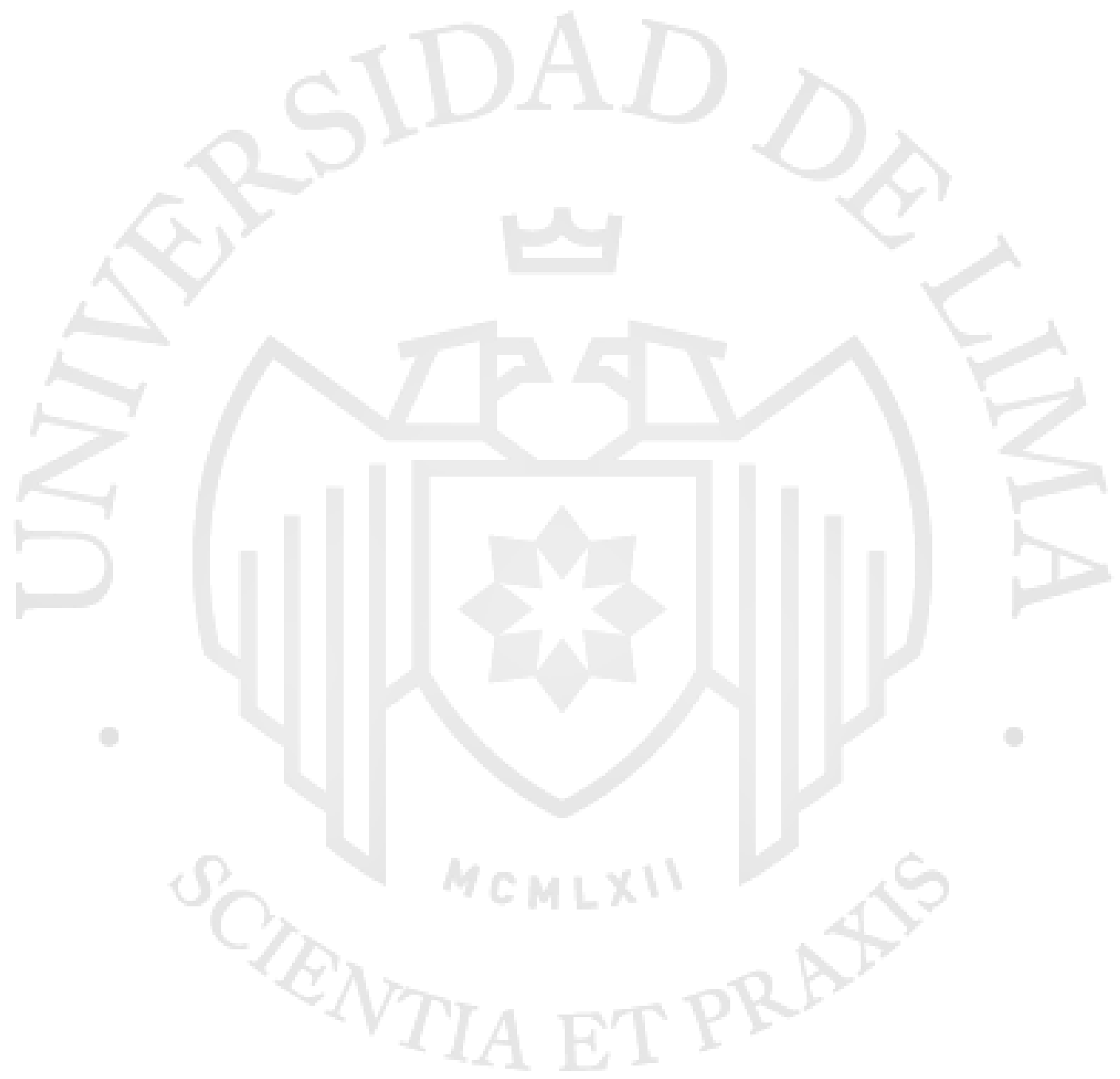




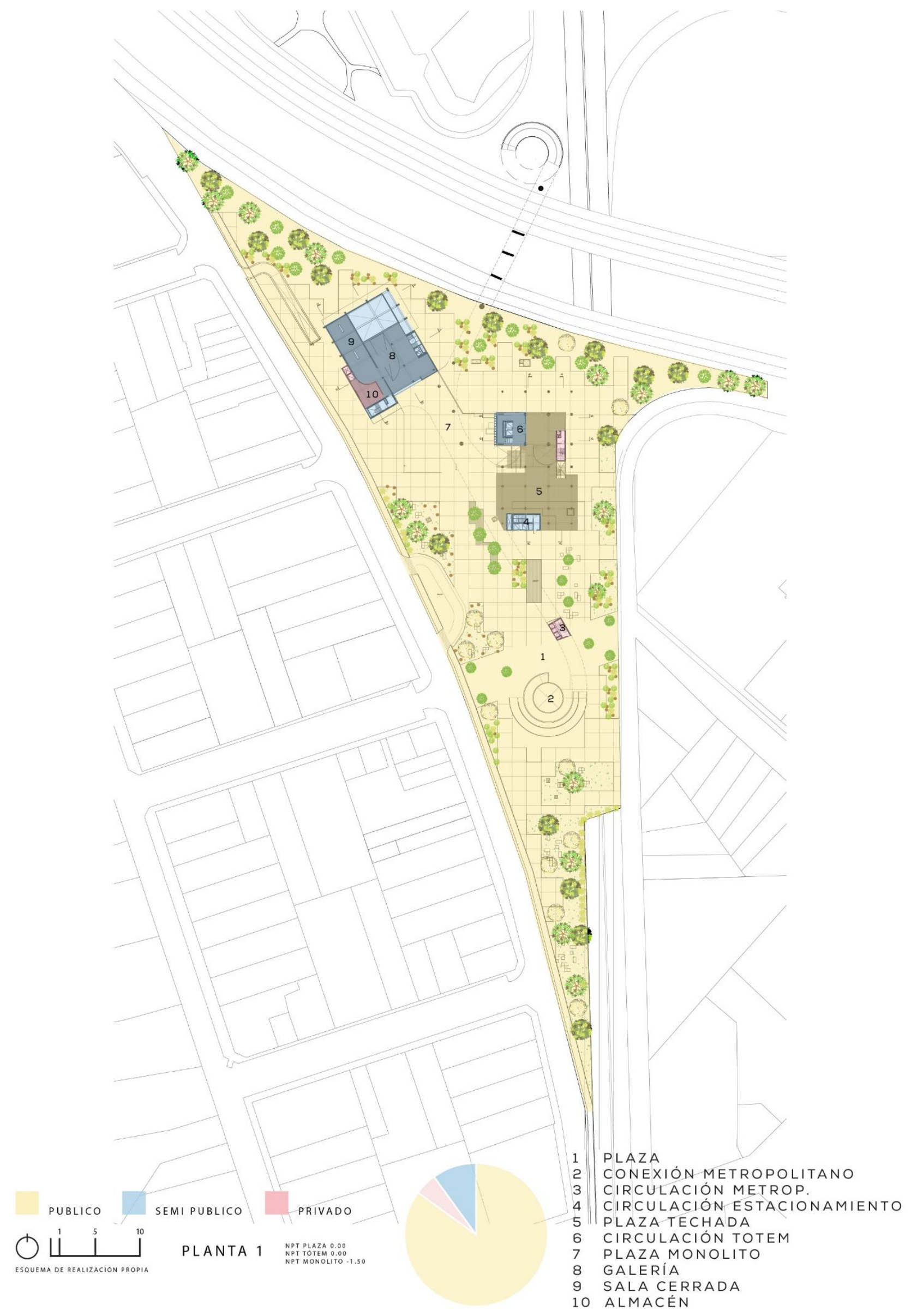




\subsection{Memoria descriptiva de arquitectura}

\subsubsection{Antecedentes}

La presente memoria descriptiva corresponde a la solución arquitectónica frente al problema de fragmentación urbana dado por: los límites físicos, como la vía de Metropolitano; Los límites virtuales como la vía expresa Paseo de la República, la av. República de panamá, av. Catalino Miranda, etc. Los limites distritales, los vacíos urbanos y las barreras visuales. Las cuales se forman cuando las vías principales o calles secundarias encuentran al final de su recorrido una "barrera" arquitectónicas de gran escala o un límite mencionado.

El terreno se eligió porque tiene las siguientes potencialidades: Está conectado al principal sistema de transporte de lima, el Metropolitano, se encuentra en un distrito de tradición cultural, está ubicado entre el límite de 3 distritos; es visible desde una vía metropolitana y tiene un micro clima templado lo largo del año.

Se ha propuesto el proyecto de inversión pública y privada del "CENTRO CULTURAL EN LA ESTACIÓN PLAZA LAS FLORES DE BARRANCO” el cual está resolviendo las problemáticas dichas y urbanísticas, proyectado como un hito de conexión urbana y animador urbano, otorgando a la cuidad un espacio público, peatonal, educativo y cultural que necesita la cuidad.

El proyecto se presenta con un alto Nivel de permeabilidad y considera al peatón en cada momento, convirtiendo el límite del vacío urbano y vías en un espacio compartido.

La Plaza es un espacio público físico intermedio que cohesiona físicamente los 4 espacios autónomos: las zonas 2 y 3 de Barranco, y Miraflores y Surco. Con claros pasos peatonales a Nivel de la vereda y recibos peatonales, el trazado respeta las vías existentes y las reúne al centro del proyecto, para que el peatón pueda continuar su camino sin ser interrumpido por límites físicos. 


\subsubsection{Descripción del terreno.}

El terreno elegido para el “CENTRO CULTURAL EN LA ESTACIÓN PLAZA LAS FLORES DE BARRANCO” se encuentra en la intercepción de la Vía expresa Paseo de la República con la av. República de Panamá y la av. Catalino Miranda.

Está en límite de los distritos de Miraflores, Barranco y Surco.

El terreno forma es de forma triangular y esta al borde a la Vía expresa Paseo de la República.

De acuerdo al plano topográfico, el terreno cuenta con los siguientes linderos y medidas perimétricas:

- Av. Paseo de la Republica $229.68 \mathrm{mts}$.

- Av. Rosendo Vidaurre $378.72 \mathrm{mts}$.

- Av. República de Panamá 331.91 mts.

El área total del terreno es de $17171.15 \mathrm{~m} 2$.

Es un terreno plano, con una pendiente trasversal de $1 \%$. Por ubicación tiene una zonificación urbana OU (otros usos). Y dentro de los planos de zonificación urbana, cuenta como Berma Central.

La zona en donde se desarrollará el proyecto está ubicada a una altitud de 96 msnm. 

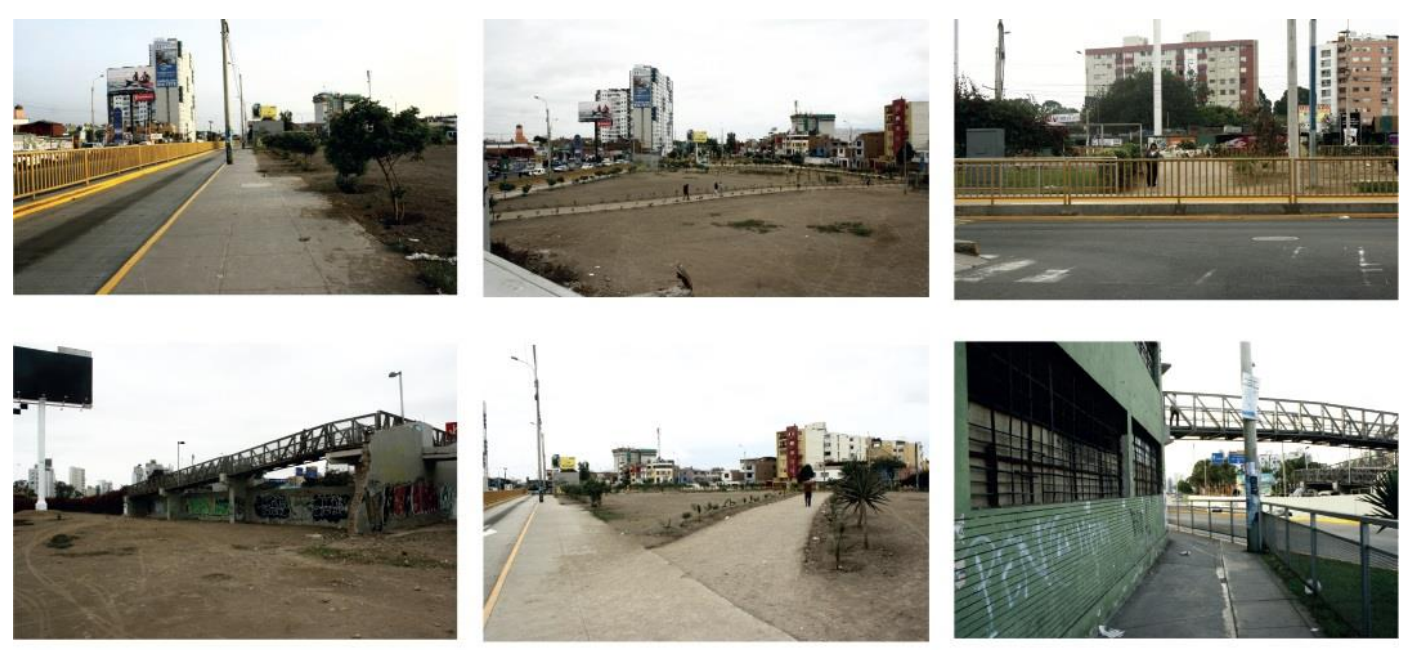

INTERIOR DEL TERRENO

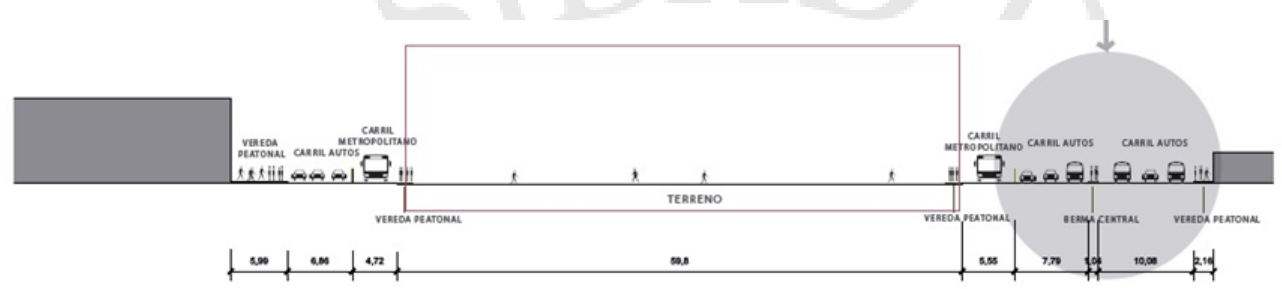

\section{Imagen actual del terreno}

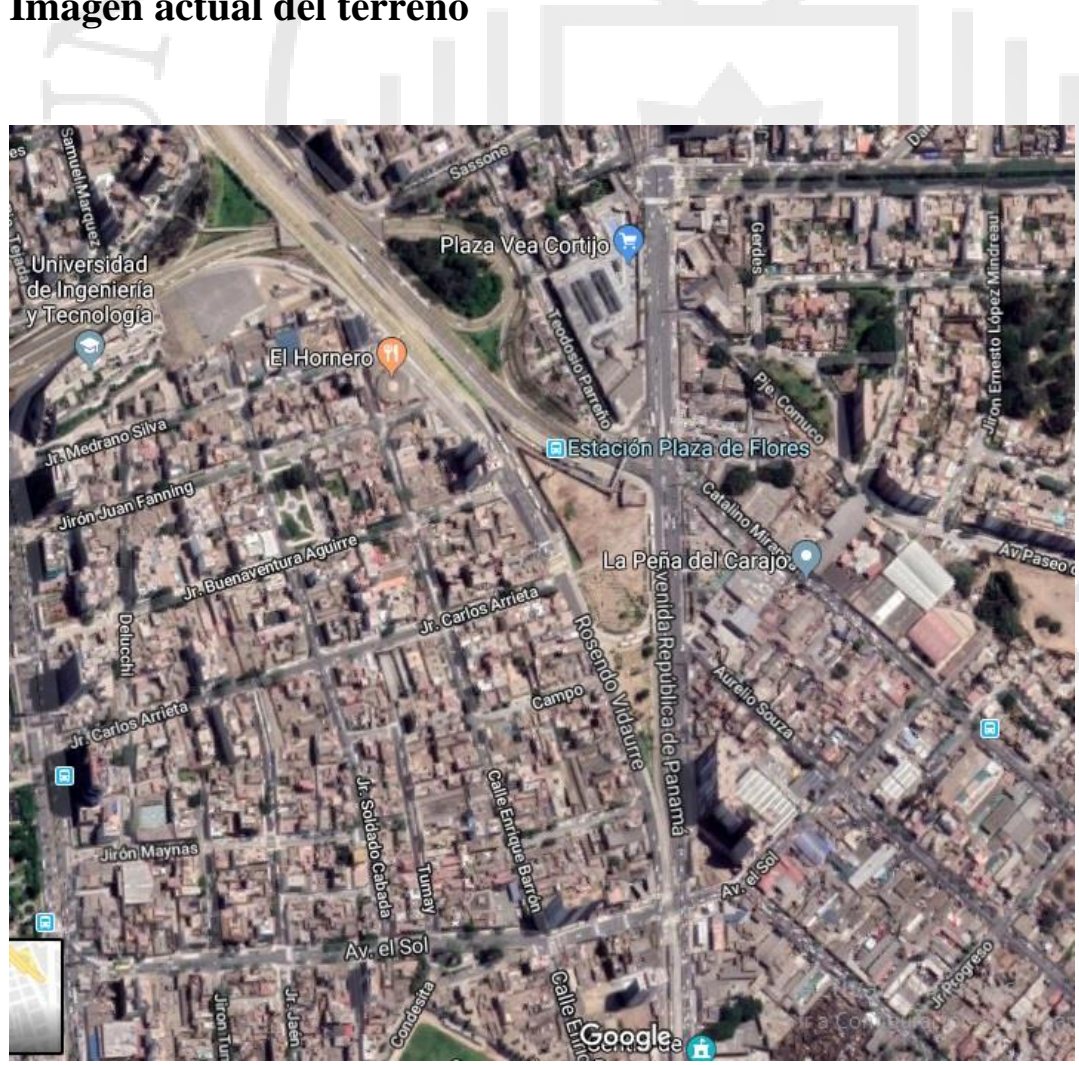




\section{Terreno con proyecto vía expresa Paseo de la República}

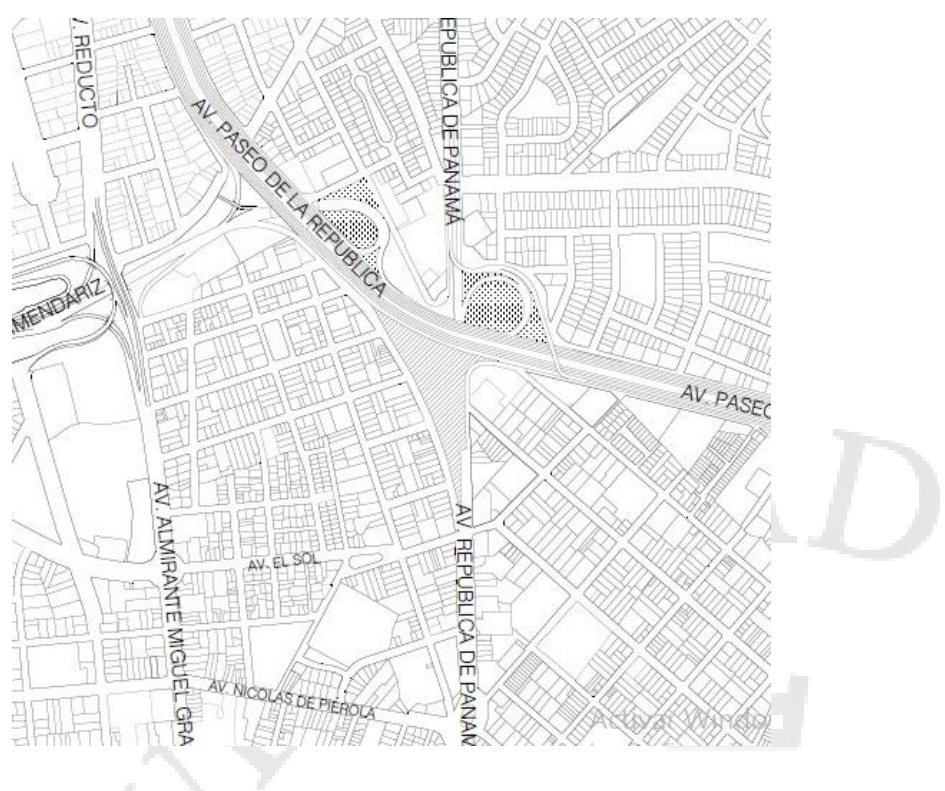

\subsubsection{Vías de acceso.}

Se puede acceder al terreno a través de las siguientes vías:

- Av. Paseo de la República: vía que conecta al terreno desde el centro histórico de Lima, pasando por el centro financiero de la cuidad. Es un eje de norte a sur de Lima.

- Av. República de Panamá: es la vía que conecta a otras arterias principales de la cuidad como son la av. Benavides y la Av. Angamos.

- Av. Francisco Bolognesi: vía que conecta el terreno con el sur de la cuidad, al distrito de chorrillos.

- Vía Bajada de Armendáriz, Vía que conecta al terreno con el circuito de playas de la costa verde, la nueva av. Costanera.

2.2.- Medios de transporte.

Terrestre.-

Existe transporte público desde numerosos puntos de la ciudad de Lima. El CENTRO CULTURAL EN LA ESTACIÓN PLAZA LAS FLORES DE BARRANCO está 
conectado con el principal sistema de transporte de lima, el Metropolitano. El proyecto contempla una Estación dentro del proyecto.

\section{Aéreo.-}

El terreno tiene acceso fácil a la Av. Costanera (circuito de playas de la costa verde) la cual es una vía rápida que llega hasta el Aeropuerto Internacional Jorge Chávez, que cubre vuelos nacionales e internacionales.

\section{Portuaria.-}

El Callao es el principal puerto marítimo del país. Se puede llegar por la Av. Costanera.

\subsubsection{Edificaciones existentes.}

Actualmente una pequeña parte del terreno está siendo ocupada por la Estación del Metropolitano, que es la Estación Plaza de Flores, cuya infraestructura será demolida y reubicada en el sótano 1 del CENTRO CULTURAL EN LA ESTACIÓN PLAZA LAS FLORES DE BARRANCO.

La Estación será operada, diseñada e implementada por Pro transporte y la Municipalidad Metropolitana de Lima.

\subsubsection{Del proyecto}

El proyecto del CENTRO CULTURAL EN LA ESTACIÓN PLAZA LAS FLORES DE BARRANCO (CCB) se emplaza en un vacío urbano que funciona como límite virtual entre 3 distritos y no aporta a la ciudad. Además, los límites físicos de la vía del Metropolitano dividen barrios que difieren en NSE y carecen de oportunidades positivas para aprovechar la ciudad por la falta de equipamiento urbano y espacios públicos.

El proyecto se presenta con un alto Nivel de permeabilidad y considera al peatón en cada momento, convirtiendo el límite del vacío urbano y vías en un espacio compartido. La Plaza es un espacio público físico intermedio que cohesiona físicamente 
los 4 espacios autónomos: las zonas 2 y 3 de Barranco, y Miraflores y Surco. Con claros pasos peatonales a Nivel de la vereda y recibos peatonales, el trazado respeta las vías existentes y las reúne al centro del proyecto, para que el peatón pueda continuar su camino sin ser interrumpido por límites físicos.

Los límites virtuales más importantes a combatir son aquellos que generan diferencias sociales y económicas. En este caso, la ciudad se ha fragmentado espacios de ganadores y perdedores, como menciona De Mattos. Principalmente, el CCB se construye como equipamiento que beneficia a varios sectores socio-económicos pero, sobre todo a aquellos que carecen de oportunidad y accesibilidad a los espacios culturales privados.

Incluso, dentro del proyecto, se busca minimizar los límites de público y privado. Mediante estrategias de diseño y gestión de los edificios, los usuarios pueden acceder a la mayor parte de espacios y entender que un equipamiento público es, precisamente, del público.

Como la fragmentación urbana viene, casi siempre, acompañada de la fragmentación social, es importante que el CCB sea una herramienta para que todos puedan ejercer sus derechos, aprovechar sus habilidades y tomar ventaja de las oportunidades que se encuentran en su medio.

Por lo tanto, el proyecto aprovecha los ángulos de una trama urbana interrumpida y se emplaza dando la fachada a todas las zonas autónomas fragmentadas por las vías metropolitanas. Así, el edificio, su Plaza y el puente-rampa, reiteran que son accesibles y públicos.

El CCB, la Plaza y el puente son elementos articuladores; cada uno con el propósito de cohesionar la ciudad a Niveles micro y macro, pero siempre priorizando al ciudadano peatón. 


\subsubsection{Propuesta arquitectónica}

El objetivo es la conexión física peatonal y rompiendo los límites que forman fragmentación urbana, dando prioridad al peatonal, el proyecto CCB tiene cruces peatonales a través de él y espacios de recibo de la trama de ejes viales existentes como:

1.- Jr Buenaventuro Aguirre

2.- Jr Carlos Arrieta

3.- Calle Campos

4.- Calle Enrique del Horne

5.- Calle Aurelio Souza

6.- Av. República de Panamá

7.- Plaza de Flores / Miraflores.

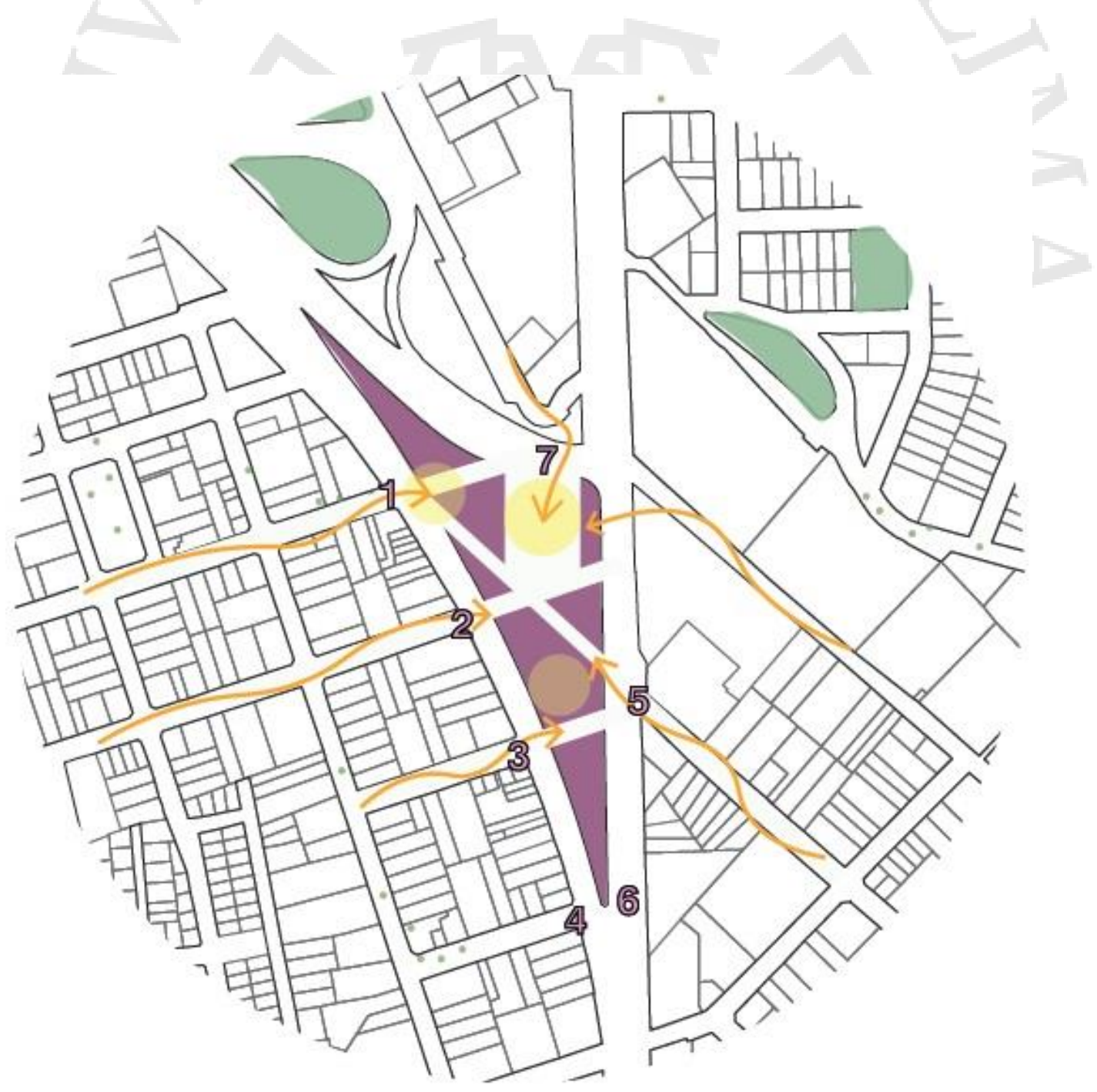

Espacios de recibo 


\subsubsection{Toma de partido}

Como el objetivo es la conexión física, peatonal y la ruptura de los límites. El proyecto del CENTRO CULTURAL EN LA ESTACIÓN PLAZA LAS FLORES DE BARRANCO (CCB) es considerado, conceptualmente, como conector urbano.

Para demostrar la conexión del proyecto, se está tomando, conceptualmente, como barrera virtual, la Av. República de Panamá (1). Se toma un núcleo de conexión (2) ubicado en la zona urbana, el cual se conecta mediante una rampa peatonal que llega hasta el corazón del proyecto. Rompiendo la barrera virtual.

Como la rampa se parte del Nivel 0, se eleva hasta el Nivel 5.40mts y regresa al Nivel 0. Esto nos sugiere una parábola, que se puede representar mediante una volumetría de escalonamiento manteniendo la escala humana (3).

Esta rampa de conexión llega a la entrada de la Estación subterránea del Metropolitano, siendo el centro de los trazados peatonales del proyecto (4). Del cual surgen espacios de reunión abiertos y de calidad.

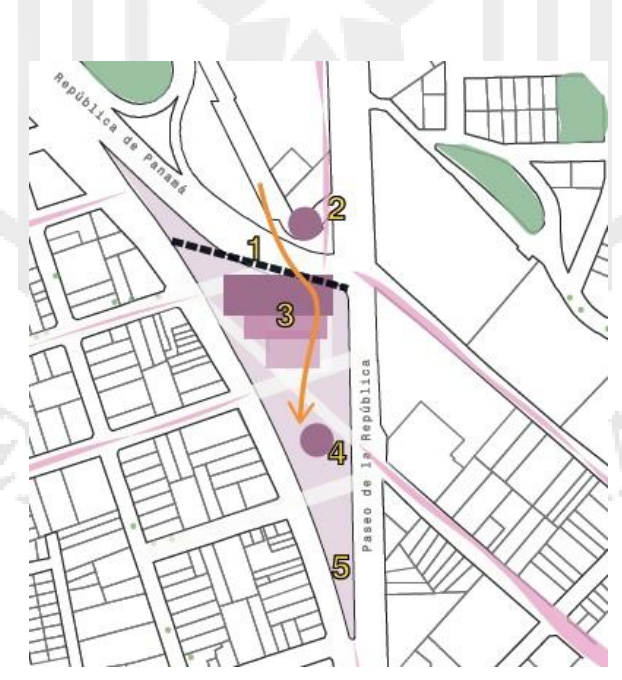

Para no interrumpir el espacio y liberar el espacio público el proyecto del CENTRO CULTURAL EN LA ESTACIÓN PLAZA LAS FLORES DE BARRANCO (CCB) va a tener volúmenes arquitectónicos elevados que respetan la escala humana y del entorno, logrando así su integración con el entorno. 
El proyecto va a tener, en los ingresos de los edificios, un desNivel que espacialmente te invita a ingresar a los volúmenes.

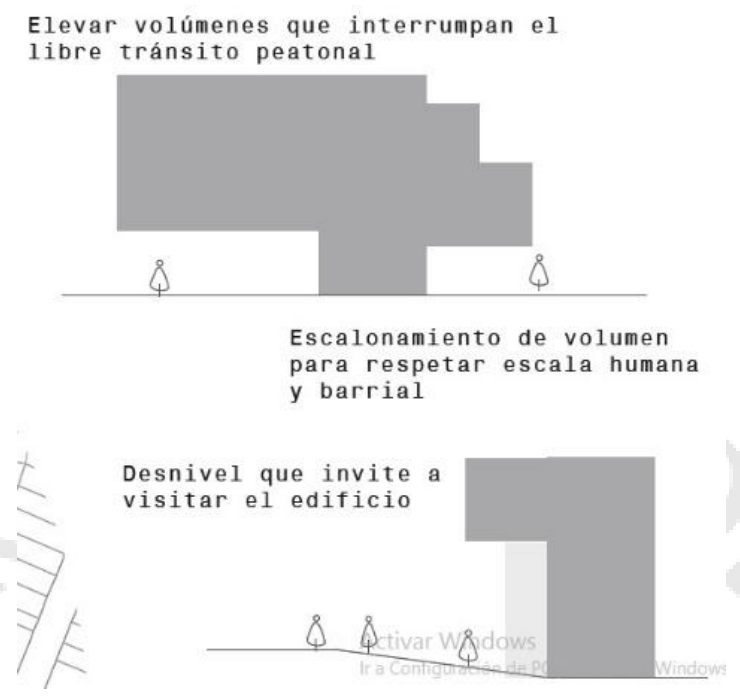

Estos volúmenes arquitectónicos se van a conectar en Niveles superiores logrando una integración de volúmenes y llevando el espacio público peatonal a Nivel superior, convirtiendo al CCB en un proyecto abierto y dinámico.

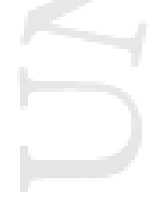

Estrato intermedio que conecte integralmente al proyecto
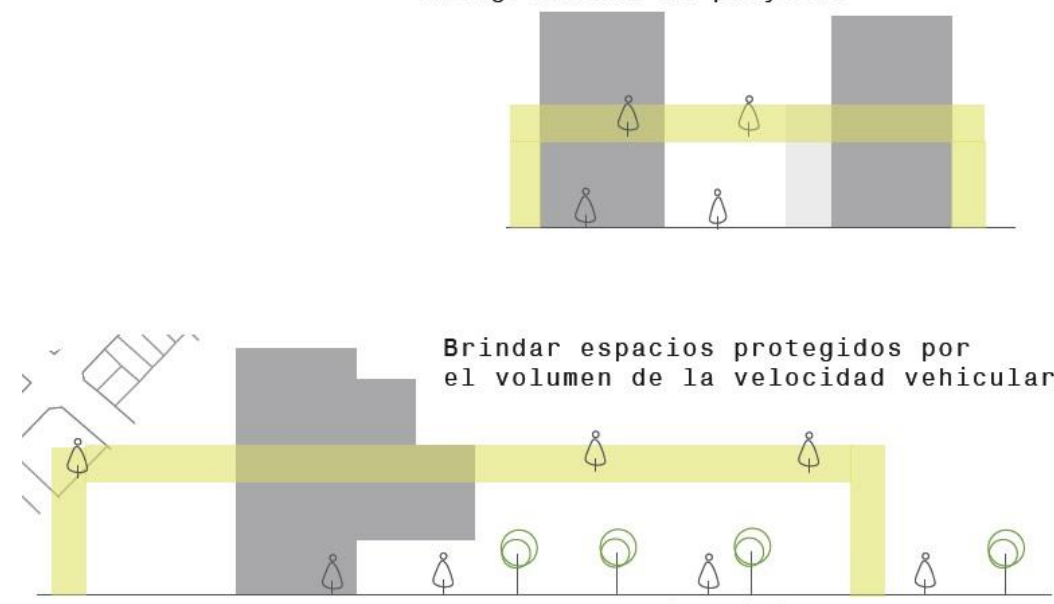

Lo descrito líneas anteriores da como resultado que el proyecto del CENTRO CULTURAL EN LA ESTACIÓN PLAZA LAS FLORES DE BARRANCO (CCB) esté formado por los siguientes componentes arquitectónicos:

- El puente: Estrato intermedio de activación y conexión espacial entre distritos (el entorno) y el proyecto. 
- El Monolito: Presencia estereotómica e hito arquitectónico, como protección y remate visual frente a la llegada de una vía rápida, Av. Paseo de la República.

- El Tótem: Edificio tectónico que integra dos escalas opuestas: la metropolitana y barrial.

- La Plaza: Espacio de integración urbana y social, de superficies y texturas variadas, con flexibilidad de usos y funciones.

\subsubsection{Zonificación}

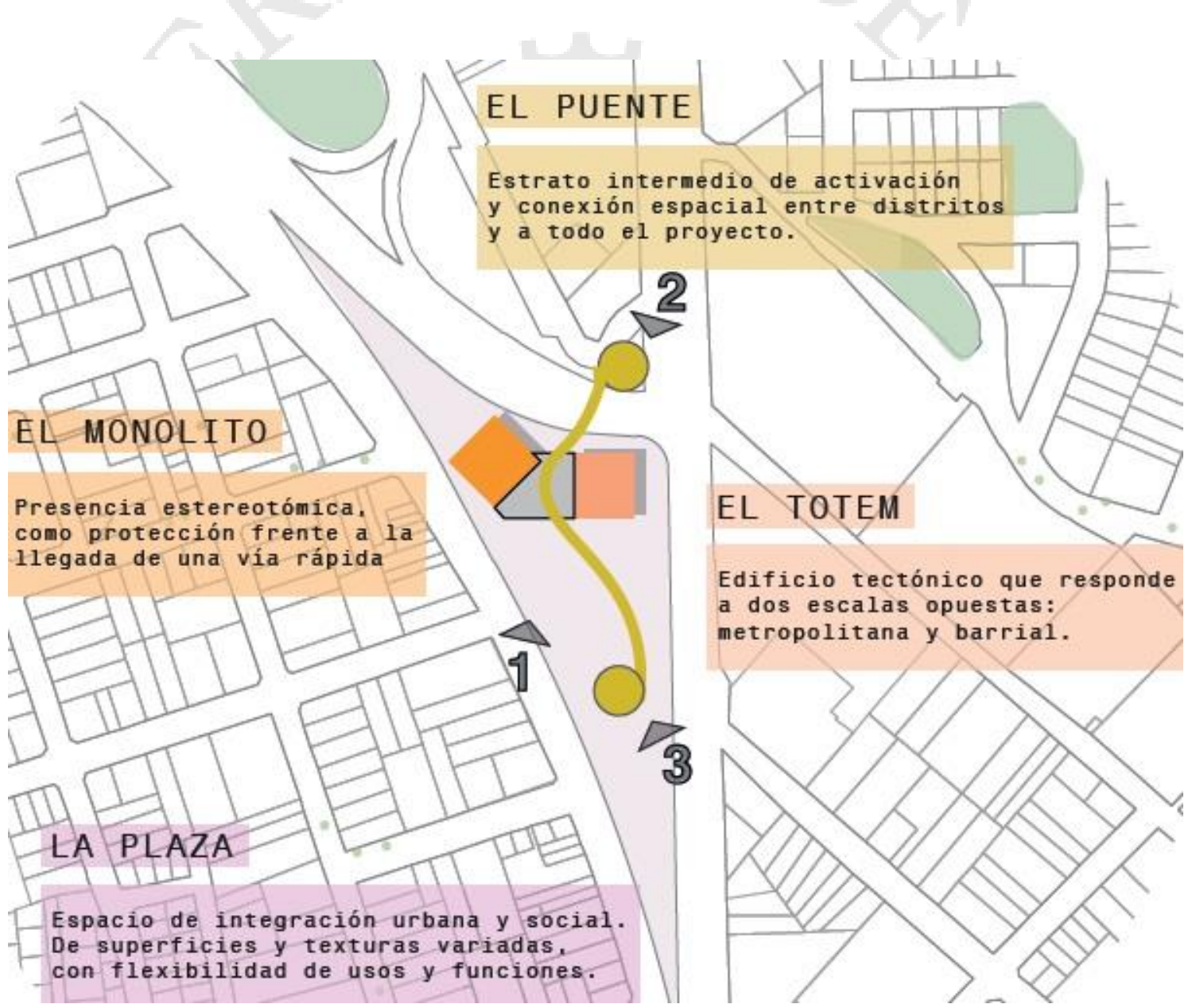

Mediante el grafico se entiende la zonificación del proyecto CENTRO CULTURAL EN LA ESTACIÓN PLAZA LAS FLORES DE BARRANCO. 
El punto 1 muestra la conexión de la Plaza pública del proyecto con el entorno.

Los puntos 2 y 3 son la conexión que brinda el puente. Esta conexión rompe las barreras que forman la fragmentación urbana en la ciudad. Esta ruptura forma 2 volúmenes arquitectónicos, que son el edificio Monolito y el edificio Tótem. En ellos se desarrollan actividades propias del CCB.

En el sótano de 1 del proyecto está ubicada la Estación del Metropolitano Plaza las Flores. Esta estación forma parte de uno de los principales sistemas de transporte de Lima.

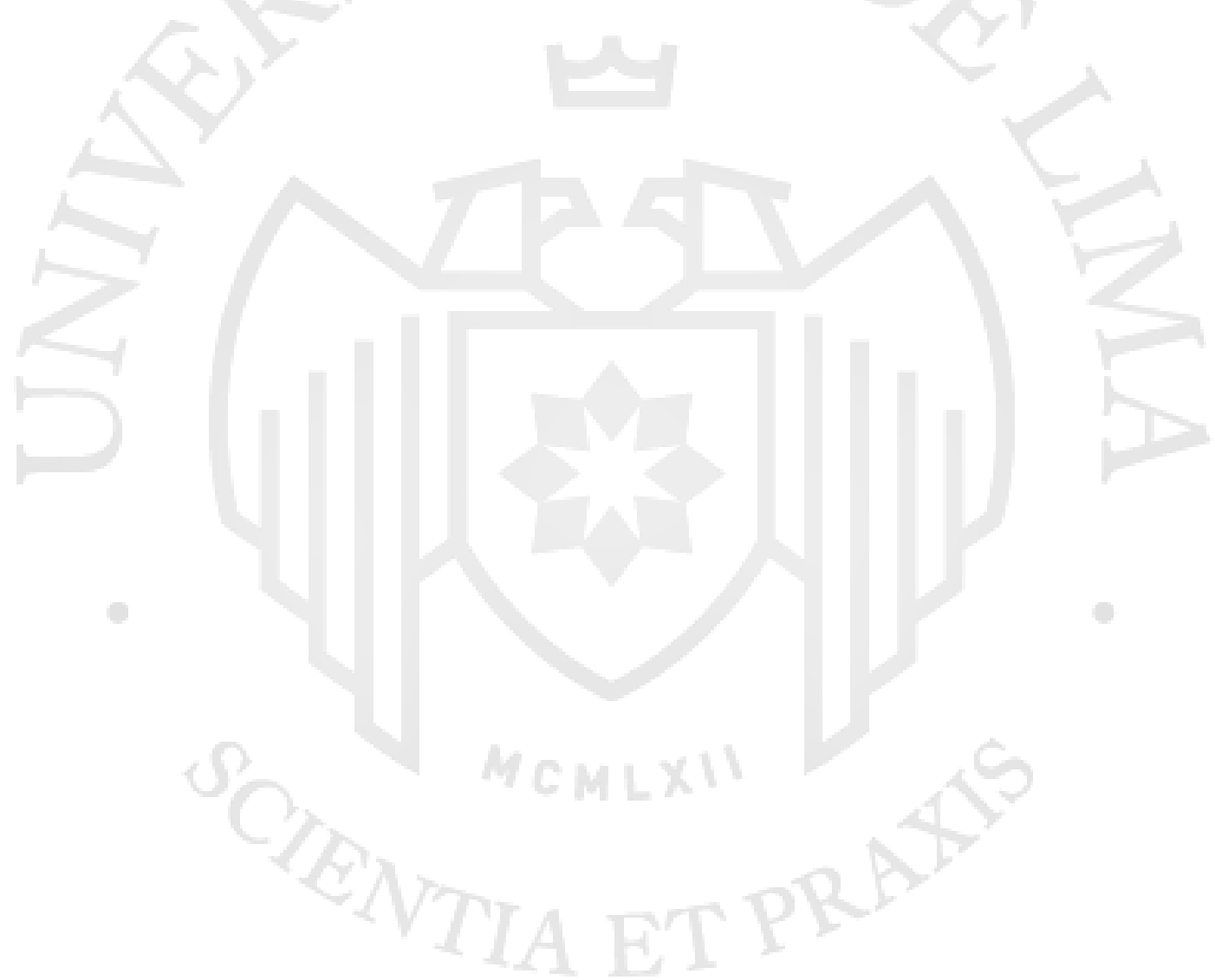




\subsubsection{Organigrama del CCB}

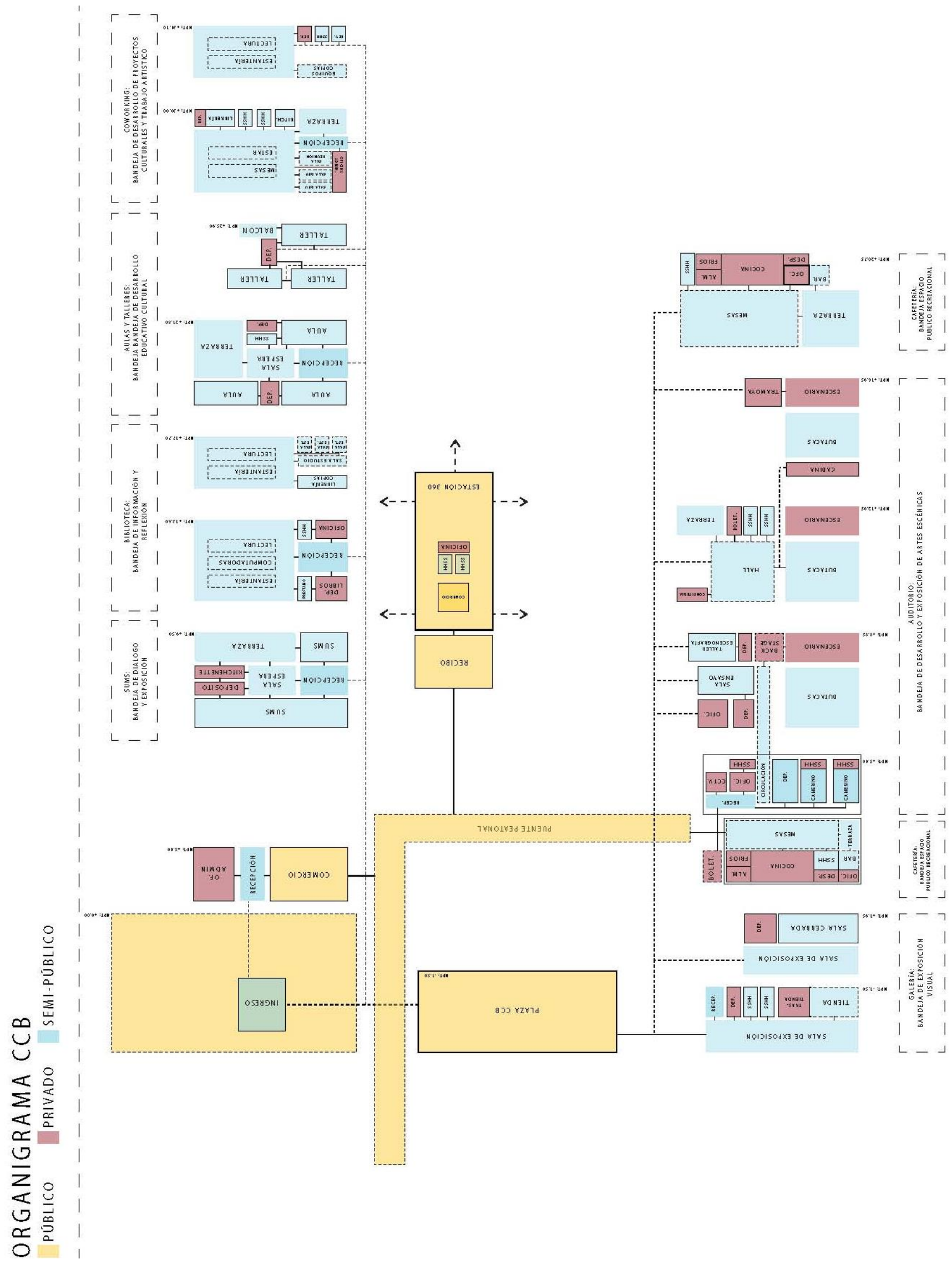




\subsubsection{El proyecto}

El proyecto del CENTRO CULTURAL EN LA ESTACIÓN PLAZA LAS FLORES DE BARRANCO es un proyecto vertical en sus 2 edificaciones y en el Nivel 0 (Nivel de calle) es un proyecto horizontal de espacio público.

La circulación vertical se da a través de ascensores y escaleras de evacuación, las cuales cuentan con ventilación forzada.

El proyecto consta de los siguientes Niveles:

SOTANO 3: Se encuentra en el Nivel -13.00, este espacio está destinado para estacionamientos de CCB. En el cual se tiene un área de 5,278 m2 y está proyectado para el parqueo de 107 vehículos. De ellos, 12 espacios son para estacionamiento de personas con discapacidad.

El ingreso es por la calle Rosendo Vidaurre y la salida es hacia la Av. República de Panamá.

El sótano 3 contiene los siguientes espacios de servicio para el CCB: Depósitos, área de inyección de aire, cuarto de bomba, control de administrativo, cisterna doméstica, cisterna ACI. El acabado de piso es de cemento pulido impermeabilizado y el acabado de muro es de cemento pulido impermeabilizado.

También cuenta con cuarto de G.E. Cuartos de tableros, sub-estación, un espacio de extracción de $\mathrm{CO} 2$. El acabado de pisos es de cemento pulido y en los muros es cemento frotachado

SSHH para el público y para personal, de acabado de cerámico de 30 x 30 para piso y pared.

El piso de las zonas de circulación peatonal de cemento pulido y la zona de circulación vehicular es de cemento frotachado. 
Cuenta con 2 baterías de ascensores, cada batería cuenta con 2 ascensores y escalera de evacuación. Las escaleras de evacuación están de acuerdo al RNE y normas de INDECI. Tiene doble puerta contra incendio y una ventilación mecánica.

La ventilación de aire es por equipos mecánicos y la extracción de CO2 también es por equipos mecánicos.

SOTANO 2: Está ubicado en el Nivel -8.50 mts. El espacio de este Nivel está siendo utilizado por la Estación las flores del Metropolitano. Los buses ingresan directamente de la vía expresa Paseo de la República y circulan por el perímetro de la planta para el recojo de pasajeros, los cuales se conectan con puertas corredizas de vidrio.

Este Nivel tiene un área de $2780.0 \mathrm{~m} 2$. Es una planta libre con zonas de espera para el público. El espacio tiene una doble altura y cuenta con un mezanine que es la zona de ingreso a la Estación. En esta planta se está considerando espacios para módulos de atención y una Estación de servicios al viajero. El acabado de piso es cemento pulido color Platinum.

También cuenta con una cafetería de $55 \mathrm{~m} 2$, con acabado de piso gris oscuro. Esta cafetería tiene 2 depósitos, con un acabado de piso de cemento pulido.

Este Nivel cuenta con 3 baños para el público, uno para hombre, otro de mujeres y un baño para personas con discapacidad. El acabado de estos espacios es de cerámico de $30 \times 30 \mathrm{~cm}$.

La circulación vertical se da por ascensores y escaleras de evacuación. Las escaleras de evacuación están de acuerdo al RNE y normas de INDECI. Tiene doble puerta contra incendio y una ventilación mecánica. Y escaleras mecánicas de conectan directamente con el mezanine ubicada en el Nivel superior.

La ventilación es a través de inyección de aire y extracción de Co2 mecánica.

SOTANO 1: Mezanine de ingreso a la Estación la del Metropolitano las flores. Está ubicada en el Nivel -3.60 mts. Se ingresa por la gran rampa que recorre el proyecto del CENTRO CULTURAL EN LA ESTACIÓN PLAZA LAS FLORES DE BARRANCO. 
Esta llega al espacio de Torniquetes de un área de $132.00 \mathrm{~m} 2$. Está conectado a la Mezanine de distribución, de un área de $251.00 \mathrm{~m} 2$. La Mezanine de distribución de conecta con la Estación a través de escaleras mecánicas, una escalera integrada de concreto y un ascensor.

En el lado sur se encuentra la Oficina de seguridad de la Estación que está sobre la cafetería de la Estación del Metropolitano, cuenta con una planta libre y un baño, el acabado de piso es de cemento pulido pigmentado color Topacio.

EDIFICIO MONOLITO NPT. -1.50: Este Nivel es el ingreso al edificio Monolito. Se ingresa a través de una Plaza pública que viene del Nivel 0 al Nivel $-1.50 \mathrm{~m}$. A esta Plaza se ingresa a través escaleras y una rampa que viene del espacio público del Nivel 0. La Plaza tiene como piso acabado cemento pulido pigmentado color Topacio.

La Plaza se conecta con el interior del edifico Monolito, recibe el espacio conectado a la Sala de exposición 01, con un área de 455.00 m2. Este es un espacio dinámico donde se pueden llevar a cabo eventos. Tiene espacios de apoyo: una zona de exposición cerrada y una tienda de $120.00 \mathrm{~m} 2$.

El acabado del piso es de cemento pulido pigmentado color Topacio, que ingresa desde la Plaza Exterior, conectando y convirtiendo 02 espacios en un gran espacio con una parte al interior y otra al exterior.

En este nivel se encuentran los ascensores de circulación vertical del edificio y las escaleras de evacuación.

NIVEL 0.00: El Nivel donde se encuentra la Plaza central de uso público del proyecto. Esta Plaza ocupa todo el terreno y contiene a los edificios Monolito y Tótem. La Plaza tiene espacios de áreas verdes y puede usarse como un gran espacio de usos múltiples, en el que se pueden desarrollar actividades culturales.

El ingreso a la Plaza es peatonal. 
EDIFCIO TOTEM NIVEL 0.00: La primera planta del edificio es libre, de doble altura y está conectada con la Plaza pública del proyecto. Es un espacio dinámico, en el cual se pueden desarrollar actividades públicas, exposiciones, ferias, etc. bajo techo.

Tiene un espacio de recibo, que es el ingreso a los Niveles superiores del edificio Tótem, y está separado por una mampara de vidrio. La mampara otorga una conexión visual entre los espacios.

A este nivel llegan las escaleras de evacuación de los niveles superiores, llevando a las personas hacia el exterior.

NIVEL 2: Está ubicado en el Nivel +5.40 y, para ambos edificios, es el segundo Nivel. Los edificios están unidos por el puente, formando en este Nivel un estrato público peatonal, al cual se puedes ingresar por la rampa o por la circulación vertical de ambos edificios.

El peatón al usar la rampa comprende y aprecia el proyecto en su totalidad como conector urbano y de espacio público.

Los espacios del Monolito son: el ingreso a un Auditorio y la boletería. Este ingreso lleva a un Hall de ascensores y escalera, que llevan al Nivel 3, de ingreso al foyer del Auditorio.

También cuenta con un restaurant con terrazas hacia la Plaza. Dentro del restaurant hay espacios de cocina completa, almacén de frio, almacén, desperdicios y Oficina administrativa. También tiene 2 baterías de baños para el público.

El Monolito tiene el ingreso para los artistas a través de la recepción, que lleva a un almacén, un almacén de vestuarios, 02 camerinos completos y SSHH. Estos camerinos están conectados al escenario, que está en un nivel superior, mediante escaleras internas y un ascensor de carga.

Para completar con la distribución, se destinó un espacio para la Oficina de Seguridad CCTV y otro espacio para la Oficina de Coordinación. 
En el Nivel del edificio Tótem, se encuentra un espacio público abierto conectado a la rampa peatonal, formando un espacio techado de usos múltiples para ferias, exposiciones, etc. Este espacio está conectado a un espacio de recepción que es el ingreso al Centro Cultural en los niveles superiores.

La recepción lleva a las Oficinas administrativas de $60.00 \mathrm{~m} 2$, que tienen un espacio para el Kitchenette y SSHH.

NIVEL 3 EDIFICIO MONOLITO: Este Nivel es NPT+ $8.85 \mathrm{~m}$. Se encuentra el escenario del Auditorio, al cual se llega desde el Nivel inferior por escaleras internas y un ascensor de carga. Al costado del escenario hay un espacio para Taller de escenografías de $80.00 \mathrm{~m} 2$, que está conectado por un Hall a la Sala de ensayos de $130.00 \mathrm{~m} 2$. Dentro de la Sala hay un espacio adyacente que es un almacén de $19.00 \mathrm{~m} 2$. Y un gran almacén del Auditorio de 116.20 m2. Estos están conectados por un Hall que lleva a una Oficina de $39.00 \mathrm{~m} 2$.

NIVEL 3 EDIFICIO TOTEM: Está a un NPT $+9.50 \mathrm{~m}$. El ingreso es a través del ascensor que viene del Nivel 1. Se llega a un Hall de recepción, y contiene 3 SUM separadas por paneles móviles y, si es necesario, forman un solo espacio. También tiene una Sala de Exposición, 02 núcleos de SSHH y 01 SSHH para personas con discapacidad.

El Hall de Recepción lleva a una Terraza abierta que puede ser utilizada como SUM al aire libre.

NIVEL 4 EDIFICIO MONOLITO: Está en el Nivel + 12.95, y es un Nivel para el público que asiste al Auditorio, al cual llegan del Nivel 2, por los ascensores o escalera, a un Hall o foyer de $156.85 \mathrm{~m} 2$. Este Hall es un espacio articulador con 02 baterías de SSHH y un SSHH de personas con discapacidad. También incluye una Confitería de $40.37 \mathrm{~m} 2$. El Foyer se conecta al Auditorio y a una Terraza.

NIVEL 4 EDIFICIO TOTEM: El Nivel es NPT+13.60m. Este Nivel incluye una Biblioteca completa, compuesta por: zona de computadoras, depósito, área de niños, zona de estantería y una Oficina administrativa. 
También cuenta con los espacios de servicio; 02 baterías de SSHH, 01 SH para personas con discapacidad y 02 escaleras de evacuación.

NIVEL 5 EDIFICIO MONOLITO: Está al NPT +16.95 m. En este Nivel se encuentra la pasarela al escenario del Auditorio, la tramoya, y está conectado por un Hall desde la escalera y ascensores de la circulación vertical.

NIVEL 5 EDIFICIO TOTEM: Está al NPT +17.70m. Este Nivel es el mezanine de la Biblioteca y cuenta con: Sala de lectura, 01 librería y Salas privadas de lectura.

NIVEL 6 EDIFICIO MONOLITO: Está al NPT +20.75 m. Este Nivel es un restaurante completo de $230.00 \mathrm{~m} 2$. Este cuenta con: Salón principal, Terraza de $430 \mathrm{~m} 2$, bar, espacio de atención, cocina, espacio para desperdicios, almacén de fríos, almacén, 02 núcleos de SSHH y 01 SSHH para personas con discapacidad.

NIVEL 6 EDIFICIO TOTEM: Está al NPT $+21.80 \mathrm{~m}$ y se llega a este Nivel por la circulación vertical a un Hall articulador, que dirige a 03 aulas. Cada aula tiene un depósito. El Nivel tiene 02 núcleos de SSHH y 01 SSHH para personas con discapacidad. Cuenta con 2 escaleras de evacuación.

NIVEL 7: Se encuentra el techo o cobertura del Monolito. En el Tótem, al NPT +25.90m, hay 03 espacios de Talleres, usados para cursos de enseñanza. Este Nivel es un complemento del Nivel inferior, de aulas y ambos están conectados por escaleras y ascensores.

NIVEL 8: Esta en el npt $+30.00 \mathrm{~m}$. Es el primer Nivel de Coworking, con las siguientes zonas: área de mesas, librería, depósito, terrazas, 02 núcleos de SSHH y 01 SSHH para personas con discapacidad.

NIVEL 9: Esta en el npt +34.10 m. Este Nivel está destinado para un Coworking de artistas, de planta libre con terraza. 
7.3.11 Cuadro de áreas

\begin{tabular}{|c|c|c|c|c|c|}
\hline EDIFICIO & NIVEL & $\begin{array}{l}\text { AREA TOTAL } \\
\text { (M2) }\end{array}$ & PROGRAMA & $\begin{array}{c}\text { AREA/ } \\
\text { PROGRAMA(M2) }\end{array}$ & AFORO \\
\hline \multirow[t]{2}{*}{ ESTACIONAMIENTO } & SOTANO 3 & $5,278.00$ & Área técnica estaciôn & 633.00 & 5.00 \\
\hline & & & Estacionamientos CCB & $4,645.00$ & - \\
\hline \multirow[t]{3}{*}{ ESTACION DE METROPOLITA } & SOTANO 2 & $3,599.00$ & Estaciôn & $2,725.00$ & $1,362.50$ \\
\hline & & & Área de control y técnica & 819.00 & 81.90 \\
\hline & & & Cafetería & 55.00 & 5.50 \\
\hline \multirow[t]{2}{*}{ MEZZANINE DE ESTACION } & SOTANO 1 & 383.00 & Espacio de distribución & 251.00 & 100.40 \\
\hline & & & Torniquetes & 132.00 & 52.80 \\
\hline PLAZA ABIERTA & NIVEL O & $15,338.00$ & Espacio paisajístico & $15,338.00$ & $5,112.67$ \\
\hline \multirow[t]{46}{*}{ TOTEM } & PLANTA 1 & 132.00 & Recibo & 110.00 & 22.00 \\
\hline & PLANTA 2 & $1,000.00$ & Recibo & 126.10 & \\
\hline & & & Comercio & 587.00 & 117.40 \\
\hline & & & Oficina 1 & 56.00 & 5.60 \\
\hline & & & Oficina 2 & 34.00 & 3.40 \\
\hline & & & Kitchenette & 4.78 & 1.91 \\
\hline & & & SSHH & 6.24 & - \\
\hline & PLANTA 3 & $1,378.00$ & SUM 1 & 90.00 & 45.00 \\
\hline & & & SUM 2 & 70.00 & 35.00 \\
\hline & & & SUM 3 & 88.00 & 44.00 \\
\hline & & & SUM 4 & 130.00 & 65.00 \\
\hline & & & Sala espera & 54.00 & 21.60 \\
\hline & & & Kitchenette & 13.00 & 5.20 \\
\hline & & & Depòsito & 21.00 & - \\
\hline & & & Sala espera & 40.00 & 16.00 \\
\hline & & & Recibo & 151.00 & 2.00 \\
\hline & & & Terraza & 555.00 & 222.00 \\
\hline & & & SSHH & 42.20 & - \\
\hline & PLANTA 4 & 851.00 & Oficina & 45.10 & 4.51 \\
\hline & & & SSHH & 42.20 & - \\
\hline & & & Área de niños & 115.00 & 23.00 \\
\hline & & & Computadoras & 65.00 & 13.00 \\
\hline & & & Depósito & 26.00 & - \\
\hline & & & Área de lectura & 250.00 & 50.00 \\
\hline & PLANTA 5 & 426.00 & Sala de lectura & 84.00 & \\
\hline & & & Librerìa & 26.80 & \\
\hline & & & Sala 1,2 y 3 & 22.80 & 12.00 \\
\hline & & & Sala 4 & 43.80 & 14.60 \\
\hline & PLANTA 6 & 851.00 & Aula 1 & 117.30 & 23.46 \\
\hline & & & Aula 2 & 88.00 & 17.60 \\
\hline & & & Aula 3 & 134.50 & 26.90 \\
\hline & & & Almacén & 44.80 & - \\
\hline & & & Depôsito & 29.10 & - \\
\hline & & & Sala de espera & 26.60 & 5.32 \\
\hline & & & Terraza & 69.50 & 27.80 \\
\hline & & & SSHH & 42.20 & - \\
\hline & PLANTA 7 & 703.00 & Taller de arte 1 & 134.00 & 13.40 \\
\hline & & & Taller de arte 2 & 116.00 & 11.60 \\
\hline & & & Taller de arte 3 & 193.50 & 19.35 \\
\hline & & & Depòsito & 16.00 & - \\
\hline & PLANTA 8 & 793.00 & Terraza & 128.33 & 51.33 \\
\hline & & & Kitchenette & 15.30 & 6.12 \\
\hline & & & Librería & 37.40 & 3.74 \\
\hline & & & Área de mesas & 364.00 & 72.80 \\
\hline & & & SSHH & 42.20 & - \\
\hline & & & Recibo & 62.00 & 24.80 \\
\hline
\end{tabular}




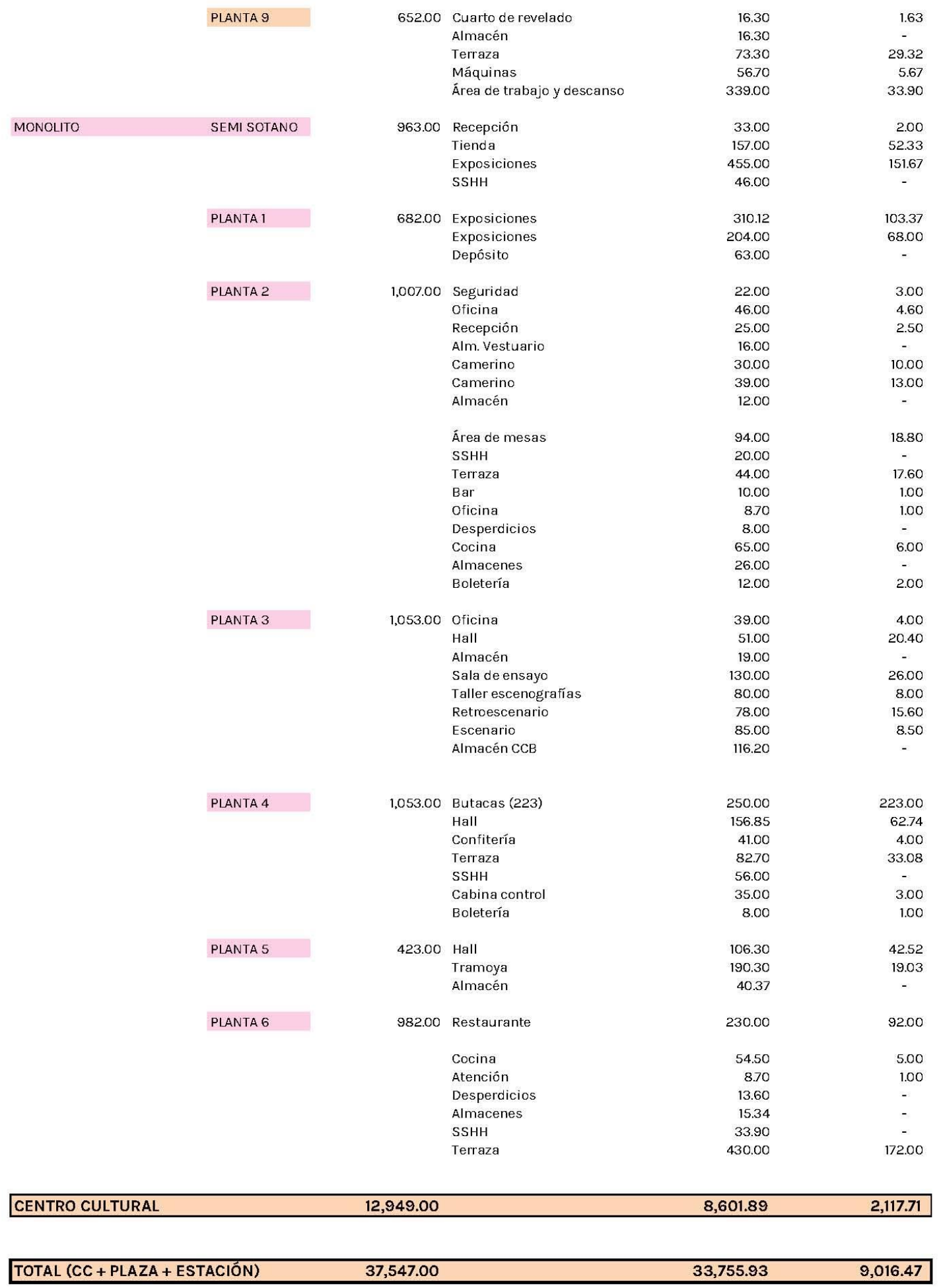




\subsection{Viabilidad económica del proyecto}

Para justificar la viabilidad económica del proyecto, se necesita determinar las variables, principalmente el presupuesto de la obra, que es el principal indicador para conocer si el proyecto es rentable.

Luego, analizaremos los ingresos que pueda generar el proyecto "Centro Cultural en La estación Plaza Las Flores de Barranco (CCB)" y, mediante el flujo de caja se verá el tiempo que demore en recuperar la inversión. Vale recalcar que el proyecto no contempla la construcción e implementación de la Estación Plaza Las Flores del Metropolitano, pues corresponde a ProInversión. Sin embargo, se ha considerado el espacio para su construcción, en el nivel -9.00m.

Asimismo, consideraremos las variables sociales de mejora para la cuidad, las personas usuarias y no usuarias. Además, existe un costo-beneficio que traerá el espacio público sobre los distritos con los cuales colinda directamente el CCB.

Estos beneficios son, por ejemplo, que el CCB otorga un espacio público, en el cual se desarrollarán actividades culturales y educativas. Estas benefician y dan oportunidades de desarrollo sociocultural y negocio a los jóvenes de Lima. Esto provoca una reacción positiva, y reduce la delincuencia, la tasa de jóvenes desocupados y la problemática vecinal. Esta última ha sido comprobado en otros espacios de Latinoamérica, según los casos estudiados previamente.

El proyecto del CCB, al estar conectado con uno de los principales sistemas públicos de transporte de Lima Metropolitana, se puede acceder fácilmente desde Lima Norte, y beneficia a la cuidad porque para acceder al CCB no tendrían que usar vehículos particulares, reduciendo su uso en algunos casos y significaría una reducción de la contaminación ambiental.

Estos indicadores sociales son el sustento para que el Estado participe en el financiamiento del proyecto, principalmente el Ministerio de Cultura, el Ministerio de Educación y el Ministerio de Trabajo y Promoción al Empleo. Este último, porque el proyecto del CCB brindará espacios e impulsará la modalidad de Co-Working y oficinas 
flexibles para jóvenes artistas y emprendedores a precios accesibles. Estos espacios tienen beneficios como la percepción de apoyo del Estado al arte, la accesibilidad a la comunidad de artistas del país, y el intercambio cultural y profesional.

\subsubsection{Presupuesto}

El presupuesto es el indicador principal para la vialidad del proyecto. Con el presupuesto podemos definir el mejor tipo de financiamiento para el proyecto y este nos muestra el tamaño y la envergadura del CCB.

Para el cálculo del presupuesto, se eligió el sistema constructivo más conveniente y se utilizaron precios por metro cuadro actuales de acuerdo con fuentes confiables del país, como la Revista Costos, Constructivo y CAPECO del año 2018.

El primer costo relevante del proyecto es el precio del terreno. Según la zonificación, es una berma central que pertenece a la Municipalidad de Lima. Sin embargo, se le considerará como un terreno en venta. Para obtener el precio por metro cuadrado del terreno, se realizó un estudio por la zona para decretar el valor de mercado. Este se obtuvo según los precios de terrenos libres en Miraflores, Barranco y Surco. Se utilizaron portales web como: Adondevivir.com (2018), Urbania.com 2018, y el estudio de mercado inmobiliario de Mantyobras (2017). Por la ubicación del proyecto la zonificación es OU y el valor del terreno está entre \$1200 y \$1800. Teniendo en cuenta que es un proyecto público, que el terreno ya es propiedad de la Municipalidad de Lima, y que su extensión es de $15,338 \mathrm{~m} 2$, consideramos el menor precio por m2.

Los costos siguientes son los relacionados al proyecto y el expediente para las licencias correspondientes. Estos costos se tomaron en base a los precios de diseño de mercado, considerando los precios de proyecto de arquitectura, estructuras, instalaciones eléctricas, instalaciones electromecánicas, instalaciones sanitarias, estudio de suelos, topografía e INDECI. Adicionalmente, se han considerado los precios para obtener las licencias en la municipalidad correspondientes, en este caso las Municipalidades de Lima y Barranco. 
Luego consideramos los costos de ejecución del proyecto, comenzando por la etapa de demolición, nivelación y excavación. En estas etapas se consideraron costos por m3 de excavación. Cabe señalar que el movimiento de tierra (excavación) no es de todo el terreno, y solo es la parte de estacionamientos, y es la Estación de Metropolitano. Esto llega a un nivel de $-13.00 \mathrm{~m}$.

El sistema constructivo empleado para el CCB, fue el porticado con placas. Los costos se obtuvieron en base a revistas especializadas, como Costos (2018), Constructivo (2018) y de varios proyectos con el mismo sistema constructivo. Para para los sótanos se tomaron ratios de Costos entre $\$ 400$ y $\$ 700$, dependiendo de los acabados. Este precio incluye las instalaciones sanitarias, eléctricas y electromecánicas.

Para la construcción de los edificios Tótem y Monolito se dividieron las áreas comerciales, que van a ser concesionadas a terceros, como a restaurantes y tiendas. Asimismo, habrá alquileres de las áreas del Centro Cultural correspondientes al Teatro, SUMs y el Co-working.

Se está considerando un costo de $\$ 750$ el metro cuadrado de construcción considerando el sistema constructivo, las instalaciones eléctricas, electromecánicas y acabados estándar. Estos acabados se deben a la estandarización de espacios versátiles, que serán intervenidos por los propios usuarios según la temporada o actividades del CCB.

Finalmente, en el presupuesto se consideran los gastos de publicidad del proyecto a cargo de una empresa especializada en marketing. 


\subsubsection{Presupuesto del proyecto}

\begin{tabular}{|c|c|c|c|c|c|}
\hline & EGRESOS & m2. & Cant \$ & $\$$ & $\%$ \\
\hline \multicolumn{2}{|c|}{ TERRENO } & 15,338 & 1200 & $(18,405,600.00)$ & $50.27 \%$ \\
\hline & LEGALES & 1 & 2000 & $(2,000.00)$ & $0.01 \%$ \\
\hline \multicolumn{6}{|c|}{ PROYECTO } \\
\hline & Arquitectura & 37,547 & 5 & $(187,735.00)$ & $0.51 \%$ \\
\hline & Estructuras & 22,209 & 1.5 & $(33,313.50)$ & $0.09 \%$ \\
\hline & Sanitarias & 22,209 & 0.5 & $(11,104.50)$ & $0.03 \%$ \\
\hline & Eléctricas & 22,209 & 0.7 & $(15,546.30)$ & $0.04 \%$ \\
\hline & Electro mecánicas & 22,209 & 0.5 & $(11,104.50)$ & $0.03 \%$ \\
\hline & Indeci & 1 & 3000 & $(3,000.00)$ & $0.01 \%$ \\
\hline & Estudio de suelos & 15,338 & 0.5 & $(7,669.00)$ & $0.02 \%$ \\
\hline & Topografía & 15,338 & 0.5 & $(7,669.00)$ & $0.02 \%$ \\
\hline \multicolumn{6}{|c|}{ LICENCIAS } \\
\hline & Anteproyecto & $0.30 \%$ & $8,002,650.00$ & $(24,007.95)$ & $0.07 \%$ \\
\hline & Proyecto & $1.70 \%$ & $8,002,650.00$ & $(136,045.05)$ & $0.37 \%$ \\
\hline \multicolumn{2}{|c|}{ SERVICIOS } & & & 4 & 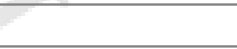 \\
\hline & Luz, agua, desagüe, gas & 30 & 100 & $(3,000.00)$ & $0.01 \%$ \\
\hline \multicolumn{2}{|c|}{ CONSTRUCCION } & $r^{\cdots+1}$ & $-{ }^{-1-4}$ & 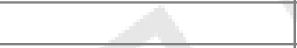 & -1 \\
\hline & Demolición / Nivelación & 1 & 6000 & $(6,000.00)$ & $0.02 \%$ \\
\hline & Excavación & 68,614 & 17 & $(1,166,438.00)$ & $3.19 \%$ \\
\hline \multicolumn{2}{|r|}{ Sótano 3 - Estacionamiento } & 5,278 & 600 & $(3,166,800.00)$ & $2=$ \\
\hline \multicolumn{2}{|r|}{ Sótano 2 - Estacionamiento } & 3,599 & 400 & $(1,439,600.00)$ & $3.93 \%$ \\
\hline & 383 & 400 & $(153,200.00)$ & $0.42 \%$ \\
\hline \multicolumn{2}{|r|}{ Paisajismo en Plaza } & 15,338 & 100 & $(1,533,800.00)$ & $4.19 \%$ \\
\hline$r-$ & 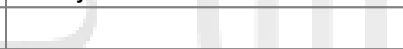 & & $5-1-1$ & $\mid$ & lL] f \\
\hline \multirow[t]{2}{*}{$t$} & Edificio Tótem - Comercio & 587 & 750 & $(440,250.00)$ & $1.20 \%$ \\
\hline & Edificio Tótem - CCB & 6,199 & 750 & $(4,649,250.00)$ & $12.70 \%$ \\
\hline \multicolumn{2}{|r|}{ Edificio Monolito - Comercio } & 1,257 & 750 & $(942,900.00)$ & $2.58 \%$ \\
\hline & Edificio Monolito - CCB & 4,906 & 750 & $(3,679,500.00)$ & $10.05 \%$ \\
\hline \multicolumn{2}{|c|}{ LEGALES } & 64 & 150 & $(9,600.00)$ & $0.03 \%$ \\
\hline \multicolumn{2}{|c|}{ GASTOS DE VENTAS } & & 4 & 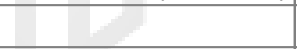 & \\
\hline \multirow{2}{*}{\multicolumn{2}{|c|}{\begin{tabular}{|l|} 
Publicidad $1 \%$ \\
Comisión 3\%
\end{tabular}}} & $1 \%$ & $1,163,985.42$ & $(11,639.85)$ & $0.03 \%$ \\
\hline & & $3 \%$ & $1,163,985.42$ & $(34,919.56)$ & $0.10 \%$ \\
\hline \multicolumn{2}{|c|}{ COSTO FINACIERO } & 5 & 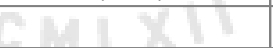 & $a-b \mid$ & $0.00 \%$ \\
\hline \multicolumn{2}{|c|}{ GERENCIA } & $3 \%$ & $-17,619,863.80$ & $(528,595.91)$ & $1.44 \%$ \\
\hline \multicolumn{2}{|c|}{ GASTO TOTAL } & & & $(36,610,288.13)$ & $100 \%$ \\
\hline
\end{tabular}

Fuente: Cuadro de elaboración propia 


\subsubsection{Financiamiento del proyecto}

El Centro Cultural en la Estación Plaza las Flores de Barranco (CCB), será financiado por inversión público-privada. El Estado intervendrá a través del Ministerio de Cultura, el Ministerio de Educación y las Municipalidades de Miraflores, Barranco y Surco. Esto proveerá las garantías financieras y las que se necesite para la adquisición del terreno y el financiamiento en una entidad bancaria.

Se está considerando un financiamiento bancario del monto total del proyecto, de

USD $\$ 36,692,702.89$ a un 12\% en un tiempo de 240 meses (20 años). Así, se podrá ejecutar el proyecto en un plazo de 20 meses y una sola etapa. Esto es gracias a las garantías financieras del estado, que funcionará como aval.

En cuanto a los inversionistas del sector privado, se hará cargo uno de los grandes grupos financieros en Perú de la actualidad, como el Grupo Intercorp, Grupo Romero, Credicorp, entre otros. Una vez que el CCB esté construido, el grupo del sector privado será el administrador del proyecto, por un promedio de 264 meses. Este será tiempo necesario para recuperar la inversión y lograr utilidades. Terminado este tiempo se licitará para encontrar un nuevo administrador o pasará a formar parte del Ministerio de Cultura para proveer de ingresos directos al Estado.

Este proyecto es considerado un proyecto social ya que brindará oportunidades a los ciudadanos, con programa de educación, cultura y trabajo. Asimismo, impulsará a reducir la delincuencia y será un foco de cultura. De esta manera, el CCB intenta ser un animador urbano más allá del espacio físico, regresando ganancias socioculturales a la ciudad. Contempla apoyar al cuidado del medio ambiente con las áreas verdes planteadas, impulsará la mejora del transporte público por encontrarse unido al eje vial del Metropolitano y su uso. Podría ser el ejemplo de la viabilidad de proyectos de gran envergadura integrados a los ejes viales y sus beneficios económicos y sociales. 


\subsubsection{Retorno de la inversión}

Para el retorno de la inversión del CCB, se han elegido varias modalidades de ingresos: la del alquiler de los espacios comerciales a concesionarios; alquiler de salas de usos múltiples, del auditorio y los salones para cursos; los planes de alquiler para el uso de los coworking; y la administración propia del CCB de los estacionamientos.

Como se mencionó previamente, para la construcción del $\mathrm{CCB}$ se necesita USD\$36, 692,702.89 aproximadamente. Para recuperar esta inversión, se ha realizado un estudio de los ingresos por áreas del CCB.

La primera zona, o área, es la de estacionamientos. El CCB tiene 107 espacios para el parqueo de los vehículos, de las cuales se establece el cobro por hora. Para calcular el tiempo de uso de los espacios, establecemos que son 16 horas al día de parqueo. Por 7 días a la semana, da un valor de 11,984 horas en 1 semana por los 107 espacios. Considerando un factor de uso del 50\% (valor habitual para calcular el uso de estacionamientos), nos da un promedio de 5,992 horas a la semana. Este valor lo multiplicamos por las 52 semanas del año y sale 311,584 horas al año. Le asignamos un valor de USD\$ 1.60 dólares por hora (S/ 5.30 soles al TC promedio). Se obtiene un ingreso anual de USD \$ 498,534.40 dólares. Consideramos un valor por hora elevado porque el CCB buscará impulsar el uso del transporte público y tiene como objetivo darle prioridad al peatón y generar ingresos de los autos privados que lleguen al CCB, a favor de los programas culturales, a manera de un 'impuesto'.

\begin{tabular}{|c|c|c|r|}
\hline Total de espacios & $\begin{array}{c}\text { Tiempo en horas } \\
\text { de uso }\end{array}$ & Días de la semana & Sub total \\
\hline 107 & 16 & 7 & 11,984 \\
\hline \multirow{2}{*}{$\begin{array}{c}\text { Espacios utilizados } \\
\text { por 1 año }\end{array}$} & & $\begin{array}{c}\text { Indicador del 50\% de } \\
\text { uso por cada hora }\end{array}$ & 5,992 \\
\hline \multirow{2}{*}{$\begin{array}{c}\text { total de horas por } \\
52 \text { Semanas }\end{array}$} & 311,584 \\
\cline { 2 - 4 } & & \multicolumn{2}{|c|}{ costo por hora } \\
\cline { 3 - 4 }
\end{tabular}


El CCB también tiene zonas comerciales para restaurantes, las cuales van a ser alquiladas a una cadena de restaurantes a manera de locatarios. Estos espacios tienen $578 \mathrm{~m} 2$ en el Edificio Tótem y, 1,257 m2 en el edificio Monolito para alquiler. Consideramos un precio del mercado para este uso de USD\$ 75 por $\mathrm{m} 2 /$ mensual. Nos da un resultado, para el Edificio Tótem de USD\$ 528,300.00 al año. Para los 1,257 m2 del Edificio Monolito, a \$75 el m2, nos da un resultado de USD\$1,131,480.00 al año de alquiler.

\begin{tabular}{|c|c|r|r|c|}
\hline \multicolumn{7}{|c|}{ Zona de comercio de edifcios } \\
\hline $\mathbf{m 2}$ & $\begin{array}{c}\text { Precio por } \mathbf{~} \mathbf{2} \\
\text { mensual }\end{array}$ & $\begin{array}{c}\text { Renta } \\
\text { mensual }\end{array}$ & $\begin{array}{c}\text { Renta por 1 } \\
\text { año }\end{array}$ \\
\hline $\begin{array}{c}\text { edificio totem } \\
\text { comercio }\end{array}$ & 587 & $\$ 75.00$ & $\$ 44,025.00$ & $\$ 528,300.00$ \\
\hline $\begin{array}{c}\text { Edificio Monolito } \\
\text { comercio }\end{array}$ & 1,257 & $\$ 75.00$ & $\$ 94,290.00$ & $\$ 1,131,480.00$ \\
\hline
\end{tabular}

Para la zona de auditorio que tiene un aforo de 223 personas, se está considerando un precio de alquiler por día de $\$ 2700.00$ dólares (S/. 8910 soles). Se considera un uso con funciones de miércoles a domingo. 20 días al mes. Da como resultado \$ 54000.00 mensual y al año \$ 648000.00 . Si consideramos un precio por entrada promedio de $\mathrm{S} / 50$ soles por persona por función, la empresa que alquile el espacio tendría un ingreso de S/. 11150 soles diarios, si realizan 2 funciones serian S/. 22300 soles por día de ingresos.

\begin{tabular}{|l|r|r|r|r|r|r|r|}
\hline \multicolumn{1}{|c|}{ PROGRAMA } & $\begin{array}{c}\text { AREA/ } \\
\text { PROGRAMA (M2) }\end{array}$ & AFORO & $\begin{array}{c}\text { ALQUILER } \\
\text { POR AFORO } \\
\text { POR DIA }\end{array}$ & $\begin{array}{c}\text { SUB TOTAL } \\
\text { POR DIA }\end{array}$ & $\begin{array}{c}\text { USO AL MES O } \\
\text { COSTO POR MES }\end{array}$ & SUB TOTAL MES & TOTAL AL AÑO \\
\hline AUDITORIO & $1,564.72$ & 223 & $\$ 2,700.00$ & 20 & $\$ 54,000.00$ & $\$ 648,000.00$ \\
\hline
\end{tabular}

Para las salas de usos múltiples, administradas por el CCB, se está considerando un ingreso de USD\$ 8.00 por persona para el ingreso. Con un aforo por las 4 salas de 189 , personas al precio dicho y operando 4 veces a la semana, obtenemos un ingreso al año de USD\$ 396,864.00 dólares por su alquiler para eventos. Principalmente, serán espacios para contratar y presentar programas al público, como el de Fuerza sin Violencia de Hombres por la Igualdad, un programa del Ministerio de Cultura que busca 
educar a la población y reducir la violencia provocada por el machismo, mediante talleres y difusión constante de información.

\begin{tabular}{|l|r|r|r|r|r|r|r|}
\hline \multicolumn{1}{|c|}{ PROGRAMA } & $\begin{array}{c}\text { AREA/ } \\
\text { PROGRAMA (M2) }\end{array}$ & AFORO & $\begin{array}{c}\text { ALQUILER } \\
\text { POR AFORO } \\
\text { POR DIA }\end{array}$ & $\begin{array}{c}\text { SUB TOTAL } \\
\text { POR DIA }\end{array}$ & $\begin{array}{c}\text { USO AL MES O } \\
\text { COSTO POR MES }\end{array}$ & SUB TOTAL MES & TOTAL AL AÑO \\
\hline SUM 1 & 90.00 & 45 & $\$ 8.00$ & $\$ 360.00$ & 16 & $\$ 5,760.00$ & $\$ 69,120.00$ \\
\hline SUM 2 & 70.00 & 35 & $\$ 8.00$ & $\$ 280.00$ & 16 & $\$ 4,480.00$ & $\$ 53,760.00$ \\
\hline SUM 3 & 88.00 & 44 & $\$ 8.00$ & $\$ 352.00$ & 16 & $\$ 5,632.00$ & $\$ 67,584.00$ \\
\hline SUM 4 & 130.00 & 65 & $\$ 8.00$ & $\$ 520.00$ & 16 & $\$ 8,320.00$ & $\$ 99,840.00$ \\
\hline Terraza & 555.00 & 222 & $\$ 2.50$ & $\$ 555.00$ & 16 & $\$ 8,880.00$ & $\$ 106,560.00$ \\
\hline
\end{tabular}

Si bien la sala de Exposiciones del Monolito tendrá salas de exposición permanente y de ingreso libre, se considera, además, su uso para eventos de lanzamientos o inauguraciones. Estos generarán ingresos esporádicos, para garantizar su mantenimiento. En base a esto, la sala de exposiciones nos muestra un ingreso según aforo, cobrando un precio de USD\$ 10.00 dólares por persona para ingresar a la exposición especial y, considerando un uso de 8 días al mes por sala, obtenemos un valor de ingreso de USD\$164,518 .00 al año. Se puede ver el detalle en el cuadro siguiente.

\begin{tabular}{|l|r|r|r|r|r|r|r|r|}
\hline \multicolumn{1}{|c|}{ PROGRAMA } & $\begin{array}{c}\text { AREA/ } \\
\text { PROGRAMA (M2) }\end{array}$ & AFORO & $\begin{array}{c}\text { ALQUILER } \\
\text { POR AFORO } \\
\text { POR DIA }\end{array}$ & $\begin{array}{c}\text { SUB TOTAL } \\
\text { POR DIA }\end{array}$ & $\begin{array}{c}\text { USO AL MES o } \\
\text { COSTO POR MES }\end{array}$ & SUB TOTAL MES & TOTAL AL AÑO & total \\
\hline Exposiciones & 310.12 & 103 & $\$ 10.00$ & $\$ 1,033.73$ & 8 & $\$ 8,269.87$ & $\$ 99,238.40$ \\
\hline Exposiciones & 204.00 & 68 & $\$ 10.00$ & $\$ 680.00$ & 8 & $\$ 164,518.40$ \\
\hline
\end{tabular}

Para las aulas y talleres, se ha tomado en cuenta el precio de cursos en otros Centros Culturales, como el de la PUCP y los cursos del MATE. Sin embargo, el CCB plantea ser accesible a un gran público, y los costos por curso, serán menores a los del mercado actual. Se considera el aforo de los espacios, cobrando un precio mensual por las clases o talleres a recibir. Luego se obtiene el ingreso mensual y al anual, como se ve en los cuadros.

\begin{tabular}{|l|r|r|r|r|r|r|}
\hline \multicolumn{1}{|c|}{ PROGRAMA } & $\begin{array}{c}\text { AREA / } \\
\text { PROGRAMA (M2) }\end{array}$ & AFORO & $\begin{array}{c}\text { USO AL MES o } \\
\text { COSTO POR MES }\end{array}$ & $\begin{array}{c}\text { SUB TOTAL } \\
\text { MES }\end{array}$ & $\begin{array}{c}\text { TOTAL AL } \\
\text { AÑO }\end{array}$ & total \\
\cline { 1 - 5 } Aula 1 & 117.30 & 23 & $\$ 40.00$ & $\$ 938.40$ & $\$ 11,260.80$ & \\
\cline { 1 - 5 } Aula 2 & 88.00 & 18 & $\$ 40.00$ & $\$ 704.00$ & $\$ 8,448.00$ & $\$ 32,620.80$ \\
\hline Aula 3 & 134.50 & 27 & $\$ 40.00$ & $\$ 1,076.00$ & $\$ 12,912.00$ & \\
\hline
\end{tabular}




\begin{tabular}{|c|c|c|c|c|c|c|}
\hline PROGRAMA & $\begin{array}{c}\text { AREA/ } \\
\text { PROGRAMA (M2) }\end{array}$ & AFORO & $\begin{array}{c}\text { USO AL MES O } \\
\text { COSTO POR MES }\end{array}$ & $\begin{array}{l}\text { SUB TOTAL } \\
\text { MES }\end{array}$ & $\begin{array}{l}\text { TOTAL AL } \\
\text { AÑO }\end{array}$ & total \\
\hline Taller de arte 1 & 134.00 & 13 & $\$ 50.00$ & $\$ 670.00$ & $\$ 8,040.00$ & \multirow{3}{*}{$\$ 26,610.00$} \\
\hline Taller de arte 2 & 116.00 & 12 & $\$ 50.00$ & $\$ 580.00$ & $\$ 6,960.00$ & \\
\hline Taller de arte 3 & 193.50 & 19 & $\$ 50.00$ & $\$ 967.50$ & $\$ 11,610.00$ & \\
\hline
\end{tabular}

En las zonas del Co-working, los afiliados tendrán acceso a todos los servicios y espacios disponibles. Se les proveerá de materiales básicos, Internet wi-fi, cafetería libre, salas de reuniones, entre otros. Se considera el aforo de 187 personas, incluyendo terrazas, a un precio mensual de $\$ 100$ a $\$ 200$ dólares de alquiler de espacio, resultando en un ingreso al año de USD\$ 5,597,480.00. Los espacios netamente de artistas tienen un menor costo que aquellos con espacios de oficina corporativa. Este ingreso es importante para el CCB:

\begin{tabular}{|c|c|c|c|c|c|c|c|c|}
\hline NIVEL & $\begin{array}{l}\text { AREA TOTAL } \\
\text { (M2) }\end{array}$ & PROGRAMA & $\begin{array}{c}\text { AREA/ } \\
\text { PROGRAMA (M2) }\end{array}$ & AFORO & $\begin{array}{c}\text { USO AL MES O } \\
\text { COSTO POR } \\
\text { MES }\end{array}$ & $\begin{array}{c}\text { SUB TOTAL } \\
\text { MES }\end{array}$ & TOTAL AL AÑO & total \\
\hline PLANTA 8 & \multirow{2}{*}{492.33} & Terraza & 128.33 & 51 & $\$ 200.00$ & $\$ 10,266.40$ & $\$ 2,053,280.00$ & \multirow{2}{*}{$\$ 4,965,280.00$} \\
\hline COWORKING & & Área de mesas & 364.00 & 73 & $\$ 200.00$ & $\$ 14,560.00$ & $\$ 2,912,000.00$ & \\
\hline PLANTA 9 & \multirow{2}{*}{412.30} & Terraza & 73.30 & 29 & $\$ 100.00$ & $\$ 2,932.00$ & $\$ 293,200.00$ & \multirow{2}{*}{$\$ 632,200.00$} \\
\hline COWORKING & & Área de trabajo y dę & 339.00 & 34 & $\$ 100.00$ & $\$ 3,390.00$ & $\$ 339,000.00$ & \\
\hline$-2=-1$ & & & & 187 & & & 19 & $\$ 5,597,480.00$ \\
\hline
\end{tabular}

\subsubsection{Cuadro resumen de ingresos del proyecto}

Para el proyecto del CCB se está considerando 220 meses de operación dando un ingreso de \$151 689027.18 dólares en 220 meses.

\begin{tabular}{|c|c|c|c|}
\hline \multicolumn{4}{|l|}{ INGRESOS } \\
\hline Alquileres & años & ingreso \$/año & ingreso $\$$ total \\
\hline Estacionamiento & $\begin{array}{l} \\
4 \\
\end{array}$ & $623,168.00$ & $11,528,608.00$ \\
\hline Edificio Tótem - Comercio & 18.5 & $528,300.00$ & $9,773,550.00$ \\
\hline+140 & 18.5 & $396,864.00$ & $7,341,984.00$ \\
\hline Aulas edificio Tótem & 18.5 & $32,620.80$ & $603,484.80$ \\
\hline Talleres edificio Tótem & 18.5 & $26,610.00$ & $492,285.00$ \\
\hline Co-working & 18.5 & $5,875,648.00$ & $108,699,488.00$ \\
\hline Edificio Monolito - Comercio & 18.5 & $1,131,480.00$ & $20,932,380.00$ \\
\hline Edificio Monolito - Exposicion & 18.5 & $164,518.40$ & $3,043,590.40$ \\
\hline Edificio Monolito - Auditorio & 18.5 & $648,000.00$ & $11,988,000.00$ \\
\hline TOTAL DE VENTA & & & $174,403,370.20$ \\
\hline
\end{tabular}

\begin{tabular}{|l|r|r|r|}
\hline UTILIDAD bruta & \multicolumn{2}{|c|}{} & $\mathbf{\$ 1 3 7 , 8 0 7 , 9 3 1 . 7 8}$ \\
\hline Impuesto & $30 \%$ & & $-\$ 41,342,379.53$ \\
\hline UTILIDAD NETA & & & $\mathbf{\$ 9 6 , 4 6 5 , 5 5 2 . 2 5}$ \\
\hline
\end{tabular}




\subsubsection{Análisis estático del CCB}

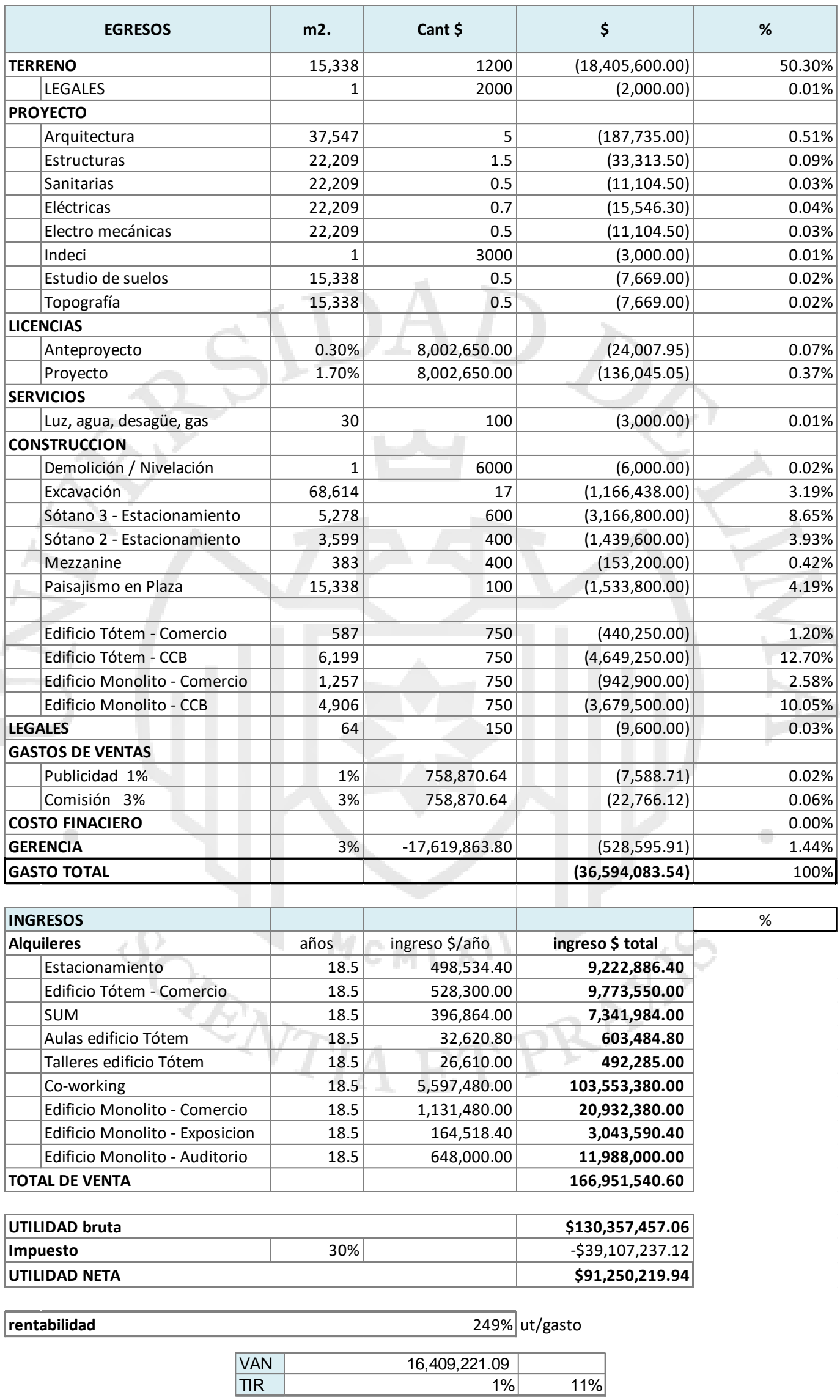




\subsubsection{Flujo de caja.}

A continuación, se muestra el cuadro completo del flujo de caja correspondiente al proyecto Centro Cultural en la Estación Plaza las Flores de Barranco.

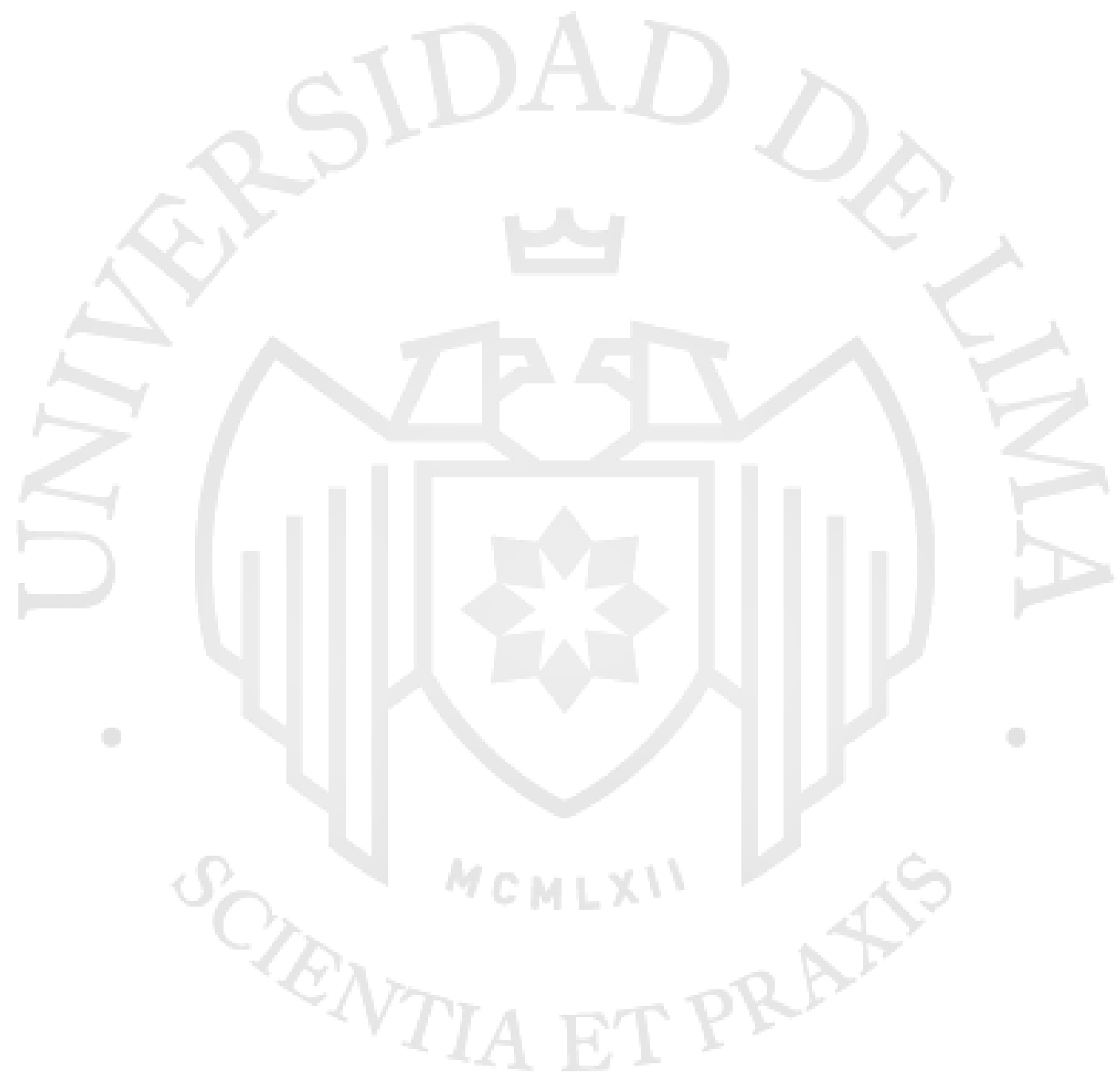




\begin{tabular}{|c|c|c|c|c|}
\hline MES & INGRESOS & FLUJO DE GASTO & $\begin{array}{l}\text { FLUJO DE CAJA } \\
\text { ECONOMICO }\end{array}$ & $\begin{array}{l}\text { FLUJO DE CAJA } \\
\text { ACUMULADO }\end{array}$ \\
\hline 0 & 0.00 & $-18,576,832.61$ & $-18,576,832.61$ & $-18,576,832.61$ \\
\hline 1 & 0.00 & $-265,054.20$ & $-265,054.20$ & $-18,841,886.81$ \\
\hline 2 & 0.00 & $-244,716.20$ & $-244,716.20$ & $-19,086,603.01$ \\
\hline 3 & 0.00 & $-273,143.72$ & $-273,143.72$ & $-19,359,746.73$ \\
\hline 4 & 0.00 & $-244,716.20$ & $-244,716.20$ & $-19,604,462.93$ \\
\hline 5 & 0.00 & $-240,423.73$ & $-240,423.73$ & $-19,844,886.66$ \\
\hline 6 & 0.00 & $-445,661.95$ & $-445,661.95$ & $-20,290,548.61$ \\
\hline 7 & 0.00 & $-208,582.45$ & $-208,582.45$ & $-20,499,131.06$ \\
\hline 8 & 0.00 & $-1,364,220.45$ & $-1,364,220.45$ & $-21,863,351.50$ \\
\hline 9 & 0.00 & $-3,364,582.45$ & $-3,364,582.45$ & $-25,227,933.95$ \\
\hline 10 & 0.00 & $-197,782.45$ & $-197,782.45$ & $-25,425,716.40$ \\
\hline 11 & 0.00 & $-1,637,382.45$ & $-1,637,382.45$ & $-27,063,098.85$ \\
\hline 12 & 0.00 & $-350,982.45$ & $-350,982.45$ & $-27,414,081.30$ \\
\hline 13 & 0.00 & $-1,740,882.45$ & $-1,740,882.45$ & $-29,154,963.75$ \\
\hline 14 & 0.00 & $-1,740,882.45$ & $-1,740,882.45$ & $-30,895,846.20$ \\
\hline 15 & 0.00 & $=-1,747,332.85$ & $-1,747,332.85$ & $-32,643,179.05$ \\
\hline 16 & 0.00 & $-2,130,782.85$ & $-2,130,782.85$ & $-34,773,961.90$ \\
\hline 17 & $\begin{array}{l} \\
\end{array}$ & $-1,641,182.85$ & $-1,641,182.85$ & $-36,415,144.75$ \\
\hline 18 & $189,717.66$ & $-2,602,232.85$ & $-2,412,515.19$ & $-38,827,659.94$ \\
\hline 19 & $379,435.32$ & $-1,057,235.67$ & $-677,800.35$ & $-39,505,460.29$ \\
\hline 20 & $758,870.64$ & $-297,782.45$ & $461,088.19$ & $-39,044,372.10$ \\
\hline 21 & $-758,870.64$ & $-271,232.61$ & $487,638.03$ & $-38,556,734.07$ \\
\hline 22 & $758,870.64$ & $-271,232.61$ & $487,638.03$ & $-38,069,096.05$ \\
\hline 23 & $758,870.64$ & $-271,232.61$ & $487,638.03$ & $-37,581,458.02$ \\
\hline 24 & $758,870.64$ & $-271,232.61$ & $487,638.03$ & $-37,093,820.00$ \\
\hline 25 & $758,870.64$ & $-271,232.61$ & $487,638.03$ & $-36,606,181.97$ \\
\hline 26 & $758,870.64$ & $-271,232.61$ & $487,638.03$ & $-36,118,543.95$ \\
\hline 27 & $758,870.64$ & $-271,232.61$ & $487,638.03$ & $-35,630,905.92$ \\
\hline 28 & $758,870.64$ & $-271,232.61$ & $487,638.03$ & $-35,143,267.89$ \\
\hline 29 & $758,870.64$ & $-271,232.61$ & $487,638.03$ & $-34,655,629.87$ \\
\hline 30 & $758,870.64$ & $-271,232.61$ & $487,638.03$ & $-34,167,991.84$ \\
\hline 31 & $758,870.64$ & $-271,232.61$ & $487,638.03$ & $-33,680,353.82$ \\
\hline 32 & $758,870.64$ & $-271,232.61$ & $487,638.03$ & $-33,192,715.79$ \\
\hline 33 & $758,870.64$ & $-271,232.61$ & $487,638.03$ & $-32,705,077.77$ \\
\hline 34 & $758,870.64$ & $-271,232.61$ & $487,638.03$ & $-32,217,439.74$ \\
\hline 35 & $758,870.64$ & $-271,232.61$ & $487,638.03$ & $-31,729,801.72$ \\
\hline 36 & $758,870.64$ & $-271,232.61$ & $487,638.03$ & $-31,242,163.69$ \\
\hline 37 & $758,870.64$ & $-271,232.61$ & $487,638.03$ & $-30,754,525.66$ \\
\hline 38 & $758,870.64$ & $-271,232.61$ & $487,638.03$ & $-30,266,887.64$ \\
\hline 39 & $758,870.64$ & $-271,232.61$ & $487,638.03$ & $-29,779,249.61$ \\
\hline 40 & $758,870.64$ & $-271,232.61$ & $487,638.03$ & $-29,291,611.59$ \\
\hline 41 & $758,870.64$ & $-271,232.61$ & $487,638.03$ & $-28,803,973.56$ \\
\hline 42 & $758,870.64$ & $-271,232.61$ & $487,638.03$ & $-28,316,335.54$ \\
\hline 43 & $758,870.64$ & $-271,232.61$ & $487,638.03$ & $-27,828,697.51$ \\
\hline 44 & $758,870.64$ & $-271,232.61$ & $487,638.03$ & $-27,341,059.48$ \\
\hline 45 & $758,870.64$ & $-271,232.61$ & $487,638.03$ & $-26,853,421.46$ \\
\hline 46 & $758,870.64$ & $-271,232.61$ & $487,638.03$ & $-26,365,783.43$ \\
\hline 47 & $758,870.64$ & $-271,232.61$ & $487,638.03$ & $-25,878,145.41$ \\
\hline 48 & $758,870.64$ & $-271,232.61$ & $487,638.03$ & $-25,390,507.38$ \\
\hline 49 & $758,870.64$ & $-271,232.61$ & $487,638.03$ & $-24,902,869.36$ \\
\hline 50 & $758,870.64$ & $-271,232.61$ & $487,638.03$ & $-24,415,231.33$ \\
\hline 51 & $758,870.64$ & $-271,232.61$ & $487,638.03$ & $-23,927,593.31$ \\
\hline 52 & $758,870.64$ & $-271,232.61$ & $487,638.03$ & $-23,439,955.28$ \\
\hline 53 & $758,870.64$ & $-271,232.61$ & $487,638.03$ & $-22,952,317.25$ \\
\hline$=54$ & $758,870.64$ & $-271,232.61$ & $487,638.03$ & $-22,464,679.23$ \\
\hline 55 & $758,870.64$ & $-271,232.61$ & $487,638.03$ & $-21,977,041.20$ \\
\hline 56 & $758,870.64$ & $-271,232.61$ & $487,638.03$ & $-21,489,403.18$ \\
\hline 57 & $758,870.64$ & $-271,232.61$ & $487,638.03$ & $-21,001,765.15$ \\
\hline 58 & $758,870.64$ & $-271,232.61$ & $487,638.03$ & $-20,514,127.13$ \\
\hline 59 & $758,870.64$ & $-271,232.61$ & $487,638.03$ & $-20,026,489.10$ \\
\hline 60 & $758,870.64$ & $-271,232.61$ & $487,638.03$ & $-19,538,851.08$ \\
\hline 61 & $758,870.64$ & $-271,232.61$ & $487,638.03$ & $-19,051,213.05$ \\
\hline 62 & $758,870.64$ & $-271,232.61$ & $487,638.03$ & $-18,563,575.02$ \\
\hline 63 & $758,870.64$ & $-271,232.61$ & $487,638.03$ & $-18,075,937.00$ \\
\hline 64 & $758,870.64$ & $-271,232.61$ & $487,638.03$ & $-17,588,298.97$ \\
\hline 65 & $758,870.64$ & $-271,232.61$ & $487,638.03$ & $-17,100,660.95$ \\
\hline 66 & $758,870.64$ & $-271,232.61$ & $487,638.03$ & $-16,613,022.92$ \\
\hline 67 & $758,870.64$ & $-271,232.61$ & $487,638.03$ & $-16,125,384.90$ \\
\hline 68 & $758,870.64$ & $-271,232.61$ & $487,638.03$ & $-15,637,746.87$ \\
\hline 69 & $758,870.64$ & $-271,232.61$ & $487,638.03$ & $-15,150,108.84$ \\
\hline 70 & $758,870.64$ & $-271,232.61$ & $487,638.03$ & $-14,662,470.82$ \\
\hline 71 & $758,870.64$ & $-271,232.61$ & $487,638.03$ & $-14,174,832.79$ \\
\hline 72 & $758,870.64$ & $-271,232.61$ & $487,638.03$ & $-13,687,194.77$ \\
\hline 73 & $758,870.64$ & $-271,232.61$ & $487,638.03$ & $-13,199,556.74$ \\
\hline 74 & $758,870.64$ & $-271,232.61$ & $487,638.03$ & $-12,711,918.72$ \\
\hline 75 & $758,870.64$ & $-271,232.61$ & $487,638.03$ & $-12,224,280.69$ \\
\hline 76 & $758,870.64$ & $-271,232.61$ & $487,638.03$ & $-11,736,642.67$ \\
\hline 77 & $758,870.64$ & $-271,232.61$ & $487,638.03$ & $-11,249,004.64$ \\
\hline
\end{tabular}




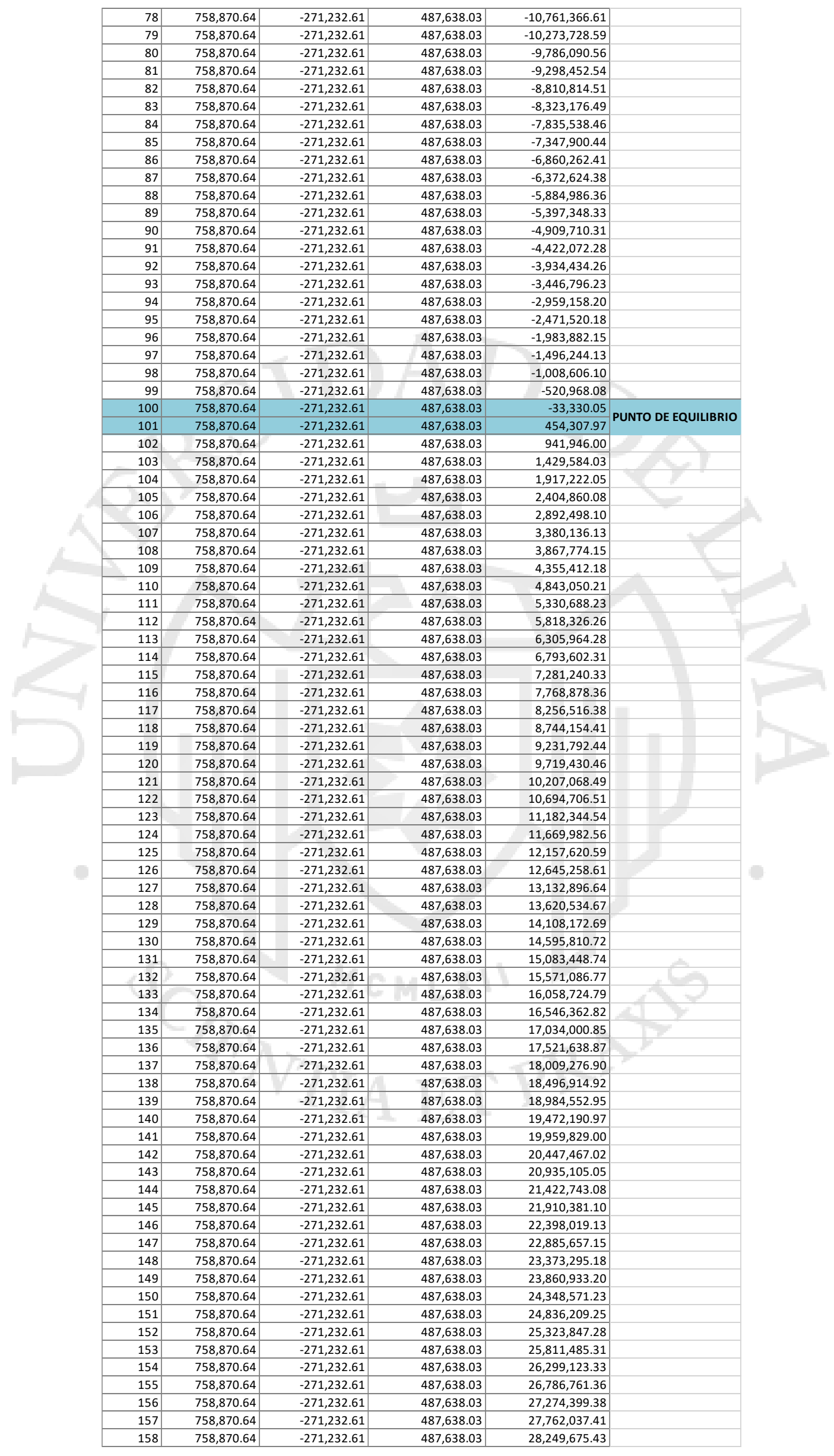




\begin{tabular}{|c|c|c|c|c|}
\hline 159 & $758,870.64$ & $-271,232.61$ & $487,638.03$ & $28,737,313.46$ \\
\hline 160 & $758,870.64$ & $-271,232.61$ & $487,638.03$ & $29,224,951.49$ \\
\hline 161 & $758,870.64$ & $-271,232.61$ & $487,638.03$ & $29,712,589.51$ \\
\hline 162 & $758,870.64$ & $-271,232.61$ & $487,638.03$ & $30,200,227.54$ \\
\hline 163 & $758,870.64$ & $-271,232.61$ & $487,638.03$ & $30,687,865.56$ \\
\hline 164 & $758,870.64$ & $-271,232.61$ & $487,638.03$ & $31,175,503.59$ \\
\hline 165 & $758,870.64$ & $-271,232.61$ & $487,638.03$ & $31,663,141.61$ \\
\hline 166 & $758,870.64$ & $-271,232.61$ & $487,638.03$ & $32,150,779.64$ \\
\hline 167 & $758,870.64$ & $-271,232.61$ & $487,638.03$ & $32,638,417.66$ \\
\hline 168 & $758,870.64$ & $-271,232.61$ & $487,638.03$ & $33,126,055.69$ \\
\hline 169 & $758,870.64$ & $-271,232.61$ & $487,638.03$ & $33,613,693.72$ \\
\hline 170 & $758,870.64$ & $-271,232.61$ & $487,638.03$ & $34,101,331.74$ \\
\hline 171 & $758,870.64$ & $-271,232.61$ & $487,638.03$ & $34,588,969.77$ \\
\hline 172 & $758,870.64$ & $-271,232.61$ & $487,638.03$ & $35,076,607.79$ \\
\hline 173 & $758,870.64$ & $-271,232.61$ & $487,638.03$ & $35,564,245.82$ \\
\hline 174 & $758,870.64$ & $-271,232.61$ & $487,638.03$ & $36,051,883.84$ \\
\hline 175 & $758,870.64$ & $-271,232.61$ & $487,638.03$ & $36,539,521.87$ \\
\hline 176 & $758,870.64$ & $-271,232.61$ & $487,638.03$ & $37,027,159.89$ \\
\hline 177 & $758,870.64$ & $-271,232.61$ & $487,638.03$ & $37,514,797.92$ \\
\hline 178 & $758,870.64$ & $-271,232.61$ & $487,638.03$ & $38,002,435.95$ \\
\hline $\begin{array}{r}179 \\
\end{array}$ & $758,870.64$ & $-271,232.61$ & $487,638.03$ & $38,490,073.97$ \\
\hline 180 & $758,870.64$ & $-271,232.61$ & $487,638.03$ & $38,977,712.00$ \\
\hline 181 & $758,870.64$ & $-271,232.61$ & $487,638.03$ & $39,465,350.02$ \\
\hline 182 & $758,870.64$ & $-271,232.61$ & $487,638.03$ & $39,952,988.05$ \\
\hline 183 & $758,870.64$ & $-271,232.61$ & $487,638.03$ & $40,440,626.07$ \\
\hline 184 & $758,870.64$ & $-271,232.61$ & $487,638.03$ & $40,928,264.10$ \\
\hline 185 & $758,870.64$ & $-271,232.61$ & $487,638.03$ & $41,415,902.13$ \\
\hline 186 & $758,870.64$ & $-271,232.61$ & $487,638.03$ & $41,903,540.15$ \\
\hline 187 & $758,870.64$ & $-271,232.61$ & $487,638.03$ & $42,391,178.18$ \\
\hline 188 & $758,870.64$ & $-271,232.61$ & $487,638.03$ & $42,878,816.20$ \\
\hline 189 & $758,870.64$ & $-271,232.61$ & $487,638.03$ & $43,366,454.23$ \\
\hline 190 & $758,870.64$ & $-271,232.61$ & $487,638.03$ & $43,854,092.25$ \\
\hline 191 & $758,870.64$ & $-271,232.61$ & $487,638.03$ & $44,341,730.28$ \\
\hline 192 & $758,870.64$ & $-271,232.61$ & $487,638.03$ & $44,829,368.30$ \\
\hline 193 & $758,870.64$ & $-271,232.61$ & $487,638.03$ & $45,317,006.33$ \\
\hline 194 & $758,870.64$ & $-271,232.61$ & $487,638.03$ & $45,804,644.36$ \\
\hline 195 & $758,870.64$ & $-271,232.61$ & $487,638.03$ & $46,292,282.38$ \\
\hline 196 & $758,870.64$ & $-271,232.61$ & $487,638.03$ & $46,779,920.41$ \\
\hline 197 & $758,870.64$ & $-271,232.61$ & $487,638.03$ & $47,267,558.43$ \\
\hline 198 & $758,870.64$ & $-271,232.61$ & $487,638.03$ & $47,755,196.46$ \\
\hline 199 & $758,870.64$ & $-271,232.61$ & $487,638.03$ & $48,242,834.48$ \\
\hline 200 & $758,870.64$ & $-271,232.61$ & $487,638.03$ & $48,730,472.51$ \\
\hline 201 & $758,870.64$ & $-271,232.61$ & $487,638.03$ & $49,218,110.53$ \\
\hline 202 & $758,870.64$ & $-271,232.61$ & $487,638.03$ & $49,705,748.56$ \\
\hline 203 & $758,870.64$ & $-271,232.61$ & $487,638.03$ & $50,193,386.59$ \\
\hline 204 & $758,870.64$ & $-271,232.61$ & $487,638.03$ & $50,681,024.61$ \\
\hline 205 & $758,870.64$ & $-271,232.61$ & $487,638.03$ & $51,168,662.64$ \\
\hline 206 & $758,870.64$ & $-271,232.61$ & $487,638.03$ & $51,656,300.66$ \\
\hline 207 & $758,870.64$ & $-271,232.61$ & $487,638.03$ & $52,143,938.69$ \\
\hline 208 & $758,870.64$ & $-271,232.61$ & $487,638.03$ & $52,631,576.71$ \\
\hline 209 & $758,870.64$ & $-271,232.61$ & $487,638.03$ & $53,119,214.74$ \\
\hline 210 & $758,870.64$ & $-271,232.61$ & $487,638.03$ & $53,606,852.77$ \\
\hline 211 & $758,870.64$ & $-271,232.61$ & $487,638.03$ & $54,094,490.79$ \\
\hline 212 & $758,870.64$ & $-271,232.61$ & $487,638.03$ & $54,582,128.82$ \\
\hline 213 & $758,870.64$ & $-271,232.61$ & $487,638.03$ & $55,069,766.84$ \\
\hline 214 & $758,870.64$ & $-271,232.61$ & $487,638.03$ & $55,557,404.87$ \\
\hline 215 & $758,870.64$ & $-271,232.61$ & $487,638.03$ & $56,045,042.89$ \\
\hline 216 & $758,870.64$ & $-271,232.61$ & $487,638.03$ & $56,532,680.92$ \\
\hline 217 & $758,870.64$ & $-271,232.61$ & $487,638.03$ & $57,020,318.94$ \\
\hline 218 & $758,870.64$ & $-271,232.61$ & $487,638.03$ & $57,507,956.97$ \\
\hline 219 & $758,870.64$ & $-271,232.61$ & $487,638.03$ & $57,995,595.00$ \\
\hline \multirow[t]{3}{*}{220} & $758,870.64$ & $-271,232.61$ & $487,638.03$ & $58,483,233.02$ \\
\hline & VAN & & 16409221.09 & \\
\hline & TIR & $1 \%$ & $11 \%$ & \\
\hline
\end{tabular}




\subsubsection{Conclusiones parciales.}

El proyecto del CCB, será construido en una sola etapa de 20 meses con la inversión de USD \$ 36,676,510.83 por Intercorp. Luego, será administrado por este, por 18.5 años y generará un ingreso de USD\$58,483,233.02 al finalizar los 220 meses. A partir de este mes, el acumulado de ganancias será mayor, puesto que el crédito bancario ya fue cancelado en su totalidad.

La Tasa Interna de Retorno muestra un $11 \%$, indicando que existe un porcentaje de retorno y el proyecto es económicamente viable. Sin embargo, el bajo porcentaje se debe a que el proyecto busca brindar programas accesibles a todos los niveles socioeconómicos. Es decir, las ganancias provenientes del programa del CCB, deberán provenir de cursos y alquileres por debajo del mercado actual, al que algunos artistas y espectadores no pueden acceder. Se espera que, además, impulsadores y gestores culturales importantes generen ganancias adicionales al CCB sin perjudicar al público objetivo.

Esto es el resumen de ingresos netamente relacionados al CCB. Sin embargo, Intercorp podría tener beneficios a manera de efectos secundarios. Tales son el marketing positivo, y la posibilidad de ofrecer a los usuarios del CCB promociones exclusivas mediante el uso de la tarjeta Interbank. Además, es conocido que Intercorp ha invertido recientemente en impulsar la educación de calidad en centros como la Universidad Tecnológica del Perú. Es conocido, entonces, que el grupo mantiene interés por la inversión en educación accesible y de calidad. En este caso, apostaría por la educación dirigida a las artes. 


\subsection{Memoria descriptiva de estructuras.}

El Centro Cultural En La Estación Plaza Las Flores de Barranco se construyó con una estructura porticada de concreto de vigas rectangulares y columnas circulares que varían su sección cuando están en pisos superiores del edificio Tótem.

Es importante la sección circular en la primera planta, donde la planta libre funciona a manera de sala hipóstila de paseo peatonal y funciones múltiples. A partir de la segunda planta, las columnas centrales toman forma rectangular, para quedar alineadas con los muros y generar espacios arquitectónicamente 'limpios'. Las columnas en esquinas se mantienen circulares pues, en la mayoría de las plantas, los bordes del edificio son circulaciones.

Se muestra una vista de la 3ra Planta del Edificio Tótem en la imagen siguiente:

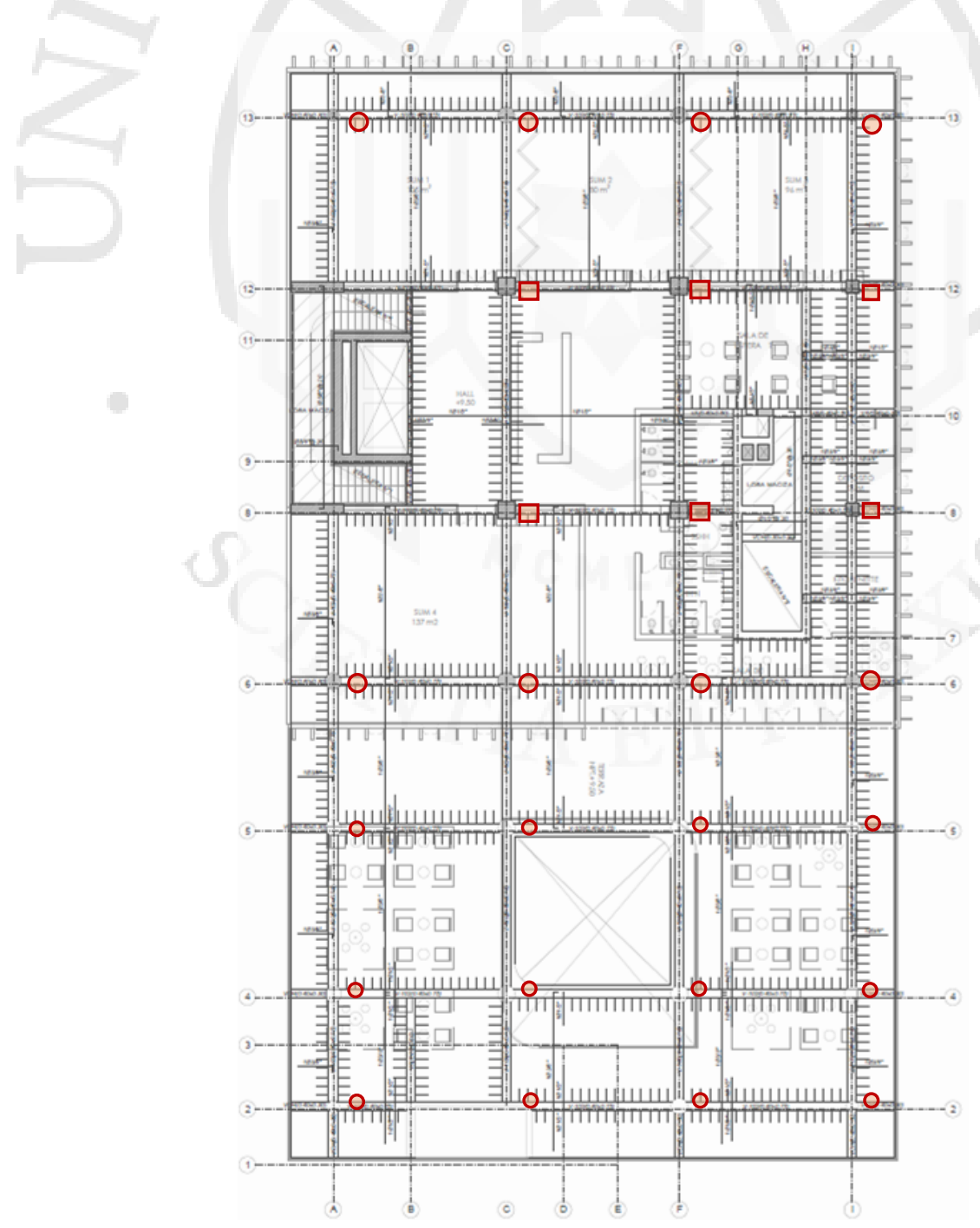


La cimentación del proyecto está compuesta por zapatas aisladas y zapatas excéntricas conectadas mediante vigas de cimentación (ver Planos E-01). Todos los elementos de la cimentación son de concreto armado, y las zapatas tienen una altura mínima de $1.60 \mathrm{~m}$ y las vigas de cimentación son de sección de 0.40 x 0.70m.

El tipo de suelo para esta cimentación se obtuvo del estudio de suelos, el cual indica un suelo tipo GP (SUCS) de grava arenosa, y con una resistencia de presión admisible del suelo de $4 \mathrm{Kg} / \mathrm{cm} 2$.

Los pórticos estructurales de concreto armado están formados por las vigas de techo, que tienen una base que va desde $10 \mathrm{~s} 0.30 \mathrm{~m}$ a $0.40 \mathrm{~m}$ de ancho, y un peralte que va desde $0.40 \mathrm{~m}$ a $0.95 \mathrm{~m}$ de altura. Las columnas de concreto de los pórticos son circulares, de diámetro variable en altura que va desde los $0.55 \mathrm{~m}$ a $1.10 \mathrm{~m}$. Las columnas cuadradas de concreto armado son variables en altura y nacen de las columnas circulares de los pisos inferiores. Las secciones de estas columnas cuadradas varían en su base desde $1050.60 \mathrm{~m}$ a $0.80 \mathrm{~m}$ y su peralte varía desde $0.60 \mathrm{~m}$ a $0.80 \mathrm{~m}$.

El techo de todos los pisos es una losa aligerada que transfiere las cargas de gravedad hacia las vigas y estas a su vez, a las columnas. La losa aligerada es de 20 $\mathrm{cm}$ con ladrillos de arcilla de que se conectan mediante viguetas de concreto armado de ancho de $10 \mathrm{~cm} \mathrm{y}$, sobre ellas, hay una losa de $5 \mathrm{~cm}$ con refuerzos de acero corrugado.

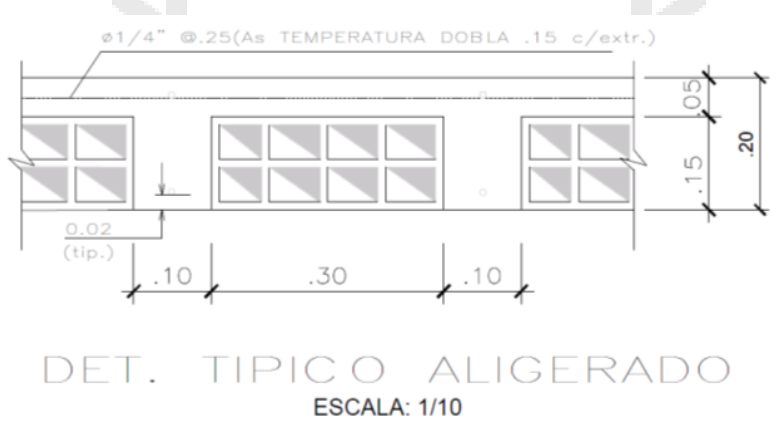

Plano: Detalle Losa Aligerada

Para este proyecto, los muros de albañilería y los paneles divisorios se consideran como peso en la estructura, pero no se considera su aporte estructural en la rigidez de la estructura. 
Finalmente, los elementos estructurales usados para la caja de los ascensores y escaleras son placas de concreto armado que, en conjunto con las vigas y columnas, complementan los pórticos como sistema estructural aportando mayor rigidez lateral.

\subsection{Memoria descriptiva de instalaciones eléctricas}

El proyecto cuenta con una subestación de baja tensión, desde donde se distribuye y abastece a ambos edificios del Centro Cultural y la Plaza. Esta se encuentra ubicada en el sótano de nivel $-13.00 \mathrm{~m}$, con acceso desde la rampa de estacionamiento, hasta el patio de maniobras.

En el terreno del proyecto, no existía una subestación que centralizara la energía. Es por ello, que se define la ubicación en base al mejor acceso peatonal y vehicular. Se ubica en un espacio técnico del estacionamiento (nivel $-13.00 \mathrm{~m}$ ) donde se ubican los controles sanitarios y electromecánicos del proyecto. Junto a la subestación, se ubica el cuarto de tableros y el grupo electrógeno general. Al necesitar un amplio espacio para los equipos, se ubican en el sótano, donde no interfieran con los espacios continuos y abiertos sobre el nivel del suelo.

A continuación, se muestra el plano del Área técnica, ubicada en el nivel -13.00. $\mathrm{Y}$, en naranja, los espacios mencionados en orden de izquierda a derecha.

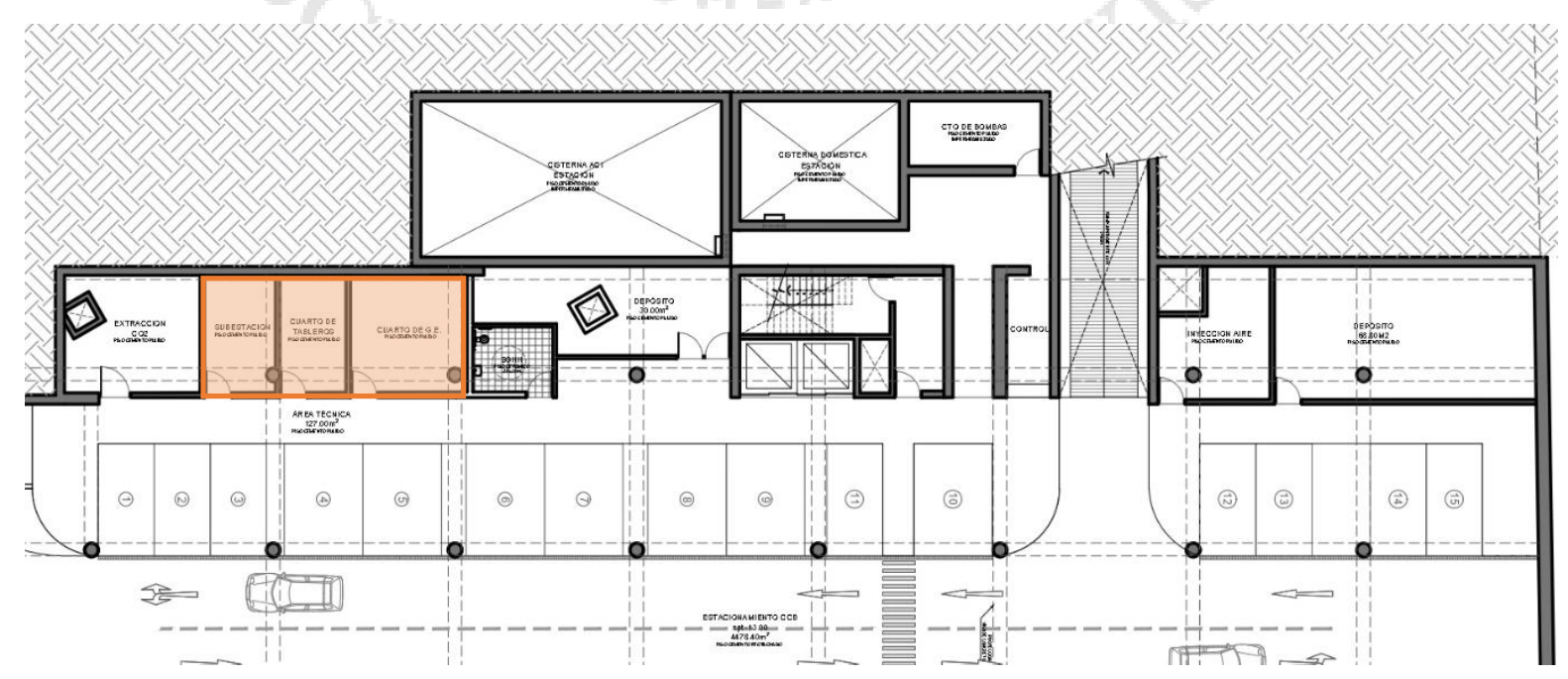


Para el cálculo de la potencia contratada se tomó en cuenta el área techada (W/m2), y la cantidad de equipos eléctricos y mecánicos, teniendo en consideración los factores de demanda respectivos de acuerdo con Código Nacional de Electricidad Utilización.

El tablero eléctrico general TG alimenta a los tableros eléctricos de distribución TD-1 y TD-2 ubicados en la primera planta de cada edificio, y en las plantas superiores, para alimentación de los circuitos de iluminación, tomacorrientes y de fuerza.

Los tableros eléctricos están diseñados para empotrar y no interferir los pasillos y espacios, equipado con interruptores de fuerza e interruptores termomagnéticos de capacidad adecuada a los equipos que alimentan. Todos los tableros eléctricos se ubican en el cuarto eléctrico diseñado para el ingreso solo del personal técnico de mantenimiento, ubicado en el sótano npt. -13.00.

El cableado eléctrico fue diseñado de acuerdo a la normativa vigente y es del tipo y sección de acuerdo a la carga que alimenta.

Los equipos de iluminación consideran la tecnología led y la iluminación de los ambientes proyectados velan por la calidad, la intensidad, la dirección y el contraste equilibrado de la luz y disponen de una iluminación uniforme sobre el plano de trabajo y áreas de comercio.

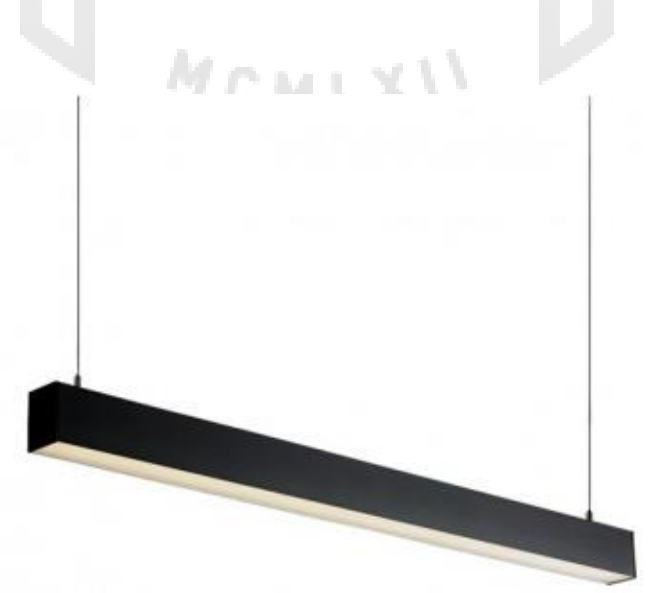

Imagen: Luminaria considerada en espacios de trabajo colgante tipo aluminio, LED.

Fuente: Led Studio 
Los niveles de iluminación fueron determinadas según las tablas indicadas en el Reglamento Nacional de Edificaciones. Se ha empleado el sistema de iluminación directa con artefactos led para interior y exteriores.

\begin{tabular}{|l|c|c|}
\hline \multicolumn{1}{|c|}{ AMBIENTES } & $\begin{array}{c}\text { ILUMINANCIA } \\
\text { EN SERVICIO } \\
\text { (lux) }\end{array}$ & CALIDAD \\
\hline $\begin{array}{l}\text { Áreas generales en edificios } \\
\text { Pasillos, corredores }\end{array}$ & 100 & $\mathrm{D}-\mathrm{E}$ \\
Baños & 100 & $\mathrm{C}-\mathrm{D}$ \\
Almacenes en tiendas & 100 & $\mathrm{D}-\mathrm{E}$ \\
Escaleras & 150 & $\mathrm{C}-\mathrm{D}$ \\
\hline \multicolumn{2}{|l|}{} \\
\hline Oficinas & 200 & $\mathrm{C}-\mathrm{D}$ \\
Archivos & 300 & $\mathrm{~A}-\mathrm{B}$ \\
Salas de conferencia & 500 & $\mathrm{~A}-\mathrm{B}$ \\
Oficinas generales y salas de cómputo & 750 & $\mathrm{~A}-\mathrm{B}$ \\
Oficinas con trabajo intenso & 1000 & $\mathrm{~A}-\mathrm{B}$ \\
\hline
\end{tabular}

\begin{tabular}{|l|l|l|}
\hline Centros de enseñanza & & \\
\hline Salas de lectura & 300 & A - B \\
Salones de clase, laboratorios, talleres, gimnasios & 500 & A - B \\
\hline
\end{tabular}

\begin{tabular}{|l|l|l|}
\hline Tiendas & 300 & B - C \\
Tiendas convencionales & 500 & B - C \\
Tiendas de autoservicio & 750 & B - C \\
\hline Tiendas de exhibición & & \\
\hline Edificios Públicos & 150 & B - C \\
Salas de cine & 200 & B - C \\
Salas de conciertos y teatros & 300 & B - C \\
\hline Museos y galerias de arte & & \\
\hline Iglesias & \\
\hline
\end{tabular}

Tabla: Iluminancia para espacios al interior, RNE.

Los circuitos de tomacorrientes se han distribuido a cada ambiente, a los equipos ubicados, con toma a tierra para garantizar la seguridad de las personas y equipos y serán empotrados y adosados de acuerdo con la zona de distribución

El proyecto contempla la instalación de artefactos de iluminación de emergencia ubicados en las salidas de evacuación tal como se indica en los planos de seguridad respectivos y estarán conectadas al circuito de iluminación considerados en el Centro Cultural.

El sistema de puesta a tierra está diseñado para conectarse a los tableros eléctricos de distribución proyectados mediante un cable desnudo de cobre. 


\subsection{Memoria descriptiva de instalaciones sanitarias.}

Al tratarse de un proyecto vertical con variaciones significativas de niveles, se contemplan instalaciones sanitarias que trasladan y soportan grandes presiones de agua. Por este motivo se ha implementado un único núcleo central de cisternas para el abastecimiento de agua potable y agua contra incendios ubicado en el estacionamiento del proyecto (NPT -13.00), desde cual se abastece a todos los niveles de la edificación, mediante tuberías troncales y montantes convenientemente proyectadas.

Al igual que las demás especialidades, fueron ubicadas en este sótano por corresponder al CCB, y no a la estación del Metropolitano (NPT -9.00). Sin embargo, es posible abastecer de servicios a la estación en caso se requiera.

El núcleo está conformado por una cisterna de agua potable (Cisterna 1), una cisterna de agua contra incendios (CACI 1), un cuarto de bombas, un cuarto de tableros eléctricos y los ductos que contienen las montantes de distribución. A continuación, se muestra la distribucion en el Área técnica (npt -13.00), de la Cisterna CACI 1, la Cisterna 1, y el Cuarto de bombas (en naranja, de izquierda a derecha)

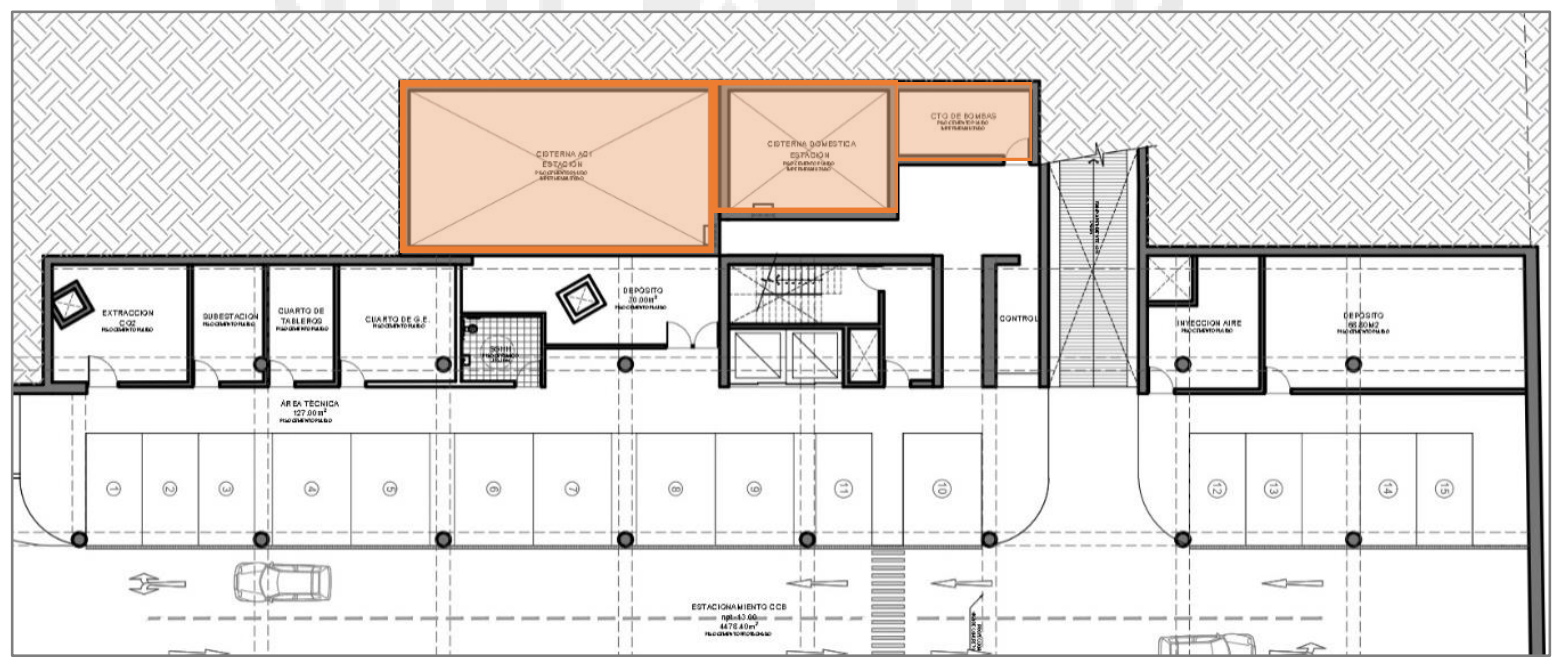

El abastecimiento de agua hacia la cisterna se da directamente desde la red pública, no sin antes pasar a través de su medidor ubicado de forma accesible dentro del anillo público exterior. 
Para el cálculo de la dotación diaria de agua potable se utilizaron los valores específicos asignados por el Reglamento Nacional de Edificaciones para cada uso y se multiplicaron por la cantidad de metros cuadrados y/o aforo. Para obtener la capacidad final de la cisterna, los valores se multiplicaron por un factor de seguridad de 2.0 , con la finalidad de conseguir una autonomía de dos días.

\begin{tabular}{|l|l|}
\hline TIPO DE ESTABLECIMIENTO & DOTACION DIARIA \\
\hline Cines, teatros y auditorios & $3 \mathrm{~L}$ por asiento \\
\hline Circos, hipódromos, parques de atracción y similares & $1 \mathrm{~L} \mathrm{por} \mathrm{espectador}$ \\
\hline Comedores de hasta 40m2 & $2000 \mathrm{~L}$ \\
\hline Comedores de 41 a $100 \mathrm{~m} 2$ & $50 \mathrm{~L} \mathrm{por} \mathrm{m2}$ \\
\hline Comedores de más de 100m2 & $40 \mathrm{~L}$ por m2 \\
\hline Oficinas & $6 \mathrm{~L} / \mathrm{d}$ por m2 útil \\
\hline Depósitos & $0,50 \mathrm{~L} / \mathrm{d}$ por m2 útil \\
\hline Locales comerciales de mercancía seca & $6 \mathrm{~L} / \mathrm{d}$ por m2 útil \\
\hline Fuente: NORMA IS.010. Reglamento Nacional de edificaciones, 2006. \\
\hline
\end{tabular}

De igual forma, el dimensionamiento de la cisterna de agua contra incendio se realizó tomando en cuenta que la Edificación será clasificada con riego ligero, por lo cual se ha previsto solo el uso de las áreas que son atendidas mediante gabinetes contra incendio, según lo que indica el RNE. A130.

El cuarto de bombas está compuesto por tres grupos de electrobombas con una función específica. En primer lugar, cuatro electrobombas de presión constante y velocidad variable para abastecer el sistema de agua potable, dos de las cuales se encuentran en funcionamiento y las otras dos son de respaldo. De forma similar el sistema de agua contra incendio está suministrado por una electrobomba principal contra incendio y su respectiva electrobomba sostenedora de presión (jockey). Finalmente, se colocaron dos electrobombas sumidero para el desagüe del sótano y limpieza de cisternas. Todas conectadas y administradas desde un área de tableros eléctricos.

La cantidad de aparatos necesarios para los servicios higiénicos de cada zona se calcularon en base a las tablas del reglamento nacional de edificaciones. Estos se encuentran organizados en zonas húmedas a poca distancia de los ductos de distribución 
para facilitar la llegada y salida de instalaciones. Las montantes de agua y desagüe se encuentran dentro de dichos ductos y se conectan de forma vertical con los cuartos de bombeo y cisternas. La distribución a cada SS.HH. y Lavaderos, se realiza mediante tubería alimentadora y distribuyéndose a cada ramal, adecuadamente dimensionadas, con una llave de interrupción general, distribuyéndose posteriormente a cada salida para los aparatos sanitario.

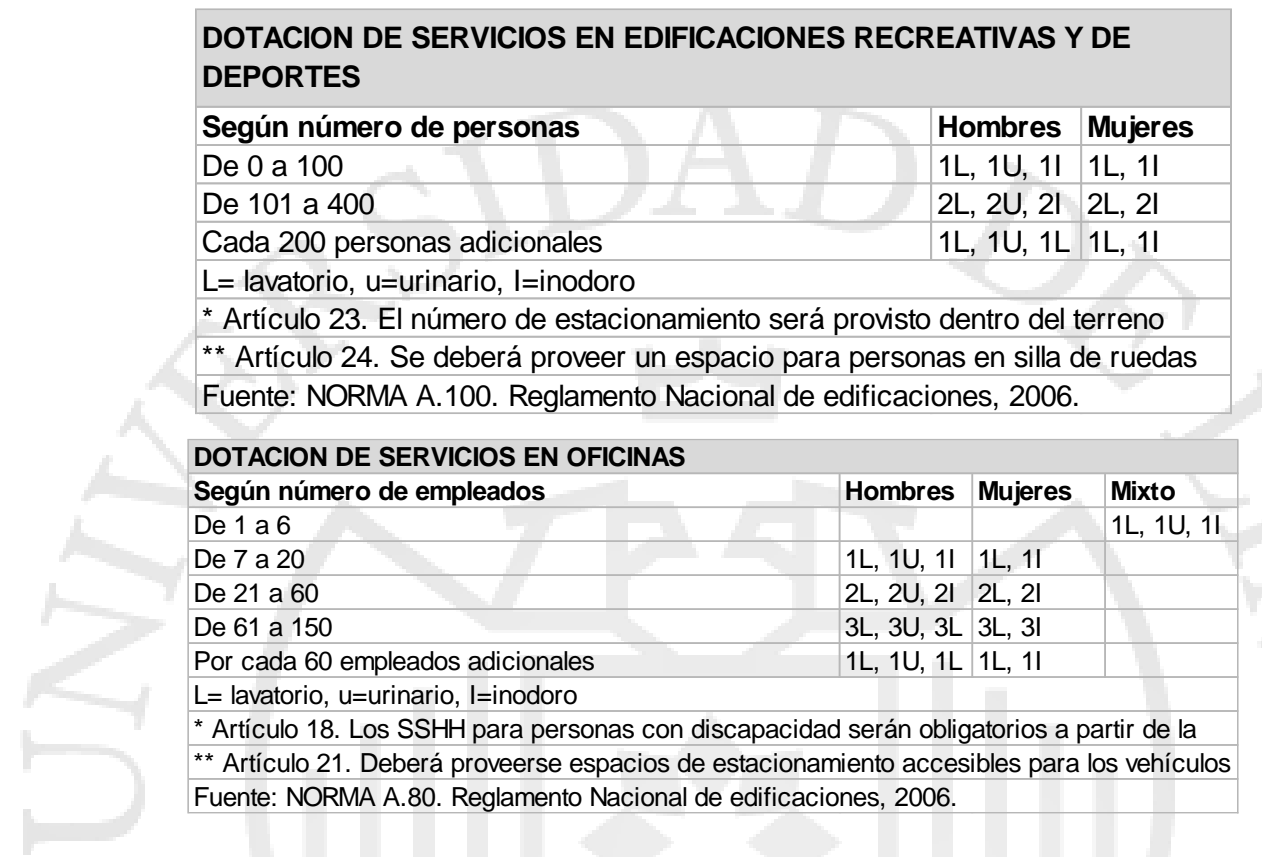

La distribución de los servicios higiénicos está, principalmente, en núcleos verticales, para facilitar la conexión de estos a las redes de abastecimiento, desagüe y ventilación. En el caso de los restaurantes y servicios adicionales dentro de las aulas de arte, se procuró acercar los aparatos sanitarios a las redes existentes.

Se ha planteado la bajada de los desagües correspondientes para cada uno de los servicios higiénicos de la propiedad mediante montantes de desagüe convenientemente ubicadas hasta el primer piso y hasta la conexión de desagüe, ubicada en la fachada de la edificación. Se ha diseñado un sistema de ventilación mediante tuberías instaladas por muros de la edificación, de tal forma que se obtenga una máxima eficiencia en todos los puntos que requieran ser ventilados.

Considerando que Lima tiene una precipitación relativamente baja, los techos canalizan el agua proveniente de las lluvias, por lo que se instalaron drenajes pluviales en todos los techos para la correcta evacuación del agua. 


\subsection{Memoria descriptiva de instalaciones mecánicas.}

El CCB tiene 3 tipos de espacios clasificados según la ventilación que se plantea. El primer tipo incluye espacios cerrados, como el auditorio y las salas de exposición, donde se utiliza aire acondicionado cuando está ocupado por espectadores o actores. El sistema considerado es de chillers instalados en el piso superior, cerca de los depósitos del restaurante).

El segundo tipo son los espacios de ventilación cruzada, donde se plantean vanos específicamente para acondicionar el ambiente y prescindir del uso de aire acondicionado. Estos son los salones del CCB, la biblioteca, el coworking, oficinas y los recibos. Se complementa con ventiladores y equipos de inyección de aire. La fachada fue planteada de vidrio, con ventanas oscilantes al alcance del usuario. Además, se diseñó con lamas verticales que controlen ligeramente el paso del sol por los 3 meses de verano de Lima (ver De-03). Durante los demás meses nublados, la disposición vertical favorece la entrada de luz, versus una disposición de lamas horizontales, que bloquean la luz diurna. De esta manera, se intenta controlar el paso del calor de la luz solar y maximizar el confort interno.

Finalmente, el tercer tipo de espacio comprende a los sótanos de estacionamiento, con equipos de inyección de aire y extracción de Co2. Estos espacios se plantearon en el área técnica del Estacionamiento (npt -13.00) y en dos extremos. Los ductos fueron planteados para extraer el aire a la superficie sobre la plaza, a un nivel de $2.00 \mathrm{~m}$, que no perjudique al peatón ni al usuario del edificio en el segundo nivel (npt +4.90). Asimismo, los SSHH consideran ductos de ventilación, de 60x60cm o mayores, según la normativa del RNE. Aquellos que no ventilen directamente al exterior, cuentan con ventilación mecánica, que pasará por ductos de similar dimensión.

A continuación, se muestra la ubicación del Cuarto de Extracción de Co2 y el de Inyección de aire dentro del área técnica, en naranja. 


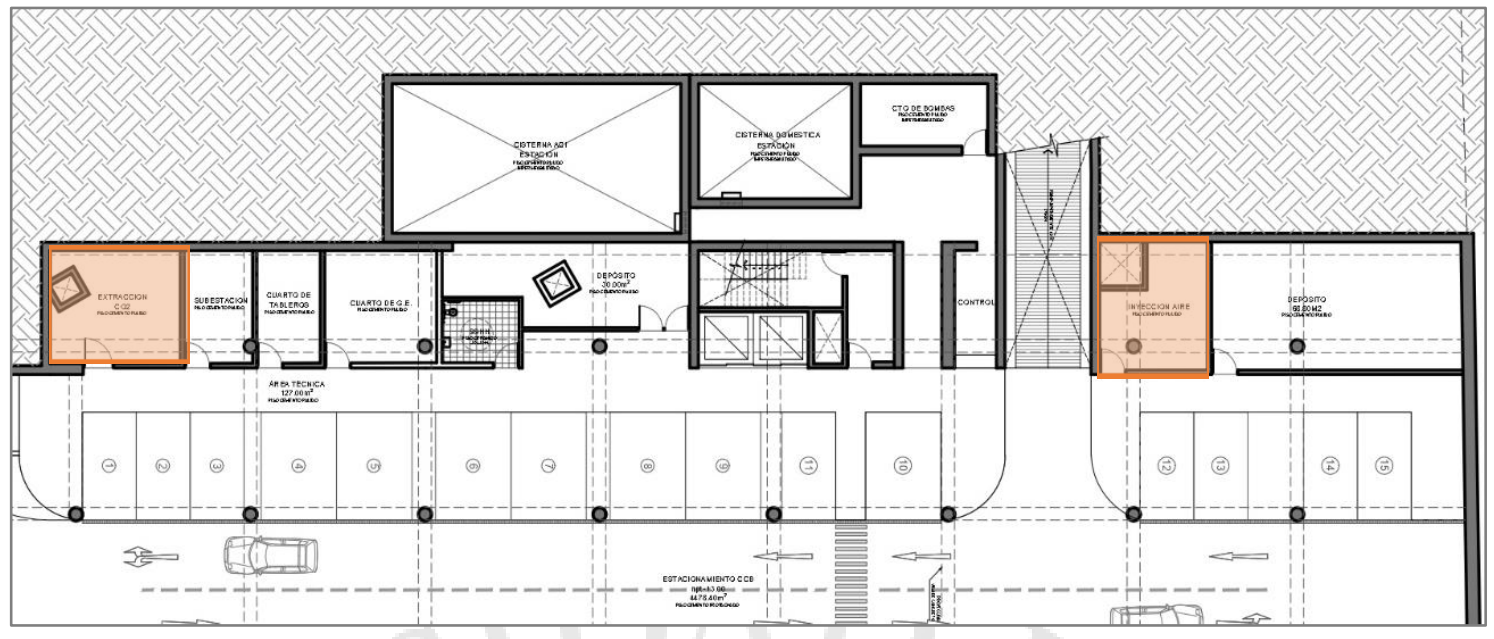

Los demás espacios, como el estrato comercial, bares y restaurante, se encuentran total o parcialmente al aire libre y no requieren de ventilación artificial.

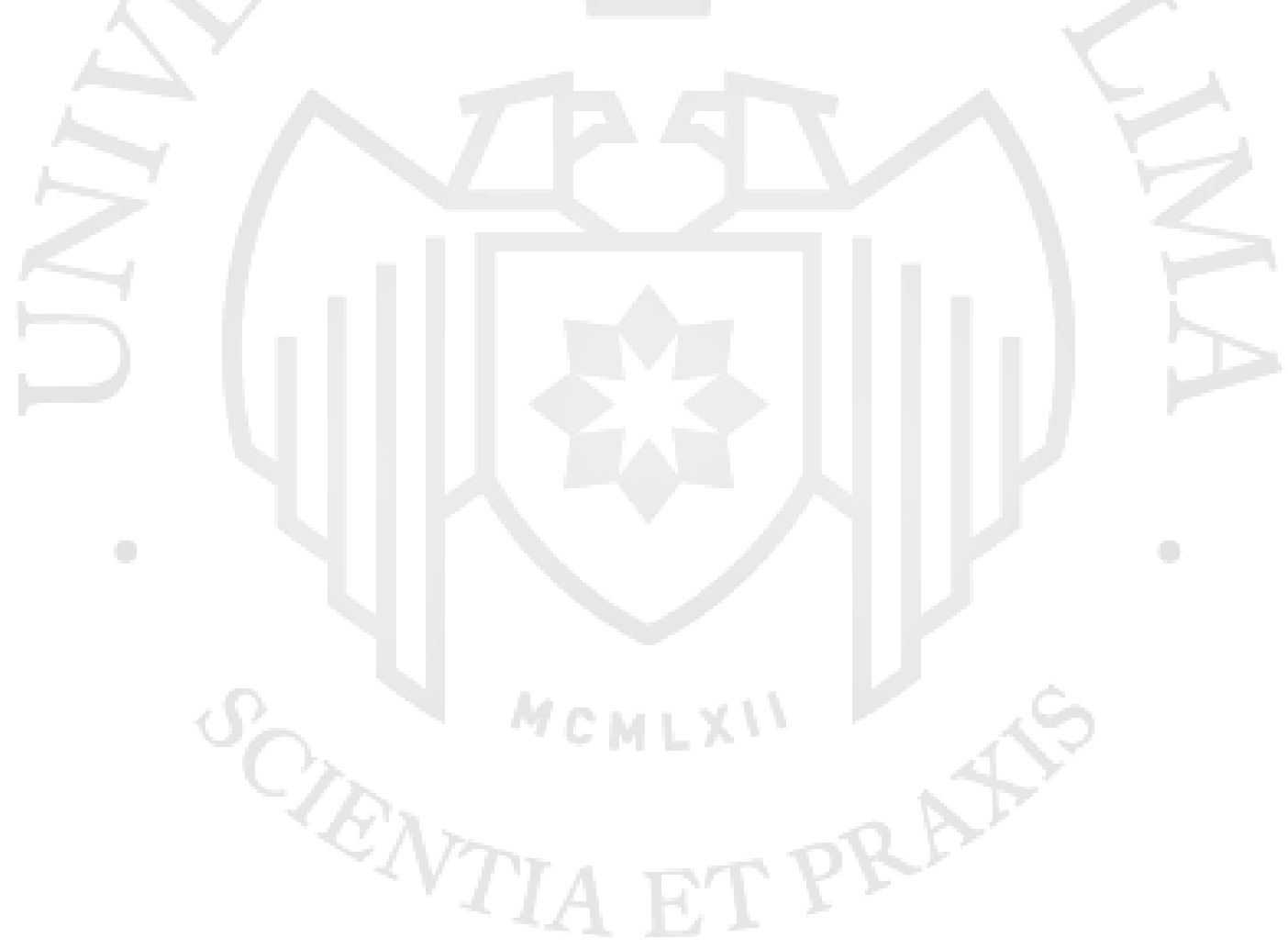




\subsection{Plan de Marketing}

En el año 2018, el Gobierno planteó el presupuesto Público Anual para el año, que destinaba $1.9 \%$ del total a la Cultura y el Deporte. Sin embargo, entre Defensa y Seguridad Nacional y Orden Público y Seguridad obtuvieron el 9.4\% del presupuesto (Andina Agencia Peruana de Noticias, 2018). Podríamos considerar que el Centro Cultural de Barranco se presenta ante un contexto que prioriza la reacción sobre la prevención en problemática de seguridad.

Es por ello, que el Plan de Marketing impulsa el Centro Cultural como un animador urbano, que ocupe al ciudadano en su desarrollo y el de la comunidad. El CCB será considerado un espacio alegre, abierto, accesible, seguro y de cooperación comunitaria.

Además de los espacios arquitectónicos brindados, el proyecto fue planteado y concebido teniendo en cuenta la gestión que se realizaría dentro. Es importante trabajar ambos aspectos de la mano y en paralelo, pues un buen espacio físico no funciona por sí solo. Son los administradores, gestores y usuarios los que animan los edificios, la plaza y la ciudad.

A través de una entrevista al portal Gestiopolis, citaremos a Hernán Palacios ${ }^{31}$, quien presenta su plan de Principios Estratégicos de Marketing Cultural:

a. Administrar de acuerdo con su misión: El principal lineamiento del CCB es la accesibilidad. Los espacios y la gestión del proyecto se basaron en la competencia y oferta existente, pero el proyecto plantea costos más accesibles a los del mercado y un programa más flexible.

b. Focalizarse de forma más directa en sus verdaderas capacidades: Si se tiene el espacio, condiciones y facilidades para realizar un proyecto, se logrará en el

\footnotetext{
${ }^{31}$ Ingeniero Comercial, mención Economía, Universidad de Chile; Máster en Economía, Duke University, USA. Profesor Asociado Adjunto y Director del Diplomado en Marketing de la Escuela de Administración UC.
} 
mismo CCB. De lo contrario, debe mantenerse alianzas con otras asociaciones culturales y, sobre todo, auspiciadores.

c. Focalizarse en la calidad: El CCB crecerá y mutará constantemente, de acuerdo con la necesidad del mercado y del usuario. Para ello, es importante la flexibilidad y calidad de espacios proyectados. La publicidad, los entregables, el material, los cursos y las muestras se linearán según los más altos entandares.

d. Conocer a sus consumidores mediante técnicas de investigación de mercados: mantener interesado al público regular y buscar la forma de llegar al mercado potencial. Debe mantenerse la vigencia y expandir la oferta.

e. Crear accesibilidad: Más allá de lo físico, la accesibilidad se relaciona a la oferta de producto y posicionamiento. Ampliar el primero y mantener el segundo.

f. Concentrarse en el largo plazo

g. Integrar el arte al diario vivir: Lo más importante para el CCB y que engloba a todas las primeras estrategias es enseñar y mantener la cultura en el imaginario colectivo de la ciudad. No debe mantenerse dentro del terreno del proyecto, si no llevarlo a la práctica en el día a día de los usuarios y no-usuarios. Crear oportunidades novedosas para llevar el arte a todo el público, apoyados por los mismos usuarios. Mostrar que el arte se puede integrar a la cotidianidad de la gente y hacer su vida más placentera.

El isotipo básico del CCB tendrá algunos colores de su fachada, que además, son los colores CMYK a partir de los cuales se pueden generar todos los colores en una impresión.
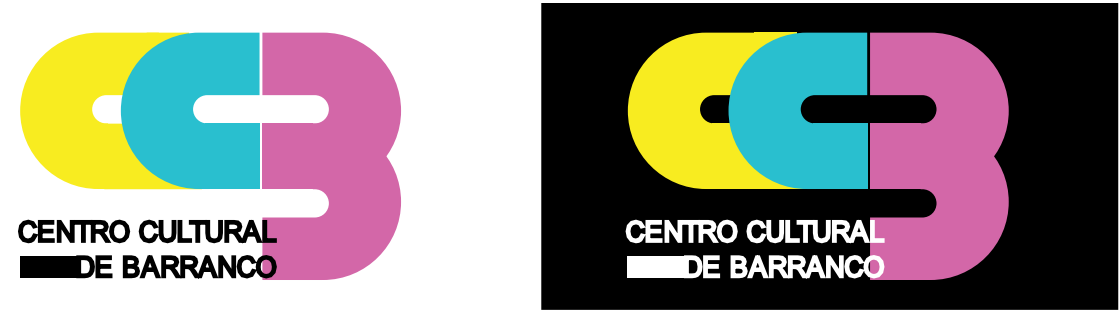

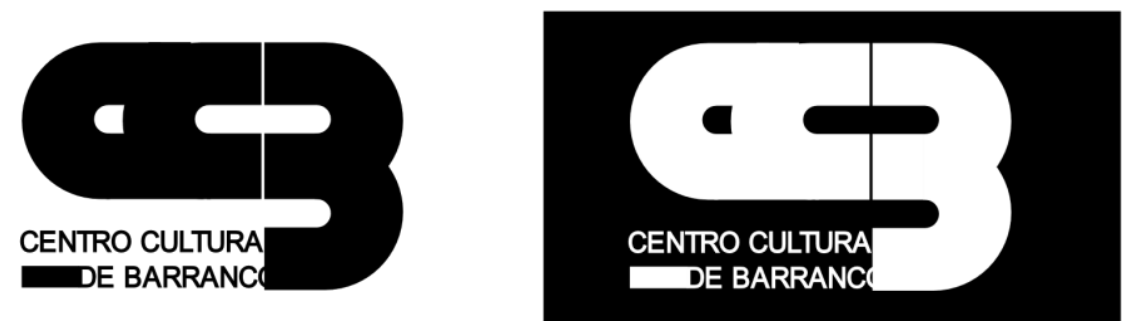

Se plantea un moodboard de publicidad referentes culturales nacionales e internacionales, de lo que el Centro Cultural comunica desde su gestión. Sin embargo, es importante que los artistas puedan generar su propio material dependiendo de la muestra.
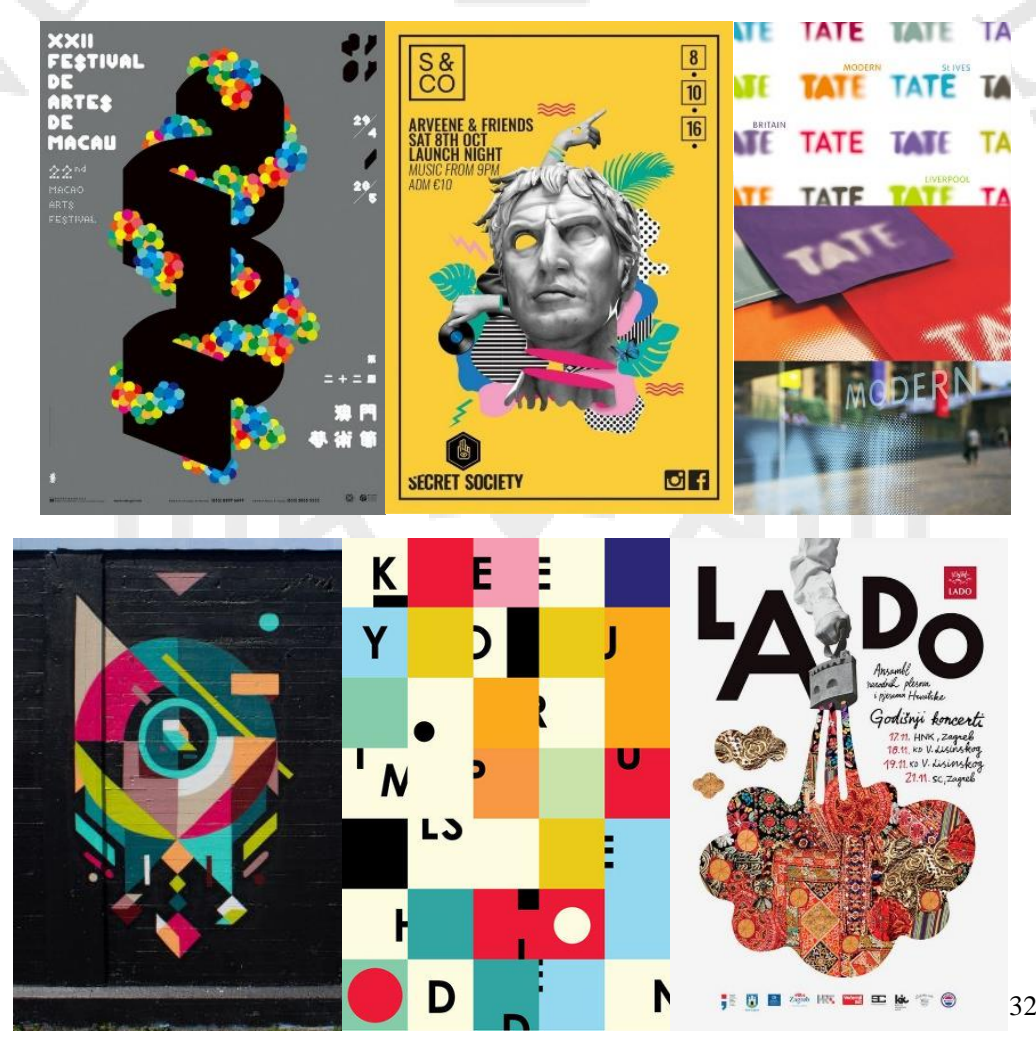

${ }^{32}$ Imágenes de Pinterest: Festival de Artes de Macau, Secret Society, TATE. 
Como parte de la Toma de Partido del proyecto, se consideró el público al que iban a atender los edificios y la plaza. Por eso, fue uno de los primeros pasos pensar $\operatorname{arquetipos}^{33}$ de usuarios del CCB:

\section{Arquetipo 1}

Miguel está cursando 3ro de secundaria y vive cerca a la estación Las Flores en Barranco. Miguel lleva su guitarra al colegio todos los días y pasa por el CCB para practicar un rato antes de regresar a su casa. En el CCB conoció a Matt, un estudiante del colegio Alfonso Ugarte que también toca guitarra, y juntos han formado una banda para participar en un concurso de talento que ha lanzado el CCB. Luego de ensayar compran algo de comer en la cafetería y conversan sobre sus planes luego del colegio.

\section{Arquetipo 2}

Gabriela acaba de terminar una especialización en gestión de negocios y ha emprendido un negocio de paisajismo. Ella trabaja de manera independiente en el coworking del CCB donde ha conocido a diferentes personas del sector, gracias a un taller de arte topiario que se dictó en una sala SUM. Su negocio ha crecido exponencialmente los últimos meses gracias a la facilidad del espacio y cercanía para articular con sus grupos de interés. Sus proveedores están alrededor del CCB, sus clientes recurrentes disfrutan reunirse en el CCB debido a los cómodos espacios para desarrollar proyectos juntos. Además, sus aliados estratégicos son representantes de ferias y eventos que se dan en el CCB y alrededores.

\section{Arquetipo 3}

Melissa y Carlos tienen 2 hijas de 3 y 4 años, y viven en Barranco. Están suscritos al boletín virtual del CCB y saben cuándo habrá actividades de su interés. Algunos fines de semana llevan a Catalina y Valeria al CCB donde siempre hay shows de títeres, cuenta cuentos, musicales y dinámicas para niños y niñas. Melissa y Carlos se toman un café mientras las niñas participan de estos eventos y conversan sobre sus planes como familia. Carlos es pintor y algunas de sus obras están en exhibición en la galería del CCB, donde además dicta talleres de vez en cuando.

\footnotetext{
${ }^{33}$ Modelos que sirven como ejemplo o pauta a seguir o reproducir. Prototipo ideal como ejemplo de perfección a algo.
} 


\section{Arquetipo 4}

Henry es técnico electricista y trabaja en el Centro de Lima. Luego de un largo día de trabajo, Henry llega a la estación Las Flores y se compra un snack en un stand dentro del CCB. Casi siempre toma un breve descanso en la zona de terraza entre los dos edificios del CCB porque le gusta mucho ver las diferentes activaciones culturales que realizan ahí. Ha visto shows de danza contemporánea, danzas costumbristas, mini conciertos, teatro en vivo, entre otras disciplinas. Siempre llega a casa con una historia que contar a su familia, de lo que ha pasado en su breve paso por el CCB.

\section{Arquetipo 5}

Doña Charo y Don Abelardo han vivido en Barranco toda su vida. Son fanáticos de los espectáculos culturales, pero para ellos moverse por la ciudad es complicado a su edad. Desde que inauguraron el CCB, asisten con regularidad a los conciertos y obras de teatro que promocionan en el auditorio. Don Abelardo y Doña Charo celebraron hace poco 40 años de casados y lo celebraron yendo con toda la familia a cenar a un restaurante en el CCB y luego asistieron a un concierto de gala de música criolla que se dio en el auditorio.

En base a ellos y a los referentes estudiados, se plantearon los espacios y programas del CCB. Todos los tipos de usuario deben ser considerados, de manera que se puedan cumplir los puntos planteados de las Estrategias Básicas del Marketing cultural.

Finalmente, la promoción y comunicación del CCB es la que lo hará mantenerse vigente en el imaginario colectivo. Además, lo posicionará como un referente cultural de Lima y, lo que se quiere comunicar de los espacios, se verá reflejado en la publicidad del Centro. 


\subsection{Cortes y elevaciones}
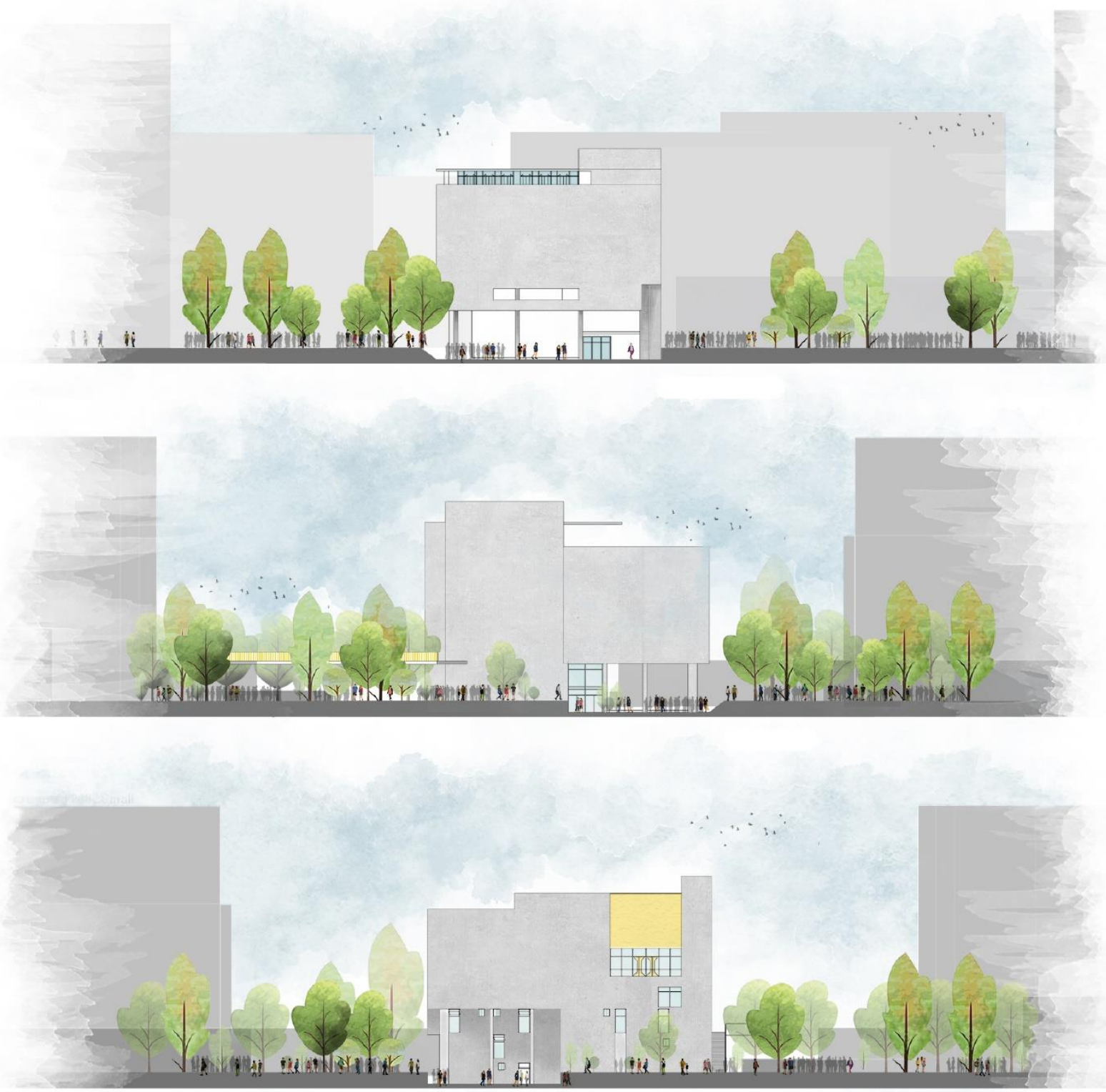

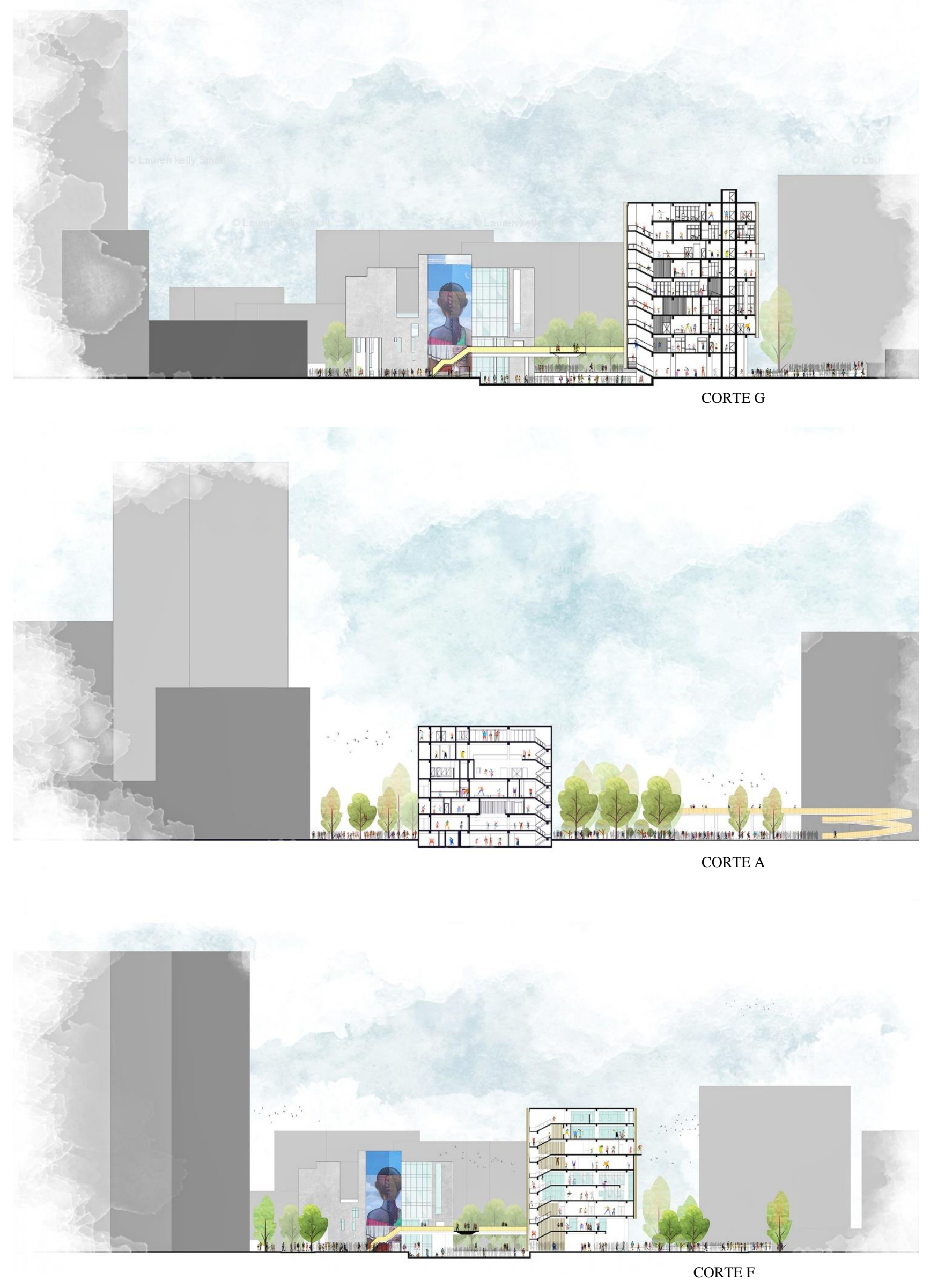


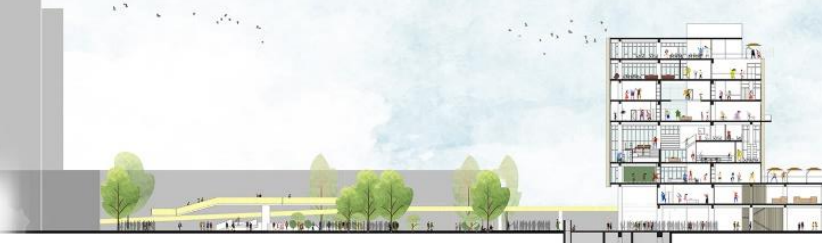
प'

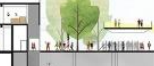

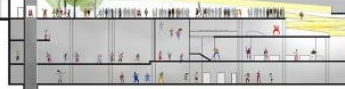

CORTE E 

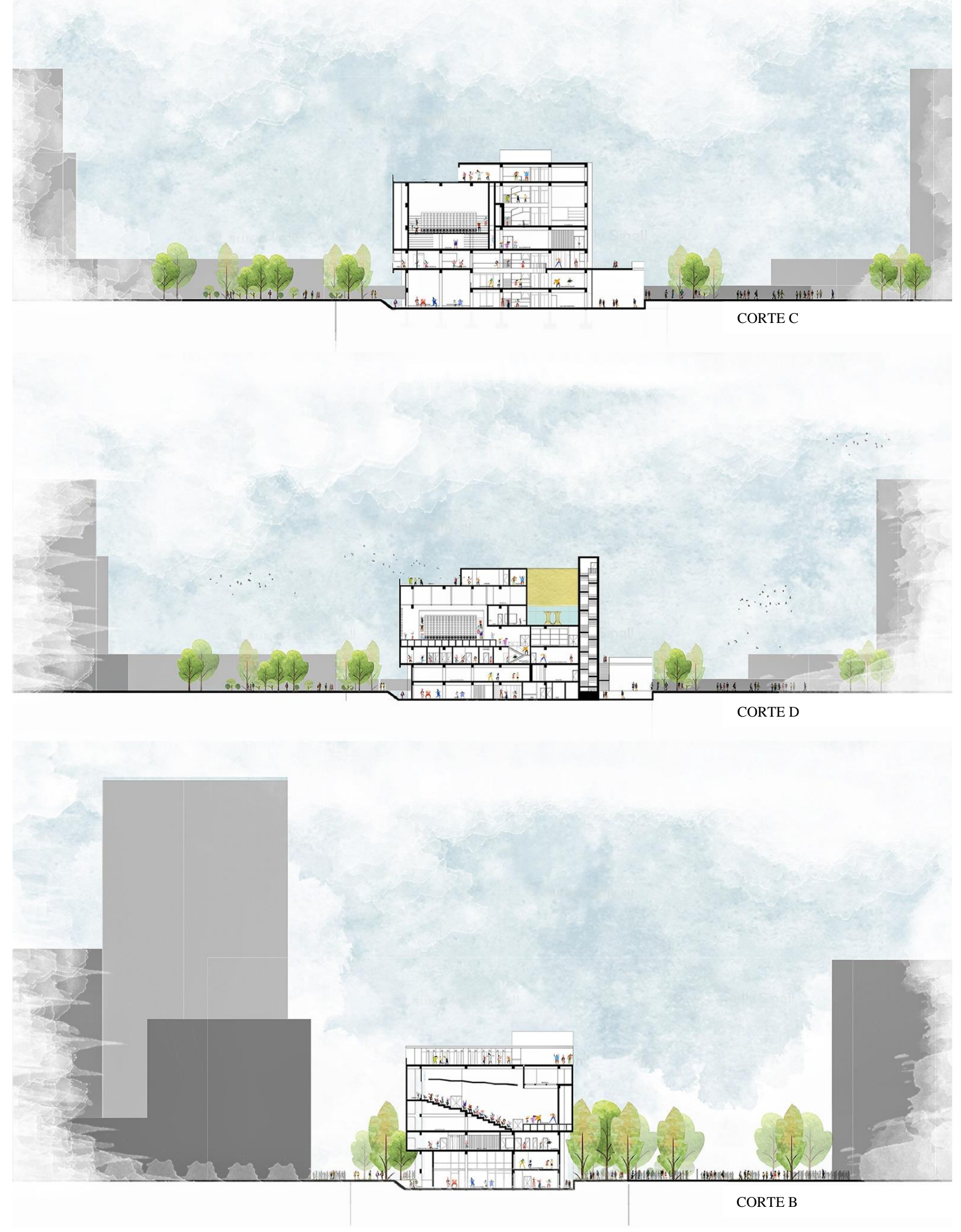


\subsection{Vistas 3D}

7.11.1 Vistas aéreas de la plaza y puente

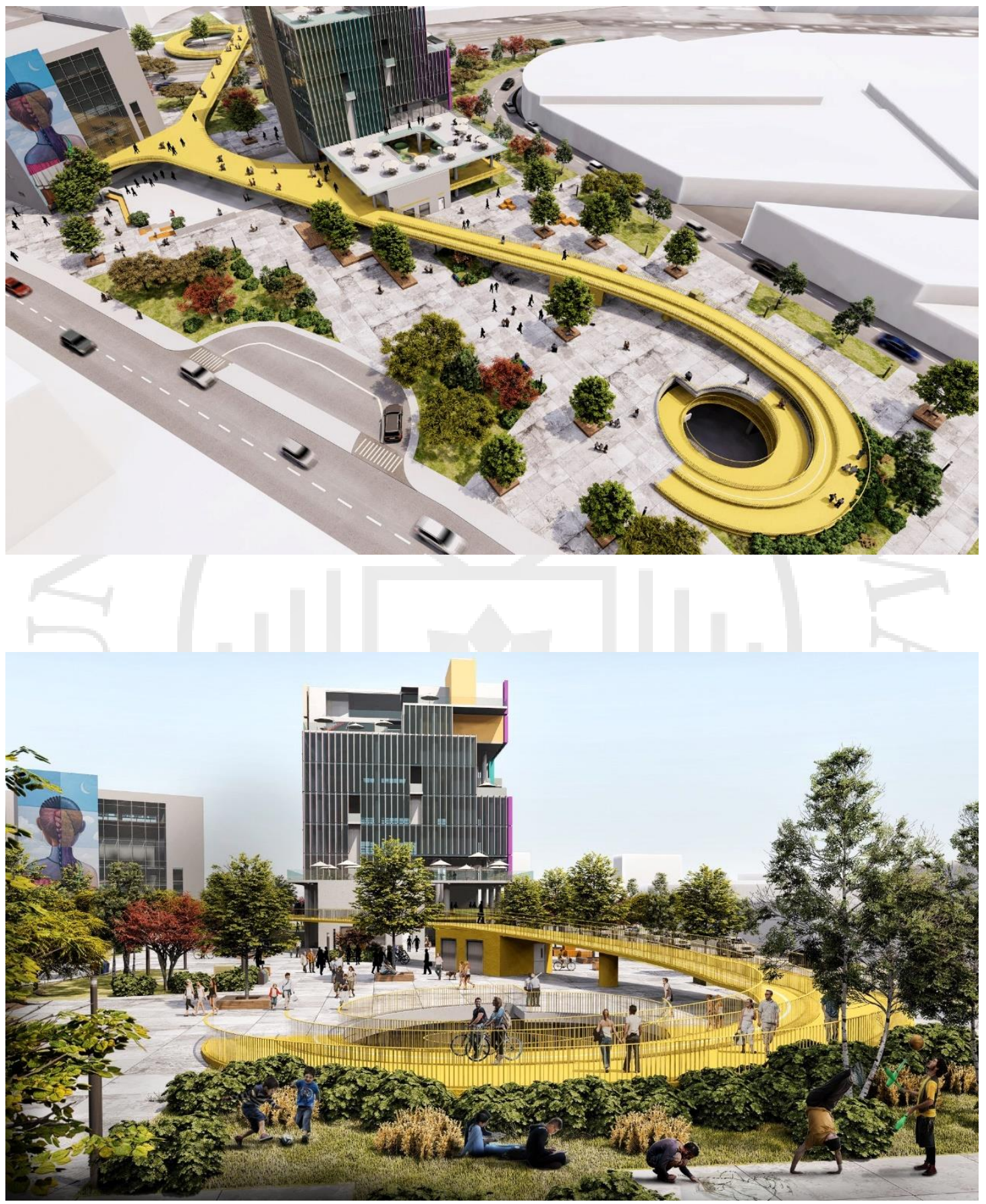




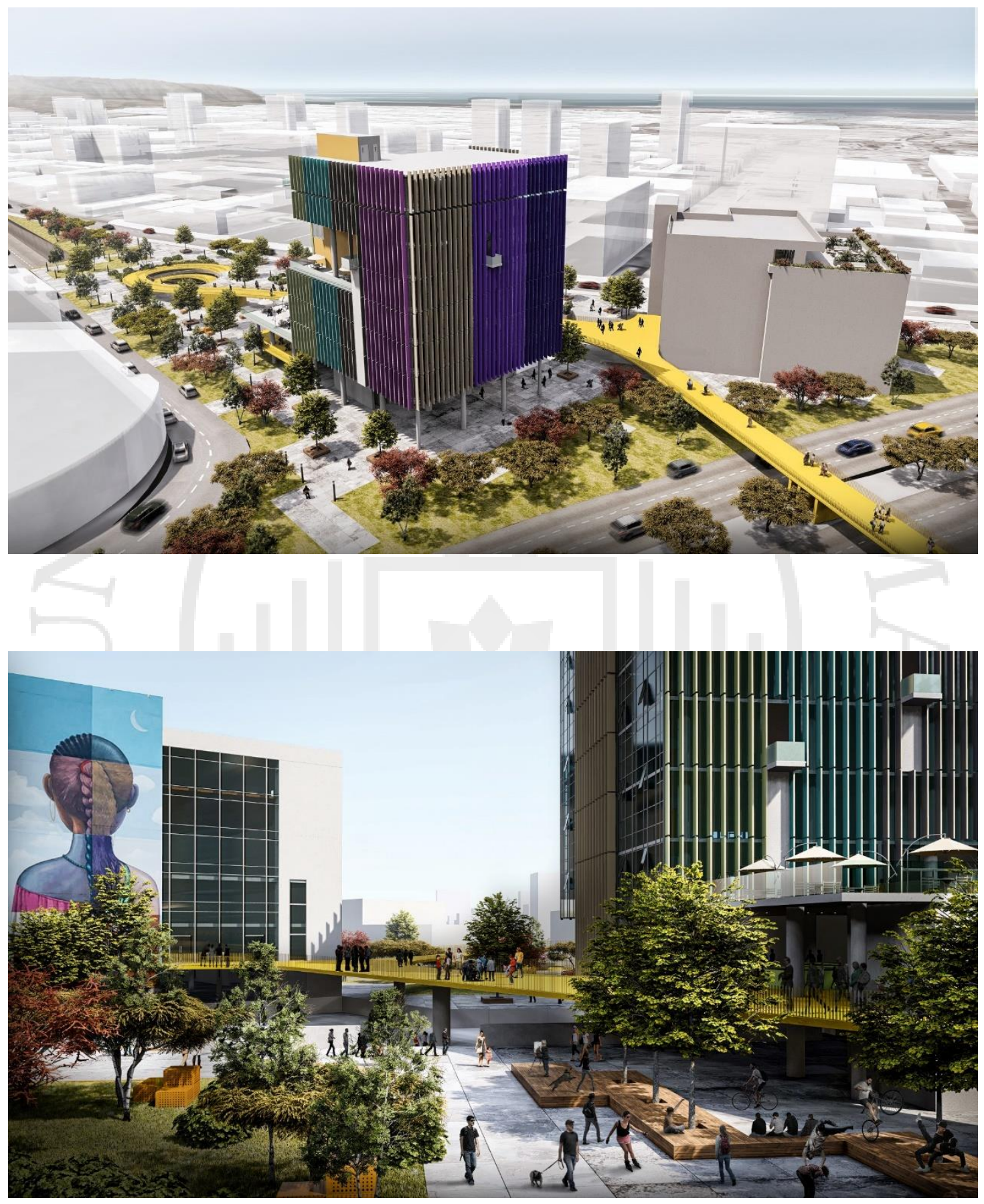




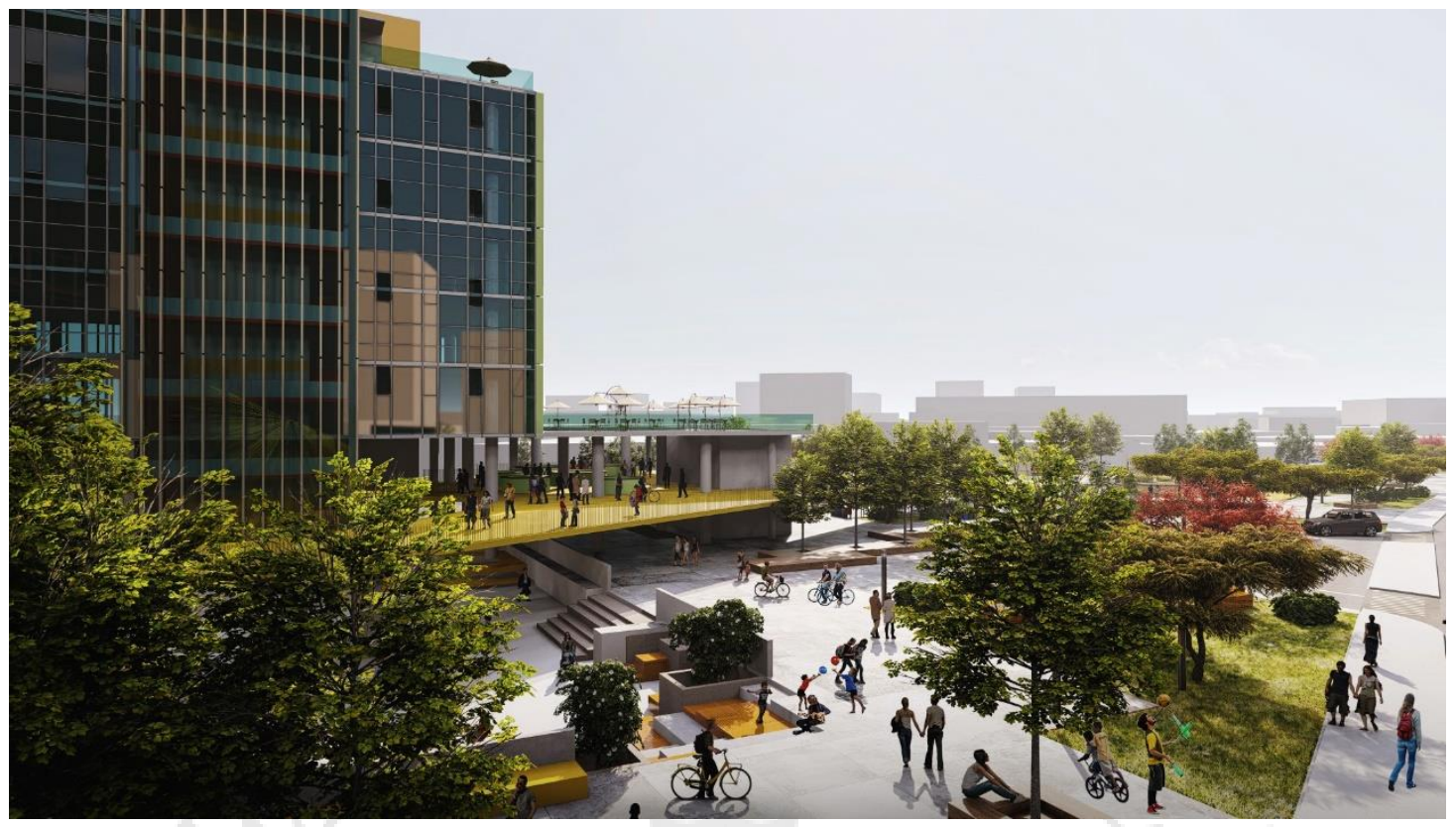

7.11.2 Vistas peatonales de la plaza

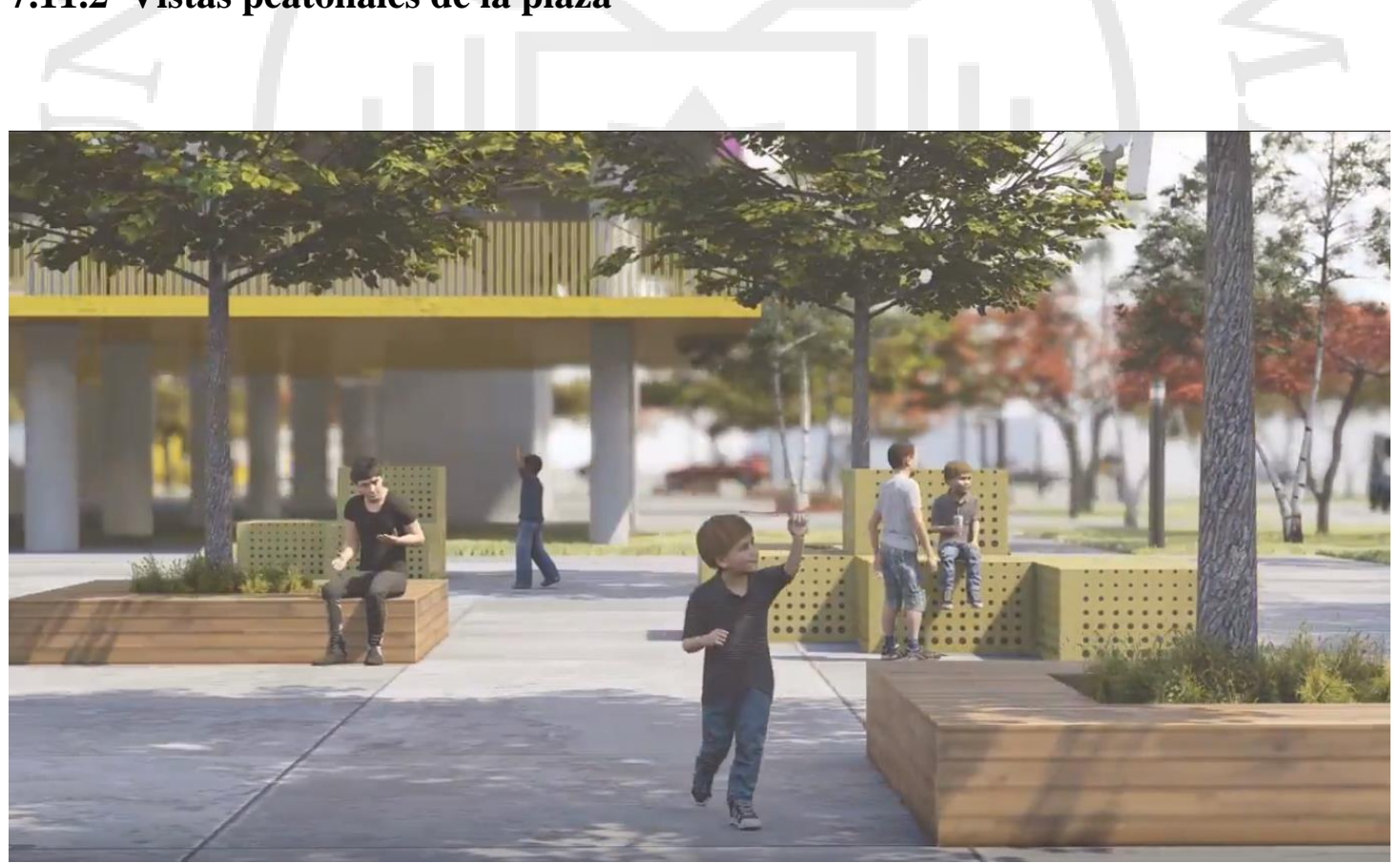



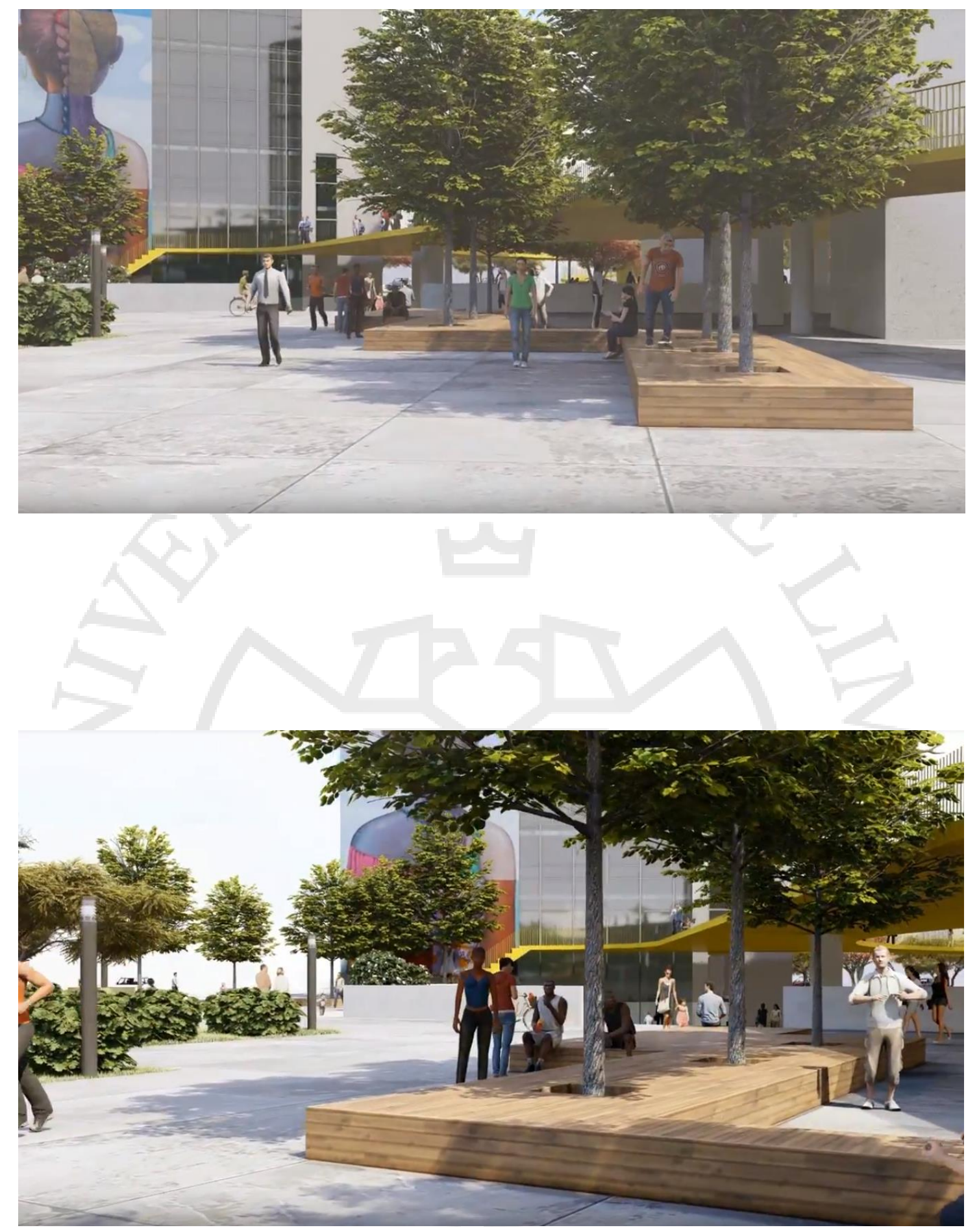


\subsubsection{Estación del Metropolitano}

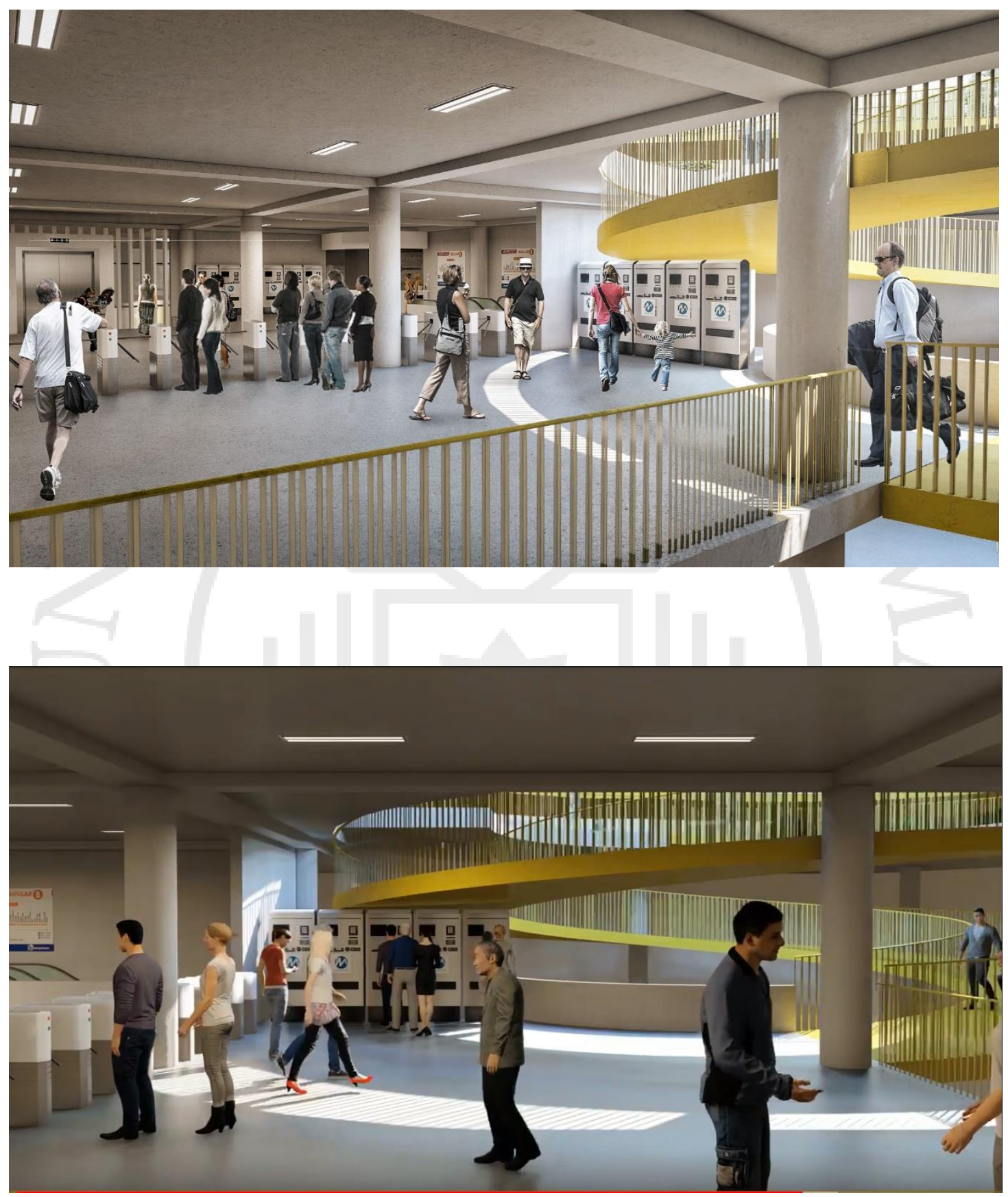


7.11.4 Terraza del Tótem, vista aérea

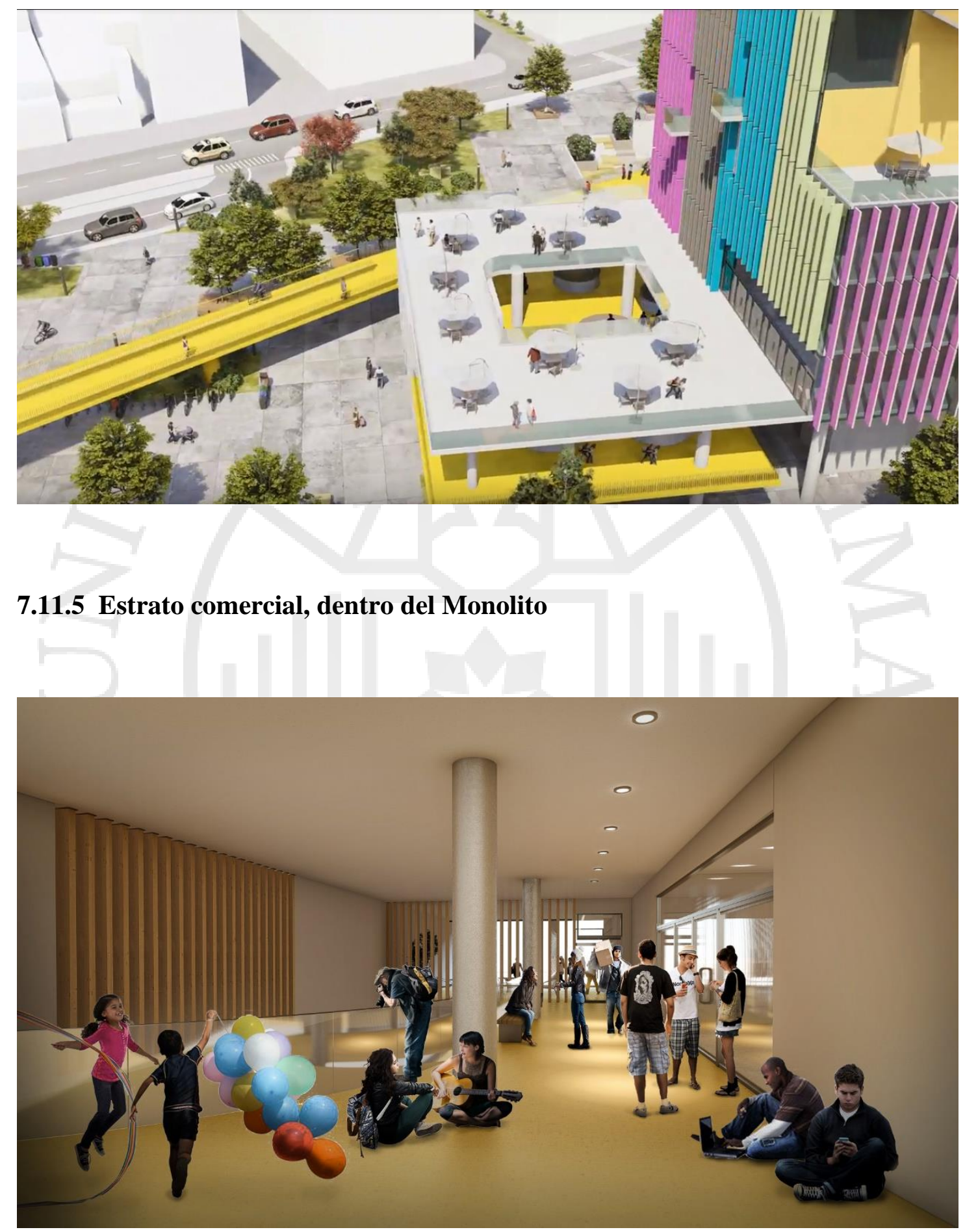



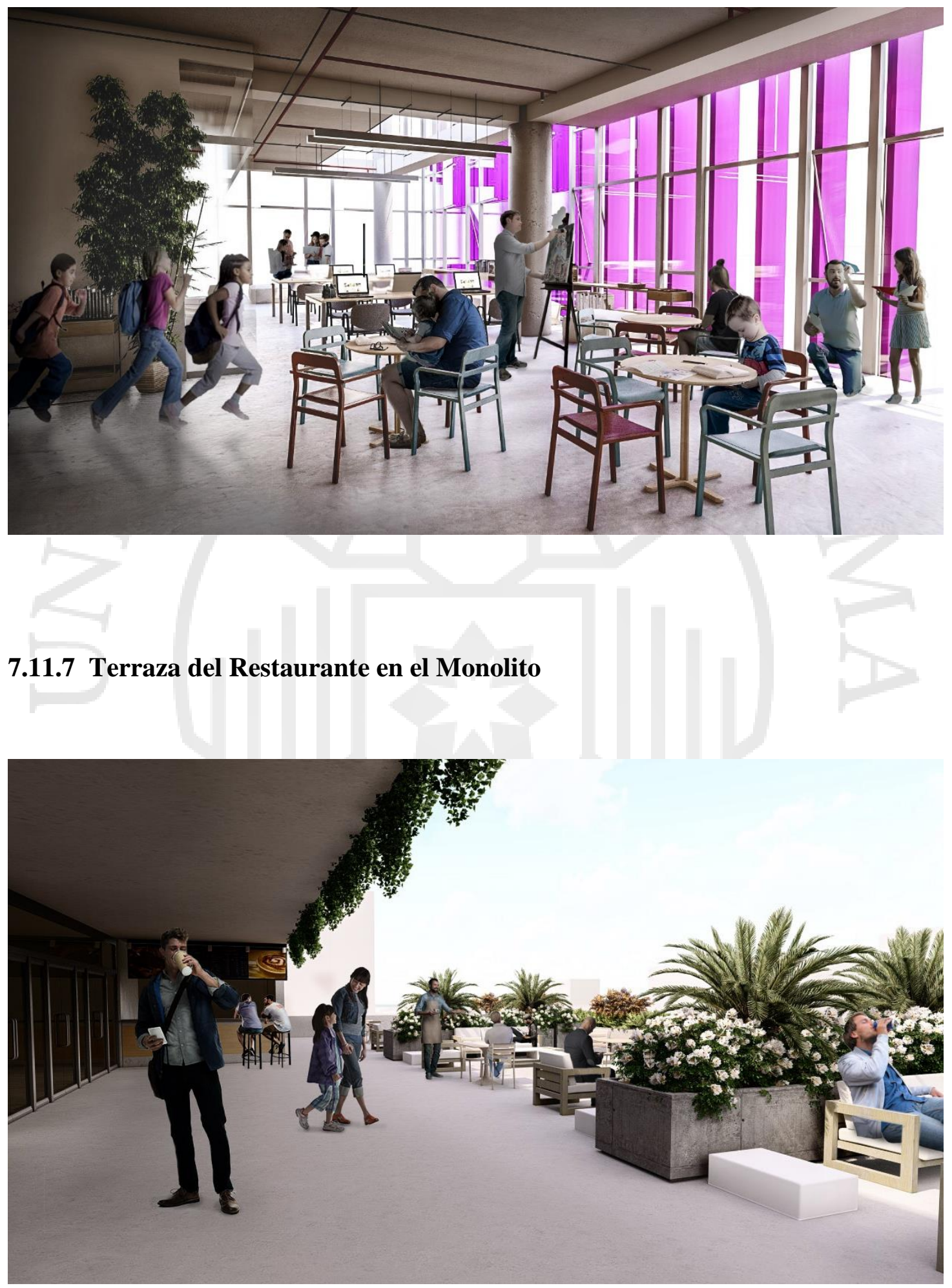


\section{Bibliografía}

Ábalos + Sentkiewicz. (s.f.). Estación de alta velocidad. Recuperado el 20 de septiembre de 2016, de Ábalos + Sentkiewicz: http://abalossentkiewicz.com/es/projects/estacion-de-alta-velocidad/

Alcaldía de Quito. (14 de Octubre de 2015). Reconstrucción de 44 paradas del trole avanza. Recuperado el 26 de septiembre de 2016, de Agencia Pública de Noticias de Quito: http://noticiasquito.gob.ec/Noticias/news_user_view/reconstruccion_de_44_pa radas_del_trole_avanza--16243

Alley, S., \& McQuade, M. (. (2011). Landform Building: Architecture's New Terrain. Lars Müller Publishers.

Andina Agencia Peruana de Noticias. (28 de Noviembre de 2018). Presupuesto Público 2018: conoce la distribución por sectores. Andina.

Apaolaza, R., Blanco, J., Lerena, N., López-Morales, E., Lukas, M., \& Rivera, M. (2016). Transporte, desigualdad social y capital espacial: análisis comparativo entre Buenos Aires y Santiago de Chile. Íconos, 19-41.

Arce, J., Vargas Vila, J., \& Zucchetti, A. (2015). PLAM 2035: Plan de desarrollo urbano Lima y Callao 2035. Municipalidad Metropolitana de Lima, Lima.

ArchDaily. (10 de junio de 2016). Estación de autobuses de Santa Pola / Manuel Lillo + Emilio Vicedo. Recuperado el 20 de septiembre de 2016, de ArchDaily: http://www.archdaily.co/co/789220/estacion-de-autobuses-de-santa-polamanuel-lillo-plus-emilio-vicedo

Arcia, D. (30 de septiembre de 2014). ¿Puede surgir de un cerro de basura un maravilloso jardín urbano? [mensaje en un blog]. Recuperado el 02 de octubre de 2016, de Ciudades http://blogs.iadb.org/ciudadessostenibles/2014/09/30/de-un-cerro-de-basura-aun-jardin-urbano/

Ascher, F. (julio de 2005). Ciudades con velocidad y movilidad múltiples: un desafío para los arquitectos, urbanistas y políticos. $A R Q(60), 10-19$.

Augé, M. (2000). Los no lugares: espacios del anonimato (5ª ed.). España: Gedisa.

Autoridad Portuaria de Guijón. (2008). ABC de la intermodalidad. Guijón: Autoridad Portuaria de Guijón.

Avellaneda, P. G. (2008). Movilidad cotidiana, pobreza y exclusión social en la ciudad de Lima. Anales de Geografía, 28(2), 9-35.

Ayuntamiento de Madrid. (s.f.). Plaza Elíptica.

Bertalanffy, L. v. (1989). Teoría General de los Sistemas. Fundamentos, desarrollo, aplicaciones. (Séptima ed.). México DF: Fondo de Cultura Económica.

Bojovic, M. (30 de enero de 2013). Uptdate on Logrño High Speed Train Station: Phase One - Completed/Abalos +Sentkiewicz Arquitectos. Recuperado el 1 de octubre de 2016, de Evolo Revista digital: http://www.evolo.us/architecture/update-onlogrono-high-speed-train-station-phase-one---completed-abalossentkiewiczarquitectos/

Bordieu, P. (2003). La miseria del mundo. México DF: FCE.

Borja, J. (2000). El espacio público, ciudad y ciudadanía. Barcelona, España: -.

Brundtland, I. (1987). Comisión Mundial para el Medio Ambiente y Desarrollo. Naciones Unidas: Naciones Unidas.

Camara de Comercio de Bogotá. (2009). Observatorio del espacio público de Bogotá. Bogotá. 
Cámara de Comercio de Bogotá. (2009). Renovación urbana y participación públicoprivada: una opción para la sostenibilidad del sistema integrado de transporte público en Bogotá. Bogotá.

Capel, H. (1975). La Definición de lo Urbano. Estudios Geográficos, 265-301.

Carbajal López, E., Aragón Casas, L. G., \& Dávila Cajahuanca, C. B. (2013). Optimización basada en simulación de un sistema de Tránsito Público Masivo. 11th Latin American and Caribbean Conference for Engineering and Technology, (pág. 04). Cancún.

Cárdenas Grisales, J. (1998). Ingeniería del Tránsito: Fundamentos y aplicaciones. Mexico DF, Mexico: Alfaomega.

Casagrande, M. (01 de Marzo de 2010). Un arquitecto y una arquitectista conversan. (Julakim, Entrevistador)

Centro Cultural Estación Mapocho. (2013). Espacios. Obtenido de Centro Cultural Estación Mapocho: http://www.estacionmapocho.cl/infraestructura/espacios/

Chacón Blanco, M. C. (Abril de 2010). Concepto, objetivos y funciones de la animación social. Innovación y experiencias educativas, 29.

Chaparro, I. (2002). Evaluación del impacto socioeconómico del transporte urbano en la ciudad de Bogotá. El caso del sistema de transporte masivo Transmilenio. En I. Chaparro, Serie Recursos Naturales e Infraestructura. Santiago de Chile: Cepal, Naciones Unidas.

Concesionaria Vía Expresa SUR S.A. (2015). Estudio definitivo de Ingenería. Lima: GyM.

Construcción y vivienda. (08 de Febrero de 2017). Edificio Ser-K: Nueva oferta inmobiliaria en el distrito de Barranco. Construcción y Vivienda.

Costa, G. (09 de febrero de 2015). Contaminación vehicular en Lima, por Gino Costa. Obtenido de El Comercio: https://elcomercio.pe/lima/contaminacion-vehicularlima-gino-costa-332350

Cruzado, D. (04 de Febrero de 2018), Barranco espera elevar hasta 20 pisos altura de edificios . Gestión.

De Mattos, C. A. (Diciembre de 2006). Modernización capitalista y transformación metropolitana en América Latina: cinco tendencias costitutivas. America Latina: Ciudade, campo e turismo., págs. 41-73.

Echeverrí Cardona, J. (2012). La casa de todos: La experiencia de la transformación cultural en Medellín desde el Centro de Desarrollo Cultural de Moravia. Medellín, Colombia: Municipio de Medellín.

Ecoproyecta. (28 de abril de 2013). Estación de autobuses y biblioteca en Ronda (Málaga). Recuperado el 20 de septiembre de 2016, de Ecoproyecta: http://www.ecoproyecta.es/estacion-de-autobuses-y-biblioteca-en-rondamalaga/

Empresa pública Metropolitana de Transporte de pasajeros. (2016). Historia de la Empresa. Recuperado el 26 de septiembre de 2016, de Trolebús: http://www.trolebus.gob.ec/index.php?option=com_content\&view=article\&id $=73 \&$ Itemid $=475$

Exit Architects. (2012). Cuentos para el andén. Ronda, Málaga, España.

Gamboa Saper, P. (2003). El sentido urbano del espacio público. Bitácora, 13-18.

García Calderón, J. (Junio de 2015). El plam2035 para Lima y Callao. ARKINKA, 235, págs. 38-47.

Gehl, J. (2004). Ciudades para la gente. Buenos Aires: Infinito.

Gehl, J. (2006). La humanización del espacio público: la vida social entre los edificios. Barcelona, España: Editorial Reverté. 
Gehl, J. (22 de Julio de 2014). Socialización en el espacio público. Revista Disonante. (L. Cardona, Entrevistador) Mexico DF, Mexico: Revista Disonante.

Goba (Pty) Ltd. (2013). Development of the Integrated Rapid Public Transport Network: Technical Note: Station Parameter Assessment and Capacity. Final Report prepared for the eThekwini Municipality, Report No. TN 2012-07-041700 . Pietermaritzburg .

Gonzales de Olarte, E., \& del Pozo Segura, J. (2012). Lima, una ciudad policéntrica. Un análisis a partir de la localización del empleo. Investigaciones Regionales, 29-52.

Google Inc., Instituto Nacional de Estadística. (02 de marzo de 2018). Public Data. Obtenido de

Google: https://www.google.com.pe/publicdata/explore?ds=bk0jtrua8ulr2_\&met_y=pe rsons\&hl=es\&dl=es

Gordon, K. (26 de octubre de 2012). Estación de Trenes de Alta Velocidad en Logroño / Ábalos + Sentkiewicz arquitectos. Recuperado el 1 de octubre de 2016, de ArchDaily: http://www.archdaily.pe/pe/755792/high-speed-train-station-inlogrono-abalos-sentkiewicz-arquitectos

Gutierrez, A. (2005). Transporte público y exclusión social. Reflexiones para una discusión en Latinoeamérica tras la década del '90. XIII Congreso Latinoamericano de Transporte Público y Urbano, CIDATT-Centro de Investigación y de Asesoría del-Transporte, Lima, Tema III, capítulo 12 (pág. 14). Lima: CIDATT.

Hermant, L. (2014). Towards Appropriate BRT Station Design from a Pedestrian Spatial Utility Perspective. South Africa: CE Projects.

Instituto Metropolitano de Planificación. (Junio de 1992). Plan de Desarrollo Metropolitano de Lima-Callao 1990-2010 - Parte VII. Recuperado el 3 de octubre de 2016, de Sociedad de Urbanistas del Perú: http://www.urbanistasperu.org/inicio/PlanMet/PlanMet\%20$\% 20$ Parte\%20VII.pdf

Jirón, P., \& Mansilla, P. (Setiembre de 2014). Las consecuencias del urbanismo fragmentador en la vida cotidiana de habitantes de la ciudad de Santiago de Chile. EURE.

La Rioja. (05 de diciembre de 2011). Estación de autobuses de Logroño. Recuperado el 20 de septiembre de 2016, de La Rioja - WikiRioja: http://wikirioja.com/index.php?title=Estación_de_autobuses_de_Logroño

Lerner, J. (2014). Urban Acupuncture. Washington: Island Press.

Lynch, K. (2010). La imágen de la ciudad. Barcelona, España: Graficas 92.

Martignoni, J. (13 de febrero de 2013). Centro de Desarrollo Cultural Moravia. Recuperado el septiembre 20 de 2016, de Arqa: http://arqa.com/gallerypage? $\mathrm{id}=369518$

Ministerio de Cultura. (2016). ¿Quiénes somos? Obtenido de Ministerio de Cultura: http://www.cultura.gob.pe/es/informacioninstitucional/quienessomos

Ministerio de Desarrollo e Inclusión Social. (s.f.). MIDIS. Obtenido de MIDIS PERÚ: www.midis.gob.pe

Ministerio de Vivienda. (2010). CE.030 OBRAS ESPECIALES Y COMPLEMENTARIAS. Lima: Ministerio de Vivienda.

Miralles-Guasch, C., \& Cebollada i Frontera, A. (2003). Movilidad y transporte. Opciones políticas para la ciudad. Madrid: Fundación Alternativas. 
Mogollón, N. (2006). Tesis de grado: Ley del Distrito Metropolitano en la que se encarga la organización y la operación del transporte urbano de pasajeros al Municipio de Quito. . Quito, Ecuador: Escuela Politécnica del Ejército.

Moliní, F., \& Salgado, M. (2010). Superficie artificial y viviendas multifamiliares en España, dentro del debate entre ciudad compacta y dispersa. (D. d. Madrid, Ed.) Boletín de la Asociación de Geógrafos Españoles(54), 125-147.

Montezuma, R. (2003). Ciudad y transporte. La movilidad urbana. En N. Unidas, La ciudad inclusiva (págs. 175-192). Santiago de Chile: CEPAL.

Montoya, J. I., Gómez, O., Quintanilla, O., Andavert, D., Dávalos, A., \& Farreras, J. (15 de Enero de 2011). Moravia como ejemplo de transformación de áreas urganas degradadas: tencologías apropiadas para la restauración integral de cuentas hidrográficas. NOVA - Publicación cientifica en Ciencias Biomedicas, págs. 38-65.

MTC: Ministerio de transportes y comunicaciones. (s.f.). MTC: Ministerio de tranportes y comunicaciones. Obtenido de MTC: Ministerio de tranportes y comunicaciones.

Municipalidad de Barranco. (2016). Propuesta del Plan Concertado de Cultura 20162021. Municipalida de Barranco, Agenda 21. Lima: Municipalidad de Barranco.

Municipalidad Metropolitana de Lima. (2012). Plan Regional de Desarrollo Concertado de Lima 2012 - 2025. Lima: MML.

Municipalidad Metropolitana de Lima. (2016).Gerencias de la Municipalidad de Lima. Obtenido de Municipalidad de Lima: http://www.munlima.gob.pe/gerencias

Muñoz, R. (26 de noviembre de 2012). La reforma del transporte público y la calidad de vida. Recuperado el 1 de octubre de 2016, de PUCP PuntoEdu: http://puntoedu.pucp.edu.pe/opinion/la-reforma-del-transporte-publico-y-lacalidad-de-vida/

Nates Cruz, B. (Junio de 2011). Soportes teóricos y etnográficos sobre conceptos de territorio. Co-herencia, 8(14), 209-229.

Ortiz de Zevallos, A. (1992). Urbanismo para sobrevivir en Lima. Lima: Apoyo.

Oviedo Lira, J. A. (14 de abril de 2011). PLANMET: Plan de Desarrollo Metropolitano de Lima y Callao 1990-2010 [mensaje en un blog]. Recuperado el 08 de septiembre de 2016, de UrbVial: http://urbvial.blogspot.pe/2011/04/planmetplan-de-desarrollo.html

Perú 21. (03 de marzo de 2017). Accidente en la Panamericana Sur: ¿Por qué los peatones no utilizaron un paradero autorizado? Obtenido de Perú 21: https://peru21.pe/lima/accidente-panamericana-sur-peatones-utilizaronparadero-autorizado-67563

Plazola Cisneros, A. (2001). Enciclopedia de arquitectura Plazola . México D.F.: Plazola Editores.

Prieto Pérez, S. (2007). The ideal city. Ars medica. Revista de humanidades., 2:215234.

PROTRANSPORTE. (2013). PROTRANSPORTE: Instituto metropolitano de transporte de Lima. Obtenido de PROTRANSPORTE, Quienes somos: www.protransporte.gob.pe

RAE. (s.f.). Real Academis de la Lengua Española.

Rioja2. ( 04 de julio de 2016). Así será la nueva estación de autobuses de Logroño. Recuperado el 20 de septiembre de 2016, de Rioja2: http://www.rioja2.com/n105379-3-asi-sera-la-nueva-estacion-de-autobuses-de-logrono/ 
Rodriguez, D., \& Vergel Tovar, E. (Enero de 2013). Sistemas de transporte público masivo tipo BRT (Bus Rapid Transit) y desarrollo urbano en América Latina. Land Lines, 16-24.

SANCHEZ ELIZALDE, N. (2014). Centro Cultural Integrador. Quito, Ecuador: Pontificia Universidad Católica del Ecuador.

Secchi, B. (Enero de 1993). Un'urbanistica di spazi aperti. Casabella, 597-598.

Tord, L. E. (2015). Barranco: Historia, leyenda y tradición. Lima, Lima, Perú: Fondo Editorial - USMP.

Trachana, A. (Junio de 2013). Procesos emergentes de transformación del espacio público. Bitácora(22).

Transmilenio. (2005). Cinco años construyendo futuro. Bogotá.

UNESCO. (2008). Agenda21. UNESCO, UCGLU. UNESCO.

UNICEF. (2000). Enrédate. Obtenido de Enrédate: UNICEF: www.enredate.org

Universidad Politécnica de Madrid. (27 de mayo de 2015). Implantación de una línea circular de autobús urbano en Logroño. Obtenido de MateWiki: https://mat.caminos.upm.es/wiki/Implantaci\%C3\%B3n_de_una_1\%C3\%ADne a_circular_de_autob\%C3\%BAs_urbano_en_Logro\%C3\%B1o\#Conclusiones

Urazán Bonells, C. F., \& Rondón Quintana, H. A. (agosto de 2010). Relación entre el espacio público y la infraestructura de un sistema de transporte masivo. Caso Transmilenio en Bogotá. Studiositas, 5(2), 37-48.

Villamil, P. (03 de mayo de 2011). Centro Cultural Gabriela Mistral-Chile.II [entrada en un blog]. Recuperado el 27 de septiembre de 2016, de arquitectura y tecnología: http://arqytec.blogspot.pe/2011/05/centro-cultural-gabrielamistral.html

Wright, L., \& Hook, W. (2010). Guía de Planificación de Sistemas BRT. Nueva York: Institute for Transportation \& Development Policy.

Yütronic, C. (s.f.). Arquitectura en Acero. Recuperado el 26 de septiembre de 2016, de Centro Cultural Gabriela http://www.arquitecturaenacero.org/proyectos/recuperacion-restauracion-yreciclaje/centro-cultural-gabriela-mistral 
Anexos

Láminas de contexto y proyecto

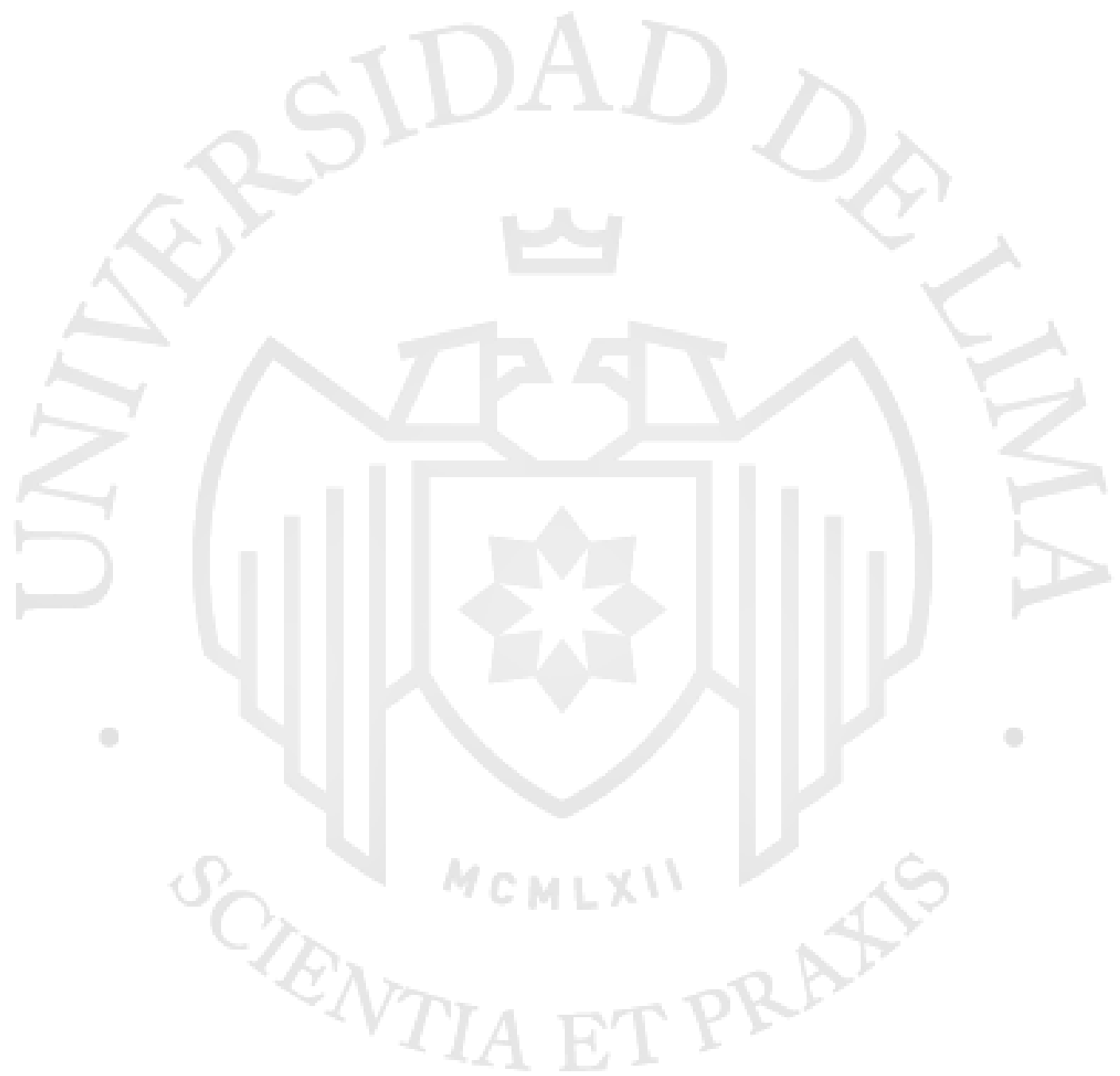




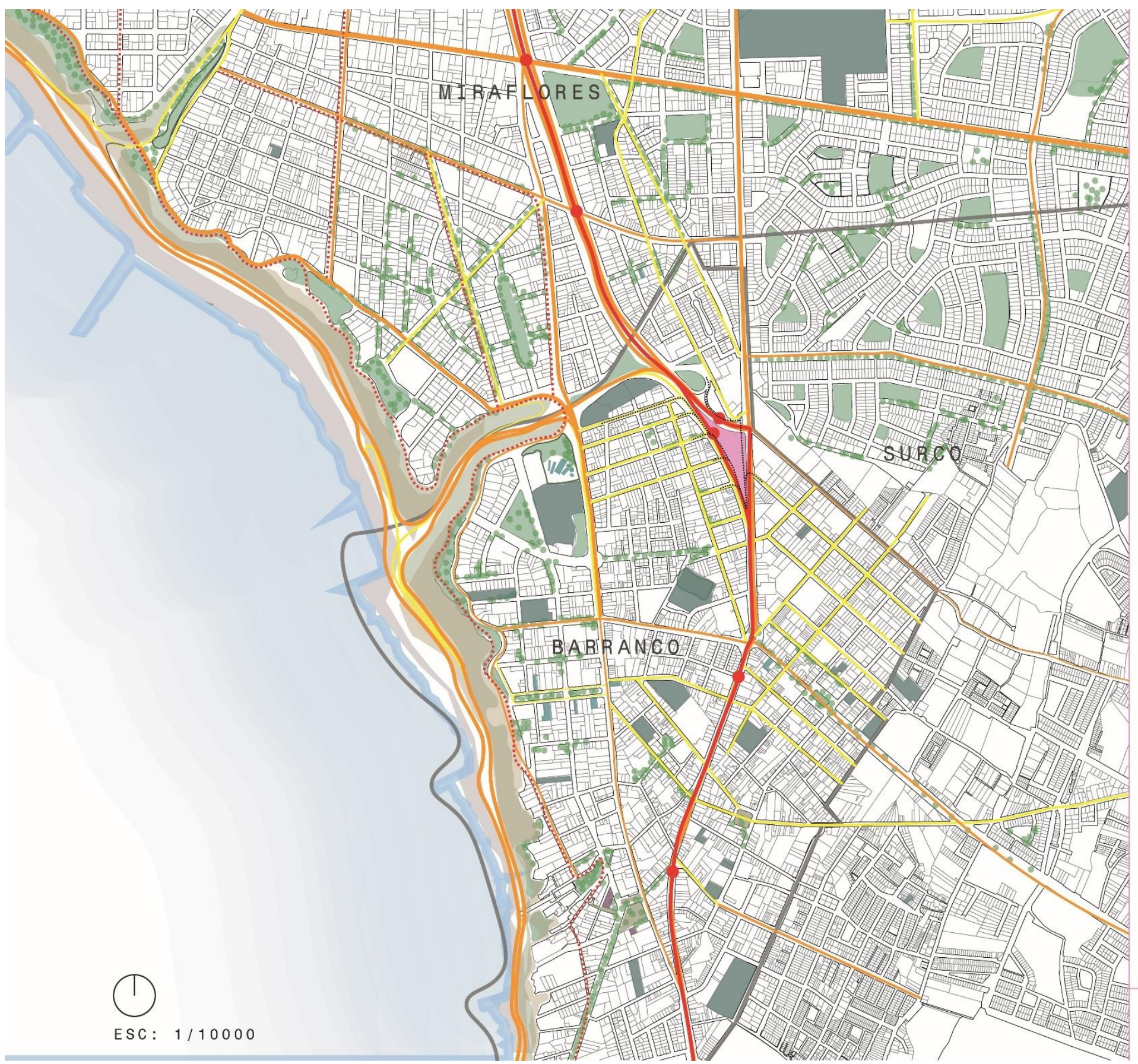

TERRENO

LIMITE DISTRITAL

...... CAMINOS PEATONALES

".... CIClovia

CALLE SECUNDARIA

VIA PRINCIPAL

METROPOLITANO

INSTITUCIONES

GUVERNAMENTALES

INST I TUCIONES

EDUCAT IVA

ESPACIOS CULTURALES

$Y$ DE ARTE

PLAZAS

PARQUES PUBLICOS

PARQUES CERRADOS

ACANT I LADO

$100 \%$

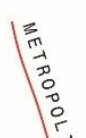

$57 \%$

$96 \%$

$74 \%$

$74 \%$

$53 \%$

$53 \%$

$76 \%$

$0 \%$

$43 \%$

$4 \%$

$26 \%$

$47 \%$

$24 \%$

ANALISIS CONTEXTUAL

EQUIPAMIENTO Y VÍAS
BARAACO-SUROO-MIRAFLOAES

LAM

01 


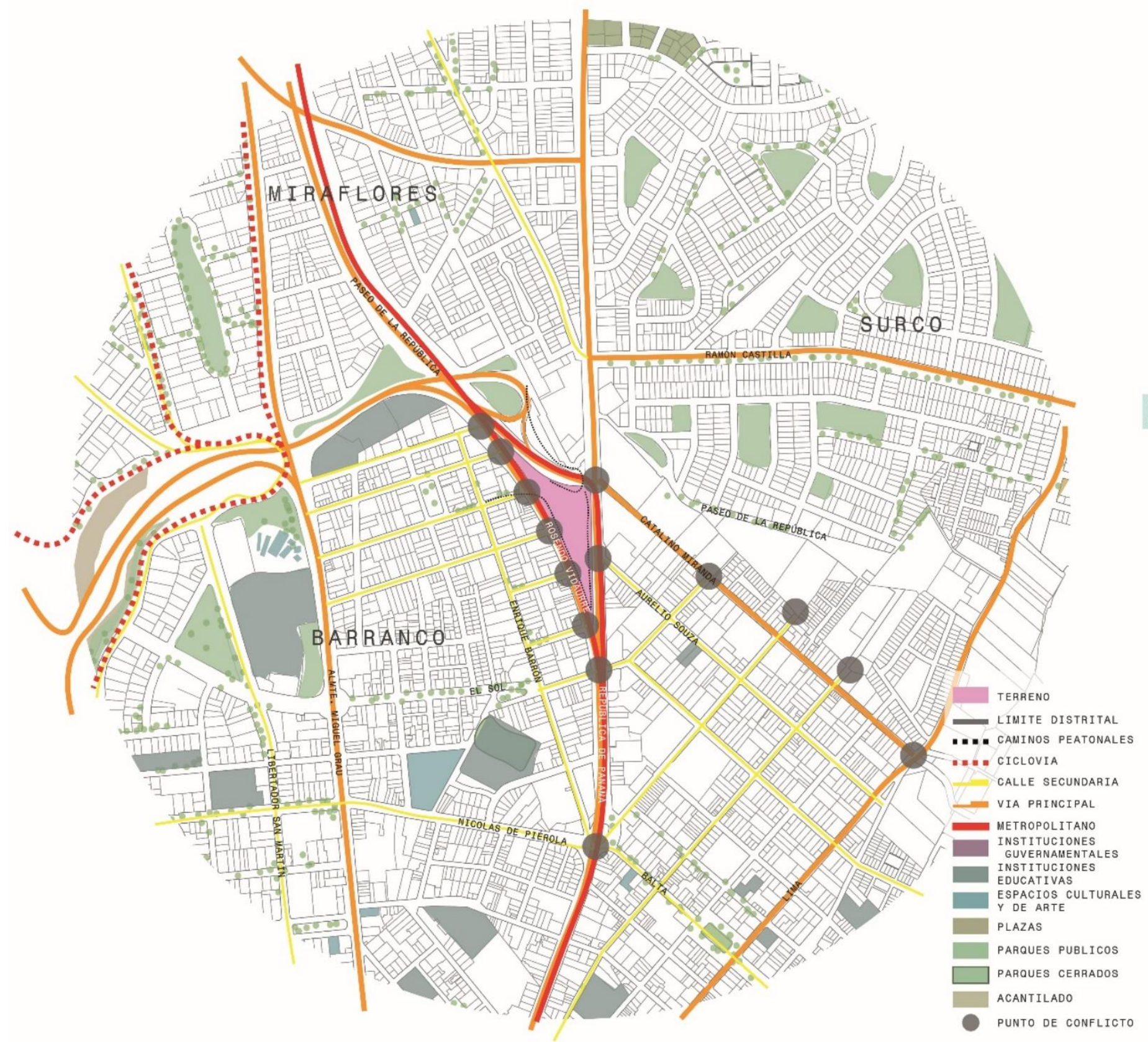

El terreno es un vacio urbano que interrum pe la conexión física entre los 3 distritos y dificulta la accesibilidad de todos a espalimites, el paso peatonal y las vías vehiculares son interrumpidas, generando que toda circuculación desemboque en él.

Sin embargo, los conflictos de tránsito, mala iluminacion, ausencia de confort caminar yla limitación de circulacion, vaeden ser convertidos y aprovechar el encuentro y activar los bordes físicos y virtuales creados a su alrededor por la via del Metropolitano y Paseo de la República.

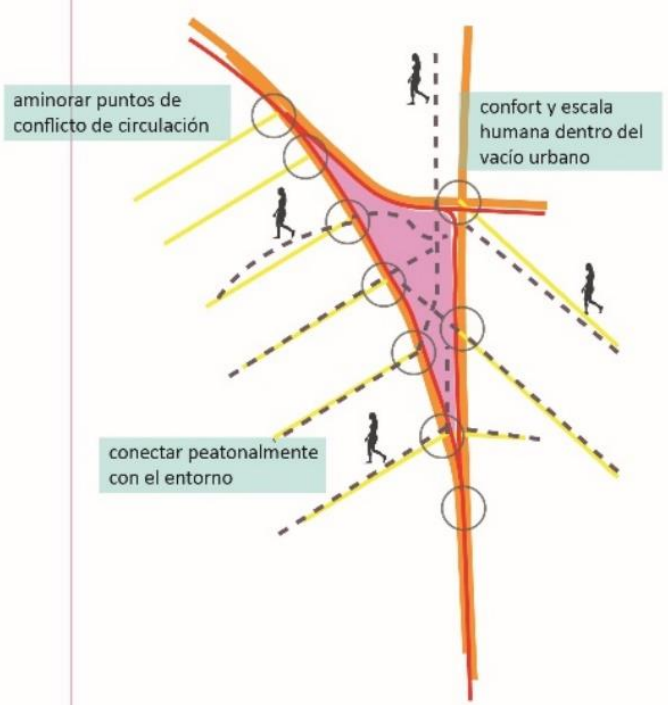

El vacío urbano es un espacio para generar caminos peatonales, ciclovias y la oportunidad de desembarcar usuarios del Metropolitano hacia otros espacios de interés cercanos (culturales, espacios públicos, malecón, etc)

ANALISIS CONTEXTUAL 


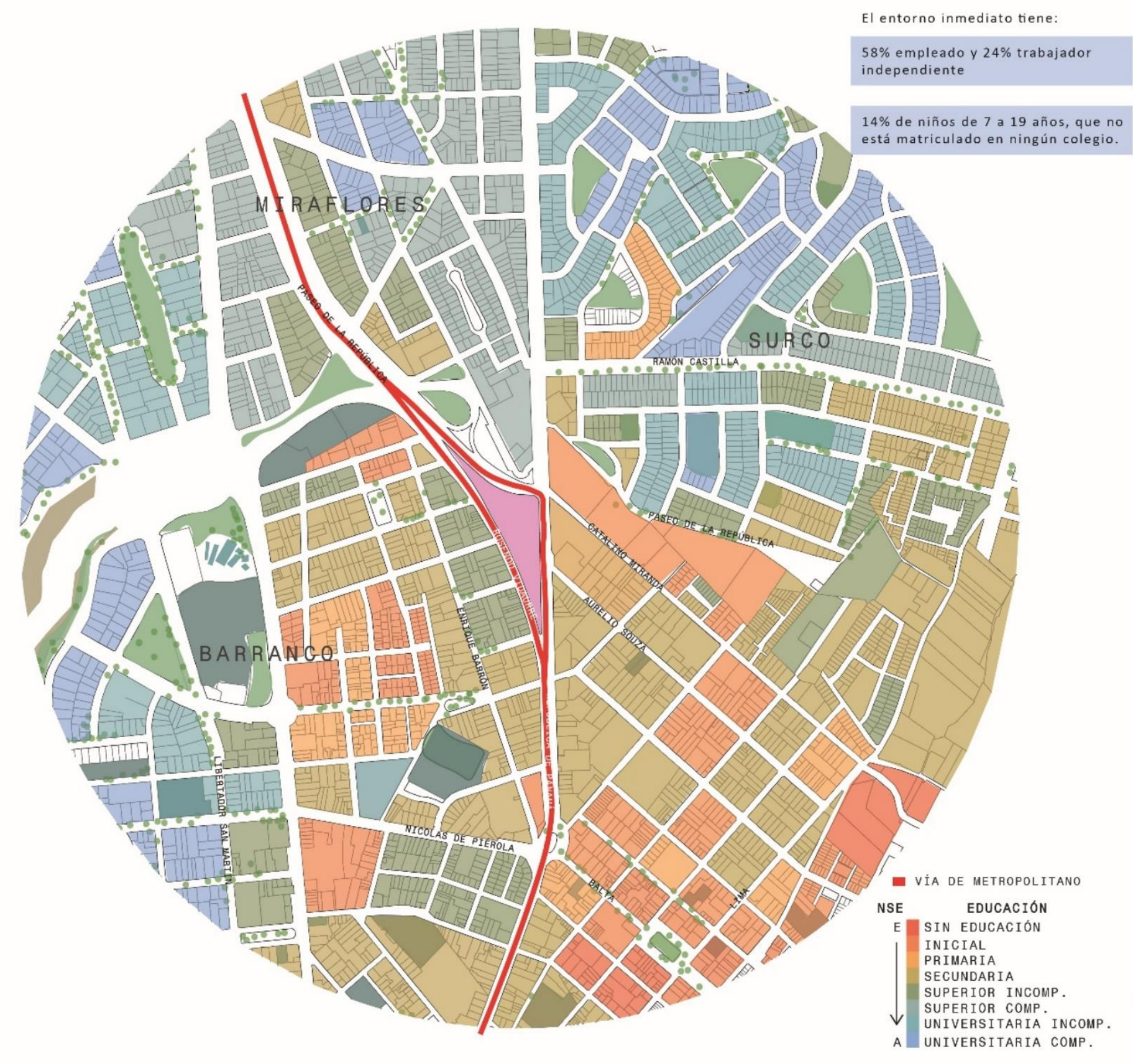

Las variables de NSE y educación a ambos extremos de la via del Metropoliano, difieren y preocupan, considerando que son dos pertenecen al mismo distrito.

Al lado Oeste de la vía, predomina el NSE B yla población con nivet de instruccion superior completa. Mientras, al Este, mayor el NSE C-D y aquellas personas con nivel de instrucción secundaria.

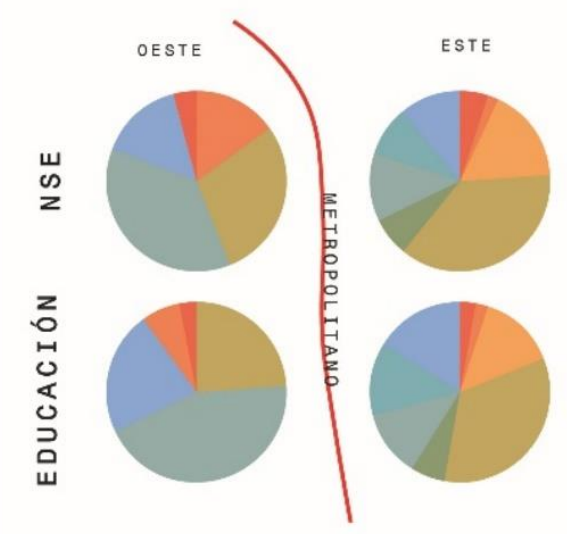

El programa debe contemplar

actividades y espacios de trabajo para el $24 \%$ de trabajadores independientes, además de entretenimiento para el público en general.

Debe organizarse programas de oficios alternativos para quienes no tuvieron superiores y/o técnicos.

Lo más importante es proyectar un espacio para los niños que no van a la escuela y talleres en las tardes. Este debe considerar sus necesidades de recreación y socialización positiva. Además de brindar servicios públicos que les ensene oficios artisticos $y$ educar alternativamente con arte $y$ cultura.

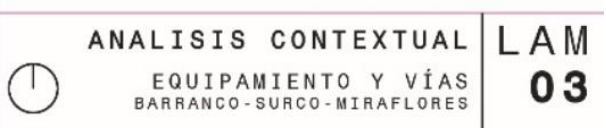




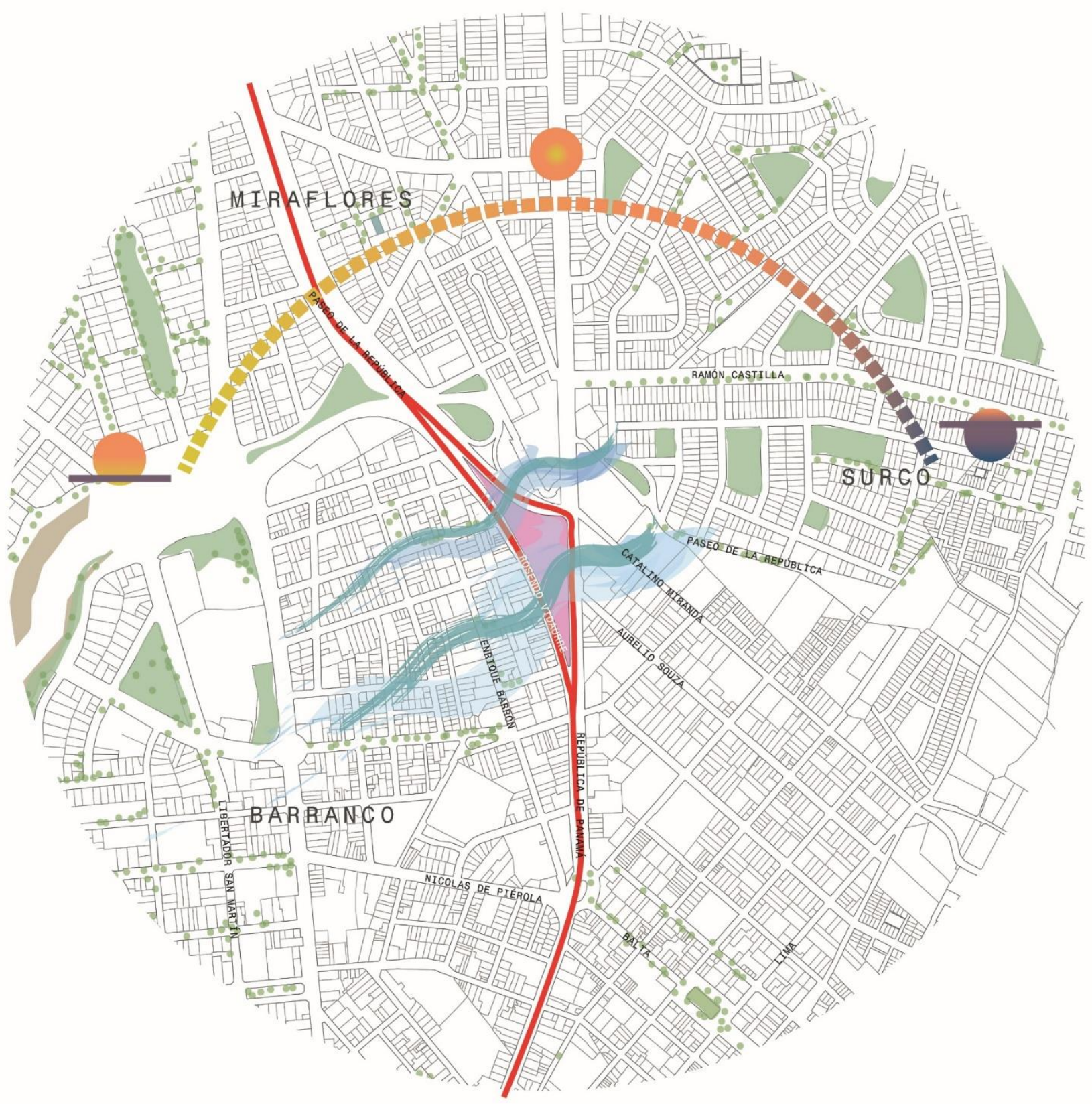

- vía del metropolitano

a altura $95.00 \mathrm{msnm}$

- ASOLEAMENTO

- VIENTOS DE SUROESTE A NORESTE

VELOCIDAD $3 M / S$

TEMPERATURA PROMEDIO DEL AIRE :

ENERO - MARZO
$21^{\circ} \mathrm{C}$ A $29^{\circ} \mathrm{C}$
ABRIL-JUNIO
$17^{\circ} \mathrm{C}$ A $27^{\circ} \mathrm{C}$
JULIO-SEPTIEMBRE
$15^{\circ} \mathrm{C}$ C $19^{\circ} \mathrm{C}$
OCTUBRE-DICIEMBRE
$15^{\circ} \mathrm{C}-19^{\circ} \mathrm{C}$

HUMEDAD RELATIVA PROM. :

D I C I EMBRE - ABR I L

NOCHE $90 \%$

NECHE

MAYO - NOVIEMBRE

NOCHE $90 \%$

MEDIODIA $80 \%$

Las fachadas este y oeste del proyecto deberán ser las más protegidas.

\section{La pendiente del terreno es de menos de $5.00 m$ de problema para el proyecto.}

FUENTE：Senamhi (2016)

\begin{tabular}{rr|r} 
analisis de terreno & L A M \\
medio ambiente & $\mathbf{0 4}$
\end{tabular} 
- plaza/bulevar

- parque público

- PARQUE PRIVADO

- área Verde inuti BERMA CENTRAL

- via del metropolitano

ADA / 3) 1 计 IIt 53 \& (1)
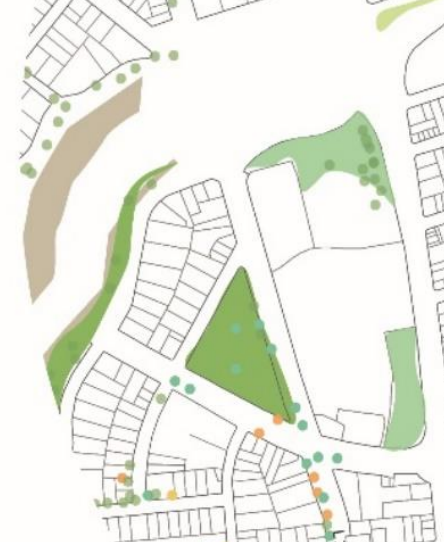

ESPECIES DE ÁRBOLES CONECIESTC ARBOLE

- MEIJO

- PALO VERDE

- eucalipto

- palmeras (Varios)

- TIPA TIPUANA

- PONCIANA

- araucaria

- OTROS

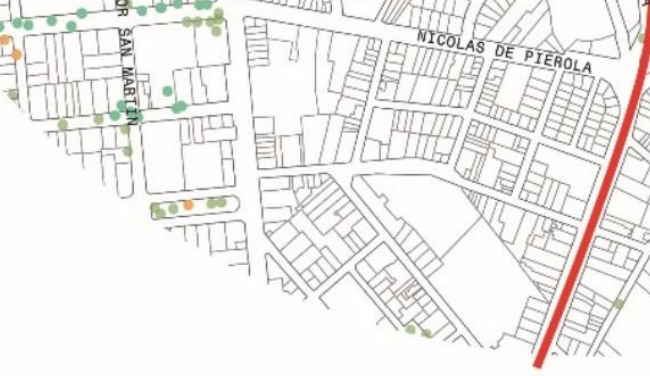

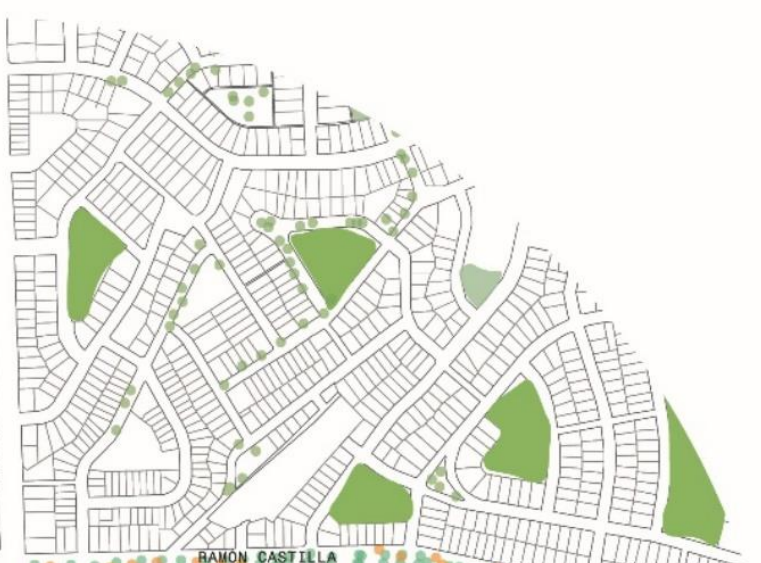

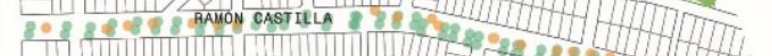
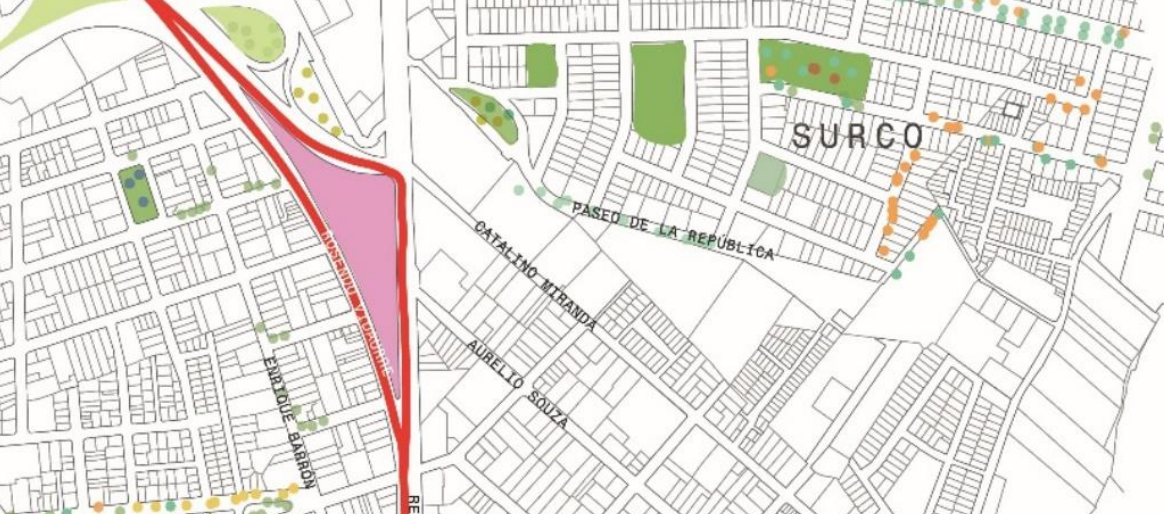

10.

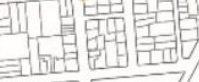

픈교 $A B / B A N C O=$
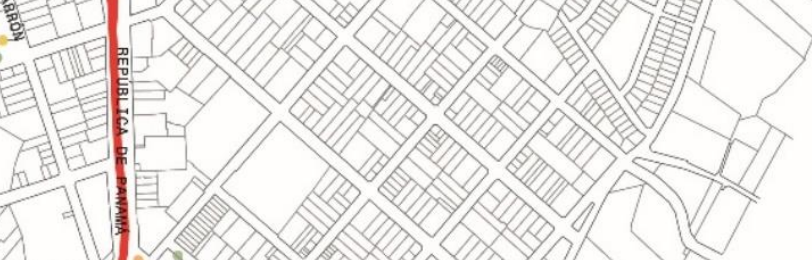
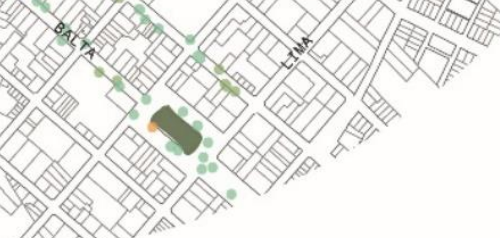

Las areas verdes del lado Oeste de la vía del Metropolitano, significan el doble de los espacios verdes al Este de la vía. La falta de areas verdes es mayor en la zona 3 de Barranco.

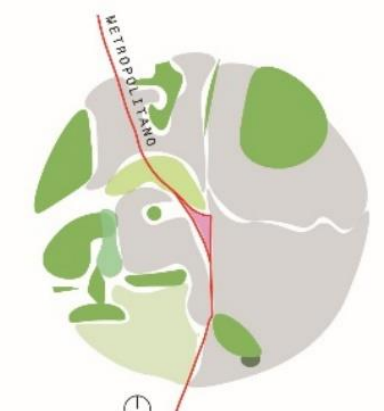

Se considerará espacios de masas arbóreas para brindar áreas verdes dentro del proyecto. Se utilizarán (principalmente) las 3 especies más encontradas en Barranco urco y Miraflores:

ESPECIES IDENTIDAD:
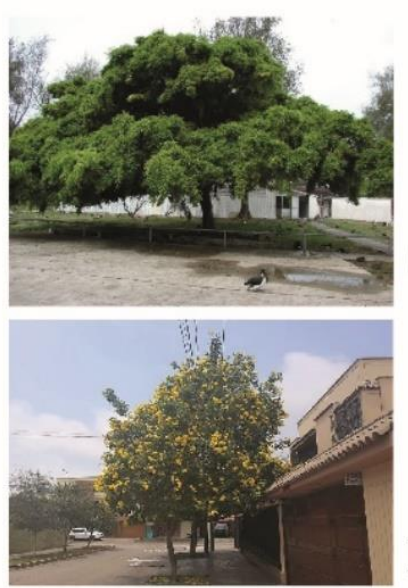

TIPAANA

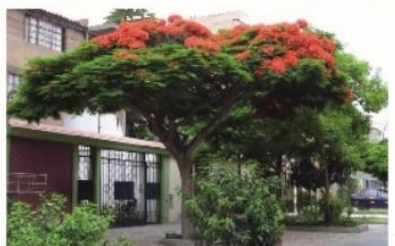

ANALISIS DE TERRENO L A M (1) sistema de áreas verdes 


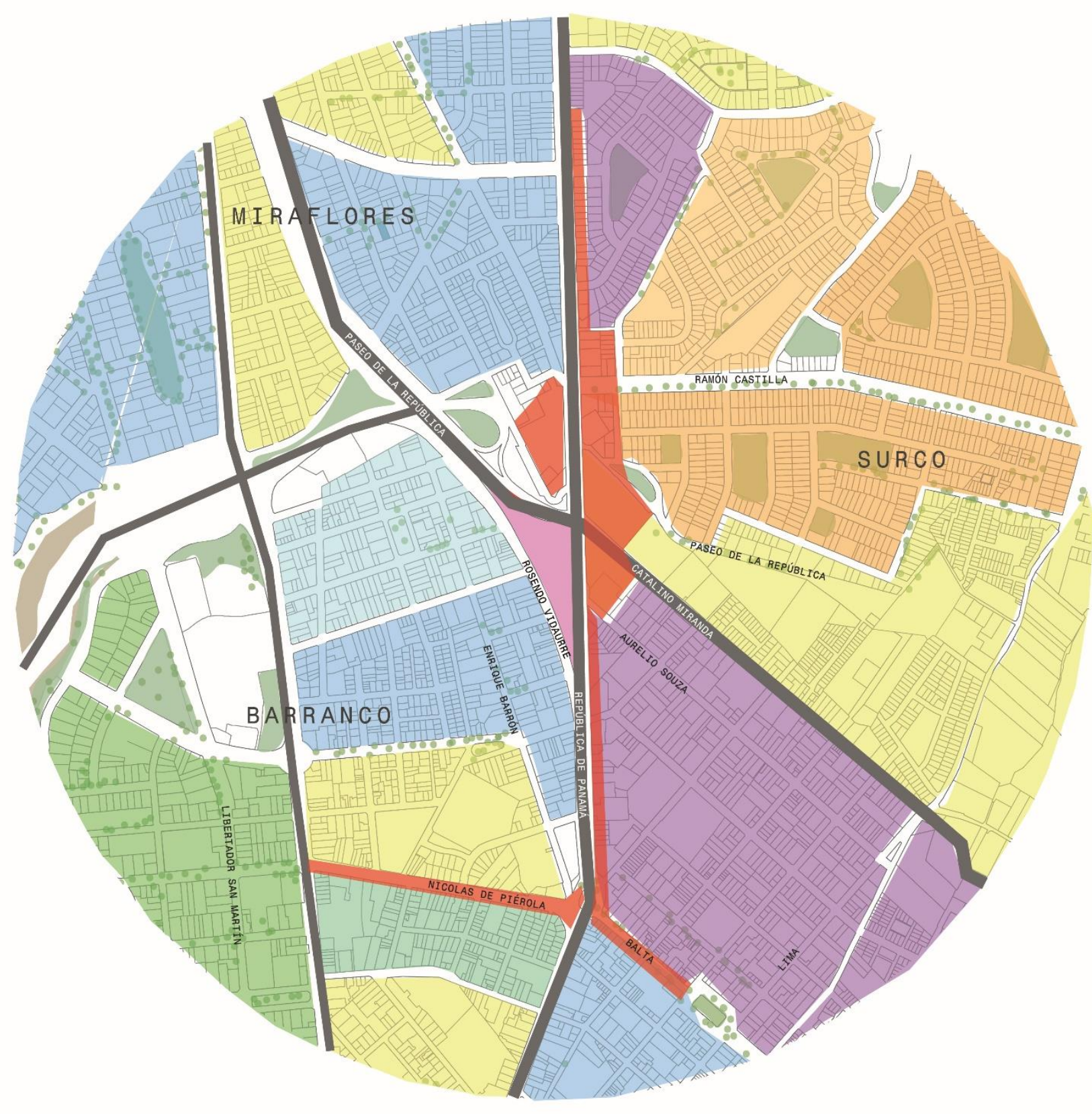

EN LOS 3 DISTRITOS EXISTEN BARRIOS DIFERENCIADO

EN BARRANCO EXISTE LA MAYOR DIFERENCIA ENTRE LAS

ALGUNOS BARRIOS ESTÁN

DETERMINADOS POR LA

MUN I C I PAL IDAD PERO

OTROS, HAN SIDO PROPUESTOS

POR NSE Y PERCEPCIÓN Y DE

ESTADO DE INFRAESTRUCTURA.

LÍMITES FÍSICOS

Vía del Metropolitano

LÍMITES VIRTUALES

Avenidas de comercio

industria (mercados y

supermercados

desarticulados, talleres

de mecánica)

ANALISIS DE TERRENO

(1) LIMITES, BORDES 

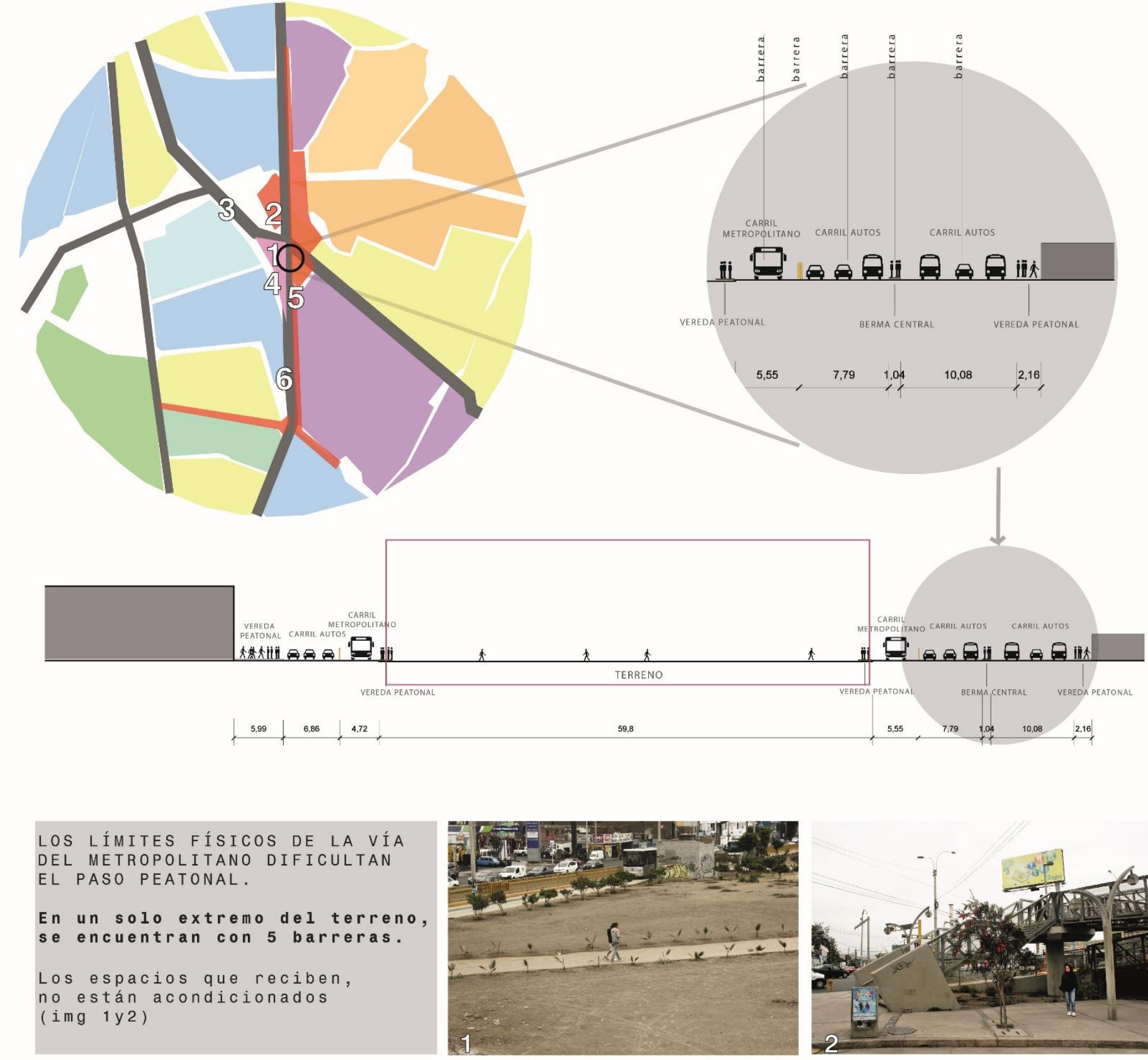
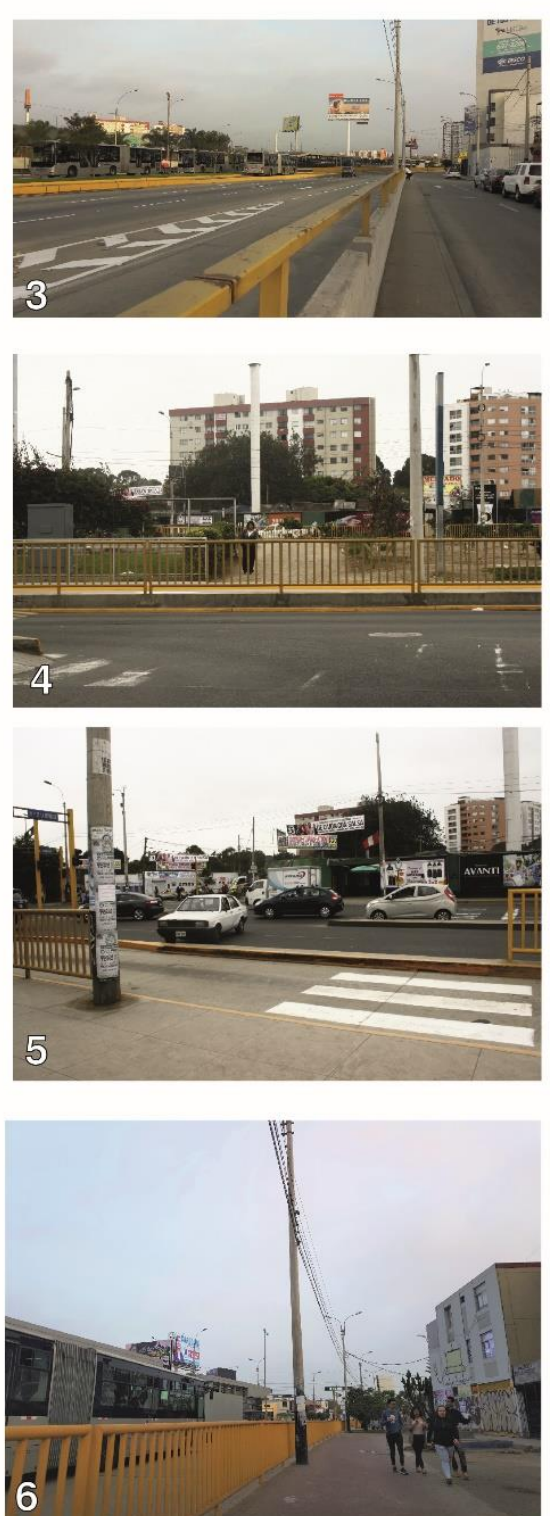

(1)

ANALISIS DE TERRENO L A M LIMITES, BORDES

07 

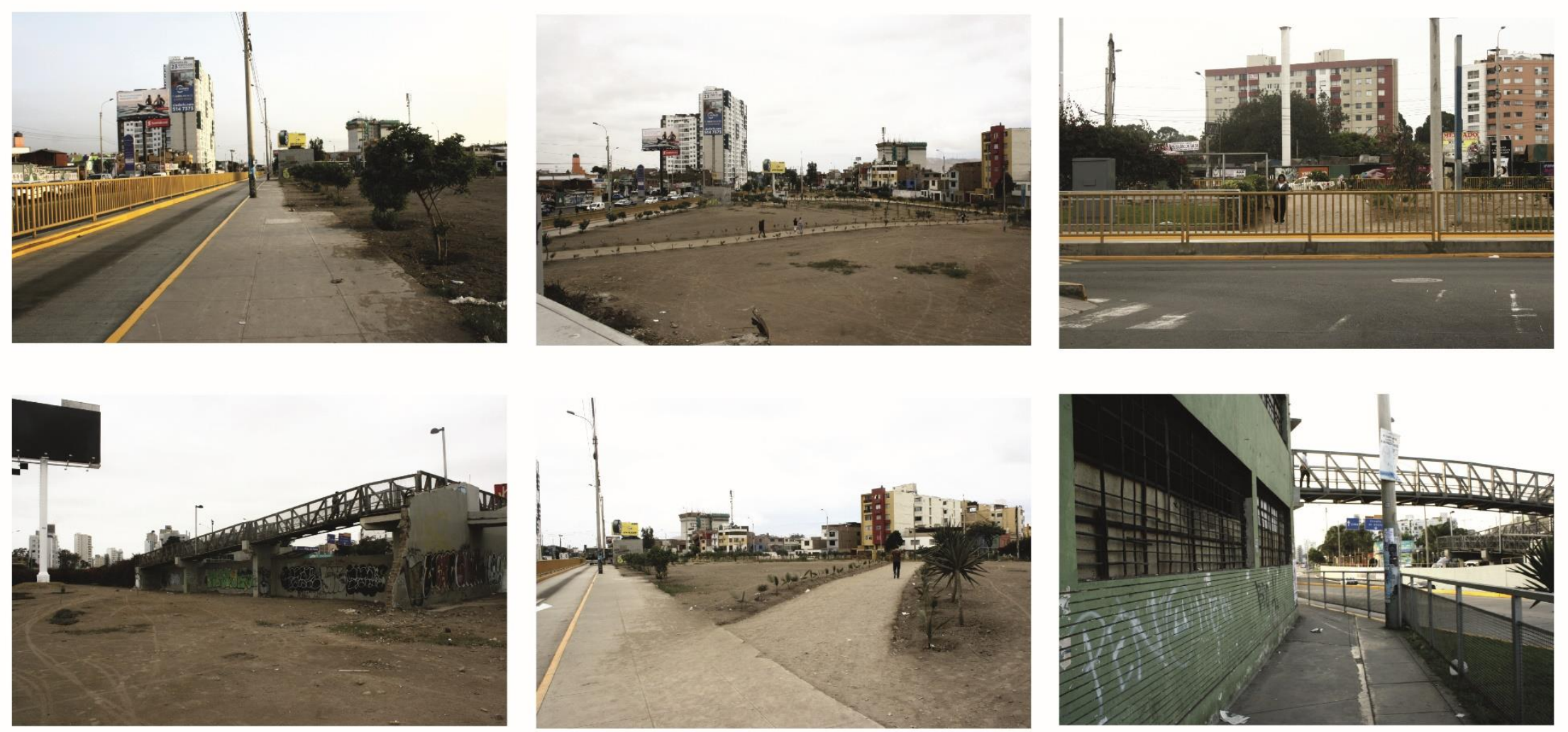

INTERIOR DEL TERRENO

(1) \begin{tabular}{r|r} 
ANALISIS DE TERRENO & LAM \\
LEVANTAMIENTO & $\mathbf{0 8}$ \\
FOTOGRAFICO &
\end{tabular} 


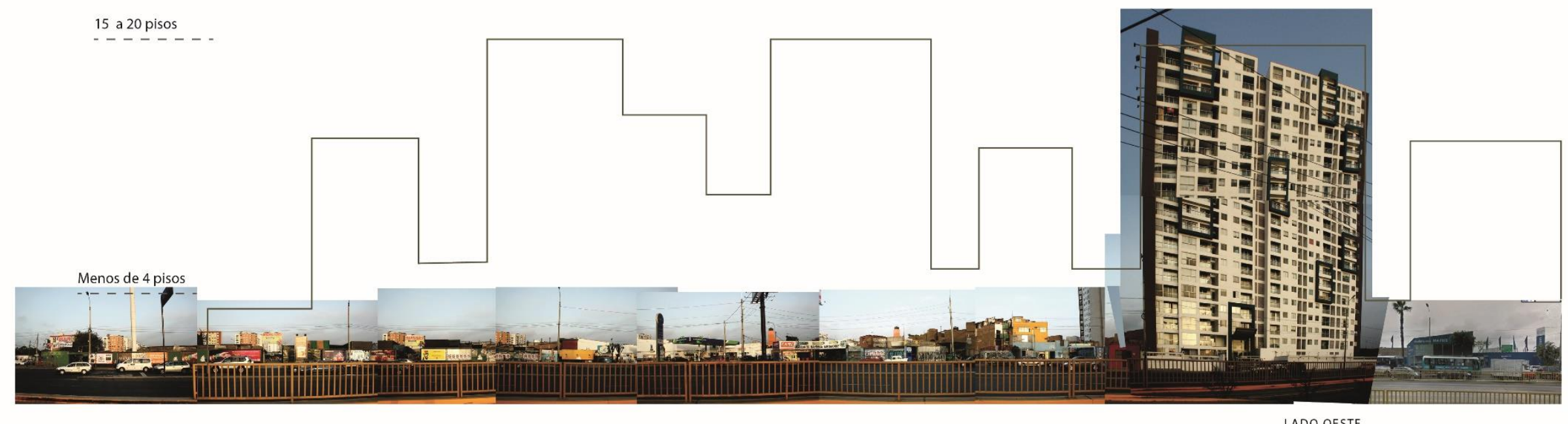

LADO OESTE

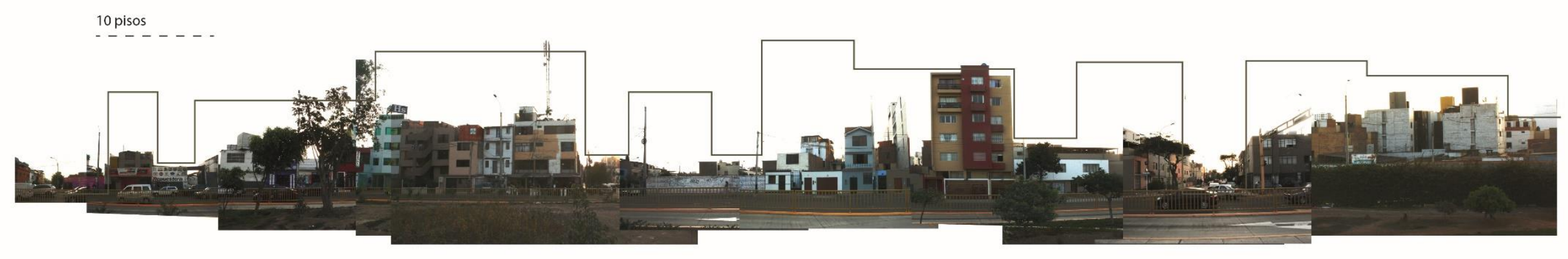

LADO ESTE

El perfil urbano alrededor del terreno, actualmente presenta alturas y dunciones mixtas.

Muchos edificios son vivienda de dos pisos o vivienda taller. Sin embargo, se proyecta

cambiar la zonificacion a Residencial Alta, y permitir la construccion de edificios de vario

pisos.

Es importante aprovechar el vacío urbano para crear un descanso entre el crecimiento

urbano yque la nueva población del área cuente con espacios de esparcimiento.

(1) \begin{tabular}{r|r} 
Analisis de terReno & LAM \\
LeVANTAMIENTO & $\mathbf{0 9}$ \\
FOTOGRÁFICO &
\end{tabular} 


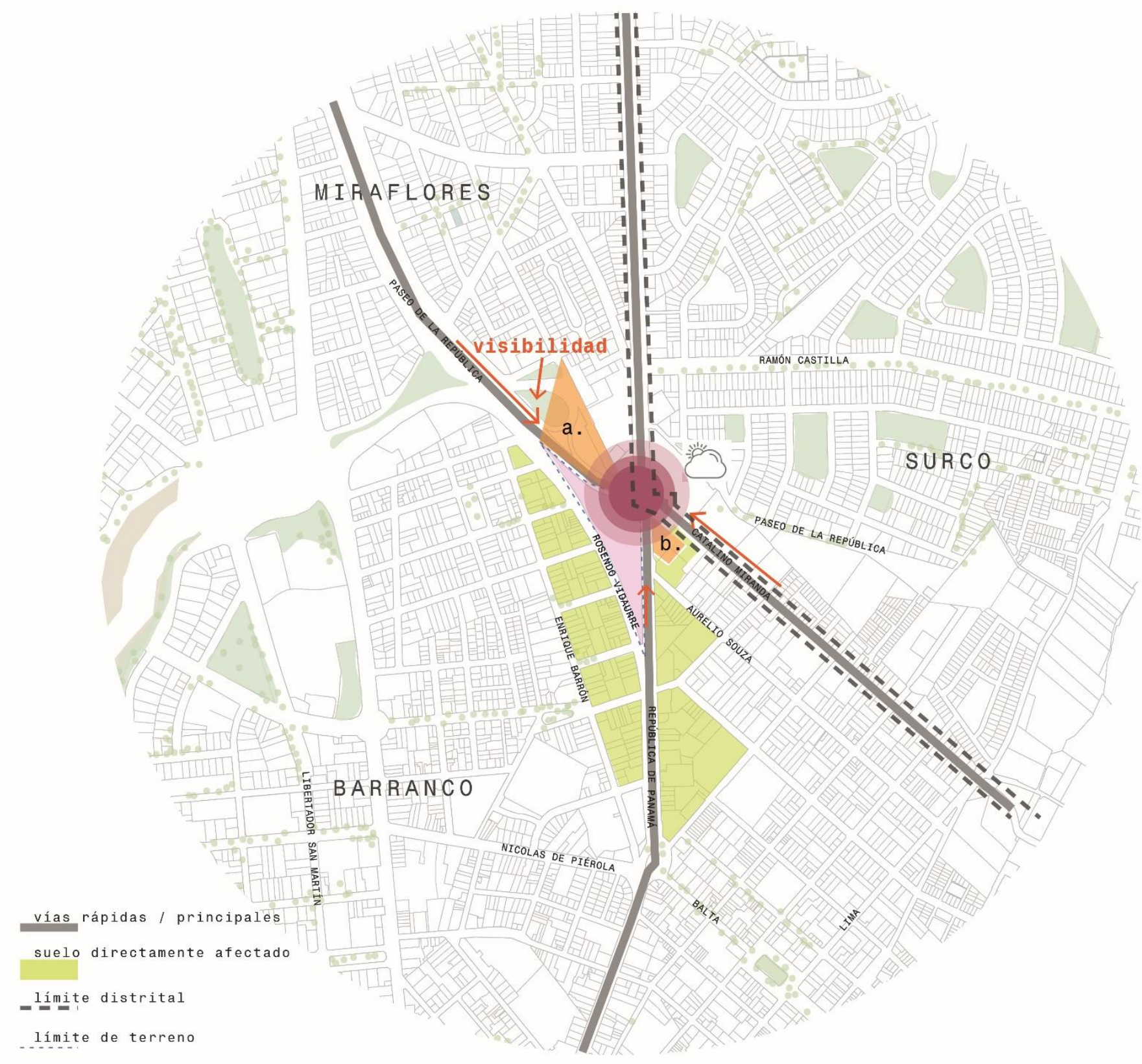

POTENCIALIDADES :

\section{El terreno:}

- Se encuentra en un distrito de tradición cultural. Es el encuentro entre 3 distritos.

- Visibilidad desde una vía Uicrolita.

templado a 10

largo del año.

\section{El programa en el terreno:}

- Podrá atender a una población nueva, que llega con el

crecimiento inmobiliario. - Aumentará el valor del m2 aledaño.

Conectará dos comercios

florales independientes (a y b)

\section{LIMITACIONES :}

\section{El terreno:}

La proyección de la Vía Expresa Sur supone una mayor división urbana.

\section{El programa en el terreno:}

- La morfología triangular supone mayores retos en emplazamiento.

Podria ser insuficiente la luz natural en épocas

- Mantener las vías rápidas cerca a un espacio recreacional, podría ser peligroso por la contaminación visual, auditiva y la velocidad.

ANALISIS DE TERRENO
POTENCIALIDADES 


\begin{tabular}{|c|c|c|c|c|c|c|c|c|c|c|c|}
\hline EDIFCIO & NIVEL & $\begin{array}{c}\text { AREA TOTAL } \\
\text { (M2) }\end{array}$ & PROGRAMA & $\begin{array}{l}\text { AREA PROGRAMA } \\
\text { (M2) }\end{array}$ & AFORO & EDIFICIO & NIVEL & $\begin{array}{c}\text { AREA TOTAL } \\
(\mathrm{M} 2)\end{array}$ & PROGRAMA & $\begin{array}{l}\text { AREA/ PROGRAMA } \\
\text { (M2) }\end{array}$ & AFORO \\
\hline \multirow{38}{*}{$\begin{array}{l}\text { ESTACIONAMENTO } \\
\text { ESTACION DE MERROPOUTANC } \\
\text { MEZZANINE DE ESTACION }\end{array}$} & SOTANO 3 & $5,278.00$ & $\begin{array}{l}\text { Area técnica estación } \\
\text { Estacionamientos CCB }\end{array}$ & $\begin{array}{r}633.00 \\
4,645.00\end{array}$ & 5.00 & \multirow[t]{34}{*}{ MONOLTO } & SEMISOTANO & 963.00 & $\begin{array}{l}\text { Recepción } \\
\text { Tienda } \\
\text { Fxposiciones }\end{array}$ & $\begin{array}{r}33.00 \\
157.00 \\
45550\end{array}$ & \multirow{2}{*}{$\begin{aligned} 2.00 \\
5233 \\
15167\end{aligned}$} \\
\hline & O SOTANO 2 & \multirow[t]{2}{*}{$3,599.00$} & \multirow{2}{*}{$\begin{array}{l}\text { Estación } \\
\text { Area de control y técnica } \\
\text { Cafeteria }\end{array}$} & $\begin{array}{r}2,725.00 \\
819.00\end{array}$ & $\begin{array}{r}1362.50 \\
8190\end{array}$ & & \multirow{3}{*}{ PLANTA1 } & \multirow{3}{*}{682.00} & SSHH & $\begin{array}{r}43600 \\
46.00\end{array}$ & \\
\hline & & & & 55.00 & ${ }_{5.50}$ & & & & $\begin{array}{l}\text { Exposiciones } \\
\text { Exxposiciones }\end{array}$ & $\begin{array}{l}310.12 \\
20400\end{array}$ & \multirow{2}{*}{$\begin{array}{l}103.37 \\
68.00\end{array}$} \\
\hline & SOTANO 1 & 383.00 & $\begin{array}{l}\text { Espaciode distribución } \\
\text { Torniquetes }\end{array}$ & $\begin{array}{l}251200 \\
132.00\end{array}$ & $\begin{array}{l}100.40 \\
52.80\end{array}$ & & & & Depósito & 63.00 & \\
\hline & NIVELO & $15,338.00$ & Espacio pais ajistico & $15,338.00$ & $5,12.67$ & & PLANTA2 & $1,007.00$ & $\begin{array}{l}\text { Seguridad } \\
\text { Oficina } \\
\text { Recepción } \\
\text { Alm. Vestuario } \\
\text { Camerino } \\
\text { Camerino } \\
\text { Almacén }\end{array}$ & $\begin{array}{l}22.00 \\
46.00 \\
25.00 \\
16.00 \\
30.00 \\
39.00 \\
1200\end{array}$ & $\begin{array}{r}3.00 \\
4.60 \\
2.50 \\
10.00 \\
13.00\end{array}$ \\
\hline & PLANTA2 & 1,000.00 & Recibo & 26.10 & & & & & Area de mesas & 2400 & \multirow{2}{*}{18.80} \\
\hline & & & $\begin{array}{l}\text { Comercio } \\
\text { Oficina } 1\end{array}$ & $\begin{array}{l}587.00 \\
58.00\end{array}$ & $\begin{array}{c}17.40 \\
5.60\end{array}$ & & & & 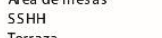 & 20.00 & \\
\hline & & & $\begin{array}{l}\text { Oficina } 2 \\
\text { Kitthente }\end{array}$ & $\begin{array}{r}34.00 \\
34.78\end{array}$ & - & & & & $\begin{array}{l}\text { Terraza } \\
\text { Bar }\end{array}$ & $\begin{array}{l}44.00 \\
0.00\end{array}$ & \multirow{2}{*}{$\begin{array}{l}7.60 \\
1.00 \\
1.00\end{array}$} \\
\hline & & & 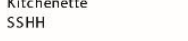 & $\begin{array}{l}.4 .28 \\
6.24\end{array}$ & 191 & & & & $\begin{array}{l}\text { Oficina } \\
\text { Des perdicios }\end{array}$ & $\begin{array}{l}8.70 \\
8.00\end{array}$ & \\
\hline & PLANTA3 & $1,378.00$ & sum 1 & 90.00 & 45.00 & & & & $\begin{array}{l}\text { Cocina } \\
\text { Almacenes }\end{array}$ & $\begin{array}{l}65.00 \\
26.00\end{array}$ & 6.00 \\
\hline & & & $\begin{array}{l}\operatorname{suM} 2 \\
\text { SUM3 }\end{array}$ & $\begin{array}{l}70.00 \\
88.00\end{array}$ & $\begin{array}{l}35.00 \\
44.00\end{array}$ & & \multirow{3}{*}{ PLANTA3 } & & Boletería & 12.00 & 2.00 \\
\hline & & & $\begin{array}{l}\text { SUM } 4 \\
\text { Sala espera }\end{array}$ & $\begin{array}{l}130.00 \\
55.00\end{array}$ & $\begin{array}{l}65.00 \\
2.160\end{array}$ & & & 1053.00 & $\begin{array}{l}\text { Oficina } \\
\text { Hall }\end{array}$ & $\begin{array}{l}39.00 \\
5500\end{array}$ & \multirow{2}{*}{$\begin{array}{r}4.00 \\
20.40\end{array}$} \\
\hline & & & Kitchenette & 33.00 & 5.20 & & & & Almacén & $\begin{array}{l}1500 \\
19.00\end{array}$ & \\
\hline & & & $\begin{array}{l}\text { Depósito } \\
\text { Sala espera }\end{array}$ & $\begin{array}{r}2100 \\
40.00\end{array}$ & $\therefore .00$ & & & & $\begin{array}{l}\text { Sala de ensayo } \\
\text { Taller escenografias }\end{array}$ & $\begin{array}{l}130.00 \\
80.00\end{array}$ & $\begin{array}{l}26.00 \\
8.00\end{array}$ \\
\hline & & & Recibo & 15100 & 2.00 & & & & Retroescenario & 78.00 & \multirow{2}{*}{$\begin{array}{l}10.00 \\
15.50 \\
8.50\end{array}$} \\
\hline & & & $\begin{array}{l}\text { Terraza } \\
\text { SSHH }\end{array}$ & $\begin{array}{r}\begin{array}{r}55.500 \\
42.20\end{array} \\
-\end{array}$ & 222.00 & & & & $\begin{array}{l}\text { SEscenario } \\
\text { Almacén CCB }\end{array}$ & $\begin{array}{l}85.00 \\
16.20\end{array}$ & \\
\hline & PLANTA4 & 851.00 & $\begin{array}{c}\substack{\text { Oficina } \\
\text { sstm }} \\
\text { s. }\end{array}$ & 45.10 & 4.51 & & PIANTA4 & & & & \\
\hline & & & Area de niños & 15.00 & 23.00 & & PLANIA4 & 1053.00 & $\begin{array}{l}\text { Butll } \\
\text { Hall (223) }\end{array}$ & $\begin{array}{l}230.85 \\
156.85\end{array}$ & $\begin{aligned} 223.00 \\
62.74\end{aligned}$ \\
\hline & & & $\begin{array}{l}\text { Computadoras } \\
\text { Deposito }\end{array}$ & $\begin{array}{l}65.00 \\
26.00\end{array}$ & B..00 & & & & $\begin{array}{l}\text { Confiteria } \\
\text { Terraza }\end{array}$ & $\begin{array}{l}4100 \\
82.7\end{array}$ & $\begin{array}{r}4.00 \\
33.08\end{array}$ \\
\hline & & & Area de lectura & $\begin{array}{l}250.00 \\
250\end{array}$ & 50.00 & & & & SSHH & $\begin{aligned} 56.00 \\
5600\end{aligned}-100$ & 30.00 \\
\hline & PLANTAS & 426.00 & $\begin{array}{l}\text { Sala de lectura } \\
\text { Lubreriacta }\end{array}$ & $\begin{array}{l}84.00 \\
26.80\end{array}$ & & & & & $\begin{array}{l}\text { Cabina control } \\
\text { Boletería }\end{array}$ & $\begin{array}{r}35.00 \\
8.00\end{array}$ & $\begin{array}{l}3.00 \\
100\end{array}$ \\
\hline & & & $\begin{array}{l}\text { Salta } 2 \text { y3 } \\
\text { Sala } 4\end{array}$ & $\begin{array}{l}22.80 \\
43.80\end{array}$ & $\begin{array}{l}p .00 \\
\mu .60\end{array}$ & & PLANTAS & 423.00 & $\begin{array}{l}\text { Hall } \\
\text { Tramoya } \\
\text { Almacen }\end{array}$ & $\begin{array}{l}10630 \\
190.30 \\
40.37\end{array}$ & $\begin{array}{l}42.52 \\
19.03\end{array}$ \\
\hline & PLANTAG & 851.00 & $\begin{array}{l}\text { Aula } 1 \\
\text { Aula } 2\end{array}$ & $\begin{array}{l}177.30 \\
88.00\end{array}$ & $\begin{array}{r}23.46 \\
17.60\end{array}$ & & $\begin{array}{l}\text { PLANTA6 } \\
\end{array}$ & 982.00 & Restaurante & 230.00 & 92.00 \\
\hline & & & $\begin{array}{l}\text { Aula } 3 \\
\text { ancén }\end{array}$ & 134.50 & 26.90 & & & & Cocina & 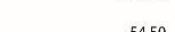 & \\
\hline & & & $\begin{array}{l}\text { Ambech } \\
\text { Deposito }\end{array}$ & 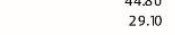 & & & & & Atención & $\begin{aligned} 5450 \\
8.70\end{aligned}$ & $\begin{array}{l}5.00 \\
100\end{array}$ \\
\hline & & & $\begin{array}{l}\text { Salalde espera } \\
\text { Terzaz }\end{array}$ & $\begin{array}{l}26.60 \\
6950\end{array}$ & $\begin{array}{r}5.32 \\
2780\end{array}$ & & & & $\begin{array}{l}\text { Desperdicios } \\
\text { almacoes }\end{array}$ & $\begin{array}{l}13.60 \\
15.34\end{array}$ & \\
\hline & & & SSHH & 42.20 & & & & & SSHH & 33.90 & $\therefore$ \\
\hline & PLANTA7 & 703.00 & $\begin{array}{l}\text { Taller de arte } 1 \\
\text { Taller de arte } 2 \\
\text { Taller dearte } 3\end{array}$ & $\begin{array}{l}134.00 \\
116.00 \\
193.50\end{array}$ & $\begin{array}{l}13.40 \\
1.100 \\
19.35\end{array}$ & & & & & & 120.00 \\
\hline & & & Depossito & & & & & & & & \\
\hline & PLANTA8 & 793.00 & $\begin{array}{l}\text { Terraza } \\
\text { Kitchenette }\end{array}$ & 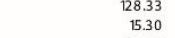 & $\begin{array}{c}5133 \\
6.12\end{array}$ & & & & & & \\
\hline & & & $\begin{array}{l}\text { Libreria } \\
\text { Area demesas }\end{array}$ & $\begin{array}{r}3740 \\
36400\end{array}$ & $\begin{array}{r}3.74 \\
72.80\end{array}$ & & & & & & \\
\hline & & & 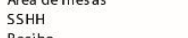 & $\begin{array}{l}304.40 \\
42.20 \\
6200\end{array}$ & 2480 & & & & & & \\
\hline & PLANTA9 & 652.00 & Cuarto de revelado & & ${ }_{163}$ & & & & & & \\
\hline & & 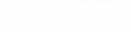 & Almacén & $\begin{array}{l}1.30 .30 \\
16.30\end{array}$ & ${ }^{103}$ & & & $6,786.00$ & & $5,061.35$ & $1,097.96$ \\
\hline & & & Terraza & 73.30 & $\begin{array}{r}29.32 \\
2.67\end{array}$ & & & & & & \\
\hline & & & $\begin{array}{l}\text { Maquinas } \\
\text { Area de trabjoj y descanso }\end{array}$ & 339.00 & $\begin{array}{r}3.67 \\
33.90\end{array}$ & TOTAL ICC + PLAZA & ACIÓN) & $31,384.00$ & & $29,659.35$ & $7,818.73$ \\
\hline & & & & & & & & & & & PROYECTO \\
\hline & & & & & & & & & & $\mathrm{PR}$ & MAA Y AFORO \\
\hline
\end{tabular}


ORGANIGRAMA CCB

PÚblico PRIVAdo SEMI-PÚblico

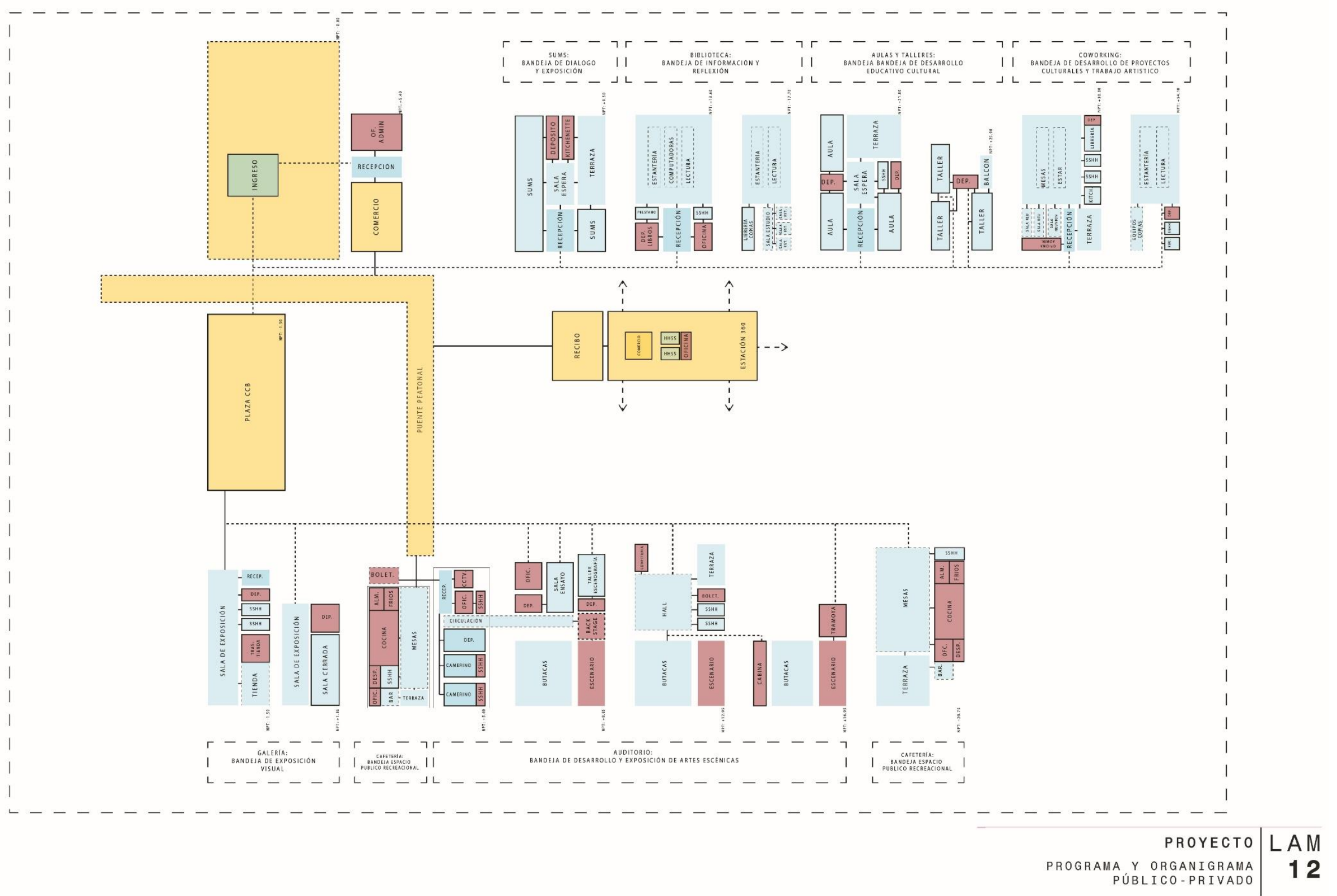



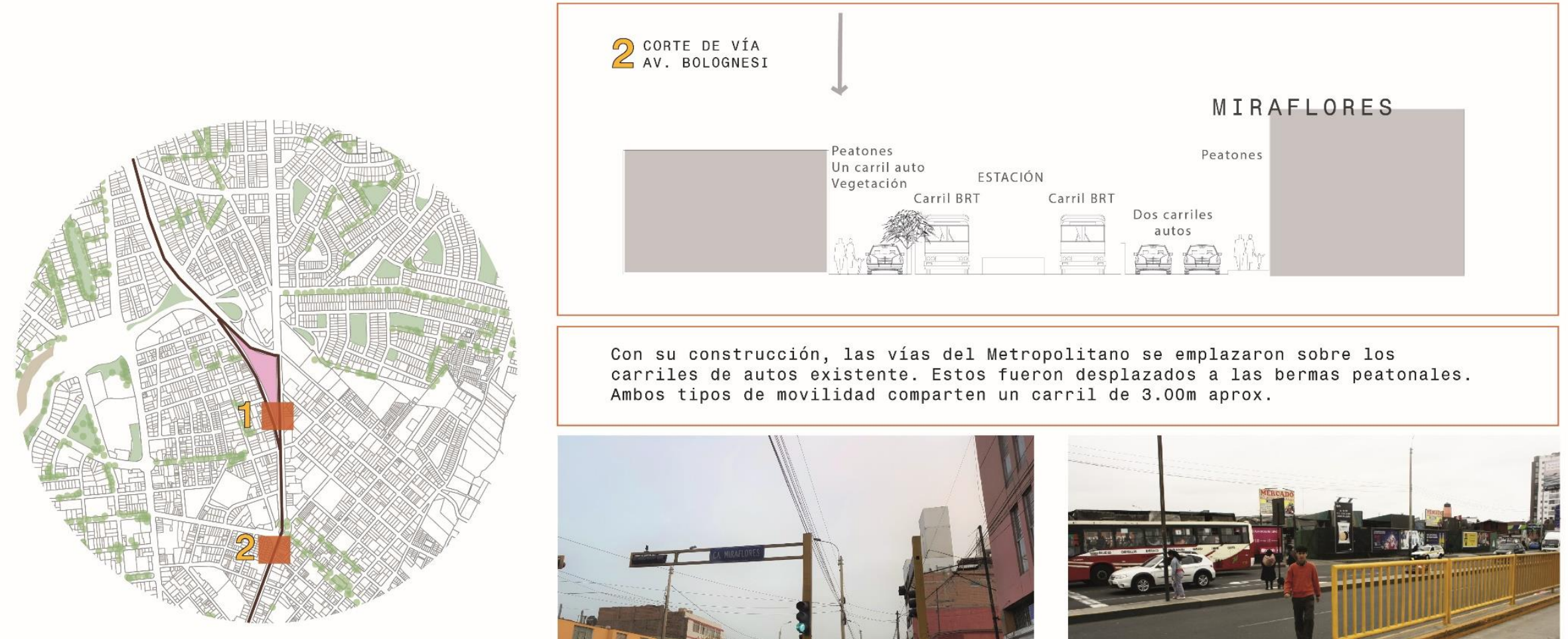

Con su construcción, las vías del Metropolitano se emplazaron sobre los

carriles de autos existente. Estos fueron desplazados a las bermas peatonales. Ambos tipos de movilidad comparten un carril de $3.00 \mathrm{~m}$ aprox.

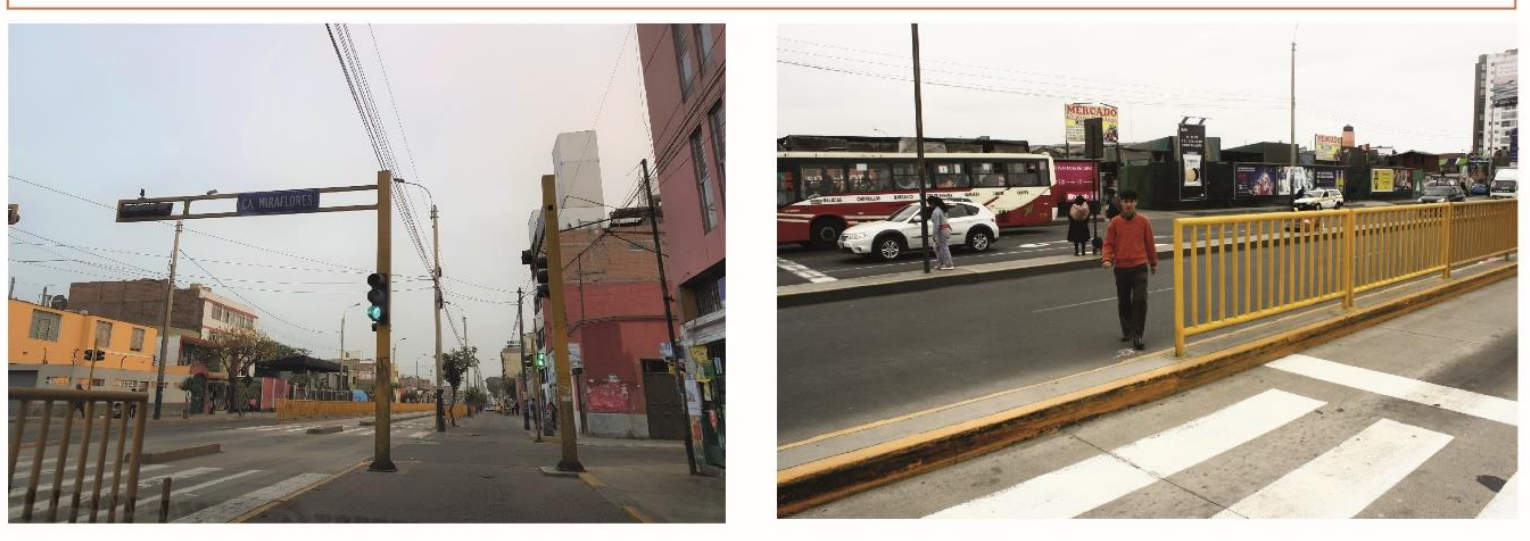

ๆ CORTE DE VÍÁ

vias rápidas / principales

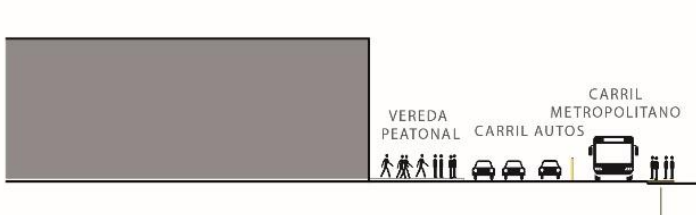

suelo directamente afectado

- 1 immite distrital

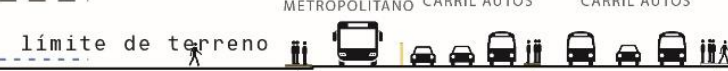

Vereda PeAtonal

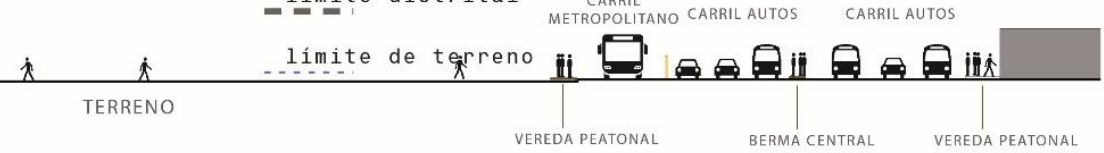




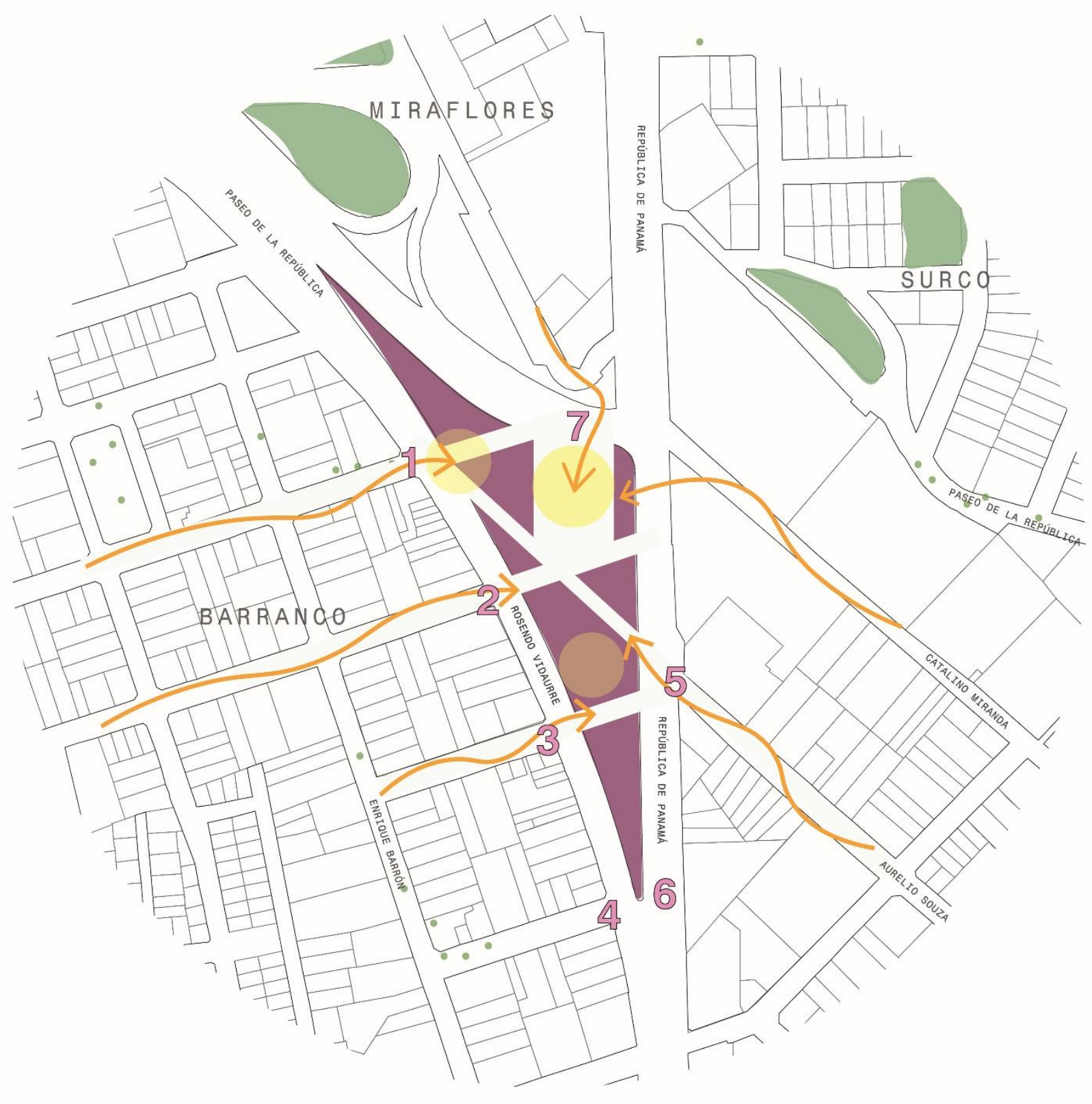

\section{OBJETIVOS :}

Conexión física de Barranco

Continuidad en ejes viales.

1. Jr Buenaventuro Aguirre

2. Jr Carlos Arrieta

3. Calle Campos

4. Calle Enrique del Horne

5. Calle Aurelio Souza

7. Plaza de Flores / Miraflores

\section{Prioridad peatonal}

Acondicionamiento de cruces peatonales a través del terreno

Espacios de recibo al usuario

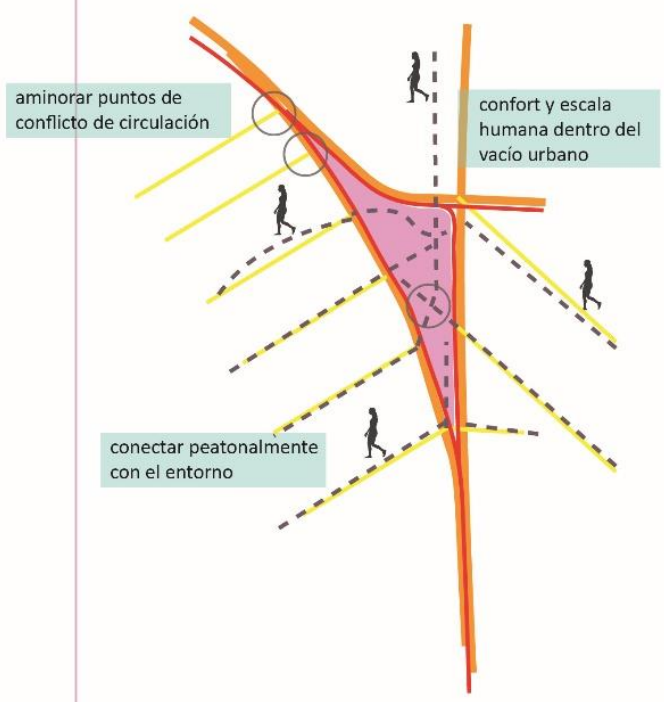

Para eliminar los puntos de conflicto de circulación, se trazan las vías aledañas dentro del terreno, para entender los espacios que deben ser mantenidos como circulaedificio y el esparcimiento en general.

\begin{tabular}{r|r} 
Proyecto & L A M \\
14
\end{tabular} 


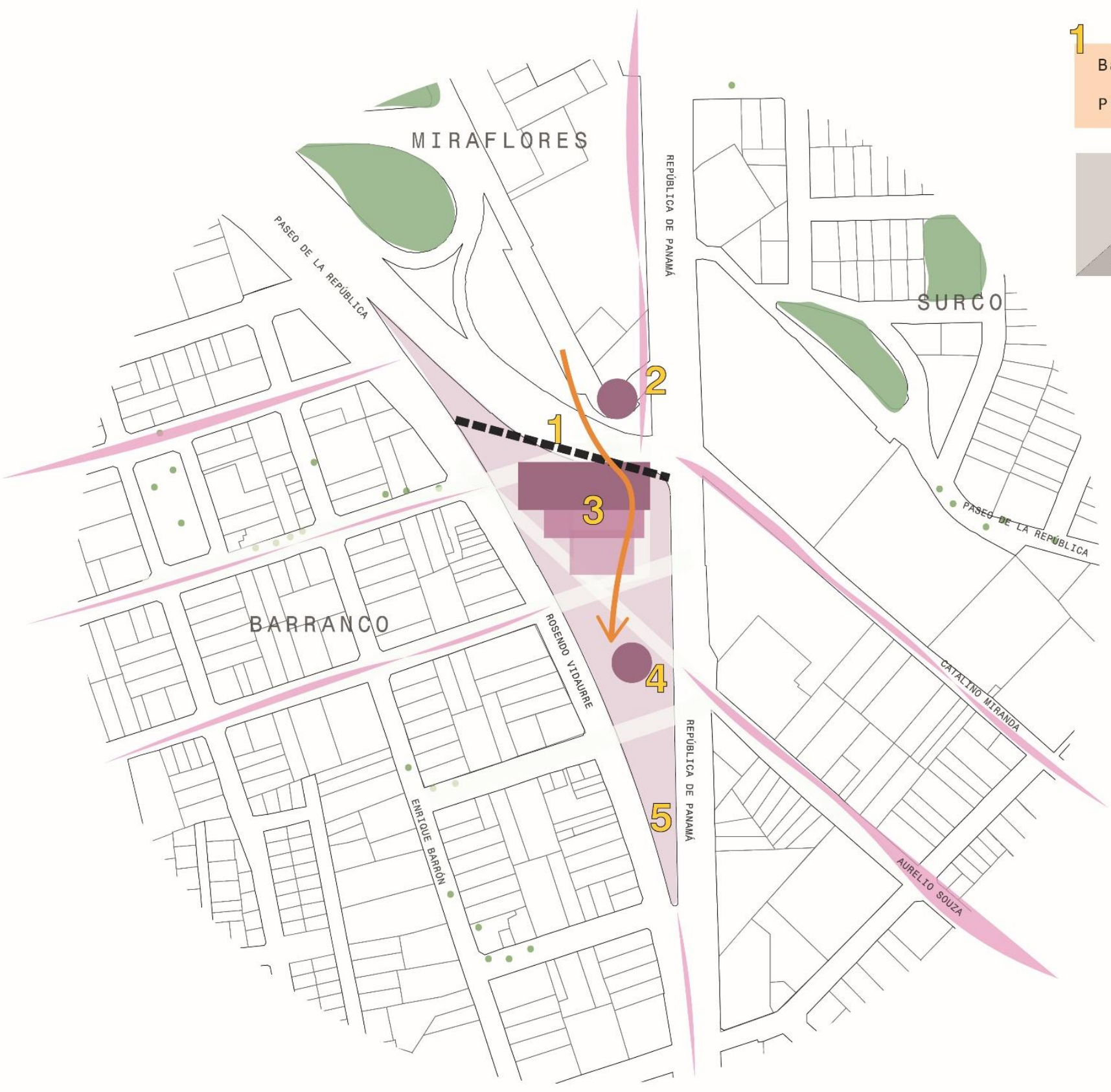

Barrera frente a una vía rápida.

Protección de la escala barrial.

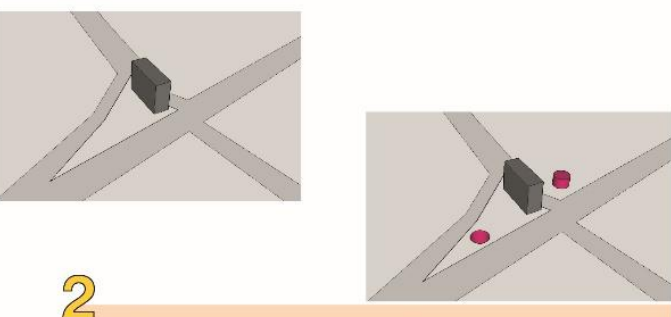

Núcleo de conexión

con la estación

Perforar para permitir

el cruce peatonal aéreo desde Miraflores.

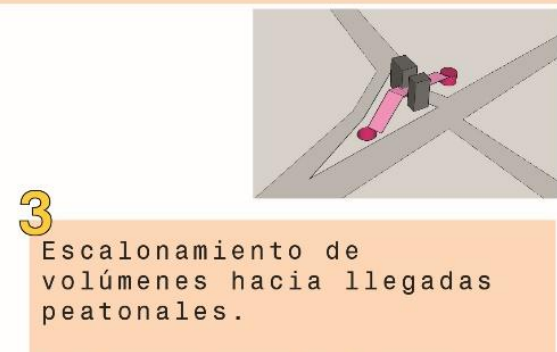

Mantener escala humana.

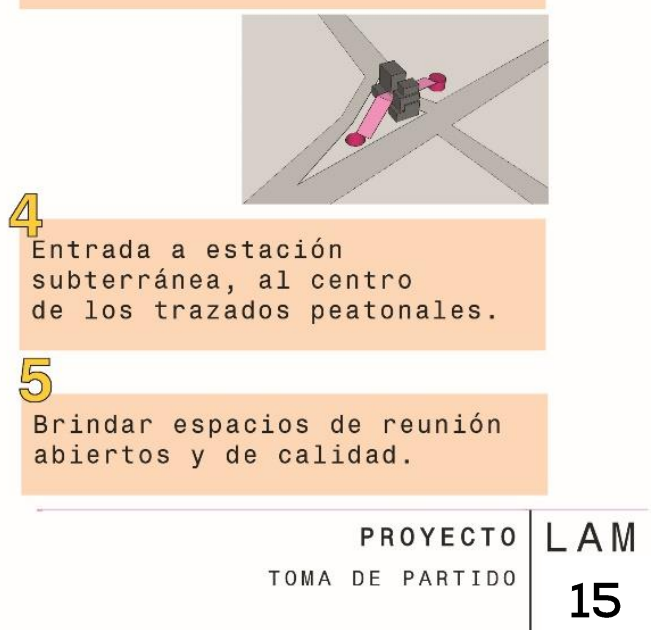




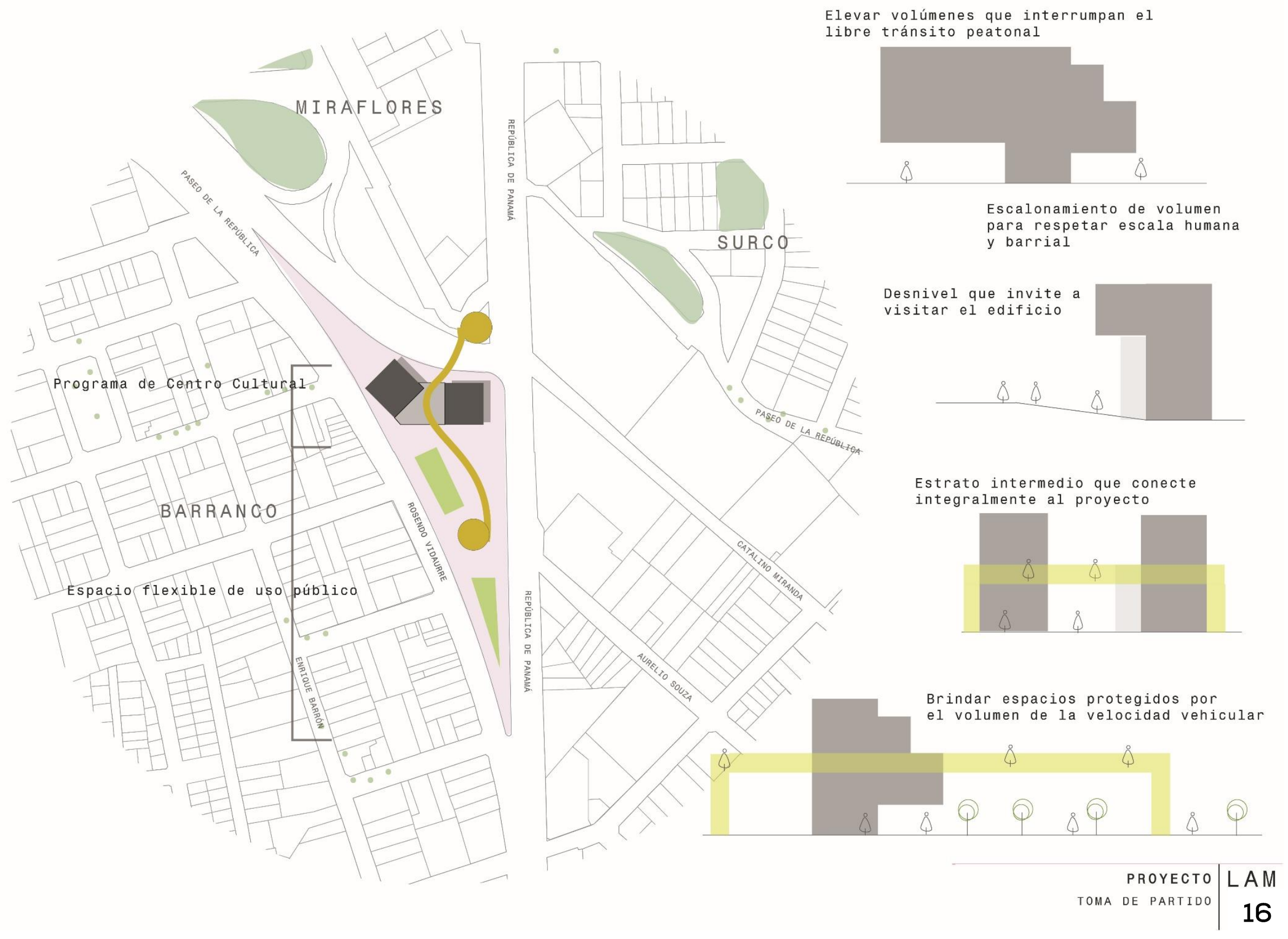



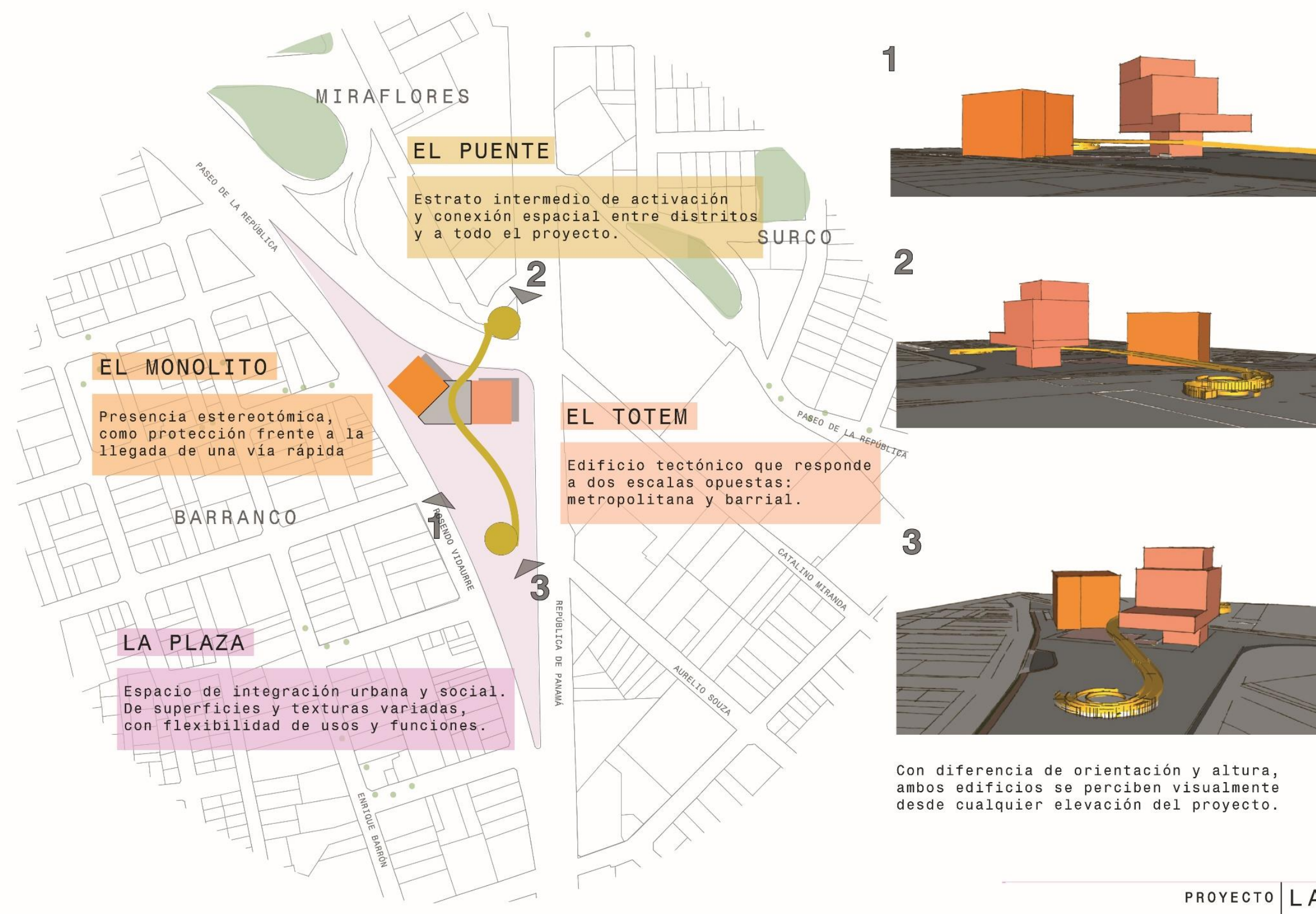

2

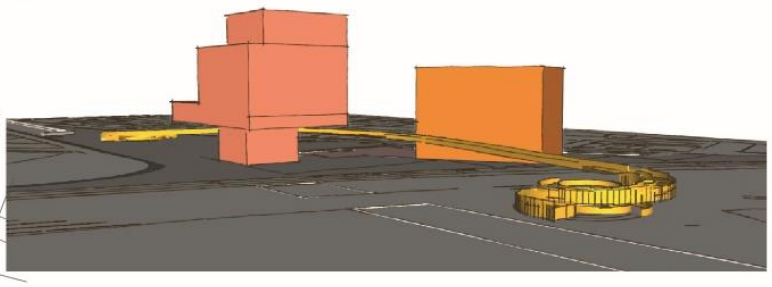

STEA

3

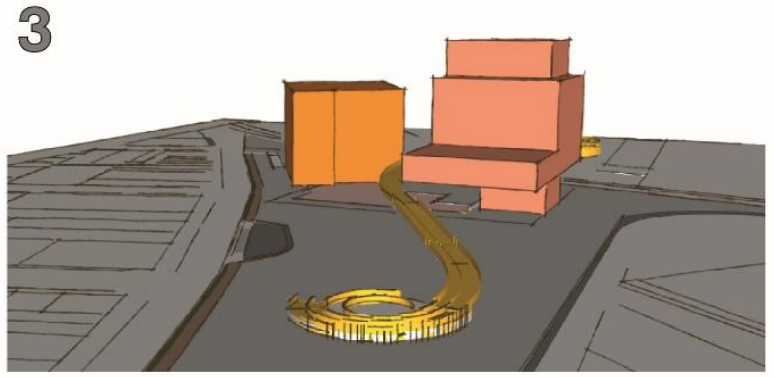

Con diferencia de orientación y altura, ambos edificios se perciben visualmente desde cualquier elevación del proyecto. 